\title{
Het Arbo-effect van medezeggenschap
}

Citation for published version (APA):

Popma, J. R. (2003). Het Arbo-effect van medezeggenschap. [Doctoral Thesis, Maastricht University]. Kluwer. https://doi.org/10.26481/dis.20031029jp

Document status and date:

Published: 01/01/2003

DOI:

10.26481/dis.20031029jp

Document Version:

Publisher's PDF, also known as Version of record

\section{Please check the document version of this publication:}

- A submitted manuscript is the version of the article upon submission and before peer-review. There can be important differences between the submitted version and the official published version of record.

People interested in the research are advised to contact the author for the final version of the publication, or visit the DOI to the publisher's website.

- The final author version and the galley proof are versions of the publication after peer review.

- The final published version features the final layout of the paper including the volume, issue and page numbers.

Link to publication

\footnotetext{
General rights rights.

- You may freely distribute the URL identifying the publication in the public portal. please follow below link for the End User Agreement:

www.umlib.nl/taverne-license

Take down policy

If you believe that this document breaches copyright please contact us at:

repository@maastrichtuniversity.nl

providing details and we will investigate your claim.
}

Copyright and moral rights for the publications made accessible in the public portal are retained by the authors and/or other copyright owners and it is a condition of accessing publications that users recognise and abide by the legal requirements associated with these

- Users may download and print one copy of any publication from the public portal for the purpose of private study or research.

- You may not further distribute the material or use it for any profit-making activity or commercial gain

If the publication is distributed under the terms of Article $25 \mathrm{fa}$ of the Dutch Copyright Act, indicated by the "Taverne" license above, 
Het Arbo-effect van medezeggenschap 


\author{
Promotores: \\ Prof. dr. A.J.C.M. Geers (Universiteit Maastricht) \\ Prof. dr. A.C.J.M. Wilthagen (Universiteit van Tilburg)

\section{Beoordelingscommissie:} \\ Prof. dr. M. Faure (voorzitter) \\ Prof. dr. W.L. Buitelaar (Universiteit van Amsterdam) \\ Prof. dr. J.K.M. Gevers (Universiteit van Amsterdam) \\ Prof. dr. A. Knotter \\ Dr. W. Rauws
}

ISBN 9013009425

NUR 807

Binnenwerk: Pre Press, Zeist

Omslagontwerp: Frank Brinkhuis

\title{
C J. Popma 2003
}

Voorzover het maken van kopieèn uit deze uitgave is toegestaan op grond van artikel 16b Auteurswet $1912 \mathrm{j}^{\circ}$ het Besluit van 1974, Stb. 351, zoals gewijzigd bij Besluit van 23 augustus 1985, Stb. 471 en artikel 17 Auteurswet 1912, dient men de daarvoor wettelijk verschuldigde vergoedingen te voldoen aan de Stichting Reprorecht (Postbus 3060, 2130 KB Hoofddorp). Voor het overnemen van (een) gedeelte(n) uit deze uitgave in bloemlezingen, readers en andere compilatiewerken (artikel 16 Auteurswet 1912) dient men zich tot de uitgever te wenden (Kluwer bv, Postbus 4, 2400 MA Alphen aan den Rijn).

Samensteller(s) en uitgever zijn zich volledig bewust van hun taak een zo betrouwbaar mogelijke uitgave te verzorgen. Niettemin kunnen zij geen aansprakelijkheid aanvaarden voor onjuistheden die eventueel in dere uitgave voorkomen.

All rights reserved. No part of this production may be reproduced, stored in a retrieval system, or transmitted in any form by any means, electronic, mechanical, photocopying, recorfing or otherwise, without written permission of the publisher. 


\section{Inhoud}

1. Inleiding: arbeidsomstandigheden en medezeggenschap 9

1.1. Aanleiding voor het onderzoek en vraagstelling 11

1.2. Zelfregulering en arbeidsomstandigheden 14

1.3. Arbeidsomstandigheden, zelfregulering en medezeggenschap 19

2. Arbeidsomstandighedenrecht en arbeidsverhoudingen:

lineaire geschiedenis of cirkelgang 23

2.1. Methodologische voorbeschouwing en vraagstelling 23

2.2. Vuur (1850-1919) 34

2.3. Water (1919-1963) 61

2.4. Aarde (1963-1980) 72

2.5. Lucht (1980-1999) 82

2.6. Slotbeschouwing: terug bij af? 100

3. De formele positie van de ondernemingsraad 103

3.1. De taak van de OR 104

3.2. Basisvoorwaarden voor overleg 109

3.2.1. Overlegrecht 109

3.2.2. Informatierecht 110

3.2.3. Faciliteiten 116

3.2.4. Instellen commissies 121

3.2.5. Rechtsbescherming 123

3.2.6. Samenvatting $\quad 125$

$\begin{array}{ll}\text { 3.3. Rechten en bevoegdheden } & 125\end{array}$

$\begin{array}{lr}\text { 3.3.1. Initiatiefrecht } & 127\end{array}$

3.3.2. Instemmingsrecht 128

3.3.3. Overeenstemmingsrecht $\quad 140$

3.3.4. Adviesrecht 141

3.4. OR en arbodienst 145

3.5. OR en Arbeidsinspectie 148

3.6. Samenvatting 152 
4. Arbobeleid en medezeggenschap in de praktijk

4.1. Arbobeleid en medezeggenschap: univariate analyse

4.1.1. Taakopvatting

4.1.2. Basisvoorwaarden voor medezeggenschap 167

4.1.2.1. Overlegrecht

4.1.2.2. Informatievoorziening

4.1.2.3. Tijd en deskundigheid

4.I.2.4. $V G W(M)$-commissies 174

4.1.3. Het gebruik van bevoegdheden 177

4.1.3.1. Instemmingsrecht 177

4.I.3.2. Adviesrecht 186

4.1.4. OR en arbodienst 187

4.1.5. OR en Arbeidsinspectie 189

4.1.6. Samenvatting en conclusie 193

4.2. Achtergrondfactoren en functioneren $O R$

4.2.1. Aandacht voor arbo-en verzuimbeleid 198

4.2.2. Aantal initiatieven 202

4.2.3. Overleg en informatie 204

4.2.4. Adviesrecht 207

4.2.5. Instemmingsrecht 208

4.2.5.1. Aantal instemmingsaanvragen 209

4.2.5.2. Aantal malen gepasseerd 210

4.2.5.3. Reactie OR op instemmingsaanvraag 212

4.2.6. Samenvatting en conclusies 213

4.3. Conclusies 216

5. Het arbo-effect van medezeggenschap 219

5.1. Medezeggenschap en arbobeleid 225

5.1.1. Risico-inventarisatie en Plan van Aanpak 225

5.1.2. Het contract met de arbodienst 227

5.2. Medezeggenschap en arborisico's 232

5.3. Medezeggenschap en ziekteverzuim 235

5.4. Conclusie 239

6. Casestudies 241

6.1. Methodologische verantwoording 241

6.2. Bouw 247

6.3. Bank- en verzekeringswezen 264

6.4. Samenvatting en conclusies 274 
7. Samenvatting, bedenkingen en enige ideeën

7.1. Samenvatting van de belangrijkste bevindingen 278

$\begin{array}{ll}\text { 7.2. Enige bedenkingen } & 281\end{array}$

$\begin{array}{ll}\text { 7.3. Enige ideeèn } & 287\end{array}$

$\begin{array}{ll}\text { Literatuur } & 299\end{array}$

$\begin{array}{lr}\text { Summary } & 313\end{array}$

$\begin{array}{lr}\text { Bijlagen } & 319\end{array}$

$\begin{array}{ll}\text { Lijst geïnterviewden } & 327\end{array}$

$\begin{array}{ll}\text { Over de auteur } & 329\end{array}$

Trefwoordenregister 33। 



\section{Inleiding: arbeidsomstandigheden en medezeggenschap}

Roestrood lag hij daar opeens, in april 2002. Gend. Midden in het U, doelloos naar het scheen. Daarna was maandenlang zijn stille verschijning te zien, spiegelend in het water bij ons om de hoek, alsof hij altijd daar gelegen had. Aan de ketting. zoveel was na verloop van tijd wel duidelijk. Verder was het echter gissen naar komaf of bestemming van de oude chemicaliëntanker. Tot hij op 18 juli werd omgetoverd tot decor van een door Greenpeace geënsceneerde sloopopera. Uit informatie van de milieuorganisatie bleek dat het schip waarschijnlijk ontmanteld zou gaan worden op een zogeheten sloopstrand, ergens in India, Pakistan of Bangladesh. Korte films die op de bakboordflank van de tanker werden geprojecteerd, gaven een impressie van de erbarmelijke omstandigheden waaronder de slopers hun werk moesten doen.

De Gerd is één van de vijftig schepen die door Greenpeace worden gevolgd in het kader van de Operatie Schoon Schip.' Met die operatie wil Greenpeace aandacht vragen voor het feit dat jaarlijks honderden schepen uit elkaar worden gehaald op Aziatische sloopstranden. De schepen zitten vol giftig afval, zoals asbest en zware metalen, en worden goeddeels met de hand gesloopt door laaggeschoolde arbeiders zonder adequate beschermingsmiddelen. Het asbest verwaait, de chemicaliën worden zonder omhaal in zee geloosd. Een handelwijze die niet alleen bijzonder schadelijk is voor het milieu, maar tevens levensbedreigend voor de arbeiders.

De schrijnende omstandigheden op de Aziatische sloopstranden zijn het resultaat van keuzes: keuzes uiteraard van de Indiase of Bengalese aannemer, maar ook van de oorspronkelijke, Noorse eigenaar. Deze verkocht het afgeschreven schip aan dubieuze tussenhandelaren, voor een prijs ver onder de sloopwaarde. Hoewel de oorspronkelijke eigenaar met de verkoop de iure wellicht zijn verantwoordelijkheid had ontlopen, blijft de more natuurlijk overeind dat hij met de verkoop het leven van honderden tamelijk weerloze arbeiders riskeert - arbeiders die nauwelijks een stem hebben en zich niet geruggensteund weten door beschermende wetgeving.

Bovenstaand voorbeeld illustreert dat de gevaren waaraan arbeiders zijn blootgesteld bij hun werk niet natuurnoodwendig zijn. Gevaarlijk werk, meer in het bij-

1 http://www.greenpeaceweb.org/shipbreak/finalvoyage.asp 
zonder de ongelijke distributie van gevaren ${ }^{2}$, is de consequentie van al dan ret bewuste beslissingen: "The risks the decision maker takes and has to take becote a danger for those affected." 3 Waar gevaarlijk werk wordt gekarakteriseerd is risico, als sociale artefact, wordt het onderwerp van sociologische studie. Hierij gaat het dan niet alleen om het ontstaan of de constructie van risico's, maar evazeer om de interpretatie van wat als risico wordt (h)erkend. ${ }^{4}$ Wat als 'risico' gelt, is inzet van werkelijkheidsdefinities die mede afhangen van de relatieve invloed un betrokkenen. ${ }^{5}$ In hoeverre bepaalde risico's acceptabel worden geacht, is as afhankelijk van definitiemacht, van de (mede)zeggenschapsverhoudingen.

Gevaren voor de veiligheid en gezondheid belagen echter niet louter de stemlee arbeiders in de Derde Wereld. Integendeel. Uit de ILO-cijfers blijkt dat de kans ip werkgerelateerde sterfte in India relatief zelfs lager ligt dan in het rijke Westermet name doordat in de Euro-Amerikaanse zone veel meer werkgerelateerde vrmen van kanker voorkomen. ${ }^{6}$ In Nederland wordt een kwart van het ziekteverzum en 35 procent van de arbeidsongeschiktheid toegeschreven aan de arbeidsbelastig of de arbeidsomstandigheden. ${ }^{7}$ Het feit dat westerse werknemers hun werk vrrichten onder de paraplu van beschermende wetgeving én veelal medezeggenschp hebben omtrent hun arbeidsomstandigheden - hetzij via de vakbond, hetzij via $t j$ -

2 De kans op een ernstig ongeval is voor Indische arbeiders 80 promille, terwijl die kans voor arbeiders in de Euro-Amerikaans handelszone slechts 30 is. Overigens is de kans op een ernstig ongeval in de rest van Aziè zelfs nog twee keer zo hoog als in India: 157 per 1000 werknemers. J. Takala (2002) Introductory Report: Decent Work - Safe Work, XVIth Worid Congress on Safety and Health at Work, Vienna, 27 may 2002. Een andere cause célèbre betreffende de ongelijke risicospreiding is uiteraard het zinken van de Titanic: van de eerste-klasreizigers overleefde $62 \%$ de ramp, veel meer dan de $2 \mathrm{e}(41 \%)$ en $3 \mathrm{e}$ klas $(25 \%)$.

3 N. Luhmann (1993), Risk: A sociological theory, Berlin/New York: De Gruyter, p. 107, Vgl. ibid. p. 21-22

4 Luhmann 1993. p. 6 "If only for epistemological reasons we may not assume that such a thing as risk exists, and that it is only a matter of discovering and investigating it."

5 Een voorbeeld hiervan is de manier waarop de 'moderne' beroepsziekte RSI in de belangstelling is gekomen. RSI is een complex van aandoeningen aan het bewegingsapparaat als gevolg van repeterende arbeid dat, ten onrechte, vooral wordt geassocieerd met beeldschermwerk. Hoewel lager opgeleide werknemers significant vaker RSI-klachten hebben dan hoger opgeleiden (CBS (2002), INDEX, feiten en ciifers over onze samenleving, no. 10 -december 2002, p. 15) én veel minder vaak computerwerk verrichten, is de aandoening pas werkelijk onder de aandacht gekomen toen ook goed opgeleide computerwerkers - niet in de laatste plaats journalisten - ermee geconfronteend werden en de term 'muisarm' werd geintroduceerd.

6 Takala 2002. Daarmee wil overigens niet gezegd zijn dat de arbeidsomstandigheden in het Westen dus slechter zijn dan in bijvoorbeeld India: e.e.a. is sterk afhankelijk van onder meer de aard van de werkzaamheden (hoogindustrieel, agrarisch. dienstverlening). de gebruikte grondstoffen, en de stand der techniek en wetenschap. F, van Waarden, J. Den Hertog. H. Vinke en T. Wilthagen (1997). Prospects for safe and sound jobs: the impact of future trends on costs and benefits of occupational health and safery. Den Haag: Vuga. p. 13ff

7 E.A.P Koningsveld en J.C.M. Mossink (1997), Kernciifers maatschappelijke kosten van arbeidsomstandigheden in Nederland. Den Haag: VUGA/ministerie van Sociale Zaken en Werkgelegenheid, p. 14 resp. 18: Stichting van de Arbeid (1999). Nota 'Beperking ziekteverzuim en instroom in de WAO: Den Haag: Publicatienr. 6/99, p. 12 resp. 14 
voorbeeld ondernemingsraden - is dus geen garantie voor een veilige en gezonde werkplek. Ook in het Westen, ook in Nederland worden keuzes gemaakt over wat als acceptabel risico wordt aanvaard of wordt onvoldoende rekening gehouden met de risico's van bepaalde werkzaamheden. Het is de vraag of werknemers in staat zijn voldoende tegenmacht te ontwikkelen om die keuzes te beìnvloeden of de risico's onder de aandacht te brengen.

\subsection{Aanleiding voor het onderzoek en vraagstelling}

In deze studie staat de betrokkenheid van werknemers bij het arbeidsomstandighedenbeleid in hun bedrijf centraal. Aanleiding voor het onderzoek was de nota Heroriëntatie arbobeleid en Arbowet, een adviesaanvraag van het kabinet aan de Sociaal-Economische Raad die uiteindelijk zou uitmonden in de Arbeidsomstandighedenwet $1998 .^{8}$ In de nota wordt decentralisatic van het arbeidsomstandighedenbeleid bepleit: minder overheidsbemoeienis, mér zelfregulering. De expliciete aanname daarbij is dat zelfregulering tot 'maatwerk' op bedrijfsniveau leidt, en daarmee de effectiviteit van het arbobeleid ten goede komt.

Als een van de randvoorwaarden voor decentralisatie geldt, blijkens de nota, actieve betrokkenheid van werknemers: "Vergroting van de beleidsvrijheid op ondernemingsniveau vergroot het belang van werknemersbetrokkenheid bij de invulling van de beleidsvrijheid. Het mobiliseren van de inbreng en deskundigheid van werknemers is een belangrijke voorwaarde voor een goed arbeidsomstandighedenbeleid. Actieve werknemersbetrokkenheid is een kwalitatieve prikkel en leidt tevens tot een meer evenwichtige afweging van belangen van werkgever en werknemers." 9 Deze expliciete nadruk op het belang van medezeggenschap leidde echter niet tot een versterking van de positie van met name ondernemingsraden. Volgens de nota "kan in het algemeen worden gesteld dat de aangrijpingspunten voor betrokkenheid van de OR in het regelcomplex van Arbowet en WOR voldoende adequaat zijn". ${ }^{10}$ Het wettelijk kader voor medezeggenschap zou dan ook niet aangepast hoeven worden - al was het feitelijk gebruik van de bestaande mogelijkheden "punt van aandacht". II

\section{Vraagstelling}

In deze studie worden twee veronderstellingen uit de heroriëntatie-nota nader onder de loep genomen: ten eerste dat betrokkenheid van werknemers bij het arbobeleid een kwalitatieve impuls betekent, ten tweede dat de "aangrijpingspunten voor betrokkenheid [..] voldoende adequaat zijn".

8 SZW (1996), Nota Heroriëntatie arbobeleid en arbowet: Adviesaanvraag aan de SER. Den Haag: Ministerie van Sociale Zaken en Werkgelegenheid, maart 1996

9 SZW 1996, p. 20

10 Ibid., p. 21

11 Ibid. 
De centrale vraagstelling voor dit onderzoek luidt derhalve:

1. Leidt medezeggenschap, in het bijzonder door de ondernemingsraad, tot beere arbeidsomstandigheden?

2. Zijn ondernemingsraden voldoende geëquipeerd om de hun toebedachte rol op het gebied van arbeidsomstandigheden naar behoren te vervullen?

2a. formeel, dat wil zeggen op grond van de Arbowet en met name de Wet op le ondernemingsraden

2b. in de praktijk, dat wil zeggen bij hun activiteiten op bedrijfsniveau

Hiermee is al direct een tamelijk strikte inperking van het onderzoeksdomein gegven. Medezeggenschap of werknemersvertegenwoordiging op het gebied van viligheid en gezondheid beperkt zich immers niet tot ondernemingsraden. Op diverse niveaus wordt door met name de vakbonden invloed uitgeoefend op het arbeicsomstandighedenbeleid en de Arbowetgeving - op nationaal niveau door bijvorbeeld adviezen van de SER omtrent regelgeving en specifieke arborisico's ${ }^{12}$, en ip brancheniveau door arbo-afspraken in CAO's ${ }^{13}$ of arboconvenanten ${ }^{14}$. Desondanks $\mathrm{zal}$ deze studie hoofdzakelijk aandacht besteden aan het functioneren van onderremingsraden, omdat de zorg voor veiligheid en gezondheid primair een kwestie is die op bedrijfsniveau gestalte krijgt. De inspanningen die vakbonden zich getrocsten zijn daarbij toch vooral instrumenteel, onder meer door het versterken van le positie van ondernemingsraden als werk'nemersvertegenwoordigers op dé werkvloer $^{15}$ én door het beïnvloeden van wet- en regelgeving. Ook de invloed van individuele werknemers, bijwoorbeeld door hun inbreng in het werkoverleg ${ }^{16}$, door inschakeling van de Arbeidsinspectie, of door civielrechtelijke procedures ${ }^{17}$, blijft

12 Sinds zijn oprichting in 1950 heeft de SER (in casu zijn commissie arbeidsomstandigheden en, in de periode 1983-1994, de Arboraad) bijna 120 adviezen doen uitgaan (waarvan méér dan 100 in de laatste 20 jaar) - zowel op beleidsmatig niveau als rond concrete thema's zoals bijvoorbeeld MAC-waarden. Over bijvoorbeeld de totstandkoming van MAC-waarden en de 'politieke' dimensie van de adviestrajecten ter zake vgl. R. Bal (1998), Grenzenwerk-Over het organiseren van normstelling voor de arbeidsplek, Enschede: Twente University Press

13 SZW (2002-a). Arbobalans 2002: Arbeidsrisico's, effecten en maatregelen in Nederland, Den Haag: Ministerie van Sociale Zaken en Werkgelegenheid, p. 67-69

14 SZW (2002-b), Arboconvenanten nieuwe stijl: rapportage over de periode 1999-2002, Den Haag: Ministerie van Sociale Zaken en Werkgelegenheid, p. 9-19

15 Zo bevatten diverse convenanten afspraken over de betrokkenheid en facilitering van ondernemingsraden. SZW 2002-b, p. 20-21

16 Deze verplichting uit artikel 13 van de Arbowet staat overigens, in het kader van de vermindering van de administratieve lastendruk, op de nominatie geschrapt te worden. In juli 2003 heeft de regering hiertoe een wetsvoorstel ingediend bij de Tweede Kamer. Kamershikken II, 2002 2003, 28986 , nr. 3, p. 1

17 Zo kan de werkgever op grond van artikel 7:611 BW dwingen gezondheidsschade toebrengende activiteiten te staken (overigens een theoretische mogelijkheid, die in de praktijk zal stuiten op vrees voor verstoorde arbeidsverhoudingen of andere repercussies). Daarnaast beoogt het Bureau Beroepsziekten FNV werkgevers via civielrechtelijke weg aan te zetten tot een preventief arbobeleid. J. Popma en J. Bus (2000). Beschadigd Bestaan: Een boekje open over benepsziekten. Amsterdam: FNV Bureau Beroepsziekten, p. $29 \mathrm{ff}$ 
hier goeddeels buiten beschouwing. Dit hangt samen met de focus van deze studie op de hoofdlijn van het overheidsbeleid, dat de beleidsvrijheid in hoge mate koppelt aan formele medezeggenschap en daarmee de ondernemingsraad een centrale rol toebedeelt.

Hoewel het accent in deze studie dus ligt op het functioneren van ondernemingsraden op het gebied van arbeidsomstandigheden en het effect daarvan op de veiligheid en gezondheid van werknemers, wordt de positie van de $\mathrm{OR}$ uiteraard niet volledig los gezien van de andere niveaus van werknemersbetrokkenheid. Integendeel. Het functioneren van ondernemingsraden is immers ingebed in een groot aantal structurele condities (wet- en regelgeving, institutionele setting. machtsbronnen) die, zowel actueel als historisch, voor een belangrijk deel mede onder invloed staan van de vakbeweging of, in meer algemene termen, de resultante zijn van historisch wisselende machts- en arbeidsverhoudingen. Op diverse punten zullen daarom dwarsverbanden worden gelegd tussen de verschillende niveaus. Zo is bijvoorbeeld de huidige, formeel tamelijk sterke positie van de ondernemingsraad niet los te zien van de historische bijdrage van de vakbeweging én de huidige ondersteuning door de vakbeweging middels voorlichting. scholing en de afspraken in convenanten. Daarnaast is de relatie tussen OR en achterban van belang, omdat zeker bij een werkplekgerelateerde problematiek als veiligheid en gezondheid signalen van de werkplek onontbeerlijk zijn voor goed functionerende medezeggenschap.

Een secundaire vraagstelling in dit onderzoek betreft dan ook:

2.c. Welke structurele condities (wet- en regelgeving, institutionele kaders, hulpbronnen en interpretatiekaders) zijn van invloed op het overleg en het handelen van ondernemingsraden op het gebied van arbeidsomstandigheden?

2.d Hoe hebben die structurele condities zich in de loop der tijd ontwikkeld binnen het kader van zich ontwikkelende arbeidsverhoudingen?

\section{Opbouw van deze studie}

Met het oog op de logische opbouw van deze studie worden de gestelde vragen in omgekeerde volgorde behandeld. Hoofdstuk 2 schetst een tamelijk uitgebreide geschiedenis van de medezeggenschap op het gebied van veiligheid en gezondheid, uitmondend in een eerste beschrijving van de huidige positie van de ondernemingsraad. Daarbij ligt het accent op de ontwikkeling van de wetgeving ter zake, maar er zal ook gekeken worden naar andere structurele condities voor het functioneren van ondernemingsraden. De historische schets is ingekaderd vanuit het perspectief van zich ontwikkelende arbeidsverhoudingen. Omgekeerd wordt, zij het ondergeschikt aan deze hoofdlijn, aangegeven hoe de strijd voor menswaardige arbeid van invloed is geweest op de ontwikkeling van de arbeidsverhoudingen in Nederland.

Hoofdstuk 3 belicht de juridische positie van de ondernemingsraden op het gebied van arbeidsomstandigheden in met name de Wet op de ondernemingsraden en de Arbowet. Daarbij zal blijken dat de formele positie van de OR tamelijk sterk is. In hoofdstuk $4 \mathrm{zal}$, aan de hand van vooral survey-gegevens, worden nagegaan of de OR zijn (wettelijke) taken ook in de praktijk gestalte kan geven. Hoofdstuk 5 
beoogt, wederom op basis van survey-onderzoek, een inschatting te maken van tet daadwerkelijke effect van de betrokkenheid van ondernemingsraden op het arbeilsomstandighedenbeleid binnen ondernemingen. Hoofdstuk 6 probeert vervolgens de gevonden statistische verbanden uit de eerdere hoofdstukken meer reliëf te geven door een tweetal branche-beschrijvingen. De methodologische verantwoording én de operationalisatie van met name de kernvragen zal in de respectievelijke hoo'dstukken nader worden uitgewerkt.

In hoofdstuk 7, tot slot, wordt een aantal conclusies uit de eerdere hoofdstukken oij elkaar gezet en zal het antwoord op de twee hoofdvragen van deze studie worden gegeven. Ook bevat dit slothoofdstuk een aanzet voor discussie over mogelijke versterking van werknemersvertegenwoordiging inzake veiligheid en gezondheid in verband met de arbeid.

\subsection{Zelfregulering en arbeidsomstandigheden}

Op de achtergrond speelt overigens nog een derde vraag, die het bredere kacer vormt voor deze studie:

\section{Leidt zelfregulering tot betere arbeidsomstandigheden?}

Het idee, of wellicht de ideologie dát zelfregulering tot betere arbeidsomstandigteden ferut, is nameñjk niet cen gedacńte die pas in de heronèntatie-nota is gefanceerd. Het is een regelmatig terugkerend thema in de afgelopen decennia, ingegeven door de ervaring dat centrale regulering door de overheid in ieder geval óók niet tot de gewenste resultaten heeft geleid. De onvrede met overheidsregulering steekt voor het eerst de kop op begin jaren ' 70 , wanneer blijkt dat de regelgeving steeds minder in staat is in te spelen op de snelle ontwikkelingen in bedrijven en in de samenleving in het algemeen, en spiegelbeeldig daaraan de gereguleerden zich steeds vaker aan de regels onttrekken doordat de handhaving tekort schiet (voor een uitgebreid overzicht van alle bedenkingen tegen het centralistische 'command-andcontrol'-paradigma vgl. paragraaf 2.5).

Als oplossing voor de toenemende incongruentie tussen regelgeving en maatschappij valt een aantal strategieën te verzinnen: versterking van de implementatie door de overheid (strenger toezicht), terugtred van de overheid (deregulering), of vormen van beheerste zelfregulering. ${ }^{18}$ In Nederland ligt begin jaren ' 80 , mede met het oog op de zorgwekkende economische situatie, de nadruk op pure deregulering dat wil zeggen het schrappen van 'verstikkende' regels die de vrije ontwikkeling van de economie in de weg zouden staan. ${ }^{19}$ Eind jaren ' 80 verschuift het accent

18 G. Teubner (1986), After legal instrumentalism: strategic models of post-regulatory law, in:

G. Teubner (ed.), Dilemmas of Law in the welfare state, New York: De Gruyter, p. 299-325

19 Met name ingefluisterd door de Commissie Deregulering in verband met de economische ontwikkeling (naar haar voorzitter de Commissie Van der Grinten) en de Commissie Vermindering en vereenvoudiging van overheidsregelingen (Commissie Geelhoed), Vgl. Kamerstukken II, 1982 1983,17931 , nrs. 5 en 9 
meer richting zelfregulering en decentralisatie van de regelgeving. Decentralisatie kan worden gedefinieerd als de verschuiving van bevoegdheden en verantwoordelijkheden van een hoger naar een lager besluitvormingsniveau, met als doel dat partijen op het lagere niveau worden uitgenodigd een eigen beleid te maken ${ }^{20}$ - decentralisatie dus als randvoorwaarde voor zelfregulering. Het concept 'zelfregulering' zelf wordt al begin jaren " 70 geintroduceerd op het gebied van arbeidsomstandigheden, door de commissie die de herziening van de veiligheidswetgeving in het Verenigd Koninkrijk voorbereidde. ${ }^{21}$ Deze zogeheten Robens Committee ontwikkelde echter geen scherpe definitie van de term 'self-regulation', noch werd het bereik van zelfregulering duidelijk afgebakend. 'Zelfregulering' leek meer een oproep aan werkgevers dan een accurate demarcatie van de onderscheiden verantwoordelijkheden van overheid en bedrijfsleven. ${ }^{22}$

De preciezere uitwerking van het concept 'zelfregulering' wordt, althans in Nederland, eind jaren ' 80 ter hand genomen. Van Driel definieert zelfregulering als een corpus van "niet-statelijke regels die al dan niet in samenwerking met anderen worden vastgesteld door degenen voor wie de regels bestemd zijn respectievelijk hun vertegenwoordigers, en waarbij het toezicht op de naleving mede door deze groepen wordt uitgeoefend." 23 Geelhoed definieert zelfregulering als "een vorm van bindende normstelling door een representatief kader uit de groep van belanghebbenden. [..] Deze vorm van regulering onderscheidt zich - in zijn zuivere vorm - van wetgeving, doordat de normen privaatrechtelijk zijn."24 Daarnaast is in zijn zuivere vorm ook het toezicht op de naleving van de normen privaatrechtelijk van aard. Maatschappelijke organisaties zijn, bij zuivere zelfregulering, "geheel zelf verantwoordelijk [..] voor de regelgeving op een bepaald terrein en tevens voor de uitvoering, controle en handhaving van de regelgeving." 25

Op het gebied van arbeidsomstandigheden is echter, zeker in de Nederlandse situatie, geen sprake van zuivere zelfregulering maar van een mix van private en publiekrechtelijke elementen. Hoewel zeker in de normstelling allengs meer privaatrechtelijke elementen worden opgenomen, bijvoorbeeld door $\mathrm{CAO}$-afspraken

20 Vgl. F. Tros (2000), Decentralisering van arbeidsverhoudingen: Een onderzoek naar de arbeidsvoorwaardenvorming in de Nederlandse private sector in de periode 1982-2000. Universiteit van Utrecht: diss., p. 25 Decentralisatie is, in meer fundamentele zin, ook uitvloeisel van één van de beginselen van behoorlijke regelgeving, te weten het beginsel van het juiste orgaan: wat naar zijn aard bij lagere lichamen behoort, behoort daardoor te worden geregeld. $\mathrm{Vgl}$. Aanwijzing 8 uit de Aanwijzingen voor de regelgeving.

21 Robens Committee (1972). Safety and Health at Work. Report of the Committee 1970-1972. London: Her Majesty's Stationery Office

22 H. Genn (1988), Great Expectations: The Robens Legacy and Employer Self Regulation, Paper presented to the Symposium of the British Factory Inspectorate, Universiteit van Amsterdam, p. 4-5

23 M. van Driel (1989), Zelfregulering, Deventer: Kluwer, p. 2

24 L.A. Geelhoed (1993), Deregulering, herregulering en zelfregulering, in: Eijlander, Ph., P.C. Gilhuis en J.A.F. Peters (red), Overheid en zelfregulering. Alibi voor vrijblijvendheid of prikkel tot actie, Zwolle: W.E.J. Tjeenk Willink, p. 49-50

$25 \mathrm{Ph}$. Eijlander (1993), De wet stellen: Beschouwingen over onderwerpen van wetgeving. Zwolle: W.E.J. Tjeenk Willink, p. 229 
en convenanten of door uitwerking van globale wettelijke voorschriften in meer specifieke normalisatienormen ${ }^{26}$, blijft de overheid in laatste instantie verantwoordelijk voor het uitvaardigen van zogeheten 'basisnormen' ${ }^{27}$ Daarnaast is, zeket in de handhaving, de centrale rol weggelegd voor de overheid, in de gedaante van de Arbeidsinspectie. Ook de elementen van zelfregulering die wel een rol spelen in de arbowetgeving impliceren geen zuivere zelfregulering, maar behoren veeleer tot de categorie 'vervangende' en 'geconditioneerde zelfregulering'. ${ }^{28} \mathrm{Bij}$ vervangerde zelfregulering laat de overheid het initiatief aan belanghebbenden, maar behoudt zij zich het recht voor met wetgeving te komen als bepaalde beschermenswaardge belangen (bijvoorbeeld de veiligheid en gezondheid van werknemers) onvoldoende in de private normen worden gedekt. ${ }^{29} \mathrm{Bij}$ geconditioneerde zelfregulering stelt de overheid globale doelvoorschriften op, maar geeft zij de geadresseerde partijen (binnen duidelijke randvoorwaarden, die soms expliciet in een wettelijke regeling zijn vastgelegd) de vrijheid om zelf nadere afspraken te maken over de wijze warop aan de globale doelvoorschriften tegemoet wordt gekomen.

Het arbeidsomstandighedenbeleid van de Nederlandse overheid en met name de Arbowet legt sterk het accent op geconditioneerde zelfregulering of, in iets scherpere bewoordingen, "enforced selfregulation' ${ }^{30}$. De overheid geeft de sociale partners op bedrijfsniveau de vrijheid om zelf te voldoen aan de wettelijke voorschriften, maar wel binnen een tamelijk strikt kader van 'spelregels'. Die spelregels

26 Bij normalisatie maken betrokkenen, op basis van consensus, afspraken over bijvoorbeeld de afmetingen van arbeidsplaatsen (norm NEN 1824) of de inrichting van een beeldschermwerkplek (NEN 2449). Een norm is een "Technische specificatie of een ander document dat voor het publliek verkrijgbaar is, met medewerking en in onderlinge overeenstemming of met algemene goedkeuring van alle betrokken partijen is opgesteld, op de gezamenlijke resultaten van wetenschappen, technologie en ervaring is gebaseend, op het optimale voordeel voor de gemeenschap in haar geheel is gericht en door een bevoegde instelling op nationaal, regionaal of internationaal niveau is goedgekeurd." (ISO/IEC Guide 2, Standardization and related activities - General vocabulary, 1996) Overigens behoeft consensus niet unanimiteit te impliceren. Vgl. J.R. Popma (1999. a), Verprivaatrechtelijking van arbeidsomstandigheden? In: P.F. van der Heijden, R.H. van het Kaar en A.C.J.M. Wilthagen (red.), Naar een nieuwe rechtsorde van de arbeid?, Den Haag: SDU/HSI, p. 17Iff

27 Onder basisnormen worden verstaan "alle normen die betrekking hebben op de belangrijkste arbeidsomstandighedenrisico 's en een basisniveau van bescherming bieden tegen die risico's" en "alle normen die voortvlocien uit internationale verplichtingen (EG-richtlijnen en door Nederland geratificeerde IAO-verdragen op arbeidsomstandighedenterrein)". Arbeidsomstandighedenbesluit (Stb. 1997, 60), p. 126

28 Geelhoed 1993, p. 49-50

29 Een voorbeeld hiervan is dat de sociale partners medio jaren ' 90 de tijd kregen om tot afspraken te komen over preventie van blootstelling aan oplosmiddelen, met op de achtergrond de mogelijkheid dat de overheid een vervangingsplicht voor oplosmiddelrijke verfsoorten zou komen indien de sociale partners er niet uitkwamen. Kamerstukken II, 1995-1996, 24400 XV, nr. 38

30 1. Ayres en J. Braithwate (1992), Responsive Regulation: Transcending the Deregulation Debate, New York/Oxford: Oxford Socio-Legal Studies, p. 101 ff. Vgl. M.H. Schaapman en A.J.C.M. Wilthagen (1998), Regulering van arbeidsomstandigheden en milieu-effecten: tussen publick en privaat, in: G.H. Addink, A.M. Knol en R. Knegt (red.), Privatisering: effectiviteit en legitimiteit, Zwolle, W.E.J. Tjeenk Willink, p. 171 
bestaan sinds de wijziging van de Arbowet in 1994 in hoofdlijnen uit:

- een zorgplicht van de werkgever ten aanzien van zijn werknemers (art. 3 Arbowet en art. 7:658 BW) én ten aanzien van derden (art. 10 Arbowet);

- een verplichting tot het voeren van een arbeidsomstandighedenbeleid (art. 3 Arbowet);

- op basis van een risico-inventarisatie en -evaluatie en een plan van aanpak (art. 5 Arbowet):

- in samenwerking met de ondernemingsraad, personeelsvertegenwoordiging of de belanghebbende werknemers (art. 12 Arbowet);

- daarbij ondersteund door een arbodienst (art. 14 Arbowet) ${ }^{31}$;

- in laatste instantie onder toezicht van de overheid in de gedaante van de Arbeidsinspectie (artt. 24-28 Arbowet).

De kern van dit systeem, te weten de zorgplicht, de beleidsverplichting en de samenwerking met de werknemers, bestond echter al in de Arbowet 1980 (de risico-inventarisatie en de verplichte ondersteuning door de arbodienst zijn geìntroduceerd in $1994^{32}$ ). Sterker nog, in vrijwel dezelfde vorm is dit systeem terug te vinden in de Britse Health \& Safety at Work Act (HASAWA) uit 1974, een wet die was doordesemd van Robens' filosofie van zelfregulering (vgl. paragraaf 2.5). Het idee van zelfregulering op het gebied van veiligheid en gezondheid is dus behoorlijk persistent, en de beleidsvrijheid zou blijkens de heroriëntatie-nota zelfs nog versterkt moeten worden. Het vertrouwen of, scherper gesteld, het geloof van de overheid in arbo-zelfregulering is echter niet of nauwelijks geschraagd door serieus onderzoek. In een enkele buitenlandse studie is wel een positief effect van zelfregulering gevonden. ${ }^{33}$ Andere onderzoekers daarentegen zijn aanmerkelijk sceptischer. In een studie over de effecten van de Health \& Safety at Work Act analyseert Dawson de ontwikkeling van het aantal arbeidsongevallen, als één van de indicatoren voor veilige arbeidsomstandigheden. Met inachtneming van allerlei methodologische haken en ogen, concludeert Dawson dat in de vijf jaar ná invoering van de HASAWA het aantal ongevallen in het Verenigd Koninkrijk was gedaald, maar

31 Daarnaast moet de werkgever onder meer zorg dragen voor voorlichting en onderricht aan werknemers (art. 8 Arbowet) en incidenteel informatie verstrekken aan omwonenden (art. 7), ongevallen en beroepsziekten melden (art. 9), en adequate bedrijfshulpverlening organiseren (art. 15)

32 De verplichting om een arbodienst in te schakelen is bovendien een verplichting van afgeleide aard: de figur van de arbodienst is in 1994 geîntroduceerd ter implementatie van de Europese Kaderrichtlijn betreffende de tenuitvoerlegging van maatregelen ter bevordering van de verbetering van de veiligheid en de gezondheid van de werknemers op het werk (Richtlijn 89/391 EEG, PbEG 1989, L 183). Artikel 7 van de Kaderrichtlijn verplicht primair tot het inschakelen van deskundige werknemers uit het bedrijf zelf, en pas indien dat niet kan van een externe arbodienst. Blijkens de considerans bij de Richtlijn werd hiermee niet alleen beoogd het deskundigheidsniveau binnen bedrijven op een hoger peil te brengen, maar expliciet ook de werknemers intensiever te betrekken bij het arbobeleid in hun organisatie

33 J. Rees (1988), Reforming the workplace: a study of self-regulation in occupational safety. Philadelphia: University of Pennsylvania Press 
dat na 1980 weer een significante stijging van het aantal ongevallen viel te signaleren. ${ }^{34}$

Een replicatie 'vanuit de losse pols' van dergelijk onderzoek in Nederland aat eveneens een weinig rooskleurig beeld zien. Na invoering van de eerste Arbowd in 1983, die in feite al de geest van zelfregulering ademde (vgl. paragraaf 2.4), wijen de meeste kwantitatieve indicatoren bepaald niet op een duidelijke verbetering van de arbeidsomstandigheden. De ongevallenstatistieken in Nederland vertoonden weliswaar een dalende trend, maar die daling werd niet versterkt na 1983,35 pok het ziekteverzuim daalde nauwelijks na $1983^{36}$, to de invoering van het eigen isico in de Ziektewet (TZ, Wulbz) medio jaren '90. Deze daling was overigens naar tijdelijk. gezien de stijging sinds $1998 .{ }^{37}$ Het instroompercentage in de WAO dialde evenmin na $1983 .^{38}$ De daling van het percentage medio jaren ' 90 kan ook lier primair worden verklaard door repressieve maatregelen, zoals een verscherpt kuringsregime (TBA/TAV) en de introductie van financiële prikkels (Pemba).

Uiteraard zijn bovenstaande gegevens te grof om een serieuze conclusie aan te erbinden. Zo hangt bijvoorbeeld de ontwikkeling van het ziekteverzuim sterk sarten met de conjunctuur ${ }^{39}$. en wordt het hoge instroompercentage in de WAO in de periode na 1974 mede toegeschreven aan misbruik van de wet als gunstige afvlieiingsregeling. Wel is duidelijk dat de genoemde gegevens niet noden tot een critiekloze omarming van zelfregulering op het gebied van arbeidsomstandighedel. ${ }^{40}$ Integendeel: de jaarlijkse monitor arbeidsomstandigheden, een onderzoek dat tiet

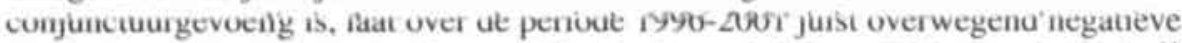
trends zien (met name voor nieuwe risico's als werkdruk en RSI, zie tabel 1.1 ). ${ }^{41}$ Ook in Europees perspectief zijn de arbeidsomstandigheden de laatste jaren alleen

34 S. Dawson, P. Willman, A. Clinton en M. Bamford (1988), Safety at work: The limits of selfregulation, Cambridge, Cambridge Univ. Press; Vgl, ook H. Genn (1988), Great Expectations: The Robens Legacy and Employer Self Regulation. Paper presented to the Symposium of the British Factory Inspectorate, Universiteit van Amsterdam

35 D.J. Klein Hesselink (1995), Ongevallenregistratie in bedrijf: over de melding, registratie en analyse van arbeidsongevallen. Amsterdam: NIA, p. 15

36 SVR (1993). Kroniek van de sociale verzekeringen, tabel 4.1. Amsterdam: Sociale Verzekeringsraad

37 CBS (1999), Statistisch bulletin no.17, 19 april 1999 en CBS (2003), Sociaal-economische Maandstatistiek, januari 2003. p. 70

38 UWV (2002), Kroniek van de sociale verzekeringen 2002, Amsterdam: UWV, p. 98

39 M.M.G. Fase en L.M. Keijzer (1991). Ziekteverzuim en conjunctuur, in: Economisch-statistische berichten. 76, nr. 3083, p. 372-375

40 Zo plaatste ook de ILO al in 1985 vraagtekens bij het klakkeloos omarmen van zelfregulering: "allowing undertakings to solve their own problems is not without its risks". Dit met het oog op de Noorse wetgeving, die ook sterk van invloed was op de Nederlandse Arbowet (vgl. par. 2.3). $\mathrm{Vgl}$. A.C.J.M. Wilthagen (1993), Het overheidstoezicht op de arbeidsomstandigheden, Groningen: Wolters-Noordhoff, p. 33

41 CBS/ministerie van Sociale Zaken en Werkgelegenheid (2001). Arbeidsomstandigheden 2001: monitoring via personen, Den Haag/Voorburg: Elsevier, SZW (2002-a). Arbobalans 2002: Arbeidsrisico's, effecten en maatregelen in Nederland, Den Haag: Ministerie van Sociale Zaken en Werkgelegenheid

42 P. Paoli en D. Merlié (2001). Third European survey on working conditions. Dublin: European Foundation for the Improvement of Living and Working Conditions 
maar belastender geworden. ${ }^{42} \mathrm{Al}$ met al is dit voldoende aanleiding om niet alleen het concept zelfregulering zélf maar ook de bewieroking van medezeggenschap als één van de schragende elementen van dat concept met de nodige argwaan te bezien.

Tabel 1.1. Arbeidsomstandigheden in Nederiand

\begin{tabular}{|l|l|l|l|}
\hline & 1996 & 2000 & 2001 \\
\hline Kracht gebruiken & 24 & 23 & 22 \\
Langdurig zelfde houding & 45 & 42 & 46 \\
Repeterende bewegingen & 41 & 42 & 44 \\
Beeldschermwerk & 38 & 43 & 46 \\
Tijdsdruk & & & \\
In hoog tempo werken & 31 & 31 & 30 \\
Onder tijdsdruk én in hoog tempo & 41 & 40 & 41 \\
\hline
\end{tabular}

\subsection{Arbeidsomstandigheden, zelfregulering en medezeggenschap}

Het geloof in werknemersvertegenwoordiging rond arbeidsomstandigheden dateen al van medio jaren '70, zoals blijkt uit het reeds genoemde rapport van de Britse Robens Committee én de eerste versie van de Nederlandse Arbowet uit 1980. De betrokkenheid van werknemers(vertegenwoordigers) was volgens toenmalig minister Boersma van Sociale Zaken zelfs de belangrijkste noviteit van de Arbowet. ${ }^{43}$ In de loop der jaren is de ratio achter deze werknemersbetrokkenheid overigens licht verschoven, zowel in ideologisch als in theoretisch opzicht.

In de jaren ' 70 was het idee van werknemersvertegenwoordiging in sterke mate gemotiveerd vanuit politieke en normatieve uitgangspunten. Zo viel het denken over medezeggenschap van werknemers inzake veiligheid en gezondheid te plaatsen in de bredere discussie omtrent de democratisering van de samenleving in het algemeen. Ook werd medezeggenschap als zodanig gezien als bijdrage tot de humanisering van de arbeid, als waarde op zichzelf. Daarnaast werd medezeggenschap normatief gegrondvest in het zelfbeschikkingsrecht en de eis van de bescherming van de lichamelijke integriteit: de werknemer zet zijn lichaam in voor arbeid, en heeft het recht om over dit lichaam te beschikken en invloed uit te oefenen op het bedrijfsbeleid. ${ }^{44}$ In dit kader zijn bijvoorbeeld de artikelen 3 en 11 Europees Sociaal Handvest (1961) van belang. Naast deze principiële overwegingen werden ook meer instrumentele redenen voor medezeggenschap aangevoerd. Zo zou werk-

43 SER (1976), Advies inzake vernieuwing van de wetgeving betreffende de gezondheid en de veiligheid bij de arbeid, Den Haag: Sociaal-Economische Raad, SER 76/18, bijlage I, p. 1

44 J.K.M. Gevers (1982), Zeggenschap van werknemers inzake gezondheid en veiligheid in bedrijven. De rechtsontwikkeling in de lidstaten van de Europese Gemeenschap, Deventer: Kluwer, p. 58-64 
nemersbetrokkenheid bijdragen aan het veiligheidsbesef en de motivatie van de werknemers en met name een middel zijn om de kennis van de arbeidsomstandigheden op de werkvloer te mobiliseren (zowel door het signaleren van knelpunten als bij het ontwikkelen van oplossingen voor de problemen). ${ }^{45}$ In meer algemene zin werd medezeggenschap zelfs gezien als een bijdrage aan het innovatief verrnogen van bedrijven. ${ }^{46}$

In de loop der jaren is de meer principiële dimensie van medezeggenschap als democratisch recht of als instrument van zelfbeschikking allengs naar de achiergrond verschoven. De praktische motieven bleven overeind, aangevuld met rechitstheoretisch geinspireerde overwegingen. In het kader van de theorievorming rond zelfregulering wordt een evenwichtige belangenafweging gezien als een van de schragende elementen van het systeem - niet alleen als een van de beginselen van behoorlijke regelgeving ${ }^{47}$ of als democratische legitimatie bij gedecentraliseerde besluitvorming. maar ook als terugkoppelingsmechanisme binnen te reguleren (sub)systemen. ${ }^{48}$ Dit laatste punt is ontleend aan het paradigma van het reflexief recht, dat is gebaseerd op het systeemtheoretische inzicht dat maatschappelijke systemen slechts zeer ten dele openstaan voor externe regulering. Systemen, zoals bedrijven, volgen ten principale hun eigen interne axiomata (in casu winst/verlies) zonder acht te slaan op eventuele externe suboptimalisering (zoals bijvoorbeeld arbeidsongeschiktheid, hetgeen tot begin jaren ' 90 vooral een maatschappelijk probleem was en géén probleem voor het bedrijf). Regulering van (sub)systemen nu kan slechts effectief zijn als wordt aangesloten bij de systeeminterne logica én door het systeem te stimuleren om te reflecteren op de effecten van het eigen functioneren. ${ }^{49}$ Aansluiting bij de fundamentele code van het subsysteem 'bedrijf' werd onder meer nagestreefd door het inbouwen van financiële prikkels bij verzuim en arbeidsongeschiktheid (TZ, Wulbz. Pemba). Het versterken van het leervermogen van systemen vereist interne 'checks' op de externe effecten van het systeem. Dit vereist de opbouw van 'discursieve structuren', waardoor die effecten bespreekbaar worden. In dit kader is medezeggenschap niet langer een instrument om individuele participatie te vergroten of machtsverhoudingen te neutraliseren, maar om langs discursieve weg te vermijden dat het (sub)systeem zichzelf opblaast doordat het de grenzen vanuit de systeemomgeving uit het oog verliest. ${ }^{50}$ Medezeggenschap dus als instrument van zelfcontrole van het bedrijf, en níet langer intrinsiek gemoti-

45 Gevers 1982, p. $52-58$

46 Kamerstukken II, 1979-1980, 15800 , hoofdstuk XV, nr. 2, p. 80

47 I.C. van der Vlies (1993). Handboek wetgeving, Zwolle: W.E.J. Tjeenk Willink, p. 163-164

48 H.D. Stout en N.J.H. Huls (1992), Reflexiviteit, autopoiese en rechtsstatelijkheid, in:. N.J.H. Huls en H.D. Stout (red.), Reflecties op neflexief recht, Zwolle: W.E.J. Tjeenk Willink. p. 227

49 R. Rogowski en T. Wilthagen (1994), Reflexive Labour Law: An Introduction, In: Rogowski. R. en Wilthagen, T. (eds), Reflexive Labour Law, Deventer/Boston: Kluwer. p. 6ff

50 G. Teubner (1983), Substantive and reflexive elements in modern law, in: Law \& Society Review. 17.p. 273 
veerd. ${ }^{51}$ Maar ook: medezeggenschap als een van de basiscriteria voor een 'adequaat zelfreguleringsproject, dat wil zeggen zelfregulering die voldoet aan de idealen van een sociale rechtsstaat. ${ }^{52}$

Los van de precieze onderbouwing van het belang van werknemersbetrokkenheid rond arbeidsomstandigheden - principieel, pragmatisch, theoretisch - kan men zich afvragen of medezeggenschap ook iets oplevert in de zin van grotere veiligheid en gezondheid. In Nederland is deze vraag niet systematisch onderzocht; dat is dan ook de reden voor dit onderzoek. Voor een eerste, voorzichtig positief antwoord op deze vraag zijn wel enige indicaties uit andere landen. Uit Britse studies blijkt dat in 'unionised' bedrijven, dat wil zeggen met een redelijke organisatiegraad én vakbondswerk op de werkvloer, de arbeidsomstandigheden beter lijken te zijn dan in 'non-unionised' bedrijven. ${ }^{53}$ Frans onderzoek wijst in dezelfde richting. ${ }^{54}$ Terwijl het verondersteld gunstige effect van zelfregulering op de veiligheid en gezondheid in de vorige paragraaf dus met de nodige scepsis is bezien, lijkt een meer welwillende opstelling met betrekking tot de bijdrage van medezeggenschap hier op zijn plaats. Sterker nog, de veronderstelling zou zelfs kunnen postvatten dat zónder medezeggenschap de experimenten met zelfregulering nog negatiever zouden zijn uitgepakt. ${ }^{55}$ Vandaar het belang van deze studie, die is geschreven vanuit de intentie om de positie van werknemers op het gebied van veiligheid en gezondheid bij de arbeid te versterken.

51 Door medezeggenschap theoretisch een bredere functic te geven dan louter behartiging van het bedrijfsbelang (zoals in de WOR 1950) of zelfs het belang van de werknemers van het bedrijf. krijgt medezeggenschap een relevantie die maatschappelijk van aard is. Het is in dit licht geen toeval dat met name ondernemingsraden de laatste jaren steeds meer maatschappelijke verantwoordelijkheden naar zich toegeschoven hebben gekregen, zoals de zorg voor het milieu of de bevordering van arbeidsdeelname van minderheden of gehandicapten (art. 28 WOR) - nog los van het feit dat ondernemingsraden hier helemaal niet op zitten te wachten. Vgl. H.A. Weening en S.M. Teulings (2001), Betrokkenheid groeit met de tijd: Veranderingen in de agenda van onderne. mingsraden. Den Haag: ministerie van Sociale Zaken en Werkgelegenheid, p. 28-43 Vgl. J. Popma (2001), Eigen bedrijf eerst? in: OR-Informatie, 19 april 2001, p. 30-31

52 Stout 1992, p. 229-230. Voor een overzicht van andere eisen van rechtsstatelijkheid vgl. Popma 1999-a, p. 167ff

53 B. Reilly, P. Paci en P. Holl (1995), Unions Safety Committees and Workplace Injuries, in: British Joumal of Industrial Relations, 22, p. 273-288; D. Walters en K. Frick (2000), Worker participation and the Management of Occupational health and Safety: Reinforcing or Conflicting Strategies, in: Frick, K et al. (eds.), Systematic Occupational Health and Safety Management, Amsterdam/Oxford: Pergamon, p. 45. Ashford en Caldart zien de 'union-setting' als één van de vijf centrale variabelen in de ontwikkeling van het arbeidsomstandighedenrecht. N. Ashford en C.C. Caldart (1991), Technology, Law and the Working Environment, New York: Van Nostrand Reinhold, p. 2

54 G. Filoche (2001), Vingt ans de comités d'hygiène et sécurité et des conditions de travail, Paris: CES, Journaux Officiels, 12 novembre 2001

55 Een gedachte die ook voeding vindt in de ervaringen in Nieuw-Zeeland, waar vergaande deregulering zónder gelijktijdige introductie van 'countervailing power' tot tamelijk treurigstemmende ontwikkelingen heeft geleid. E. Rasmussen, F. Lamm en B. Snelders (1999), New Zealand: Deregulation of Employment Relations, Occupational Health and Safety and Social Welfare in the 
Post-1984 Period, in: F, van Waarden en J. Simonis (ed.) (1999), Deregulating imperfect markets: On the role of institutions on Markets, Amsterdam: Thela Thesis, p. 104-106 Ook de beoogde versterking van de positie van safery representatives (anno 2000) in het Verenigd Koninkrijk was ingegeven door het inzicht dat het oude systeem van zelfregulering niet werkelijk van de grond kwam. D. Walters (2002), United Kingdom: From a piecemeal transposition to a third way, in: D.R. Walters (ed), Regulating Health and Safety in: Management in the European Union: A study of the Dynamics of Change, Bruxelles: P.I.E,-Peter Lang, p. $262 \mathrm{ft}$ 


\section{Arbeidsomstandighedenrecht en arbeidsverhoudingen: lineaire geschiedenis of cirkelgang}

In hoofdstuk I is aangegeven dat de zorg voor de veiligheid en gezondheid van werknemers een vraagstuk is van arbeidsverhoudingen. Ook de historische ontwikkeling van de arbowetgeving, die in dit hoofdstuk wordt geschetst, is ingebed in een systeem van arbeidsverhoudingen. Dat systeem van arbeidsverhoudingen $k a n$ in zijn meest globale vorm worden getypeerd als de min of meer bestendige relaties tussen drie partijen: werkgevers, werknemers en, zeker op het gebied van arbeidsomstandigheden, de overheid.' Die zich reproducerende relaties tussen actoren of collectieven zijn op hun beurt gestructureerd door regels, bronnen en normatieve en interpretatiekaders, die zichzelf ook weer historisch hebben ontwikkeld. Zo heeft juist de strijd voor veilige en gezonde arbeidsomstandigheden, en dan met name eind negentiende en begin twintigste eeuw, een katalytisch effect gehad in de wordingsgeschiedenis van dat systeem. ${ }^{2}$

\subsection{Methodologische voorbeschouwing en vraagstelling}

Dit hoofdstuk schetst de ontwikkeling van het arbeidsomstandighedenrecht als een verstrengelde ontwikkeling van recht en arbeidsverhoudingen. Veelal wordt een dergelijke geschiedenis geschetst als een rechte lijn: niet alleen in de zin van chronologie (wat uiteraard onbestrijdbaar is), maar ook inhoudelijk als een min of meer lineaire ontwikkeling. Ook de indeling van dit hoofdstuk lijkt zo'n rechte lijn te suggereren: 1841 -1919 (par. 2.2), 1919-1963 (par. 2.3), 1963-1980 (par. 2.4), 19801999 (par. 2.5). De wetgeving op het gebied van arbeidsomstandigheden vertoont echter geen recht-toe-recht-aan diachronie, en al helemaal geen evolutionaire ontwikkeling. Wat in de honderd jaar na de eerste arbowetgeving (1874) is opgebouwd, moet blijkens de aanhoudende roep om deregulering kennelijk weer worden ontmanteld. Zo heeft Wilthagen de vraag opgeworpen of de dereguleringsoperatie uiteindelijk niet terugleidt naar de periode waarin de regeling van veiligheid

\footnotetext{
1 W. Albeda, W.J. Dercksen en F.H. Tros (1998), Arbeidsverhoudingen in Nederland, Alphen a/d Rijn: Samsom, p. 11. Vos (1982, p. 16) typeert arbeidsverhoudingen als 'relaties', i.c. tussen werkgevers(organisaties), werknemers(organisaties) en overheid, en Reynaerts en Nagelkerke ( 1982, p. 16) zien arbeidsverhoudingen als 'processen van interacties' tussen dezelfde actoren. Vgl, P.L.M. Leisink (1989), Structurering van arbeidsverhoudingen: een vergelijkende studie van medezeg. genschap in de grafische industrie en in het streekvervoer, Van Arkel. Utrecht, p. 5-10

2 R.J.S. Schwitters (1991), De risico's van de arbeid: Het ontstaan van de Ongevallenwet in sociologisch perspectief. Groningen: Wolters-Noordhoff. p. 289
} 
en gezondheid een kwestie was van 'vrij' overleg tussen werkgever en werkneter, waarmee de ontwikkeling als een cirkelgang gekarakteriseerd zou kunnen wordn. ${ }^{3}$ Indachtig Herakleitos' woord "begin en einde van de cirkel zijn hetzelfde" (fagment B 103), zal deze vraag, zó er al gedereguleerd is, aan het eind van dit hofdstuk ontkennend worden beantwoord.

Niet alleen inhoudelijk, ook analytisch kent een lineaire benadering haar beperingen. Ten eerste verleidt een lineaire geschiedschrijving tot een evolutionaire, fuctionalistische of zelfs teleologische duiding van historische ontwikkelingn. ${ }^{4}$ Evolutionaire en functionalistische geschiedstheorieën hebben wellicht de chame dat ze een meer samenhangend verhaal opleveren dan een historiografie die hitorische ontwikkelingen op voorhand als richtingloos beziet. Zij vormen echter en belemmering voor de onbevangen interpretatie van processen op empirisch niveu. ${ }^{5}$ Ten tweede rust een lineaire geschiedenis al te zwaar op een sequentiële invuling van causaliteit: wat is, moet uit de daarvoor liggende diachronie worden verklard. Historisch specifieke instituties ontstaan echter ook en vooral vanuit de synchroie. de structurele context van het moment zélf. ${ }^{6}$ Hierbij dient gedacht te worden aarde economische en technologische context, maar ook de sociale, culturele en polieke inbedding. ${ }^{7}$

Daarnaast dient te geschiedschrijving zich rekenschap te geven van de vaak tegngestelde individuele of collectieve belangen, van de anti-thetische krachten die ahter het ontstaan van historisch specifieke maatschappelijke constellaties schuilgan (maar soms utieraard ook manifest zijn). $0^{\circ}$ De geschiedenis dient zo te worden bezien "daß das Endresultat stets aus den Konflikten vieler Einzelwillen hervorgeht, wovon jeder wieder durch eine Menge besonderer Lebensbedingungen zu dem gemacht wird, was er ist: es sind also unzählige einander durchkreuzende Kräfte, eine unendliche Gruppe von Kräfteparallelogrammen, daraus eine Resultante - das geschichtliche Ergebnis - hervorgeht." ${ }^{.9}$ Ook de geschiedenis van de arbowetgeving zal hier worden beschreven als de resultante van principieel instabiele krachtsverhoudingen, waarbij de balans nu eens ten gunste van de werkgevers en dan weer van de arbeiders uitslaat.

3 T. Wilthagen (1997), Occupational safety and health policies in the Netherlands: Coming full circle?. Paper presented at the international conference on Institutions, Markets and (economic) Performance: Deregulation and its consequences, Utrecht

4 Teleologie is de leer dat de geschiedenis gericht is op een immanent of transcendent einddoel

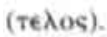

5 P. Veyne (1979), Comment on écrit l'histoire, Paris: Editions de Seuil, p. 233

6 Ibid. p. $203 \mathrm{ff}$

7 A.G. Nagelkerke en A.C.J.M. Wilthagen (2002), De arbeidsverhoudingen aan het begin van de $21^{\text {ste }}$ eeuw. Op weg naar een institutioneel mozaiek, in: A.G. Nagelkerke en A.C.J.M. Wilthagen (red.). Arbeidsverhoudingen in ontwikkeling, Deventer: Kluwer, p. 7-11

8 Veyne 1979, loc, cit. De term 'ontstaan' speelt een belangrijke rol in het werk van de franse historicus Michel Foucault, en refereert aan de betekenis van strijd die achter historische fenomenen schuil gaat. "De analyse van de Entstehung moet het spel van krachten laten zien, hun gevecht tegen elkaar, hun strijd tegen ongunstige omstandigheden". M. Foucault (1981), Nietzsche, de genealogie, de geschiedschrijving. in: M. Foucalt/G. Deleuze (1981), Nietzsche als genealoog en nomade. Nijmegen: SUN. p. 20

9 F. Engels (1890), Brief an J. Bloch, 21.9.1890, MEW Band 37, p. 464 


\section{Structuratietheorie}

Dat de krachtsverhoudingen principieel instabiel zijn en er geen inherent doel (telos) ten grondslag ligt aan historische ontwikkelingen, impliceert echter níet dat geschiedschrijving louter descriptief kan zijn of gespeend blijft van samenhang. Er zijn wel degelijk regelmatigheden of patronen te ontwaren, zij het binnen een begrensde tijd/ruimte - wat Giddens noemt episodes: "a number of acts having a specifiable beginning and end." ${ }^{.10}$ In sociologische termen gaat het bij een historische schets dus om de analyse van (tijdelijk min of meer stabiele) sociale systemen door middel van de identificatie van de factoren die die systemen constitueren én ze hun tijdelijke stabiliteit verlenen.

Die stabiliteit ontstaat, aldus Giddens, door het principe van recursiviteit. Dit concept verwijst naar de term recursio, ofwel terugloop. Wil (maatschappelijk of taal-)handelen mogelijk zijn, dan is een gedeeld kader van regels en interpretaties vereist. Maatschappelijke verhoudingen kunnen slechts bestaan bij de gratie van impliciet of expliciet erkende regels. Omgekeerd geeft het herhaald gebruik van die regels weer stabiliteit aan de gedeelde regels en interpretatiekaders. Wat bijvoorbeeld geldt als een betekenisvolle zin, is afhankelijk van gedeelde grammaticale regels. Het herhaald gebruik van als 'grammaticaal juist' te kenmerken zinnen bestendigt op zijn beurt de 'autoriteit' van de onderliggende grammaticale structuur ten overstaan van de leden van de taalgemeenschap. Ook voor niet-talige handelingen geldt dat individuele actoren putten uit gedeelde regels en overige handelingsvoorwaarden (i.c. bronnen), en door hun handelen die regels en handelingsvoorwaarden reproduceren: "agents also reproduce the conditions that make [..] action possible." "1

Door het gebruik van regels en bronnen ontstaat recursie of 'feed-back', en door herhaalde feed-back krijgt een bepaald kader een min of meer vaste structuur, in de betekenis die Giddens hieraan geeft: "rules and resources recursively implicated in social reproduction; institutionalized features of social systems have structural properties in the sense that relationships are stabilized across time and space." 12 Bij regels valt, in het kader van dit onderzoek, uiteraard vooral te denken aan rechtsregels, maar Giddens wijst ook op het belang van interpretatieve kaders. ${ }^{13}$ Bij bronnen kan worden gedacht aan materiële bronnen, maar ook aan kennis, prestatie-

10 A. Giddens (1984), The constitution of society, Cambridge: Polity Press, p. 244

11 Giddens 1984, p. 26. Vgl. Leisink 1989, p. 31: "De regels en hulpbronnen geven structuur aan het individuele handelen. Tegelijkertijd reproduceert de actor door zijn handelen de regels en hulpbronnen als structurele eigenschappen van het sociale systeem." Giddens definieert bronnen dan ook als "structured properties of social systems, drawn upon and reproduced by knowledgeable agents in the course of interaction". Giddens 1984, p. 15

12 Giddens 1984, p. xxxi

13 Giddens 1984, p. 29ff. Daarnaast wijst Giddens nog op het normatieve element in regelgeleid handelen, en wel vanuit het concept van sancties (p. 30). Dit lijkt me echter minder fundamenteel en ook minder onderbouwd dan de andere drie structurele componenten, zodat ik het normatieve kader vooralsnog buiten beschouwing laat 
kwalificaties, sociale relaties, vormen van samenwerking, geweld, prestige en dergelijke. $^{14}$

Schema 2.1.1. Recursie als reproductie van handelingsstructuur

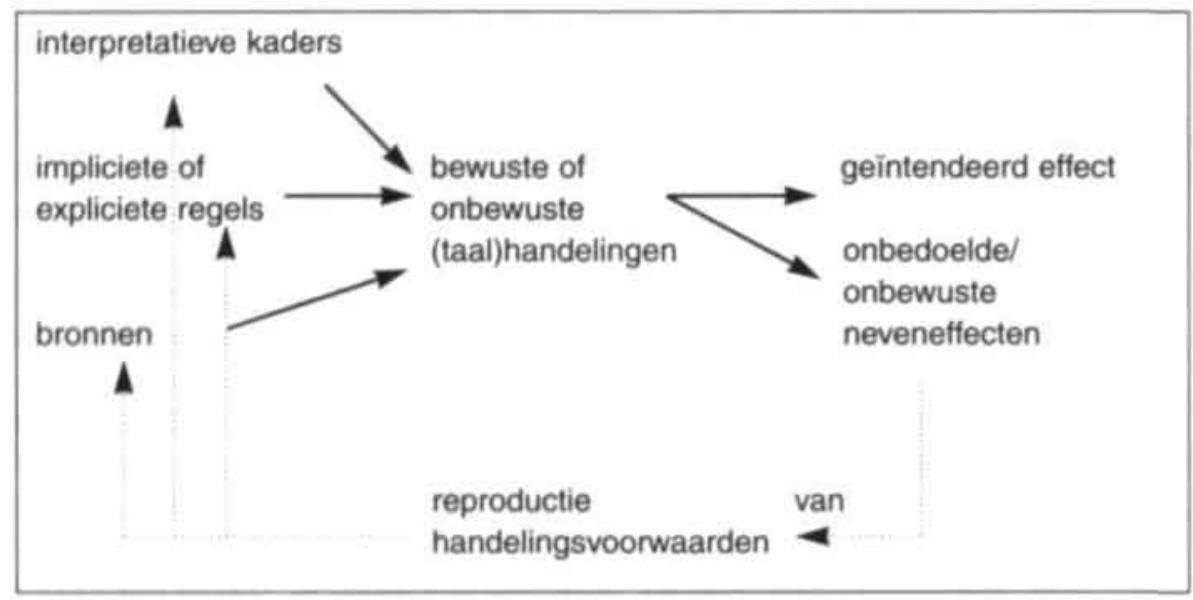

\section{Arbeidsomstandigheden en arbeidsverhoudingen}

De arbeidsverhoudingen in Nederland, om naar het thema van dit hoofdstuk terug te keren, zijn op te vatten als een systeem, in de zin van zich reproducerende relaties tussen actoren of collectieven ${ }^{15}$ : relaties die zijn gestructureerd door regels en bronnen, die op hun beurt weer worden gereproduceerd door het herhaald beroep dat op die regels en bronnen wordt gedaan in dagelijkse praktijken. Hetzelfde geldt

14 Voor een zeer uitgebreide index van diverse bronnen in diverse domeinen, vgl.V.M. Bader en A. Benschop (1988), Ongelijkheden: pro-theorie van sociale ongelijkheid en collectief handelen, Wolters-Noordhoff: Groningen, p. 129ff, in het bijzonder p. 138-140. Hierbij dient opgemerkt dat de bronnen waarover actoren (kunnen) beschikken mede bepalen welke interpretatie van regels geldend gemaakt kan worden door de actoren in een interactie-situatie (Leisink 1989, p. 33-34. Dit machtsaspect van 'taalspelen' is zeer pregnant uitgewerkt in J.F. Lyotard (1983), Le differend, Paris: Minuit. Omgekeend worden bronnen 'gefocused' door normatieve- en interpretatiekaders. (Giddens 1984, p. 15) Kennis én normatieve uitgangspunten (waaronder legitimerende verhalen) zijn essentièle elementen in situatiedefinities en daarmee van invloed op handelingsmogelijkheden en feitelijk handelen. (Bader en Benschop, op. cit., p. 73). Het is op dit punt overigens van belang elke vorm van transcendentie van systemen of instituties af te wijzen. Weliswaar is het niet zo dat individuele actoren systemen maken, maar zij reproduceren én transformeren die systemen "in the continuity of praxis". Systemen zijn geen transcendente entiteiten met cen eigen leven, zij hebben nooit een zelfstandig bestaan, zij zijn de immanent gegroeide kristallisaties van concrete praktijken. (Veyne 1979, p. 237) Ook Giddens stelt: "To say that structure is a 'virtual order' of transformative relations means that social systems, as reproduced social practices, do not have 'structures' but rather exhibit 'structural properties' and that structure exists [..] only in its instantiations in such practices" (Giddens 1984, p. 17)

15 Giddens 1984, p. 25 
uiteraard voor het overleg over veiligheid en gezondheid. Dit overleg wordt in belangrijke mate ingekaderd door wettelijke regels, met name de Wet op de ondernemingsraden en de Arbowet (voor een uitgebreide behandeling zie hoofdstuk 3 ). Daarnaast kunnen werkgevers en werknemersvertegenwoordigers putten uit diverse bronnen, en delen zij tot op zekere hoogte de normatieve- of interpretatiekaders (wat beschouwen beiden als aanvaardbare risico's, en vanuit welke impliciete waarden komt die aanvaarding tot stand?). Door het regelmatig overleg verkrijgen de gedeelde regels voor dat overleg op hun beurt legitimiteit - tenzij op grote schaal blijkt dat partijen de regels aan hun laars lappen of als ontoereikend of juist verstikkend ervaren. In die gevallen zal druk ontstaan om de regels aan te scherpen of anderszins te wijzigen.

Hierbij ontstaat een nieuwe laag in het simpele structuratie-theoretische schema 2.1.1. De recursieve kringloop bestaat weliswaar op het bedrijfsniveau (in het overleg bestuurder/OR, maar zeker wat arboregels betreft ook in de interactie tussen individuele werkgever en werknemer), maar de ontwikkeling van die regels vindt vooral plaats op hogere niveaus. Hierbij kunnen drie niveaus worden onderscheiden, waarbij op elk niveau het proces van regelgeving is ingebed in systemen van arbeidsverhoudingen, waartussen ook weer verbindingen ontstaan. Zo is in toenemende mate sprake van regelgeving op internationaal niveau (in het bijzonder vanuit de Europese Unie), die mede wordt beìnvloed door de sociale partners, in casu de werkgeversorganisatie Unice en het Europees Verbond van Vakverenigingen. ${ }^{16}$ Op landelijk niveau legt de wetgever nieuwe arboregels ter advisering voor aan de Sociaal-Economische Raad. ${ }^{17}$ Ten slotte is in bescheiden mate sprake van decentralisatie van arboregelgeving naar CAO's en in convenanten. Hierbij zijn uiteraard de vakbonden en de werkgeversorganisaties betrokken, maar bij de convenanten ook het ministerie van Sociale Zaken en Werkgelegenheid. Tussen de diverse niveaus is geregeld contact, waarbij signalen uit de praktijk via vakbonden en werkgeversorganisatie uiteindelijk in het traject van wetgeving terecht zullen komen.

Een andere tekortkoming in schema 2.1.1 is dat de systemen bestuurder/OR en werkgevers/vakbonden (om ons hiertoe te beperken) niet alleen gestructureerd zijn door regels, bronnen, en interpretatiekaders, maar ook ingebed zijn in een (relevante) omgeving. Het systeem 'onderneming' wordt beïnvloed door allerhande externe factoren zoals economische en technologische ontwikkelingen, bedrijfs-

16 H.G. de Gier en C. Vos (1995), Eumpese en Nederlandse arboregelgeving, Lemma: Utrecht, p. 61ff. Een ontwikkeling van toenemend belang is de uitwerking van Europese richtlijnen door middel van normalisatie. In het Comité Européen de Normalisation worden concrete normen uitgewerkt, die ook effect kunnen hebben op de arbeidsomstandigheden. Dit normalisatieproces wordt in hoge mate gedomineerd door vertegenwoordigers uit de industrie. De werknemers zijn vertegenwoordigd door het Technisch Bureau voor Veiligheid en Gezondheid van het EVV, maar die vertegenwoordigers hebben géén stemrecht

17 Zoals al vermeld in hoofdstuk 1 heeft de SER (in casu zijn commissie arbeidsomstandigheden en, in de periode 1983-1994, de Arboraad) sinds zijn oprichting in 1950 bijna 120 adviezen doen uitgaan, waarvan méér dan 100 in de laatste 20 jaar 


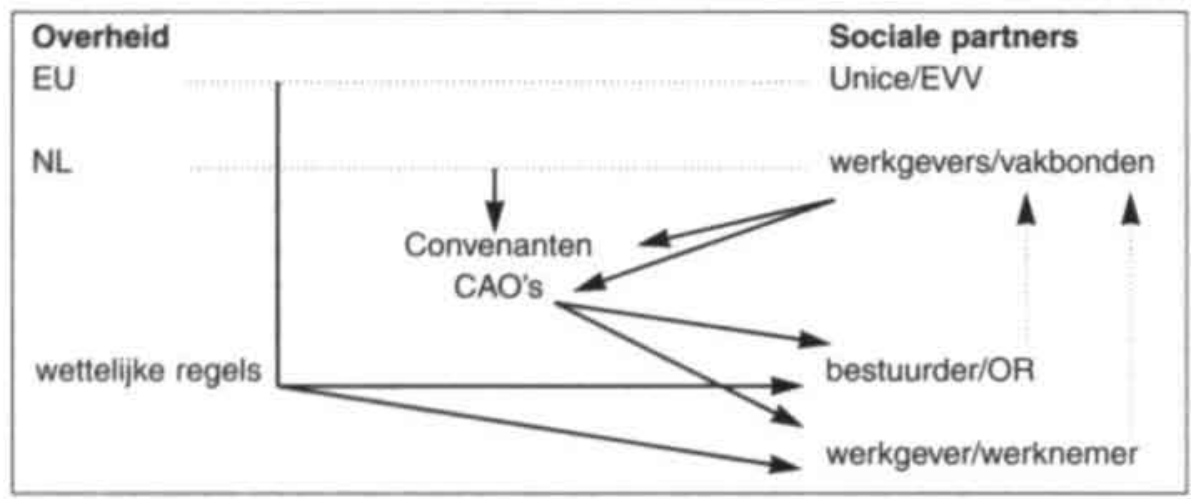

kundige inzichten, en demografische, sociale en culturele trends. ${ }^{18}$ Ook aspecten zoals ondernemingsdoel(en), strategie, bedrijfsstructuur en bedrijfscultuur dienen bij een volledige analyse van het arbeidsomstandighedenbeleid in ogenschouw genomen te worden. ${ }^{19}$ Hierbij kan, wellicht ten overvloede, worden opgemerkt dat 'doelen' en 'strategie' zelf ook geen eenheid zijn, maar de uitkomst van krachtenverhoudingen en belangenstrijd binnen het bedrijf (zowel binnen de bedrijfstop als tussen bestuurder/OR). Op de institutioneel hogere niveaus spelen deels dezelfde factoren (ook werkgeversorganisaties en bonden zullen zich rekenschap geven van bijvoorbeeld technologische ontwikkelingen), maar deels ook andere. ${ }^{20}$ Terwijl het niveau van de onderneming bijvoorbeeld wordt beïnvloed door bedrijfskundige inzichten, wordt het optreden van de overheid meer ingegeven door bestuurskundige inzichten. Verder zullen normatieve overwegingen eerder doorklinken op institutioneel niveau dan op het niveau van de alledaagse praktijk, waar wellicht de strategische overwegingen weer zwaarder zullen wegen.

18 Voor een uitgebreid overzicht voor relevante omgevingsfactoren op het gebied van arbeidsomstandigheden zie F, van Waarden, J, den Hertog, H. Vinke en T. Wilthagen (1997), Prospects for safe and sound jobs: the impact of future trends on costs and benefits of occupational health and safety. Den Haag: Vuga, p. 19-64

19 Vgl. G.L.J.M. Zwetsloot en P.P.M. Sprengers (1992), Op zoek naar synergie: Het combineren van arbo-, milieu- en kwaliteitszorg door koploperbedrijven, Den Haag: Ministerie van Sociale Zaken en Werkgelegenheid, p. 10

20 In het algemeen kan worden gesteld dat het relatieve gewicht van omgevingsfactoren varieert naar gelang het analyseniveau. Voor veel bedrijven zal de internationale concurrentiepositie wellicht minder belangrijk zijn, maar voor het overleg op landelijk niveau kan het cen strategische factor zijn voor werkgevers. Als gevolg van de internationalisering van het bedrijfsleven veranderen de machtsverhoudingen tussen werknemers en werkgever, met name onder de dreiging van regime shopping: "favouring countries which impose few restrictions on employers' freedom of action and avoiding those which maintain a regulatory framework supportive of employee rights and conditions", R. Hyman (1998), Industrial Relations in Europe: Crisis or Reconstruction?, in: A.C J.M. Wilthagen (ed.), Advancing Theory in Labour Law and Industrial Relations in a Global Contex, Amsterdam/New York/Oxford/Tokio, North-Holland, p. 186 
Al met al ontstaat een recursieve 'loop' die is weergegeven in schema 2.1.3

Schema 2.1.3. Het systeem van arbeidsverhoudingen in bredere context.

$\begin{aligned} & \text { Normativiteit/ } \\ & \text { Legitimering } \\ & \text { Mensbeeld, waarden } \\ & \text { (Politieke) ideologie } \\ & \text { legitimerende verhalen }\end{aligned}$
$\begin{aligned} & \text { Sturingsconcepties } \\ & \text { Bestuurskundige } \\ & \text { inzichten } \\ & \text { politieke omgeving }\end{aligned}$

Uiteraard zijn de relaties ook onderling complex verweven. Technologische innovaties kunnen invloed uitoefenen op organisatievormen en tot nieuwe arbeidsrisico's leiden. Aan de andere kant komt technologische ontwikkeling niet als autonoom domein tot ontwikkeling, maar wordt zij deels of zelfs goeddeels aangejaagd door economische belangen, worden technologieën ontwikkeld met het oog op een bepaalde productiestructuur, en ontwikkelen zij zich binnen bepaalde arbeidsverhoudingen. Bovendien werken de omgevingsfactoren nooit rechtstreeks in op de partijen, maar worden zij geünterpreteerd door de actoren én kunnen zij door de actoren worden beïnvloed: "De aanpassing aan contingenties is niet een 
automatisme, zoals bij zelfregulerende systemen, maar wordt bemiddeld door het handelen van het top-management dat strategische keuzes maakt."2l

Wijziging in een van de genoemde elementen werkt zeker door in andere domeinen. Het schema laat een veelheid aan mogelijke wederzijdse relaties zien:

- de invloed van de diverse structurerende factoren op het handelen van partijen (en dat op diverse niveaus) en omgekeerd de reproductie en transformatie van die structuren door bewust of onbewust handelen van de actoren;

- de invloed van externe factoren op de handelingsvoorwaarden (bijvoorbeeld van de economische ontwikkeling op het normatieve kader en de politieke legitimiteit);

- de invloed van externe factoren op de opstelling van actoren, maar omgekeerd ook de pogingen van de actoren om sturing te geven aan de omgeving 22 ;

- enzovoort.

Een volgend punt van aandacht is dat werkgever en werknemer lijken te worden gepresenteerd als subjectieve identiteiten. Die identiteit is echter versplinterd. Zeker de collectieve actoren kenmerken zich - ook bij eventuele uiterlijke eensgezindheid - door een veelheid van doelstellingen, belangen en verlangens. De adviezen van geìnstitutionaliseerde overlegorganen (Stichting van de Arbeid, SER) zijn, soms openlijk en soms meer verhuld in de vorm van vage compromissen, de neerslag van soms parallelle maar veelal ook strijdige belangen. Dat de overheid een eenheid zou zijn, ten slotte, is al decennia lang achterhaald door de beleidssociologie. Rond het thema arbeidsomstandigheden staan de departementen van Sociale Zaken en Werkgelegenheid enerzijds en Economische Zaken anderzijds niet zelden tegenover elkaar, terwijl uiteraard de wetgever zélf een constellatie is van diverse politieke partijen met verschillende inzichten en opvattingen.

Vraagstelling, analyseniveau, inperking van het onderzoeksveld

Het 'systeem arbeidsverhoudingen' is dus buitengewoon complex. Om tot een overzichtelijke en zinvolle afbakening te komen, zullen binnen het schema dan ook beredeneerde keuzes moeten worden gemaakt ten aanzien van de vraagstelling, het niveau van analyse, het relatieve gewicht van de onderscheiden structurerende elementen, en de invloed van de omgevingsfactoren.

\footnotetext{
21 Leisink 1989, p. 78

$22 \mathrm{Vgl}$. bijvoorbeeld de activiteiten van het FNV Steunpunt Technologie dat, eind jaren " 80 . beoogde technologische ontwikkelingen te beïnvloeden met het oog op onder meer humanisering van de arbeid en betere arbeidsomstandigheden, en wel door 'vormgeving vooraf'. A.A.F. Brouwers, F. Vaas, en F.D. Pot (1987), Sociaal Imventief Automatiseren: integratie van arbeid en techniek in de onnwerpfase, Amsterdam: FNV Steunpunt Technologie, p. 9-12. Overigens werden dergelijke pogingen tot vakbondsinterventie in de Scandinavische landen al sinds de jaren ' 70 met succes ondernomen. P. Ehn en M. Kyng (1991), De 'Collective Resource Approach': Een Scandinavische werknemersaanpak van systeemontwerp. in: M. van Klaveren en S. Kooistra (1991), Sociaal Ontwerpen: Werknemers beinvloeden vormgeving en organisatie van hun werk, Utrecht: Jan Van Arkel, p. 13-29
} 
Zoals al eerder is aangegeven, gaat het in dit hoofdstuk om een verstrengelde ontwikkeling van arbeidsomstandighedenrecht en arbeidsverhoudingen. Uiteengerafeld betekent dit in eerste aanleg een dubbele vraagstelling:

1. Uit welke regels, bronnen en interpretatiekaders putten actoren tijdens hun overleg en hun handelen op het gebied van arbeidsomstandigheden? en

2. Hoe heeft die structuur van regels, bronnen en interpretatiekaders zich in de loop der tijd ontwikkeld?

De behandeling van de eerste vraag zal worden uitgesteld tot de volgende hoofdstukken, met name hoofdstuk 3 en 4 . In hoofdstuk 3 wordt geschetst welke regels en bronnen de werknemers tot hun beschikking hebben. Het gaat daarbij dan overigens vrijwel uitsluitend om het niveau van de onderneming (OR/bestuurder), en met een zwaar accent op de formele regels (Arbowet en Wet op de ondernemingsraden). In hoofdstuk $4 \mathrm{zal}$ worden aangegeven in hoeverre de ondernemingsraden daadwerkelijk gebruik maken van de regels en bronnen. In het vervolg van dit hoofdstuk staat vooral de tweede vraag, die naar de historische ontwikkeling van de arbowetgeving, centraal. Subvragen zijn:

- Wat is de invloed van de betrokken partijen, en welke belangen of doelstellingen hebben zij op het gebied van veiligheid en gezondheid bij de arbeid?

- Wie heeft welke bronnen gemobiliseerd ${ }^{23}$, welke regels en interpretatiekaders aangeroepen, en met welk effect? wie bepaalt welke middelen valide zijn binnen een gegeven context, en waarom kan de dominante partij dat op die wijze bepalen?

- Wat is de invloed van de omgevingsfactoren?

- Waar komt de balans in de verhoudingen op uit (in casu: welke regels komen tot stand, en waarom juist in die bepaalde redactie)?

Daarmee verstrengeld kan hier vanuit structuratietheoretisch perspectief nog een derde vraag aan toegevoegd worden, die overigens met het oog op deze studie van secundair belang is:

3. Welke effecten heeft de ontwikkeling van de wetgeving op het gebied van veiligheid en gezondheid gehad op de ontwikkeling van de arbeidsverhoudingen in Nederland?

Als subvragen kunnen gelden:

- Hoe heeft het overleg over veiligheid en gezondheid de posities binnen het systeem van arbeidsverhoudingen veranderd (interdependenties)?

- Welke effecten hebben de regels op het gebied van arbeidsomstandigheden en medezeggenschap voor de relatieve posities (asymmetrieën) van werknemers en werkgevers?

- Hoe heeft de identiteit/subjectiviteit van de arbeiders in Nederland zich ontwikkeld als afgeleide van de strijd voor veiligheid en gezondheid?

23 "De actuele onderhandelingsmacht wordt door de beschikkingsmacht over directe en indirecte bronnen globaal gestructureerd - zij wordt tevens beinvloed door de kansen om deze bronnen te mobiliseren en te gebruiken. door strategische competenties en strategisch falen en door een groot aantal externe handelingskansen." Bader/ Benschop 1988, p. 176 
Het analytisch niveau is, in het kader van dit hoofdstuk althans, primair dat vanhet landelijke institutioneel overleg. Dit heeft vooral te maken met de vanouds cenralistische inslag van het Nederlandse systeem van arbeidsverhoudingen. ${ }^{24}$ Aan de andere kant zijn de onderscheiden niveaus zoals gezegd wel met elkaar verbonien (zo zullen de vakbondsvertegenwoordigers geïnformeerd worden door contacien met OR- of kaderleden of rechtstreeks door werknemers ${ }^{25}$ ) en zullen er wel dejelijk impulsen uitgaan van het ondernemingsniveau tot verandering van arbeidsierhoudingen. Een probleem hierbij was echter dat er nauwelijks historische literatiur voorhanden is die de ontwikkeling van arbeidsrisico's en de maatregelen op bedrijfs(tak)niveau behandelt. In het kader van deze studie zou een eigen historich onderzoek op dat niveau, hoe wenselijk ook, te ver voeren. ${ }^{26}$

Wat betreft het relatieve gewicht van de onderscheiden structurerende elementel regels, bronnen, betekenisverlening en legitimering - valt niet op voorhand te beargumenteren waarom het accent op één der elementen gelegd zou moeten worden. Uiteraard weegt mobilisatie van (machts)bronnen door vooral de vakbonien zwaar $^{27}$, maar voor met name de christelijke organisaties van werknemers en wekgevers spelen ook diepgewortelde interpretatiekaders een rol. Door de overheid, op haar beurt, worden legitimerende verhalen ingebracht als rationalisering voor de eigen positie in het systeem van arbeidsverhoudingen. De regels op het gebied an arbeidsomstandigheden, ten slotte, zijn wellicht minder van belang bij de strucuratie van de verhoudingen op institutioneel niveau. De regels rond medezegg $\mathbf{n}$ -

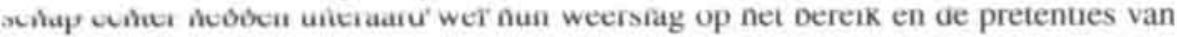
het centraal overleg.

De inperking van het aantal relevante omgevingsfactoren wordt gestuurd door het dominante niveau van analyse. Aangezien in dit hoofdstuk het individuele - en het ondernemingsniveau minder prominent behandeld worden, zal ook nauwelijks of geen aandacht worden besteed aan specifieke elementen uit de omgeving van dat systeemniveau (i.c. ondernemingsdoelen, strategie en bedrijfscultuur). De ontwikkeling van het bedrijfskundige denken komt wél aan de orde, omdat nieuwe concepten van bijvoorbeeld participatief management het denken over de betrokken-

24 Albeda/Dercksen/Tros 1998, p. 72; Reynaerts/Nagelkerke 1982, p. 110

25 Bijvoorbeeld door enquêtes onder ondernemingsraden. zoals bij de voorbereiding van de zogeheten Arbosterrengids van de FNV, J. Hooiveld, (1996), Arbosterrengids; Handleiding voor beoordeling medezeggenschap en arbodienst, Amsterdam: FNV Centrum Ondernemingsraden: J. Hooiveld en G. Kuiperij (1999). Arboprof: Arbosterrengids 2000, Amsterdam/Zeist: FNV/Kerckebosch

26 Voor een interessante historische studie naar het veiligheidsbeleid in de britse katoenindustrie vgl. A. McIvor (1997), State Intervention and Work Intensification. The Politics of occupational Health and Safety in the Britisch Cotton Industry, c. 1880-1914, in: A. Knotter. B. Altena en D. Damsma (eds.), Labour, social policy and the welfare state, Amsterdam: IISG

27 Van Peijpe richt zich in zijn onderzoek naar de ontwikkeling van het loonvormingsrecht sterk op het gebruik van machtsbronnen. Hij identificeert in zijn studie zeven typen machtsbronnen: economische, juridische. politieke en ideologische macht, informatie, kennis en bekwaamheden. organisatic en geweldsmiddelen. T. van Peijpe (1985), De ontwikkeling van het loomormingsrechr, Nijmegen: Ars Aequi Libri, p. 51-56 
heid van werknemers bij het bedrijfsbeleid wel degelijk mede beìnvloeden. Daarnaast is er ook rechtstreeks een tamelijk duidelijke link te leggen tussen bedrijfskundige inzichten en de regulering van arbeidsomstandigheden. ${ }^{28}$

Afbakening van het onderzoeksveld, in de zin van inperking van de complexiteit, is dus maar zeer ten dele mogelijk. Een deel van de vraagstelling is verwezen naar een ander chapiter, en ook de analytische niveaus zijn grosso modo opgesplitst en verdeeld over hoofdstukken, maar het aantal structurerende elementen en omgevingsfactoren is nauwelijks te reduceren zonder verlies van relevante informatie. Als dan ook nog een historische dimensie binnen het systeem wordt geintroduceerd, dus naast de synchrone ook een diachrone as, dreigt de complexiteit te groot te worden. Het concept van de min of meer gesloten episodes komt hieraan ten dele tegemoet, zeker in de presentatie van de bevindingen. Om de presentatie te versterken, is een indeling gemaakt in vier perioden: vuur (1841-1919), water (1919-1963), aarde (1963-1980) en lucht (1980-1999). Deze metaforische aanpak, geïnspireerd door de presokratische natuurfilosofie, is een instrument om een veelheid aan verspreid materiaal te ordenen en overzichtelijk te presenteren. De metafoor perst de 'werkelijkheid' in het gareel. Metaforiek kan daarnaast een werkelijkheid-ontsluitend effect hebben (tenzij men, dat dient gezegd, de metaforen niet verheft tot reèle entiteiten).

Als richtsnoer kan hierbij gelden Herakleitos' woord (fragment B 30):

\begin{abstract}
"Deze wereldorde heeft noch één der Goden noch één der mensen tot stand gebracht, maar zij was altijd en is en zal zijn: eeuwig-levend vuur, opflakkerend naar maten en uitdovend naar maten."
\end{abstract}

Dit fragment herinnert ten eerste nog eens aan de eerdere stelling dat de arbeidsverhoudingen in Nederland mede hun wortels vinden in het revolutionaire vuur eind negentiende eeuw, in de strijd voor menswaardige arbeid. Ten tweede wordt uit de dominante interpretatie van fragment B 30 een ontwikkeling gedestilleerd die mijns inziens ook van toepassing is op de geschiedenis die hieronder wordt geschetst. Het vuur, bron van alle leven, condenseert allengs tot water en zelfs aarde, en verliest mét die verdichting zijn levenskracht. ${ }^{29}$ In dit hoofdstuk wordt een ontwikkeling geschetst die in hoofdlijnen neerkomt op een steeds verder gaande verdichting ( wetgever sinds begin jaren ' 80 als 'verstikkend' wordt gekenschetst (een opvatting die door de werknemers overigens niet gedeeld werd). Ook de ontwikkeling van de

28 K.T. Nielsen (2000), Organizational theories implicit in various approaches to OHS Management, in: K. Frick et al. (eds.), Systematic Occupational Health and Safety Management, Amsterdam/Oxford: Pergamon, p. 99-123

29 "De ontwikkeling van het vuur verloopt in een verdichting (muкvwors)". F. Sassen (1974), Geschiedenis van de wijsbegeente der Grieken en Romeinen, Amsterdam: Meulenhoff, p. 18. In één fragment slechts, i.c. B 76, spreekt Herakleitos over lucht. Dit fragment wordt echter als apocrief beschouwd, en de exegese laat dit fragment bij mijn weten vrijwel volledig buiten beschouwing 
arbeidsverhoudingen in Nederland valt goed te typeren aan de hand van de periodisering vuur-water-aarde-lucht. De periode 1841-1919 zal, in paragraaf 2.2, worden geduid als een tijdperk van opflakkerend revolutionair vuur, van strijd voor de verbetering van de positie van de arbeiders - een strijd die ook een belangrijke rol heeft gespeeld in het ontstaan van het huidige stelsel van arbeidsverhoudingen. In paragraaf $2.3 \mathrm{zal}$ de episode 1919-1963 worden gekenschetst als een tijd van voortkabbelend overleg. In de periode 1963-1980, die wordt belicht in paragraaf 2.4, zijn de institutionele arbeidsverhoudingen volledig uitgekristalliseerd - maar volgens critici versteend. Vooral de werkgevers willen meer lucht: zij dringen aan op een kentering in de regelgeving (waaronder de Arbowet). Deze kentering wordt beschreven in paragraaf 2.5 .

\subsection{Vuur (1850-1919)}

Strijd is de vader van alles, de koning van alles. Dezen betoont hij als Goden, de anderen als mensen - dezen laat hij slaven worden, de anderen vrijen.

\section{Herakleitos, Fragment B 53}

De wetgeving op het gebied van veiligheid en gezondheid in verband met de arbeid kent een lange geschiedenis. Deze hangt nauw samen met de ontwikkeling van de industrie in de laatste decennia van de achttiende eeuw, de wrange gevolgen daarvan voor de arbeiders en de macht van het proletariaat om beschermende regelgeving af te dwingen.

De vroegste wetgeving dateert uit het begin van de negentiende eeuw, in casu in Engeland (1802). Ook in andere Europese landen wordt de eerste beschermende wetgeving al vóór 1850 geïntroduceerd: in Duitsland in 1839, in Frankrijk in $1842 .{ }^{30}$ In België kondigt Leopold 1 in 1842 wetgeving tegen de kinderarbeid aan, al zal daadwerkelijke effectuering van dat voornemen nog lange tijd op zich laten wachten. ${ }^{31}$ In Nederland voelt de overheid zich echter niet geroepen tot enige wetgevende activiteit. Pas in het laatste kwart van de negentiende eeuw wordt een voorzichtig begin gemaakt met sociale wetgeving - in eerste aanleg middels het zogeheten Kinderwetje van Van Houten uit 1874.

De relatief late ontwikkeling van de wetgeving in Nederland kan worden toegeschreven aan een aantal factoren. Onbekendheid met de erbarmelijke toestand van de arbeiders kan overigens niet als verklaring gelden. Die was immers al in 1841 in kaart gebracht middels een ministeriële enquête naar de omstandigheden van de

30 J.K.M. Gevers (1982), Zeggenschap van werknemers inzake gezondheid en veiligheid in bedrijven. De rechtsontwikkeling in de lidstaten van de Eumopese Gemeenschap. Deventer: Kluwer, p, 29-31

31 G. Delvaux et al. (1987), Hondend jaar sociaal recht in België, Brussel: Ministerie voor Tewerkstelling en Arbeid etc... p. 17 
arbeidende klasse (in het bijzonder naar de wijdverbreide kinderarbeid). ${ }^{32}$ En verklaring is wel de normatieve dominantie van het economisch liberalisme en het individualistisch mensbeeld: de Staat diende zich te onthouden van inmenging in de 'vrije arbeidsrelatie' tussen patroon en arbeider, en eventuele ongevallen werden de individuele slachtoffers zelf aangerekend als een 'persoonlijk tekort'. ${ }^{33}$ Dit is op zichzelf echter nog geen verklaring voor de late ontwikkeling van de wetgeving juist in Nederland. Ook in andere landen, en zeker in Engeland, was het liberalisme immers zeer dominant.

Een meer steekhoudende verklaring is de late ontwikkeling van de Nederlandse industrie. ${ }^{34}$ Niet dat de arbeidsomstandigheden in de industrièle bedrijven slechter waren dan die in de vroegere manufacturen of bij de arbeid op het land, waardoor nu toch eindelijk wetgeving gepast zou zijn. Waarschijnlijk waren de omstandigheden in de manufacturen en op het land zelfs nog slechter dan in de negentiende-eeuwse fabrieken en werkplaatsen. ${ }^{35}$ De opkomst van de industrie leidde echter tot een toenemende behoefte aan beter geschoolde arbeiders. ${ }^{36}$ Die behoefte was ook een belangrijke motor achter de toegenomen aandacht voor onderwijs, wat tevens een impuls vormde bij het bestrijden van de kinderarbeid. ${ }^{37}$ Diverse werkgevers in met name Twente pleitten voor 'half-time' werk voor kinderen, opdat zij in de 'vrije tijd' behoorlijk geschoold zouden kunnen worden. ${ }^{38}$ Het liberale Kamerlid Van Houten. de geestelijk vader van het zogeheten Kinderwetje uit 1874, maakte geen geheim van de economische motieven achter zijn wetsvoorstel: "Niet eene enkele misdaad ten aanzien van kinderen gepleegd beweegt mij hier, maar de overtuiging dat de kinderarbeid den oekonomische toestand van de maatschappij desorganiseert."39

32 J, van Drongelen (1990), De ontwikkeling van de Arbeidsinspectie in een veranderende wetgeving, Maastricht: Universiteit Maastricht (diss.), p. 17, Ook internationaal waren de omstandig. heden van het plebs al in kaart gebracht. Klassiek is F. Engels (1845), Die Lage der arbeitenden Klasse in England: nach eigner Anschauming und authentischen Quellen, MEW 2, 325-506 Ook verlichte industrièlen zoals de Leidse textielondernemer Le Poole of de medicus Coronel hadden at in 1859 resp. 1863 aangedrongen op wettelijke maatregelen ter bescherming van met name kind-arbeiders. Vgl. A.J.C.M. Geers (1988), Recht en humanisering van de arbeid, Deventer: Kluwer, p. 27

33 Schwitters 1991, p. 77ff

34 C.P.M. Romme (1939), Vijfig jaar Arbeidswet 1889-1939, Haarlem: H.D. Tjeenk Willink, p. 14

$35 \mathrm{Vgl}$. voor een overzicht van de omstandigheden der arbeidende klasse I.J. Brugmans (1925). De arbeidende klasse in Nederland in de negentiende eeuw 1813-1870. I le druk (1978) Utrecht: Spectrum, p. 169-193 en het klassieke Kapitaal en arbeid in Nederland van Henriëtte Roland Holst (1902), Kapitaal en arbeid in Nederland: bijdrage tot de economische geschiedenis der 19e eeuw. Amsterdam: Soep.

36 J.A. de Jonge (1968), De industrialisatie in Nederland tussen 1850 en 19/4. Amsterdam, (Nijmegen, Sun Reprint, 1978), p. 290; Geers 1988, p. 27

37 Geers 1988, p. 29

38 L. Karsten (1990), De achturendag: arbeidstijdverkorting in historisch perspectief 1817. 1919. Amsterdam: IISG, p. 196-199. Overigens werd ook door niet-industriële werkgevers gepleit voor een verbod op kinderarbeid met het oog op de "behoefte aan ontwikkelde arbeiders". Cf. Van Drongelen 1990, p. 72

39 Handelingen Tweede Kamer, 1873-1874, p. 1375, geciteerd in Romme, 1939. p. 5 
Een andere factor die wetgeving in de weg stond, was het ontbreken van een sterk ontwikkeld bewustzijn bij de arbeiders en met name het gebrek aan organisatie. Tot 1850 bestond de 'arbeidende klasse' in feite niet: zij had, om terug te grijpen op de conceptualiseringen van Giddens (vgl. par. 2.1), geen betekenis binnen de toenmalige interpretatiekaders, ${ }^{40}$ Zeker in Nederland was van een 'arbeidende klasse' geen sprake, maar hooguit van één grote groep armen: "Hun ellende was niet die van den modernen proletarièr, voor wien uit wrangste derven het verzet ontstaat dat verheft. de hoop die verzacht, de gemeenschapszin die veredelt. Hun ellende was die van stompzinnige schepselen, zwak van fysieke, nog zwakker van geestelijke krachten. lijden zonder uitzicht en van hun degradatie onbewust." ${ }^{n 1}$ Eerst door hun initiële organisatie, omstreeks 1870 , ontstond iets van klassenbewustzijn. "Het is duidelijk dat tot die tijd van de arbeiders als stuwende kracht ter verbetering van de arbeidsomstandigheden weinig tot niets kon worden verwacht."42 De initiatieven tot verbetering van de omstandigheden van de arbeidende klasse kwamen tot die tijd vooral uit de hoek van sociaal bewogen geneeskundigen zoals Samuel Coronel, progressieve liberalen en een enkele literator: in het bijzonder Jacob Jan Cremer, wiens klaagschrift Fabriekskinderen ${ }^{43}$ uit 1863 Thorbecke ertoe bracht een Staatscommissie in te stellen die de toestand van de fabriekskinderen zou moeten onderzoeken. $^{44}$

\section{Kinderwetje Van Houten (1874)}

Het rapport van de enquêtecommissie, dat verscheen in 1869 , vermocht niet de overheid te verleiden tot wetgeving. ${ }^{45}$ Pas in $1873 \mathrm{kwam}$ het liberale kamerlid Van Houten met een eerste initiatiefvoorstel - volgens Geers mede naar aanleiding van de oprichting in 1871 van de eerste echte vakbond, het Algemeen Nederlandsch Werklieden Verbond (ANWV). Roland Holst is stellig over wie als kampioen van het Kinderwetje moet worden aangemerkt: "Ondanks de pogingen van meelijdende bourgeois, de vertoogen van geneeskundigen, en het verschijnen van het rapport der regeeringskommissie in ' 69 , ondanks de algemeene bekendheid van onmenschelijke toestanden en stelselmatig bedreven kindermoord op groote schaal, duur-

40 In de eerste helft van de $19^{\circ}$ eeuw werd met termen als 'volk' of 'proletariaat' gerefereerd aan iedereen behalve een klein aantal aristocraten en uitbuitende burgers. Pas tegen het midden van de $19^{\circ}$ eeuw krijgt de term 'proletariaat' een meer specifieke betekenis, verbonden aan de steeds duidelijker te identificeren klasse van loonarbeiders die met de ontwikkeling van het kapitalisme ontstond. Vgl. H. Draper, (1977-1990), Karl Marx's Theory of Revolution, (4 Vol.) New York/London: Monthly Review Press, hoofdstuk 6-7

41 H. Roland Holst, Kapitaal en Arbeid in Nederland, geciteerd door Geers 1988, p. 25. Vgl. ook Van Drongelen 1990, p. 14

42 Geers 1988, p. 26

43 J.J. Cremer (1988), Fabriekskinderen: een bede maar niet om geld. Schoorl: Conserve ( $2^{e}$ druk)

44 Bij de samenstelling van de commissie werden overigens de verklaarde voorstanders van een wettelijke regeling, zoals voomoemde Coronel, geweend door de liberalen. W. Buitelaar en $\mathbf{R}$. Vreeman (1985), Vakbondswerk en kwaliteit van de arbeid. Nijmegen: SUN, p. 48

45 Geers 1988, p. 28 
de het tot ' 74 eer de bourgeoisie, ter wille der publieke opinie, zich verwaardigde zelfs een schijnstoot tegen de kinder-exploitatie te doen. De uitbreiding der Internationale door Europa, haar korte verschijning in Nederland, de donderslag der Parijsche Kommune en .... de agitatie van het Alg. Ned. Werklieden-Verbond waren noodig om de paskwillige wet-van Houten tot stand te brengen, die de ruim 3100 zes- tot twaalfjarige fabriekskinderen tot hun twaalfde jaar beschermde ... op papier." 46

Voor Roland Holst was duidelijk dat de initiatieven van de progressieve liberalen vooral gezien moesten worden als een middel om het opkomend klassenbewustzijn af te remmen. ${ }^{47}$ Het lijkt echter toch onweerlegbaar dat de progressief liberalen, al waren ze wellicht tegen de klassenstrijd, wel degelijk een belangrijke bijdrage hebben geleverd. ${ }^{48}$ Ook de motieven achter de 'burgerlijke' initiatieven zijn waarschijnlijk niet louter economisch-instrumenteel, in de zin van het instandhouden en waar nodig ontwikkelen van het arbeidsleger en het beteugelen van de dreigende revolutie. ${ }^{49}$ Hoewel de werkelijke beweegredenen van politieke actoren uiteraard nooit volledig transparant te maken zijn, is het zeer wel denkbaar dat de opstelling van de diverse betrokkenen werd ingegeven door een mix van motieven. ${ }^{50}$

Overigens had het Kinderwetje van Van Houten uit 1874 de arbeiders inhoudelijk bitter weinig te bieden: uiteindelijk alleen een verbod op arbeid voor kinderen onder de twaalf jaar, met uitzonderingen voor onder meer huishoudelijke en landarbeid (het leeuwendeel van de kinderarbeid). Louter de allerjongsten vonden beschutting onder de beschermende vleugels van de overheid. Met betrekking tot de verhouding tussen werkgever en volwassen arbeider bleef de fictie overeind dat dezen in een vrije verhouding zouden staan. Het werd althans niet tot de tak van de overheid gerekend voor de mannelijke arbeider op te komen (noch voor de vrouwelijke arbeiders). Dit bijzonder magere resultaat kan, mede in het licht van de dominante libe-

46 Roland Holst 1902, p. 188. Overigens moet die "agitatie" van het ANWV niet worden geheroïseerd: aanvankelijk vertoonde de bond, die op dat moment nog nauwelijks wortels had in fabrieken en werkplaatsen, weinig belangstelling voor de problematiek van de kinderarbeid. Maar een paascongres, vlak voor de parlementaire behandeling, van tweehonderd afgevaardigden die meer dan 14.000 arbeiders vertegenwoordigden, was op dat moment de grootste arbeidersdemonstratic ooit. G. Harmsen en B. Reinalda (1975), Voor de bevrijding van de arbeid: beknopte geschiedenis van de Nederlandse vakbeweging, Nijmegen: Sun, p. 47. Belangrijker dan gerichte agitatie voor de Kinderwet was de algemeen ervaren sociale onnust sinds het eind van de jaren ' 60. 47 Roland Holst 1902, p. 157: "De industrieèle onderneming trad op gehuld in het gewaad der filantropie, die in haar ruime plooien al zoveel schandelijks heeft verborgen." ibid. p. 102. Ook de christelijk-sociale werkgevers werden in hun beijvering om een oplossing voor de 'sociale quaestie' in belangrijke mate gedreven door het streven naar sociale vrede. Schwitters 199I, p. 169

48 Buitelaar/Vreeman 1985, p. 47-48 Voor de arbeidsjurist A.N. Molenaar was de invloed van de arbeidersbeweging juist minimaal, en was de wetgeving vooral ingefluisterd door de stem van het geweten van de progressief-liberalen. Vgl. Geers 1988, p. 63

49 Overigens werd ook op het paascongres van het ANWV door de arbeiders zelf gewezen op het belang van sociale vrede: "In naam der rust en orde van de maatschappij vragen wij zo'n wet, omdat we de ruwe kracht der verwaarloosde vreezen." Geciteerd in Van Drongelen 1990, p. 72

50 Geers 1988, p. 63-64, Van Drongelen 1990, p. 72-73 
rale ideologie en bij ontstentenis van een stem der arbeiders in het parlement ${ }^{51}$, worden opgevat als een indicatie van de buitenparlementaire machteloosheid van de arbeidersbeweging in die tijd. Als belangrijke oorzaak van die machteloosheid wordt wel gewezen op het ontbreken van eenheid in doelstelling en organisatie. ${ }^{52}$ De vakbeweging was, zeker tot het eind van de negentiende eeuw, ernstig verdeeld: "Haar vinden wij verlamd door inwendige tweedracht. Nog afgezien van den kleinen omvang der 'neutrale' vakvereenigingen, makt de innerlijke onrust en onvastheid, die in hen heerscht en waarvan een voortdurend gedobber het gevolg is, hen onmachtig de taak der vakvereenigingen [..] naar behoren te vervullen." 53

Hoewel het Kinderwetje materieel dus weinig te bieden had, moet de betekenis ervan toch niet onderschat worden: met de Kinderwet werd "voor het eerst wettelijk ingegrepen in de tot dan vrije verhouding tussen werkgever en werknemers." 54 Ook de marxistische historicus Ger Harmsen ziet het Kinderwetje, hoe gebrekkig en uitgehold ook, als een wet van grote principiële betekenis: "Het was een overwinning van het beginsel dat de overheid tot taak had de ekonomies zwakken in het produktieproces te beschermen. De 'Internationale' zag het ingrijpen van de overheid als een nederlaag van het liberale beginsel dat alles overgelaten moest worden aan het spel der vrije krachten in het ekonomiese leven. [..] En ook al was deze wet slechts in geringe mate onder invloed van de arbeidersbeweging in Nederland tot standgekomen, toch zegeviert hier het beginsel van de arbeidersbeweging, $\mathrm{nl}$. het bewust regelend ingrijpen in het blinde spel der ekonomiese krachten ten gunste van de arheiders." 55

\section{Arbeidswet 1889}

Hoewel het Kinderwetje Van Houten principieel dan wel een doorbraak betekende, bleek hij al gauw ernstig gemankeerd. Ten eerste was de werkingssfeer te beperkt, reden waarom van de zijde van de arbeiders al direct in 1874 werd aangedrongen op uitbreiding van de wet. ${ }^{56}$ Ten tweede was niet precies duidelijk wat nu precies onder het verbod viel. ${ }^{57}$ Voorts bleek de wet in de praktijk nauwelijks effectief met name vanwege het ontbreken van adequaat toezicht. ${ }^{58}$ De ontoereikendheid

51 Pas in $1885 \mathrm{kwam}$ de voorman van de georganiseerde meubelmakers Bernardus Heldt voor de Liberale Unie in het district Sneek als eerste werkman in de Tweede Kamer. Heldt was tevens voorzitter van het ANWV.

52 W. van Voorden, A.G. Nagelkerke en W.F. de Nijs (1992). Macht in banen: arbeidsverhoudingen in theorie en beleid, Leiden/Antwerpen: Stenfert Kroese, p. 189

53 Roland Holst 1902, p. 201-202. Vgl. Van Drongelen 1990, p. 69

54 Geers 1988, p. 35. Vgl. Van Drongelen 1990, p. 21

55 Harmsen/Reinalda 1975 , p. $47-48$

56 H.J. Romeijn (1895), Eenige opmerkingen naar aanleiding van de Arbeidswet, Leiden: Los, p. 48

57 Van Drongelen 1990, p. 22

58 Geers 1988, p. 34. Van Drongelen citeert hierover uitgebreid S.Sr. Coronel. De arbeid van kinderen tegenover de wetgeving, in: De Economist, 1873, pp. 660-661. Aandrang van onder meer het Comité ter bespreeking van de Sociale Quaestie en het ANWV om, met name op het punt van het toezicht, de wet te verbeteren vond geen gehoor bij de regering. Van Drongelen 1990, p. 20 
van de wet zorgde ervoor dat de discussie over de wettelijke bescherming aanhield. Diverse partijen onderbouwden hun opvattingen met onderzoek naar de arbeidsomstandigheden van de arbeiders. In 1880 publiceerde een commissie bestaande uit de Vereeniging tot Bevordering van Fabrieks- en Handwerknijverheid, de Maatschappij tot Nut van het Algemeen en het ANWV een rapport met de conclusie dat in geen beschaafd land "de wetgeving op de kinderarbeid zoo gebrekkig, zoo verregaand onvolledig is als in Nederland." 59 In hetzelfde jaar werd ook vanuit meer radicale hoek onderzoek verricht. In het najaar van 1880 publiceerden het weekblad Recht voor Allen en De Werkmansbode (ANWV) een Nederlandse bewerking van de 'Enquête Ouvrière', die door Karl Marx was ontworpen en was gepubliceerd in La Revue Socialiste van 20 april $1880 .{ }^{60}$ De enquête beoogde vooral bewustwording van vooruitstrevende burgers én moest de aanzet vormen tot wetgeving, met name op het gebied van arbeidstijden. ${ }^{61}$ In 1886 hield het ANWV nógmaals een enquête, die resulteerde in het rapport Een bij de wet geregelde arbeids. dag en een pleidooi voor een tien-urige werkdag. ${ }^{62}$

Mede naar aanleiding van de genoemde enquêtes, maar vooral als reactie op demonstraties van werklozen en harde confrontaties tussen radicale socialisten en de politie in Amsterdam eerder dat jaar, werd in oktober 1886 een parlementaire enquête ingesteld "omtrent het tegengaan van overmatigen arbeid en omtrent de toestand van fabrieken en werkplaatsen met het oog op de veiligheid, de gezondheid en het welzijn der werklieden". ${ }^{3}$ Het ging hierbij niet meer alleen om kinderarbeid, maar voor het eerst ook om de veiligheid en gezondheid van arbeiders in het algemeen. ${ }^{64}$ De radicale arbeiders keerden zich overigens tegen de enquête, met name omdat zij twijfelden aan "de onpartijdigheid der arbeidersenquête, daar geene

59 Geciteerd bij Geers 1988, p. 35

60 Buitelaar/Vreeman 1985, p. 43ff. De eerste arbeidersenquêtes hadden vooral ten doel inzicht in de siuatie van de arbeiders te komen teneinde hun positie te verbeteren (ibid. p. 39). Daarnaast had werknemersonderzoek tot doel het bewustzijn en de kennis van de arbeiders zelf te vergroten en zo de vakbondsorganisatie op te bouwen, diende het als aanzet tot vakbondsactie, en als instrument om erkenning van de vakbondsorganisatie af te dwingen (ibid, p. 84)

61 De resultaten van de enquête bleven overigens ongepubliceerd tot 1898. Ferdinand Domela Nieuwenhuis, de voorman van de radicale Sociaal-Democratische Bond en initiatiefnemer tot de enquête, verwoordde de uitkomsten met kracht in zijn pamflet Blanke Slaven: "Men verplettert den werkman. Men stompt zijn geest af door spanning en overmatig langen werktijd, men spaart hem de ongezonde voorwaarden van den arbeid niet. Men neemt niet eens de noodige voorzorgsmaatregelen om hem te behoeden voor schadelijke invloeden. Men vergiftigt hem in fabrieken. Men laat hem dampen en stoffen inademen, die hem bedwelmen en op den duur vermoorden. Men neemt de vrouw. Men onttrekt haar aan haar huis, aan haar gezin. Men maakt een lastdier van haar, erger nog dan van den man." F. Domela Nieuwenhuis, Een vergeten hoofdstuk: Blanke slaven, gecit. in: Buitelaar/Vreeman 1985, p. 46

62 B.H. Heldt (1886), Een bij de wet geregelde arbeidsdag: Rapport van het Alg. Ned. Werkliedenverbond, Amsterdam: Brinkman/v.d. Meulen. Vgl. Karsten 1990, p. 217

63 Karsten 1990, p. 217. Ook in bijvoorbeeld Belgiè vormden hevige rellen in het voorjaar van 1886 de aanstoot tot de eerste sociale wetgeving. Delvaux 1987, p. 7ff

64 Geers 1988, p. 37 
arbeiders daarin zitting genomen hebben." 65 De Sociaal-Democratische Bond van Domela Nieuwenhuis zette in een grimmige verklaring zeven bezwaren tegen de enquête op een rij, waaronder naast de eenzijdige samenstelling "uit voorstanders van de kapitalistische produktiewijze en een enkelen handlanger van dezulken" ook "het gemis aan waarborgen voor hen die wegens hun verklaringen voor de commissie door hun werkgevers uit hun brood worden gestooten." 66

Uit het parlementaire onderzoek onder 146 getuigen, waaronder 53 arbeiders, bleek dat het nog immer bedroevend gesteld was met de arbeidsomstandigheden in de fabrieken. ${ }^{67}$ Het commissielid Heldt vatte het bij een latere gelegenheid als volgt samen: "Wat toch is de toestand van 90 à 95 pct. van de werklieden? Zij worden op den leeftijd van twaalf jaren in de werkplaatsen gestuurd, om daar hun leven lang onder het verrichten van veelal zeer eentoonigen en zwaren arbeid, gedurende lange dagen, veelal ook nachten en Zondagen, te blijven, zonder eenig ander vooruitzicht, dan dat zij, wanneer zij te oud of te versleten zijn om het werk behoorlijk te verrichten, weggestuurd en prijsgegeven te worden aan de armoede [..] Daarbij staan deze werklieden in de werkplaatsen bloot aan allerlei gevaren van verminking door vergroeiingen en ongelukken, en zelfs van gedood te worden, in welke gevallen zij en hunne gezinnen hulpeloos gelaten en in diepere armoede gedompeld worden." 68

$\mathrm{Na}$ de enquête was de fictie van een gelijkwaardige relatie tussen werkgever en arbeider nauwelijks nog houdbaar. Voor de regering waren de bevindingen van de commissie dan ook aanleiding te komen tot een ontwerp van wet "houdende bepalingen tot het tegengaan van overmatigen arbeid van jeugdige personen en vrouwen". ${ }^{69}$ Het wetsontwerp voorzag in een verbod op arbeid voor kinderen beneden de twaalf jaar, een verbod op nachtarbeid voor vrouwen, en de mogelijkheid om bij AMvB bepaalde gevaarlijke werkzaamheden te verbieden voor jongeren onder de zestien jaar. Volgens Geers ontmoette het wetsontwerp, in tegenstelling tot het Kinderwetje, betrekkelijk weinig weerstand: het werd met slechts één stem tegen (Domela Nieuwenhuis) aangenomen. ${ }^{70}$ Opvallend aan de totstandkoming van de Arbeidswet is echter juist het nogal vinnige karakter van de parlementaire behandeling - in het geval van Domela Nieuwenhuis is de typering 'onparlementair' wellicht meer op zijn plaats ${ }^{71}$-, het grote aantal amendementen, de tientallen 'adres-

65 Eindverslag der Commissie, p. 16, in: J. Giele (1981), Een kwaad leven: de arbeidersenquê. te van 1887 (deel 3), Nijmegen: Link

66 Giele 1981, p. 324-325. Met 'de handlanger van het kapitaal' werd allicht ANWV-voorzitter Heldt bedoeld, die ook zitting had in de Commissie.

67 Eindverslag der Commissie, Bijlagen Tweede Kamer, zitting 1886-1887, 105.5 Opgenomen in: Giele 1981. Overigens vond de Bestuurdersbond der Sociaal-Democratische Vereeniging de uitkomsten onvolledig. en hield vervolgens zelf ook nog een enquête. Karsten 1990, p. 218

68 Handelingen Tweede Kamer, 1888-1889, p. 852

69 Kamerstukken II, 1888-1889, 53, no. 1-2 Vgl. Buitelaar/Vreeman 1985, p. 49

70 Geers 1988, p. 39

71 Kenmerkend is Domela's venijnige aantijging jegens de andere Kamerleden: "Uwe schitterende huizen hebben tot cement het bloed der arbeiders en hunne gezinnen" (Handelingen Tweede Kamer, 1888-1889, p. 842), waarop de voorzitter eiste dat Domela zijn taal zou kuisen. 
sen' van belanghebbenden aan de regering ${ }^{72}$ én een tamelijk felle protestbijeenkomst van arbeiders een week voor de parlementaire behandeling. ${ }^{73}$ Mede als gevolg van de adressen en amendementen werd de wet tijdens de parlementaire behandeling ingrijpend gewijzigd. ${ }^{74}$

De algemene beschouwingen over het wetsontwerp zijn illustratief voor de verschuivende opvattingen omtrent de mate van staatsinmenging, in het bijzonder in relatie tot de rol van de arbeiders(vertegenwoordiging). De tegenstanders van wetgeving beriepen zich, naast het gebruikelijke argument dat wetgeving het particuliere initiatief zou blokkeren en fnuikend zou zijn voor de concurrentiepositie, ook op de versterkte positie van de arbeiders: "In de vakvereenigingen hebben de werklieden een langzaam maar zeker werkend middel om ten aanzien van duur en inrichting van den arbeid zoo voordelig mogelijke voorwaarden te verkrijgen, als de belangen der industrie. die met de hunne samenhangen, toelaten."75 Het katholieke Kamerlid Schaepman daarentegen bewandelde in zijn argumentatie vóor staatsinterventie juist de omgekeerde weg: door de teloorgang van de gilden en corporaties is "het vereenigingsleven tusschen de arbeiders volkomen gebroken op gewelddadige wijze. Op dit oogenblik staat de arbeider niet langer als een maatschappelijke kracht tegenover de meester, maar als individu, als enkel persoon."76 De ontbinding van de organisatorische en vooral ook morele cohesie tussen patroon en werklieden rechtvaardigde volgens Schaepman staatsingrijpen - zij het alleen in geval van uitwassen. Voor het overige betoonde Schaepman zich een voorstander

72 Aanvankelijk vrijwel uitsluitend door werkgevers en de Kamers van Koophandel (TK 18881889,53 , nr. 10, laat zien dat van de 44 adressen er 42 van werkgevers waren, en slechts één van de afdeling Uithuizen van het ANWV), en in een later stadium relatief iets vaker van vakverenigingen ( 8 van de 20 , de overige van werkgevers)

73 Bij de bijeenkomst waren, nasst organisator Domela Nieuwenhuis, slechts vier van de honderd Kamerleden aanwezig (Heldt, Goeman Borgesius, Kerdijk en Gildemeester), hetgeen voor Domela reden was zijn scepsis te uiten over de initiatieven tot het oprichten van zogeheten Kamers voor Arbeid (zie noot 77): "Men kan niet juist zeggen, dat aan den kant der arbeiders de verwachting is opgewekt, als zoude er veel waarde worden gehecht over hetgeen zij over dergeijike wetsontwerpen hebben gedacht" (Handelingen Tweede Kamer, 1888-1889, p. 871). Typerend voor de angst voor dit soort bijeenkomsten beetindigt dagblad De Standaard (12 maart 1889) de beschrijving van de "groote Volksmeeting": "De meeting liep in de beste orde af."

74 Romeijn 1895, p. 50-51

75 Kamerstukken II, 1888-1889, 53, nc. 4 (voorlopig verslag), p. 3

76 Handelingen Tweede Kamer, 1888-1889, p. 856 
van een zo groot mogelijke rol voor 'maatschappelijke verbanden', een idee dat ook door andere confessionele Kamerleden werd uitgedragen. ${ }^{77}$

Ook in de verdediging van minister Kerdijk tegenover de tegenstanders van de wet speelde de positie van de arbeiders een rol. De minister vreesde "dat over elke ingrijpende verandering, die het wetsontwerp in kracht en betekenis zal verminderen, de tegenstanders eener vreedzame ontwikkeling der maatschappelijke toestanden zullen jubelen in hunne binnenkamer en dat zij er in het openbaar gebruik van zullen maken tot bemoeilijking van het pogen, om langs den vreedzamen weg te komen tot verbetering van zóoveel, wat in onze maatschappij ten nadeele van de misdeelden, helaas, bestaat."78

Uiteindelijk werd op 5 mei 1889 de Arbeidswet vrijwel unaniem aangenomen. De wet behelsde met name een verbod op arbeid voor kinderen onder de twaalf jaar en een verbod op nachtarbeid voor vrouwen en jongeren onder de veertien jaar, en een elfurige werkdag en een verbod op nachtwerk voor vrouwen en mannelijke arbeiders onder de zestien jaar. Daarnaast introduceerde artikel 4 de mogelijkheid, bij AMvB te effectueren, tot een verbod op werkzaamheden die tot gevaar voor de gezondheid of het leven kunnen leiden - voor jongeren in het algemeen, en voor vrouwen in fabrieken en werkplaatsen. Hiermee werd voor het eerst de mogelijkheid geschapen om voorschriften te stellen aan de inrichting van de werkplek. Daarmee behoorde de wet meer tot de veiligheidswetgeving zoals die vanaf 1895 tot stand zou komen dan tot de wetgeving rond de (overmatige) arbeidstijden. ${ }^{79}$ Ten slotte voorzag de wet in de instelling van een toezichthoudende instantie: de Arbeidsinspectie. ${ }^{80}$

77 Het Christen-Historische Kamerlid De Savornin Lohman bepleitte, ó́k met het oog op de sociale vrede, het oprichten van lokale corporatieve verbanden. Deze zouden kunnen optreden als raadgever voor de overheid (Handelingen Tweede Kamer, 1888-1889. p. 850). Tot op dat moment werden bij de advisering over wetgeving. 6́6k bij de Arbeidswet, naast de Raad van State alleen de Kamers van Koophandel geadresseerd. Het idee voor paritaire Raden was al eerder gelanceerd in het verkiezingsprogram (1888) van de Anti-Revolutionairen, die zogeheten 'Kamers van Arbeid' op corporatieve grondslag in het leven wilden roepen. Dit zou ook voor de arbeiders een organisatic moeten worden om zich tot de regering te wenden - en omgekeerd: de regering stelde dat het bijzonder moeilijk was "lieden uit de arbeidende klasse tot het geven van inlichtingen te bewegen, en de daartoe geschikte personen te vinden. (Handelingen Tweede Kamer, 1888-1889. p. 843). De Kamers van Arbeid werden door Abraham Kuyper gezien als mogelijke opvolgers van de gilden, die "de Franse revolutie had vernietigd. zonder er iets voor in de plaats te stellen" én als middel om de sociale vrede te bewaren. Uiteindelijk werd bij wet van 2-5-1897 (Stb. 1897, 141) de oprichting van Kamers van Arbeid mogelijk, met overigens bijzonder weinig succes. $\mathrm{Vgl}$. C. Helderman (2001). De Kamers van Arbeid 1897-1922. Een mislukte poging tot bedrijfsorganisatic, in: Tjidschrift voor Sociale Geschiedenis, 27/1, p. 77-98

78 Handelingen Tweede Kamer. 1888-1889, p. 848

79 Deze mogelijkheid werd geëffectueerd in het Koninklijk Besluit van 15 juli 1891. Cf. Geers 1988, p. 41

80 Dit instituut was niet voorzien in de ontwerp-wet (terwijl toch het gebrek aan toericht als één van de belangrijkste tekortkomingen van het Kinderwetje werd gezien), maar onder druk van de Kamer uiteindelijk toch opgenomen. Wel was de formatie van de inspectie bij de wet beperkt tot het weinig imponerende aantal van drie inspecteurs. 
Net zoals de Kinderwet van 1874 kan de Arbeidswet met de nodige ambivalentie worden beschouwd. Inhoudelijk was het, zeker voor de arbeidersbeweging, slechts een kleine stap voorwaarts. Domela Nieuwenhuis stemde, zoals gezegd, tegen. De wet stelde niets voor, de arbeiders zouden er de schouders over ophalen. ${ }^{81}$ Domela bepleitte nog maar eens de acht-urige werkdag én een uitbreiding van de wetgeving naar volwassen mannelijke arbeiders, en wenste er verder het zwijgen toe te doen. ${ }^{82}$ Ook de meer gematigde ANWV-voorman Heldt toonde zich onbevredigd, en met hem "de groote groep werklieden, die naast en achter mij staan en [..] die reeds in 1874 onbevredigd zijn gebleven." 83

Aan de andere kant is met de Arbeidswet 1889 weer een voorzichtige stap gezet op weg naar verdere bescherming van de arbeiders. Bovendien werd nu, meer dan bij de Kinderwet, erkend dat de Staat een taak had in de bescherming van zijn onderdanen: "De Staat [treedt] niet buiten zijn kring als hij den, niet voor één keer maar regelmatig zwakkere beschermt tegen de wederpartij en tegen zichzelven." 84 Ook voor de katholieke voorman Romme was de Arbeidswet 1889, in retrospectief, een belangrijke ommekeer. Met de Arbeidswet 1889 is de overheid "de feitelijke onvrijheid van den arbeider te hulp [gekomen] wanneer die feitelijke onvrijheid voerde tot wat als een misstand werd aangemerkt en op geen andere wijze dan door Staatsinmenging de misstand te verhelpen was. ${ }^{-85}$ Dat de naleving vooralsnog te wensen overliet - adequaat toezicht was alleen al door het beperkte aantal inspecteurs volstrekt onmogelijk - en met name dat de mannelijke arbeiders nog steeds waren uitgesloten van wettelijke bescherming, doet aan het belang van deze doorbraak niet af.

\section{Veiligheidswet 1895}

Dat de Staat op het gebied van veiligheid en gezondheid een verantwoordelijkheid heeft jegens zijn onderdanen werd, vijf jaar na de Arbeidswet, door de regering zelf 'vanzelfsprekend' geacht. Dit blijkt althans uit de Memorie van Toelichting bij de volgende schrede op het pad der arbeidsbescherming - in casu de Veiligheidswet 1895. Sterker nog, ook de wens om de mannelijke werknemers wettelijk te beschermen werd volgens de regering "vrij algemeen erkend." 86 Directe aanleiding voor het ontwerp-Veiligheidswet uit 1893 was met name de rapportage van de "Staatscommissie tot verzameling van gegevens voor de kennis van de maatschappelijke toestanden der arbeiders, van de verhoudingen tusschen werkgevers en arbeiders, en van den toestand van fabrieken en werkplaatsen met het oog op de veiligheid en gezondheid der arbeiders" 87 . Daaruit bleek dat nog steeds sprake was van "tal van

81 Handelingen Tweede Kamer, 1888-1889, p. 871

82 Handelingen Tweede Kamer, 1888-1889, p. 838

83 Handelingen Tweede Kamer, 1888-1889, p. 851

84 Wet van 5 mei 1889 (Stb. 1889, 48), met inleiding en aanteekeningen van J. Oppenheim. p. 11

85 Romme 1939. p. 7

86 Kamersnikken II, 1893-1894, 111, nr. 3 (MvT), p. 4

87 Ingesteid bij wet van 19 januari 1890 (Stb. 1890, 1) 
ongunstige toestanden waaruit ziekten of ongevallen voortsproten, die geheel $\sigma$ gedeeltelijk hadden kunnen worden voorkomen." 88 De bevindingen van de com missie Rochussen waren unisono (in mineur) met de eerste rapportages van d Arbeidsinspectie. Blijkens het jaarverslag van de inspectie waren in 1891 bijn tweeduizend ernstige ongevallen gerapporteerd ${ }^{89}$, waarbij 54 doden vielen t betreuren op een beroepsbevolking van nog geen 2 miljoen arbeiders. ${ }^{90}$ Eén van d drie inspecteurs rapporteert: "Bij mij vestigt zich de overtuiging dat een deel de werkgevers zonder wettelijke voorschriften zeer lang wachten zal voor en aleer zi tot maatregelen overgaan." 91

Verdere impulsen tot wetgeving gingen uit van onder meer de oprichting van d 'Vereeniging tot Voorkoming van Ongelukken in Fabrieken en Werkplaatsen' i $1890^{92} \mathrm{en}$, in hetzelfde jaar, een congres naar aanleiding van de 'Eerste Neder landsche Tentoonstelling tot Bevordering van Veiligheid en Gezondheid i Fabrieken en Werkplaatsen' te Amsterdam. ${ }^{93}$ Tijdens het congres werd op voor dracht van het liberale Kamerlid Goeman Borgesius een motie aangenomen waari werd aangedrongen op verdergaande wetgeving op het gebied van veiligheid. ${ }^{9}$ Dergelijke aandrang ging ook uit van een adres, in 1892, van het ANWV aa Koningin-Regentes Emma, waarin herinnerd werd "aan hetgeen zij op 15 septembe 1891 in de Troonrede had toegezegd over de te treffen maatregelen in het belang va de veiligheid en gezondheid in fabrieken en werkplaatsen." ${ }^{.19}$ Verder ging een niet t onderschatten invloed uit van de aanhoudende sociale onrust, met een sterk oplaai

88 Kamerstukken II, 1893-1894, 111 , nr. 3 (MvT), p. 4. De Commissie Rochussen publiceerde in totaal 29 verslagen en een eindverslag. De ontwerpwet werd nog vóor het verschijnen van het eindverslag aan de Tweede Kamer aangeboden. Cf. Van Drongelen 1990, p. 77-78

89 Ongevallen met een verzuim van minder dan twee dagen hoefden niet te worden gerapporteend.

90 CBS (2001). Tweehondend jaar statistiek in tijdreeksen, 1800-1999, Voorburg/Heerlen: CBS. p. 20

91 Kamerstukken II, 1893-1894, 111, nr. 3 (MvT), p. 4

92 Deze vereniging, waaraan werd deelgenomen door zowel werkgevers als arbeiders, had als doel de bevordering van 'de gezondheid en de veiligheid van werklieden bij het verrichten van arbeid in of voor eenig bedrijf'. Geers 1988, p. 43

93 Over de tentoonstelling en het congres: J. Stoop (1982), Geschiedenis van veiligheid en gezondheid in arbeidsomstandigheden in Nederland, Delft: Technische Hogeschool, p. 39ff. Het Comité van aanbeveling bij de tentoonstelling bestond uit 50 personen. waaronder één vertegenwoodiger van de arbeiders (Heldt). Het congres werd bezocht door 300 deelnemers, waaronder 10 vertegenwoordigers van het ANWV. éen van de christelijke vakbond Patrimonium, en éen van de RK Volksbond.

94 A.H.W. Hacke (1940), "Een greep uit het vele"; Gedenkboek ter herinnering van het vijftigjarig bestaan van de Arbeidsinspectie. Groningen: Wolters, p. 16

95 W. de Vries (1970), De imvloed van werkgevers en werknemers op de totstandkoming van de eerste sociale verzekeringswet in Nederland (De Ongevallenwet 1901). Deventer: Kluwer. p. 37 
end stakingsvuur in de periode 1888-1890. ${ }^{96}$ Ten slotte zij gewezen op de befaamde encycliek Rerum Novarum (1891), waarin paus Leo XIII 'de toestand der arbeiders in het kapitalisme' aan de orde stelde en die een belangrijke impuls betekende voor het katholieke denken over de sociale kwestie. ${ }^{97}$ In zijn encycliek drong de paus aan op sociale wetgeving, onder meer om de maatschappelijke vrede te bewaren. ${ }^{98}$

De Veiligheidswet was overigens lang niet zo omstreden als de Arbeidswet 1889. In de Kamer was, op een enkel achterhoedegevecht na, inderdaad "vrij algemeen erkend" dat ook de volwassen man bescherming behoefde. Het verzet van de oppositie, die vreesde voor belemmering van de industrie en de vrije relatie tussen werkgever en arbeider, werd gepareerd door een heldere stellingname van minister Van der Sleyden: "de tusschenkomst van den wetgever af te wijzen met een beroep op de vrijheid van arbeid, kan reeds daarom niet opgaan, omdat [.. ] in zoo vele gevallen van vrijheid geen sprake kan zijn. De zorg voor het dagelijksch brood dwingt hem den arbeid te aanvaarden, ook al stelt hij zich desbewust aan ernstige gevolgen bloot. Bovendien bedenke men, dat de gezondheid van den arbeider wordt bedreigd door vele gevaren, waarvan het bestaan hem zelfs geheel onbekend kan zijn." 99

Buiten de Kamer trok de nieuwe wet betrekkelijk weinig aandacht. Het aantal adressen van werkgevers aan de Tweede Kamer was op de vingers van één hand te tellen. ${ }^{100}$ De vakbeweging was evenmin bijzonder betrokken bij de Veiligheidswet. omdat zij haar speerpunt had gekozen in de verhevigde strijd voor de acht-urige werkdag - vooral onder invloed van de Tweede Internationale (1889). ${ }^{101}$ De

96 S. van der Velden (2000), Stakingen in Nederland: Arbeidersstrijd 1830-1995, Amsterdam: IISG/NIWI, p. 321. Overigens werd slechts zelden gestaakt puur met het oog op de verbetering van de arbeidsomstandigheden. Uit het onderzoek van Van der Velden blijken een behoorlijk loon en menswaardige werktijden veruit de belangrijkste motieven voor stakingen te zijn. De prachtige stakingen-database van het IISG (http://www.iisg.nl/databases/stakingen/) laat in de $19^{e}$ eeuw slechts eén staking zien waarbij arbeidsomstandigheden een centrale rol hebben gespeeld - in casu bij de bakkerijstakingen in Leeuwarden 1872. Ook Harmsen geeft aan dat de strijd voor veilige arbeidsomstandigheden niet het belangrijkste motief was voor de arbeiders om het werk neer te leggen, maar al vanaf de eerste spontane stakingen toch primair de hoogte van het loon. Harmsen/Reinalda 1975, p. 33ff

97 M. Algra (1989), "Wie zwijgt, wordt niet gehoord"; Geschiedenis van de medezeggenschap in Nederland, Den Haag: Delwel, p. 23-24. J.P. Windmuller, C. de Galan en A.F. van Zweeden (1987). Arbeidsverhoudingen in Nederland, Utrecht: Het Spectrum, 6de druk, p. 32. De Encycliek stelde dat de overheid bij het behartigen van de belangen van het individu "op geheel bijzondere wijze is gehouden tot belangstelling in het lot der lagere, onvermogende klasse. De meerbemiddelden toch hebben minder steun aan de Overheidsbescherming; zij vinden vaak in eigen kracht reeds voldoende steun en genoegzame hulp; de minder bedeelden echter, de menschen zonder hulpmiddelen, zijn bijna ten eenenmale van bescherming door de overheid afhankelijk. De werklieden alzoo, die voor het meerendeel in dien toestand verkeeren, behooren door de overheid onder hare bijzondere hoede te worden genomen." Geciteerd in A.E. Bles (1907), De Wet op de arbeidsovereenkomst, Den Haag: Belinfante, deel I, p. 471

98 Karsten 1990, p. 350

99 Kamerstukken II. 1894-1895, 15, nr. 2 (Memorie van Antwoord), p. 14

100 Handelingen Tweede Kamer. 1894-1895, p. 1291

101 Karsten 1990, p. 193 
Veiligheidswet bleek dus geen onderwerp waarover de klassenstrijd zou ontbraden, al smeulde in de Kamer toch nog heel zachtjes iets van revolutionair vuur. En aantal Kamerleden wilde namelijk de behandeling van de wet uitstellen tot de nieawe kieswet eindelijk zou zijn aangenomen: "Tegen behandeling van wetsontwerpen van sociale aard, gelijk het onderhavige, geldt [..] de bedenking dat de klasse cer werklieden, wier belangen daarbij in de eerste plaats betrokken zijn, door de g:ldende beperkte kiesbevoegdheid niet in staat is, op de te nemen beslissingn invloed uit te oefenen." 102

De behandeling van het wetsontwerp werd evenwel gewoon voortgezet en was, 1a de inleidende schermutselingen, verder een tamelijk technische kwestie. De vet strekte zich uit over de arbeid verricht in "fabrieken en werkplaatsen", dat wil zggen alle open of besloten ruimten waarin 'enig bedrijf' werd uitgeoefend waanij een krachtwerktuig of oven wordt gebruikt óf tien of meer personen aanweaig plachten te zijn (art. 1). ${ }^{103}$ Artikel 6 en 7 openden de mogelijkheid om bij AM:B voorschriften te geven met betrekking tot de veiligheid respectievelijk met betrókking tot de inrichting van de werkplaats. ${ }^{104}$ Ook kon de Arbeidsinspectie ten anzien van de in artikel 6 en 7 genoemde onderwerpen nadere eisen stellen omtrut de wijze van uitvoering van de in de $\mathrm{AMvB}$ vastgelegde voorschriften. Voorts regide de wet het toezicht op de naleving van de voorschriften (artt. 9-15) ${ }^{105}$, het berop tegen eisen van de Arbeidsinspectie (artt. 16-18) en de strafbaarstelling (artt. 9 24).

Hoewel de Veiligheidswet primair de inrichting van de werkplek viseerde en viel minder dan de Arbeidswet de relatie tussen werkgever en arbeider beoogde te reguleren, werd de aanvaarding van de wet door een deel van de Kamer toch beschouwd als de "[ondubbelzinnige huldiging] van het beginsel, dat de wetgever het recht heeft om, zoo nodig, de contractsvrijheid te beperken in het belang van de maatschappelijk zwakken." ${ }^{106}$ Ook anderszins werd de veiligheidswetgeving in een breder kader van arbeidsverhoudingen geplaatst. Ten eerste werd de noodzaak van wetgeving gekoppeld aan de zwakke positie van de vakbeweging: "Waar de vak-

102 Kamerstukken II, 1894-1895, 15, nr. I (voorlopig verslag), p. I

103 In het wetsontwerp was sprake van 20 of meer personen, hetgeen bij amendement van de Kamerleden Kerdijk en Hartogh werd verlaagd tot 10. Kamerstukken II, 1894-1895, 15, nr. 9. Een verderstrekkend voorstel voor uitbreiding van de werkingssfeer (amendement Heldt) werd met 19 tegen 57 stemmen verworpen.

104 In het Veiligheidsbesluit 1896 (Stb. 1896, 215) werden voorschriften gegeven omtrent afmetingen. vrije-luchtruimte, daglicht, uitzicht, voorkomen/beperken brand- en explosiegevaar, kleednimten, privaten en urinoirs (ex art. 6 van de Veiligheidswet), temperatuur, luchtverversing, verlichting, gevaarlijke dampen/gassen/stof, voorkomen van ongevallen, en zitgelegenheid (ex. art. 7 van de Veiligheidswet). Besluit en wet traden op 1 januari 1897 in werking. Interessant is nog artikel 2 van de wet, dat stelde dat bij oprichting of uitbreiding van een bedrijf de gemeente in kennis moest worden gesteld, én dat het bouwplan onderworpen zou kunnen worden aan de beoordeling van de inspecteur.

$105 \mathrm{Na}$ een wijziging van de Arbeidswet 1889 en aanname van de Veiligheidswet 1895 kon in 1896 het aantal inspecteurs van de Arbeidsinspectie worden uitgebreid. Van Drongelen 1990. p. $82-89$

106 Kamerstukken II, 1894-1895, 15, nr. 1 (voorlopig verslag), p. 2 
vereenigingen in onze volkstoestanden niet voldoende ontwikkeld zijn om daarvan een krachtig optreden voor de belangen van de werkman te kunnen verwachten, daar is de tusschenkomst van den wetgever noodzakelijk."107 Ten tweede werd wederom gepleit voor een voortvarende wettelijke regeling van zogeheten Kamers van Arbeid, "waarin de vertegenwoordigers van de patroons en van de werklieden, die tegelijk dus deskundigen en belanghebbenden zouden zijn, in onderling overleg het noodige licht voor den wetgever zouden kunnen ontsteken. Het hooren van dergelijke Kamers over ontwerpen van wet van socialen aard zou [..] aan de deugdelijkheid der wetgeving op dit gebied zeer ten goede komen, ter vermijding [..] dat misschien op bloote theorieën gegrondveste maatregelen worden afgekondigd, waarvan de onuitvoerbaarheid of het ondoeltreffende bij voorbaat ware vast te stellen." 108

\section{Controleurs van de arbeid}

Evenmin als de Arbeidswet 1889, blijkens de gegevens van de commissieRochussen en de Arbeidsinspectie, als bij toverslag de grauwsluier der erbarmelijke arbeidsomstandigheden over de arbeiders weg kon trekken, leidde de Veiligheidswet tot een plotselinge verbetering van hun lot. Slechts weinig werkgevers waren werkelijk doordrongen van het belang van veiligheidsmaatregelen. ${ }^{109}$ Ook de arbeiders toonden zich echter weinig enthousiast: "Zeker in de vroege jaren 'leven' de beschermende bepalingen niet of nauwelijks bij hen, die er het meeste profijt van kunnen hebben [..] Inkrimping van verdiensten wordt gevreesd (door bemoeilijking van overwerk) [..], belediging zelfs door 'kinderachtige' veiligheidsmaatregelen. Zo zien wij bij de beschermde personen naast onverschilligheid zelfs weerstand nopens de wet aan het werk." 110 Het toezicht liet bovendien nog steeds te wensen over. Mede door de soms vijandige opstelling van werkgevers én arbeiders konden "de voorschriften en intenties van de Arbeidswet en de Veiligheidswet slechts met zeer veel moeite tot gelding worden gebracht." 111 Een andere verklaring voor de gebrekkige handhaving is, ondanks de uitbreiding in 1886, het volstrekte gebrek aan tijd en de te grote afstand van de inspecteurs tot de werkvloer. ${ }^{112}$ Van meerdere kanten werd dan ook gepleit voor het betrekken van de arbeiders bij het toezicht op de werkplek zelf. H.F. Kuyper, een van de drie eerste inspecteurs, achtte het "wenschelijk [..] dat de arbeiders zelf de ontduikingen der wet aan het

107 Kamerstukken II. 1894-1895, 15, nr. I (voorlopig verslag). p. 2.

108 Kamerstukken II, 1894-1895, 15, nr. I (voorlopig verslag), p. I

109 A. Den Hoed (1991). Het complement der industrialisering, in: H. Binneveld, (red), Een zak van vertmuwen: Arbeidsinspectie 1890-1990. Den Haag: Sdu, p. 31

110 J.J.M. Van der Ven (1958), Rechtssociologische aantekeningen bij de Arbeidswet 1919. Vereniging van Arbeidsrecht, p. 7-8

III A.C.J.M. Wilthagen (1993). Het overheidstoezicht op de arbeidsomstandigheden: een onderzoek naar het functioneren van de Arbeidsinspectie. Groningen: Wolters-Noordhoff. p. 39

112 Van Drongelen 1990, p. 94 
licht brengen. [De] wetten op de arbeid vinden geen beter opzichters en uitvoerders dan de belanghebbenden, dat zijn de arbeiders." 113

Eerder al, bij de behandeling van de Arbeidswet, had Domela Nieuwenhuis gepleit voor inspecteurs die door de arbeiders zelf zouden worden gekozen. ${ }^{114}$ In 1896 bepleitte het progressief liberale Kamerlid Kerdijk, onder wiens ministeriële verantwoordelijkheid de Arbeidswet tot stand was gekomen, in het Sociaal Weekblad eveneens de instelling van 'Commissiën uit werklieden-vereenigingen' die als taak zouden moeten hebben "de uitvoering van de Arbeidswet na te gaan, klachten over niet-naleving dier wet in ontvangst te nemen, [en] naar aanleiding daarvan overleg te plegen met de inspecteurs van den arbeid."115 Deze commissieèn, "bestaande uit mannen, door de werklieden zelven uit hun midden aangewezen" zouden enerzijds "in arbeiderskringen onverschilligheid [kunnen] bestrijden, het besef van den plicht tot medewerking wakker roepen of versterken, en aansporen om feiten, strijdig met de wet, niet te verzwijgen. Anderzijds bieden zij verhoogden waarborg, dat de herkomst der klachten, die zij overbrengen, verborgen zal blijven."116 Hetzelfde Weekblad, overigens van liberale signatuur, publiceerde in 1898 een bijtend stuk over het falende toezicht op de Arbeidswet, waarin de (anonieme) schrijver bepleitte dat voor met name de vakverenigingen een toezichthoudende taak zou worden weggelegd. ${ }^{117}$

Het voorstel werd een decennium later, bij een ingrijpende reorganisatie van de Arbeidsinspectie, overgenomen door minister Talma. Volgens de minister bestond er "alle aanleiding over te gaan tot de aanstelling van eene nieuwe klasse van ambtenaren, die, onder den titel van 'controleurs van den arbeid', in het bijzonder uit de arbeiders benoemd, onder de bevelen der districtshoofden werkzaam gesteld worden. Personen van voldoende ontwikkeling, die als arbeider het bedrijfsleven grondig hebben leeren kennen, zullen niet zelden beter dan eenig ander inlichtingen kunnen geven omtrent de in het belang van den arbeid te geven voorschriften. Hunne ervaring zal veelal er toe kunnen bijdragen, dat de maatregelen worden genomen, die bij de minste opoffering van de zijde van den werkgever het meest nuttige effect voor den arbeider opleveren."118 Opvallend is hier, dat de controleurs niet door de arbeiders zélf zouden moeten worden gekozen, of aangewezen door de vakvereniging, maar zouden worden aangesteld als ambtenaar (tegen een vergoe-

113 Ibid.

114 Handelingen Tweede Kamer, 1888-1889, p. 841. Domela was tegen benoeming van de Kroon, omdat aldus de macht in handen bleef van "de klasse waartegen de arbeiders moesten worden beschermd." Hacke 1940, p. 16

115 A. Kerdijk, Noodige medewerking, in: Sociaal Weekblad 1896, geciteerd in Van Drongelen 1990, p. 94

116 Kerdijk 1896, p. 241. Kerdijk was zich bewust van de kwetsbare positie van de individuele arbeider, reden waarom er een commissie ingesteld moest worden. "Waar de broodwinning in gevaar kan komen, deinst de overgroote meerderheid ervoor terug. zich bloot te stellen aan wraakneming door den patroon, die immers juist door zijn niet-gehoorzamen aan de wet blijk heeft gegeven van een ruim geweten. [..] Zoo beveelt de tusschenkomst van commissièn [..] zich aan."

117 Van Drongelen 1990. p. 94

118 Kamerstukken II. 1908-1909, 211, nr. 3 (MvT), p. 3 
ding van 800 tot 1200 gulden jaarlijks). De 'controleur van de arbeid' werd geìntroduceerd in een AMvB van 10 augustus 1909 (Stb. 289), als ambtenaar van de Arbeidsinspectie. 119

Doel van de instelling van de Controleurs was "eenerzijds de voorlichting te krijgen van mannen die op velerlei gebied een ander licht zouden kunnen doen vallen op de taak, die de Arbeidsinspectie te behartigen heeft, anderzijds bij den dienst personen te betrekken, die eerder het vertrouwen zouden hebben van hun klassegenoten." 120 De Controleurs werden geworven uit de ontwikkelde arbeiders, waarbij rekening werd gehouden dat de vakbeweging in zijn verschillende politieke schakeringen werd vertegenwoordigd. ${ }^{121} \mathrm{De}$ Controleurs vervulden een taak als toezichthouder op de werkplek én als opsporingsambtenaar, en waren met dezelfde bevoegdheden toegerust als de 'echte' inspecteurs van de Arbeidsinspectie. Camminga spreekt vol lof over de bijdrage van de Controleurs, die formeel tot in de jaren ' 80 een plek in het bestel hadden ${ }^{122}$, maar uiteindelijk als achterhaald instituut verdwenen bij de reorganisatie van begin jaren ' $90 .{ }^{123}$

\section{Object van bescherming}

Hoewel op de effectiviteit van de Arbeidswet 1889 en de Veiligheidswet 1895 aan het eind van de negentiende eeuw nog veel viel af te dingen, betekenden beide wetten in meerdere opzichten een grote stap voorwaarts in de bescherming van de arbeidende klasse. De belangrijkste doorbraak was zonder meer dat, aan het eind van de eeuw, vrijwel geen twijfel meer bestond aan het belang en de normatieve juistheid van bescherming van de arbeiders; aanvankelijk alleen met betrekking tot

119 In het Mijnreglement van 1906 was de oprichting van 'arbeiderscommissies' verplicht gesteld voor $100+$ bedrijven: "Bij elke mijn, waar in den regel meer dan honderd arbeiders in dienst zijn, bestaat eene arbeiderscommissie welker taak is, wenschen, bezwaren en klachten betreffende de veiligheid, de gezondheid en den arbeid, voor zoover die haar gegrond voorkomen, ter kennis te brengen van de bestuurders van de mijn." De commissie bestond uit zes, door de arbeiders uit hun midden gekozen, leden. Zij fungeerden als doorgeefluik voor de klachten en wensen van de arbeiders naar de directie. Ten minste één maal per maand werd hierover met de directie gesproken. Geers (1988, p. 54-55) identificeent de bepalingen in het mijnreglement als de eerste wettelijke regeling van medezeggenschap inzake veiligheid en gezondheid. Overigens waren er in diverse bedrijven, met name van verlichte ondernemers als Van Marken, ook al op vrijwillige basis werknemers betrokken bij het veiligheidsbeleid. Gevers 1982, p. $159 / 160$

120 J.J. Camminga (1934), lets over de taak van de Controleurs van den Arbeid, in: H.A. van Usselsteyn (1934), Gedenkboek naar aanleiding van het feit dat 25 jaar geleden de Arbeidsinspectie gesteld werd onder leiding van den Directeur-Generaal van den Arbeid, Groningen: J.B. Wolters, p. 59

121 Van Drongelen 1990, p. 135

122 lbid., p. 457

$123 \mathrm{Vgl}$. Wilthagen 1993, p. 50 
de zogeheten personae miserabiles ${ }^{124}$, uiteindelijk ook met betrekking tot de vol wassen mannelijke arbeider (die tot dan geacht werd voldoende voor zichzelf op $t$ kunnen komen).

Zonder twijfel is deze verschuiving mede te danken geweest aan de nobele strevin gen van verlichte liberalen en sociaal bewogen confessionelen, maar de doorbraal van de sociale wetgeving kwam zeker ook tot stand onder druk van de toenemend sociale onrust. Vór 1870 was van een arbeidersklasse in Nederland hoegenaam: geen sprake. ${ }^{125}$ Vanaf die tijd ontwikkelde zich echter voor het eerst een vorm va klassenbewustzijn, dat zich steeds nadrukkelijker begon te manifesteren: de oprich ting van vakverenigingen, een ontluikende arbeiderspers, een aantal enquêtes va: met name het ANWV en de SDB ${ }^{126}$, de introductie van de Eerste Internationale it Nederland (1869) en vooral een toenemend aantal stakingen. ${ }^{127}$ Weliswaar wen vrijwel nooit gestaakt voor betere arbeidsomstandigheden of meer veiligheid op d werkplek. Met name de roep om menswaardige werktijden was echter wél een va: de belangrijkste motieven om te staken.

Hoewel eind negentiende eeuw de arbeiders langzamerhand erkend werden al 'object van zorg' (dat wil zeggen als te beschermen persoon), kregen zij nog nie zelf een actieve rol toebedacht in het veiligheidsbeleid op bedrijfsniveau of in $d$ branche (typerend genoeg werden de controleurs van de arbeid aangesteld als amb tenaren en niet, zoals Domela had bepleit, als afgevaardigden van de arbeiders,). D arbeiders waren nog geen 'subject': zij waren nog onvoldoende krachtig (een va de argumenten voor staatsinterventie) $)^{128}$, te zeer verdeeld ${ }^{129}$, en te weinig georga niseerd om als aanspreekpunt te gelden voor de wetgever. Juist rond de voortgaande ontwikkeling van de sociale wetgeving echter kristalliseerde de subjectiviteit

124 Tot de personae miserabiles in sensu strictu behoorden met name de armen, weduwen en wezen, maar sinds de code civil (1810) en het Burgerlijk Wetboek (1838) ook de gehuwde vrouw. In de discussie over de sociale wetgeving werd dit opgerekt tot kinderen en vrouwen in het algemeen. Overigens werd al tijdens de parlementaire behandeling van de Veiligheidswet 1895 opgemerkt dat vrouwen in feite niet tot de personae miserabiles gerekend mochten worden: "Het gaat niet aan de vrouwen onder de personae miserabiles te rangschikken, en het wordt hoog tijd, dat de wetgever het recht der vrouw, om als gelijke van den man te worden behandeld, in zijn volle omvang erkenne." Kamerstukken II, 1894-1895, 15, nr. 1 (Voorlopig Verslag), p. 2

125 I.J. Brugmans (1925), De arbeidende klasse in Nederland in de negentiende eeuw 18131870, 11e druk (1978) Utrecht: Spectrum, p. 222

126 Buitelaar/Vreeman 1985, p. 39-55

127 Als eerste serieuze stakingen worden over het algemeen aangemerkt die van de scheepstimmerlieden en typografen in Amsterdam, in 1869. Harmsen/Reinalda 1975, p. 40ff; Brugmans 1925 , p. $273 \mathrm{ff}$. In 1869 beliep het aantal gestaakte dagen ruim meer dan 30.000 dagen, met ook in 1872. 1875 en met name tussen 1888-1890 flinke uitschieters. Van der Velden 2000. p. 320-321

128 Ook Molenaar merkt op dat wetgeving vereist was "omdat de organisatie der arbeiders te zwak [bleek] om aan overmatigen eischen der ondernemers weerstand te bieden." A.N. Molenaar (1927), Bronnen van Arbeidsrecht. Leiden: Van Doesburgh. p. 16

129 De verdeeldheid tussen de vakverenigingen liep met name langs levensbeschouwelijke lijn: zo keende de christelijke vakvereniging Patrimonium (1876) zich juist tégen sociale wetgeving, omdat zij meer zag in de dialoog tussen patroon en werklieden en zelfs tegen de kinderwetgeving. omdat deze ingreep in de door God gegeven taak van ouders: Geers 1988. p. 36 
van de arbeidende klasse zich verder uit: in eerste instantie rond de Ongevallenwet 1901, maar in het bijzonder in de voortdurende strijd voor een kortere arbeidstijd.

\section{Ongevallenwet 1901}

Waren de arbeiders nog nauwelijks georganiseerd, zeker gold dat voor de ondernemers. ${ }^{130}$ De werkgevers waren soeverein, en tot het eind van de jaren ' 80 had de overheid hoegenaamd geen invloed - zeker niet op het terrein van het sociale beleid. ${ }^{131} \mathrm{Bij}$ de behandeling van de Veiligheidswet hadden meerdere Kamerleden echter al met enige zorg bij de regering geïnformeerd welke verdere sociale wetgeving het land in de nabije toekomst te wachten stond. ${ }^{132}$ Het besef, bij met name de Twentse industrieel D.W. Stork, dat de ondernemers geconfronteerd zouden worden met nog meer sociale wetten, en dat zij tot op dat moment - afgezien van adressen via de Kamers van Koophandel - nauwelijks invloed hadden op het wetgevingsproces, zou een belangrijke stimulans zijn voor de aaneensluiting van de werkgevers. ${ }^{133}$ De Ongevallenwet 1901 was in dit proces de katalysator. Hoewel de Ongevallenwet in feite geen wetgeving op het gebied van arbeidsomstandigheden is (maar op het terrein van de sociale zekerheid), heeft zij veel invloed gehad op de institutionalisering van de arbeidsverhoudingen in Nederland - reden om de totstandkoming wat uitgebreider te beschrijven.

Aan het eind van de jaren ' 80 deed zich, vooral uit vrees voor sociale onrust ${ }^{134}$, de behoefte gevoelen aan een regeling voor de compensatie van arbeiders die als gevolg van het werk schade aan de gezondheid hadden opgelopen en als gevolg daarvan niet langer konden voorzien in het onderhoud van zichzelf en hun gezin. De industrialisatie leidde ertoe dat het ongevallenprobleem groter werd, en het besef groeide dat er een oplossing moest komen voor de getroffen arbeiders. ${ }^{135}$ Weliswaar kende het Burgerlijk Wetboek een regeling voor civielrechtelijke aansprakelijkheid, maar in de praktijk kwam het zelden tot schadevergoeding. Ten eer-

130 Brugmans merkt op dat het ontbreken van een duidelijk herkenbare klasse van ondernemers ook vertragend werkte op de ontwikkeling van een klassenbewustzijn bij de arbeiders. Brugmans 1925. p. 189

131 Algra 1989, p. 13

132 Kamerstukken II. 1894-1895, 15, nr.I (Voorlopig Verslag), p. I

133 J. Bruggeman en A. Camijn (1999), Ondernemers verbonden: 100 jaar centrale onderne. mingsorganisaties in Nederland, Den Haag: VNO/NCW, p. 78

134 Schwitters 1991, p. 264

135 Overigens had een aantal ondernemers, zoals de Delftse industrieel Van Marken (in 1878) en de al genoemde Stork (in 1883), zelf al een regeling getroffen in de vorm van ziekenfondsen die overigens goeddeels werden betaald uit de lonen van de arbeiders zelf. Voor Van Marken waren de fondsen niet alleen een blijk van sociaal werkgeverschap, maar ook een manier om de tegenstelling tussen kapitaal en arbeid te overbruggen. Ook waren de fondsen een manier om geschoold personeel aan het bedrijf te binden. Schwitters 1991, p. 172-178; p. 165; Bruggeman/Camijn 1999. p. 61-67. In 1889 was 7.5\% van de werknemers verzekerd via fabrieksfondsen. J.A. van Genabeek (1998), Fabrieks- en bedrijfstakfondsen 1890-1950, in: Jacques van Gerwen en Marco H.D. van Leeuwen, Studies over zekerheidsarrangementen. Risico's, risicobestrijding en verzeke. ringen in Nederland vanaf de Middeleeuwen, Amsterdam/Den Haag: NEHA. p. 318 
ste diende de onrechtmatigheid van het handelen van de werkgever aangetoond te worden, hetgeen veelal ondoenlijk was. Ten tweede hadden de arbeiders tijdens een eventueel proces geen aanspraak op loon en dus geen inkomsten. Ten derde waren de proceskosten niet op te brengen. ${ }^{136}$

Het eerste ontwerp van de Ongevallenwet dateerde van 15 februari 1897. Dit zogeheten ontwerp Van der Sleyden voorzag in de oprichting van een Rijksverzekeringsbank, die betaald zou moeten worden door de ondernemers. Uitvoering door een overheidsinstantie was volgens de regering de enige garantie voor de rechten van arbeiders, meer in ieder geval dan wanneer de arbeiders waren overgeleverd aan welwillende regeling door hun werkgever. ${ }^{137}$ Het ontwerp Van der Sleyden werd evenwel ingetrokken als gevolg van een kabinetswisseling later dat jaar. Het nieuwe kabinet diende, in april 1898, een aangepast wetsontwerp in dat volledig publiekrechtelijk van opzet was. De werkgevers kregen een premieplicht, te voldoen aan de overheid, die de getroffen arbeiders een uitkering zou geven. Het ontwerp-Lely riep scherp verzet op bij een aantal werkgevers, met name bij de kringen rond Stork. Deze ondernemers hadden niet zozeer principiële bezwaren tegen een verplichte verzekering, integendeel: Stork en bijvoorbeeld ook Van Marken waren wel voor een verplichte verzekering, onder meer om de concurrentie eveneens te binden aan een regeling en zo afwenteling onmogelijk te maken. ${ }^{138}$ De bezwaren betroffen vooral de bureaucratische, centralistische uitvoering van de verzekering. Het ontwerp-Lely ondermijnde de vrijwillige (en betere) arrangementen die sommige ondernemers al hadden getroffen, zou tot hogere kosten leiden, en greep te veel in in de relatie werkgever/arbeider. Een aantal Kamers van Koophandel stuurde adressen aan de Tweede Kamer, de tot dan toe gebruikelijke manier om invloed uit te oefenen op de wetgever, en Van Marken lobbyde bij toenmalig premier Pierson. Veel bereikte men hiermee echter niet, vooral omdat de betrokkenen geen representatieve organisatie vertegenwoordigden. Tijdens een protestbijeenkomst tegen de voorziene Ongevallenwet, op 19 juni 1899, bepleitte Stork daarom de oprichting van een permanente vereniging. Stork voorzag dat de overheid nog meer sociale wetgeving in petto had, die door een goed georganiseerd platform beïnvloed zou moeten worden. ${ }^{139}$ Uiteindelijk leidde de bijeenkomst tot de oprichting van de Vereeniging van Nederlandsche Werkgevers, de eerste werkgeversorganisatie in Nederland en voorloper van het latere VNO.

De werkgevers vonden, in hun verzet tegen de Ongevallenwet, een bondgenoot in de anti-revolutionairen rond Abraham Kuyper. Weliswaar hadden de confessionelen geen bezwaar tegen financiële compensatie voor getroffen arbeiders, integendeel. $\mathrm{Zij}$ opteerden echter voor particulier initiatief in plaats van een door de Staat

136 Bruggeman/Camijn 1999, p. 63 Vgl. ook Geers 1988, p. 59

137 Schwitters 1991. p. 275-276: De Vries 1970, p. 62-64

138 Schwitters 1991, p. $277-278$

139 Bruggeman/Camijn 1999, p. 78. De juistheid van dit inzicht bleek later bijvoorbeeld uit de strijd rond de Ziektewet, de volgende loot aan de stam van de sociale wetgeving. Dankzij een perfect georganiseerd verzet wisten de werkgevers het ontwerp en de invoering van de Ziektewet tweeènhalf decennia op te houden - van 1904. het moment waarop Kuyper een ontwerp aan de Tweede Kamer stuurde, tot 1929 (ibid. p, 61 ) 
opgelegde en uitgevoerde regeling. Kuyper diende een amendement in dat de uitvoering van de Ongevallenwet in handen legde van paritaire bedrijfsverenigingen. Dit zogeheten Groot Amendement kwam tot stand in samenspraak met de werkgevers, en droeg ook duidelijk de sporen van de invloed van de industrie. ${ }^{140}$ Hoewel het Groot Amendement in de Tweede Kamer werd verworpen, bleek de Eerste Kamer het plan van Kuyper en de werkgevers gunstiger gezind.

Als tegenwicht tegen de succesvolle lobby van de werkgevers riepen de SDAP, dagblad Het Volk en de Algemeene Nederlandsche Timmerliedenbond in de loop van 1900 een 'Landelijk Komité inzake de Ongevallenwet' in het leven, waar later ook het ANWV zich bij aansloot. ${ }^{141}$ Het Landelijk Komitee stelde een petitie op, belegde protestvergaderingen in 40 plaatsen, en organiseerde op 27 mei 1900 een landelijke protestbijeenkomst in Den Haag met 7000 deelnemers. De inderhaast in elkaar geknutselde coalitie bleek evenwel verscheurd door ideologische verschillen. en wist nauwelijks een vuist te maken. "Zo stonden de zaken aan de vooravond van de behandeling van het wetsontwerp in de Eerste Kamer: een krachtige, in de VNW en talrijke omvangrijke adressen samengebalde oppositie, die zich van de belangrijkste steun in de Senaat verzekerd wist. Aan de werknemerszijde viel [..] nog nauwelijks van een kamp te spreken; eerder van een te hoop lopen van allerlei groeperingen uit bepaalde lagen van het Nederlandse volk." ${ }^{42}$ De Eerste Kamer stemde het wetsontwerp-Lely inderdaad af. Op 22 juni 1900 diende de minister een nieuw wetsontwerp in, dat voorzag in de mogelijkheid dat bedrijven eigen-risicodrager worden of onderlinge verzekeringsmaatschappijen oprichten. ${ }^{143}$ Half juli 1900 organiseerden het Landelijk Komitee en het ANWV een actieweek tegen de wet, maar uiteindelijk werd het ontwerp Lely-II aangenomen door de Eerste Kamer. ofwel "de vertegenwoordiging van de driedubbel overgehaalden geidzak."144

De totstandkoming van de Ongevallenwet, in concluderende zin, hing op paradoxale wijze samen met de ontwikkeling van de arbeidsverhoudingen in Nederland. Bij de vormgeving van de Ongevallenwet speelde, nauw verhuld, het streven naar sociale vrede een belangrijke rol: "deze nieuwe wet zal strekken tot pacificatie en de onaangename hatelijke processen tussen werkman en werkgever uit de wereld helpen." ${ }^{145}$ De opname van een zogeheten pacificatie-artikel impliceerde het einde van de mogelijkheid voor arbeiders om hun werkgever civielrechtelijk aansprake-

\section{De Vries 1970, p. 219}

141 Reden voor de trage reactie van de kant der arbeiders was dat het oorspronkelijke wetsvoorstel meer bood dan zij hadden durven hopen. Pas toen Kuyper en de werkgevers succes leken te gaan hebben, kwam "een Gideonsbende van de socialistische - in nog mindere mate de liberaal georganiseerde en in het geheel niet de confessionele - werknemers in actie", met name omdat ze bang waren dat de arbeiders te zwak zouden staan in de paritair bestuurde bedrijfsverenigingen die Kuyper voorstelde. Ibid. 1970, p. 219. p. 451

142 Ibid. 1970 , p. 334

143 In 1890 kende Nederland 1068 'onderlinges' (verenigingen die voor en door de leden verzekeringen verzorgden). Ongeveer de helft van deze onderlinges waren beroepsgebonden fondsen, vakverenigingen en werkliedenverenigingen (zie Van Genabeek 1998, p. 318).

144 Het Volk, 7 december 1900, geciteerd in De Vries 1970, p. 447

145 Minister Cort van der Linden. geciteerd in: Geers 1988, p. 58-59. Vgl. ook Bruggeman/Camijn 1999. p. 110 
lijk te stellen: de werkgever betaalde premie voor de verzekering en werd in ruil daarvoor bevrijd van zijn civielrechtelijke aansprakelijkheid voor de gevolgen van bedrijfsongevallen. ${ }^{146}$ Maar hoewel de verzekeringsgedachte de sociale rust begunstigde, vormde "de strijd waartoe zij aanzette [..] een nieuwe fase in de sociale verhoudingen in Nederland. Het leidde tot de oprichting van een landelijke werkgeversorganisatie, en voor het eerst stonden organisaties van werkgevers en werknemers op nationaal niveau tegenover elkaar."147 De Ongevallenwet luidde het begin in van een voortschrijdend proces van institutionalisering van de arbeidsverhoudingen in Nederland. Dit proces werd versneld tijdens de Eerste Wereldoorlog en zou culmineren in de Ziektewet 1929, die bepaalde dat paritair bestuurde bedrijfsverenigingen de uitvoering van de sociale zekerheid ter hand zouden moeten nemen. ${ }^{148}$ Voor een uitgebreidere beschrijving van dit institutionaliseringsproces zie paragraaf 2.3 .

\section{Arbeidswet 1919}

Hoewel de Ongevallenwet rond één thema de scherpste puntjes van het vrije kapitalisme afvijlde, bleven er na $1900 \mathrm{nog}$ genoeg heikele kwesties over. Als belangrijkste smeulde de kwestie van de arbeidstijden, een brandhaard die met grote regelmaat opflakkerde. In Engeland werd al sinds 1833 gestreden voor een acht-urige werkdag, op I mei 1886 braken in de Verenigde Staten bloedige vechtpartijen uit mssen stakers en stakingsbrekers over de kwestie, en in 1889 riep het Internationafe Arbeiders Congres (Tweede Internationale) de acht-urige werkdag uit tot hét speerpunt van de arbeidersstrijd. Daarmee kwam ook in Nederland de acht-urige werk-

146 Artt. 87-88 Ongevallenwet 1901, artt. 93, lid 2 en 95, lid 2, Ongevallenwet 1921. Vgl, L. Bier (1988), Aansprakelijkheid voor bedrijfsongevallen en beroepsziekten: de civielrechtelijke aansprakelijkheid voor de aan de arbeid gerelateende persoonsschade. Deventer: Kluwer, p. 139 141. Vgl. J. Veenis en A.C.J.M. Wilthagen (1998), Civielrechtelijke arbo-zaken: een verkenning van de praktijk en van de mogelijkheden tot monitoring. Den Haag: Ministerie van Sociale Zaken en Werkgelegenheid. p. 5. Troelstra stelde al dat het pacificatie-artikel gezien moest worden als "gebruik van macht, om het zwijgen op te leggen aan den roep om recht." Handelingen Tweede Kamer 1899-1900, p. 402, geciteerd in Bier 1988, p. 140. De radicalere arbeiders waren ook geen voorstander van een wettelijke ongevallenregeling. $\mathrm{Zij}$ gingen ervan uit dat de civielrechtelijke aansprakelijkheid van de werkgever deze zou dwingen tot veilig werken én de arbeider de gelegenheid zou bieden tot verhaal/wraak (schuldaansprakelijkheid als vorm van vergelding). P. de Jong et al. (1995), Arbeid, recht en risico: beweging in de regulering van arbeidsomstandigheden, in: P. de Jong et al. (red.), Arbeid, recht en risico, Amsterdam: Siswo, p. 14 Het idee van het preventieve effect van aansprakelijkheidsclaims is ook het leidende principe geweest achter de oprichting van het Bureau Beroepsziekten van de FNV in 2000. J. Bus en J. Popma (2000). Beschadigd bestaan: een boekje open over beroepsziekten. Amsterdam: FNV Bureau Beroepsziekten, p. 5

147 Schwitters 1991, p. 289

148 Een bipartite organisatie die overigens in de Arbeidsbemiddelingswet 1930 nog een stap te ver bleek te zijn: de wet voorzag slechts in de mogelijkheid om tot een bipartite uitvoering te komen, maar legde daarnaast veel gewicht bij publieke territoriale uitvoering (gemeentes). C.C.A.M. Sol (1999). Arbeidswoorzieningsbeleid in Nederland: de mol van de overheid en de sociale partmers, Den Haag: Sdu, p. $74 \mathrm{ff}$ 
dag op de prioriteitenlijst van de vakbeweging, met I mei 1890 als startdatum van een bijna dertigjarige strijd voor menswaardige arbeidstijden. ${ }^{149}$ Een strijd van lange adem dus, die ook in Nederland een betere organisatie van de vakbeweging en een intensievere samenwerking met politieke partijen vereiste. ${ }^{150}$ Rond de eeuwwisseling kwam de steun vanuit de politiek daadwerkelijk van de grond.

Op 24 december 1906 diende het SDAP-Kamerlid Schaper, als tussenstap naar de acht-urendag, een motie in voor een tien-urige werkdag. Om de motie kracht bij te zetten, organiseerde de SDAP samen met het Nederlandsch Verbond van Vakvereenigingen (opgericht in 1906) op 2 maart 1907 een congres voor beperking van de arbeidstijd voor volwassen mannen, en zetten beide organisaties een enquête uit onder de arbeiders omtrent de naleving van de Arbeidswet 1889. ${ }^{151}$ Uit deze enquête, Arbeidersleven, bleek dat de Arbeidswet veelvuldig werd overtreden. Ondanks de ontluisterende gegevens uit de enquête, ondanks de argumentatie dat de arbeidstijdverkorting géén kostenverhoging voor de industrie tot gevolg zou hebben ${ }^{152}$, en ondanks de welwillende opstelling in met name katholieke kring ${ }^{153}$, werd de motie Schaper echter met 49 tegen 28 stemmen verworpen.

149 Overigens kent de strijd voor kortere arbeidstijden ook voór 1890 al een eerbiedwardige gesschiedenis. Zo was ook de eerste 'officiële' staking, die van de scheepstimmerlieden in 1869. was vooral gericht op kortere arbeidstijden. Karsten 1990, p. 203

150 Karsten 1990, p. 193ff

151 De SDAP had al eerder, in 1902, onderzoek gedaan naar de arbeidstijden van arbeiders (Arbeidsduur in Nederland). Buitelaar/Vreeman 1985, p. 75-80. Ook onder afzonderlijke beroepsgroepen, zoals de posterijen (1902), Bakkersgezellen (1905) en Handels- en Kantoorbedienden (1906) waren al onderzoeken uitgevoerd. In het algemeen maakte de vakbeweging in het begin van de $20^{\complement}$ eeuw betrekkelijk vaak gebruik van het enquête-wapen, met name omdat de officięle statistieken als onbetrouwbaar werden ervaren. Bondsinitiatieven leveren meer op dan 'onafhankelijk' onderzoek, omdat de arbeiders bang zijn tegenover autoriteiten hun mond open te doen. Buitelaar/Vreeman 1985, p. 74 resp. 64

152 De arbeidstijdverkorting zou volgens de SDAP-enquête moeten worden gecompenseerd door een toegenomen arbeidsprestatie: "De verkorting van arbeidsduur oefent op de lichamelijke kracht en de intelligentie van den arbeider een bij uitstek gunstige invloed; hij kan nu in een beperkter tijd meer presteeren." NVV/SDAP (1908). Arbeidersleven in Nederland: resultaten der enquête, ingesteld door het Ned. Verbond van Vakvereenigingenin het najaar van 1907 naar de wenschelijkheid en mogelijkheid van beperking van den arbeidsduur voor volwassenen tot 10 uren per etmaal en afschaffing respectievelijk beperking van nacht- en kinderarbeid. Amsterdam: Sociaal-democratische Arbeiderspartij en het Ned. Verbond van Vakvereenigingen, p. 153 Harmsen en Reinalda merken terecht op dat de Enquête 'Arbeidersleven in Nederland' vooral werd uitgevoerd onder georganiseerden: de toch al schrikbarende uitkomsten waren dus waarschijnlijk nog positief vertekend. Harmsen/Reinalda 1975, p. 133

153 Confessionelen uit de kring rond Aalberse verwachtten een heilzame werking van een kortere werkdag. Immers "overmatige arbeidsduur doodt den levenslust, doodt de belangstelling in het hogere, het edele, het ideale, doodt het weerstandsvermogen tegen de bekoring to lager zingenot, en voert ten gevolge daarvan tot egoïsme, onverschilligheid voor het lot van anderen en voor eigen toekomst, misbruik van drank, zorgeloosheid en algemeene ontevredenheid." Ch.A.M. Raaijmakers (1908), Arbeidsduur voor volwassen mannen, in: Sociale Studiën, III.5, p. 335-336. Arbeidsduurverkorting belooft dat "op den duur het zedelijk gehalte en de intellectueele ontwikkeling van het volk zullen verhoogd worden [..] en een zonnestraal van geluk en tevredenheid zal doordringen tot het leven van de lagere klassen" (ibid.). 
Als één van de redenen voor het falen van de strijd voor menswaardige arbeidstijden werd door de katholieke hoogleraar Raaijmakers aangevoerd dat de werknemers slecht georganiseerd waren en de stakingskas onvoldoende gevuld was: "Organisatie en werkstaking mogen een middel zijn om een korteren arbeidsduur te verkrijgen; dit middel staat alleen ter beschikking van een bepaald gedeelte der arbeiders, terwijl degenen die het 't meest zouden noodig hebben, het dikwijls niet kunnen aanwenden." 154 Wat hierbij echter meeweegt, en wellicht nog zwaarder dan de vakbondsorganisatie, was het simpele gegeven dat de arbeidende klasse nog geen stemrecht had en de SDAP slechts met zeven zetels in de Tweede Kamer vertegenwoordigd was. Ook had de voorkeur, juist onder confessionelen, voor vrijwillige regeling door 'beroepsstanden' een fnuikend effect op wettelijke regelgeving. De terughoudende opstelling van de confessionelen bleek eens te meer uit de minimale wijziging van de Arbeidswet in 1911. ${ }^{155}$ De Anti-Revolutionaire minister Talma beperkte weliswaar de arbeidsduur van jongeren en vrouwen en de mogelijkheden tot nachtwerk voor deze groepen, maar een regeling voor mannelijke arbeiders blijft nog steeds onbespreekbaar; mannen hoorden immers niet tot de personae miserabiles.

Het duurde tot 1919 vooraleer de achturendag wettelijk was geregeld. Gegeven de weerstanden tegen een wettelijke regeling van een decennium eerder was dat overigens een tamelijk snelle omslag, die samenhing met een aantal ingrijpende wijzigingen in de politieke en arbeidsverhoudingen in de jaren na 1914: de sterk stijgende organisatiegraad van de vakbonden ${ }^{156}$, een sterke aanwas van het ledental van de SDAP en de invoering van het algemeen kiesrecht voor mannen in 1917 (waardoor de arbeiderspartijen 30 procent van de Kamerzetels haalden ${ }^{157}$ ). In 1918 was bovendien het aantal gestaakte dagen hoger dan ooit tevoren. ${ }^{158}$ Dit alles bezien tegen de achtergrond van de Russische Revolutie en de sociale onrust in met name Midden-Europa, is het verklaarbaar dat de ontwikkelingen op de tijdgenoten de indruk moeten hebben gemaakt "alsof de kalm aanrollende golf zich plotseling tot een dreigende branding verhief". 159

154 Raaijmakers 1908. p. 349-350

155 De Arbeidswet 1911 verbood arbeid door 13-jarigen, verhoogde de leeftijdsgrens voor jongeren tot 17 jaar, en de duur van de arbeidsdag voor vrouwen en jeugdigen werd verlaagd naar 10 uur.

156 Niet in de laatste plaats met het oog op de door de vakverenigingen georganiseerde werkloosheidskassen, maar ook doordat de vakbeweging steeds meer geaccepteerd werd (onder meer door het toenemend aantal CAO's na 1911. maar ook door de gematigde opstelling tijdens de Eerste Wereldoorlog) en vakbondsleden minder hoefden te vrezen voor ontslag of zwarte lijsten. Vgl. o.a. S. Mok (1947), De Vakbeweging: ontwikkelingsschets en problemen, Amsterdam: Vrij Nederland, p. 144: A. van den Berg (1999), De vakbeweging. 1907-1997, in: R. van der Bie en P. Dehing (red.), Nationaal Goed: Feiten en cijfers over onze samenleving (ca.) 1800-1999. Voorburg/Heerlen: CBS, p. 130

157 Voor een overzicht van de ontwikkeling van het zetelaantal voor de 'linkse' partijen zie: Van der Velden 2000, p. 329

158 Van der Velden 2000 , p. 321-322

159 L. Heerma van Voss (1994), De doodsklok van den goeden ouden tijd, Amsterdam: IISG, p. 23 
Het is evident dat de angst voor de revolutie van doorslaggevende betekenis is geweest voor het tot stand komen van allerhande sociale wetgeving, in het bijzonder de regeling van de achturendag. ${ }^{160}$ Nog op 9 november 1918 had de regering zeer terughoudend gereageerd op initiatieven om te komen tot een regeling van de arbeidsduur van volwassen arbeiders, maar een maand later meldde zij zo spoedig mogelijk met een wettelijke regeling te komen. ${ }^{161}$ In haar proclamatie van 20 november 1918 sprak Koningin Wilhelmina van "het verlangen de voorgenomen hervormingen door te zetten en aan te vullen met de snelheid die past bij den polsslag van deze tijd". ${ }^{162}$ Ook de Vereeniging van Nederlandsche Werkgevers (VNW) ging, in november 1918, akkoord met de eis van werknemers tot een achturige werkdag. ${ }^{163}$ Vele bedrijven, waaronder Philips, Calvé en Van Houten, wachtten de wetgeving niet af en voerden in november zélf een achturige werkdag in. ${ }^{164}$

Op 11 april 1919 diende minister Aalberse een voorstel in voor een nieuwe wet, 'houdende bepalingen ter beperking van de arbeidsduur in het algemeen en tot het tegengaan van gevaarlijke arbeid van jeugdige personen en vrouwen.' In het wetsvoorstel was voor het eerst een regeling opgenomen voor een achturige werkdag, en wel voor élke werknemer - dus 6́6k voor de mannelijke arbeider. Daarmee was, volgens Geers, de principiële, ideologische en politieke strijd omtrent wettelijke maatregelen ter bescherming van de werknemers gestreden. ${ }^{165}$ Die bewering is echter wat al te boud: nog geen twee jaar na de inwerkingtreding in 1920 werd (zoals Geers zelf ook aangeeft), als gevolg van de economische crisis de achturige werkdag weer verlengd tot $8 \frac{1}{2}$ uur en de 45 -urige werkweek opgeschroefd naar 48 uur; dit ondanks een demonstratief congres van de NVV op I november 1921. ${ }^{166}$ In 1923 werkte 82 procent van de arbeiders alweer 48 uur. ${ }^{167}$ Desondanks betekende de Arbeidswet in principiële zin toch wel "de doodsteek voor de klassieke liberale theorie dat de arbeidsovereenkomst slechts gezien moest worden als een contract tussen twee individuen, waar de overheid buiten moest blijven." 168 Ideologisch bezien, en daarin heeft Geers gelijk, is het point of no return gepasseerd: dat arbeiders recht hebben op wettelijke bescherming is sinds 1919 niet meer serieus ter discussie gesteld.

Overigens sputterde de katholieke minister Aalberse tijdens de Kamerbehandeling

160 Harmsen/Reinalda 1975, p. 132. Zie ook Bruggeman/Camijn 1999, p. 100

161 Gecit. in Van Drongelen 1990, p. 188-189

162 Ibid. 1990, p. 187

163 Bruggeman/Camijn 1999, p. 101

164 Heerma van Voss 1994, p. 39

165 Geers 1988, p. 53

166 Heerma van Voss 1994, p. $48 \mathrm{ff}$

167 Ibid. 1994. p. 52

168 Ibid. 1994. p. 13. Overigens werd al in de behandeling van de wet op de arbeidsovereenkomst (1907) het besef verwoord dat het 'vrije contract' in feite een overeenkomst was tussen ongelijke partijen. waarbij de wetgeving ervoor moest zorgen dat in het arbeidscontract een vorm van ongelijkheidscompensatie zou worden opgenomen: "Het komt er slechts op aan dat men het sluiten van zoodanige contracten met genoegzame waarborgen omkleedt aan de zijde der zwakkere partij, waardoor deze de gelijke wordt harer wederpartij." Memorie van Antwoord bij het ontwerp van de Wet op de arbeidsovereenkomst, geciteerd in: Bles 1907, p. 114 
op één punt nog wel tegen: "Een arbeidswet als de nu voorgestelde zou onnodig zijn, wanneer bij werkgevers en werknemers de organisatie in voldoende mate tot ontwikkeling ware gekomen, en de Overheid zou kunnen volstaan met wettelijke sanctie te verleenen aan tusschen de wederzijdsche organisaties, na vrij overleg, tot stand gekomen regelingen". ${ }^{169}$ Deze gedachte, dat de overheid zich zou kunnen of zelfs moeten beperken tot het toezicht op privaat vastgestelde regelingen, zal na 1919 nog geregeld de kop opsteken, in het bijzonder in de discussies sinds de jaren 80 (vgl. par. 2.5).

\section{Tussenbalans}

De periode 1870-1919, de 'formatieve periode in de ontwikkeling van de sociale politiek en het stelsel van sociale zekerheid', ${ }^{170}$ valt te typeren als een tijdperk van strijd: strijd voor betere arbeidsomstandigheden en betere arbeidstijden (waarbij het accent mettertijd verschuift van veiligheid naar werktijd) ${ }^{171}$, strijd met name ook voor de erkenning van de rechten van de arbeiders en van de institutionele positie van hun vertegenwoordigers. De relatieve hitte van die strijd en de wisselende uitkomsten hangen mijns inziens nauw samen met een aantal factoren uit het analytisch schema 2.1.3.

Zelfs al houdt een analyse zich verre van 'laatste instantie'-verklaringen, tóch lijkt evident dat met name de economische ontwikkelingen in de betreffende periode een belangrijke rol hebben gespeeld. Aanvankelijk was de negentiende eeuw zonder meer te typeren als de era van de ondernemers: de vraag naar arbeid was zo beperkt en de armoede zo groot, dat de arbeiders (zo die term al gebruikt kan worden) nauwelijks een vuist konden maken voor meer menswaardige arbeidsomstandigheden. Sterker nog: arbeid was tot eind jaren ' 50 dermate schaars, dat het in dienst nemen van een arbeider welhaast kon worden gezien als blijk van barmhartigheid van de zijde van de ondernemer, als 'gift' aan de arme. ${ }^{172}$ De term 'werkgever' als opvolger van 'patroon' heeft daarmee tevens een in mijn ogen tamelijk sterke normatieve lading. Deze speelde, ook nadat de alleenheerschappij van de ondernemers was vervangen door een 'klassenmaatschappij', nog een belangrijke rol in de discussies over de verhouding staat/bedrijf en over de rechten van arbeiders, en heeft mijns inziens ook heden ten dage nog weinig aan kracht ingeboet. Met de opkomst van de industrie echter groeide de behoefte aan goed geschoold personeel, en met de toenemende schaarste aan gekwalificeerde arbeiders kwamen deze in principe in de positie om eisen te stellen aan de arbeidsomstandigheden en de arbeidstijden, al zou in de praktijk de loonstrijd toch veelal prevaleren. Tot het eind van de negentiende eeuw legde de toegenomen competentiemacht van de arbeiders echter nog niet bijzonder veel gewicht in de schaal. Pas in de eerste twee decennia van de twintigste

169 Kamerstukken $/ 1$ 1918-1919, 408.5 (Memorie van Antwoord), geciteend in Van Drongelen 1990, p. 195

170 Bruggeman/Camijn 1999. p. 21

171 Buitelaar/Vreeman 1985, p. 84

172 Brugmans 1925, p. 189 
eeuw kwam de vakbond als serieuze gesprekspartner duidelijker in beeld, met name door een toenemende organisatiegraad en een betere interne organisatie, maar ook door een tamelijk gematigde opstelling tijdens met name de Eerste Wereldoorlog. Het gemak waarmee de Arbeidswet 1919 al in 1922 deels weer werd teruggedraaid, is echter een niet mis te verstane eerste indicatie dat de betrokkenheid en bescherming van de arbeiders aan conjuncturele schommelingen blootstaan.

Naast de economische context speelde ook de technologische ontwikkeling een rol. zij het een tweeslachtige. Enerzijds leidde de technologische ontwikkeling tot een industriële revolutie en, door het toenemend aantal arbeiders in de industrie en de schaalvergroting bij de productie, tot een toenemende gevaarzetting en een daadwerkelijk toenemend aantal ongevallen. Aan de andere kant bood de technologische ontwikkeling de mogelijkheid om meer geavanceerde veiligheidstechnieken in te zetten - zoals bij de veiligheidstentoonstelling 1890 werd getoond. Deze ambivalentie in de technologische ontwikkeling en de keuzes die worden gemaakt in de toepassing van bepaalde technieken is inzet van bedrijfspolitieke keuzes en daarmee een arbeidsverhoudingenvraagstuk - dat hier verder niet uitgediept zal worden. In de strijd om sociale wetgeving, in casu op het gebied van veiligheid en gezondheid, speelden naast economische en technologische factoren ook normatieve aspecten een rol. Zoals gezegd was aanvankelijk het normatief beladen 'werkgever'-schap dominant, aangevuld met zowel een traditioneel protestants-christelijk paternalisme ${ }^{173}$, een door alle confessionelen gedragen verzoeningsdenken (tegen de socialisten), én het idee dat wetgeving de ontwikkeling van morele en zedelijke waarden in de weg zou staan: "Stelt de wetgever het ethisch minimum vast, zoo vervult hij een voortreffelijke taak [..] Maar gaat de wetgever verder en vervolgt hij overal, waar het ontluikt, het autonome recht met den gesel van de uniformiteit en de lasso van den dwang, dan zal op den duur [..] de zedelijke grondslag van ons handelen verloren gaan. Wij zien dan alleen naar de wet en lezen uit haar af wat geoorloofd is en wat niet."174 $\mathrm{Na} 1874$ echter groeide allengs het besef van de redelijkheid van rechtsbescherming van de zwakkeren ${ }^{175}$. Dit besef kan worden beschouwd als een van de pijlers onder het modernistische paradigma van het arbeidsrecht. ${ }^{176}$ Zeker met de erkenning van de volwassen mannelijke arbeider heeft een fundamentele verschuiving plaatsgevonden in het mensbeeld ${ }^{177}$, die eigenlijk tot in de jaren ' 70 van de twintigste eeuw bepalend is voor het denken over regelgeving op het gebied van veiligheid en gezondheid.

$173 \mathrm{Vgl}$ de gememoreerde opstelling van Patrimonium tegen sociale wetgeving, maar ook de opstelling van Kuyper.

174 Molenaar 1927, p. 25

175 Niet alleen in het arbeidsrecht, maar ook in bijvoorbeeld het huurrecht ontstond in de jaren

'70 van de $19^{c}$ eeuw een vorm van ongelijkheidsnivellering, of 'vermaatschappelijking' van het recht. Van Peijpe 1985, p. 12

176 P.F, van der Heijden. Een nieuwe rechtsorde van de arbeid: op zoek naar een andere architectuur van het arbeidsrecht. In: NJB, Jaargang 72 (1997), p. 1837

177 G.J.J. Heerma van Voss (1996), Van onmondige arbeid tot calculerende burger: Het mensbeeld in het arbeidsomstandighedenrecht 1946-1996, in: C.J. Loonstra, H.W.M.A. Staal en W. Zeijlstra (red.). Arbeidsrecht en mensbeeld 1946-1996, Deventer: Kluwer, p. 143 
De interpretatie van diverse maatschappelijke ontwikkelingen hangt uiteraard sterk samen met de zojuist geschetste normatieve inkadering: aanvankelijk bestónd de arbeidersklasse nauwelijks, en zij kon dus ook haar interpretatie van de erbarmelijke levensomstandigheden niet tot gelding brengen. De armoede en de ellende waren een individueel lot van de arme, níet een uitvloeisel van maatschappelijk bepaalde productie- c.q. klassenverhoudingen. Pas de voorzichtige subjectwording van de arbeiders als klasse, juist ook door de strijd voor een menswaardig bestaan, maakt het mogelijk dat bijvoorbeeld het concept van de emancipatie van die arbeiders, een tweede pijler onder het arbeidsrechtelijk paradigma ${ }^{178}$, is opgekomen én daarmee een leidend beginsel werd achter de ontwikkeling van de sociale wetgeving. Een remmende ontwikkeling op de sociale wetgeving ging uit van de confessionele interpretatie van de verhouding tussen werkgever en arbeiders. Daarbij impliceert alleen al de term 'patroon' een goedertierenheid die interpretaties van arbeidsverhoudingen als fundamentele ongelijkheid en daarmee sociale wetgeving als ongelijkheidscompensatie in de weg staat.

Regels waaruit geput kon worden in de strijd voor betere leef- en arbeidsomstandigheden waren aanvankelijk uiterst beperkt. Voor de werkgevers was de arbeidsverhouding. gegrondvest in artikel 1638-1639 BW, de codificatie van een vrijwel absolute machtspositic. De machtsongelijkheid werd weliswaar ten dele gecompenseerd in de Wet op de arbeidsovereenkomst (1907), maar het axioma van de 'persoonlijk onderschikkende arbeid' (het zogeheten 'instructierecht') handhaafde nog steeds een fundamentele ongelijkheid in het hart van de arbeidsverhouding. De normen uit de Arbeidswet en de Veiligheidswet (in het bijzonder de AMvB's) gaven de individuele werknemer weliswaar recht op bescherming. gekoppeld bijvoorbeeld aan het klachtrecht, maar die regels waren voor het voeren van een strijd voor nieuwe regelgeving nauwelijks ondersteunend. Het verbod op staking, het zogeheten coalitieverbod, werd in 1872 afgeschaft, maar stakingen met het oog op betere arbeidsomstandigheden waren toch schaars. ${ }^{179}$ Belangrijk is, wellicht op dat moment nog niet praktisch maar wél principieel, de pacificatie van de civielrechtelijke aansprakelijkheid in het BW door de Ongevallenwet. Dit sloeg de arbeiders een middel uit handen om in te zetten - eventueel gekoppeld aan een collectieve strategie, zoals heden ten dage door het Bureau Beroepsziekten.

Regels zijn slechts één van de bronnen die de arbeiders (en uiteraard ook de ondernemers) kunnen mobiliseren in de strijd om de regelgeving. De arbeiders en dan met name hun vertegenwoordigers hebben er in de loop van een halve eeuw strijd voor betere leef- en arbeidsomstandigheden legio ingezet, zoals onderzoeken/enquêtes, adressen, demonstraties, agitatie in de pers en in het parlement, en stakingen. Allianties met derden, bijvoorbeeld vooruitstrevende geledingen binnen de wetenschap of zelfs de verlichte bourgeoisie, zijn bij mijn weten schaars. Ook een

178 Van der Heijden 1997, p. 1837

179 Een uitzondering was een staking, in 1916, voor betere arbeidsomstandigheden in het leger. Vgl. D. Schilp (1967), Dromen van de revolutie, Amsterdam: Wereldbibliotheek. Voor een overzicht van het aantal institutionele beperkingen op de stakingsvrijheid zie Van der Velden 2000. p. 261-262 
voor de hand liggend bondgenootschap met de Arbeidsinspectie kwam niet van de grond. Integendeel: zeker in het begin werden de inspecteurs gezien als afgevaardigden van de burgerlijke staat of op zijn best als ongewenste bemoeials. Politieke allianties waren er wel, zeker na oprichting van het NVV in 1906, maar de arbeiderspartijen kregen door het beperkte kiesrecht tot 1918 nauwelijks voet in het parlement. Een belangrijke doorbraak kwam met de interne organisatie van de vakbeweging. Juist de gebrekkige organisatie van de vakbeweging was volgens NVV-voorman Kupers een van de hoofdoorzaken voor de trage wetgeving in Nederland. ${ }^{180}$ Het belang van een georganiseerd, institutioneel overleg wordt echter vooral duidelijk ná 1919 en zal een van de centrale thema's zijn in de volgende paragrafen.

\subsection{Water (1919-1963)}

Vurige levenskrachten sterven als ze verwateren ......

Herakleitos, Fragment B 36

De revolutionaire stemming van eind 1918, die van doorslaggevende betekenis was voor de totstandkoming van de Arbeidswet, hield niet lang aan: "De revolutie ebde

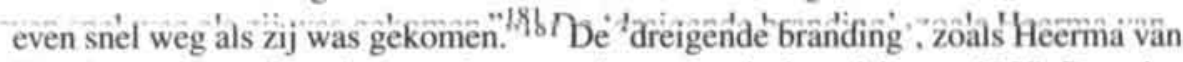
Voss het verwoordde, sloeg te pletter op de economische crisis van 1920. De achturige werkdag werd, op aandrang van de werkgevers, ten dele teruggedraaid. Maar net zo min als de revolutie volledig uit de lucht kwam vallen, gezien de voorafgaande decennia van incidenteel oplaaiende agitatie, was het na 1920 volledig gedaan met de arbeidsbescherming en de invloed van de arbeiders. Weliswaar werden de arbeidstijden weer opgerekt, maar bij lange na niet tot het niveau van begin twintigste eeuw. ${ }^{182}$ De legitimiteit van wettelijke regulering van de arbeidstijden en de arbeidsomstandigheden werd nauwelijks nog serieus betwist.

Daarnaast waren steeds meer werkgevers ervan overtuigd dat de vakbonden moesten worden gezien als serieuze onderhandelingspartners - sommige contre-caur, uit angst voor de revolutie, maar sommige ook door de coöperatieve opstelling van de bonden vlak voor en tijdens de Eerste Wereldoorlog. Daarin speelde de opkomst van de CAO een belangrijke rol: landelijke CAO's reguleerden de arbeidsmarkt en zorgden voor gegarandeerde arbeidsrust over de looptijd van de overeenkomst. ${ }^{183}$ Werkgevers en overheid pasten zich steeds meer aan bij het bestaan van de vakbonden en waren zelfs bereid deze tot op zekere hoogte bij fundamentele besluitvormingsprocessen op nationaal niveau of binnen de bedrijfstak te accepteren als

180 E. Kupers, in: Romme 1939, p. 14

181 Bruggeman/Camijn 1999, p. 101

182 In de periode rond de eeuwwisseling werkte meer dan $40 \%$ van de volwassen mannen méér dan II uur per dag. $\mathrm{Vgl}$. Arbeidsinspectie (1910), Eenige gegevens omtrent werktijden in de industrieele bedrijven, Den Haag: Departement van Landbouw, Nijverheid en Handel, p. 7

183 Anno 1920 waren bijna 1000 CAO's afgesloten, met een dekking van 22.000 bedrijven en ruim 2,7 miljoen werknemers. Bruggeman/Camijn 1999, p. 179 
partners. ${ }^{184}$ De installatie van de (tripartite) Hooge Raad voor de Arbeid in 1920 , een "adviescollege der Regeering", was een eerste formele erkenning van de positie van de vakbonden. ${ }^{185}$ Ook hierbij was het streven naar sociale vrede een achterliggend motief. ${ }^{186}$ Doel van de Raad was het betrekken van 'maatschappelijke organen' (i.c. de vakverenigingen van werkgevers én arbeiders) bij de ontwikkeling van sociale wetgeving, zij het hooguit in de vorm van advies. ${ }^{187}$ De Hooge Raad speelde een grote rol bij de snelle uitbreiding van de arbeidswetgeving na 1918 , vooral met betrekking tot de talrijke uitvoeringsbesluiten van de Arbeidswet in $1920-1921 .^{188}$

\section{Medezeggenschap op bedrijfsniveau}

Ook op bedrijfsniveau werd de medezeggenschap van de arbeiders allengs meer erkend. In het begin van de jaren ' 20 kenden ongeveer 100 bedrijven een vorm van medezeggenschap in de vorm van een zogeheten 'bedrijfskern'. ${ }^{189}$ De figuur van de kern, een vertegenwoordiging van de arbeiders, was in 1878 geïntroduceerd door de industrieel J.C. Van Marken bij de Gist en Spiritusfabriek Delft en in 1883 bij de machinefabriek van Stork in Hengelo. Deze kernen waren met name gericht op het geregeld overleg met de arbeiders inzake de uitvoering van een aantal sociale voorzieningen zoals een uitkering bij ziekte of spaarregelingen. Terwijl de vakbonden zich aanvankelijk hadden verzet tegen de kernen als instrument om de vakbeweging buiten de deur te houden ${ }^{190}$, werd rond de Eerste Wereldoorlog de kern welwillender tegemoet getreden. In incidentele gevallen verliep de verkiezing van de kernleden zelfs via de vakbond. ${ }^{191}$

184 Windmuller/De Galan/Van Zweeden 1983, p. 79

185 Koninklijk Besluit van 4 oktober 1919 (Stb. 591)

186 Bruggeman/Camijn 1999, p. 104. Ook Van Bottenburg betitelt de Hooge Raad als een pacificatie-instrument, dat ook bijzonder goed als zodanig werkte omdat de elites een hecht netwerk gingen vormen en men iedereen binnenboord wilde houden. M. van Bottenburg (1995), Aan den Arbeid:: in de wandelgangen van de Stichting van de Arbeid, 1945-1995, Amsterdam: Bert Bakker, p. 20

187 In het organisatiebesluit was de mogelijkheid opgenomen dat de Hooge Raad, in opdracht van de Minister, zélf regelingen zou kunnen ontwerpen (art. 1, lid 3), die de status zouden krijgen van een soort publiekrechtelijke collectieve arbeidsovereenkomst. Zo veel mogelijk zou men die regelingen overlaten aan het overleg van de organisaties van werkgevers en arbeiders, die in die commissies vertegenwoordigd zouden zijn. De overheid zou die regelingen moeten sanctioneren (vgl. Van Drongelen 1990, p. 195). In de praktijk is deze mogelijkheid nooit toegepast. A.W. Quint (1940). Twintig jaar Hooge Raad van Arbeid. Haarlem: H.D. Tjeenk Willink. p. 15. De invloed van de adviezen van de Hooge Raad was echter groot: $80 \%$ van de adviezen werd geheel of gedeeltijk opgevolgd. Ibid, p. 18

188 Ook adviseerde de Hooge Raad de regering over medezeggenschap en bedrijfsorganisatie. Hooge Raad van Arbeid (1923). Preadvies van Commissie XII over vraagpunten betreffende bedriffsonganisatie, etc., Den Haag: Hooge Raad van Arbeid.

189 Centraal Verslag der Arbeidsinspectie 1922, aangehaald in R.H. van het Kaar (red.). De ondermemingsraad (losbladig), Deventer: Kluwer, InL. 2, p. 4

190 Harmsen/Reinalda 1975, p. 143

191 Algra 1989. p. 54 
Daarnaast kwam het dénken over medezeggenschap in een stroomversnelling, en wel langs diverse ideologische lijnen. Vanuit confessionele hoek, met name door de katholieke hoogleraar Veraart, werd gewerkt aan het idee van de publiekrechtelijke bedrijfsorganisatie als tegenwicht tegen enerzijds het chaotische kapitalisme met zijn conjunctuurcycli en anderzijds de dreiging van het socialisme. ${ }^{192}$ Veraarts notie van paritaire bedrijfsraden sloot aan bij de katholieke opvattingen omtrent corporatisme en het subsidiariteitsbeginsel: op termijn zouden de bedrijfsraden in samenwerking met de overheid (mede)wetgever moeten worden op het gebied van sociale wetgeving. ${ }^{193}$ De opvattingen van Veraart vonden aanvankelijk brede steun in katholieke kring, maar waren weinig revolutionair. ${ }^{194}$ In 1920 trokken de katholieke ondernemers bovendien hun steun voor het idee van bedrijfsraden in, hetgeen het einde betekende van de R.K. Bedrijfsradenbeweging.

De ideeën uit socialistische hoek waren radicaler. In 1920 publiceerde de SDAP een rapport waarin medezeggenschap werd gezien als een eerste stap in de "vermaatschappelijking van de produktie ter voorbereiding van de vestiging van het socialisme." 195 Elk bedrijf zou een door de vakbeweging gecontroleerde, zij het uit alle werknemers te kiezen, personeelsraad moeten instellen. Deze zou met de directie moeten overleggen over productieverhoging, het aannemen en ontslaan van arbeiders, overwerkregelingen, werktijdverkorting enzovoort. Op bedrijfstakniveau zouden bedrijfsraden moeten worden ingesteld, bestaande uit werkgevers, werknemers, overheid en consumenten, die de werkelijke socialisatie van de productie zouden moeten organiseren. ${ }^{196}$ In 1923 waren de ambities van de SDAP echter al getemperd. In het rapport "Bedrijfsorganisatie en medezeggenschap" schetsten SDAP en NVV bedrijfsorganisatie weliswaar als tussenstap naar socialisatie van het particuliere bedrijf, maar "zonder aan het partikuliere karakter van het bedrijf een einde te maken."197 Doel van de socialisatie was niet langer economische zeggenschap. maar "dat de gemeenschap demokratiese zeggenschap krijge over de voortbrenging"198 - bijvoorbeeld door afspraken over standaardisering en verbetering van de

192 Vgl. W.G.J.M. Tomassen (1974), Het R.-K. bedrijfsradenstelsel (1919-1922): De cerste poging tot publiekrechtelijke bedrijfsorganisatie op organisch-solidaristische grondslag binnen de moderne industriële samenleving, Leiden, z.n.

193 Windmuller/De Galan/Van Zweeden 1983, p. 69. Overigens wilde de Anti-Revolutionair Talma in de periode 1908-1913 al bipartite Raden van de Arbeid instellen (werkgevers/werknemers onder leiding van een onafhankelijke voorzitter). met als taak medewerking bij de uitvoering van sociale wetten én de bevoegdheid verordeningen uit te schrijven. Bruggeman/Camijn 1999, p. 97

194 T. van Zeeland (1993), De juiste katholieke moraal en ethiek in handel \& industrie, in: Tilburg. tijdschrift voor geschiedenis, monumenten en cultuur, jaargang 11 (3), p. 62-78

195 F.M. Wibaut (1920). Het socialisatievraagstuk: rapport uitgebracht door de Commissie aangewezen uit de S.D.A.P. Amsterdam: Ontwikkeling

196 Werkgroep Economisch-Historisch Seminarium (1972), Medezeggenschap en conjunctuur in de jaren na de Eerste Wereldoorlog. Universiteit van Amsterdam, p. 289

197 J. van den Tempel et al. (1923), Bedrijfsorganisatie en medezeggenschap: rapport uitgebracht door de Kommissie ingesteld door N.V.V. en S.D.A.P., Amsterdam: Ontwikkeling, p. 25 198 Ibid., p. 7 
bedrijfstechniek en over verbetering van de vakopleiding. Deze weinig revolutionaire vorm van bedrijfsbeheer zou moeten worden uitgeoefend door tripartite bedrijfsraden op bedrijfstakniveau. Deze bedrijfsraden zouden ook verboden moeten kunnen uitvaardigen op "verouderde, gevaarlike of voor de gezondheid schadelike produktie-methoden". ${ }^{199}$ De verorderingen op bedrijfstakniveau zouden moeten worden goedgekeurd door een tripartite Centraal Ekonomiese Raad.

Op het niveau van de afzonderlijke ondernemingen zouden, in bedrijven met meer dan 20 werknemers, ondernemingsraden ingesteld moeten worden. De taken van deze OR'en waren beperkt: met name toezicht op naleving van de CAO, uitwerking van CAO-bepalingen op bedrijfsniveau voor zover de CAO daarvoor ruimte liet (een idee dat in onder meer de arbowetgeving aan het eind van de twintigste eeuw nieuw leven zou worden ingeblazen - vgl. par. 2.5), overleg over de handhaving van de orde en de goede gang van zaken in de onderneming, toezicht op de naleving van de arbeidswetten en contact met de Arbeidsinspectie.

$\mathrm{Na} 1923 \mathrm{kwam}$ een tamelijk abrupt einde aan de medezeggenschapsdiscussie. ${ }^{200}$ Als gevolg van de aanhoudende laagconjunctuur zetten de werkgevers de aanval in op de lonen, en de bonden hadden bij gevolg geen tijd meer voor theoretische bespiegelingen over medezeggenschap en bedrijfsorganisatie. ${ }^{201}$ Zeker na de beurskrach van 1929 en de daaropvolgende crisisjaren was het revolutionaire vuur gedoofd en zijn bespiegelingen over een democratische bedrijfsorganisatie schaars. ${ }^{202}$ Medio jaren ' 30 herkreeg het concept van de bedrijfsorganisatie serieuze aandacht, maar dan primair als instrument om de crisis te beheersen. ${ }^{203} \mathrm{Na}$ de Tweede Wereldoorlog werd een "ontwerp van een hoofdstuk ener wettelijke regeling van de publiekrechtelijke organisatie van het bedrijfsleven" gepubliceerd - de eerste aanzet tot de Wet op de ondernemingsraden van $1950 .{ }^{204}$

\section{Medezeggenschap in de arbeidstijden- en veiligheidswetgeving}

Tegen deze achtergrond van allengs zich uitkristalliserende arbeidsverhoudingen, kregen de arbeiders begin jaren ' 20 voor het eerst een plaats toebedeeld in de arbeidswetgeving anders dan louter als te beschermen categorie. In 1922 werd, door aanpassing van artikel 28 van de Arbeidswet, de mogelijkheid geboden tot afwijking van sommige wettelijke normen "indien zoowel vakverenigingen van

\footnotetext{
199 Ibid. p. 97

200 Werkgroep Economisch-Historisch Seminarium 1972, p. 292

201 Ibid. p. 319
}

202 Overigens bleek uit de uitvoeringspraktijk van de Ziektewet 1929 dat de samenwerking tussen werkgevers en vakbonden in de bedrijfsvereniging ook wel van de grond kwam zónder theorievorming, en tot ieders tevredenheid. Zie ook Bruggeman/Camijn 1999. p. 109-110

203 Van Bottenburg 1995, p. 24-25

204 A.A. van Rhijn et al. (1947), Ondernemingsnaden: Rapport uitgebracht op 19 september 1947 door de commissie ter bestudering van het vraagstuk ener wettelijke regelingvan de onderne. mingsraden, Den Haag: Staatsdrukkerij en Uitgeverijbedrijf. Het rapport-Van Rhijn ademde zeer sterk de geest van samenwerking die na de oorlog heerste, en legde het prerogatief in de bedrijfsvoering eenzijdig bij de ondernemer. Desondanks waren ook de vakbonden overwegend positief over het ontwerp. Voor een kritische beschouwing vgl. Harmsen/Reinalda 1975, p. 317-319 
werkgevers als van arbeiders in een bedrijf - of bij ontstentenis hiervan eene behoorlijke vertegenwoordiging van werkgevers en arbeiders uit een bedrijf - van oordeel zijn, dat het gewenscht is in eene onderneming of in eene groep van ondernemingen waarin dat bedrijf wordt uitgeoefend, af te wijken van het bepaalde bij de artikelen 22, derde lid [verbod op zondagsarbeid voor mannen]. 23 [verbod op zaterdagmiddagwerk voor mannen] of 24 [maximum werktijden]." De overheid zou hiervoor dan een vergunning moeten afgeven. Het betrof hier zogeheten verschuivingsvergunningen, waarbij het aantal gewerkte uren het jaarmaximum van 2500 uur niet mocht overschrijden. ${ }^{205}$ Van de mogelijkheid tot afwijking van de standaardvoorschriften werd zelden gebruik gemaakt, niet in de laatste plaats omdat de werkgevers vreesden voor een veto van de bonden: "Men beoefent aldus zijn bedrijf a la merci der werknemers en dit is een eersten stap op den weg der bedrijfsraden." 206

Hoewel de zogeheten novelle van 1922 in de praktijk weinig effect had ${ }^{207}$, impliceerde zij wel een principiële doorbraak. Voor het eerst, zo stelde Diepenhorst in retrospectief, waren "patroons en arbeiders [..] niet langer object van de publieke regeling van den Staat, maar door georganiseerd overleg zelve subject, dragers en grondleggers der arbeidsregeling." 208 De katholieke voorman Romme plaatste de novelle van 1922 in het kader van een bredere discussie over de verhouding tussen overheid en sociale partners. Romme achtte "zelfwerkzaamheid in en door bedrijfsgemeenschappen" de belangrijkste waarborg voor individuele vrijheid, en nodeloos Staatsingrijpen de belangrijkste bedreiging voor de vrijheid. ${ }^{209}$ De voormalig minister van Sociale Zaken zag dat in de Arbeidswet "nog schuchter een verandering [is] opgekomen door de groeiende mogelijkheid, dat op andere wijze dan door Staatsinmenging misstanden uit den weg te ruimen zijn." 210

Ook na 1922 werd geleidelijk meer plek ingeruimd voor medezeggenschap op het gebied van veiligheid en gezondheid. In 1929 nam de Hooge Raad van Arbeid het initiatief tot het instellen van veiligheidscommissies in bedrijven. ${ }^{211}$ Hoewel de Raad de tijd nog niet rijp achtte voor wettelijke regeling, kwam het voorstel in 1931 toch terecht in het ontwerp voor een nieuwe Veiligheidswet. ${ }^{212}$ Artikel 21 van het

205 Van Drongelen 1990, p. 197. Dit model van beleidsvrijheid binnen wettelijk vastgestelde grenzen zou tegen het eind van de $20^{\circ}$ eeuw weer opduiken in de Arbeidstijdenwet van 1996. Wet van 23 november 1995, houdende bepalingen inzake de arbeids- en rusttijden (Arbeidstijdenwet). Stb. 1995. 598. Naast artikel 28, lid 7, van de Arbeidswet 1919 is ook artikel 97 van belang, dat de vakverenigingen het recht gaf de minister te verzoeken om verlening of intrekking van een vergunning. Vgl. Hacke, A.H.W. (1931), De sociaal-economische beteekenis der Arbeidswet (19/9), Groningen: Wolters, p. 87-88

206 Steenfabrikant M.J. van Löben Sels, Klei, 15/8/1921, geciteerd in Heerma van Voss 1994. p. 56

207 Van Drongelen 1990, p. 198

208 P.A. Diepenhorst, Rede in: Romme 1939, p. 22-23

209 Romme 1939. p. 10-11

210 ibid. p. 9

211 Quint 1940, p. 29

212 Eerder al figureerde de Veiligheidscommissie in artikel 19bis van de Stuwadoorswet van 27 juli 1931 (Stb. 331). 
wetsontwerp dichtte de commissie een adviserende taak toe, "bestaande in de bevordering van de veiligheid en het voorkomen van schade aan de gezondheid bij en door de arbeid in eene onderneming." Daarnaast had de commissie, blijkens de Memorie van Toelichting, als taak "het bevorderen van de orde en [..] het opwekken van de arbeiders om voortdurend op eigen veiligheid en gezondheid bedacht te zijn." 213 Deze redactie was voornamelijk ingegeven door een akkoord ter zake tussen de gezamenlijke bonden en de Vereeniging van Nederlandsche Werkgevers. ${ }^{214}$ De Veiligheidscommissies zouden moeten worden ingesteld op grond van een AMvB, dan wel op basis van vrijwilligheid (waarna de overheid de vrijwillige commissie zou moeten erkennen). De commissies zouden moeten functioneren op grond van een reglement dat eveneens bij AMvB zou worden vastgesteld. Dit reglement zou niet generiek gelden, maar toegesneden moeten zijn op de aangewezen bedrijfstak. "Hierdoor wordt het mogelijk gemaakt met het bijzondere karakter en de bijzondere behoeften van elk bedrijf rekening te houden"215. Deze gedachte is een voorafschaduwing van het concept van 'maatwerk', dat in de jaren ' 90 opgang zou doen (vgl. par. 2.5). Het opstellen van het reglement zou een overheidstaak blijven, overigens "na het horen van de vakverenigingen van werkgevers en van arbeiders". Ook erkenning (of opheffing) van de Veiligheidscommissies was pas mogelijk na overleg met vakverenigingen. Beide bepalingen zijn een duidelijke indicatie van de inmiddels tamelijk onomstreden positie van de vakverenigingen. 'vo'ii jaren' 30, op het gebied van veligheid en gezondheid. Ook vormden zij op papier $^{216}$ een bijdrage aan de verdere institutionalisering van de arbeidsverhoudingen in Nederland; al was bijvoorbeeld de Ziektewet 1929, met zijn paritair bestuurde bedrijfsverenigingen, zonder meer van groter belang.

\section{Decentralisatie en arbeidsverhoudingen}

De parlementaire behandeling van wat uiteindelijk de Veiligheidswet 1934 zou worden, is meer in het algemeen illustratief voor het inzicht over de verschuivende verhouding tussen overheid en sociale partners. In de Kamercommissie die de parlementaire behandeling voorbereidde, werd de vraag opgeworpen "of de tijd niet reeds rijp geacht kon worden, om geheel of ten deele met het streng ambtelijke karakter der Veiligheidswet te breken [..] Decentralisatie zoowel op het terrein der veiligheidsvoorschriften zelve als op dat der uitvoering is onvermijdelijk, gezien de groote verscheidenheid en de omstandigheden waarmede rekening dient te worden gehouden". ${ }^{217}$ Het 'ambtelijk karakter' van het wetsvoorstel gold met name het accent op regelgeving middels AMvB's en de delegatie aan de Arbeidsinspectie. De commissie overwoog van haar kant een zwaardere rol voor "de organen van het maatschappelijk leven", in het bijzonder de bedrijfsverenigingen. "De nieuwe wij-

\footnotetext{
213 Kamerstukken II. 1931-1932,217, nr.3. p. 13

214 Geers 1988, p. 69

215 Kamerstukken II. 1931-1932, 217, nr.3. p. 15

216 Aan het uiteindelijke artikel in de Veiligheidswet 1934 is nooit uitvoering gegeven. Geers 1988, p. 70

217 Kamersfukken II. 1933-1934, 71.1 (Verslag bijzonder commissie), p. I
} 
ze van uitvoering van sociale wetten [i.c. de Ongevallenwet en de Ziektewet. JP] biedt het grote voordeel, dat de Staat zich meer en meer kan terugtrekken op zijn eigen terrein en dat aan de samenwerkende organisaties van werkgevers en arbeiders een taak kan worden toebedeeld, die geheel ligt in de lijn der maatschappelijke evolutie." 218

"De vraag is echter, of de ontwikkeling van het sociale organisatiewezen reeds voldoende is gevorderd, om in staat te worden geacht op dit terrein een deel der Staatstaak over te nemen." 219 Een meerderheid van de commissie beantwoordde deze vraag negatief: "de samenwerking tusschen werkgevers en werknemers [is] nog niet van zoodanige aard, dat thans reeds de uitvoering der wet in handen van bedrijfsorganen kan worden gelegd." 220 Dit oordeel werd door de minister onderschreven, reden waarom hij vasthield aan de ambtelijke opzet van de Veiligheidswet. Ook buiten de Kamer werd ingezien dat de overheid vooralsnog een centrale rol zou moeten blijven spelen in de bescherming van de arbeiders: "Nog is het vereenigingsleven van arbeiders en patroons niet tot zoodanige sterkte gestaald. nog kenmerkt het zich niet door zodanig harmonieus overleg, dat de overheid haar directe bemoeiing mag terugtrekken en de overgang van heteronoom tot autonoom recht als werkelijkheid [..] mag worden begroet."22!

Het accent in de arbeidsbeschermende regelgeving bleef in de jaren ' 30 dan ook sterk liggen op heteronome regulering: gedetailleerde overheidsvoorschriften die door een externe instantie (i.c. de Arbeidsinspectie) werden gehandhaafd. Zowel de Veiligheidswet 1934 als de Arbeidswet 1919 vormden een kader voor een stroom maatregelen van bestuur die na 1920 de fabrieken en werkplaatsen overspoelde ${ }^{222}$, en niet alleen fabrieken en werkplaatsen: stapsgewijs zou de werkingssfeer worden uitgebreid tot andere sectoren. ${ }^{223}$ Voorts werd de Veiligheidswet zélf na 1934 twintig keer gewijzigd, en het Veiligheidsbesluit Fabrieken en Werkplaatsen zelfs meer dan dertig maal. ${ }^{224}$ Daarnaast werd het toezicht door de Arbeidsinspectie verscherpt. ${ }^{225}$

\section{Ibid. \\ 219 Ibid. \\ 220 Ibid., p. 2 \\ 221 Diepenhorst 1939, p. 23}

222 Bijvoorbeeld het Loodwitbesluit (1938) en het Electrotechnisch veiligheidsbesluit (1938). Uiteindelijk zouden meer dan 30 specifieke veiligheidsbesluiten worden uitgevaardigd. Voor een overzicht zie Heerma van Voss 1996, p. 145. Naast de op de Veiligheidswet en Arbeidswet gegrondveste regelgeving was voorts regelgeving op grond van bijvoorbeeld de Wet op de Gevaarlijke Werktuigen (1952) van invloed op de arbeidsomstandigheden van de arbeiders.

223 Landbouwveiligheidsbesluit (1950, Stb. K107, Veiligheidsbesluit Stuwadoorsarbeid (1950), Veiligheidsbesluit Binnenvaart (1963) en Veiligheidsbesluit Restgroepen (1990)

224 Ter nadere illustratie: het Landbouwveiligheidsbesluit werd bijvoorbeeld gewijzigd in 1956. 1959. 1964, 1966, 1971, 1975 en 1978, en bijvoorbeeld het Electrotechnisch veiligheidsbesluit 1957, 1974 en 1982

225 Met name de eerste jaren na de inwerkingtreding van het Arbeidsbesluit (1920) werden jaarlijks duizenden eisen gesteld door de Arbeidsinspectie (in 1923 bijna 35.000 per jaar, en de daarop volgende jaren jaarlijks zo'n 25.000). Van Drongelen 1990, p. 207 
Hoewel de periode na de Eerste Wereldoorlog dus een verdere uitbouw te zien gaf van de vakorganisaties en een intensivering van hun onderlinge relaties, was in dezelfde periode dus sprake van toenemende staatsbemoeienis en vergaande centralisatie van de regelgeving. 226 De arbeidsomstandighedenwetgeving kenmerkte zich in essentie door een grote dominantie van de overheid, die immer nog de rol van beschermer der 'onmondige arbeider' vervulde. ${ }^{227}$ De regelgeving was niet alleen sterk centralistisch maar tevens bijzonder gedetailleerd van aard, en het toezicht op de naleving van de regels was primair een overheidstaak (hoewel ook werknemers vaker een klacht durfden in te dienen) ${ }^{228}$. Dit centralistische reguleringsparadigma bleef tot ver in de jaren ' 60 in feite onomstreden. ${ }^{229}$ Ook de eerste Wet op de ondernemingsraden van 1950 veranderde hier weinig aan: weliswaar kende de WOR 1950 de OR een taak toe als toezichthouder op "de naleving van de wettelijke voorschriften ter bescherming van de werknemers in de onderneming. alsmede op de inrichtingen, in het belang van de veiligheid, gezondheid en hygiëne op de schaft- en kleedgelegenheden" (art. 6. lid 2d), maar door het gebrek aan bevoegdheden was de OR een tamelijk tandeloos instituut. ${ }^{230}$ De invloed van ondernemingsraden op het gebied van arbeidsomstandigheden was dan ook beperkt. $^{231}$

\section{Tussenbalans}

In de periode tussen 1919 en medio jaren ' 60 was de strijd voor betere arbeidsomstandigheden aanmerkelijk minder heftig dan in het tijdperk 1850-1919. ${ }^{232} \mathrm{Het}$ revolutionaire vuur is geblust door een aantal factoren, waarbij in eerste instantie

226 Van Voorden/Nagelkerke/de Nijs 1992, p. 201

227 Heerma van Voss 1996. p. 141

228 Eind jaren ' 20 werden jaarlijks meer dan 4000 klachten ingediend bij de Arbeidsinspectie, waarvan meer dan de helft "van de zijde der arbeiders (met inbegrip der vakvereenigingen)." Ongeveer een kwart van de klachten werd anoniem ingezonden. "Deze zijn waarschijnlijk eveneens van arbeiderszijde afkomstig." A.H.W. Hacke (1931), De sociaal-economische beteekenis der Arbeidswet (1919), Groningen: Wolters, p. 67. Ter vergelijking: in 2001 werd krap de helft van dit aantal klachten ingediend. Arbeidsinspectie (2002), Jaarverslag 2001. Den Haag: Arbeidsinspectie, p. 17

229 T. Wilthagen (1994). Reflexive Labour Law: An Introduction, In: R. Rogowski en T. Wilthagen, (eds), Reflexive Labour Law, Deventer/Boston: Kluwer, p. 350

$230 \mathrm{Vgl}$. G. van Dongen, P.S. Hoekstra, H.K. van der Veer en J.E. Wigboldus (1999), Medezeggenschap op de drempel van de 21 e eeuw: over de verantwoondelijkheid van werknemers. onderneming en de ondememingsraad, Alphen a/d Rijn, Samsom, p. 133

231 I.A.C. van Haren (1991), De medezeggenschap van de werknemers in het arbeidsomstandighedenrecht, in: A.J.C.M. Geers (red), Schets arbeidsomstandighedenrecht, Deventer. Kluwer 232 Ook in Europees perspectief bezien staat in de periode tot medio jaren '60 de aandacht van vakbonden voor arbeidsomstandigheden op een laag pitje. L. Vogel (1993). Prevention at the Workplace: An initial review of how the 1989 Community framework Dinective is being imple. mented, Brussel: TUTB, p. 17. Vogel wijst ook op een bepaalde mate van na-oorlogse heroïek en opofferingsgezindheid onder de arbeiders. $\mathrm{Vgl}$. op dit punt bijvoorbeeld het werk van de Duitse filosoof Ernst Jünger, met name diens Der Arbeiter (1933). Zie J. Popma (1991). The worker: on nihilism and technology in Emst Jünger, Brussels: EHSAL, p. $20 \mathrm{ff}$ 
toch weer de economische ontwikkelingen van doorslaggevend belang lijken. Op grond van een analyse van de periode 1920-1930 veronderstelt een werkgroep van de Universiteit van Amsterdam "een duidelijk verband tussen de neergaande conjunctuur en de ontwikkeling van de medezeggenschapsgedachte."233 Ook voor de periode na 1930 kan worden gesteld dat de macht van de bonden duidelijk conjunctuurgevoelig is: er is weinig stakingsactiviteit ${ }^{234}$. de spaarzame acties en stakingen stranden ${ }^{235}$, het ledental van met name het NVV daalt sterk (van 336.000 in 1933 naar 283.000 in 1937), en "de massale werkloosheid maakte de vakbeweging vrijwel vleugellam." ${ }^{236}$ In tijden van economische neergang is er bovendien weinig financiële ruimte voor investeringen in veiligheid en gezondheid, en heeft ook de vakbeweging uiteraard andere prioriteiten. Zo werd het verzet van het NVV, eind 1921, tegen de wijziging van de Arbeidswet gebroken doordat diverse bonden bereid waren de 48 -urige werkweek te accepteren als daarmee loonsverlaging voorkomen kon worden. ${ }^{237}$ De bronnen waaruit de arbeiders zouden kunnen putten waren dan ook nagenoeg opgedroogd.

$\mathrm{Na}$ de crisisjaren belandde Nederland vervolgens in de Tweede Wereldoorlog, en in de naoorlogse periode had de wederopbouw voorrang boven eventuele maatregelen in de sfeer van arbeidsbescherming. Ook de discussie over de medezeggenschap van de arbeiders - die toen overigens al 'werknemers' werden genoemd - was bijzonder compromisgericht: het streven naar socialisatie en economische zeggenschap op ondernemingsniveau werd ingeruild voor een uitbouw van de institutionele rol van de vakbeweging (op landelijk niveau) bij de constructie van een rationele economische orde én, niet eens secundair, het voorkomen van werknemersradicalisme. ${ }^{238}$ In het bijzonder de totstandkoming van de Stichting van de Arbeid is hierbij van belang: deze werd in 1943 zodanig opgezet dat de vakorganisaties zich nadrukkelijk verplichtten af te zien van een actieve rol op bedrijfsniveau. in ruil voor een ruime vertegenwoordiging in officiële economische lichamen ter advisering van de regering - hetgeen werd vastgelegd in de Stichtingsdeclaratie van 1943. ${ }^{239}$ De fixatie op de sociaal-economische ordening en de keuze voor een vergaande centralisering van de arbeidsverhoudingen ${ }^{240}$ impliceerde dat het thema

233 Werkgroep Economisch-Historisch Seminarium 1972, p. 319

234 Albeda/Dercksen/Tros 1998, p. 229

235 Harmsen/Reinalda 1975 , p. 175

236 Bruggeman/Camijn 1999, p. 26

237 Heerma van Voss 1994, p. 48

238 E. Engelen (2000), Economisch burgerschap in de onderneming: Een oefening in concreet utopisme, Amsterdam: Thela Thesis, p. 110. Ook Windmuller (op. cit. p. 80) en Van Voorden wijzen op de disciplinerende taak van de vakbeweging. Van Voorden spreekt in dit verband van worker control. Van Voorden/Nagelkerke/De Nijs 1992, p. 185

239 Windmuller/De Galan/Van Zweeden 1983, p. 96. Vgl. Harmsen/Reinalda 1975, p. 230. Zie ook Bruggeman/Camijn 1999. p. 213 en 30

240 Overigens was de kiem voor deze centralistische benadering al voor de Tweede Wereldoorlog gelegd. Vgl. W, van Voorden et al, op. cit., p. 201, en Bruggeman/Camijn (1999), p. 30. In zijn algemeenheid kenmerkte de opstelling van NVV en CNV zich al vanaf het begin door een centralistische inslag, onder meer doordat zij door hun zwakke positie in bedrijven sterk hechtten aan collectieve afspraken voor gehele bedrijfstakken. Albeda/Dercksen/Tros 1998, p. 72. 
arbeidsomstandigheden praktisch buiten het gezichtsveld van de vakbeweging raakte: "Binnen dit compromis is [..] nauwelijks aandacht mogelijk voor de kwaliteit van de arbeid en een meer participatoire inrichting van het productieproces," 241 Veiligheid en gezondheid zijn immers bij uitstek kwesties die op de werkvloer spelen.

De regels voor de arbeidsbescherming waren in deze periode nauwelijks van invloed op de ontwikkeling van arbeidsverhoudingen. De Arbeidswet en de Veiligheidswet verschaften de vakbeweging, zeker in vergelijking met de Ziektewet 1929, slechts een zeer beperkte rol. In de praktijk werd die rol bovendien nauwelijks ingevuld. Omgekeerd is echter de mate van institutionalisering zeker wél van invloed geweest op de ontwikkeling van de regelgeving. Aanvankelijk werden de arbeidsverhoudingen nog te onvolwassen geacht om de regelgeving aan de sociale partners over te laten, en zeker na de Tweede Wereldoorlog voelden deze zich weinig geroepen om een leidende rol op zich te nemen. Het gevolg was dat het initiatief vrijwel uitsluitend bij de overheid kwam te liggen. Dat de overheid een centrale rol kreeg toebedeeld, is grotendeels te herleiden op die afzijdigheid van de organisaties. Daarnaast achtte de overheid zelf, zoals al aangegeven bij de behandeling van de Veiligheidswet 1934, de organisaties nog te weinig volwassen om hun een belangrijke rol toe te bedelen.

Dat de reguleringsstrategie niet alleen centralistisch was maar ook tamelijk detaillistisch. hangt ten dele ook weer samen met deze onvolgroeide arbeidsverhoudingen: zolang werkgevers en vakbonden nog niet in staat waren om op bedrijfstak- of bedrijfsniveau tot afspraken te komen, zag de overheid zich genoodzaakt zélf de voorschriften tot op de werkvloer uit te werken. Daarnaast hing het type regulering echter sterk samen met de technologische ontwikkeling en de op dat moment dominante bedrijfskundige inzichten. ${ }^{242}$ Met name de Tayloristische opvattingen over rationele bedrijfsvoering, die na de Eerste Wereldoorlog ook in Nederland opgang deden, verleidden al snel tot een nadruk op standaardisering en top-down sturing van werkprocessen, alsmede een scherpe scheiding tussen management, uitvoering en toezicht. In feite impliceerde deze scheiding van sturing en uitvoering de onttrekking van het kennismonopolie aan de geschoolde arbeider ten gunste van het wetenschappelijk management. Deze kennisverschuiving had als gevolg dat de deskundigheidsmacht van de arbeiders werd gebroken. ${ }^{243}$ In meer wijsgerige terminologie kan gesteld worden dat het Taylorisme de arbeiders tot op zekere hoogte hun

241 Engelen 2000, p. 39

242 Voor een interessante beschouwing over de relatie tussen reguleringsstrategie enerzijds en met name bedrijfskundige ontwikkelingen zie: Nielsen 2000 , p. 99-123

243 C.J. Loonstra (1990), Gezag. medezeggenschap en collectieve actie, Groningen: WoltersNoordhoff, p. 59. Over de effecten van het Taylorisme op het denken over veiligheid en gezondheid vgl. Vogel 1993, p. 14-18 
subjectiviteit ontnam. ${ }^{244}$ Als het al geen bewuste strategie was, dan toch op zijn minst een teken van wantrouwen in het eigen vermogen van de individuele werknemer. ${ }^{245}$ Dit mensbeeld was ook impliciet in de centralistische en detaillistische reguleringsstrategie in de onderhavige periode. Getracht werd de wetten te vervolmaken door de veiligheidsbesluiten met grote regelmaat te moderniseren en de werkingssfeer tot andere sectoren uit te breiden ${ }^{246}$, maar in feite kwam de werknemer in de Veiligheidswetgeving nauwelijks voor: "Hij is vooral een te beschermen object en geen zelfstandig drager van enige verantwoordelijkheid." 247

De dominantie van de overheid, ten slotte, ontnam op haar beurt het initiatief bij de arbeiders zelf. De permanente stroom, ja zelfs stortvloed aan gedetailleerde regels bluste het revolutionaire vuur van voor 1923. Niet dat dat per definitie erg is: strijd om des strijds willen is wellicht een al te romantische visie op de arbeidsverhoudingen. Het resultaat van decennia agitatie voor betere arbeidsbescherming was immers dat er in het interbellum een tamelijk omvattend stelsel van regels was ontstaan, dat zonder meer een verbetering van de positie der arbeiders betekende. Desondanks ontstond al in de jaren ' 50 onbehagen bij de meer radicale arbeiders. die de afwezigheid van de vakbonden in de bedrijven als een gemis ervoeren. ${ }^{248}$ Dit onbehagen zou in de loop van de jaren ' 60 uitmonden in een roep om meer medezeggenschap van werknemers. Daarnaast ontstond allengs meer twijfel over de centralistische reguleringsstrategie, waarvoor in dezelfde periode óók een alternatief zou worden gezocht. Deze beide ontwikkelingen komen aan de orde in de volgende paragraaf.

244 Van der Velden 2000, p. 93. In de jaren '30 werd een dergelijke de-subjectivering vanuit verschillende hoeken ook toegejuicht. Vgl. J. Herf (1986), Reactionary modernism: Technology, culture and politics in Weimar and the Third Reich. Cambridge University Press, p. 103: "Like a part of a machine, his virtue lies in his replaceability within the minute division of labour". Eén van de belangrijkste manifesten van dit reactionair modernisme was het boek Der Arbeiter: Herrschaft und Gestalt (1932), dat een lofzang was op de vernietiging van het humanisme door de techniek. Vgl. J. Popma (1991), The worker: on nihilism and technology in Ernst Jünger, Brussels: EHSAL 245 Nielsen 2000, p. 101

246 Heerma van Voss 1996, p. 145

247 A.J.C.M. Geers en J.H. Kwantes (1992), Veilig en wel: De Arbeidsomstandighedemwet en de rol van de $O R$. Alphen a/d Rijn: Samsom, p. 53

248 Albeda/Dercksen/Tros 1998, p. 168 


\title{
2.4. Aarde (1960-1980)
}

... enerzijds aarde, anderzijds vlammend weer ( $\pi \rho \eta$ orth $\rho) . .$.

249

\author{
Herakleitos, Fragment B 31
}

In het kielzog van de twee vlaggenschepen der arbeidsbescherming, de Arbeidswet 1919 en de Veiligheidswet 1934, was eind jaren '50 een 'mer à boire' aan voorschriften ontstaan - een reservoir dat ook in de jaren ' 60 regelmatig werd bijgevuld. ${ }^{250}$ Het tayloristische denken vierde immer nog hoogtij ${ }^{251}$, en spiegelbeeldig daaraan de detaillistische reguleringsstrategie van de overheid. Rond 1970 voltrok zich echter een omslag in dit denken, door het besef dat er een praktische grens is aan het regulerend vermogen van de overheid. ${ }^{252}$ De veiligheidswetgeving richtte zich primair op technische aspecten in de bedrijfsvoering, maar door het toenemend tempo van de technologische ontwikkeling liep de regelgeving steeds verder achter bij de praktijk. Dit gold zelfs voor de voorschriften die via de betrekkelijk snelle weg van Algemene Maatregelen van Bestuur tot stand waren gekomen. De regelgeving was bovendien verdicht tot een ondoordringbare, bijkans versteende materie, waarbij ook nog het wetstechnische probleem kwam dat sommige arbeidssituaties onder meerdere veiligheidsbesluiten tegelijk vielen. ${ }^{253}$ Voor de doodlopende

249 De term $\pi \rho \eta \sigma t h \rho$ heeft de vertalers van Herakleitos voor problemen gesteld. De standaard-

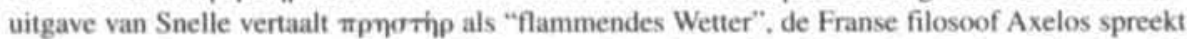
over $\pi p \eta$ othp als onweer, bliksem. K. Axelos, Héraclite et la philosophie, Paris : Minuit, p. 98 Vergeer gaat in zijn proefschrift uitgebreid in op de mogelijke betekenis van het als enigmatisch te betitelen begrip, en komt met de spitsvondige vertaling 'zeevlam'. Deze term verwijst naar een bepaalde type zware mist die, onder invloed van de wind, als een soort kringelende waseming van vurige tongen uit de zee verrijst. Zo interpreteert hij de wereldordening als een permanente dynamische balans tussen dood (aarde) en leven (vuur). C. Vergeer (1987). Als een akker in de winter: over het denken van Herakleitos van Efese, Amsterdam: Universiteit van Amsterdam (diss.), p. 184ff. In het kader van deze studie is vooral van belang dat de periode na 1963 cen dubbele beweging te zien gaf: enerzijds een nog steeds toenemende regelzucht, anderzijds een oplaaiend vuur onder de arbeidsverhoudingen.

250 Van Drongelen 1990, p. 371ff. Een belangrijke stroom voorschriften is, sinds het eind van de jaren '50, terug te voeren op de Europese regelgeving op grond van de artikelen 117 en met name 118 van het EEG-Verdrag (1957). Deze artikelen, die cen harmonisatie van de sociale wetgeving in de lidstaten beogen, vormen de basis van een groot aantal richtlijnen omtrent de veiligheid en gezondheid bij de arbeid. A.J.C.M. Geers en G.J.J. Heerma van Voss (1995), Inleiding Europees Arbeidsrecht, Deventer: Kluwer, p. 143ff

251 E. Engelen (2002). Burgerschap op de werkvloer: De institutionele condities voor post-taylorisering in Nederland, in: R. Batenburg et al. (red.). Met het oog op de toekomst van de arbeid, Den Haag: Elsevier, p. 194. Vgl. W. Rammert (1982), Kapitalistische Rationalität und Organisierung der Arbeit, in: W. Littek e.a. (1982), Einfuhrung in die Arbeits- und Industriesoziologie. Frankfurt/New York: Campus-Verlag

252 "There are severe practical limits on the extent to which progressively better standards of safety and health at work can be brought about through negative regulation by external agencies." Robens Committee (1972), Safery and Health at Work. Report of the Committee 1970-1972. London: Her Majesty's Stationery Office, p. 12

253 Kamerstukken II. 1976-1977, 14 497, nr. 3. p. 2 
reguleringsstrategie diende een alternatief gevonden te worden. In diverse Europese landen werd sinds begin jaren ' 70 dan ook gezocht naar andere modellen van regulering. Deze zoektocht resulteerde halverwege het decennium in diverse landen in een nieuw type veiligheidswetgeving, waarbij 'state-retreatism' (terugtreding van de overheid) en het concept van zelfregulering sleutelbegrippen waren. ${ }^{254}$ Met name de Britse Health and Safety at Work Act (1974) en de ontwikkelingen in de Scandinavische landen waren van grote betekenis, 6́ok met het oog op de Nederlandse Arbeidsomstandighedenwet van 1980.255

\section{Radicalisering arbeidsverhoudingen}

De vraag naar nieuwe reguleringsstrategieën was overigens niet alleen ingegeven door de technologische ontwikkelingen, evenmin als het specifieke antwoord op die vraag. De ontwikkeling dient ook, en wellicht vooral, te worden bezien vanuit een bredere trend, in het bijzonder op het gebied van de arbeidsverhoudingen. In diverse landen ontstond in de loop van de jaren ' 60 een sterke roep om vergaande democratisering: niet alleen ten aanzien van de politiek, maar ook in de bedrijven en onder studenten. In de bedrijven kwam, aanvankelijk aarzelend, het bedrijvenwerk van de vakbeweging van de grond. ${ }^{256}$ Het bedrijvenwerk van met name het NVV benadrukte, in tegenstelling tot de WOR 1950, de belangenbehartiging in bedrijven en had een radicaliserend effect op het optreden van ondernemingsraden; ook al bestond er bij diverse ondernemingsraden weerstand tegen te grote invloed van de bonden. 257

Tegen deze achtergrond kwam rond de wisseling van het decennium ook een herziening van de Wet op de ondernemingsraden tot stand. In het SER-advies uit 1968 over een nieuwe WOR werd gewezen op de toegenomen mondigheid van de werknemers én werd, na het harmoniedenken dat de WOR 1950 kenmerkte, ingezien dat de belangen van werkgever en werknemers niet altijd parallel lopen. ${ }^{258}$ De erkenning van het dualistisch karakter van het vertegenwoordigend overleg kreeg gestalte in een nieuw artikel 2 in de WOR 1971. Daarin werd bepaald dat medezeggenschap niet, zoals in de WOR 1950, louter beoogde bij te dragen aan het functioneren van de onderneming, maar tevens diende ter behartiging van de belangen van de werknemers. Deze tweeledige doelstelling vormt nog steeds de ruggengraat van de moderne medezeggenschap. ${ }^{259}$ Daarnaast werd het werkterrein van de OR

\footnotetext{
254 Wilthagen 1993, p. 46

$255 \mathrm{Vgl}$. De Gier/Vos 1995, p. 14. In het bijzonder de Noorse Wet betreffende de bescherming van werknemers en de werkomgeving van 1977 was van grote invloed op de Arbowet. $\mathrm{Vgl}$. Kamerstukken II. 1978-1979, 14 497. nr. 9, p. 37ff

256 G.E. van Vliet (1979), Bedrijvenwerk als vorm van belangenbehartiging: Een onderzoek naar het funktioneren van het bedrijvenwerk van de Industriebond NVV en CNV. Alphen a/d Rijn: Samsom, p. 20-24: Harmsen/Reinalda 1975, p. 387-388

257 Over de moeizame relatie tussen OR en bedrijfsledengroepen vgl. Van Vliet 1979. p. $537-544$

258 SER (1968), Advies inzake uitbreiding bevoegdheden ondermemingsraden. Den Haag: Sociaal-Economische Raad, SER 68/13

259 R.H. van het Kaar (red.). Ondernemingsraad, losbladig. Deventer: Kluwer, inl., nr. 5-5
} 
sterk uitgebreid, met name op het gebied van het economisch beleid - een terrein dat in de WOR 1950 geheel buiten het bereik van de medezeggenschap was gebleven. De WOR 1971 kende ondernemingsraden adviesrecht toe met betrekking tot een beperkt aantal strategische en economische onderwerpen (overdracht van de zeggenschap, beëindiging of inkrimping van werkzaamheden, belangrijke reorganisaties) én bij een aantal belangrijke thema's op het gebied van sociaal beleid (aanstellings- en ontslagbeleid, beloningssystemen, en personeelsbeoordeling).

Ook de rol van de OR op het gebied van veiligheid en gezondheid kreeg een meer solide basis. De toezichthoudende rol van de ondernemingsraad, zoals in de WOR 1950 (art. 6, lid 2), bleef gehandhaafd, ondanks bezwaren die tegen de politionele rol van de OR bleken te bestaan: "De uitoefening hiervan zou een voor de bedrijfsvrede gevaarlijke doorkruising van de werkzaamheden en leidenden en toezichthoudende afdelingschefs kunnen opleveren." ${ }^{260}$ Wel werd de controlerende taak in mildere bewoordingen omschreven als het "bevorderen van de naleving van de wettelijke voorschriften ter bescherming van de in de onderneming werkzame personen" (art. 28, lid 1, WOR 1971). ${ }^{261}$ Overigens had de ondernemingsraad de facto toch cen quasi-politionele taak, omdat de veiligheidscommissie van de OR inspectierondes door het bedrijf mocht maken. ${ }^{262}$

Belangrijker is echter dat de ondernemingsraad instemmingsrecht kreeg bij onder meer werktijdregelingen én maatregelen op het gebied van veiligheid, gezondheid en de hygiène (artikel 27. lid 1, WOR 1971). ${ }^{263}$ Daarmee vormden de klassieke thema's op het gebied van de arbeidsbescherming het eerste terrein waarop de OR medezeggenschap kreeg in de volle betekenis van medebeslissingsrecht. Bijna 100 jaar na het Kinderwetje Van Houten had de arbeider zich, ten lange leste, ontwikkeld van 'object' van bescherming tot zelfstandig drager van het recht op behoorlijke arbeidsomstandigheden. Eenzelfde ontwikkeling voltrok zich tezelfdertijd in vele andere Europese landen. ${ }^{264}$

\section{Humanisering}

De subject-wording van de arbeiders kwam ook langs andere weg tot uiting. Wereldwijd (alsook in Nederland ${ }^{265}$ ) groeide in de loop van de jaren '50 het besef dat met name de Tayloristisch georganiseerde arbeid niet alleen effect had op de lichamelijke gezondheid van de arbeiders, maar ook op hun geestelijk welzijn. ${ }^{266}$

260 SER (1961), De ondernemingsraad in de literatuur, Den Haag: Sociaal-Economische Raad. p. 14

261 Een amendement van de PSP (Kamerstukken II. 1976-1977, 13 954, nr. 45) om de term "bevorderen", met zijn bijklank dat de OR een uitvoeringsorgaan van de ondernemer zou zijn, te vervangen door het meer robuuste "controleert" werd niet overgenomen.

262 Gevers 1982, p. 161

263 Dit instemmingsrecht was overigens wel geclausuleerd, in die zin dat het instemmingsrecht kwam te vervallen indien een bepaald onderwerp inhoudelijk al geregeld was in de CAO.

264 Gevers 1982, p. $77 \mathrm{ff}$

265 Kamerstukken II, 1977-1978. 14 497, nr. 4. p. 9

266 Eén van de meest aansprekende verbeeldingen van de negatieve gevolgen van de tayloristische fabricksarbeid is Chaplin's speelfilm "Modern Times" uit 1936. 
Begin jaren ' 60 deed, met name in de marxistische literatuur, het begrip 'vervreemding' opgang: de arbeider raakte als gevolg van de industriële arbeid, en in het bijzonder van de kapitalistische productieverhoudingen, vervreemd van zijn wezen, van zijn subjectiviteit. ${ }^{267}$ Spiegelbeeldig hieraan ontwikkelde zich in dezelfde periode het concept van 'humanisering van de arbeid'. ${ }^{268}$ Geers definieert dit concept in zijn proefschrift aan de hand van begrippen als zelfontplooiing, verantwoordelijkheid, autonomie en zeggenschap. ${ }^{269}$ Ook in Europees verband, in het eerste 'Sociale Actieprogramma' van de Europese Gemeenschap (1974), stonden humanisering en medezeggenschap hoog op de prioriteitenlijst. ${ }^{270}$

In de Nederlandse arbeidswetgeving was overigens al in 1890 sprake van het welzijn der werklieden bij de taakstelling van de Commissie-Rochussen. ${ }^{271}$ Ook de Arbeidswet 1919 werd door minister Aalberse in de Tweede Kamer verdedigd met een verwijzing naar "het levensgeluk, het geestelijk welzijn" van de arbeider. ${ }^{272}$ Hierbij, alsook in de roep van socialisten én confessionelen om kortere werktijden, ging het vooral om verheffing buiten het werk. In de discussie omtrent de humanisering van de arbeid anno jaren ' 60 ging het evenwel om ontplooiing in het werk. om de intrinsieke waarde van de arbeid. Geestdodende arbeid zou zoveel mogelijk voorkomen moeten worden, en de werknemer zou het werk zoveel mogelijk naar eigen inzicht moeten kunnen organiseren en moeten kunnen leren van zijn werk. Deze gedachten keerden terug in het begrip welzijn in de latere Arbeidsomstandighedenwet (1980), die mede onder invloed van de humaniseringsidealen tot stand kwam.

Eén van de karakteristieken van de humaniseringsidee was bovendien het streven naar een permanente verbetering van de kwaliteit van de arbeid. Dit streven naar optimalisering van de arbeid impliceerde een breuk met het oude reguleringsparadigma dat louter het voorkomen van gezondheidsschade beoogde. Weliswaar werden ook onder de Veiligheidswet nieuwe risico's van tijd tot tijd ondervangen door middel van periodiek aangescherpte eisen, maar de Arbeidsomstandighedenwet 1980 eiste in principe dat bij het beleid ter bescherming van de arbeid permanent rekening werd gehouden met recente ontwikkelingen in de techniek en de stand der wetenschap, teneinde "een zo groot mogelijke veiligheid [en] een zo groot mogelijke bescherming van de gezondheid" te bewerkstelligen. Van loutere minimumnormering was, althans in intentie, de ambitie van de overheid medio jaren '70 dus verschoven naar optimale arbeidsomstandigheden.

$267 \mathrm{Vgl}$. R. Blauner (1964), Alienation and Freedom. The factory worker and his industry, Chicago: University of Chicago Press: H. Popitz (1968), Der entfremdete Mensch: Zeitkritik un Geschichtsphilosophie des jungen Marx. Frankfurt am Main: Europäische Verlaganstait

268 Vgl. ook Vogel 1993, p. 18-19. Voor een overzicht van de literatuur zie: R.M. Greve (1977), Bibliography on major aspects of the humanisation of work and the quality of working life. Geneve: ILO

269 Geers 1988, p. 1

270 Vogel 1993, p. 67ff

271 Vgl. Geers 1988, p. 2

272 Handelingen Tweede Kamer, 1918-1919, p. 2876 


\section{Zelfregulering}

Volgens Engelen is "de gedachte van optimale oplossingen voor sociale problemen gestoeld op een technocratisch kennisideaal dat nauw is verweven met moderne staatsvormings- en bureaucratiseringsprocessen"273, dat wil zeggen gestoeld op het geloof in de maakbaarheid en de zegenende werking van de verzorgingsstaat. De reguleringsstrategie die lag besloten in de nieuwe Arbeidsomstandighedenwet, die in de tweede helft van de jaren ' 70 werd uitgewerkt, was echter het tegendeel van een étatistische of bureaucratische aanpak. De Arbowet 1980 beoogde juist een verschuiving van overheidsregulering naar zelfregulering. De Arbowet verscherpte de zorgplicht uit de oude Veiligheidswet én kende de werknemers een belangrijke rol toe bij de vormgeving van het beleid inzake de veiligheid, de gezondheid én het welzijn. Die werknemersbetrokkenheid was volgens minister Boersma van Sociale Zaken zelfs de belangrijkste noviteit van de Arbowet. ${ }^{274}$

Hiermee werd niet alleen tegemoetgekomen aan de eis tot democratisering en het verlangen naar zeggenschap (als element in de humanisering van de arbeid). Het was tevens een uitvloeisel van de nieuwe reguleringsfilosofie die met name in de Britse Health and Safety at Work Act (1974) tot uiting kwam en evenzeer van invloed was op het Nederlandse denken over veiligheid en gezondheid bij de arbeid. De kern van die reguleringsfilosofie, die werd verwoord in het rapport van

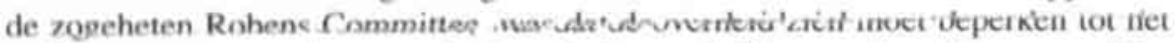
vastleggen van een algemeen kader (doelvoorschriften, spelregels) voor veiligheidsbeleid, waarbinnen bedrijven hun eigen verantwoordelijkheid zouden moeten nemen: "The primary responsibility $[\ldots]$ lies with those who create the risk and those who work with them [...] Our present system encourages too much reliance on state regulation and rather too little on responsibility and voluntary self generating effort $[\ldots]$ There is a role for government action, but [that] role should be predominantly concerned with influencing attitudes and creating a framework for better health and safety organisation and action by industry itself." 275

De primaire verantwoordelijkheid ligt bij degenen die risico's creëren én degenen die onder risicovolle omstandigheden werken: werkgevers en werknemers dus. Artikel 2 van de Health and Safety at Work Act introduceerde een zorgplicht voor werkgevers, de verplichting om een arbobeleid te ontwikkelen én dit beleid ter kennis van de werknemers te brengen. Artikel 7 schetste een aantal verplichtingen voor werknemers (waaronder de verplichting om mee te werken met de werkgever teneinde hem in staat te stellen aan zijn wettelijke verplichtingen te voldoen), en artikel 8 verplichtte werknemers om veiligheidsvoorzieningen intact te laten. De taak van de overheid was niet langer het voorschrijven van bindende normen, maar 'goal-setting'. Het uitwerken van concrete normen zou, onder toezicht van de staat-

273 Engelen 2000, p. 18

274 SER (1976), Advies inzake vernieuwing van de wetgeving betreffende de gezondheid en de veiligheid bij de arbeid, SER, Den Haag: Sociaal-Economische Raad (SER 76/18) bijlage I. p. 1

275 Robens Committee 1972, p. 7 
secretaris, goeddeels moeten geschieden door een tri-partite 'Health and Safety Commission' middels zogeheten 'approved codes of practice'. Binnen deze 'nationally enforced standards' zou wel ruimte moeten blijven om op bedrijfsniveau gezamenlijk tot een nadere uitwerking te komen.

De Nederlandse Arbowet 1980 echode deze benadering. ${ }^{276}$ Artikel 4, lid 1, van de wet verplichtte werkgevers het algemene ondernemingsbeleid "mede te richten op een zo groot mogelijke veiligheid, een zo groot mogelijke bescherming van de gezondheid en het bevorderen van het welzijn van de werknemer binnen het bedrijf of de inrichting."277 Dat dit tevens impliceerde dat de werkgever een arbeidsomstandighedenbeleid diende te voeren, kon worden afgeleid uit de verplichting om 'onderscheiden bevoegdheden en verantwoordelijkheden' vast te leggen én, voor bij $\mathrm{AMvB}$ aan te wijzen bedrijven (in de praktijk de $100+$ bedrijven), de verplichting om een arbojaarplan op te stellen.

\section{Medezeggenschap}

In artikel 13 werd vervolgens de verplichting geformuleerd om bij de uitvoering van het beleid samen te werken met de werknemers. Deze samenwerkingsplicht was ten eerste principieel gegrondvest, als spiegelbeeld van een gedeeltelijke medeverantwoordelijkheid van de werknemers (bijvoorbeeld om veiligheidsvoorschriften na te leven, ex art. 12 Arbowet, een artikel dat bij overtreding ook strafrechtelijke consequenties kon hebben voor werknemers). Ten tweede was de plicht tot samenwerking terug te voeren op verschillende internationale aanbevelingen ter zake de veiligheid en gezondheid van werknemers. ${ }^{278}$ Ten derde speelde mee dat actieve medewerking bij de uitvoering van het arbeidsomstandighedenbeleid onontbeerlijk is voor het welslagen van dat beleid: het besef was gegroeid dat medezeggenschap bij de formulering van het beleid tot draagvlak zou leiden én de kwaliteit van het beleid positief zou beïnvloeden. ${ }^{279} \mathrm{Bij}$ dit laatstgenoemde argument speelde ook de opkomst van moderne bedrijfskundige stromingen mee, in het bijzonder

276 Ook de veiligheidswetten in andere Europese landen waren exponenten van dezelfde reguleringsfilosofie, vormgegeven als kaderwetten met algemene verplichtingen voor werkgevers en werknemers. De Gier/Vos 1995, p. 14

277 Kamerstukken II, 1976-1977, 14 497, nr. 3. p. 12. Vgl. voor een kritische beschouwing over de relatie tussen de civielrechtelijke en publiekrechtelijke zorgplicht Geers, op. cit. p. $115-120$ en $148 \mathrm{ff}$

278 Bijvoorbeeld verdragen van de ILO, vgl. SER (1976), bijlage 1, p. 2

279 Gevers 1982, p. 56. 
de sociotechnische benadering, die wees op het effect van een meer participatieve vorm van bedrijfsvoering. ${ }^{280}$

Een laatste, centrale overweging achter de betrokkenheid van werknemers bij het arbobeleid was dat de Nederlandse overheid, in navolging van de Britse reguleringsfilosofie, een verschuiving wilde van prescriptive naar goal-setting normen: met name de regelgeving in AMvB's zou minder gedetailleerd moeten zijn en zich meer moeten richten op hoofdlijnen, in de praktijk nader in te vullen door de Arbeidsinspectie middels het nieuwe instrument van de Aanwijzing. ${ }^{281}$ Ook werd de mogelijkheid opengehouden dat de hoofdlijnen nader uitgewerkt zouden worden in gezamenlijk overleg tussen werkgevers en werknemers, bijvoorbeeld door de tripartite Arboraad, in CAO's (vergelijkbaar met de approved codes of practice in Groot-Brittannië) of op ondernemingsniveau.

Voor de institutionele invulling van het idee van medezeggenschap werden op drie niveaus maatregelen getroffen. Op het niveau van de individuele werknemer werd bepaald dat de werkgever verplicht was te zorgen voor adequate informatie, voorlichting en scholing inzake veiligheid en gezondheid. Hieruit volgde logischerwijs dat werknemers recht hadden op adequate informatie en voorlichting: een recht dat voordien alleen toekwam aan ondernemingsraden. ${ }^{282}$ Ook kon de werknemer in het verplichte werkoverleg zijn stem laten horen (art. 16, dat overigens pas in 1990 in werking zou treden). Daarnaast kregen werknemers het recht om, in acuut gevaarlijke situaties, het werk te onderbreken (art. 38). ${ }^{283}$ Voorts hadden werknemers het recht om een klacht in te dienen bij de Arbeidsinspectie. Van dit recht werd in de jaren na 1980 echter maar beperkt gebruik gemaakt. ${ }^{284}$

Op nationaal niveau zou een tripartite adviesraad in het leven geroepen worden en, indien wenselijk, districtscomités van die Raad. Van die laatste mogelijkheid is nooit gebruik gemaakt, maar in de periode 1980-1994 heeft wel een landelijke raad gefunctioneerd, de zogeheten Arboraad. Deze had onder meer als taak het overleg over de totstandkoming en uitvoering van algemeen verbindende voorschriften ter uitvoering van de Arbowet, en desgewenst advies uit te brengen aan de Minister. In de Arboraad waren de werknemers vertegenwoordigd door de vakcentrales FNV en CNV. Ook hadden de vakbonden op grond van artikel 21 van de Arbowet een rol in het (paritaire) bestuur van zogeheten arbo-instituten. service-instituten die dienst-

280 J.J. Boonstra (1992), Integrale organisatie-ontwikkeling: vormgeving van fundamentele veranderingspnocessen, Utrecht: Lemma, p. 13ff. Deze bedrijfskundige ontwikkeling is overigens niet zonder meer positief. De sociotechniek is niet primair ontwikkeld met het oog op humanisering van de arbeid. maar vooral met het oog op flexibiliteit, beheersbaarheid en innovativiteit. In zijn uitwerking heeft deze bedrijfskundige ontwikkeling echter wel degelijk het effect dat werknemers meer te zeggen krijgen over de organisatie van hun arbeid en dat hun werk meer voldoet aan moderne noties van zinvolle arbeid en medezeggenschap. Engelen 2002, p. 199; Albeda/Dercksen/Tros 1998, p. 206

281 SER 1976, bijlage I. p. 3

282 Geers 1988, p. 269-271

283 Ibid., p. $271-280$

284 lbid., p. $280-283$ 
verlenend zouden moeten zijn aan aangesloten ondernemingen. ${ }^{285}$ Dit artikel is nooit in werking getreden. In de praktijk participeerden de bonden wél in het bestuur van de bedrijfsgezondheidsdiensten, die voor bedrijven met meer dan 750 werknemers reeds verplicht waren sinds 1959 (Wet op de bedrijfsgeneeskunde). ${ }^{286}$ Al met al verleende de Arbowet dus een tamelijk solide institutionele rol aan de werknemersvertegenwoordigers.

Het belangrijkste niveau van medezeggenschap was, in het kader van de Arbowet, echter het niveau van het vertegenwoordigend overleg op bedrijfsniveau. In haar adviesaanvraag voorzag de overheid twee vormen van werknemersbetrokkenheid bij het arbobeleid in bedrijven, te weten veiligheidsvertegenwoordigers op de werkplek en gekozen veiligheidscommissies. In Noorwegen was in bedrijven met meer dan 5 werknemers de aanwezigheid verplicht gesteld van een veiligheidsvertrouwensman, die werd benoemd door de vakorganisaties en onder meer het recht had het werk stil te leggen bij acuut gevaar. ${ }^{287}$ In België en Frankrijk waren positieve ervaringen opgedaan met de veiligheidscommissie. De SER verwachtte evenwel weinig heil van dergelijke veiligheidsvertegenwoordigers, en voor de uitwerking van de veiligheidscommissie zocht de SER bij voorkeur aansluiting bij de Wet op de ondernemingsraden. Hooguit zou in kleinere, niet OR-plichtige bedrijven een verplichting moeten komen om veiligheidscommissies in te stellen - rechtstreeks gekozen door de werknemers, met bevoegdheden analoog aan artikel 27 en 28 van de WOR. ${ }^{288}$

Het uiteindelijke voorstel voor de Arbowet volgde op dit punt de SER: er zou meer worden aangesloten bij de bestaande structuur. ${ }^{289}$ De veiligheidscommissie zoals die in andere landen bestond, zou niet een rechtstreeks gekozen zelfstandig orgaan moeten zijn maar een vaste commissie van de OR. De mogelijkheid tot het instellen van een commissie bestond al sinds 1950, maar de WOR 1979 introduceerde de mogelijkheid om 'buitenleden' aan te trekken (zie par. 3.2.4). Met name het punt van eventuele toegevoegde expertise werd als belangrijk winstpunt gezien. Kleinere bedrijven zouden eventueel, op grond van een AMvB, zogeheten arbocommissies in het leven moeten roepen (met in hoofdlijnen dezelfde rechten als de OR). ${ }^{290}$ Van deze mogelijkheid dit bij $\mathrm{AMvB}$ op te leggen is in de praktijk echter nooit gebruik gemaakt.

Afgezien van een aantal technische discussies over de afstemming van WOR en

\footnotetext{
285 Gevers 1982, p. 171; Geers 1988, p. 223

286 De instellingsgrens werd in 1982 verlaagd naar 500 werknemers.

287 Kamerstukken II, 1978-1979, 14 497, nr, 9, p. 44. Ook in Engeland werd in 1977 de figuur van de Safety Representative geintroduceerd - eveneens een door de vakbonden aangewezen kaderlid. In Nederland bestonden sinds het eind van de jaren ' 60 veiligheidscontactpersonen, die echter meestal door de werkgever waren aangewezen. Gevers 1982 , p. 160

288 SER 1976, p. 11-12

289 Kamerstukken II, 1978-1979, 14 497, nr.3, p. 15

290 Voor een vergelijking tussen beide vormen van vertegenwoordigend overleg vgl. Geers 1988, p. $181 \mathrm{ff}$
} 
Arbowet, die met name rond de WOR-wijziging in 1979 werden gevoerd, is met de Arbowet/WOR het kader voor de medezeggenschap van de werknemers tot op heden gegeven. De werkgever heeft een samenwerkingsplicht met de werknemers, in het bijzonder de OR. Complementair hieraan hebben ondernemingsraden 'overvloedige $^{291}$ overiegrechten op het gebied van veiligheid, gezondheid en welzijn, recht op de relevante informatie, scholingsrecht, bij eventuele maatregelen op het terrein van veiligheid, gezondheid of welzijn zelfs instemmingsrecht, en ook rechten in relatie tot de Arbeidsinspectie. Voor een uitgebreidere beschrijving van de formele positie en de rechten van de ondernemingsraad zij hier kortheidshalve verwezen naar hoofdstuk 3 .

\section{Tussenbalans}

De periode 1963-1980 is cruciaal in de ontwikkeling van de medezeggenschap bij het arbeidsomstandighedenbeleid in bedrijven. De toch tamelijk vanzelfsprekende rol die ondernemingsraden tegenwoordig spelen is goeddeels terug te voeren op de samenwerkingsplicht in artikel 13 van de Arbowet 1980, en de wijze waarop de medezeggenschap is georganiseerd vindt in hoofdlijnen zijn oorsprong in de WOR 1971. Het systeem van arbo-overleg en met name de formeel versterkte positie van de ondernemingsraad is in belangrijke mate te herleiden op de arbeidsverhoudingen medio jaren ' 60 , begin jaren '70. In de jaren '60 was şrake xan een gelaidaljike afbraak van het centralisme in de arbeidsverhoudingen, mede door het loslaten van de geleide loonpolitiek (1963) en van een toenemende belangenarticulatie door onder meer het bedrijvenwerk. Begin jaren ' 70 waren de arbeidsverhoudingen zelfs tamelijk gepolariseerd, met onder meer een fikse stijging van het aantal stakingen. ${ }^{292}$ Ook het overleg tussen OR en bestuurder verschoof van het harmoniemodel dat bepalend was geweest voor de WOR 1950 naar een onderhandelings- of zelfs conflictmodel. ${ }^{293}$ Een en ander betekent overigens niet dat het toekennen van meer medezeggenschap aan ondernemingsraden (en vakbonden) primair als pacificatie-strategie dient te worden beschouwd. ${ }^{294}$ Het toelaten van de vakbonden tot het geìnstitutionaliseerd overleg in het interbellum kan wel als zodanig worden gezien. Ook is de verschuiving van centrale regulering naar zelfregulering niet in de eerste plaats te danken aan het feit dat de vakbonden dit opeisten. De wens tot zelfregulering leefde al in het interbellum, maar werd toen onhaalbaar geacht wegens een onvoldoend voldragen overleg tussen de bedrijfsgenoten (vgl. par. 2.3). Door bijvoorbeeld het gestegen scholingsniveau van werknemers en de betere organisatie van de vakbonden kon de overheid zo rond 1970 meer delegeren naar de sociale partners: "de mogelijkheid voor werknemers om door middel van de vertegenwoordiging via de vakbond en $\mathrm{OR}$ op meer gelijke voet met werkgevers te onder-

\section{Gevers 1982, p. 172}

292 Van der Velden 2000, p. 323-324, vgl. Harmsen/Reinalda 1975, p. $394 \mathrm{ff}$

293 B.W.M. Hövels en P. Nas (1976), Ondernemingsruden en medezeggenschap: een vergelijkend onderzoek naar struktuur en werkwijze van ondernemingsraden, Alphen ald Rijn: Samsom. p. 11

294 Voor een kritische noot vgl. Engelen 2000, p. 110 
handelen, bood de overheid de kans om haar vergaande bemoeienis met de arbeidsomstandigheden te reduceren." 295 Ook bij latere wijzigingen van zowel de WOR als de Arbowet werd met name de toegenomen scholing van de werknemers aangevoerd als een belangrijke conditie voor meer decentralisatie.

Als verklaring voor de sterkere positie van de werknemersvertegenwoordigers kan in eerste instantie worden gewezen op de aanhoudend gunstige economische ontwikkeling sinds begin jaren ' 60 tot aan de oliecrisis van 1974. Van der Velden laat helder zien dat er een duidelijke samenhang is tussen de conjunctuur en bijvoorbeeld een stijgend ledental van de vakbonden. ${ }^{296}$ De leden eisten bovendien een rechtvaardiger verdeling van de sterk toegenomen rijkdom. ${ }^{297}$ Ook langs andere weg speelde de economische bloei een belangrijke rol in de ontwikkeling van de Arbowet én van de medezeggenschap. Mulder suggereert dat met name het concept van humanisering niet toevallig in deze periode is opgekomen: "Door de voortdurende stijging van de inkomens en het toenemen van de hoeveelheid 'vrije' tijd is het grensnut van [..] materiële voorzieningen afgenomen en zijn aspecten als werkzekerheid, plezier en bevrediging in het werk en mogelijkheden voor persoonlijke ontplooiing belangrijker geworden." ${ }^{298}$ Omgekeerd is na de economische omslag in 1974-1975, zo signaleert Geers aan de hand van SCP-gegevens, sprake van een tanende belangstelling voor medezeggenschap en kwaliteit van de arbeid: op een gegeven moment is louter het hebben van werk belangrijker dan de kwaliteit daarvan. 299

De ontwikkeling van de Arbowet is dus voor een deel toe te schrijven aan het conjunctureel oplaaien van het vuur in de Nederlandse arbeidsverhoudingen. Maar hoewel minister Albeda stelde dat "wij [met de Arbowet] te maken [hebben] met één van de belangrijkste stukken wetgeving van na de oorlog [..], een zeer fundamentele zaak met betrekking tot ons maatschappelijk bestel" 300 , zou het toch overdreven zijn te beweren dat de totstandkoming van de Arbowet dat maatschappelijk bestel nu werkelijk aan het wankelen heeft gebracht. In tegenstelling tot in de periode tot 1919. waarin de maatschappelijke strijd wél ontbrandde rond de arbeidsveiligheid, ging het in de jaren ' $60 / 70$ vooral om de economische macht binnen bedrijven. De wijzigingen van de WOR en ook wel het bedrijvenwerk waren in dit opzicht aanmerkelijk explosiever.

Daarnaast kan men, indachtig Herakleitos' woord boven deze paragraaf, stellen dat de ontwikkelingen rond de arbowetgeving enerzijds als 'vlammend' zijn te typeren, maar dat anderzijds de regelgeving toch ook steeds meer tot 'aarde' verwerd. Hoewel de kern van de Arbowet bestond uit de zorgplicht, de verplichting tot

\footnotetext{
295 Heerma van Voss 1996, p. 147

296 Van der Velden 2000, p. 330

297 Albeda/Dercksen/Tros 1998, p. 77-80

298 K. Mulder (1992). Werknemersmedezeggenschap bij particuliere ondememingen in Nederland, Alphen a/d Rijn: Samsom, p. 98

299 Geers 1988, p. 83

300 Handelingen Tweede Kamer, 1980, p. 4673
} 
samenwerking én de optimaliseringsdoelstelling (artt. 4, 13 en 3$)^{301}$, bood artikel 24 van de wet daarnaast een kader voor meer specifieke, aanvullende regelgeving zoals voorheen de artikelen 6 en 7 van de Veiligheidswet 1934, die met de inwerkingtreding van de Arbowet werd vervangen. ${ }^{302}$ Zoals al aangegeven, had de wetgever gemeld dat hij zoveel mogelijk wilde afzien van gedetailleerde Maatregelen van Bestuur, ten faveure van zogeheten doelvoorschriften. Opvallend genoeg verklaarde de SER zich in zijn advies tégen dit voornemen. De Raad bepleitte een systeem van precieze normstelling met daarnaast de mogelijkheid om van de norm af te wijken indien hetzelfde beschermingsniveau gehaald zou worden - een gedachte die twee decennia later haar weerslag zou vinden in het zogeheten 'maatwerk'artikel in de Arbowet 1998.

De minister zou zijn oorspronkelijke voornemen tot deregulering en de opvattingen van de SER 'nader in studie nemen' ${ }^{303}$, maar in de praktijk zou parallel aan de zelfreguleringsbenadering van de Arbowet de aloude centralistische regeldrift nog lange tijd na-ijlen. De oude Veiligheidsbesluiten bleven gewoon van kracht, zij het nu op grond van de Arbowet, en nog in 1990 werd het kwartet oude Veiligheidsbesluiten aangevuld met een Veiligheidsbesluit Restgroepen. Terwijl dus enerzijds, mede onder druk van het oplaaiende vuur van bedrijfsdemocratisering in de periode 1965-1976, een belangrijke doorbraak in het centralistische reguleringsparadig. ma werd beoogd, verdichtte zich anderzijds het gedetailleerde regelcomplex nog meer dan voorheen: tot een niveau dat door de werkgevers als verstikkend werd betiteld. Die kritiek trof overigens ook de Arbowet zelf die, ondanks de expliciete doelstelling om juist ruimte te scheppen voor zelfregulering, begin jaren ' 80 regelmatig figureerde als voorbeeld van doorgeschoten regeldrift. Nog voor de Arbowet volledig in werking was getreden (de eerste fase in 1983), riepen diverse partijen op de wet te dereguleren en de administratieve ballast overboord te zetten. Zij wilden meer lucht voor structureel herstel van de kwakkelende economie en voor de primaire taakstelling van het bedrijfsleven: het winstgevend produceren van goederen en diensten. ${ }^{304}$ Het thema lucht komt aan de orde in de volgende paragraaf.

\subsection{Lucht (1980-1999)}

... de lucht leeft van de dood van het vuur....

Herakleitos, Fragment B 76

De laatste twee decennia van de twintigste eeuw zijn te kenmerken als een periode van herhaalde, welhaast obsessieve roep om deregulering: op velerlei terrein, alsook op het gebied van veiligheid en gezondheid. De Arbowet 1980 was nog niet eens ingevoerd, of de aanval werd al ingezet: "Gezien de verwachte verborgen

301 Directeur-Generaal van de Arbeid A.J. de Roos (1982). De Arbeidsomstandighedenwet, in: SMA, p. 308

302 Geers spreekt in dit verband van een 'status quo' artikel. Geers 1988, p. 93

303 Kamersmkken 11. 1976-1977, 14 497, nr, 3, p, 8

304 Geers 1988, p. 105-106 
beleidskosten van deze wet zou het goed zijn om te bezien of hier niet al gedereguleerd zou kunnen worden al voor de regulering een feit is." ${ }^{305}$ Ook de staatssecretaris van Sociale Zaken en Werkgelegenheid bepleitte, met het oog op de uit de hand lopende werkloosheid, "vereenvoudiging en opschorting van de wet- en regelgeving met het oog op een structureel herstel van de werkgelegenheid". 306 Zoals wel vaker in de geschiedenis van de arbeid bleek louter het hebben van werk overwegingen over veiligheid en gezondheid in de schaduw te stellen.

$\mathrm{Na} 1983$ werd de Arbowet onderworpen aan opeenvolgende operaties ter 'deregulering ${ }^{307}$, 'zelfregulering ${ }^{308}$, 'toetsing van wetgevingskwaliteit' ${ }^{309} \mathrm{en}$, als grand finale onder één noemer, 'maatwerk, deregulering en wetgevingskwaliteit', 310 Parallel aan deze operaties bezonnen ook het ministerie van Sociale Zaken zelf en de Arbeidsinspectie zich regelmatig op hun positie. ${ }^{311}$ De overheid zou zich moeten terugtrekken op haar kerntaken, waarbij de overheidsbemoeienis zich zou moeten beperken tot het garanderen van een 'basisniveau' in de arbeidsbescherming (ernstige veiligheidsrisico's). Voor alles wat boven het basisniveau van bescherming uitstijgt, is niet de overheid primair verantwoordelijk, maar de sociale partners. ${ }^{312}$

Dat de arbowetgeving in alle voornoemde operaties tamelijk prominent aanwezig was, mag overigens verrassend heten. Zoals in de vorige paragraaf is aangegeven, impliceerde de Arbowet 1980 immers juist een breuk met het centralistische reguleringsparadigma. De vehemente kritiek die begin jaren ' 80 ten grondslag lag aan de zogeheten 'grote operaties' echode dan ook eerdere geluiden uit bijvoorbeeld de Robens Committee. De naleving van de talrijke, vaak veranderlijke en slecht op elkaar afgestemde overheidsregelingen werd volgens de voorvechters van deregulering steeds moeilijker; de regels zouden niet in overeenstemming zijn met de

305 J.J. van Duijn (1982). Macro-economische gevolgen van deregulering. Beleid en Maatschappij, geciteerd in Geers 1988, p. 105

306 Brief van de staatssecretaris van Sociale Zaken en Werkgelegenheid aan de Voorlopige ArbeidsRaad, d.d. 7 oktober 1982. geciteerd in Geers 1988, pp. 106

307 "Deregulering van overheidsregelingen". TK 1983/84, 17 391. Vgl. F.K.M. van Nispen (1986), De grote operaties, in: F.K.M. van Nispen en D.P. Noordhoek (red.), De grote operaties: De overheid onder het mes of snijden in eigen vlees. Deventer: Kluwer, p. 12

308 "Zicht op wetgeving", TK 1990/91, 22008

309 Commissie Toetsing Wetgevingskwaliteit (1994). Van keurslijf naar keurmerk. Rapport CTW $94 / 12$

310 Commissie Maatwerk, deregulering en wetgevingskwaliteit, ingesteld op 10/1/95 (Ster. 1995, nr.15). 'Maatwerk in Bescherming'. Eindrappon MDW-werkgroep Arbeidsomstandighedenwet, Den Haag, 22 juni 1995, bijlage bij Kamerstukken II, 1994-1995, 24036, nr. 8: Vgl. V.J.J.M. Bekkers (1996), De schutkleuren van het dereguleringsbeleid, in: R.A.J. van Gestel en Ph. Eijlander (red), Markt en wet. Deventer: W.E.J. Tjeenk Willink, p. 63ff

311 Ministerie van Sociale Zaken en Werkgelegenheid, Strategische verkenningen, november 1991. Vgl. Wilthagen 1993, p. 58

312 De overheid acht zich nog uitsluitend verantwoordelijk voor de vaststelling. bijstelling en handhaving van basisnormen. Onder basisnormen worden verstaan: alle normen die voortvloeien uit internationale verplichtingen (EG-richtlijnen en door Nederland geratificeerde LAO-verdragen op arbeidsomstandighedenterrein), en alle normen die betrekking hebben op de belangrijkste arbeidsomstandighedenrisico's en een basisniveau van bescherming bieden tegen die risico's. Ministerie van Sociale Zaken en Werkgelegenheid. Integraal Beleidsplan Arbeidsomstandigheden, Den Haag: december 199I 
specifieke omstandigheden in bedrijven, de toegenomen sociale gedifferentieerdheid en snelle veranderingsprocessen in de samenleving ${ }^{313}$; regelgeving loopt per definitie achter de werkelijkheid aan; rechtsstatelijk verplichte procedures zouden prompte aanpassing aan de zich steeds sneller wijzigende omstandigheden in de weg staan (zo werd de systematiek van AMvB's in de Arbowet betiteld als 'institutionele sclerose' $)^{314}$; de administratieve lastendruk vormde een te grote belasting voor bedrijven - kortom, de regelgeving was efficiënt noch effectief. ${ }^{315}$

Doordat een onoverbrugbare kloof groeide tussen instituties en regels enerzijds en praktijken anderzijds, en bovendien de handhaving te wensen overliet en de gereguleerden zich steeds vaker onttrokken aan onuitvoerbaar geachte regels, dreigde de 'interveniërende Staat ${ }^{\mathbf{3 1 6}}$ zelfs ten prooi te vallen aan een heuse legitimiteitscrisis. ${ }^{317}$ In ieder geval was sprake van een reguleringscrisis: "De diagnose luidt dat de sturingsmogelijkheden van het recht en de overheid grotelijks worden overschat en dat de effecten van sturing gering, kostbaar en soms ongewenst zijn. Het recept wordt veelal gezocht in een verder terugtredende overheid die zich beperkt tot haar kerntaken en - op basis van minder gedetailleerde, flexibeler wetgeving - meer overlaat aan het zelfregulerend vermogen van maatschappelijke sectoren." 318 Hierbij kan worden opgemerkt dat het bij het arbobeleid dan met name om geconditioneerde zelfregulering gaat., De overheid houdt namelijk namelijk de bevoegdheid de zelfregulering aan allerlei voorwaarden te binden.

\section{Europese richtlijnen}

Aangezien ook de Arbowet 1980 al in belangrijke mate was gegrondvest op het concept van zelfregulering, viel bij beide herzieningen van de wet in de loop van de jaren ' 90 bijzonder weinig eer te behalen. Integendeel, de 'heroriëntatie' op de Arbowet zou juist uitmonden in een nog meer doorwrochte constellatie, zoals hier-

313 B. de Vroom (1989), Zelfregulering, in: W, Dercksen e.a. De terugtred van regelgevers: meer regels, minder sturing?, Zwolle, W.E.J. Tjeenk Willink, p. 267-268. Ph. Eijlander (1990). Wetgeving en zelfregulering, in: H.A.M. Backx et al., Recht doen door wetgeving, Zwolle: W.E.J. Tjeenk Willink, p. 34; Vgl. N.J.H. Huls (1992), Sturing in de risicomaatschappij. Zwolle: W.E.J. Tjeenk Willink, p. 6

314 Kamerstukken II 1983-1984, 17 931, nr. 9 (Eindbericht vermindering en vereenvoudiging van overheidsregelingen), p. 167

315 Kamersnkken II 1982-1983, 17 931, nr. 3 (Tussenbericht vermindering en vereenvoudiging van overheidsregelingen). p. 11-12: TK 1983-1984, 17 931, nr, 9 (Eindbericht vermindering en vereenvoudiging van overheidsregelingen), p. 10. Voor een uitgebreider overzicht van de achtergronden vgl. L.A. Geelhoed (1986), Deregulering en de grote operaties: Achtergronden en vooruitzichten, in: F.K.M. van Nispen en D.P. Noordhoek (red.), De grote operaties: De overheid onder het mes of snijden in eigen vlees, Deventer: Kluwer, p. $40 \mathrm{ff}$

316 L.A. Geelhoed (1983), De interveniërende staat: Aanzet voor een instrumentenleer. 's-Gravenhage: Staatsuitgeverij. Geelhoed was voorzitter van de werkgroep vermindering en vereenvoudiging overheidsnegelingen.

317 Engelen 2000, p. 24, p. 111. Overigens stellen diverse commentatoren nuchter vast dat achter de politiek-ideologische discussie over de crisis van de verzorgingsstaat ook simpele bezuinigingsdoelstellingen verscholen lagen. Van Nispen 1986, p. 12. Vgl. ook Wilthagen 1997

318 Wilthagen 1993, p. 19 
onder zal blijken. Maar ook de repeterende aanvallen op de detailvoorschriften in de diverse Veiligheidsbesluiten, zo kan men achteraf vaststellen, hebben niet opgeleverd wat de kampioenen der deregulering ervan hadden gehoopt. De belangrijkste reden hiervoor is, dat de regels ter bevordering van de veiligheid en de gezondheid bij de arbeid in toenemende mate zijn voorgeschreven door de Europese Unie. ${ }^{319}$ De eerste richtlijnen verschenen eind jaren $70^{320}$, en in 1980 werd de kaderrichtlijn betreffende de bescherming van werknemers tegen de risico's van blootstelling aan chemische, fysische en biologische agentia op het werk uitgevaardigd. ${ }^{321}$ Deze kaderrichtlijn vormde de basis van diverse bijzondere richtlijnen inzake het werken met lood respectievelijk asbest, de blootstelling aan lawaai en een verbod op bepaalde specifieke agentia). ${ }^{322}$

In $1986 \mathrm{kwam}$ het Europese arbeidsomstandighedenbeleid vervolgens in een stroomversnelling, toen een nieuw artikel $118 \mathrm{~A}$ werd opgenomen in het EG-verdrag. Dit artikel was een aanvulling op artikel 118, dat harmonisatie van de sociale wetgeving in Europa beoogde. ${ }^{323}$ Artikel 118 stond al sinds 1957 in het Verdrag. maar was door de vereiste unanimiteit in de ministerraad praktisch een dode letter: met name het Verenigd Koninkrijk torpedeerde stelselmatig alle hem onwelgevallige sociale regelgeving. Artikel $118 \mathrm{~A}$ evenwel introduceerde meerderheidsbesluitvorming op het gebied van het communautaire sociaal beleid, en bepaalde de competentie van de Europese Unie ten aanzien van veiligheid en gezondheid ${ }^{324}$ : op grond van artikel 118/118A (thans art. 137/138 EU-verdrag) kan de Unie, in casu de Ministerraad, minimumvoorschriften uitvaardigen waaraan alle lidstaten zich dienen te houden en die geïmplementeerd dienen te worden in de nationale wetgeving. ${ }^{325}$ Vogel merkt hierbij op dat in feite op geen enkel terrein de competentie van

319 Voor een heldere introductie tot de Europese arbeidsomstandighedenregelgeving vigl. Geers/Heerma van Voss 1995, p. 142-165

320 Richtlijn betreffende de veiligheidssignalering op de werkplaats (nr. 77/576/EEG) en de Richtlijn betreffende de bescherming van de gezondheid van werknemers die aan vinylchloridemonomeen zijn blootgesteld (nr. 78/610/EEG)

321 Richtlijn 80/1107/EEG, PbEG 1980, L 327, later gewijzigd Richtlijn 80/1107/EEG, PbEG 1980 , L 356

322 Respectievelijk Richtlijn 82/605/EEG, PbEG 1982, L 247; Richtlijn 83/477/EEG, PbEG 1983, L 263; Richtlijn 86/188/EEG, PbEG 1986, L 137; Richtlijn 88/364/EEG, PbEG 1988, L 179

323 Over de problematische interpretatie van het begrip 'harmonisatie' zie Vogel 1993. p. $40-45$

324 Geers/Heerma van Voss 1995, p. 143; D. Walters (2002), The Framework Directive, in: D.R. Walters (ed.), Regulating Health and Safety in: Management in the European Union: A study of the Dynamics of Change, Bruxelles: P.I.E.-Peter Lang. p. 40

325 Sindsdien heeft de EU 22 zogeheten bijzondere richtlijnen uitgevaardigd, waarmee het totaal aantal in de Nederlandse regelgeving verwerkte richtlijnen op 30 staat. Voor een volledig overzicht zie: P.E. van der Poest Clement en A.H.M. Broere (2000), Handboek Arbobesluit: Rechten en verplichtingen toegelicht voor werkgever en werknemer, Den Haag: Sdu ( $3^{e}$ druk), p. 403-407, en http://nl.osha.eu.int/legislation/eu/directives.stm. Naast de arbo-richtlijnen zijn op sommige punten ook de Europese regels op het gebied van produktveiligheid van belang voor de arbeidsomstandigheden van werknemers, in het bijzonder de Machinerichtlijn (Richtlijn 89/392/EEG, PbEG 1989, L 183, later gewijzigd bij 91/368/EEG (PbEG L198) en 93/44/EEG (PbEG L175). 
de EU minder omstreden is dan juist op het gebied van veiligheid en gezondheid: "even the most fervent deregulators accept that certain forms of public regulation on health and safety matters are an essential part of the Single market" 326 . al was het maar om oneerlijke concurrentie op veiligheid ('social dumping') te voorkomen. ${ }^{327}$

Ook bij de advisering door de SER, anno 1995, over de herschikking van 38 oude arbo- en veiligheidsbesluiten tot één nieuw Arbobesluit, werd de noodzaak van beschermende regels niet principieel bestreden. ${ }^{328}$ Wel gaven de werknemersvertegenwoordigers aan dat volgens hen de herziening van de regelgeving ten onrechte werd gebruikt om $66 \mathrm{k}$ bestaande regels te schrappen, en betreurden zij dat in sommige gevallen detailvoorschriften waren vervangen door meer globaal geformuleerde doelvoorschriften. De werkgeversgeleding daarentegen beklaagde zich juist over het feit dat het ontwerp-besluit op een aantal punten verder ging dan op grond van de Europese richtlijnen en verdragen van de IAO vereist was: een glasheldere illustratie van Vogel's stelling dat Europese minimumnormen door de werkgevers op nationaal niveau veelal worden gehanteerd als maximum. ${ }^{329}$ Slechts op een aantal punten werd werkelijk strijd gevoerd, in het bijzonder rond het voornemen om de zogeheten uitzichtbepaling uit de diverse Veiligheidsbesluiten en de oude bepalingen rond zandstralen en het werken met zandsteen niet over te nemen in het nieuwe Arbobesluit. Wat het laatste twistpunt betreft kregen de werknemersvertegenwoordigers het gelijk aan hun zijde. De uitzichtbepaling werd na tamelijk fel verzet echter uiteindelijk wél geschrapt. ${ }^{330}$

Inmiddels komt 90 procent van de Nederlandse regels in de uitvoeringsbesluiten uit Brussel en 7 ILO-verdragen. ${ }^{331}$ Naar aanleiding van de parlementaire discussie rond de heroriéntatie van de Arbowet, die deels parallel werd gevoerd aan de invoering van het Arbobesluit, merkte de staatssecretaris hierover op dat wat hem betreft het wenselijk zou zijn dat "op Europees niveau meer ruimte wordt gecreëerd voor een decentrale uitvoering en voor implementatie van Richtlijnen op andere wijze dan via algemeen verbindende voorschriften. Ook is modernisering en vereenvoudiging van bestaande richtlijnen wenselijk. In Europees verband zal daarop worden

326 Vogel 1993, p. 63; Vgl. De Gier/Vos 1995, p. 57

327 Completing the Internal Market: White Paper from the Commission to the European Council. COM (85) 310 final: Walters 2002, p. 42

328 SER (1995), Advies ontwerp-Arbeidsomstandighedenbesluit. Den Haag: Sociaal-economische Raad, 95/31 I en II

329 Vogel 1993, p. 45

$330 \mathrm{Vgl}$. onder meer Kamerstukken II. 1996-1997. 24 462, nr. 14 en 1997-1998. 24 462, nr. 15. Op voorstel van de werknemersvertegenwoordigers werd wel een aantal gevaarlijke stoffen toegevoegd aan de lijst van stoffen waarvoor een arbeidsveiligheidsrapport moet worden gemaakt. Een pleidooi van de werknemersvertegenwoordigers en onafhankelijke leden om het arbojaarplan verplicht te stellen voor alle OR-plichtige bedrijven (anno 1995 nog $35+$ werknemers) vond geen gehoor bij de wetgever.

331 Arbeidsomstandighedenbesluit 15 januari 1997, Stb. 60. p. 132. 158-159 
aangedrongen." 332 Inmiddels is de Nederiandse overheid er nog niet in geslaagd daadwerkelijk succes te boeken op dit front. ${ }^{333}$

\section{Kaderrichtlijn 89/391: risico-inventarisatie}

Artikel 118A had niet alleen een fors aantal richtlijnen met minimumvoorschriften tot gevolg. Veel ingrijpender nog was de aanvaarding in 1989 van richtlijn 89/391/EEG. de zogeheten Kaderrichtlijn betreffende de tenuitvoerlegging van maatregelen ter bevordering van de verbetering van de veiligheid en de gezondheid van de werknemers op het werk. Artikel 16 van deze Kaderrichtlijn vormt het kader voor de al genoemde bijzondere richtlijnen. Belangrijker echter is dat de Kaderrichtlijn versterking en harmonisatie beoogde van de meer beleidsmatige elementen uit de arbowetgeving in de lidstaten. In Nederland leidde dit, in 1994, tot een ingrijpende aanpassing van de Arbowet.

De harmonisatie echode in essentie de eerder aangehaalde beleidsfilosofie van Robens:

- de bescherming van de veiligheid en de gezondheid van de werknemers is primair de verantwoordelijkheid van de werkgever (zorgplicht, art. 5 Kaderrichtlijn),

- de werkgever moet een adequaat veiligheidsbeleid voeren op grond van een aantal 'preventieprincipes' (art. 6),

- onder evenwichtige participatie van de werknemers en hun vertegenwoordigers (art. 11).

Dit fundamentele uitgangspunt van de Kaderrichtlijn week niet of nauwelijks af van de Arbowet $1980 . .^{334}$ Ook de preventieprincipes ( $\operatorname{art}$. 6, lid 2), zoals bestrijding van risico's aan de bron, rekening houden met de stand der techniek en aanpassing van het werk aan de mens (humanisering), waren goeddeels al aanwezig in artikel 3 van de Arbowet. Op deze punten behoefde de Arbowet dan ook niet te worden aangepast. Wel nieuw was artikel 6 , lid $2 \mathrm{~b}$, dat werkgevers verplichtte een evaluatie te maken van de risico's die niet kunnen worden voorkomen. Deze verplichting, die mede was geïnspireerd door het Noorse concept van Internkontroll (interne contro$\mathrm{e}^{335}$ ), vormde de aanleiding tot de introductie (in 1994) van de verplichte rísicoinventarisatie en evaluatie in artikel 4 van de Arbowet, het huidige artikel 5. Deze risico-inventarisatie en evaluatie vormt idealiter het fundament onder een effectief

332 Kamerstukken II, 1997-1998, 25 879, nr. 3, p. 3

333 Vgl. ook A.J.C.M. Geers (2000), Een bekoelde relatie? Nederland en het Europees arbeidsomstandighedenrecht, in: Sociaal Maandblad Arbeid, nr. 7/8, p. 300-302

334 Kamerstukken II. 1992-1993, 22 898, nr. 3, p. 3-4

335 D. Walters en P.L. Jensen (2000). The discourses and purposes behind the development of the EU Framework Directive 89/391, in: K. Frick et al. (eds.). Systematic Occupational Health and Safety Management, Amsterdam/Oxford: Pergamon, p. 94. Vgl. S. Gaupset (2000), The Norwegian Internal Control Reform - an unrealized potential, in: Frick 2000, p. 329-348. Het centrale document is Internkontroll i en samlet strategi for arbeidsmilje og sikkerhet (Interne controle in een totale strategie voor arbeidsomgeving en veiligheid) uit 1987. 
preventiebeleid, en het is dus van belang om kort stil te staan bij de intenties achter de Kaderrichtlijn en de doorwerking in de Nederlandse situatie - met name bij het effect op de arbeidsverhoudingen.

In de parlementaire behandeling van de wetswijziging kreeg het concept van risico-inventarisatie, ten onrechte, betrekkelijk weinig aandacht. Zoals Vogel terecht opmerkt, kan risico-inventarisatie en evaluatie namelijk een effectief instrument zijn om de betrokkenheid van werknemers bij het arbeidsomstandighedenbeleid in hun bedrijf te versterken. Indien risico-inventarisatie echter louter een aangelegenheid wordt van (veiligheidskundige) experts, bestaat het risico dat de (subjectieve) ervaring van de werknemers buiten beschouwing blijft en in meer algemene zin de zorg voor veiligheid en gezondheid uit handen van de werknemers wordt geslagen; dit staat immers op gespannen voet met de intenties van de Kaderrichtlijn. ${ }^{336}$ In de Memorie van Toelichting bij de wijziging van de Arbowet is niet scherp omschreven welke werkwijze de voorkeur verdient. Het vereiste niveau van deskundigheid bij de risico-inventarisatie zou moeten worden vastgesteld in overleg met de ondernemingsraad. Wel opperde de staatssecretaris expliciet de mogelijkheid om de RI\&E te laten uitvoeren door werknemers in het bedrijf, al dan niet onder toezicht van deskundigen. ${ }^{337}$ Daarmee zouden de werknemers een centrale rol kunnen gaan spelen in hun organisatie. De risico-inventarisatie en -evaluatie vormt immers, zoals gezegd, de basis van het arbobeleid.

In de praktijk na 1994 blijkt hiervan echter weinig terecht te zijn gekomen. Nog afgezien van het feit dat acht jaar na invoering van de RI\&E-verplichting 20 procent van de bedrijven met meer dan 10 werknemers zelfs nog geen risico-inventarisatie heeft uitgevoerd, blijkt ook de betrokkenheid van werknemers of werknemersvertegenwoordigers te wensen over te laten. ${ }^{338}$ In verreweg de meeste gevallen wordt de risico-inventarisatie uitgevoerd door de werkgever of leidinggevende ( 85 procent) in samenwerking met de zogeheten arbodienst ( 81 procent). ${ }^{339}$ Mede als gevolg van de centrale rol van deskundigen zijn standaard-modellen van arbodiensten dominant. ${ }^{340}$ Voor een uitgebreidere analyse van de betrokkenheid van werknemers bij de risico-inventarisatie zij hier verwezen naar paragraaf 4.1.2.

336 Vogel 1993, p. 89. Zie ook A. Karageorgiou et al. (2000), Risk assessment in four member states of the European Union, in: Frick 2000, p. 251-252

337 Kamerstukken II, 1992-1993, 22 898, nr. 3, p. II

338 E.L. van der Steeg et. al (2002), Onderzoek naar de succes- en faalfactoren van de op grond van de Arbeidsomstandighedenwet uitgevoerde risico-imventarisatie en -evaluatie. Den Haag: Ministerie van Sociale Zaken en Werkgelegenheid (werkdocument 276)

339 A. Peters en E.C. van Hoorn (2002). Arbomonitor 2001, Den Haag: Arbeidsinspectie, p. 10 Ministerie van Sociale Zaken en Werkgelegenheid (2002). Arbobalans 2002: Arbeidsrisico's, effecten en maatregelen in Nederland, p. 51-53

340 Peters 2002, p. 10. Zie ook: R. Visser en Y. Bonnet (1996), Instrumenten risico-imventarisatie en evaluatie: overzicht en ervaringen. Amsterdam: Nederlands Instituut voor Arbeidsomstandigheden 
De meest ingrijpende wijziging van de Arbowet als gevolg van de Kaderrichtlijn was echter, anno 1994, de introductie van de arbodienst. Ook hiervoor geldt dat. vanwege de grote invloed van het systeem van arbodiensten op de arbeidsverhoudingen rond het arbobeleid, een iets uitgebreidere beschouwing op zijn plaats is. De introductie van de arbodienst in artikel 17-20 van de Arbowet was een direct uitvloeisel van artikel 7 van de Kaderrichtlijn. Artikel 7 verplicht, onder het kopje "beschermings- en preventiediensten", de werkgever een of meer werknemers aan te wijzen die zich bezighouden met "de activiteiten op het gebied van de bescherming tegen en de preventie van beroepsrisico's in het bedrijf en/of de inrichting" (lid 1). "Indien de mogelijkheden in het bedrijf en/of de inrichting onvoldoende zijn om deze beschermings- en preventieactiviteiten te organiseren, moet de werkgever een beroep doen op deskundigen (personen of diensten) van buiten het bedrijf en/of de inrichting" (lid 3).

Kenmerkend voor de Nederlandse transpositie van artikel 7 van de Kaderrichtlijn was dat de werkgever voor een drietal taken verplicht een gecertificeende arbodienst moest inschakelen, te weten:

- "het verienen van medewerking aan het verrichten en opstellen van de inventarisatie en evaluatie [..] waaronder mede begrepen het adviseren daaromtrent".

- bijstand bij de begeleiding van zieke werknemers, en

- het uitvoeren van het arbeidsgezondheidskundig onderzoek (art. 18, lid 2. Arbowet 1994). ${ }^{341}$

Zeker met het oog op de laatstgenoemde taken wilde de wetgever expliciet aansluiten bij de al bestaande infrastructuur van bedrijfsgezondheidsdiensten. ${ }^{342}$ Wel zou de oude BGD bij voorkeur omgevormd moeten worden tot een 'arbobrede'. multidisciplinaire dienst. Mede met het oog op de integratie van veiligheid, gezondheid en welzijn werd aan certificatie van de arbodienst als eis verbonden dat deze zou beschikken over deskundigheid op ten minste vier terreinen: bedrijfsgeneeskunde, veiligheidskunde, arbeidshygiëne, en arbeid- en organisatiekunde. ${ }^{343}$ Die deskundigheden zouden bovendien op HBO-niveau vervuld moeten worden.

Deze hoog opgeschroefde certificeringseisen hadden echter tamelijk verstrekkende consequenties, óók voor de arbeidsverhoudingen op het gebied van arbeidsomstandigheden. Hoewel artikel 17 van de Arbowet 1994 (thans art. 14) de werkgever in principe de vrijheid liet om te kiezen tussen interne en externe deskundigen, bleek mede door de hoge certificeringseisen het organiseren van interne preventiedien-

341 Deze eis tot certificering is terug te voeren op het unanieme advies van de Arboraad, dat vreesde voor de kwaliteit van de dienstveriening. Advies van 15 april 1993, nr. R-2781

342 Kamerstukken II. 1992-1993. 22 898, nr. 6. p. 5 en nr. 3. p. 51

343 Besluit Arbodiensten (Stb. 1994; 781) Een voorstel van de PvdA (en FNV) om ook ergonomie op te nemen als één van de kerndisciplines werd niet overgenomen. De huidige regelgeving is opgenomen in hoofdstuk 2, afd. 3. Arbobesluit en met name ook de Richtlijn Certificering van de Stichting Beheer Certificatie Arbodiensten, vgl. M.M.W. (red.) (2003), Het compleet arboregelgevingboek, Amsterdam/Zeist: FNV/Kerckebosch, $6^{e}$ druk, p. $907-966$ 
sten nagenoeg onhaalbaar. In 1998 was 83 procent van de arbodienstverlening extern georganiseerd, een situatie die anno 2002 nog niet was gewijzigd. ${ }^{344}$ Met de externalisatie van de arbodienstverlening dreigde echter ook een van de centrale doelstellingen van de Kaderrichtlijn, een meer evenwichtige betrokkenheid van de werknemers, achter de horizon te verdwijnen. Dit werd de Nederlanse overheid begin 2003 althans nagedragen door de Advocaat-Generaal van het Europees Hof, in een geschil tussen de Europese Commissie en het Koninkrijk der Nederlanden over de (on)juiste implementatie van artikel 7 van de Richtlijn. ${ }^{345}$ In zijn arrest van 22 mei 2003 bevestigde het Europees Hof de zienswijze van de Advocaat-Generaal. Het Hof was het ook met de Advocaat-Generaal eens dat "evenwichtige deelneming van werkgevers en werknemers aan de activiteiten op het gebied van de bescherming tegen en preventie van beroepsrisico's" dient te worden bevorderd en dat "het nuttig effect van de richtlijn het best kan worden verzekerd door deze activiteiten bij voorrang binnen het bedrijf te organiseren". 346

Dat de "evenwichtige deelneming van werknemers" niet is gegarandeerd binnen het Nederlandse systeem van arbodienstverlening blijkt ook uit de praktijk. Terwijl de oude bedrijfsgezondheidsdiensten non-profitorganisaties waren, koos de wetgever bij de arbodienstverlening nieuwe stijl voor een commerciële structuur. Door concurrentie tussen de arbodiensten zou de kwaliteit verbeteren tegen lagere kosten. Als gevolg van de scherpe concurrentie in het bijzonder, maar van de marktverhouding in het algemeen, hebben de arbodiensten zich in sterke mate gericht op de werkgever als opdrachtgever en maakten zij hun rol als onafhankelijke deskundige ondergeschikt aan hun commerciële belang als marktpartij. Ten eerste hadden (en hebben) vele individuele werknemers klachten over de opstelling van met name bedrijfsartsen. Daarnaast stond ook de verondersteld onafhankelijke relatie tussen arbodienst en ondernemingsraad onder druk: niet zelden liet (en laat) de arbodienst de ondernemingsraad links liggen, met name bij het afsluiten van contracten tussen de arbodienst en het bedrijf, maar ook in de informatievoorziening. ${ }^{347}$

Het gebrek aan onafhankelijkheid van de arbodiensten was voor de vakbeweging al vanaf 1994 een steen des aanstoots. Bij herhaling heeft met name de FNV enquêtes uitgezet over het functioneren van arbodiensten ${ }^{348}$ en klachtenlijnen opengesteld voor individuele werknemers. ${ }^{349}$ In reactie op de negatieve uitkomsten van die

344 CBS (1999), Enquête arbodiensten, persbericht PB99-297. Anno 2002 bestonden er minder dan 50 gecertificeerde interne arbodiensten. Cf. http///nL.osha.eu.int/systems/organisations/\#arbodiensten

345 Conclusie van advocaat-generaal D. Ruiz-Jarabo Colomer in zaak C-441/01. Commissie van de Europese Gemeenschappen tegen Koninkrijk der Nederlanden, d.d. 16 januari 2003, in het bijzonder nr. 22

346 Arrest van het Hof in zaak C-441/01, Commissie van de Europese Gemeenschappen tegen Koninkrijk der Nederlanden, d.d. 22 mei 2003, nr. 54

347 J.R. Popma, C. van Rij en J. Hooiveld (2001), Arbodienstverlening tussen markt en medezeggenschap. Den Haag: Delwel. p. $52 \mathrm{ff}$

348 FNV (1995), Contacten over contracten, Amsterdam: FNV; Hooiveld 1996, p. 27-34

$349 \mathrm{Vgl}$. onder meer FNV (1998), Eindrapport meldlijn Arbo-diensten, Amsterdam: FNV en de jaarlijkse rapportages van de Helpdesk Gezondheid. Werk en Verzekeringen 
onderzoeken, ontwikkelden de bonden initiatieven om tot betere regulering van het functioneren van de arbodiensten te komen, zoals nadere afspraken in de certificeringsvoorschriften (vgl. ook par. 3.5$)^{350}$ en een protocol Arbodiensten en Werknemers. ${ }^{351}$ Daarnaast hebben de vakcentrales aangedrongen op de ontwikkeling van diverse professionele standaards voor arboprofessionals ${ }^{352}$, klachten- en geschillenregelingen ${ }^{353}$, en regelgeving door de overheid. ${ }^{354}$

Toch doen deze correcties niet af aan de principièle onevenwichtigheid die in het Nederlandse systeem van arbozorg is geslopen. Daarbij is zowel de betrokkenheid van werknemers bij de risico-inventarisatie en evaluatie in het geding als de participatie van werknemers in de beschermings- en preventiediensten (artikel 7 van de Kaderrichtlijn), Op dit laatste punt stelde de Nederlandse overheid, in haar geschil met de Europese Commissie, dat evenwichtige deelneming van werknemers aan een preventief arbobeleid "op verschillende manieren [kan] worden bewerkstelligd en niet alleen door voorrang toe te kennen aan de uitvoering ervan door de eigen werknemers. In Nederland wordt die doelstelling verwezenlijkt door de implementatie van artikel 9 van de richtlijn, dat de verplichtingen van de werkgever regelt [rond onder meer de risico-inventarisatie], en van artikel 10, dat zijn verplichting tot voorlichting van de werknemers specificeert. Ook ingeval een externe dienst met de beschermings- en preventieactiviteiten wordt belast, zorgt de Nederlandse wet voor een nauwe betrokkenheid van het eigen personeel." 355 Het Hof was echter niet overtuigd dat de Nederlandse Arbowet de betrokkenheid van de werknemers "hoe dan ook verzekert", zoals de Nederlandse gemachtigde stelde.

Of het Nederlandse systeem wel of niet tot evenwichtige betrokkenheid van de werknemers of de werknemersvertegenwoordigers leidt, is nu precies één van de hoofdthema's van dit proefschrift. Het antwoord op de kwestie zal met name worden gebaseerd op hoofdstuk 4.

\section{Heroriëntatie Arbobeleid en Arbowet}

Hoewel de introductie van de risico-inventarisatie en de arbodiensten bepaald niet onbelangrijk genoemd kan worden in zijn effecten, werd de wijziging van de Arbowet anno 1994 toch vooral opgevat als een wijziging op de oude wet van 1980. Binnen het denkraam van deregulering kon zij zelfs worden gezien als een hooguit

350 Stichting Beheer Certificatie Arbodiensten. Documenten voor de Regeling Certificatic Arbodiensten, in: Wilders 2003, p. 905-960

351 FNV. CNV en MHP (1997). Protocol arbodiensten en werknemers

352 BOA (1996), Professioneel statuut BOA; NVAB (1997). Professioneel statuut van de bedrijfsarts; B.A.V. (1997), Professioneel statuut Arboverpleegkundige

353 Branche-Organisatie Arbodiensten (1998), Reglement geschillencommissie arbodiensten. De landelijke geschillencommissie is geïnstalleerd in april 1999. Vgl. ook Branche-Organisatie Arbodiensten (2000), Uniforme Klachtenregeling Arbodiensten

354 Wet op de medische keuringen (Stb. 1997, 365). Besluit aanstellingskeuringen (Stb. 2001. 597), In 2002 is ingesteld de Commissie klachtenbehandeling aanstellingskeuringen (Stb. 2001, 598)

355 Conclusie van advocaat-generaal D. Ruiz-Jarabo Colomer, d.d. 16 januari 2003. nr. 21 
technische wijziging en zeker niet als een majeure heroriëntatie op de balans tussen overheid en (georganiseerd) bedrijfsleven. Die heroriëntatie werd, als een soort frapper toujours, wél tot drie keer toe ingezet vanuit de bredere discussie over verbetering van de wetgevingskwaliteit en deregulering. In 1987 werd de zogeheten Commissie voor de toetsing van wetgevingsprojecten geïstalleerd, die ook de wetgeving op het gebied van arbeidsomstandigheden door zou lichten. ${ }^{356}$ In 1994 verscheen het rapport Van Keurslijf naar Keurmerk van een sub-commissie, naar haar voorzitter de Commissie-De Ru geheten. ${ }^{357}$ De commissie kwam met een ambitieus advies, dat door de commissievoorzitter puntig werd samengevat in de stelling dat de Arbowet de prullenbak in kon, omdat de vrees voor steeds hoger wordende letselschadeclaims (ex art. 1638x BW) de werkgevers wel zou aanzetten tot een preventief beleid. ${ }^{358}$

Dit advies voor een vergaande verprivaatrechtelijking van het arbeidsomstandighedenrecht bleek een stap te ver. Een jaar later, in het kader van de operatie 'marktwerking, deregulering en wetgevingskwaliteit', volgde een impliciete verwerping van de scherp aangezette privaatrechtelijke strategie. Het veronderstelde preventieve effect van de claimcultuur bleek volgens de MDW-werkgroep arbeidsomstandigheden niet of nauwelijks op te treden. ${ }^{359}$ Wel herhaalde de werkgroep in haar rapport Maatwerk in bescherming nog maar eens dat werkgevers zich te zeer richten op het voldoen aan materièle detailvoorschriften (uit de Veiligheidsbesluiten), en te weinig bevoegdheden zouden hebben "om aan hun verantwoordelijkheid voor goede arbeidsomstandigheden een eigen inhoud te geven die aansluit bij de specifieke omstandigheden van het bedrijf " 360

De analyse omtrent de dwingende werking van de Veiligheidsbesluiten valt wellicht nog te delen, al gaf bijlage 2 bij het rapport (een overzicht van mogelijke vermindering van administratieve lasten) ten overvloede aan dat er op dit punt bijzonder weinig te dereguleren valt. Wat betreft de opmerking dat de werkgever "ontmoedigd [wordt] om na te denken over preventie en mogelijke verbeteringen van de arbeidsomstandigheden in het bedrijf ${ }^{.361}$ kan echter opgemerkt worden dat de concepten zorgplicht en optimalisering in artikel 3 en 4 van de Arbowet nu juist wél een beleidsuitdaging voor bedrijven behelzen. Wellicht nemen de werkgevers te weinig initiatieven op het gebied van preventie, maar dat komt niet door een ontmoediging van rechtswege. Het rapport krabde op plekken waar het niet jeukte. Op hoofdlijnen had het MDW-rapport dan ook weinig nieuws te bieden: de zorgplicht, de risico-inventarisatie en de ondersteuning door een arbodienst bleven gewoon

356 Instelling CTW 10/9/87 (Stcr. 1987. nr. 181)

357 Commissie Toetsing Wetgevingskwaliteit, Van keurslijf naar keurmerk: Wetgevingsbeleid voor veilig en gezond werk. Ministerie van Justitie, Den Haag, Rapport CTW 94/12. 15-09-1994

358 Maandblad Arbeidsomstandigheden, juni 1994, p. 323-324

359 MDW-advies 'Maatwerk in Bescherming' (1995), p. 13. Voor een meer recente onthuistering van het idee dat civielrechtelijke aansprakelijkheid leidt tot preventie vgl. C. van der Werf. M. Engelen. M. van Ewijk (2001). Wenkgeversaanspnakelijkheid bij beroepsziekten, Den Haag: Ministerie van Sociale Zaken en Werkgelegenheid/Elsevier

360 'Maatwerk in Bescherming' (1995), samenvatting p. 3

361 Ibid, samenvatting p. 3 
overeind. ${ }^{362}$ Opvallend is dat hierbij het vierde systeemkenmerk - medezeggenschap - niet genoemd werd. Dit wellicht als impliciete codificatie van de constatering dat "werknemers slechts in geringe mate betrokken [zijn] bij de bepaling van het arbobeleid binnen het bedrijf." ${ }^{363}$

De geringe status van medezeggenschap werd nog explicieter in de adviesaanvraag van het kabinet aan de SER over een 'Heroriëntatie Arbobeleid en Arbowet'. ${ }^{364}$ In de nota werd een aantal hoofdlijnen voor een nieuwe Arbowet neergezet. Een van die hoofdlijnen was dat de materiële normstelling meer door de sociale partners zou moeten worden ontwikkeld middels certificatie en normalisatie, met name als nadere uitwerking van globaal geformuleerde wettelijke voorschriften. ${ }^{365}$ Voor de (zeer) emstige risico's zou publiekrechtelijke regulering het aangewezen instrument moeten blijven. Daarnaast zou een zwaarder accent moeten komen te liggen op bestuurs- en civielrechtelijke in plaats van strafrechtelijke handhaving, zeker voor de minder ernstige risico's. Omtrent de zogeheten systeemeisen of 'spelregels' (uitvoeren risico-inventarisatie, opstellen plan van aanpak, medezeggenschap) werd opgemerkt dat ook deze bestuursrechtelijk dan wel civielrechtelijk gehandhaafd zouden moeten worden - waarbij medezeggenschap, tussen neus en lippen door, tot 'niet-essentiële' spelregel werd verklaard. ${ }^{366}$ Voor het overige werd gesteld dat "de informatie aan en het overleg met de werknemers(vertegenwoordigers) $|.$.$| in het$ algemeen van een voldoende niveau zijn" en dus inhoudelijk niet gewijzigd zouden worden. ${ }^{367}$

Op een aantal punten betekende de adviesaanvraag echter juist een stap terug: zo zou de verplichting tot het maken van een jaarplan en jaarverslag komen te vervallen, en werden de aanwijzing en het verzoek om wetstoepassing uit het instrumentarium van de Arbeidsinspectie geschrapt. Deze laatste twee instrumenten waren voor de OR of vakbond, in geval van onenigheid tussen werkgever en werknemers, althans in theorie een middel om de Arbeidsinspectie een arbitrerende rol te laten spelen. Die weg naar een onafhankelijke bondgenoot werd door de kabinetsplannen afgesneden. In zijn advies over de Heroriëntatienota vijlde de SER tamelijk eensgezind de scherpe kantjes van het voorstel af. Zo werd het onderscheid tussen (zeer) ernstige en niet-ernstige risico's als 'arbitrair' en onwerkbaar van de hand gewe$z e n^{368}$, en de civielrechtelijke handhaving van materiële regels ontraden omdat dit onder meer tot grote spanningen in de arbeidsverhoudingen zou kunnen leiden. ${ }^{369}$ Ook het verzoek om wetstoepassing zou behouden moeten worden, opnieuw

\footnotetext{
362 Ibid..p. 22

363 lbid, samenvatting p. 3

364 SZW (1966), Hemriëntatie arbobeleid en Arbowet: Adviesaanvraag aan SER, Den Haag:

Ministerie van Sociale Zaken en Werkgelegenheid (ARBO/AIS/96/00812)

365 Ibid. p. 16-18

366 Ibid. p. 9

367 lbid. p. 20

368 SER (1997), Advies heroriëntatie Arbobeleid en Arbowet, Den Haag: Sociaal-Economische Raad. SER $97 / 03$, p. 35

369 lbid. p. 37
} 
omwille van de arbeidsrust: "via dit instrument, waarbij het mogelijk is een duiding te krijgen van de betekenis van een wettelijk voorschrift door een onpartijdig en gezaghebbend instituut, de Arbeidsinspectie, kan voorkomen worden dat conflicten escaleren en arbeidsverhoudingen verstoord raken." 370 Verschil van inzicht ontstond wel rond het thema medezeggenschap. Anders dan de werkgevers waren de werknemersvertegenwoordigers en de onafhankelijke leden namelijk van mening dat in het algemeen de condities voor medezeggenschap werden ondergraven: het schrappen van het jaarplan en jaarverslag werd afgewezen, en ook het verzoek om wetstoepassing zou gehandhaafd moeten blijven.

\section{Wetsvoorstel Arbeidsomstandighedenwet 1998}

Het onderscheid emstig/niet-ernstig was niet meer terug te vinden in het uiteindelijke Voorstel van wet, dat begin 1998 aan de Tweede Kamer werd aangeboden. ${ }^{371}$ Wel hield het kabinet vast aan zijn voornemen het arbojaarplan en jaarverslag te schrappen, evenals het verzoek om wetstoepassing. De verplichting voor werkgevers om de ondernemingsraad een exemplaar van de risico-inventarisatie en -evaluatie te zenden zou ook niet meer door de Arbeidsinspectie moeten worden gehandhaafd, maar civielrechtelijk door de OR zelf. Ten slotte werd ook de expliciete plicht van de arbodienst geschrapt, om samen te werken met de ondernemingsraad.

Vanuit zowel de vakbeweging als de wetenschap werd deze aanval op de medezeggenschap bekritiseerd. ${ }^{372}$ Ten dele had deze kritiek ook effect. Zo bleef de samenwerking met de ondernemingsraad een van de verplichte taken voor de arbodienst (art. 14, lid 3e), en werd de verplichting voor de arbodienst om van alle adviezen aan de werkgever een kopie aan de OR te sturen aangescherpt (art. 14, lid 7). Het jaarplan en jaarverslag sneuvelden echter wél, om alras uit hun as te herrijzen. Het jaarplan voor $100+$ bedrijven was immers al uitgebreid tot een plan van aanpak voor álle bedrijven, al bleef onduidelijk hoe vaak een dergelijk plan opgesteld zou moeten worden. In reactie hierop werd een tweetal moties ingediend over de gewenste periodiciteit van het plan van aanpak (jaarlijks, driejaarlijks) ${ }^{373}$, waarna staatssecretaris Hoogervorst bij wijze van compromis met het voorstel kwam dat over de voortgang van het plan van aanpak jaarlijks schriftelijk gerapporteerd zou

\footnotetext{
370 Ibid. p. 45

371 Kamerstukken II, 1997-1998, 25879, nr. 1-2
}

372 FNV. Brief aan de leden van de Vaste Commissie voor Sociale Zaken en Werkgelegenheid, 19 maart 1998: CNV, Brief aan de leden van de Vaste Commissie voor Sociale Zaken en Werkgelegenheid, 2 april 1998; A.J.C.M. Geers en J.R. Popma (1998), Voorstel Arbeidsomstandighedenwet 1998, in: Sociaal Maandblad Arbeid, juni 1998, p. 247-257. Daarnaast werd volgens deze critici te weinig aandacht besteed aan welzijnsaspecten in het algemeen en werkdruk in het bijzonder, en werden kanttekeningen geplaatst bij het vertrouwen van de overheid in de risico-inventarisatic. In meer principièle zin bekritiseerde Rottier het onderscheid tussen doelvoorschriften en middelvoorschriften. H. Rottier (1998), 'Het poedeltje in de magnetron - enkele onderwerpen uit het wetsvoorstel Arbeidsomstandighedenwet 1998 kritisch beschouwd, in: Sociaal Recht juni 1998

373 Kamerstukken II, 25879 , nrs. 17 resp. 29 
moeten worden aan de ondernemingsraad of pvt. ${ }^{374}$ Hoewel het arbojaarverslag voor de $100+$ bedrijven met de rechterhand werd geschrapt, werd het met de linkerhand feitelijk voor alle bedrijven ingevoerd ( $a r t .4$, lid 2). In hoofdstuk 3 wordt uitgebreider ingegaan op de formele rechten van de OR bij het arbobeleid.

\section{Maarwerk}

Alle voornemens tot deregulering ten spijt, werd de Arbowet dus in feite helemaal niet gedereguleerd. Op een aantal punten werd de wet zelfs uitgebreid, zoals de verplichte voortgangsrapportage. Uiteindelijk bleek de operatie 'Herorièntatie Arbowet' niet veel meer dan een cosmetische ingreep - op twee daadwerkelijke wijzingen na. De eerste, tamelijk majeure wijziging betreft de introductie in de Arbeidsomstandighedenwet 1998 van het instrument der bestuurlijke boete (artt. 33-43 Arbowet 1998). In de praktijk wordt dit instrument ook redelijk vaak gehanteerd: in 2001 werden 2664 boetes uitgedeeld ( 11 procent van het aantal bezochte bedrijven), met een totaal boetebedrag van meer dan vijf miljoen euro. ${ }^{375} \mathrm{De}$ belangrijkste aanleidingen voor het opleggen van een boete waren, blijkens een tussenrapportage uit 2002, het ontbreken van een risico-inventarisatie en -evaluatie ( 23 procent) en het ontbreken van adequate maatregelen bij valgevaar ( 22 procent). ${ }^{376}$ De tweede wijziging is theoretisch interessant in verband met het thema van dit onderzoek, maar praktisch vooralsnog van zeer beperkte waarde. Artikel 17 van de Arbowet 1998 introduceerde, onder het kopje "maatwerk door werkgevers en werknemers", de mogelijkheid af te wijken van wettelijke voorschriften mits geen afbreuk wordt gedaan aan het wettelijk voorgeschreven beschermingsniveau. Dit idee was al geopperd in de Arbeidswet 1922 en later in het SER-advies over de Arbowet 1980, maar dook in het advies in 1997 opnieuw op. ${ }^{377}$ Een tweede vereiste, naast behoud van het beschermingsniveau, is dat de afwijking van de voorschriften vastgelegd moet worden in een $\mathrm{CAO}$ dan wel in een regeling waarover overeenstemming is bereikt met de ondernemingsraad of de personeelsvertegenwoordiging. Dit overeenstemmingsrecht is sterker dan het instemmingsrecht, omdat bij weigering van instemming de bestuurder in beroep kan gaan bij de kantonrechter (art. 36 WOR), terwijl bij het ontbreken van overeenstemming van de OR geen beroep openstaat. ${ }^{378}$

Het model van wettelijke basisnormen met daaraan gekoppeld de mogelijkheid om in overleg met de vakbonden of de ondernemingsraad/pvt van die normen af te wijken, was eerder opgenomen in de Arbeidstijdenwet 1996 en heeft sindsdien enige

374 Kamerstukken II, 25879 , nr. 36

375 Arbeidsinspectie (2003), Jaarverslag 2002, p. 22

376 A. Peters en A. Vaas (2002), De bestuurlijke boete in de arbowet: evaluatie 2001, Den Haag: Arbeidsinspectie, p. 16

377 SER 1997, p. 27-28

378 F.W.H. Vink (2002), Inzicht in de ondermemingsraad: Een toelichting bij de Wet op de Ondernemingsraden. Den Haag: Sdu. p. 131 
furore gemaakt in de sociale wetgeving. zowel op nationaal ${ }^{379}$ als op Europees niveau. ${ }^{380}$ Naast het expliciete doel om meer ruimte te creëren voor maatwerk ${ }^{381}$, heeft deze strategie van driekwart-dwingend recht als nevengeschikt doel dat de sociale partners worden aangezet tot intensiever overleg over sociale thema's. In zijn advies over de Arbowet stelt de SER dat "wordt bevorderd dat arbeidsomstandigheden in het (CAO-)overleg tussen werkgever(s) en werknemers een steviger plaats gaan innemen. De reeds jaren gewenste branche-gerichte aanpak, die echter nog nauwelijks van de grond is gekomen, krijgt daardoor mogelijk een impuls." 382 Daarmee zou 'arbo'-potentieel een van de instrumenten worden om de arbeidsverhoudingen in Nederland te versterken. In de praktijk gaat van de regeling overigens, vooralsnog. geen enkele impuls uit. Een belangrijk knelpunt is namelijk dat van de Europese regels niet mag worden afgeweken, en dat van de resterende, specifieke nationale regels alleen mag worden afgeweken indien de minister bij AMvB de mogelijkheid tot maatwerkafspraken heeft geopend. Tot op heden heeft nog nimmer een dergelijke AMvB het licht gezien. Om in de terminologie van Herakleitos te blijven: gebakken lucht dus. ${ }^{383}$

\section{Convenanten en $\mathrm{CAO}$ 's}

Wat zeker wél een impuls is voor het aanhalen van het overleg, is de strategie van arboconvenanten die sinds begin 1999 in werking is gezet. Hoewel het fenomeen van het arboconvenant al enige tijd op beperkte schaal voorkwam ${ }^{384}$. heeft het ministerie van Sociale Zaken en Werkgelegenheid het arboconvenant een impuls willen geven middels de nota Arboconvenanten nieuwe stijl van 15 januari 1999 -

379 Met name in artikel 2 van de (Wet financiering loopbaanonderbreking (Stb. 1998, 411), artikel 2 van de Wet Aanpassing Arbeidsduur (Stb. 2000, 114), en artikel 4.7 van de wet Arbeid en Zorg (Stb. 2001, 567). Van der Heijden spreekt in dit verband van 'adaptief arbeidsrecht'. P.F, van der Heijden (1997), Ongelijkheden in beweging, in: L. Betten et al. (red), Ongelijkheidscompensatie als roode draad in het recht: Liber amicorum voor M.G. Rood, Deventer, Kluwer. p. 65

380 Zo laat bijvoorbeeld de regelgeving rond Europese Ondernemingsraden veel ruimte om. binnen een tamelijk open geformuleerd verplichting tot het oprichten van een EOR. in overleg te komen tot een precieze invulling van het uiteindelijke model van medezeggenschap. (Richtijn 94/95/EG, 22 september 1994. PbEG L. 254, 30-9-1994: 64). Alleen wanneer de betrokkenen geen overeenstemming bereiken over de concretisering van de verplichting, treedt de standaardregeling uit de Richtlijn in werking. Vgl. T. van Peijpe (1996). Het subsidiaire regelingsmodel van de Europese OR, SMA 1996, p. 369

381 Onder meer Kamerstukken II 1998-1999, 26358, nrs. II en 32. Vgl. ook Notitie (zelf)regulering: relatie wetgever, sociale partners/medezeggenschapsorgaan in de arbeidsverhoudingen, Kamerstukken I. 1999-2000, nr. 222a

382 SER 1997, p. $27-28$

383 Op het gebied van arbeidstijden wordt duidelijk veel vaker gebruik gemaakt van de overlegregeling. Hierbij wordt echter lang niet altijd overieg met de OR gevoend. J.W.M. Mevissen et al. (2001), Arbeidstijden in overleg? Evaluatie van de Arbeidstijdenwet, Den Haag: Elsevier/Ministerie van Sociale Zaken en Werkgelegenheid.

384 Bijvoorbeeld Arboconvenant agrarische sectoren ( 7 juli 1994), Rubberconvenant (14 februari 1995), branche-overeenkomst Kinderopvang (1I december 1997). 
en dan niet in de laatste plaats door de financiéle paragraaf in die nota, die een flìnke subsidie in het vooruitzicht stelde voor een periode van vier jaar. ${ }^{385}$ In de convenanten zouden (kwantitatieve) afspraken gemaakt moeten worden over het terugdringen van de (branchespecifieke) prioritaire arbeidsrisico's - met name fysieke belasting, werkdruk, RSI. lawaai en OPS. Bij voorkeur zouden de convenantsafspraken opgenomen moeten worden in CAO-afspraken in de betrokken branches, zodat zij algemeen verbindend verklaard kunnen worden. Daarnaast zijn in een zeer beperkt aantal gevallen delen van het convenant opgenomen in beleidsregels, waarmee de convenantsafspraken kunnen worden gehandhaafd door de Arbeidsinspectie. $^{386}$

De strategie van arboconvenanten is, zeker in kwantitatieve zin, redelijk succesvol te noemen. Begin 2003 waren er ongeveer 40 convenanten ondertekend, waaronder in een flink aantal branches die zichzelf hadden aangemeld. Dit aantal was aanmerkelijk hoger dan in 1999 als doelstelling was geformuleerd. ${ }^{387}$ Bovendien lijken de convenanten ook een eerste effect te hebben. Verheugd signaleerde staatssecretaris Rutte van Sociale Zaken en Werkgelegenheid eind 2002: "Het effect van arboconvenanten reikt verder dan de directe werkingssfeer. Niet eerder hebben de onderwerpen arbeidsomstandigheden en verzuim- en reintegratiebeleid zo hoog op de agenda van de sociale partners in sectoren gestaan als de laatste jaren." 388 Ook was door de uitvoering van de arboconvenanten een aantal speciale uitvoeringsorganisaties ontstaan die veelal waren ondergebracht bij al bestaande paritaire brancheorganen van de sociale partners. De bedoeling is dat zij ook na afloop van de arboconvenanten blijven bestaan, waarmee de aandacht voor arbeidsomstandigheden op brancheniveau stevig is verankerd.

Niet alleen op brancheniveau, ook op bedrijfsniveau geeft de convenantenaanpak een fikse impuls aan de arbeidsverhoudingen rond het thema arbeidsomstandigheden. Ten eerste prijken diverse prioritaire arborisico's inmiddels hoog op de agenda van het overleg (vgl. ook hoofdstuk 6). Ten tweede beogen diverse convenanten de positie van ondernemingsraden en personeelsvertegenwoordigingen bij het arbeidsomstandighedenoverleg te versterken - dit als uitvloeisel van de bewuste strategie van de overheid om werknemers meer te betrekken bij de totstandkoming

385 Kamerstukken II 1998-1999. 26 375, nr. I. Een maand eerder al was de staatssecretaris van SZW mede-ondertekenaar van de gemeenschappelijke verklaring van Kabinet en Stichting van de Arbeid over Arboconvenanten, 3 december 1998. In het regeerakkoord was de convenantenaanpak reeds aangekondigd. Kamerstukken II 1998-1999, 26 024, nummer 9, p. 33-34

386 Beleidsregel 5.2-2, Fysieke belasting in kinderdagverblijven. Beleidsregel 5.3 Tillen op bouwplaatsen Voornemens tot een beleidregel zijn onder meer uitgesproken in het Arboconvenanten meubelindustrie (Stert. 2002, 203, p. 3) en timmerindustrie (Stcrt. 2002, 242, p. 23). De strategie om de sociale partners te stimuleren de convenantsafspraken op te nemen in CAO's heeft een groot aantal juridische haken en ogen, waarnaar op het moment van afsluiting van dit proefschrift nog studie werd gedaan door het ministerie. Ook los van de koppeling aan convenanten worden in CAO's echter wel, en in toenemende mate, arbo-afspraken gemaakt. Zie Arbobalans 2002, p. 68-69

387 Kamersfukken II, 2002-2003, 25883 , nr. 12, p. 2

388 Ibid. p. 3 
en met name de uitwerking van de convenanten. ${ }^{389}$ Een eerste analyse van de afspraken op papier stemt overigens niet bijzonder enthousiast. In veel convenanten gaan de afspraken over de positie van de OR/pvt niet of nauwelijks verder dan intenties, het bevorderen van communicatie, het verstrekken van informatie (hetgeen wettelijk al verplicht is) en het verzorgen van voorlichting. Wel worden in sommige branches de al genoemde expertisecentra opgezet, en in de helft van de branches worden branchespecifieke werkboeken ontwikkeld. ${ }^{390} \mathrm{Bij}$ afsluiting van deze studie liep nog onderzoek naar de effectiviteit van het strategieplan en de daadwerkelijke betrokkenheid van medezeggenschappers in de praktijk.

\section{Tussenbalans}

De periode na 1980 stond, zeker in het begin van dat decennium, zeer sterk onder invloed van de treurige economische ontwikkeling. De economische crisis leidde tot een afbrokkelend geloof in de maakbaarheid van de samenleving en inzicht in de grenzen van het overheidsbeleid. In de periode 1945-1975 werd "de bestendig lijkende economische groei [..] toegeschreven aan een succesvol ingrijpen van de overheid. Aan zelfvertrouwen ontbrak het in de publieke sfeer zeker niet. [..] In dezelfde periode werden de mogelijkheden voor de - verdere - verwetenschappelijking van het overheidsbeleid hoger aangeslagen dan ooit." 391 Zeker na 1980 was dit laatste denkbeeld sterk aan erosie onderhevig. De legitimatie van de sturende overheid kwam onder druk te staan; de grands reçits, zoals Lyotard het noemde, hadden hun geloofwaardigheid verloren. ${ }^{392}$

Tegen deze achtergrond, én vanuit nieuwe bestuurskundige inzichten, ontwikkelde zich bovendien een nieuwe conceptie van de rol van de overheid. De reactie op de sturingspretenties van de verzorgingsstaat en het interventionalistisch recht, werd bestuurswetenschappelijk gefundeerd in theorieèn omtrent reflexief recht. ${ }^{393}$ Uitgangspunt van dit systeemtheoretisch geìnspireerde paradigma is dat maat-

389 KPMG-BEA (2000), Strategieplan arboconvenanten en werknemersvertegenwoordigingen, Den Haag: Elsevier/ministerie van Sociale Zaken en Werkgelegenheid

$390 \mathrm{Vgl}$. Arboconvenanten nieuwe stijl: napportage over de periode 1999-2002, Den Haag: ministerie van Sociale Zaken en Werkgelegenheid. AVB/SBA/02 85270, 2 december 2002

391 L.A. Geelhoed (1986), Deregulering en de grote operaties: Achtergronden en vooruitzichten. in: F.K.M. van Nispen en D.P. Noordhoek (red.), De grote operaties: De overheid onder het mes of snijden in eigen vlees, Deventer: Kluwer, p. 38

392 J.-F. Lyotard (1979), La condition postmoderne: rapport sur le savoir, Paris: Minuit

393 H.D. Stout en N.J.H. Huls (1992), Reflexiviteit, autopoiese en rechtsstatelijkheid, in: N.J.H. Huls en H.D. Stout (red.), Reflecties op reflexief recht, Zwolle: W.E.J. Tjeenk Willink, 1992, p. 219. Als oerbron van het reflexief-rechtelijk paradigma geldt $G$. Teubner (1983), Substantive and reflexive elements in modern law, in: Law \& Society Review, 17. Ook in de nota Zicht op wetgeving (TK 1990-1991, 22008, nrs. 1-2, p. 26) wordt Teubner als inspiratiebron genoemd. Voor een geacheveerde uitwerking van Teubners theorie op het gebied van arbeidsomstandigheden rie Ton Wilthagen (1992), Recht in een gesloten samenleving: het debat over reflexief recht en autopoiesis, in: Recht der werkelijkheid, jg. 13, ar. 1, en met name A.C.J.M. Wilthagen (1994), Reflexive rationality in the Regulation of Oecupational Safety and Health, in: R. Rogowski en T. Wilthagen (eds), Reflexive Labour Law, Deventer/Boston: Kluwer, p. 345-376 
wel een onderstroom. De jaren '70 gaven een omslag te zien in het denken over de verhouding tussen overheid en sociale partners op het gebied van veiligheid en gezondheid. De overheid zou meer moeten terugtreden, en de zorg voor de veiligheid en gezondheid met een gerust hart aan de sociale partners over kunnen laten. Dit werd mogelijk geacht omdat de werknemers zich sinds die periode vertegenwoordigd wisten door twee redelijk geaccepteerde instituties, namelijk de vakbonden en de ondernemingsraad. In meer wijsgerige termen waren de werknemers niet langer object van regulering, maar zélf subject van regelgeving. De ongelijkheid tussen werkgever en werknemers was gecompenseerd door bijvoorbeeld de toekenning van diverse rechten aan de laatstgenoemden en het toegenomen scholingsniveau. Het overleg over veiligheid en gezondheid in verband met de arbeid werd gezien als een overleg tussen gelijkwaardige partijen. Dit denkbeeld van een gelijkwaardige relatie tussen werkgever en werknemer(s) lijkt veel op het negentiende-eeuwse liberalisme dat de ideologische legitimatie vormde voor overheidsabstinentie op het gebied van veiligheid. Voor Wilthagen was dit reden om de vraag op te werpen of daarmee de kring rond was (en in feite de rechtsbescherming terug bij af). ${ }^{403}$

Hoewel inderdaad sprake is van een zekere gelijkenis, denk ik echter dat deze vraag ontkennend beantwoord moet worden. De positie van de werknemer anno 2003 is toch institutioneel veel sterker verankerd dan die van zijn overgrootvader aan het eind van de negentiende eeuw. De werknemers (en in het bijzonder ondernemingsraden) kunnen putten uit een veelheid aan regels en bronnen. Daarnaast is principieel ook niet omstreden dat de overheid in laatste instantie altijd een verantwoordelijkheid houdt voor de veiligheid en gezondheid van de burger. De discussies over de terugtredende overheid worden veeleer vanuit effectiviteitsoverwegingen gevoerd en minder vanuit ideologisch liberalisme of een principieel subsidiariteitsdenken.

Het regelsysteem rond arbo-medezeggenschap wordt uitgebreid beschreven in hoofdstuk 3 . In dit hoofdstuk is aangegeven dat die regels het resultaat zijn van decennia van harde strijd en van stille institutionaliseringsprocessen. Die ontwikkeling is mede beïnvloed door een aantal omgevingsfactoren, waarvan mijns inziens de economische ontwikkeling de meest bepalende factor is: de aandacht voor arbeidsomstandigheden én de mogelijkheden tot medezeggenschap zijn ten dele conjunctureel van aard. Het huidige regelsysteem is de resultante van verschuivende machtsverhoudingen, van arbeidsverhoudingen op nationaal, sectoraal en bedrijfsniveau. Omgekeerd heeft (de ontwikkeling van) de wetgeving op het gebied van veiligheid en gezondheid ook zijn weerslag gehad op de ontwikkeling van de arbeidsverhoudingen in Nederland. Zeker rond de vorige eeuwwisseling, tot ongeveer 1919, heeft de strijd voor menswaardige arbeid mede bijgedragen aan het ontstaan van de vakbeweging en de verwerving van een institutionele positie. Aan het eind van de twintigste eeuw is die strijd wellicht nog niet gestreden, maar zij is niet meer van bijzonder grote invloed op de ontwikkeling van de arbeidsverhoudingen. In sommige gevallen zal het overleg rond bijvoorbeeld arboconvenanten zeker effect hebben op de verhoudingen in een branche, maar 'arbo' is zeker geen thema meer waaraan de klassenstrijd weer zal ontbranden. 
gezondheidsbescherming het regelgevingsproces effectief werd beïnvloed. ${ }^{400}$ Ook de positie van de werknemersvertegenwoordigers in de SER was tamelijk sterk. Zij hadden op diverse punten de meeste onafhankelijke leden aan hun zijde én de adviezen van de SER vonden redelijk weerklank in de uiteindelijke wetsvoorstellen. ${ }^{40 I}$ Terwijl in het laatste kwart van de negentiende en de cerste decennia van de twintigste eeuw de vakbeweging nog veelvuldig in actie kwam en moest komen voor een betere kwaliteit van de arbeid, bewoog zij zich aan het einde van de twintigste eeuw als een volledig geaccepteerde partij in de institutionele circuits. Die onomstreden institutionele positie is een van de belangrijkste bronnen waaruit de vakbeweging kan putten - mede omdat vanuit het concept van zelfregulering betrokkenheid van "all parties involved" als essentiële voorwaarde voor een goed beleid wordt gezien: corporatisme niet vanuit een doorwrochte ideologie, zoals in het christelijk-sociale denken, maar gelegitimeerd vanuit effectiviteitsoverwegingen en abstracte beleidstheorie, ${ }^{402}$

Inmiddels is, aan het begin van de eenentwintigste eeuw, arbo nauwelijks meer een thema waar nog bikkelharde strijd over wordt gevoerd. Het revolutionaire vuur is gedoofd. Dat betekent echter niet dat het arbobeleid in rook is opgegaan. Het is evenmin in de lucht komen te hangen. Het is veeleer stevig gegrond in de tamelijk hechte structuur van de Nederlandse polder, en elke voorgenomen wijziging van de regels loopt keurig langs de kanalen van de SER.

\subsection{Slotbeschouwing: terug bij af?}

Ter afronding van dit historische overzicht is het een goede zaak de balans op te maken van anderhalve eeuw arbeidsomstandighedenrecht én arbobeleid van de overheid. In hoofdlijnen valt de volgende ontwikkeling te schetsen. Tot het eind van de negentiende eeuw had de overheid, afgezien van de 'paskwillige' Kinderwet uit 1874, geen serieuze bemoeienis met de bescherming van de arbeiders tegen de gevaren van het werk. Het economisch liberalisme vierde hoogtij: de verhouding tussen patroon en arbeider werd gezien als een vrije relatie, waarbij zeker de mannelijke arbeider geacht werd zijn eigen belangen te kunnen behartigen. Eerst met de Arbeidswet 1889 werd een duidelijke taak aan de overheid toebedeeld, wat onder meer bleek uit de instelling van de Arbeidsinspectie. Toch duurde het nog tot 1919 tot ook de mannelijke werknemers object van beschermende regelgeving wer-

den. Nadien werd de veiligheidsregelgeving aanmerkelijk uitgebreid, tot feitelijk medio jaren ' 90.

Deze betrekkelijk dominante rol van de overheid was, op beleidsmatig niveau, even-

400 Walters 2002, p. $48 \mathrm{ff}$

401 Vgl. J.P. Balkenende (1992). Overheidsregelgeving en maarschappelijke organisaties, Alphen a/d Rijn: Samsom H.D. Tjeenk Willink, p. 35

402 Evenzo werd de discussie over de arbowetgeving begin jaren ' 90 niet meer gevoerd vanuit het ideaal van humanisering, maar met nuchtere verwijzingen naar het positieve effect van preventie op het ziekteverzuim en het arbeidsongeschiktheidsvolume. 
wel een onderstroom. De jaren '70 gaven een omslag te zien in het denken over de verhouding tussen overheid en sociale partners op het gebied van veiligheid en gezondheid. De overheid zou meer moeten terugtreden, en de zorg voor de veiligheid en gezondheid met een gerust hart aan de sociale partners over kunnen laten. Dit werd mogelijk geacht omdat de werknemers zich sinds die periode vertegenwoordigd wisten door twee redelijk geaccepteerde instituties, namelijk de vakbonden en de ondernemingsraad. In meer wijsgerige termen waren de werknemers niet langer object van regulering, maar zélf subject van regelgeving. De ongelijkheid tussen werkgever en werknemers was gecompenseerd door bijvoorbeeld de toekenning van diverse rechten aan de laatstgenoemden en het toegenomen scholingsniveau. Het overleg over veiligheid en gezondheid in verband met de arbeid werd gezien als een overleg tussen gelijkwaardige partijen. Dit denkbeeld van een gelijkwaardige relatie tussen werkgever en werknemer(s) lijkt veel op het negentiende-eeuwse liberalisme dat de ideologische legitimatie vormde voor overheidsabstinentie op het gebied van veiligheid. Voor Wilthagen was dit reden om de vraag op te werpen of daarmee de kring rond was (en in feite de rechtsbescherming terug bij af). ${ }^{403}$

Hoewel inderdaad sprake is van een zekere gelijkenis, denk ik echter dat deze vraag ontkennend beantwoord moet worden. De positie van de werknemer anno 2003 is toch institutioneel veel sterker verankerd dan die van zijn overgrootvader aan het eind van de negentiende eeuw. De werknemers (en in het bijzonder ondernemingsraden) kunnen putten uit een veelheid aan regels en bronnen. Daarnaast is principieel ook niet omstreden dat de overheid in laatste instantie altijd een verantwoordelijkheid houdt voor de veiligheid en gezondheid van de burger. De discussies over de terugtredende overheid worden veeleer vanuit effectiviteitsoverwegingen gevoerd en minder vanuit ideologisch liberalisme of een principieel subsidiariteitsdenken.

Het regelsysteem rond arbo-medezeggenschap wordt uitgebreid beschreven in hoofdstuk 3 . In dit hoofdstuk is aangegeven dat die regels het resultaat zijn van decennia van harde strijd en van stille institutionaliseringsprocessen. Die ontwikkeling is mede beïnvloed door een aantal omgevingsfactoren, waarvan mijns inziens de economische ontwikkeling de meest bepalende factor is: de aandacht voor arbeidsomstandigheden én de mogelijkheden tot medezeggenschap zijn ten dele conjunctureel van aard. Het huidige regelsysteem is de resultante van verschuivende machtsverhoudingen, van arbeidsverhoudingen op nationaal, sectoraal en bedrijfsniveau. Omgekeerd heeft (de ontwikkeling van) de wetgeving op het gebied van veiligheid en gezondheid ook zijn weerslag gehad op de ontwikkeling van de arbeidsverhoudingen in Nederland. Zeker rond de vorige eeuwwisseling, tot ongeveer 1919, heeft de strijd voor menswaardige arbeid mede bijgedragen aan het ontstaan van de vakbeweging en de verwerving van een institutionele positie. Aan het eind van de twintigste eeuw is die strijd wellicht nog niet gestreden, maar zij is niet meer van bijzonder grote invloed op de ontwikkeling van de arbeidsverhoudingen. In sommige gevallen zal het overleg rond bijvoorbeeld arboconvenanten zeker effect hebben op de verhoudingen in een branche, maar 'arbo' is zeker geen thema meer waaraan de klassenstrijd weer zal ontbranden.

403 Wilthagen 1997 



\section{De formele positie van de ondernemingsraad}

Hoewel medezeggenschap rond veilige en gezonde arbeidsomstandigheden op diverse niveaus gestalte krijgt - internationaal, nationaal, brancheniveau - ligt het zwaartepunt van het arbeidsomstandighedenbeleid toch op het niveau van individuele ondernemingen. ' De basis van het arbobeleid op ondernemingsniveau is primair de zorgplicht van de werkgever. Daarnaast wordt bijzonder gewicht toegekend aan de samenwerking tussen werkgever en werknemers. ${ }^{2}$ De kern van de Arbowet bestaat, zeer kort samengevat, uit:

- een zorgplicht van de werkgever ten aanzien van zijn werknemers (art. 3 Arbowet en art. 7:658 BW) én ten aanzien van derden (art. 10 Arbowet):

- een verplichting tot het voeren van een arbeidsomstandighedenbeleid (art. 3 Arbowet):

- op basis van een risico-inventarisatie en -evaluatie en een plan van aanpak (art. 5 Arbowet);

- in samenwerking met de ondernemingsraad, personeelsvertegenwoordiging of de belanghebbende werknemers (art. 12 Arbowet);

- daarbij ondersteund door een arbodienst (art. 14 Arbowet);

- in laatste instantie onder toezicht van de overheid in de gedaante van de Arbeidsinspectie (artt. 24-28 Arbowet).

De ondernemingsraad of personeelsvertegenwoordiging, wier rol in deze paragraaf uitgebreid wordt besproken, nemen in dit stelsel dus een belangrijke positie in. Schematisch ziet die positie er als volgt uit (waarbij de paragraaf-nummers dienen als schematische paragraaf-indeling):

1 In de Arbowet wordt geen definitie van het begrip onderneming gegeven. In de Wet op de ondernemingsraden wordt onder 'onderneming' verstaan "elk in de maatschappij als zelfstandige eenheid optredend organisatorisch verband waarin krachtens arbeidsovereenkomst of krachtens publiekrechtelijke aanstelling arbeid wordt verricht" (WOR, art. I, lid I sub c). De Arbowet adresseert werkgevers en werknemers, waarbij het verrichten van arbeid 'krachtens arbeidsovereenkomst of publiekrechtelijke aanstelling' bepalend is in de definitie van beide geadresseerden en daarmee de werkingssfeer van de wet (Arbowet, art. 1. lid 1). In ieder geval is de Arbowet dus van kracht op elke vorm van ondernemingsgewijze productie (waaronder ook begrepen overheidsinstellingen en non-profitorganisaties). Daarnaast vallen, blijkens artikel 2 van de Arbowet, ook werkzaamheden die niet plaatsvinden in een werkgever/werknemersrelatie onder zijn werkingssfeer. Te denken valt aan vrijwilligerswerk of werkzaamheden van stagiaires.

2 Reeds in de Arbowet 1980 vormde, aldus toenmalig Directeur-Generaal van de Arbeid A.J. de Roos, de combinatie van zorgplicht enerzijds en samenwerkingsplicht anderzijds de 'kern van de structuur van de Arbowet'. A.J. de Roos (1982), De Arbeidsomstandighedenwet, SMA, p. 308 


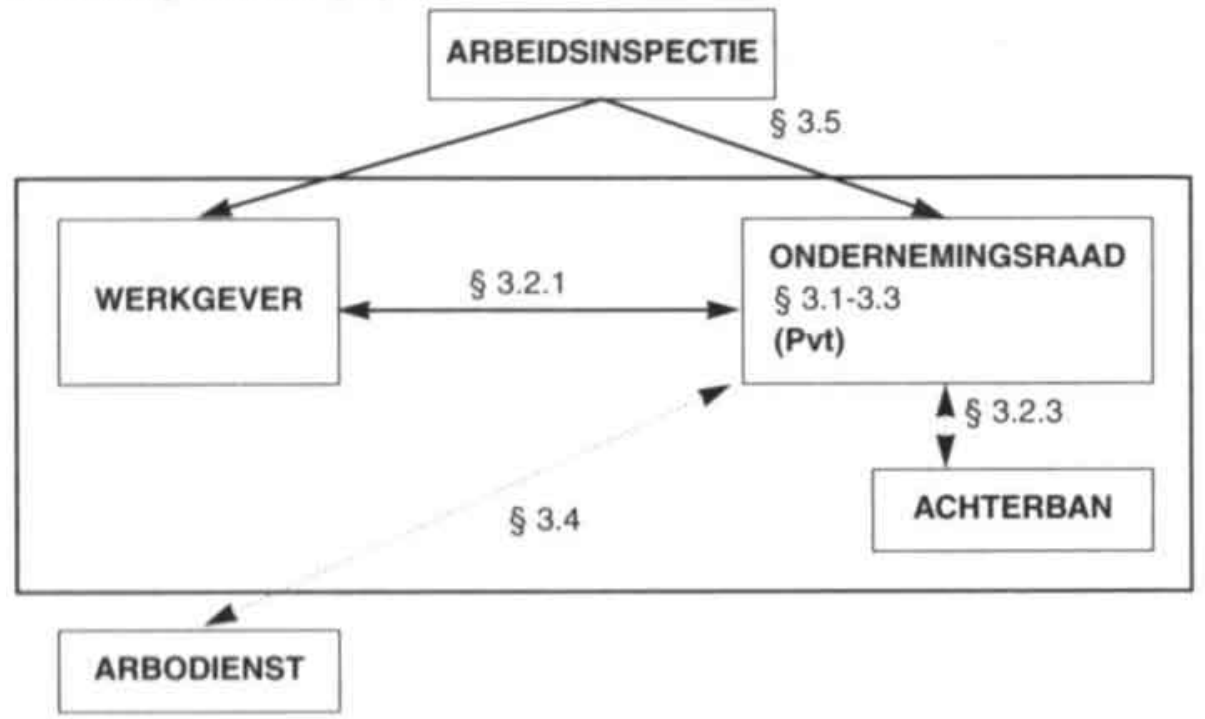

In de navolgende paragrafen wordt een schets gegeven van de formele positie van de ondernemingsraad en de pvt in het arbeidsomstandighedenbeleid. ${ }^{3}$ Hierbij zal omwille van de leesbaarheid overwegend de ondernemingsraad genoemd worden. omdat de positie van de personeelsvertegenwoordiging op het gebied van arbeidsomstandigheden op hoofdlijnen niet veel afwijkt van die van de OR. Waar dit wel het geval is, zal het verschil ter plekke worden aangegeven. In hoofdstuk $4.1 \mathrm{zal}$ worden bezien hoe de OR zijn formele positie in de praktijk daadwerkelijk inkleurt.

Bij de beschrijving van de taken, middelen en bevoegdheden van de medezeggenschappers zal, waar nodig of wenselijk, een historische benadering worden gevolgd. De middelen, meer precies: de faciliteiten en bevoegdheden, zijn de OR namelijk niet altijd even ruim toebedeeld geweest als in de Arbowet 1998 en de meest recente versie van de Wet op de ondernemingsraden. Vooruitlopend op de nadere beschouwing kan worden gesteld dat de ondernemingsraad sinds de eerste versie van de WOR uit 1950 allengs meer formele mogelijkheden heeft gekregen.

\subsection{De taak van de $O R$}

De wetgeving op het gebied van arbeidsomstandigheden legt, zoals al meermalen is aangegeven, de verantwoordelijkheid voor de veiligheid en gezondheid van de

3 De personeelsvertegenwoordiging als formele medezeggenschapsfiguur dateert van de wijziging van de Wet op de Ondernemingsraden in 1998 (art. 35e). Wet van 14 februari 1998 tot wijziging van de Wet op de ondernemingsraden en titel 7.10 (arbeidsovereenkomst) van het nieuw Burgerlijk Wetboek, Sth. 1998, 107. Voor een uitgebreide introductie vgl. F.W.H. Vink en Th.H.A. van Leeuwen (2002), Inzicht in de personeelsvertegenwoondiging: Medezeggenschap in de kleine ondermeming, Den Haag: Sdu ( $2^{e}$ druk) 
werknemers primair bij de werkgever. Hij wordt daarbij echter geacht samen te werken met de werknemers. Spiegelbeeldig daaraan stelt de wetgeving de werknemers tot taak zich min of meer intensief te bemoeien met de zorg voor de arbeidsomstandigheden in hun bedrijf of instelling. De opvattingen omtrent hoe die samenwerking er precies uit zou moeten zien, zijn in de loop der tijd echter verschoven.

\section{Voor 1970}

Tot begin jaren zeventig was de rol voor de werknemers uiterst beperkt. "In de Veiligheidswet komt de werknemer nauwelijks voor. Hij is vooral een te beschermen object en geen zelfstandige drager van enige verantwoordelijkheid. ${ }^{4}$ Werknemers werden geacht de veiligheidsvoorschriften na te leven, desnoods onder dwang of dreiging van strafrechtelijke vervolging. ${ }^{5}$ Wel opende artikel 21 van de Veiligheidswet 1934 de mogelijkheid tot het instellen van veiligheidscommissies, die onder meer een adviserende of voorlichtende taak zouden moeten krijgen. De AMvB die de samenstelling, bevoegdheden en werkwijze van de commissie zou moeten regelen, is echter nooit in werking getreden. ${ }^{6}$ Hoewel in de praktijk wel diverse veiligheidscommissies zijn opgericht, bood de Veiligheidswet 1934 de werknemers juridisch gezien geen enkel houvast om zich actief een eigen verantwoordelijkheid voor de veiligheid toe te eigenen.

Ook in de eerste Wet op de ondernemingsraden van 1950 was de rol van de werknemers, in casu de ondernemingsraad, op het gebied van veiligheid en gezondheid beperkt. Krachtens artikel 6 , lid 2 onder d, had de OR de bevoegdheid toezicht te houden op de naleving van de wettelijke voorschriften ter bescherming van de werknemers in de onderneming, alsmede op de inrichting van de werkplek in het belang van de veiligheid, de gezondheid en de hygiëne en op de schaft- en kleedgelegenheden. Formele bevoegdheden om deze taak naar behoren in te vullen ontbraken echter. De praktische betekenis van de WOR 1950 op het gebied van de veiligheid en gezondheid bij de arbeid was dan ook, aldus Geers, "nagenoeg nihil".?

\section{WOR 1971}

De tweede versie van de Wet op de ondernemingsraden, de WOR 1971, betekende tot op zekere hoogte een doorbraak op het gebied van medezeggenschap - zowel wat betreft de taakstelling van de OR als wat betreft zijn bevoegdheden. Was de WOR 1950 nog uitsluitend gericht op het bedrijfsbelang, waarbij de OR als taak had "onder erkenning van de zelfstandige functie van de ondernemer, naar vermogen bij te dragen tot een zo goed mogelijk functioneren van de onderneming", de WOR 1971 introduceerde voor het eerst een duale taak: naast een bijdrage aan het functioneren van de onderneming tevens behartiging van de belangen van de werk-

\footnotetext{
4 A.J.C.M. Geers en J.H. Kwantes (1992). Veilig en wel: de Arbeidsomstandighedenwet en de nol van de OR, Alphen a/d Rijn: Samsom. p. 53

5 A.J.C.M. Geers (1988), Recht en humanisering van de arbeid. Deventer: Kluwer. p. 67

6 Ibid., p. $69-70$

7 Ibid. p. 77
} 
nemers - zij het dat de bestuurder nog wél de voorzitter van de ondernemingsraad was, zodat van een echte werknemersvertegenwoordiging nog niet kan worden gesproken.

Daarnaast kreeg de ondernemingsraad een aantal formele bevoegdheden, zoals advies- en instemmingsrecht en het recht deskundigen in te schakelen. De specifieke taakomschrijving op het gebied van veiligheid en gezondheid bij de arbeid werd vastgelegd in artikel 28. Artikel 28, lid 1, van de WOR 1971 verlangde van de ondernemingsraad dat deze "zoveel als in zijn vermogen ligt de naleving in de onderneming van de wettelijke voorschriften op het gebied van [..] ter bescherming van de in de onderneming werkzame personen [bevordert]."

Deze laatste taakopvatting sloot aan bij de toezichthoudende taak uit de WOR 1950 , maar verschoof het accent van 'toezicht op' naar 'bevordering van' de naleving van de wettelijke voorschriften. Deze stimuleringstaak van de OR bleef ook in volgende versies van de WOR overeind, zij het dat in de WOR 1990 de bevordering van 'het welzijn in verband met de arbeid' wordt toegevoegd. Aanleiding hiervoor was de introductie van de term 'welzijn' in de Arbowet van $1980 .^{8}$

Naast de stimuleringstaak gaf artikel 23 WOR de OR het recht om alle onderwerpen die hij van belang achtte op de agenda van de overlegvergadering te zetten. Daarmee werd het arbeidsomstandighedenbeleid binnen bedrijven formeel onderwerp van overleg (zie verder par. 3.2.1). Dawnast verleende artikel 27 , lid id. WOR de ondernemingsraad een tamelijk zware bevoegdheid op het gebied van veiligheid en gezondheid, in casu het instemmingsrecht (zie verder par. 3.3.2). Deze beide cruciale rechten, het overlegrecht én het instemmingsrecht, gaven de ondernemingsraad een centrale rol op het terrein van veiligheid en gezondheid.

\section{WOR 1979 en Arbowet}

Vanaf het begin van de jaren ' 70 woedden discussies omtrent zowel de regeling van de medezeggenschap van de werknemers als de arbeidsbeschermende wetgeving. Het harmoniemodel dat met name de WOR 1950 had gekenmerkt, maakte plaats voor meer conflictueuze arbeidsverhoudingen, althans wat betreft de WOR 1979 (in de Arbowet ademden de opvattingen omtrent medezeggenschap nog vooral de geest van gezamenlijk belang). De verscherpte opvattingen omtrent de medezeggenschap van werknemers mondden uit in een roep om verdergaande bevoegdheden van de OR. Overigens hadden deze discussies, alsook de daaruit voortvloeiende wijzigingen in de WOR in 1979, weinig directe betekenis voor de medezeggenschap rond veiligheid en gezondheid; althans niet voor de takopvatting, maar wel voor bijvoorbeeld de faciliteitenregeling (zie par. 3.3).

De gewijzigde opvattingen omtrent medezeggenschap van werknemers hadden echter wel effect op de veiligheidswetgeving. Terwijl de oude Veiligheidswet werknemers vooral zag als objecten van zorg, werden zij allengs meer als rechtssubjec-

8 Overigens werden de welzijinsbepalingen in de Arbowet 1980 pas in 1990 (derde tranche) van kracht. 
ten gezien die zelf zouden moeten kunnen meebeslissen omtrent (de inrichting van) hun arbeid. Betrokkenheid van werknemers bij de 'humanisering van de arbeid' werd gezien als intrinsieke waarde. ${ }^{9}$ Deze opvatting omtrent de positie van werknemers als rechtssubject ging bovendien gepaard met een afnemend geloof in centrale. detaillistische overheidsregulering van omstandigheden op bedrijfsniveau (vgl. par. 2.4). Daarmee werd de betrokkenheid van werknemers niet alleen op ideologische gronden gemotiveerd, maar ook vanuit effectiviteitsoverwegingen. Samenwerking op bedrijfsniveau zou de kwaliteit van het veiligheidsbeleid én het draagvlak voor dat beleid ten goede komen.

Deze concepties van de rol van de werknemers bij het arbeidsomstandighedenbeleid vonden hun weerslag in de Arbowet 1980, met name in de verplichte samenwerking tussen werkgever en werknemers op bedrijfsniveau (artikel 13). ${ }^{10}$ Bovendien werd de werkgever verplicht vooraf overleg te voeren met de OR over het ondernemingsbeleid "voor zover dat van aanwijsbare invloed kan zijn op de veiligheid, de gezondheid of het welzijn van de werknemers" (art. 4, lid 4. Arbowet). ${ }^{11}$ Overigens werden deze samenwerkingsverplichtingen pas ingevoerd in de derde tranche van de Arbowet (in oktober 1990). ${ }^{12}$

\section{WOR 1998/Arbowet 1998}

In de periode na de WOR 1979/Arbowet 1980 is in de taken van de OR, zo op het oog althans, niets essentieels gewijzigd. ${ }^{13}$ Ook na de opeenvolgende wijzigingen in de WOR heeft de OR nog immer zijn stimuleringstak, overlegrecht en instemmingsrecht. Ook de samenwerkingsverplichtingen in de oude Arbowet zijn in de Arbowet 1998 meegenomen - althans bij eerste lezing.

\section{Geers 1988, p. 86 en 91}

10 Ook op institutioneel niveau werd samenwerking tussen werkgevers en werknemers gestimuleerd middels de instelling van een landelijke Arboraad. Geers 1988, p. $246 \mathrm{ft}$

II $\mathrm{Om}$ in bedrijven zonder ondernemingsraad het formele overleg te bevorderen, introduceerde art. 14 van de Arbowet 1980 de figuur van de arbocommissie. Voor bepaalde categorieën bedrijven en instellingen zou, middels een $\mathrm{AMvB}$, instelling van een arbocommissie verplicht gesteld kunnen worden (art. 14, lid 2). Ook afzonderlijke bedrijven zouden hiertoe, middels een aanwijzing van het Districtshoofd van de Arbeidsinspectie, verplicht kunnen worden (art. 14. lid 3). De leden van de arbocommissie zouden gekozen moeten worden uit de werknemers (in bedrijven waar formeel werkoverleg was ingesteld op getrapte wijze, middels een afvaardiging uit het werkoverleg naar de arbocommissie, (art. 14, lid 4), terwijl de bevoegdheden grosso modo gelijk zouden moeten lopen met die van de OR. In de praktijk is de verplichting een arbocommissie in te stellen nooit in werking getreden, zodat hier verder niet op de arbocommissie wordt ingegaan. Uitgebreider: Geers 1988, p. I82ff. Voorts I.A.C. van Haren (1991), De medezeggenschap van werknemers in het arbeidsomstandighedenrecht, in: A.J.C.M. Geers (red.), Schets arbeidsomstandighedenrecht, Deventer: Kluwer, p. $70 f f$.

12 Besluit van 12 september 1990 (Stb. 488).

13 Wel is in 1998 de medezeggenschap in kleinere bedrijven zwaarder aangezet. In bedrijven met minder dan 50 maar méér dan 10 werknemers kan de werkgever vrijwillig een personeelsvertegenwoordiging instellen (WOR. art. 35c. lid 1). Indien een meerderheid van de werknemers dat wenst of hierover in de CAO afspraken zijn gemaakt, is de werkgever hiertoe verplicht (WOR. art. 35c, lid 2). Deze pvt heeft expliciet een taak in het overleg over de werktijden en arbeidsomstandigheden in het bedrijf (WOR, art. 35c, lid 3). 
Toch blijkt bij preciezere lezing van de jongste formulering van de samenwerkingsplicht een verschuiving te zijn opgetreden, die een stap terug lijkt te zijn. Het oude artikel 4, lid 4, bepaalde zoals gezegd dat de werkgever overleg moest voeren over het ondernemingsbeleid "voor zover dat van aanwijsbare invloed kan zijn op de veiligheid, de gezondheid of het welzijn van de werknemers." Hiermee beoogde de wetgever dat werkgevers vóoraf de gevolgen van voorgenomen beslissingen in zouden schatten. Veiligheid en gezondheid moesten, in theorie althans, integraal onderdeel uitmaken van de afwegingen van de ondernemingsleiding.

Artikel 12, lid 1, van de Arbowet 1998 stelt evenwel: "Bij de uitvoering van het arbeidsomstandighedenbeleid werken de werkgever en werknemers samen. De werkgever voert [..] vooraf overleg [..] over de uitvoering van het arbeidsomstandighedenbeleid." Deze formulering lijkt te impliceren dat de taak van de werknemers(-vertegenwoordigers) zich beperkt tot overleg over de uitvoering van het arbobeleid. De samenwerking dreigt zich bovendien te beperken tot het arbobeleid in engere zin. dat wil zeggen de planmatige aanpak van gesignaleerde risico's, en níet een geìntegreerde, preventieve benadering in het algemene ondernemingsbeleid. ${ }^{14}$ Terwijl de oude formulering een pro-actieve opstelling vereiste, beperkt de Arbowet 1998 zich tot een reactieve systematiek van risico-inventarisatie/plan van aanpak. Weliswaar is een risico-inventarisatie ook vereist in geval van gewijzigde werkmethoden of werkomstandigheden (art. 5, lid 4, Arbowet 1998), maar lang niet altijd wordt die inventarisatie als preventieve toets uitgevoerd.

In hoeverre deze herformuleringen daadwerkelijk een essentiële verschuiving betekenen, is lastig in te schatten. Er is geen onderzoek gedaan naar de wijze waarop in de praktijk invulling is gegeven aan de verplichting om overleg te voeren over het ondernemingsbeleid als bedoeld in artikel 4 van de Arbowet 1980 (of 1994). Te vrezen valt dat het overleg over het beleid zich veelal reeds beperkte tot overleg over arbobeleid in engere zin. Aan de andere kant stelt artikel 11, lid 2, van de Europese Kaderrichtlijn 89/391 dat de OR vooraf tijdig dient te worden geraadpleegd over "alle maatregelen (cursivering JP) die van wezenlijke invloed kunnen zijn op de veiligheid en de gezondheid". Hiermee blijft in feite het oude overlegrecht op grond van artikel 4 overeind. Toch is het schrappen van de overlegverplichting uit de Arbowet mijns inziens een stapje terug, omdat de oude tekst het initiatief en de verantwoordelijkheid om de arbogevolgen van het beleid aan te geven bij de werkgever legde, terwijl de WOR alertheid van de ondernemingsraad vereist. ${ }^{15}$

Met deze bedenkingen in het achterhoofd, kan al met al toch gesteld worden dat de OR in de loop van vijftig jaar een steeds nadrukkelijker rol heeft gekregen op het gebied van veiligheid, gezondheid en welzijn bij de arbeid: in vergelijking met de Veiligheidswet 1934 een algemene samenwerkingstaak (in de Arbowet) en, meer ingevuld in de WOR, overlegrecht plus een verschuiving van een toezichthoudende naar een stimulerende en toetsende rol waar het de naleving van de wettelijke regels betreft. De belangrijkste winst in vergelijking met de oude Veiligheidswetgeving is echter het instemmingsrecht.

$14 \mathrm{Vgl}$. Jan Popma (1998), Nieuwe Arbowet kan beter, in: OR-Informatie, Jg. 24, nr. 3, p. 37-38

15 Vgl. Geers 1988, p. 117 
Om aan de hem toebedeelde taken invulling te kunnen geven. dient de OR te beschikken over voldoende middelen en bevoegdheden. In paragraaf 3.2 wordt eerst ingegaan op een aantal basisvoorwaarden voor medezeggenschap, en komen vervolgens de faciliteiten van de OR en zijn leden aan de orde. In paragraaf 3.3 wordt een beeld geschetst van (de ontwikkeling in) de bevoegdheden van de ondernemingsraad. Hierbij zal, waar afwijkende bepalingen gelden voor personeelsvertegenwoordigingen, apart aandacht worden besteed aan de rechten en bevoegdheden van de pvt.

\subsection{Basisvoorwaarden voor medezeggenschap}

\subsubsection{Overlegrecht}

Zoals uit paragraaf 3.1 blijkt, kent zowel de WOR als de Arbowet de ondernemingsraad een centrale rol toe in het overleg over het arbeidsomstandighedenbeleid. Die overlegverplichting impliceert uiteraard een overlegrecht. Het algemene overlegrecht is opgenomen in artikel 23 van de Wet op de ondernemingsraden: de OR heeft het recht een overlegvergadering uit te roepen (art. 23. lid 1. WOR), waarna de bestuurder in de zin der WOR verplicht is aan een dergelijke oproep gehoor te geven. ${ }^{16}$ Zo nodig kan een onwillige wederpartij (na bemiddeling van de bedrijfscommissie) door een beroep op de kantonrechter worden gedwongen gehoor te geven aan de uitnodiging tot overleg (art. 36 WOR). In de overlegvergadering kunnen "alle aangelegenheden de onderneming betreffende" aan de orde worden gesteld, dus uiteraard ook het arbeidsomstandighedenbeleid.

Dit algemene overlegrecht op grond van de WOR kan vanuit de Arbowetgeving nog worden aangevuld met een bijzonder overlegrecht rond specifieke arbeidsomstandighedenthema's. Zo schrijft bijvoorbeeld artikel 5, lid 3. van de Arbowet 1998 voor dat de werkgever moet overleggen over de voortgang van het plan van aanpak alvorens deze voortgang neer te leggen in een (jaarlijkse) rapportage. Bij dit overleg komt in ieder geval aan de orde het al dan niet meer actueel zijn van de risicoinventarisatie en -evaluatie. Ook in het Arbobesluit is een aantal overlegverplichtingen opgenomen, met name gericht rond het gevaarlijke-stoffenbeleid. ${ }^{17}$

In de eerdere versies van de Arbowet was het overlegrecht, zoals eerder aangegeven (par. 3.1), mijns inziens sterker geformuleerd: de werkgever was verplicht vooraf overleg te voeren met de OR over het ondernemingsbeleid "voor zover dat van aanwijsbare invloed kan zijn op de veiligheid, de gezondheid of het welzijn van

16 Opmerkelijk genoeg is het algemeen overlegrecht niet van overeenkomstige toepassing op de pvt: in art. $35 \mathrm{c}$ ontbreekt een verwijzing naar art. 23 WOR. Sprengers gaf al in 1996 terecht aan dat hiermee een principiële weeffout in art. $35 \mathrm{c}$ dreigde te sluipen, omdat zonder algemeen overlegrecht in feite ook het gebruik van de verdere bevoegdheden in de lucht komt te hangen. L.C.J. Sprengers (1996), Personeelsvertegenwoordiging een ongewenste wetgevingsvrucht, in: SMA. nr. $7 / 8$, pp. $461-470$

17 Arbobesluit art. 4.46, lid 2 (asbest) en 4.92 (biologische agentia). Ook diverse Europese richtlijnen verplichten tot overleg tussen werkgever en werknemers (bijvoorbeeld art. 6, lid 3c, Kaderrichtlijn 89/391, maar ook diverse bijzondere richtlijnen). 
de werknemers" (art. 4, lid 4, Arbowet 1980, lid 7 Arbowet 1994). Het overlegrecht van de $\mathrm{OR}$ is op dit punt beperkt tot het recht op overleg over de uitvoering van het arbeidsomstandighedenbeleid. Aan de andere kant staat het de ondernemingsraad uiteraard altijd vrij om ook in het overleg omtrent advies- of instemmingsplichtige besluiten én in het overleg over de algemene gang van zaken (art. 24 WOR) expliciet aandacht te besteden aan de "invloed op de veiligheid, de gezondheid of het welzijn van de werknemers" (zie ook paragraaf 3.3.2 en 3.3.4).

Deze mogelijkheid bestaat al sinds 1979: artikel 31a, lid 6 respectievelijk 31b, lid 2 verplichtten tot vooraankondiging van voorgenomen beleid (halfjaarlijks resp. jaarlijks), Deze 'mededelingsplicht' is in de jongste redactie van artikel 24 WOR aangescherpt. Sinds 1998 is in het eerste lid namelijk bepaald dat de ondernemer tijdens het halfjaarlijkse overleg mededeling doet over besluiten die hij in voorbereiding heeft met betrekking tot aangelegenheden die uiteindelijk kunnen uitmonden in een advies- of instemmingsplichtig besluit. Daarbij is expliciet vastgelegd dat ondernemer en OR afspraken moeten maken over tijdstip en wijze waarop de ondernemingsraad in de besluitvorming wordt betrokken. Als de bestuurder een besluit neemt zonder dat hij in een eerder stadium mededeling heeft gedaan van zijn voornemens, dan is niet ondenkbeeldig dat bij een eventueel beroep tegen de uitvoering van dat besluit (art. 26 WOR) de Ondernemingskamer dit zal meewegen als een procedurele nalatigheid. Schending van de verplichtingen in art. 24, lid 1 , is echter niet altijd eenvoudig vast te stellen. ${ }^{18}$ Tot op heden heeft de Ondernemingskamer overigens nog nooit een vonnis gewezen waarbij artikel 24 in deze zin aan de orde is gesteld.

Naast het recht tot overleg met de bestuurder heeft de ondernemingsraad ook het recht zich onderling te verstaan - hetzij door het individuele recht op 'onderling beraad' (art. 18, lid 1), hetzij door onderlinge vergaderingen. Het recht op onderlinge vergaderingen is overigens niet expliciet in de WOR opgenomen, maar kan worden afgeleid uit artt. 14 lid 2, 16 lid 1 en 17 lid 2 WOR. Ook heeft de ondernemingsraad het recht om "de in de onderneming werkzame personen" te raadplegen (art. 17. lid 1 jo. 18, lid 1). Omtrent de faciliteiten voor deze vormen van beraad uitgebreider paragraaf 3.2 .3 .

\subsubsection{Informatierecht}

Teneinde zijn (overleg)taak naar behoren te kunnen vervullen, heeft de ondernemingsraad recht op informatie.

\section{Algemeen informatierecht}

De basis voor het informatierecht is artikel 31, lid 1, van de Wet op de ondernemingsraden: "De ondernemer is verplicht desgevraagd aan de ondernemingsraad en aan de commissies van die raad tijdig alle inlichtingen en gegevens te verstrekken

18 L.C.J. Sprengers (1998), Wijziging art. 24 WOR: wordt de ondernemingsraad nu werkelijk een denktank van de ondernemer?, in: Sociaal Recht, p. 367-370. Zie ook R.H. van het Kaar (red.). Ondermemingsraad, losbladig. art. 24, aantekening 2 
die deze voor de vervulling van hun taak redelijkerwijze nodig hebben. De inlichtingen en gegevens worden desgevraagd schriftelijk verstrekt." 19 Deze informatieplicht dateert al van de WOR 1950, die de bestuurder van een onderneming verplichtte "alle inlichtingen te verstrekken, welke de ondernemingsraad behoeft voor de uitoefening van de hem [..] toegekende bevoegdheden" (art.6. lid 5 sub a). De verplichting om informatie desgevraagd schriftelijk te verstrekken is in de WOR 1971 geïntroduceerd (art. 30, lid 3). Er zijn geen eenduidige criteria vastgelegd omtrent de vraag wat 'redelijkerwijze' is. In voorkomende gevallen kan de ondernemingsraad een beroep doen op de kantonrechter, zij het na bemiddeling van de bedrijfscommissie (art. 36, lid 2-3).

\section{Passief informatierecht}

Naast het voornoemde actieve recht voor de OR/pvt om informatie te vragen, heeft de ondernemer bovendien de verplichting bepaalde informatie ongevraagd te verstrekken. Op het terrein van het arbeidsomstandighedenbeleid zijn met name van belang de verplichtingen in artikel $31 \mathrm{~b}, 31 \mathrm{c}$ en $31 \mathrm{a}$, lid 8 , WOR, de informatieverplichtingen in de Arbowet en het Arbobesluit, en een aantal bepalingen in de Regeling Certificatie.

\section{WOR}

Artikel $3 \mathrm{lb}$ van de WOR verplicht de ondernemer de OR ten minste eenmaal per jaar schriftelijke informatie te verstrekken over het gevoerde sociale beleid binnen de onderneming. Ook moet hij mondeling of schriftelijk mededeling doen van zijn verwachtingen ten aanzien van het dat jaar te voeren sociale beleid. De verwijzing naar de artikelen 27 en 28 van de WOR impliceert dat hieronder ook het gevoerde beleid inzake de arbeidsomstandigheden moet worden verstaan. Artikel 31c WOR verplicht de ondernemer de ondernemingsraad zo spoedig mogelijk te informeren over eventuele voornemens tot het verstrekken van een adviesopdracht aan een deskundige buiten de onderneming, met betrekking tot instemmingsplichtige aangelegenheden (en daarmee vrijwel alle zaken op het gebied van arbeidsomstandigheden, vgl. par. 3.3.2).

Hoewel dit niet expliciet wordt genoemd, vormt artikel $3 \mathrm{lb}$ ook de basis voor het verstrekken van gegevens omtrent ziekteverzuim en uitstroom van werknemers naar de WAO. Dit soort informatie kan, zeker indien zij is uitgesplitst naar bijvoorbeeld afdelingen of functiegroepen, van belang zijn voor de OR om inzicht te krijgen in knelpunten binnen de organisatie of bijvoorbeeld de effectiviteit van het gevoerde verzuimbeleid. In dit licht is van belang dat "[de] gegevens kwantitatief zodanig [worden] gespecificeerd dat daaruit blijkt welke uitwerking de verschillende onderdelen van het sociale beleid hebben gehad voor afzonderlijke bedrijfsonderdelen en functiegroepen," (art. 3lb, lid 1).

19 In ondernemingen waarin een personeelsvertegenwoordiging is ingesteld, mag de ondernemer de gevraagde informatie ook mondeling verstrekken (art. 35c, lid 6, en art. 35d, lid 3). 
Artikel 31a, lid 8, verplicht ondernemers die ingevolge artikel 12.2 of 12.4 van de Wet milieubeheer een milieujaarverslag moeten opstellen, dit verslag zo spoedig mogelijk ter kennis te stellen van de ondernemingsraad en het ook te bespreken. Hoewel in het milieuverslag niet rechtstreeks sprake zal zijn van het arbeidsomstandighedenbeleid binnen een onderneming, liggen relaties tussen milieubelastende factoren en bijvoorbeeld de mogelijke blootstelling aan gevaarlijke stoffen of geluidsbelasting voor de hand. Zeker in bedrijven waarin milieubeleid en arbobeleid in onderlinge samenhang worden gezien, kan het overleg over het milieujaarverslag een ingang bieden om ook de arbeidsomstandigheden aan de orde te stellen. Ook kan gewezen worden op de relatie met artikel 6 van de Arbowet 1998. Dit artikel legt bedrijven die het risico lopen van zware ongevallen (met name bedrijven in de procesindustrie) een groot aantal registratieverplichtingen op. ${ }^{20}$ Ook moeten de aangewezen bedrijven een arbeidsveiligheidsrapport opstellen (afdeling 2.2 Arbobesluit). Hoewel de Arbowet 1998 niet expliciet stelt dat de voornoemde informatie ter kennis moet worden gesteld van de OR (zoals wel het geval was bij het arbeidsveiligheidsrapport in de oudere versies van de Arbowet), is de ondernemer op grond van artikel 11, lid 2, van het Besluit risico's zware ongevallen ( $\mathrm{Brzo}$ ) verplicht te overleggen met de ondernemingsraad over het veiligheidsrapport. Dit is, zeker via de omweg van artikel 31 , lid 1 , WOR voldoende basis om de informatie op te vragen.

\section{Arbowet}

Het arbeidsveiligheidsrapport is een zeer specifiek soort informatie, die slechts voor een beperkt aantal ondernemingsraden van belang zal zijn. Van meer belang is artikel 12, lid 2, van de Arbowet 1998. Dit verplicht de werkgever om de OR of de personeelsvertegenwoordiging een afschrift van de risico-inventarisatie en -evaluatie (RI\&E) toe te zenden. ${ }^{21}$

Daarnaast valt uit de Arbowet 1998 een aantal andere zaken te destilleren waarover de OR of personeelsvertegenwoordiging moet worden geïnformeerd. De OR heeft recht op:

- een overzicht van alle ongevallen met verzuim (art. 5, lid 1. jo. art. 9, lid 1);

- een exemplaar van het plan van aanpak (art. 5. lid 2), dat overigens deel moet uitmaken van de RI\&E;

- de schriftelijke rapportage over de voortgang van het plan van aanpak (art. 5 . lid 2);

- onverwijlde melding van ernstige arbeidsongevallen in het bedrijf (art. 9, lid 2);

- een afschrift van alle adviezen van de arbodienst aan de werkgever (art. 14, lid 7).

20 De precieze uitwerking staat in het Besluit risico's zware ongevallen 1999 (Stb. 1999, 234). Bijlage I bij het Besluit bevat een lijst met categorieèn van bedrijven die onder het Besluit vallen. Dit Besluit vindt zijn juridische grondslag mede in de Wet milieubeheer, die tevens de grondslag vormt voor het Besluit milieuverslaglegging (Stb, 1998, 655).

21 De Richtlijn Certificering Arbodiensten (par. 2.7.1) verplicht ook de arbodienst de ondernemingsraad een exemplaar van de RI\&E en zijn advies hierover toe te zenden. 
Dit laatste punt is lange tijd een heet hangijzer geweest in de relatie tussen werkgevers en ondernemingsraden. Ten onrechte overigens. De verplichting om de ondernemingsraad een afschrift te verstrekken van adviezen van de arbodienst aan de werkgever was reeds in 1994 opgenomen in de Arbowet (art. 18, lid 4), "Een afschrift van een advies, op grond van het eerste lid, onderdeel $a$ of $d$ [d.w.z. een advies aan de werkgever omtrent de risico-inventarisatie en -evaluatie respectievelijk een advies aan de ondernemingsraad], wordt door de [deskundige] werknemers [..] of diensten, gezonden aan de andere partij. Bij het ontbreken van een ondernemingsraad zorgt de werkgever ervoor dat de inhoud van een aan hem gericht advies zo spoedig mogelijk ter kennis van de belanghebbende werknemers wordt gesteld." Overigens had ook de werkgever recht op een afschrift van alle adviezen die de arbodienst aan de ondernemingsraad uitbracht.

De tekst van de wet was dus duidelijk genoeg: de (interne of externe) arbodienst was verplicht om zélf een afschrift van zijn adviezen op te sturen naar de ondernemingsraad. In de praktijk bleek echter dat arbodiensten de verantwoordelijkheid voor deze taak veelal in handen van de opdrachtgever (in de praktijk: de werkgever) legden. Met name de FNV stelde hierover regelmatig signalen te krijgen. 22

Hoewel zelfs de toch eenduidige formulering uit 1994 al tot allerlei miscommunicatie leidde, werd in de Arbowet 1998 de bepaling over het toezenden van de afschriften aanvankelijk geschrapt. Bij amendement van Kamerlid Middel van de PvdA werd voorgesteld alsnog een bepaling over de kwestie op te nemen ${ }^{23}$. een voorstel dat zonder stemming werd aangenomen. Het nieuwe lid was echter buitengewoon mistig geredigeerd: "Een afschrift van een advies als bedoeld in het derde lid, wordt gezonden aan de ondernemingsraad of personeelsvertegenwoordiging." Wie voor het toezenden verantwoordelijk was, werd door de (taalkundig) passieve formulering onduidelijk. Deze onduidelijkheid was voor de senaatsfracties van de PydA aanleiding te vragen om een "uitdrukkelijke bevestiging dat de verzendplicht in dezen op de Arbodienst rust, voor zover er sprake is van een medezeggenschapsorgaan." 24 Die bevestiging werd gegeven in de daaropvolgende Memorie van Antwoord, waarbij nog ten overvloede gesteld werd dat "de verzendplicht van de Arbodienst niet [afdoet] aan de informatieverplichtingen van de werkgever op grond van de WOR."25

\section{Arbobesluit}

Naast de informatieverplichting omtrent de zogeheten 'systeemelementen' (RI\&E, plan van aanpak, voortgangsrapportage) noemt de Arbowet verder geen inhoudelijke thema's waarover de werkgever de ondernemingsraad zou moeten informeren. Deze worden echter wel genoemd in het Arbobesluit. Met name heeft de ondernemingsraad op grond van het Arbobesluit recht op informatie met betrekking tot het

\footnotetext{
22 FNV (1995), OR en arbodienst: contacten over contracten, Amsterdam: FNV

23 Kamerstukken II, 1998/99. 25 879, nr.I8

24 Kamerstukken I, 1998/99. 25879 , nr.7 la, p. 6. Waar een medezeggenschapsorgaan ontbreekt, verschuift de informatieverplichting om onduidelijke redenen naar de werkgever.

25 Kamerstukken I, 1998/99, 25 879, nr.71b, p. 11
} 
werken met gevaarlijke stoffen, namelijk de resultaten van metingen van asbest en biologische agentia. ${ }^{26}$ Ook de resultaten van geluidsmetingen op de werkvloer dienen ter kennis te worden gesteld van de ondernemingsraad of personeelsvertegenwoordiging. ${ }^{27}$ Voorts dient de werkgever de OR/pvt te informeren over een onvoorziene blootstelling aan de genoemde gevaarlijke stoffen. ${ }^{28}$ Verder heeft de OR/pvt recht op de (niet op individuele personen te herleiden) gegevens uit het medisch onderzoek onder werknemers die werken met de genoemde gevaarlijke stoffen. ${ }^{29}$ Ten slotte dient de werkgever eventuele vrijstellingen voor het werken met gevaarlijke stoffen te melden aan de OR/pvt. ${ }^{30}$

\section{De personeelsvertegenwoordiging}

Hierboven is in de meeste gevallen geen onderscheid gemaakt tussen OR en pvt. De informatierechten zijn beide medezeggenschapsorganen namelijk gelijkelijk toebedeeld - ten minste, in de Arbowet en de daarop gebaseerde uitvoeringsregelingen. De informatierechten voor de pvt in de WOR zijn echter enigszins ingeperkt. De artikelen 31a en 3lc zijn niet van overeenkomstige toepassing voor de pvt. Wel kan zij desgewenst een beroep doen op artikel 31 lid 1: het algemene informatierecht. In afwijking evenwel van de informatieverplichtingen jegens de OR, mag de bestuurder de gevraagde informatie aan de pvt ook mondeling verstrekken (art. 35c, lid 6, WOR). Op grond van artikel 35c, lid 3, is ook 35 b, lid 4, WOR van toepassing. Dit stelt dat de ondernemer verplicht is de personeelsvertegenwoordiging te informeren over het gevoerde en te voeren sociale beleid. Dit lijkt veel op art. 31b, met dien verstande dat ook deze informatie mondeling mag worden verstrekt. Een kwantitatieve specificatie is evenmin vereist.

\section{Geheimhoudingsplicht}

De leden van de ondernemingsraad zijn verplicht tot geheimhouding van alle zaken- en bedrijfsgeheimen ten aanzien waarvan zij, in verband met opgelegde geheimhouding, het vertrouwelijk karakter moeten begrijpen (art. 20 WOR). Artikel 20 is niet overeenkomstig van toepassing verklaard voor leden van de personeelsvertegenwoordiging, maar het spreekt voor zich dat ook zij prudent met vertrouwelijke informatie om dienen te gaan.

26 Respectievelijk Arbobesluit artikel 4.50 en 4.93. Al deze verplichtingen gelden evenzeer jegens de pvt.

27 Arbobesluit ant. 6.7, lid 6

28 Arbobesluit 4.6a, lid 5 (gevaarlijke stoffen), 4.46, lid 4/4.47, lid 2 (asbest) en 4.92 (biologische agentia).

29 Arbobesluit 4. I0d, lid 3 (gevaarlijke stoffen), 4.53, lid 3 (asbest) en 4.93, lid 2 (biologische agentia). Ook aan de richtlijn Certificering Arbodiensten kan een informatierecht omtrent medisch onderzock worden ontleend (par. 2.7.4), dat verder strekt dan alleen de onderzoeken omtrent de genoemde gevaarlijke stoffen. Ook de informatie uit onderzoeken op grond van art. 5.11 Arbobesluit (beeldschermwerk) en 6.10 (geluid) dient de ondernemingsraad ter hand te worden gesteld (rapportage op functie- en afdelingsniveau).

30 Arbobesluit art. 9.15 
Van belang is de bepaling "opgelegde geheimhouding". Die oplegging kan geschieden door de bestuurder, maar ook door de ondernemingsraad zelf aan zijn leden. Het voomemen om geheimhouding op te leggen wordt zoveel mogelijk vóór de behandeling van de betrokken aangelegenheid kenbaar gemaakt. Degene die de geheimhouding verlangt, moet tevens aangeven welke gegevens onder de geheimhouding vallen en hoe lang deze dient te duren.

Schending van de geheimhoudingsplicht kan diverse sancties tot gevolg hebben: uitsluiting van het OR-werk op grond van artikel 13 (en 15, lid 5, WOR), maar ook ontslag op staande voet (art. 7:678, lid 2, aanhef en onder i, BW) of ontbinding van de arbeidsovereenkomst. Deze laatste sanctie trof een kandidaat-OR-lid die informatie had doorgespeeld aan de Arbeidsinspectie, waarbij overigens niet uitdrukkelijk geheimhouding was bedongen (uitgebreider par. 3.5). In het uiterste geval is strafrechtelijke vervolging mogelijk op grond van art. 273 Wetboek van Strafrecht. ${ }^{31}$

\section{Handhaving informatieverplichting}

De naleving van de informatieverplichtingen op grond van de WOR en de Arbowet werd tot de invoering van de Arbowet 1998 langs twee trajecten gehandhaafd: enerzijds civielrechtelijk indien de werkgever zijn algemene informatieplicht verzuimde (met een beroep op artikel 36 WOR), anderzijds bestuursrechtelijk door inschakeling van de Arbeidsinspectie. Bij miskenning van de specifieke informatieverplichtingen in de Arbowet (risico-inventarisatie en -evaluatie, arbojaarplan, arbojaarverslag) kon de OR of, bij het ontbreken daarvan, de meerderheid van de belanghebbende werknemers de Arbeidsinspectie om wetstoepassing verzoeken. In dat geval kon de Arbeidsinspectie middels een aanwijzing de werkgever opdragen de vereiste informatie te doen toekomen aan de OR of de belanghebbende werknemers (art. 35 Arbowet 1994). In de Arbowet 1998 heeft de wetgever de handhaving van de informatieverplichting geheel onder het civielrechtelijke traject (art. 36 WOR) willen schuiven. Hoewel dit accent op de civielrechtelijke handhaving bij herhaling is afgewezen door de sociale partners ${ }^{32}$, werd de transfer naar de WOR toch doorgezet.

Overigens behouden de OR/pvt en de vakbond het recht de Arbeidsinspectie te verzoeken een onderzoek in te stellen (art. 24, lid 6 Arbowet), waarbij de verzoeker kan wijzen op de tekortkomingen in de informatievoorziening. In dat geval is het nog steeds mogelijk dat de Arbeidsinspectie een eis stelt ten aanzien van de naleving van artikel 5 van de Arbowet (zij het niet ten aanzien van artikel 14, lid 7, en evenmin met betrekking tot de bepalingen in het Arbobesluit).

31 Vgl. E. Verhulp (1997), Vrijheid van meningsuiting van werknemers en amblenaren, Den Haag: Sdu/Sinzheimer Sociale Monografieěn. p. 166 en p. 158-165. Verhulp acht ook vervolging op basis van art. 272 WvSr mogelijk.

32 De SER oordeelde in zijn Advies Herorièntatie arbobeleid en Arbowet (SER 97/03, p. 44-45) dat civielrechtelijke handhaving van de samenwerkingsverplichtingen de arbeidsverhoudingen onder druk zou zetten, en de FNV oordeelde in een brief aan de Tweede Kamer ( 25 september 2000) dat sprake was van een 'systeemfout' die bovendien de drempel voor werknemers om hun informatierecht af te dwingen onnodig hoog maakte. 


\subsubsection{Faciliteiten}

Om aan zijn taak invulling te kunnen geven, dient de OR (en dienen zijn leden) naar behoren te worden gefaciliteerd: tijd, scholing, vergoeding van kosten enzovoort. De wetgeving kent faciliteiten toe op twee niveaus: ten eerste aan de $\mathrm{OR}$ als geheel dan wel zijn commissies (over het instellen van commissies zie paragraaf 3.2 .5 ), ten tweede aan individuele OR-leden. Net zoals de taken van de OR met de loop der jaren meer gewicht hebben gekregen, kan gesteld worden dat de faciliteiten op beide niveaus mettertijd uitgebreider zijn geworden.

\section{Tijd voor onderling beraad}

De WOR 1950 voorzag nog in generlei wijze in faciliteiten voor de OR of zijn leden. Wel stelde de wet dat de ondernemingsraad geacht werd een reglement op te stellen waarin onder meer een regeling getroffen zou moeten worden omtrent "de aan de leden toe te kennen schadeloosstelling voor het bijwonen van vergaderingen" (art. 16, lid 2, onder d). De WOR 1971 introduceerde een eerste echte faciliteitenregeling, die sindsdien maatgevend is geweest voor de compensatie voor het OR-werk. "De ondernemingsraad en de commissies van die raad vergaderen zoveel mogelijk tijdens de normale arbeidstijd" (art. 17, lid 1), en "de leden van de ondernemingsraad en de leden van de commissies van die raad behouden voor de tijd gedurende welke zij ten gevolge van het bijwonen van een vergadering [..] geen arbeid hebben verricht, hun aanspraak op loon dan wel bezoldiging" (art. 17, lid 3). Dit geldt evenzeer voor de overlegvergaderingen (art. 23a, lid 6), en ook de voorbereidingstijd voor vergaderingen dient in principe gewoon te worden doorbetaald. ${ }^{33}$ Ook artikel 11. lid 5, van de Europese Richtlijn "betreffende de tenuitvoerlegging van maatregelen ter bevordering van de verbetering van de veiligheid en de gezondheid van de werknemers op het werk" (89/391/EEG) stelt dat werknemersvertegenwoordigers met een specifieke taak op het gebied van veiligheid en gezondheid 'voldoende tijd met behoud van loon' moeten worden vrijgesteld en 'de nodige middelen ter beschikking' krijgen.

De faciliteiten voor het onderling beraad dateren van 1979. Tot die tijd moest het aantal uren dat de OR-leden tot hun beschikking hebben voor onderling beraad worden vastgelegd in het OR-reglement. Een minimum was niet gegeven. In de WOR 1979 werd het minimum aantal uren voor onderling beraad vastgesteld op zestig uur per jaar per OR-lid (art. 18, lid 2). ${ }^{34}$ In de regel krijgen voorzitters en

33 R.H. van het Kaar (red.). Ondernemingsraad, art. 17, aantekening 3, Vergaderingen die buiten werktijd plaatsvinden dienen te worden gecompenseerd in tijd of uitbetaald als overwerk. F.W.H. Vink (2002), Inzicht in de ondernemingsnaad: Een toelichting bij de Wet op de Ondernemingsraden, Den Haag: Sdu, p. 70. Deze faciliteiten staan ook de personeelsvertegenwoordiging ter beschikking (art. 35c, lid 3)

34 Dit minimum gold niet voor ondernemingsraden in kleinere bedrijven, de zogeheten 100-min OR (art. 35a. lid I sub f. WOR 1979) 
secretarissen ruimere faciliteiten toebemeten. ${ }^{35}$ Het minimum is ongewijzigd opgenomen in de WOR 1998. Het geldt evenzeer voor leden van de pvt (art. 35c, lid 3).

\section{Raadpleging achterban}

De tijdregeling in artikel 18 betreft ook het contact overleg met "andere personen over aangelegenheden waarbij [de OR-leden] in de uitoefening van hun taak zijn betrokken". Hieronder valt ook de raadpleging van de achterban. Het spiegelbeeldige recht voor de achterban om te overleggen met de OR is echter pas sinds de wetswijziging van 14 februari 1998 behoorlijk geregeld. Weliswaar bestond het recht op beraad met de achterban al sinds 1971, maar de achterban werd hiertoe niet gefaciliteerd. Dat dit in de praktijk soms een knelpunt was, werd ook erkend door de wetgever. ${ }^{36}$ In de Memorie van Toelichting op de wetswijziging in 1998 is door de wetgever erkend dat in sommige gevallen ook de achterban vrijaf zou moeten krijgen voor beraad met de OR, mits binnen de grenzen van het redelijke. ${ }^{37}$ Wat 'redelijk' is, is mede afhankelijk van het belang van de te bespreken thema's én dient mede bezien te worden vanuit het oogpunt van bedrijfsvoering. Blijkens de Memorie van Antwoord aan de Eerste Kamer, zal de "achterbanraadpleging door het bijeenroepen van werknemers in een personeelsbijeenkomst beperkt [..] dienen te blijven tot enkele incidentele gevallen, hooguit éen tot een paar keer per jaar". 38 In het SER-voorbeeldreglement ondernemingsraden is een handleiding opgenomen voor het maken van afspraken omtrent de achterbanraadpleging. ${ }^{39}$

Ten slotte geeft artikel 18, lid 1, de OR tevens het recht kennis te nemen van de arbeidsomstandigheden in de onderneming. Dit moet dan wel binnen de genoemde zestig uur.

Hoeveel tijd OR-leden ter beschikking staat buiten de hiervoor genoemde vormen van overleg, bijvoorbeeld voor extern overleg in een OR-platform, is niet wettelijk geregeld. Een en ander kan worden vastgelegd in een schriftelijke overeenkomst tussen de ondernemer en de ondernemingsraad (art. 32, lid 2, WOR).

Indien ondernemer en ondernemingsraad het niet eens worden over de benodigde tijd of wat verstaan moet worden onder een redelijk gebruik van faciliteiten ${ }^{40}$, dan

$35 \mathrm{Vgl}$. Beschikking van de Minister van Sociale Zaken d.d. 8 januari 1987 (nr. 86/4383. ROR 1987/5).

36 Brief van 3 april 1995 ter zake het voornemen tot herziening van de Wet op de Ondernemingsraden, Kamerstukken II. 1994/95, 24 132, nr. I. p. 13

37 Kamerstukken II. 1994/95, 24 615, nr. 3, p. 20

38 Kamerstukken I, 1995/96, 24 615, nr. 81a, p. 5

39 SER (1998). Overwegingen van de Sociaal-Economische Raad over bet achterbanberaad van de OR, in: SER-voorbeeldreglement ondememingsraden, Den Haag: Sociaal-Economische Raad. p. $99-100$

40 Naast de genoemde faciliteiten heeft de ondernemingsraad (en de pvt) nog het recht gebruik te maken van voorzieningen "die de ondernemingsraad, de commissies en de secretaris van die raad voor de vervulling van hun taak redelijkerwijze nodig hebben" (art. 17, lid 1, WOR). Te denken valt aan vergaderruimte, telefoon en andere communicatiemiddelen, en in voorkomende gevallen toevoeging van een ambtelijk secretaris. 
kunnen beide partijen zich tot de kantonrechter wenden op grond van art. 36 , lid 2 , WOR (algemene geschillenregeling). Wel dient de verzoekende partij eerst bemiddeling en advies van de bedrijfscommissie te vragen (art. 36 , lid 3 ).

\section{Scholing/deskundige ondersteuning}

Een kwalitatief goede en effectieve bijdrage van de ondernemingsraad aan (het overleg over) het arbeidsomstandighedenbeleid impliceert dat de OR ter zake kundig moet zijn. Die deskundigheid kan de OR op twee manieren organiseren: door goede scholing van de OR of de VGW-commissie dan wel door het inschakelen van (externe) deskundigen. De Wet op de ondernemingsraden voorziet op beide punten in faciliteiten.

Ten eerste hebben de leden van de ondernemingsraad een individueel scholingsrecht. Dit scholingsrecht is geïntroduceerd in de WOR 1971. "De gekozen leden van de ondernemingsraad zijn [..] gerechtigd een door de ondernemingsraad bij zijn reglement te bepalen aantal dagen per jaar te onderbreken voor het ontvangen van scholing en vorming, welke zij in verband met de vervulling van hun taak als lid van de ondernemingsraad nodig oordelen." De WOR 1971 kende geen norm voor het minimum-aantal dagen scholing dat redelijkerwijs nodig geacht mag worden. De WOR 1979 introduceerde een minimum van vijf scholingsdagen per OR-lid per jaar (art. 18, lid 3, WOR 1979), een minimum dat in de WOR 1990 niet werd gewijzigd. ${ }^{41}$ In de WOR 1990 werd voorts de mogelijkheid opgenomen een deel van de scholingsdagen te besteden aan de scholing van de leden van de VGW-commissie, zij het dat dit dus van de scholingsdagen van de OR af ging. De WOR 1998 breidde de scholingsrechten voor buitenleden van de commissie uit tot een zelfstandig scholingsrecht van minimaal drie dagen per jaar. Voor OR-leden die tevens lid zijn van een vaste commissie is het aantal scholingsdagen minimaal acht (art. 18, lid 3. WOR (998), ${ }^{42}$

De kosten voor scholing van OR-leden komen voor rekening van de ondernemer. Ten eerste worden de OR-leden tijdens hun afwezigheid in verband met de scholing gewoon doorbetaald. Eventuele scholing in eigen tijd (met name voor deeltijdwerkers) wordt in principe als overwerk aangemerkt en dient overeenkomstig te worden vergoed. ${ }^{43}$ Ten tweede komen ook de directe scholingskosten voor rekening van de werkgever. De directe scholingskosten kunnen deels worden bestreden door

4 I Dit minimum gold niet voor kleine ondernemingsraden (100-min OR, art. 35a, lid I sub f. WOR 1979 resp, 35a, lid 1 sub d, WOR 1990). Het recht op scholing komt niet toe aan de ondernemingsraad. maar aan elk individueel lid van de raad of de vaste commissies. Het is niet de bedoeling dat de OR het totaal aantal dagen bij elkaar optelt en naar eigen inzicht verdeelt over de leden. (R.H. van het Kaar (red.), Ondernemingsraad, art. 18, aantekening 2.

42 De personeelsvertegenwoordiging heeft eveneens scholingsrecht. maar het minimum-aantal scholingsdagen geldt niet voor de pvt. In geval van onenigheid over het aantal scholingsdagen kunnen zowel ondernemingsraad als personeelsvertegenwoordiging het geschil, na bemiddeling door de bedrijfscommissie, voorieggen aan de kantonrechter (art. 18. lid 4, dan wel 36. lid 2 WOR jo. art. 36, lid 3, WOR).

43 Op basis van art. 119 EG-Verdrag. JAR 1992/43, later bevestigd JAR 1996/45 resp. 1996/98. 
aanspraak te maken op een bijdrage van het GBIO (Gemeenschappelijk BegeleidingsInstituut Ondernemingsraden). ${ }^{44}$ Dit instituut ondersteunt sinds 1975 de scholing en vorming van ondernemingsraden, met name door kwaliteitsbewaking van een aantal cursusinstituten én financiële ondersteuning van OR-cursussen. Het GBIO betaalt ongeveer de helft van de cursuskosten én een deel van de accommodatie. ${ }^{45}$ In het kader van een aantal arboconvenanten zijn afspraken gemaakt over scholing en cursussen voor ondernemingsraden, al dan niet in GBIO-verband. Zo is in het Plan van Aanpak voor het Bankwezen 365.000 euro uitgetrokken voor scholing van OR'en. ${ }^{46}$

Naast hun scholingsrecht hebben ondernemingsraden tevens het recht deskundigen in te schakelen. Aanvankelijk (WOR 1971) betrof dit alleen het uitnodigen van deskundigen tot het bijwonen van een vergadering van de ondernemingsraad - waar de bestuurder dan bij zat. Tijdens de vergadering konden de leden van de ondernemingsraad de deskundige om inlichtingen en advies vragen. De ondernemer was gerechtigd tegen de uitnodiging bezwaar te maken, waarna de bedrijfscommissie zou moeten beslissen. In de WOR 1979 zijn deze bepalingen gewijzigd in het voordeel van de OR. Ten eerste kreeg de OR het recht de deskundige een schriftelijk advies te vragen. Ten tweede konden ook de OR-commissies (zie paragraaf 3.2.4) een deskundige inschakelen. Ten derde kon de ondernemer alleen nog bezwaar maken tegen het uitnodigen van een deskundige indien deze kosten in rekening bracht. In geval van bezwaar besliste de bedrijfscommissie. In de WOR 1990 en 1998 zijn deze bepalingen overeind gebleven, zij het dat de geschillenregeling bij bezwaar van de ondernemer is gewijzigd (bemiddeling bij de bedrijfscommissie, een beslissing door de kantonrechter ex. art. 36, lid 2).

Ook de personeelsvertegenwoordiging kan deskundigen uitnodigen. mits met toestemming van de ondernemer (art. $35 \mathrm{c}$, lid 3, WOR). Toestemming is niet vereist indien de deskundige geen kosten in rekening brengt.

\section{De arbodienst}

De bepalingen omtrent het uitnodigen van deskundigen zijn, voor wat betreft het arbobeleid, met name van belang met het oog op het uitnodigen van deskundigen van de arbodienst. Hieromtrent zijn aanvullende regels opgenomen in artikel 14, lid 3 sub e, van de Arbowet. Op grond van dit artikel wordt de arbodienst geacht samen te werken met de ondernemingsraad (of de personeelsvertegenwoordiging) en deze

44 Het GBIO is opgericht naar aanleiding van een advies van de SER van 19 mei 1972 (SERadvies 1972/5). Bij Wijzigingswet van 23 augustus 1974 (Stb. 538) is vastgesteld dat aan ORplichtige ondernemers een heffing kan worden opgelegd ter bevordering van de scholing en vorming van ondernemingsraadsleden. De heffingsgrondslag is vastgelegd in art. $46 a$ WOR. De heffing bestaat uit een jaarlijks vast te stellen percentage van het loon krachtens de Ziektewet. Het percentage wordt vastgelegd in een jaarlijkse verordening van de SER, die moet worden goedgekeurd door de minister van Sociale Zaken en Werkgelegenheid.

45 Cursussen voor personeelsvertegenwoordigingen vallen (nog) niet onder de GBIO-regeling. 46 In het voorjaar van 2003 waren in 14 convenanten en 12 plannen van aanpak scholingsafspraken gemaakt. 
met advies terzijde te staan. Hoe die ondersteuning door de arbodienst eruitziet en welk budget daarvoor ter beschikking zou moeten worden gesteld, is echter nergens voorgeschreven.

In paragraaf 2.3.2 van de Richtlijn Certificering Arbodiensten staat weliswaar dat de arbodienst schriftelijk moet vastleggen hoe de relatie met de ondernemingsraad is geregeld (waaronder periodiek overleg met de OR), maar minimum-normen voor de samenwerking ontbreken. Wel hebben de gezamenlijke vakbonden in 1997 een 'Protocol arbodiensten en werknemers' gepubliceerd, waarin onder meer werd voorgesteld dat de arbodienst desgevraagd en ten minste tweemaal per jaar overleg zou moeten voeren met de ondernemingsraad (voor een uitgebreidere beschouwing over de relatie OR-arbodienst zie paragraaf 3.4).

\section{Kosten/budget}

Sleutel in de voornoemde discussie over de deskundige ondersteuning van de OR is de (wettelijke) regeling van de kostenvergoeding. Terloops is op diverse plaatsen al aangegeven dat de diverse kosten rond de medezeggenschap in bedrijven voor rekening komen van de ondernemer. Het loon moet worden doorbetaald (art.17, lid 3 en 18, lid 2), de werkgever moet de benodigde voorzieningen ter beschikking stellen (art. 17, lid 1), en ook de kosten voor scholing en deskundige ondersteuning komen voor rekening van de ondernemer. Voor die gevallen waarin nog niet is voorzien, is de verantwoordelijkheid van de ondernemer nog eens expliciet vastgelegd in artikel 22 van de WOR: "De kosten die redelijkerwijze noodzakelijk zijn voor de vervulling van de taak van de ondernemingsraad en de commissies van die raad komen ten laste van de ondernemer." Deze bepaling dateert, in iets andere bewoordingen, al uit de WOR 1950. Als de ondernemer weigert kosten voor zijn rekening te nemen, kan de OR (na bemiddeling van de bedrijfscommissie) de kantonrechter om een oordeel vragen (art. 36, lid 2, WOR).

Van belang is lid 2 van artikel 22, dat stelt dat de kosten voor deskundige ondersteuning (zie hierboven) alleen voor rekening van de ondernemer komen indien hij vooraf over die kosten op de hoogte is gesteld. Dat geldt tevens voor de kosten van het voeren van gerechtelijke procedures. ${ }^{47}$

De bepaling dat de ondernemer vooraf op de hoogte moet worden gesteld, geldt niet indien de OR beschikt over een eigen budget en de kosten uit dat budget betaalt (art. 22 , lid 3, WOR). Indien de ondernemingsraad zijn budget overschrijdt, is het mogelijk dat de OR de ondernemer alsnog aanspreekt op artikel 22, lid 1. Indien deze weigert de (extra) kosten voor zijn rekening te nemen, kan de OR hier echter niet meer tegen in beroep gaan. Het budget mag niet in de plaats komen van de bepaling dat de werkgever de kosten voor scholing voor zijn rekening moet nemen, nóch voor de voorzieningen als bedoeld in artikel 17 WOR.

De vraag omtrent de kosten is vooral ook van belang in verband met het inschakelen van deskundigen van de arbodienst. Hierover is nergens expliciet vastgelegd hoe hoog het budget van de ondernemingsraad terzake zou moeten zijn, net zo min

47 R.H. van het Kaar (red.), Ondememingsraad, art, 22, aantekening 2 
welke ondersteuning de OR 'redelijkerwijs' kan vragen. Enig houvast biedt het al genoemde 'protocol arbodiensten en werknemers' (uitgebreider par. 3.4), dat een aantal 'verplichte' taken noemt (waarbij uiteraard de werkgever de kosten voor zijn rekening zou moeten nemen). ${ }^{48}$ Dat protocol is echter niet bindend.

Wel kan de OR strategisch gebruik maken van zijn wettelijke bevoegdheden bij de keuze van een arbodienst. De ondernemingsraad heeft namelijk instemmingsrecht bij onder meer de keuze van de arbodienst en de inhoud van het contract met de arbodienst (zie par. 3.3.2). Indien in het contract geen bepaling is opgenomen omtrent de facilitering van de relatie OR/arbodienst, dan kan de ondernemingsraad weigeren in te stemmen met het contract. In een beperkt aantal convenanten, met name in het hoger onderwijs, de GGZ en de gehandicaptenzorg, zijn afspraken gemaakt over deskundige ondersteuning door arbo-kenniscentra in de branche.

\subsubsection{Instellen commissies}

Eén van de methoden om zowel tijd als deskundigheid te organiseren, is het instellen van een commissie. Door het inschakelen van zogeheten 'buitenleden' (commissieleden die zelf niet in de OR zitten), kan de werklast verdeeld worden. Ook is het zo mogelijk deskundige collega's in te schakelen die wellicht geen tijd of zin hebben om zich met het algemene OR-werk bezig te houden, maar wel bereid zijn hun expertise in te zetten op een deelterrein (in dit geval het arbeidsomstandighedenbeleid).

De mogelijkheid tot het instellen van een commissie was reeds in de WOR 1950 (art. 17, lid 2) opgenomen: "De ondernemingsraad kan bij zijn reglement bepalen. dat voor bepaalde afdelingen der onderneming of ter behandeling van bepaalde onderwerpen vaste commissies al dan niet uit zijn midden worden ingesteld, die, indien en voor zover zulks bij het reglement is voorgeschreven, ten aanzien van die afdelingen of onderwerpen de bevoegdheden van de ondernemingsraad geheel of gedeeltelijk en al dan niet voorwaardelijk uitoefenen."

Deze vroegste formulering bevat in hoofdlijnen de centrale elementen van het systeem van commissies:

1. het doel of werkterrein van de commissie:

2. de samenstelling van de commissie;

3. de bevoegdheden van de commissie;

4. de bepaling dat het instellen van een commissie moet worden geregeld in een reglement.

Ad 1. Het doel of werkterrein van de commissie is in geen enkele editie van de WOR expliciet omschreven, maar van oudsher is de veiligheidscommissie en later

48 Uitgebreider de bijlage 'Aandachtspunten en aanvullende standaardvoorwaarden voor het contract met de arbodienst' bij R. van Steenbergen (1999), OR en de relatie met de arbodienst, Alphen a/d Rijn: Samsom/FNV Formaat, p. 139-155 
de commissie VGW (veiligheid, gezondheid en welzijn) de meest voorkomende vaste commissie van de OR. ${ }^{49}$

Ad 2. De samenstelling van de commissie is in de verschillende versies van de WOR op diverse manieren ingevuld. In de WOR 1971 moest de OR de vaste commissie kiezen uit zijn midden, hetgeen uiteraard geen toegevoegde waarde had in de zin van tijdwinst of aantrekken van deskundigheid. Het betekende hooguit dat een deel van de OR niet hoefde mee te vergaderen over de onderwerpen die in de vaste commissie werden behandeld. In de WOR 1979 werd bepaald dat de OR ook 'buitenleden' zou mogen aantrekken, maar dat de commissie in meerderheid uit OR-leden zou moeten bestaan. Deze eis is in de latere versies van de WOR overeind gebleven.

Ad 3. De overdracht van bevoegdheden is ook op verschillende manieren geregeld. In de WOR 1971 en 1979 kon de commissie, net als in 1950, geheel of gedeeltelijk alle bevoegdheden van de OR uitoefenen. In 1990 werd deze overdracht van bevoegdheden op één punt ingeperkt: het was de ondernemingsraad níet toegestaan zijn bevoegdheid tot het voeren van een rechtsgeding over te dragen aan de commissie. Dit is in de WOR 1998 onveranderd gebleven.

Ad 4. Tot de wetswijziging van 1990 dienden commissies te worden ingesteld bij reglement. Doordat het reglement moest worden goedgekeurd door de bedrijfscommissie, bestond een preventieve toets op het instellen van commissies. In ver-

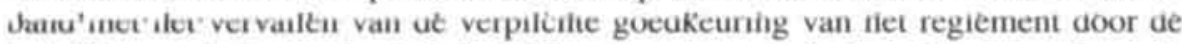
bedrijfscommissie werd ook de instelling van een commissie onder een ander regime geplaatst. In principe stelt de OR zélf zijn reglement vast, waarbij voor VGW(M)-commissies over het algemeen een 'instellingsbesluit' wordt opgesteld waarin onder meer taak, samenstelling, bevoegdheid en werkwijze van de commissie worden vastgelegd. ${ }^{50}$ Dit instellingsbesluit dient ter kennis van de ondernemer te worden gesteld. Heeft de ondernemer bezwaar tegen het instellen van de commissie, omdat hij de instelling van een commissie voor de vervulling van de ORtaken redelijkerwijs niet nodig vindt, dan kan de commissie pas worden ingesteld nadat de OR een procedure heeft gevoerd en de kantonrechter de OR in het gelijk heeft gesteld.

De leden van de commissie worden niet gekozen, maar benoemd door de ondernemingsraad. De 'buitenleden' worden benoemd voor de zittingsduur van de OR.

49 De Arbowet 1980 introduceerde daarnaast de medezeggenschapsfiguur van de arbocommissie - zulks met het oog op de vervulling van de samenwerkingsplicht in de Arbowet. Deze arbocommissie zou moeten worden ingesteld in bedrijven zónder $\mathrm{OR}$. in daartoe bij $\mathrm{AMvB}$ aangewezen bedrijfstakken of bedrijven. De arbocommissie was op hoofdlijnen cen soort OR voor arbozaken: gekozen uit en door de werknemers, met een aantal bevoegdheden die vrijwel parallel liepen aan de WOR. In de praktijk is de AMvB nooit in werking getreden en is de figuur van de arbocommissie een lege huls gebleven. Desondanks zijn er heden ten dage wel zogeheten arbocommissies actief. maar veelal zijn dat paritaire werkgroepen waarin arbofunctionarissen van een bedrijf overleggen met de OR of de VGW-commissie. Dit zijn dus geen commissies van de OR zelf

50 Het SER-Voorbeeldreglement kent ook een model instellingsbesluit voor de instelling van commissies 
zodat een nieuwe OR zelf een nieuwe commissie kan benoemen. In principe kunnen de commissieleden alleen vanuit de (kiesgerechtigde) werknemers worden gerekruteerd. De OR kan echter, in overeenstemming met de ondernemer, nietwerknemers die wel geregeld in de onderneming werkzaam zijn (gedetacheerden. uitzendkrachten) met die werknemers gelijkstellen (art. 6, lid 4. WOR).

De personeelsvertegenwoordiging kan alleen commissies instellen met toestemming van de ondernemer (art. 35c, lid 5, WOR). Tot 1998 gold deze inperking ook voor zogeheten 100- ondernemingsraden. Beroep bij de kantonrechter was niet mogelijk.

\subsubsection{Rechtsbescherming}

Leden van de ondernemingsraad en zijn commissies mogen geen schade ondervinden als gevolg van hun OR-activiteiten. Hiertoe genieten zij op grond van artikel 21 WOR bijzondere rechtsbescherming. In het algemeen geldt op grond van dit artikel een benadelingsverbod. In het bijzonder dient de werkgever bij een eventueel ontslag van de werknemer een aantal strikte procedures te volgen.

Artikel 21 WOR luidt: "De ondernemer draagt er zorg voor, dat de in de onderneming werkzame personen die staan of gestaan hebben op een kandidatenlijst bedoeld in artikel 9, alsmede de leden en de gewezen leden van de ondernemingsraad en van de commissies van die raad niet uit hoofde van hun kandidaatstelling of hun lidmaatschap van de ondernemingsraad of van een commissie van die raad worden benadeeld in hun positie in de onderneming." Dit benadelingsverbod dateert uit 1971, maar is successievelijk ook uitgebreid naar initiatiefnemers tot het oprichten van een OR in bedrijven waar die nog niet bestaat, ambtelijk secretarissen van de OR én interne deskundigen als bedoeld in artikel 14, lid 1, Arbowet $1998 .^{51}$ Op grond van artikel $35 \mathrm{c}$, lid 3 , en $35 \mathrm{~d}$, lid 2 , geldt de rechtsbescherming ook voor leden van de personeelsvertegenwoordiging.

De rechtsbescherming van OR-leden beoogt compensatie te bieden voor de kwetsbaarheid als gevolg van een eventuele kritische opstelling in het OR-werk, en is tevens bedoeld als waarborg voor de onafhankelijkheid van de OR-leden tegenover de bestuurder. Daarnaast kan het zo zijn dat het OR-werk, door de tijd die daarmee gemoeid is, ten koste gaat van de werkervaring en taakbeheersing in het overige werk en daarmee de carrièremogelijkheden negatief zou kunnen beïnvloeden. ${ }^{52}$

De rechtsbescherming is vooral van belang met het oog op de uiterste vorm van benadeling: ontslag. Sinds 1971 was ter bescherming van de OR-leden een geclausuleerd ontslagverbod opgenomen in de WOR. Op grond van de Wet flexibiliteit en

51 Wet van 14 februari 1998 tot wijziging van de Wet op de ondernemingsraden en titel 7.10 van het nieuw Burgerlijk Wetboek, Stb, 1998, 107

52 R.H. van het Kaar (red.). Ondernemingsraad, art. 21, aantekening 1. In verband met de eventuele breuk in de carrière en andere vormen van benadeling wordt veelal aangeraden dat de ORleden en de ondernemer afspraken maken in een zogeheten 'sociaal statuut'. Hierover heeft de SER aanbevelingen gedaan in het SER-Voorbeeldreglement. Zie Van het Kaar, art. 21-143ff. 
zekerheid ${ }^{53}$ zijn de desbetreffende bepalingen in 1998 getransfereerd van de WOR naar boek 7 van het Burgerlijk Wetboek. Artikel 7:670, lid 4, BW bepaalt dat de werkgever niet eenzijdig een einde kan maken aan de arbeidsovereenkomst met een werknemer die lid is van de ondernemingsraad (ook COR/GOR), vaste commissie of de personeelsvertegenwoordiging. Voor een aantal andere groepen (onder meer voormalige OR-leden, leden van voorbereidingscommissies, of deskundige werknemers zoals bedoeld in de Arbowet) geldt dat deze alleen kunnen worden ontslagen met toestemming van de kantonrechter (art. 7:670a, BW). In dat geval zal de kantonrechter nagaan of al dan niet een verband bestaat tussen de voorgenomen beěindiging van de arbeidsovereenkomst en de (vroegere) werkzaamheden voor de OR. ${ }^{54}$

Het opzegverbod in 7:670, lid 4, BW is behoorlijk hard. De werkgever kan de werknemer niet ontslaan, tenzij:

- de betrokkene schriftelijk in het ontslag toestemt:

- de werknemer nog in zijn proeftijd zit (art. 7:670b), hetgeen gezien de termijn voor verkiesbaarheid in art. 6, lid 3, WOR niet vaak voor zal komen - al kunnen commissieleden wel zonder termijn in de commissie benoemd worden:

- het gaat om ontslag op staande voet wegens een dringende, onmiddellijk aan de betrokkene meegedeelde reden (art. 7:677 BW);

- ontbinding wegens wanprestatie (art. 7:686 BW):

- sprake is van sluiting van de onderneming of het onderdeel waar de betrokkene werkt (in welk geval de werkgever moet beschikken over een vergunning van het CWI).

Ondanks dat het opzegverbod tamelijk hard is, levert het geen waterdichte baangarantie op. De werkgever kan altijd de kantonrechter verzoeken een arbeidsovereenkomst te ontbinden op grond van gewichtige redenen (art. 7:685 BW). Wat 'gewichtige redenen' zijn is niet uitputtend vastgelegd in het Burgerlijk Wetboek. Lid 2 van artikel 7:685 zelf verwijst naar omstandigheden die een dringende reden zouden opleveren als bedoeld in art. 7:677 BW. Wat voor de werkgever precies een 'dringende reden' voor opzegging zou kunnen zijn, wordt nader gespecificeerd in art. 7:678, lid 2, BW.

Daarnaast is in lid 1 van hetzelfde artikel in het algemeen bepaald dat als dringende redenen worden beschouwd "zodanige daden, eigenschappen of gedragingen van de werknemer, die ten gevolge hebben dat van de werkgever redelijkerwijze niet kan gevergd worden de arbeidsovereenkomst te laten voortduren." Dat een dergelijk beroep op de kantonrechter niet kansloos is, blijkt wel uit een (omstreden) uitspraak van het kantongerecht Tiel over een (kandidaat-)OR-lid dat de Arbeidsinspectie had ingeschakeld met een klacht over de werktijden en al doende het vertrouwen van de werkgever had geschonden (zie uitgebreider par. 3.6). ${ }^{55}$

53 Sth. 1998, 300

54 Uitgebreid Vink 2002, p. 79-85

55 Ktgr. Tiel. 10 februari 1999 (JAR 1999/223) 
Voor ambtenaren is de rechtsbescherming afwijkend geregeld. Ambtenaren die ORlid zijn kunnen niet ontslagen worden wegens het enkele feit dát zij OR-lid zijn, maar dat dit wél kan indien er meer argumenten zijn aan te voeren - zoals 'onverenigbaarheid van karakters' (ARAR, art. 99). Sprengers pleit in zijn proefschrift ervoor deze ongelijkheid, die is ontstaan toen de ontslagbescherming uit de WOR werd overgeheveld naar het $\mathrm{BW}$, recht te trekken. ${ }^{56}$

\subsubsection{Samenvatting}

Uit het bovenstaande blijkt dat de ondernemingsraad/personeelsvertegenwoordiging en zijn leden beschikken over een uitgebreid scala van faciliteiten, dat in de loop der jaren allengs is uitgebreid. De OR-leden doen hun OR-werk tijdens werktijd, met behoud van loon. Ze hebben recht op een minimum-aantal uren voor onderling beraad en voor beraad met de achterban. Omgekeerd is ook de achterban, mits binnen het redelijke, gefaciliteerd om zich te onderhouden met de ondernemingsraad.

De OR en de VGW-commissie beschikken daarnaast over scholingsrechten, met een in de loop der jaren toenemend aantal scholingsdagen. Ook kan hij aanspraak maken op deskundige ondersteuning, in het bijzonder van de arbodienst. De kosten voor scholing en ondersteuning komen in principe voor rekening van de werkgever. Ten slotte genieten OR-leden en leden van commissies rechtsbescherming.

Gesteld kan worden dat het de OR dus niet ontbreekt aan faciliteiten - op papier althans. Of hij in de praktijk ook daadwerkelijk aanspraak maakt op die faciliteiten, wordt besproken in paragraaf 4.1 .

\subsection{Rechten en bevoegdheden}

Ondernemingsraden hebben niet alleen diverse faciliteiten om invulling te geven aan hun rol op het gebied van veilige en gezonde arbeidsomstandigheden, ze beschikken ook over een aantal zogeheten 'bijzondere bevoegdheden'. Net als bij de hierboven behandelde faciliteiten, zijn die medezeggenschapsrechten in de loop der jaren allengs sterker geworden.

Het meest aansprekende OR-recht op het gebied van arbeidsomstandigheden is het instemmingsrecht (par. 3.3.2). Voorts heeft de ondernemingsraad (en de pvt) op grond van de Arbowet per 1 november 1999 een bijzondere bevoegdheid gekregen, te weten het recht van overeenstemming (par. 3.3.3). Deze bevoegdheden zijn voor de OR/pvt van groot gewicht in situaties dat de ondernemer zelf met beleidsvoorstellen komt om de arbeidsomstandigheden te verbeteren, dat wil zeggen voor reactieve medezeggenschap. Daarnaast kan medezeggenschap op het gebied van arbeidsomstandigheden echter ook meer pro-actief of preventief georiënteerd zijn. door het gebruik van het initiatiefrecht respectievelijk het adviesrecht.

Om de verschillende oriëntaties te illustreren, is het zinvol de inzet van medezeg-

56 L.C.J. Sprengers (1998), De Wet op de Ondernemingsraden bij de overheid: Op weg naar één arbeidsrecht voor ambtenaren en werknemers?. Amsterdam: Universiteit van Amsterdam (diss.). p. $492-497$ 
genschapsrechten te koppelen aan het stadium in de besluitvorming rond het arbobeleid of, in andere woorden, de plek in de arbobeleidscyclus. Het ministerie van Sociale Zaken en Werkgelegenheid schetst die beleidscyclus aan de hand van de zogeheten $4 \mathrm{~W}$-aanpak: weten, wegen, werken en waken: de werkgever spoort middels de risico-inventarisatie bestaande risico's op (weten), evalueert de risico's (wegen), en lost deze vervolgens op een planmatige wijze zo effectief mogelijk op (werken), waarbij jaarlijks de voortgang van het plan van aanpak wordt bewaakt (waken). ${ }^{57}$ Met name het plan van aanpak vereist instemming van of overeenstemming met de OR/pvt.

\section{Figuur 3.1.}

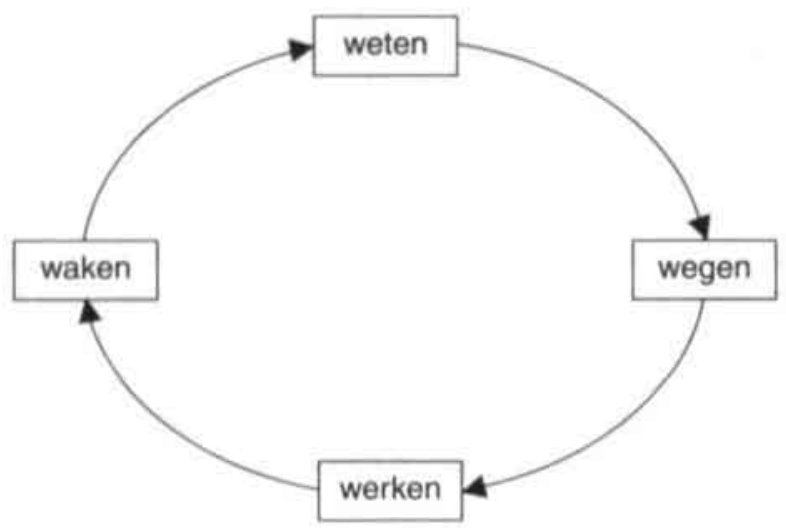

Dit model kent echter twee belangrijke manco's. Zo ontbreekt een preliminaire W, namelijk die van 'willen'. Uit diverse onderzoeken blijkt namelijk dat lang niet alle werkgevers staan te trappelen om een krachtdadig arbobeleid te voeren. In die gevallen kan de OR/pvt de werkgever aansporen door zelf het initiatief te nemen (par. 3.3.1), waarmee de OR een meer pro-actieve opstelling kiest. Belangrijker is echter nog dat de meest gangbare invulling van de voornoemde beleidscyclus zich beperkt tot het inventariseren en planmatig verhelpen van reeds bestaande risico's. Het arbobeleid is te vaak een niet-geïntegreerd onderdeel van het bedrijfsbeleid, beperkt zich tot het systematisch uit de weg ruimen van reeds bestaande risico's. Door al bij nieuwe beleidskeuzes vooraf de mogelijke gevolgen voor de veiligheid en de gezondheid in te schatten, kunnen de arbeidsomstandigheden echter veel effectiever preventief worden beïnvloed. ${ }^{58}$ In dit licht is het adviesrecht van de OR een bijzonder belangrijk arbo-instrument (par. 3.3.4). Door bij de adviesaanvrage bij bijvoorbeeld ver- of nieuwbouw of de introductie van nieuwe technologieën vóoraf een risico-inventarisatie en -evaluatie te eisen, wordt een koppeling gelegd tussen het algemene beleid en een preventief arbeidsomstandighedenbeleid.

57 SZW (1997), Anbo- en verzuimbeleid. Arbo-Informatieblad 1. Den Haag: Sdu/ministerie van Sociale Zaken en Werkgelegenheid. p. 8

58 In het AI-blad wordt hier overigens ook op gewezen (p. 14), maar in de praktijk blijkt preventieve aandacht voor arbeidsomstandigheden een ondergeschoven kindje. 
Ondernemingsraden die een afwachtende of afhoudende ondernemer willen aanzetten tot het voeren van een krachtdadig arbobeleid of concrete maatregelen, kunnen diverse routes bewandelen. Eén mogelijkheid is de argumentatieve strategie: de bestuurder tijdens de overlegvergadering wijzen op het belang van veilige en gezonde arbeidsomstandigheden. De OR heeft namelijk niet alleen passief overlegrecht, hij heeft ook het recht zelf het initiatief te nemen tot overleg (art. 23, lid 1 en 2, WOR). De OR heeft hierbij een aantal argumenten tot zijn beschikking. Het meest effectieve argument is waarschijnlijk te wijzen op de kosten van slechte arbeidsomstandigheden. Als gevolg van achtereenvolgens de TZ, de Wulbz en de Pemba worden werkgevers direct geconfronteerd met de kosten van ziekteverzuim en arbeidsongeschiktheid. Aangezien uit diverse studies blijkt dat verzuim en uitstroom naar de WAO voor een groot deel te wijten zijn aan het werk ${ }^{59}$, kan investeren in kwaliteit van de arbeid de werkgever direct geid opleveren. Additionele argumenten zijn bijvoorbeeld een hoog verloop of wervingsproblemen door een slecht imago van het bedrijf of de bedrijfstak.

Daarnaast heeft de OR het recht om tijdens én buiten de vergadering voorstellen te doen omtrent alle aangelegenheden de onderneming betreffende (art. 23, lid 3 . WOR). Dit is het zogeheten initiatiefrecht van de ondernemingsraad, dat dateert uit de WOR 1979.60 De ondernemingsraad dient voorstellen schriftelijk en voorzien van een toelichting voor te leggen aan de ondernemer (via de bestuurder). OR en bestuurder dienen ten minste één maal over het initiatief van de OR te vergaderen, waarna de ondernemer zo spoedig mogelijk schriftelijk en met redenen omkleed aan de OR meedeelt of hij diens voorstel overneemt.

Om zijn initiatief te onderbouwen heeft de ondernemingsraad het recht al die informatie in te winnen die hij nodig acht om tot een goed voorstel te komen. ${ }^{61}$ Blijkens de jurisprudentie dient de OR wel aan te geven dat hij de informatie nodig heeft voor het doen van een initiatiefvoorstel. ${ }^{62}$ Of de ondernemingsraad ook het recht heeft om zelf een risico-inventarisatie of een enquête onder het personeel uit te voeren (bijvoorbeeld in het kader van werkdrukonderzoek) is niet zeker. Artikel 18, lid 1, geeft de OR weliswaar het recht kennis te nemen van de arbeidsomstandigheden in de onderneming, maar als daar kosten aan verbonden zijn, is de werkgever niet verplicht die kosten te dragen. De COR van Aegon ving althans bot toen hij voor de kantonrechter eiste dat de werkgever de kosten voor een enquête omtrent het sociaal beleid voor zijn rekening zou nemen. ${ }^{63}$ Volgens de kantonrechter was een

59 E.A.P. Koningsveld en J.C.M. Mossink (red.) (1997), Kerncijfers maatschappelijke kosten van arbeidsomstandigheden in Nederland, Den Haag: VUGA/ministerie van Sociale Zaken en Werkgelegenheid

60 Ook art. 11. lid 1, van de Kaderrichtlijn $89 / 391$ geeft werknemers en hun vertegenwoordigers het recht om voorstellen te doen.

61 Vgl. Minister SZW, 11 juni 1986, ROR 1986, 40

62 Kamerstukken II. 1995/96, 24615, nr. 3, p. 14, (MvT wetsvoorstel Wijziging van de Wet op de ondernemingsraden)

63 ROR 1994, nr. 2 
enquête een te zwaar middel in het licht van de in de artikelen 23 en 31 gegeven bevoegdheden.

Uit de Memorie van Toelichting bij de wetswijziging van WOR 1998 bleek echter, bij de bespreking van het beraad met de achterban, dat de minister van mening was dat het uitvoeren van een enquête een geëigend en niet al te zwaar middel was om de mening van de achterban te peilen ${ }^{64} \mathrm{Bij}$ mijn weten is er sindsdien nog geen soortgelijke kwestie aanhangig gemaakt voor de kantonrechter. Het is mijns inziens echter goed denkbaar dat de rechter nu tot een ander oordeel zou komen dan in 1994, nog los van het feit dat op de uitspraak in de Aegon-zaak al de nodige kritiek te leveren valt.

Een belangrijke tekortkoming bij het initiatiefrecht is dat de werkgever zonder veel problemen voorstellen van de OR kan afwijzen. Weliswaar moet dit 'schriftelijk en met redenen omkleed', maar er is geen verweer mogelijk indien de ondernemingsraad zich niet kan vinden in de afwijzing. In het voorstel voor wijziging van de WOR 1998 is gesuggereerd dat de OR bemiddeling van de bedrijfscommissie zou moeten kunnen vragen. ${ }^{65}$ Dit voorstel werd echter niet aangenomen. Van een beroep op de kantonrechter is al helemaal geen sprake. Een ander manco betreffende het initiatiefrecht is dat dit níet ook is toegekend aan de personeelsvertegenwoordiging.

\subsubsection{Instemmingsrecht}

De zwaarste medezeggenschapsbevoegdheid op het terrein van de arbeidsomstandigheden is het instemmingsrecht. Weliswaar is het overeenstemmingsrecht uit de Arbowet (zie par. 3.3.3) formeel zwaarder en kan het adviesrecht bij een optimaal gebruik wellicht meer effect sorteren (zie par. 3.3.4), het instemmingsrecht van de OR (én van de pvt) is een combinatie van een zware bevoegdheid én een tamelijk uitgestrekt werkingsgebied.

\section{WOR 1971: introductie instemmingsrecht}

Het instemmingsrecht van de ondernemingsraad is geïntroduceerd in de WOR 1971. Artikel 27 van de WOR verleende de ondernemingsraad een recht van medebeslissen ten aanzien van een maatregel op het gebied van de veiligheid, de gezondheid of de hygiëne (27. lid 1 sub d). ${ }^{66}$ Daarmee was arbeidsomstandigheden één van de vier gebieden waarop de ondernemer ("of een andere bij de onderneming

64 Kamerstukken II, 1995/96, 24615, nr. 3, p. 20

65 Kamerstukken II, 1995/96, 24615, nr. 2, art. I, onderdeel J, sub 6, en nr. 3, (MvT), p. 15

66 In het oorspronkelijke wetsvoorstel werden de maatregelen omtrent veiligheid en gezondheid overigens onder het adviesrecht geschaard. Een motie van de Wieldraajer (PvdA) c.s. om het instemmingsrecht fors uit te breiden werd afgestemd. Een iets bescheidener motie van ARP/KPV/VVD om werktijdregelingen en maatregelen op het gebied van veiligheid en gezondheid onder het instemmingsrecht te brengen (Kamerstukken II, 1969/70, 10 355, nr. 22) werd wel aangenomen 
betrokken persoon") de ondernemingsraad vooraf om instemming moest vragen alvorens hij een besluit zou kunnen nemen. ${ }^{67}$

Indien de ondernemingsraad weigerde in te stemmen met een voorgenomen besluit, dan kon de ondernemer vervangende toestemming vragen aan de bedrijfscommissie (art. 27, lid 3). Indien de ondernemer uitvoering gaf aan een regeling zonder instemming van de ondernemingsraad of in weerwil van het onthouden van diens instemming, dan konden individuele personen schriftelijk een beroep doen op de nietigheid van het besluit: mits binnen één maand nadat het besluit ter kennis van de daarbij betrokkenen is gebracht (art. 27, lid 4). De ondernemer die het niet eens was met een beroep op nietigheid, kon de kantonrechter binnen cen maand een beslissing ter zake vragen (art. 27, lid 4). ${ }^{68}$ Het tweede lid van artikel 27 beperkte het instemmingsrecht: de ondernemingsraad had anno 1971 geen instemmingsrecht wanneer het betrokken onderwerp reeds 'regeling had gevonden' in een CAO, een andere regeling tussen de ondernemer en één of meer betrokken vakorganisaties, of een arbeidsvoorwaardenregeling vastgesteld door een publiekrechtelijk orgaan. ${ }^{69}$ In hoofdlijnen is de systematiek van het instemmingsrecht in de volgende edities van de WOR overeind gebleven:

- de ondernemer heeft bij een te nemen besluit ter zake de veiligheid of de gezondheid in verband met de arbeid vooraf instemming nodig van de OR (tenzij een en ander reeds in de $\mathrm{CAO}$ is geregeld).

- indien hij die instemming niet krijgt kan hij vervangende toestemming vragen,

- regelingen die zonder instemming van de ondernemingsraad zijn getroffen zijn vernietigbaar (zie hieronder).

Wel heeft het instemmingsrecht in de loop der jaren diverse modulaties ondergaan.

\section{WOR 1979: duidelijker procedure}

In de WOR 1979 werd het instemmingsrecht uitgebreid met een aantal andere thema's op het gebied van sociaal- en personeelsbeleid. Deze uitbreiding had geen

67 De andere drie onderwerpen waren het arbeidsreglement, pensioen-, winstdelings- of spaarregelingen, en werktijd- of vakantieregelingen. Overige thema's op het gebied van sociaal- of personeelsbeleid die later wel onder het instemmingsrecht zouden ressorteren, zoals beloning, opleiding of personeelsbeoordeling, vielen in de WOR 1971 nog onder het adviesrecht.

68 Een deel van de bijzondere commissie van de Tweede Kamer was het met die mogelijkheid van vervangende toestemming niet eens. "Als de instemming er niet is behoort de zaak niet door te gaan. Er is een medebeslissingsrecht of niet". (Kamerstukken II. 1969/70, 10 355, nr. 5, p. 16). Desondanks werd het wetsvoorstel op dit punt ongewijzigd aangenomen.

69 R.H. van het Kaar (red.), Ondermemingsraad, Inleiding 8-8 
direct effect voor het deelterrein veiligheid en gezondheid. ${ }^{70}$ Een wijziging ten opzichte van de WOR 1971 betrof wel de vervanging van de term hygiëne door het begrip welzijn in verband met de arbeid. Deze terminologische aanpassing was met name bedoeld om meer aan te sluiten bij de terminologie in de ontwerp-arbeidsomstandighedenwet die op dat moment voorlag.

Belangrijker was dat in de WOR 1979 een aantal procedurele aspecten werd aangescherpt. Ten eerste moesten ondernemer en ondernemingsraad voortaan minimaal één keer met elkaar overleggen over een voorgenomen besluit. Bovendien werden meer eisen gesteld aan de vorm van het voorgenomen besluit: de werkgever moest het besluit schriftelijk voorleggen aan de OR, waarin opgenomen "een overzicht van de beweegredenen voor het besluit alsmede van de gevolgen die het besluit naar te verwachten valt voor de in de onderneming werkzame personen zal hebben". Voorts werd de procedure rond nietige besluiten enigszins gewijzigd. Terwijl in de WOR 1971 alleen betrokken personen zich op de nietigheid van besluiten konden beroepen, werd die verantwoordelijkheid in 1979 aan de OR toegekend. Indien de ondernemer uitvoering gaf aan een instemmingsplichtig besluit zonder instemming van de ondernemingsraad, dan diende deze binnen een maand na schriftelijke mededeling van het besluit óf, bij gebreke van een schriftelijke mededeling, binnen een maand nadat hij kennis heeft genomen dat uitvoering wordt gegeven aan het besluit schriftelijk een beroep te doen op de nietigheid van dat besluit.

\section{WOR 1990: samenloop met Arbowet}

Ook de WOR 1990 leverde een aantal wijzigingen op. Een kleine wijziging betrof de wijze waarop de ondernemer zijn uiteindelijke besluit kenbaar moest maken. In lid 2 werd bepaald dat dit schriftelijk moest worden meegedeeld, onder vermelding van de datum met ingang waarvan de ondernemer het besluit zal uitvoeren. Daarnaast werd de procedure om vervangende toestemming te vragen gewijzigd. Gold in eerdere edities van de WOR de bedrijfscommissie als de instantie waar de ondernemer vervangende toestemming kon vragen, sinds 1990 is een gang naar de kantonrechter vereist - overigens na bemiddeling van de bedrijfscommissie (art. 36 . lid 5, jo. art. 27, lid 4).

70 Een uitzondering vormen de regelingen op het gebied van het aanstellingsbeleid, die in 1979 werden getransfereerd van het adviesrecht naar het instemmingsrecht, die zijdelings relevantie kunnen hebben voor het arbobeleid gezien de introductie van aanstellingskeuringen met het oog op risico-selectie. Op grond van de Wet terugdringing ziekteverzuim (1994) en de Wet uitbreiding loondoorbetalingsverplichting bij Ziekte (Wulbz, 1996), werden werkgevers medio jaren ' 90 namelijk verplicht het loon van zieke werknemers voor eigen rekening te nemen. Om het (financiěle) risico van hoog verzuim te minimaliseren, namen steeds meer bedrijven hun toevlucht tot aanstellingskeuringen teneinde werknemers 'met een vlekje' zoveel mogelijk buiten de poort te houden (Ctsv (1995), Verzaimbeleid voor eigen risico: Gedragsreacties van grote werkgevers op de financièle prikkels in de Ziektewet. Zoetermeer, p. 107-116 en 189. SZW-werkgeverspanel 1997-1998, Den Haag. 1999, p. 79-88). Overigens heeft ook de wetgever middels de Wet medische keuringen (Stb. 1997, 365) gepoogd risico-selectie door middel van aanstellingskeuringen of gezondheidsvragen tijdens sollicitatiegesprekken te verhinderen. 
Ingrijpender was evenwel de wijziging van lid 3 van artikel 27. Dit derde lid stelde het instemmingsrecht buiten werking "indien en voorzover de betrokken aangelegenheid reeds inhoudelijk is geregeld in een collectieve arbeidsovereenkomst". Hieraan werd een verdere beperking toegevoegd: instemming werd "evenmin vereist met betrekking tot een regeling [op het gebied van de veiligheid, de gezondheid of het welzijn in verband met de arbeid] voor zover ter zake een aanwijzing kan worden gegeven of een eis kan worden gesteld als bedoeld in de Arbeidsomstandighedenwet".

Aanleiding voor deze wijziging waren eerder geconstateerde problemen in de samenloop van rechten en procedures in de WOR enerzijds en de Arbowet 1980 anderzijds. ${ }^{71}$ Deze kwestie was eerder aangezwengeld door de Voorlopige Arbeidsraad (VAR) in zijn advies over de inwerkingtreding van de Arbowet. ${ }^{72}$ Naast een discussie over de faciliteitenregeling voor medezeggenschappers in beide wetten, speelde met name de afstemming tussen het instemmingsrecht krachtens de WOR en de mogelijkheid om op grond van de Arbowet een verzoek tot wetstoepassing in te dienen. Dit verzoek tot wetstoepassing was een instrument om de Arbeidsinspectie uitleg te vragen van voorschriften op grond van de Arbowet (zie ook paragraaf 3.5). De inspecteur kon zijn opvatting ter zake vastleggen in een aanwijzing of een eis. Hierin werd dan in finesse aangegeven waar de werkgever zich aan te houden had.

Indien de ondernemer uitvoering gaf aan een besluit zonder de instemming van de $\mathrm{OR}$, dan stonden de ondernemingsraad twee mogelijkheden open om de uitvoering van het besluit aan te vechten. De eerste, zoals hierboven aangegeven, was het inroepen van de nietigheid. De tweede bestond uit het indienen van een verzoek om wetstoepassing. Ook als de ondernemer zich niet wilde neerleggen bij een weigering van de OR om in te stemmen met een voorgenomen besluit stonden twee wegen open. De gang naar de kantonrechter voor vervangende toestemming of een verzoek tot wetstoepassing. Hangende de procedure kon echter onduidelijkheid ontstaan over welke maatregelen het bedrijf geacht werd te nemen.

In haar brief aan de SER stelde de staatssecretaris van SZW voor het instemmingsrecht niet van toepassing te laten zijn in situaties op (deel)onderwerpen ten aanzien waarvan bij of krachtens de Arbowet voorschriften zijn gesteld. ${ }^{73}$ De SER kon zich in zijn advies over de samenloop tussen de WOR en de Arbowet met de strekking van het voorstel verenigen, beseffende dat daarmee het instemmingsrecht ter zake 'een subsidiair recht' zou worden. ${ }^{74}$

Tijdens de Kamerbehandeling van het voorstel om het instemmingsrecht te laten vervallen "voor zover een aanwijzing kan worden gegeven of een eis kan worden

71 Brief van de staatssecretaris van Sociale Zaken en Werkgelegenheid, 10 augustus 1984, aan de SER.

72 Voorlopige Arbeidsraad, 17 juni 1982, nr.2

73 Brief van de staatssecretaris van Sociale Zaken en Werkgelegenheid, 10 augustus 1984, aan de SER.

74 SER (1986), Advies samenloop Wet OR en Arbo-wet, Den Haag: Sociaal-Economische Raad (SER 86/06), p. 16-17 
gesteld"75, bleek de Tweede Kamer zich in meerderheid te kunnen vinden in de voorgenomen oplossing voor de samenloop tussen de WOR en de Arbowet. Slechts de PvdA was "niet overtuigd van de wijsheid" van de gekozen oplossing. Volgens haar zou deze leiden tot een aanmerkelijke inperking van de invloed van de OR. ${ }^{76}$ $\mathrm{Bij}$ amendement van het lid Leijnse werd geopperd in ieder geval de formulering "kan worden gegeven of [..] kan worden gesteld" aan te scherpen tot "is gegeven of $[.$.$] is gesteld". 77$ Te vrezen viel namelijk dat de formulering "kan worden" in het wetsartikel zo ruim geïnterpreteerd zóu worden dat louter de mogelijkheid tot het inzetten van de genoemde instrumenten impliceerde dat de OR geen instemmingsrecht had. Aangezien uit de handhavingspraktijk volgens Leijnse geconcludeerd kon worden dat de Arbeidsinspectie nogal eens naliet gebruik te maken van haar juridisch instrumentarium, zou dit betekenen dat het recht van de OR volledig in de lucht zou komen te hangen. ${ }^{78}$ Het amendement werd evenwel verworpen ${ }^{79}$, waarna lid 3 overeenkomstig het wetsvoorstel werd gewijzigd.

\section{Onduidelijkheden na 1990}

De vrees van Leijnse bleek uiteindelijk gegrond. Zo was bij de invoering van het stelsel van arbodiensten, begin jaren '90, aanvankelijk onomstreden dat de OR instemmingsrecht had bij de keuze van de arbodienst: "De ondernemingsraad heeft on hacie van [ ] artikel 27 [. , van de Wlet op do ondermomingsradon over do organisatie van de deskundige ondersteuning in het bedrijf instemmingsrecht." 80 In verband met de afstemming van het instemmingsrecht met de bevoegdheden van de Arbeidsinspectie werd dit instemmingsrecht vervangen door een overlegrecht in artikel 17, lid 2, Arbowet. ${ }^{81}$ Dat was het begin van langjarig gekrakeel. Hoewel volgens de minister het overlegrecht op grond van de Arbowet materieel hetzelfde was als het instemmingsrecht, werd dit in de praktijk toch anders ingevuld. ${ }^{82}$ De werkgevers brachten meermalen het verweer in stelling dat de Arbeidsinspectie een eis kon stellen aangaande de aansluiting bij een arbodienst, en dat de OR derhalve géén instemmingsrecht toe zou komen. Herhaalde Kamervragen over de kwestie verplichtten opeenvolgende ministers één en andermaal duidelijkheid te verschaffen over de portee van het instemmingsrecht.

\footnotetext{
75 Kamerstukken II, 1987/88, 20 583, nr.2, artikel I onder Y

76 Kamerstukken II, 1987/88, 20 583, nr.5, p. 7

77 Kamerstukken II. 1987/88, 20 583, nr.18

78 Handelingen II, 7-150, 10 oktober 1988

79 Handelingen II, 9-204, 18 oktober 1988

80 Kamerstukken II. 1992-1993, 22 898, nr. 3, p. 18 en 51

81 Cf. Kamerstukken II. 1992-1993, 22 898, nr. 6, p. 28-29
}

82 Ook bij de totstandkoming van de Kaderrichtlijn was omstreden hoever de bevoegdheden van de werknemers op dit punt reikten. Het Europees Parlement bepleitte een instemmingsrecht bij de organisatie van de preventiedienst op grond van artikel 7 Kaderrichtijn, maar uiteindelijk werd dit afgezwakt tot 'consultatie', waarbij onduidelijk bleef wat de precieze status van dit consultatierecht was. D. Walters en P.L. Jensen (2000). The discourses and purposes behind the development of the EU Framework Directive 89/391, in: K. Frick et al. (2000), Systematic Occupational Health and Safery Management, Amsterdam/Oxford: Pergamon, p. 90 
Toch kon al aan de Kamerbehandeling van de WOR 1990 eenduidig worden ontleend hoe de verhouding tussen het instemmingsrecht en de bevoegdheden van de Arbeidsinspectie moet worden beoordeeld. In de Memorie van Antwoord stelde de minister dat het wetsvoorstel "geen materiële wijziging" van de medezeggenschapsrechten beoogde, maar louter een procedurele afstemming. ${ }^{83}$ Aan de hand van een aantal casusposities die waren ontleend aan een brief van de FNV over de kwestie, gaf de minister vervolgens een glasheldere uitleg over de afgrenzing van beide bevoegdheden. Omtrent de keuze voor de meest doelmatige beschermingsmiddelen, bijvoorbeeld, stelde hij dat "[i]n zoverre als de beslissing van de Arbeidsinspectie de ondernemer bij het ter beschikking stellen van persoonlijke beschermingsmiddelen vrijheid laat in de keuze uit alternatieven [..] die keuze onderworpen [is] aan het instemmingsrecht van de ondernemingsraad." 84 Dit werd later in meer algemene zin herhaald: "Waar de Arbeidsinspectie [een eis stelt of een aanwijzing geeft] behoudt de ondernemingsraad zijn instemmingsrecht voor zover de eis of de aanwijzing de ondernemer keuzevrijheid laat hoe daaraan te voldoen." 85

Geheel in lijn met deze interpretatie oordeelde ook de rechtbank Rotterdam dat indien de Arbeidsinspectie geen aanwijzing heeft gegeven of geen eis heeft gesteld, de OR instemmingsrecht behoudt. ${ }^{86}$ Het betrof hier de vraag of een alcoholverbod voor inwonende schepelingen van veerboten (6́́k tijdens hun vrije tijd) instemmingsplichtig was. Weliswaar was de werkgever bevoegd regelen uit te vaardigen "in het belang der veiligheid", maar onder verwijzing naar de wetsgeschiedenis oordeelde de kantonrechter dat een dergelijke regeling wel degelijk instemmingsplichtig was nu de Arbeidsinspectie niet daadwerkelijk van zijn bevoegdheid gebruik had gemaakt.

\section{Keuze van de arbodienst}

Desondanks zetten de werkgevers de ruime interpretatie van lid 3 ook later in als barricade tegen het instemmingsrecht van de OR. Dit speelde, zoals gezegd, met name bij de keuze van de arbodienst. In een brief naar aanleiding van de behandeling van de gewijzigde Arbowet in 1994 gaf toenmalig minister De Vries van Sociale Zaken en Werkgelegenheid een helder exposé over de verhouding tussen de bevoegdheden van de Arbeidsinspectie en het overlegrecht in de Arbowet enerzijds en het instemmingsrecht uit de Wet op de ondernemingsraden anderzijds. ${ }^{87}$ In zijn brief gaf de minister een zeer ruime uitleg van het overlegrecht in de Arbowet: het overlegrecht in de Arbowet is gelijkwaardig aan het instemmingsrecht op grond van de WOR, alleen de beroepsprocedure is anders. ${ }^{88}$

83 Kamerstukken II, 1987/88, 20583 , nr.6, p. 6

84 Kamerstukken II. 1987/88, 20583 , nr.6, p. 26

85 Kamerstukken II, 1987/88, 20 583, nr.9, p. 5

8627 april 1993, ROR 1993, nr.21

87 Kamerstukken II. 1993/94, 23 253, nr.14

88 Ibid, p. 2 
Aangaande de vraag of de ondernemingsraad instemmingsrecht heeft bij de keuze van de arbodienst merkte de minister op dat "de Arbeidsinspectie [wel zal] toetsen of de werkgever daadwerkelijk overleg heeft gevoerd en of er sprake is van een gecertificeerde arbodienst, maar [..] geen aanwijzing [zal] geven met welke gecertificeerde arbodienst de werkgever een contract moet sluiten." Als de aanwijzing van de Arbeidsinspectie beleidsruimte voor de werkgever overlaat, en dat is dus het geval bij de keuze van de arbodienst, gold volgens de minister de eerdere opvatting dat "het voorgenomen besluit op het punt van de invulling van die vrijheid onderworpen is aan het instemmingsrecht van de ondernemingsraad." 89

Onder verwijzing naar de voornoemde brief nam de Memorie van Antwoord aan de Eerste Kamer ter zake de Wet uitbreiding loondoorbetalingsplicht bij ziekte (Wulbz) weer wat gas terug. Aangezien de Arbeidsinspectie een aanwijzingsbevoegdheid heeft inzake de keuze van de arbodienst, valt die keuze niet onder het instemmingsrecht. Maar waar een aanwijzing uitblijft, kan de OR weer instemmingsrecht opeisen indien de keuze consequenties heeft voor het verzuimbeleid en dus voor de werknemers. ${ }^{90}$ Bovendien is de inhoud van het contract blijkens de Memorie van Antwoord direct instemmingsplichtig, zodat de OR langs deze weg zijn invloed kan doen gelden..$^{91}$

Ook in een later stadium zwalkt het standpunt van de overheid. In 1996, in de aanloop tot de wijziging van de WOR in 1998, achtte de minister van Sociale Zaken de keuze van de arbodienst instemmingsplichtig. ${ }^{92}$ Dit nar as leiding van onderzoek van de FNV waaruit bleek dat slechts in 15 procent van de gevallen de OR zijn instemmingsrecht in de praktijk had kunnen brengen. ${ }^{93}$ In het algemeen overleg over de verzelfstandiging van de certificering van arbodiensten in mei 1998 stelde de staatssecretaris dat de OR instemmingsrecht heeft bij de keuze van de dienst, waarbij ó́k de verlenging van het contract expliciet werd genoemd. ${ }^{94}$ In een brief over de resultaten van de FNV-klachtenlijn arbodiensten stelde hij vervolgens dat arbodiensten, alvorens een contract met een bedrijf af te sluiten, eerst bij de OR/pvt moeten nagaan of deze geen bezwaar hebben tegen uitvoering van het contract - vrij vertaald of zij instemming hebben verleend. ${ }^{95}$ In de Sociale Nota 1999 werd echter weer alleen het contract met de arbodienst als instemmingsplichtig betiteld. ${ }^{96}$

89 Kamerstukken II, 1993/94, 23 253. nr.14, p. 3, Kamerstukken II, 1987/88, 20 583, nr. 6, p. 7

90 Kamerstukken I. 1995/96, 24 439, nr. 134b. p. 29

91 Kamerstukken I. 1995/96, 24439 , nr. 134b, p. 28

92 Kamerstukken II, 1996/97, 24615 , nr. 28, p. 35

93 FNV, brief van 10 mei 1995, ook aangehaald in Kamerstukken II, 1995/96, 24615, nr. 3, p.

94 Kamerstukken II. 1997/98, 25883 , nr. 5, p. 5

95 Brief van 9 juli 1998 over actiepunten naar aanleiding van bevindingen van de FNV-meldlijn klachten arbodiensten, Kamerstukken II. 1997-1998, 25 883, nr. 6. p. 2

96 Sociale Nota 1999, Kamerstukken II. 1998/99, 26202, nr. 2. p. 89 
De meest zwaarwegende passages omtrent de huidige status van het instemmingscht zijn evenwel te vinden in de wetsgeschiedenis van de Arbeidsomstandighedenwet 1998. In de Memorie van Toelichting bij het wetsvoorstel is de reikwijdte van het instemmingsrecht namelijk expliciet vastgelegd. "Het instemmingsrecht van de OR en de pvt, alsmede het adviesrecht van werknemers bij het ontbreken van een OR of pvt, geldt [..] voor alle regelingen op het gehele terrein van het arbeidsomstandighedenbeleid van het bedrijf. Daaronder vallen dus ook meer specifieke punten, zoals;

- de risico-inventarisatie en -evaluatie en het daartoe behorende plan van aanpak;

- de verplichtingen zoals bedoeld in artikel 6, eerste lid, onder b, c en d;

- de wijze waarop de deskundige bijstand wordt ingericht (dit betreft onder meer het contract met de arbodienst);

- het aanwijzen van bedrijfshulpverleners;

- de periodiciteit van het arbeidsgezondheidskundig onderzoek"97

Tijdens de behandeling van de Arbowet werd een en ander nog eens herhaald, waarbij ook verzuimregelingen (bijvoorbeeld de wijze van ziekmelding, controlevoorschriften of arbeidsvoorwaardelijke prikkels ${ }^{98}$ ) expliciet werden genoemd. ${ }^{99}$ Wat nergens expliciet wordt genoemd maar wel degelijk onder het instemmingsrecht valt, is bijvoorbeeld:

- het aanwijzen van functies waarvoor aanstellingskeuringen worden uitgevoerd;

- maatregelen op het gebied van seksuele intimidatie (bijvoorbeeld het aanwijzen van een vertrouwenspersoon), agressie en geweld.

In 2001 heeft de ondernemingsraad, op grond van artikel 88 van de Invoeringswet SUWI (Structuur uitvoeringsorganisatie werk en inkomen) ook instemmingsrecht gekregen bij het reïntegratiebeleid in het algemeen en de keuze van het reintegratiebedrijf in het bijzonder. ${ }^{100}$

\section{Analyse}

De formuleringen in de Memorie van Toelichting en in de Handelingen lijken dus glashelder. Toch valt op de opvatting van de wetgever dat het instemmingsrecht een ruim bereik heeft wel het een en ander af te dingen. Dat afspraken over het PAGO, aanstellingskeuringen of bijvoorbeeld een klachtenprocedure omtrent seksuele intimidatie onder het instemmingsrecht vallen, is niet meer dan logisch. Maar de toekenning van instemmingsrecht bij de risico-inventarisatie of het plan van aanpak

97 Kamerstukken II, 1997/98, 25879, nr.3, p. 19

98 Cf. Jan Popma (1999), Paardenmiddel tegen ziekteverzuim heeft veel bijwerkingen, in: $O R$ Informatie, 28 mei 1999, p. 29-31

99 Handelingen Tweede Kamer 1998-1999. nr. 16, Tweede Kamer, p. 969

100 Stb. 2001, 625 
lijkt wat al te ruimhartig. Wat bijvoorbeeld de consequenties zijn indien de ondernemingsraad weigert in te stemmen met een risico-inventarisatie is volstrekt onduidelijk. ${ }^{101}$ Mag het bedrijf dan geen risico-inventarisatie uitvoeren en is het bij gevolg in overtreding (beboetbaar op grond van artikel 33, lid 1, Arbowet)? Kan de kantonrechter vervangende goedkeuring hechten aan de RI\&E? Op grond van welke criteria is de weigering van de OR om in te stemmen 'onredelijk' als bedoeld in artikel 27 , lid 4, WOR? Is een risico-inventarisatie überhaupt wel een 'regeling'? En een plan van aanpak, is dat een voorgenomen besluit, of alleen de specifieke maatregelen op grond van dat plan?

Ook op de stelling dat de wijze van organisatie van de deskundige ondersteuning als een instemmingsplichtige regeling kan worden aangemerkt, valt wel een en ander af te dingen. Dat is in ieder geval gedaan door de Ondernemingskamer in zijn beslissing in het geding tussen de bestuurder en de Centrale Ondernemingsraad van de Sociale Verzekeringsbank (SVB) omtrent het besluit tot opheffing van de interne arbodienst. ${ }^{102}$ In het geschil liepen twee procedures naast elkaar. Ten eerste stelde de COR voor de Ondernemingskamer dat de bestuurder ten onrechte geen instemming had gevraagd over de opheffing van de arbodienst, maar louter advies. Tezelfdertijd was de COR een procedure begonnen over het instemmingsrecht bij de bedrijfscommissie, omdat sprake zou zijn van een nietig besluit (waar immers geen instemming voor was gevraagd). De bedrijfscommissie oordeelde dat het gewraakte voorgenomen besluit inderdaad instemming van de centrale OR behoefde, én dat de SVB een "meer gepreciseerde uiteenzetting" omtrent de beweegredenen voor het voorgenomen besluit zou moeten leveren. In zijn uitspraak over het preliminaire verzoek oordeelde het Hof daarentegen dat "het besluit tot opheffing van een interne arbodienst in redelijkheid niet [kan] worden gezien als een besluit, houdende een regeling op het gebied van het ziekteverzuim als bedoeld in artikel 27 eerste lid onder $\mathrm{d}$ WOR." Een nadere motivering van dit oordeel, dat door diverse juristen als 'wonderlijk' is betiteld ${ }^{103}$. ontbrak. Desgevraagd antwoordde de president van de Ondernemingskamer in het blad OR-Informatie dat sprake was van een organisatorische keuze die de structuur van de onderneming betrof, die derhalve eerder onder het adviesrecht op grond van artikel 25 , lid 1 , onder $\mathrm{d}$ en e, WOR zou vallen. De wetsgeschiedenis legde volgens de president op dit punt weinig gewicht in de schaal. ${ }^{104}$

Bij de beoordeling van de vraag 'wel of geen instemmingsrecht' moet dus kenne-

101 Overigens heeft de ondernemingsraad uiteraard géén instemmingsrecht m.b.t. de vraag óf er een RI\&E moet komen. Dat is immers een wettelijke verplichting. Maar de OR zou kunnen weigeren in te stemmen met de inhoud van de inventarisatie (bijvoorbeeld omdat bepaalde risico's onvoldoende aan bod komen) dan wel de evaluatic (bijvoorbeeld omdat de ernst van bepaalde risico's volgens de OR onderschat wondt).

102 JAR 1999/nr.147

103 Juristen hebben de uitspraak van het Hof, gezien de wetsgeschiedenis, als 'wonderlijk ' betiteld. Prof. mr Ad Geers (1999), Verwondering, in: OR-Informatie, jaargang 25, nr. 11, p. 31. Mr. Cees van Leeuwen (1999), Advies of instemming?, in: OR-Informatie, jaargang 25, nr. 10. p. 37 104 Jan Popma (2000). FNV-idee proefproces niet zonder risico's, in: OR-Informatie, jg. 26, nr. 3, p. 14-17 
lijk verder gekeken worden dan louter de wetsgeschiedenis, en is een meer technische benadering op zijn plaats. Of een voorgenomen besluit instemmingsplichtig is, moet aan een aantal criteria worden afgemeten ${ }^{105}$ :

1. het moet gaan om een voorgenomen besluit, dat wil zeggen dat het om een concrete beslissing moet gaan;

2. het besluit betreft vaststelling/wijziging/intrekking van een regeling;

3. de regeling moet aanwijsbaar betrekking hebben op één of meer van de in het eerste lid van artikel 27 genoemde limitatieve opsomming, waaronder regelingen op het gebied van arbeidstijden en arbeidsomstandigheden;

4. de regeling moet gelden voor alle of voor een groep van de in de onderneming werkzame personen;

5. de regeling moet niet al inhoudelijk zijn geregeld in de voor de onderneming geldende $\mathrm{CAO}$ of in een door een publiekrechtelijk orgaan vastgestelde regeling van de arbeidsvoorwaarden (indien een bepaalde regeling in de CAO ruimte overlaat voor nadere invulling op bedrijfsniveau, is wat betreft die nadere invulling wél instemming vereist);

Als de drie belangrijkste twistpunten - risico-inventarisatie en -evaluatie, plan van aanpak, keuze arbodienst - langs deze maatlat worden gelegd, is de conclusie niet eenduidig. Afgezien van het laatste criterium, is de cruciale kwestie wat cen regeling is. ${ }^{106}$ Algemeen aanvaard is dat regelingen een besluit van algemene strekking zijn (d.w.z. betrekking moeten hebben op "alle in de onderneming werkzame personen of op een of meer groepen daarvan", criterium 4) ${ }^{107}$ én een permanent karakter hebben (waarbij het niet gaat om de tijdsduur als wel het gegeven dat de regeling voor herhaalde toepassing vatbaar is ${ }^{108}$ ).

In dit licht bezien lijkt in eerste instantie duidelijk dat de OR geen instemmingsrecht heeft (of zou moeten hebben) bij de risico-inventarisatie een -evaluatie. Een risico-inventarisatie, althans het schriftelijke stuk dat het resultaat is van het inventarisatie-proces, is simpelweg geen voorgenomen besluit. Het lijkt ook onzinnig dat de kantonrechter bij een eventueel geschil ter zake vervangende goedkeuring zou moeten hechten aan de risico-inventarisatie. Hier wreekt zich dat in de Arbowet 1998 geen mogelijkheid meer is opgenomen een verzoek tot wetstoepassing te richten tot de Arbeidsinspectie. Wat mijns inziens echter zeker wel instemmingsplichtig is, is de manier waarop de risico-inventarisatie wordt opgezet: wie voert de inventarisatie uit, welke methode wordt gehanteerd, welke criteria worden meegewogen in de risico-evaluatie, worden bepaalde afdelingen intensiever beoordeeld enzovoorts. De gekozen werkwijze is voor herhaalde toepassing vatbaar, en de uit-

\footnotetext{
105 Vgl. R.H. van het Kaar (red.), Ondernemingsraad, art. 27, aant. 1

106 Overigens verplicht artikel 11, lid 2, van de kaderrichtlijn 89/391/EEG tot overleg bij alle 'maatregelen die van wezenlijke invloed kunnen zijn op de veiligheid en de gezondheid' - maar overleg is nog geen instemmingsrecht. En in de WOR 1971 was nog gewoon sprake van 'maatregelen'. Onduidelijk is waarom in de latere redactie van artikel 27 deze omschrijving is vervangen door 'regeling'.

107 Kamerstukken II. 1975/76, 13 954, nr. 3, p. 23 en 44. Zie ook Vink 2002, p. 129

108 R.H. van het Kaar (red.), Ondernemingsraad, art. 27, aant. 3
} 
voering heeft consequenties voor alle werknemers (of een groep indien alleen een bepaalde afdeling wordt geïnventariseerd).

Bovendien makt ook het plan van aanpak onderdeel uit van de RI\&E (Arbowet art.5, lid 2). Wellicht kan langs deze slinkse omweg ook het schriftelijke stuk onder het instemmingsrecht worden gemanoeuvreerd. Of het plan van aanpak instemmingsplichtig is, is op zijn beurt echter ook weer te betwijfelen: is een plan wel een regeling? $\mathrm{Bij}$ nadere beschouwing lijkt mij dat deze vraag bevestigend kan worden beantwoord. Als het goed is, wordt in het plan van aanpak immers een aantal knopen doorgehakt: een verdeling van taken en verantwoordelijkheden, een concrete tijdsplanning, en niet te vergeten een budget. ${ }^{109}$ Het totale plan kan mijns inziens dus als een concrete beslissing worden gezien, die bovendien betrekking heeft op alle of een groep van werknemers. Dat het plan wellicht niet direct in zijn totaliteit wordt uitgevoerd, maar bijvoorbeeld over een langere tijdsspanne wordt uitgesmeerd, doet niet ter zake: de keuze om een niet-prioritair risico pas over een jaar aan te pakken, is op het moment van vaststelling van het plan een concrete beslissing.

Maar zelfs als het totale plan niet instemmingsplichtig zou zijn, dan nog kan de OR/pvt er strategisch mee omgaan door elk concreet punt uit het plan als instemmingsplichtig te beschouwen. Die strategie vindt tevens voeding in de wetsgeschiedenis van de WOR. In het voorstel voor de WOR 1990 werden ook heel comcrete matregeien aís de keuze van een bepaaid soort persoonfijke beschermingsmiddelen als instemmingsplichtig bestempeld. ${ }^{110}$ Concrete uitwerkingen van doelbepalingen in het toenmalige Veiligheidsbesluit werden eveneens als regeling aangemerkt - een interpretatie die van groot belang is met het oog op de nadere invulling van de doelbepalingen in het Arbobesluit. ${ }^{111}$

De keuze van de arbodienst, ten slotte, kan in weerwil van de uitspraak van het Hof in de SVB-zaak mijns inziens wél worden opgevat als een regeling op het gebied van arbeidsomstandigheden. Ten eerste is duidelijk dat het een concreet voorgenomen besluit betreft. Of dat besluit ook een regelingkarakter heeft, is een tweede. In ieder geval is het besluit voor herhaling vatbaar (bijvoorbeeld door beëindiging of verlenging van het contract). Daarnaast heeft de keuze van een arbodienst mijns inziens wel degelijk ook 'betrekking op' alle of een groep werknemers - weliswaar niet direct, maar de keuze voor een bepaalde arbodienst kan ook consequenties hebben voor de arbodienstverlening aan de werknemers. Sommige arbodiensten zijn beter thuis in een bepaalde branche, bijvoorbeeld, of hebben een relatie met een reïntegratiebedrijf of verzekeraar. Sommige arbodiensten staan een preventieve aanpak voor, terwijl andere zich profileren als verzuimjagers.

Bovendien geldt hier net als bij het plan van aanpak dat, zelfs al zou de keuze van of een contract met een arbodienst niet instemmingsplichtig zijn, de onderne-

109 De verdeling van taken en verantwoordelijkheden is verplicht op grond van artikel 3, lid 2. van de Arbowet 1998. Artikel 5, lid 2, van de Arbowet vereist dat het plan van aanpak aangeeft binnen welke termijn eventuele maatregelen worden genomen.

110 Kamerstukken II. 1987/88, 20583 , nr. 6, p. 26

111 Kamerstukken II, 1987/88, 20 583, nr. 9. p. 5 
mingsraad strategisch met zijn bevoegdheden kan omgaan. Het contract bevat immers zonder twijfel elementen die wél als afzonderlijke regeling opgevat kunnen worden, bijvoorbeeld de vorm van verzuimcontrole of - begeleiding, het aanbieden van een arbeidsomstandighedenspreekuur, of de uitvoering van periodieke arbeidsgezondheidskundige onderzoeken. Langs de omweg van deze concrete elementen in het contract kan de ondernemingsraad invloed uitoefenen op het totale contract én de keuze van de arbodienst.

\section{Conclusie}

Al met al kan uit deze lange uiteenzetting worden geconcludeerd dat het instemmingsrecht van de ondernemingsraad op het gebied van arbeidsomstandigheden inderdaad zeer ver strekt (voor personeelsvertegenwoordigingen is het instemmingsrecht, op grond van artikel $35 \mathrm{c}$, lid 3, WOR van overeenkomstige toepassing). In principe kan de ondernemer nimmer eenzijdig besluiten over arboregelingen nemen of zelfs maar maatregelen treffen op het gebied van arbeidsomstandigheden, ziekteverzuim of reïntegratie (art. 35d WOR). Hij moet het voorgenomen besluit schriftelijk vastleggen en minimaal één keer over het voornemen overleggen, waarna de ondernemingsraad een redelijke termijn moet krijgen om tot een oordeel te komen.

Passeert de ondernemer de ondernemingsraad of pvt wél, dan kan deze schriftelijk een beroep doen op de nietigheid (mits binnen een maand nadat hij kennis heeft genomen van het besluit of dat hem gebleken is dat de ondernemer inmiddels uitvoering geeft aan een instemmingsplichtig besluit). Bij een beroep op nietigheid kan de ondernemingsraad de kantonrechter verzoeken de ondernemer te verbieden uitvoering te geven aan het besluit (art. 27, lid 6, jo. art. 36, lid 7. WOR). Bij zijn oordeel zal de kantonrechter zeker rekening houden met de procedure als genoemd in artikel 27. lid 2, én de vooraankondigingsplicht als bedoeld in artikel 24, lid 1. en artikel $31 \mathrm{~b}$, lid 2, WOR. Van zijn kant kan de ondernemer bij de kantonrechter een beroep doen op vervangende toestemming (art. 27, lid 4, WOR) respectievelijk de kantonrechter verzoeken te verklaren dat de OR ten onrechte een beroep heeft gedaan op de nietigheid (art. 27, lid 6, WOR) ${ }^{112}$. De ondernemingsraad kan tegen de vervangende toestemming in beroep gaan bij de rechtbank (binnen twee maanden) en in cassatie bij de Hoge Raad. Omgekeerd kan de ondernemer in beroep gaan als de kantonrechter de vervangende toestemming niet geeft. Wanneer een zaak spoed vereist, kunnen beide partijen zich in kort geding tot de president van de rechtbank wenden met het verzoek een voorlopige voorziening te treffen (art. $289 \mathrm{Rv}$ ).

112. Een verzoek bij de kantonrechter op grond van artikel 27 , lid 4 of 6 , is niet ontvankelijk indien met betrekking tot dezelfde aangelegenheid een eis is gesteld als bedoeld in de Arbeidsomstandighedenwet (art. 36, lid 4, WOR). 


\subsubsection{Overeenstemmingsrecht}

Waar aan het instemmingsrecht nog een hele geschillenprocedure is gekoppeld waar ook de werkgever zijn toevlucht toe kan nemen, is de OR in de Arbowet 1998 een recht toebedeeld dat formeel nog zwaarder weegt dan het instemmingsrecht: het overeenstemmingsrecht op grond van artikel 17 Arbowet 1998. Artikel 17 Arbowet, het zogeheten 'maatwerk-artikel', stelt dat bedrijven van bepaalde middelvoorschriften in het Arbobesluit (en andere bij of krachtens de Arbowet vastgestelde bepalingen) mogen afwijken mits dit is vastgelegd in een $\mathrm{CAO}$, een ambtelijke rechtspositieregeling of $\mathrm{PBO}$-verordening, of een regeling waaromtrent de werkgever schriftelijk overeenstemming heeft bereikt met de ondernemingsraad of de personeelsvertegenwoordiging. Dit maatwerk-artikel is een uitvloeisel van een advies van de SER omtrent het creëren van grotere beleidsvrijheid op bedrijfsniveau. ${ }^{113}$ Bedrijven kunnen zo alternatieve methoden ontwikkelen om het vereiste beschermingsniveau te bereiken, zoals vastgelegd in de doelvoorschriften in het Arbobesluit.

Formeel is dit recht voor de OR buitengewoon sterk. Het overeenstemmingsrecht, dat mede is ontleend aan de Arbeidstijdenwet ${ }^{114}$, kent namelijk geen beroepsprocedure voor het geval de werkgever en OR/pvt niet tot overeenstemming komen. Het betreft hier dus een vetorecht voor het medezeggenschapsorgaan. ${ }^{115}$ Hoe sterk het overeenstemmingsrecht ook oogt, in de praktijk is de waarde ervan beperkt. Werkgever en OR kunnen namelijk niet naar believen afwijken van de doelvoorschriften in het Arbobesluit (of de Arboregeling of beleidsregels). Ten eerste mogen de afspraken tussen werkgever en OR in geen geval afbreuk doen aan het beschermingsniveau dat is neergelegd in het Arbobesluit. Belangrijker is, ten tweede, dat afwijken alleen is toegestaan indien hiervoor bij algemene maatregel van bestuur toestemming is verleend. Het aantal bepalingen dat hiervoor in aanmerking komt is evenwel minimaal. Zo'n 90 procent van de bepalingen in het Arbobesluit en de aanvullende regelgeving vloeit namelijk rechtstreeks voort uit 26 richtlijnen van de Europese Unie (en 4 ILO-verdragen) ${ }^{116}$, die bindend zijn voor de lidstaten (althans wat betreft het te bereiken resultaat). ${ }^{117}$ Weliswaar heeft de staatssecretaris van Sociale Zaken in 1998 aangegeven in Europees verband te streven naar meer speel-

113 SER (1997) Advies Heroriëntatic arbobeleid en Arbowet, Den Haag: Sociaal-Economische Raad (97/03), p. 35-37

114 Wet van 23 november 1995, houdende bepalingen inzake de arbeids- en rusttijden, Sth. 1995. 598

I15 Overigens geldt het vetorecht bij de Arbeidstijdenwet slechts de zogeheten 'standaandregeling', dat wil zeggen de meest strikte normen in de wet. Indien een voorgenomen besluit inzake de werktijden wél binnen de kaders van de standaardregeling valt, heeft de OR instemmingsrecht krachtens artikel 27, lid I onder b, van de WOR. Vgl. M. Volkers en M. Heesters (1996), Handboek arbeidstijden en medezeggenschap; gebruiksaanwijzing bij de Arbeidstijdenwet. Amsterdam: FNV, p. 35-37

116 Arbeidsomstandighedenbesluit, Nota van Toelichting, Stb. 1997, 60, p. 121-122. C.J. Vos en H.J. de Gier (1995), Europese en Nederlandse arboregelgeving. Utrecht: Lemma, p. 182-183

117 A.J.C.M. Geers en G.J.J. Heerma van Voss (1995), Inleiding Eumopees arbeidsrecht, Deventer: Kluwer, p. $20 \mathrm{ff}$ en p. 143ff 
ruimte ${ }^{118}$, maar de haalbaarheid van dit streven mag niet al te rooskleurig worden ingeschat. ${ }^{119}$ En omtrent de resterende 10 procent waar wel al speelruimte bestaat. heeft het ministerie van Sociale Zaken en Werkgelegenheid in 1999 aangegeven dat die regels over het algemeen zo nieuw zijn dat zij vooralsnog niet voor maatwerk zullen worden opengesteld. ${ }^{120}$ Medio 2003 was dit inderdaad ook nog nooit gebeurd.

Ondanks deze kritische opmerkingen is nog wel interessant op te merken dat, voor zover werkgevers in bedrijven met minder dan 50 werknemers (op termijn) gebruik willen maken van de mogelijkheid tot maatwerk, zij hierover moeten overleggen met een personeelsvertegenwoordiging - zelfs in bedrijven met minder dan 10 werknemers (art. 35d WOR). ${ }^{121}$ Dat betekent dat via deze omweg ook de (formele) medezeggenschap in kleine bedrijven gestimuleerd wordt - al moet ook hier niet al te veel van worden verwacht. ${ }^{122}$

\subsubsection{Adviesrecht}

Hoewel met het oog op veilige en gezonde arbeidsomstandigheden het instemmingsrecht de meest in het oog springende bevoegdheid van de OR is, is in de inleiding tot deze paragraaf al aangegeven dat het niet de enige en wellicht niet eens de belangrijkste bijzondere bevoegdheid van de OR is. Formeel is het instemmingsrecht zonder twijfel sterker, maar substantieel is het adviesrecht idealiter van minstens even grote potentie. Het adviesrecht betreft immers een aantal zwaarwegende thema's, die indirect nauw kunnen samenhangen met de arbeidsomstandigheden in een onderneming.

Het adviesrecht dateert uit de WOR 1971, en is in de opeenvolgende wijzigingen van de wet allengs uitgebreid. De ondernemer dient de OR advies te vragen over voorgenomen besluiten op een aantal limitatief opgesomde thema's, waarbij de ondernemer een overzicht moet verstrekken van:

- de beweegredenen voor het besluit;

- de gevolgen die het besluit naar het oordeel van de ondernemer voor de in de onderneming werkzame personen zal hebben;

- de maatregelen die worden getroffen om de eventuele negatieve gevolgen op te vangen.

118 Kamerstukken II 1997/98, 25879 , nr. 3, p. 5 en in het bijzonder 25879 nr. 47

119 Cf. H. Rottier (1998), Het poedeltje in de magnetron - enkele onderwerpen uit het wetsvoorstel Arbeidsomstandighedenwet 1998 kritisch beschouwd, in: Sociaal Recht, 1998-6, p. 173

120 Cf. Jan Popma (1999), Maatwerkartikel voorlopig lege huls, in: OR-Informatie, Jg. 24, nr. 4. p. $34-35$

121 Kamerstukken II, 1997/98, 25 879, nr. 3 (MvT), p. 19, Kamerstukken I, 1998/99, 25879. ne.71b (MvA), p. 4

122 Evaluatie van de Arbeidstijdenwet leert dat nauwelijks pvt'en zijn opgericht. Zie ook P.R.A. Oeij en P.A. Stoppelenburg (1998), Naleving van de Wet op de Ondermemingsraden: stand van zaken 1997. Den Haag: ministerie van Sociale Zaken en Werkgelegenheid, p. 48: 0,24\% van de 10-min bedrijven had in 1997 een personeelsvertegenwoordiging ingesteld 
In het kader van dit onderzoek zijn uiteraard vooral de gevolgen voor de veiligheid en de gezondheid van de werknemers van belang.

De thema's waarop het adviesrecht betrekking heeft zijn (met tussen haakjes het jaar waarop de thema's onder het adviesrecht zijn gebracht) ${ }^{123}$ :

a. overdracht van de zeggenschap over de onderneming of een onderdeel daarvan (1971):

b. het vestigen van, dan wel het overnemen of afstoten van de zeggenschap over, een andere onderneming, alsmede het aangaan van, het aanbrengen van een belangrijke wijziging in of het verbreken van duurzame samenwerking met een andere onderneming, waaronder begrepen het aangaan, in belangrijke mate wijzigen of verbreken van een belangrijke financiële deelneming vanwege of ten behoeve van een dergelijke onderneming (1971/1979);

c. beèindiging van de werkzaamheden van de onderneming of van een belangrijk onderdeel daarvan (1971);

d. belangrijke inkrimping, uitbreiding of andere wijziging van de werkzaamheden van de onderneming (1971):

e. belangrijke wijziging in de organisatie van de onderneming (1971), dan wel in de verdeling van bevoegdheden binnen de onderneming (1979):

f. wijziging van de plaats waar de onderneming haar werkzaamheden uitoefent (1971):

g. het groepsgewijze werven of inlenen van arbeidskrachten (1979);

h. het doen van een belangrijke investering ten behoeve van de onderneming (1979);

i. het aantrekken van een belangrijk krediet ten behoeve van de onderneming (1979);

j. het verstrekken van een belangrijk krediet en het stellen van zekerheid voor belangrijke schulden van een andere ondernemer, tenzij dit geschiedt in de normale uitoefening van werkzaamheden in de onderneming (1998);

k. invoering of wijziging van een belangrijke technologische voorziening (1998):

1. het treffen van een belangrijke maatregel in verband met de zorg van de onderneming voor het milieu, waaronder begrepen het treffen of wijzigen van een beleidsmatige, organisatorische en administratieve voorziening in verband met het milieu (1998):

$\mathrm{m}$. vaststelling van een regeling met betrekking tot het zelf dragen van het risico in het kader van de WAO/Pemba (1997) ${ }^{124}$ of de Ziektewet $(2003)^{125}$;

123 In de WOR 1971 viel een aantal onderwerpen die sinds 1979 instemmingsplichtig zijn ook nog onder het adviesrecht, waaronder beloningssystemen, beoordelingssystemen en het aanstellings- en ontslagbeleid.

124 Wet premiedifferentiatie en marktwerking bij arbeidsongeschiktheidsverzekeringen (Stb. 1997. 175) en Besluit van 2 september 1997 tot vaststelling van de data van de inwerkingtreding van de Wet premiedifferentiatie en marktwerking bij arbeidsongeschiktheidsverzekeringen (Stb. 1997, 391).

125 Wet van 14 november 2002 tot Wijzigingen van de Ziektewet en enkele andere wetten in verband met de invoering van eigenrisicodragen door de werkgever (Wet eigenrisicodragen Ziektewet, Stb. 2002. 584 en Stb. 2003. 72) 
n. het verstrekken en het formuleren van een adviesopdracht aan een deskundige buiten de onderneming betreffende een der hiervoor bedoelde aangelegenheden (1979/1998).

Personeelsvertegenwoordigingen hebben adviesrecht krachtens artikel $35 \mathrm{c}$, lid 3 . jo. $35 \mathrm{~b}$, lid 5 , WOR. Het adviesrecht beperkt zich echter tot voorgenomen besluiten die kunnen leiden tot "verlies van de arbeidsplaats of tot een belangrijke verandering van de arbeid, de arbeidsvoorwaarden of de arbeidsomstandigheden van ten minste een vierde van de in de onderneming werkzame personen."

Een aantal van de in artikel 25 genoemde onderwerpen, met name de meer strategische zaken zoals overnames en kredietstelling, zijn nauwelijks relevant voor de veiligheid en gezondheid van werknemers. Hooguit - zij het zeker niet onbelangrijk - is de continuilteit van het bedrijf in het geding ( 1 a, b, c, i, j).

$\mathrm{Bij}$ de andere thema's wegen de 'arbo'-gevolgen zwaarder, met name voorgenomen investeringen ( $1 \mathrm{~h}$ ) of technologische innovatie (1k). De beoordeling van dergelijke voorgenomen besluiten vereist dat de ondernemingsraad zicht heeft op de gevolgen voor de werknemers (art. 25, lid 3, WOR), waaronder de eventuele arbogevolgen. Dit impliceert mijns inziens dat het voorgenomen besluit altijd vergezeld dient te gaan van een gedegen risico-inventarisatie en -evaluatie, waarin prospectief een inschatting van de risico's wordt gemaakt én maatregelen worden gesuggereerd die getroffen kunnen worden om voorzienbare negatieve gevolgen onder controle te brengen. ${ }^{126}$ Zonder adequate RI\&E kan de OR in feite niet tot een behoorlijk advies komen.

Een zelfde redenering gaat op voor het adviesrecht met betrekking tot uitbreiding van de werkzaamheden (lid 1d) of wijzigingen binnen de organisatie dan wel de verdeling van bevoegdheden (lid le). Ook dergelijke besluiten dienen gepaard te gaan met een risico-inschatting. Wat betekent uitbreiding van de werkzaamheden bijvoorbeeld voor de werkdruk? Wat zijn de arborisico's van nieuwe productieprocessen? Heeft de reorganisatie gevolgen voor bijvoorbeeld het 'regelvermogen' van de werknemers en daarmee voor hun welzijn? Hoe is de functionele communicatie tussen de verschillende afdelingen geregeld? Leidt een verschuiving van de bevoegdheden tot zwaardere verantwoordelijkheden en daarmee tot extra psychische belasting)?

Ook verplaatsing van de onderneming (1f) heeft allerlei arbo-aspecten. Zo krijgen werknemers wellicht te maken krijgen met langere reistijden, hetgeen tot oververmoeidheid kan leiden of, als gevolg van een moeizamer combinatie arbeid/zorg of werk/privé, de psychische belasting kan vergroten. Voorts impliceert verplaatsing van de onderneming dat een nieuw of verbouwd bedrijfsgebouw wordt betrokken. Ver-/nieuwbouw is een belangrijk moment om arbo-eisen aan de werkplek te realiseren. Werkplekken en arbeidsmiddelen moeten, op grond van de Arbowet (artikel 3 , lid 1), voldoen aan de stand der wetenschap, en ten minste aan de normen in of

126 De verplichting een RI\&E op te stellen kan ook worden afgeleid van de bepaling in art. 5 . lid 3. Arbowet dat "de inventarisatie en evaluatie wordt aangepast zo dikwijls als [..] gewijzigde werkmethoden of werkomstandigheden [..] daartoe aanleiding geven." 
op grond van het Arbobesluit (in het bijzonder hoofdstuk 3 en 6 respectievelijk 7) en de Wet gevaarlijke werktuigen.

Ook het aangaan van duurzame samenwerking met een andere onderneming (lid Ib) of het groepsgewijze werven of inlenen van arbeidskrachten (lid Ig) kan vanuit arboperspectief worden beoordeeld. Bij samenwerking tussen bedrijven ontstaat licht onduidelijkheid over bijvoorbeeld de verdeling van verantwoordelijkheden of het toezicht op de veiligheid - reden waarom artikel 19 van de Arbowet voorschrijft dat de betrokken werkgevers hierover afspraken moeten maken. ${ }^{127} \mathrm{Het}$ inhuren van derde werknemers stelt eveneens bijzondere eisen, bijvoorbeeld aan de voorlichting en instructie van uitzendkrachten. ${ }^{128}$

\section{Analyse}

De ondernemingsraad heeft in het adviesrecht een tamelijk krachtig instrument om invloed uit te oefenen op of ten minste aandacht te vragen voor de arbogevolgen van voorgenomen besluiten. Op de vraag in welk stadium van het besluitvormingstraject sprake is van een 'voorgenomen besluit' wordt hier verder niet uitgebreid ingegaan. ${ }^{129}$ Van belang is wel dat het advies van de OR 'van wezenlijke invloed' (art. 25, lid 2) moet kunnen zijn. Het overleg moet dus in ieder geval plaatsvinden voor het besluit daadwerkelijk is genomen. ${ }^{130}$ Zo wordt ook voorkomen dat de risico-inventarisatie en -evaluatie zich richt op reeds ontstane risico's: de RI\&E moet al in de ontwerpfase van nieuwbouw of een nieuwe productie-organisatie worden uitgevoerd, en niet een knelpunteninventarisatie zijn nadat het gebouw is neergezet of de nieuwe productie-organisatie is ingevoerd.

Daarnaast is van belang dat het tijdstip waarop de OR wordt ingeschakeld mee kan wegen bij een eventuele beroepsprocedure tegen het definitieve besluit. Als de OR namelijk onvoldoende gelegenheid heeft gehad te adviseren of als hij geheel gepasseerd is, kan hij beroep aantekenen bij de Ondernemingskamer van het Gerechtshof te Amsterdam (art. 26 WOR). De Ondernemingskamer zal het beroep primair toetsen op de procedurele kant van de zaak. Indien de bestuurder zijn mededelingsplicht op grond van artikel 24 WOR heeft verzaakt of anderszins de OR te laat heeft ingeschakeld, zal de Ondernemingskamer al snel concluderen dat de ondernemer het genomen besluit dient in te trekken of hem verbieden het besluit uit te voeren (art. 26. lid 5, WOR). Ook het ontbreken van informatie omtrent de gevolgen en maatregelen van een voorgenomen besluit (bijvoorbeeld de afwezigheid van een

127 Bijzondere bepalingen hieromtrent gelden voor de bouw, in casu hoofdstuk $\mathrm{II}$, afdeling 5. van het Arbobesluit (dat de regels uit het oude Bouwprocesbesluit bevat).

128 Uitzendkrachten lopen meer kans op een bedrijfsongeval dan werknemers in vaste dienst. H. Leertouwer, P.J.M. Martens en H.F.H. Lommers (2002), Meldingsplichtige en dodelijke arbeidsongevallen: Ciifers over het jaar 2001, Den Haag: Arbeidsinspectie, p. II

129 Zie uitgebreid R.H. van het Kaar (red.), Ondernemingsraad, art. 25, aantekening 6

130 Artikel 11, lid 2, van Kaderrichtlijn $89 / 391$ stelt dat de werknemersvertegenwoordigers vooraf tijdig geraadpleegd moeten worden over onder meer alle maatregelen die van wezenlijke invloed kunnen zijn op de veiligheid en de gezondheid. Van belang zijn hier de termen 'vooraf' en 'tijdig', al wordt in de Kaderrichtlijn niet duidelijk aangegeven wat 'tijdig' is. 
op grond van het Arbobesluit (in het bijzonder hoofdstuk 3 en 6 respectievelijk 7) en de Wet gevaarlijke werktuigen.

Ook het aangaan van duurzame samenwerking met een andere onderneming (lid 1b) of het groepsgewijze werven of inlenen van arbeidskrachten (lid lg) kan vanuit arboperspectief worden beoordeeld. Bij samenwerking tussen bedrijven ontstaat licht onduidelijkheid over bijvoorbeeld de verdeling van verantwoordelijkheden of het toezicht op de veiligheid - reden waarom artikel 19 van de Arbowet voorschrijft dat de betrokken werkgevers hierover afspraken moeten maken. ${ }^{127}$ Het inhuren van derde werknemers stelt eveneens bijzondere eisen, bijvoorbeeld aan de voorlichting en instructie van uitzendkrachten. ${ }^{128}$

\section{Analyse}

De ondernemingsraad heeft in het adviesrecht een tamelijk krachtig instrument om invloed uit te oefenen op of ten minste aandacht te vragen voor de arbogevolgen van voorgenomen besluiten. Op de vraag in welk stadium van het besluitvormingstraject sprake is van een 'voorgenomen besluit' wordt hier verder niet uitgebreid ingegaan. ${ }^{129}$ Van belang is wel dat het advies van de OR 'van wezenlijke invloed' (art. 25, lid 2) moet kunnen zijn. Het overleg moet dus in ieder geval plaatsvinden voor het besluit daadwerkelijk is genomen. ${ }^{130}$ Zo wordt ook voorkomen dat de risico-inventarisatie en -evaluatie zich richt op reeds ontstane risico's: de RI\&E moet al in de ontwerpfase van nieuwbouw of een nieuwe productie-organisatie worden uitgevoerd, en niet een knelpunteninventarisatie zijn nadat het gebouw is neergezet of de nieuwe productie-organisatie is ingevoerd.

Daarnaast is van belang dat het tijdstip waarop de OR wordt ingeschakeld mee kan wegen bij een eventuele beroepsprocedure tegen het definitieve besluit. Als de OR namelijk onvoldoende gelegenheid heeft gehad te adviseren of als hij geheel gepasseerd is, kan hij beroep aantekenen bij de Ondernemingskamer van het Gerechtshof te Amsterdam (art. 26 WOR). De Ondernemingskamer zal het beroep primair toetsen op de procedurele kant van de zaak. Indien de bestuurder zijn mededelingsplicht op grond van artikel 24 WOR heeft verzaakt of anderszins de OR te laat heeft ingeschakeld, zal de Ondernemingskamer al snel concluderen dat de ondernemer het genomen besluit dient in te trekken of hem verbieden het besluit uit te voeren (art. 26, lid 5, WOR). Ook het ontbreken van informatie omtrent de gevolgen en maatregelen van een voorgenomen besluit (bijvoorbeeld de afwezigheid van een

127 Bijzondere bepalingen hieromtrent gelden voor de bouw, in casu hoofdstuk II. afdeling 5. van het Arbobesluit (dat de regels uit het oude Bouwprocesbesluit bevat),

128 Uitzendkrachten lopen meer kans op een bedrijfsongeval dan werknemers in vaste dienst. H. Leertouwer. P.J.M. Martens en H.F.H. Lommers (2002), Meldingsplichtige en dodelijke arbeidsongevallen: Cijfers over het jaar 2001, Den Haag: Arbeidsinspectic, p. 11

129 Zie uitgebreid R.H. van het Kaar (red.). Ondernemingsraad, art. 25, aantekening 6

130 Artikel 11. lid 2, van Kaderrichtlijn 89/391 stelt dat de werknemersvertegenwoordigers vooraf tijdig geraadpleegd moeten worden over onder meer alle maatregelen die van wezenlijke invloed kunnen zijn op de veiligheid en de gezondheid. Van belang zijn hier de termen 'vooraf' en 'tijdig', al wordt in de Kaderrichtlijn niet duidelijk aangegeven wat 'tijdig' is. 
werknemers al dan niet georganiseerd in een dienst" (artikel 14, lid 1, Arbowet). ${ }^{132}$ In de praktijk betekent dit dat de werkgever een arbodienst moet inschakelen soms een interne arbodienst, maar zeker voor de kleinere bedrijven meestal een externe. Juist dit laatste punt was voor de Europese Commissie mede aanleiding om te stellen dat het Nederlandse systeem van arbodienstverlening niet in overeenstemming was met de Kaderrichtlijn 89/391 (vgl. par. 2.5). Op het moment van afsluiting van deze studie had het Europees Hof nog geen uitspraak gedaan over het geschil, reden waarom hieronder de situatie medio 2003 wordt beschreven.

De taken van de arbodienst zijn, blijkens lid 3 van artikel 14, met name:

a. het verlenen van medewerking aan het verrichten en opstellen van een risicoinventarisatie en -evaluatie waaronder het toetsen ervan en adviseren daaromtrent:

b. verzuimbegeleiding;

c. de uitvoering van arbeidsgezondheidskundig onderzoek en de uitvoering van aanstellingskeuringen (indien de werkgever deze laat verrichten);

d. het houden van een arbospreekuur.

De arbodienst heeft, op grond van lid 3 sub $\mathrm{f}$, voorts als taak "het adviseren aan onderscheidenlijk nauw samenwerken met de ondernemingsraad of de personeelsvertegenwoordiging [..] inzake de genomen en de te nemen maatregelen, gericht op het arbeidsomstandighedenbeleid". 133 Hoe die samenwerking eruit moet zien, is niet expliciet omschreven in de wet. Ook in hoofdstuk 2 van de Arboregeling, waar de taken van de arbodienst nader zijn gespecificeerd, is niets te vinden over de ondersteuning van de ondernemingsraad. Het Arbobesluit laat zich evenmin uit over de relatie arbodienst/OR. Hoe deze relatie in strikte zin er dient uit te zien, is wél opgenomen in de Regeling Certificatie Arbodiensten die de basis vormt voor de certificering van arbodiensten. ${ }^{134}$

De Regeling zelf bevat overigens ook weinig specifieke voorschriften, maar veeleer een aantal aandachtspunten. Zo valt uit paragraaf 2.3 .2 van de Regeling, over de relatie met de opdrachtgever, op te maken dat de arbodienst periodiek moet overleggen met de ondernemingsraad - hoe vaak dat overleg moet plaatsvinden blijft echter ongewis. In paragraaf 2.3 .1 staat dat in het contract afspraken moeten worden gemaakt "inzake de communicatie met de werknemersvertegenwoordiging".

132 Deze verplichting is voor hoog-risicobedrijven in werking getreden op 1 januari 1996, voor de overige bedrijven op 1 januari 1998.

133 Overigens kende de Arbowet 1980 voor sommige bedrijven, met name de bedrijven met meer dan 500 werknemers, ook al de verplichting om zich aan te sluiten bij een bedrijfsgezondheidsdienst, cen veiligheidsdienst of een gecombineerde arbodienst (artt. 18, 19 resp. 17). In alle gevallen diende de dienst samen te werken met de ondernemingsraad (art. 17, lid 4, art. 18, lid 3 . art. 19. lid 3). De eerste wettelijke regeling van de bedrijfsgezondheidsdienst dateert zelfs al van 1959 (Stb. 56) en het Besluit verplichtstelling bedrijfsgezondheidsdiensten (Kb 13/11/1974, Stb. 740). Zie uitgebreider: Geers 1988, p. 202-224

134 M.M.W. Wilders (red.) (2003), Het compleet arbo-regelgevingboek, Amsterdam/Zeist: FNV/Kerckebosch, p. $905-946$ 
maar de richtlijn schrijft niet expliciet voor hoe die communicatie eruit zou moeten zien.

Een beperkt aantal inhoudelijke eisen is wel te vinden in paragraaf 2.7 van de Regeling. Daarin is voorgeschreven dat de arbodienst de OR de volgende informatie moet doen toekomen:

- een exemplaar van risico-inventarisaties en het advies van de arbodienst daarover, rechtstreeks aan de ondernemingsraad toe te sturen (par. 2.7.1);

- verzuimgegevens boven het individuele niveau (par. 2.7.2);

- rapportage over het arbospreekuur (onder waarborging van de privacy van individuele werknemers (par. 2.7.3):

- gegevens uit het periodiek arbeidsgezondheidskundig onderzoek (op functie- en afdelingsniveau, onder waarborging van de privacy van individuele werknemers (par. 2.7.4).

Voorts is, zoals al aangegeven in paragraaf 3.2.2, in de behandeling van de Arbowet 1998 vast komen te staan dat adviezen van de arbodienst aan de werkgever tegelijkertijd rechtstreeks naar de OR dienen te worden opgestuurd. ${ }^{135}$

Naast deze inhoudelijke bepalingen valt uit de Regeling nog een aantal procedurele aandachtspunten te destilleren:

- betrokkenheid van de OR bij de beoordeling van de RI\&E (par. 2.7.1);

- advisering aan de OR omtrent de implementatie van maatregelen (par. 2.7.1);

- advisering aan de werkgever en de OR over de opzet, het doel en de inhoud van eventuele aanstellingkeuringen (par. 2.7.6);

- jaarlijkse rapportage over de eigen dienstverlening aan de opdrachtgever én het medezeggenschapsorgaan (par. 2.10.2).

Van belang is tevens de al eerder gememoreerde verplichting dat de arbodienst, alvorens het contract met een onderneming te tekenen, bij de ondernemingsraad dient na te gaan of deze met de uitvoering van het contract instemt (par. 2.3.1 Regeling Certificering Arbodiensten). ${ }^{136}$

Het onvoldoende naleven van de bovengenoemde voorschriften kan door de certificerende instelling worden opgevat als een tekortkoming ('minor non conformity note'). Het volledig ontbreken van een eis uit de Richtlijn is een 'major NCN', Al deze non confomity notes moeten binnen drie maanden zijn opgelost. Zo niet, dan krijgt de arbodienst geen certificaat of wordt een certificaat ingetrokken. Het nietnaleven kan blijken tijdens het certificeringsproces door de certificerende instelling

135 Kamerstukken I, 1998/99, 25879, nr.71a, p. 6

136 Brief van 9 juli 1998 over actiepunten naar aanleiding van bevindingen van de FNV-meldlijn klachten arbodiensten, Kamerstukken II, 1997/98. 25 883, nr. 6. p. 2 
zelf, maar ook uit klachten (bijvoorbeeld van ondernemingsraden) die zijn opgetekend in het klachtenregister van de Geschillencommissie Arbodiensten. ${ }^{137}$

De hierboven beschreven elementen uit de Regeling Certificering Arbodiensten hebben mede tot doel de "onafhankelijkheid ten opzichte van de werkgever" (art. 14, lid 2, Arbowet) te waarborgen. In de praktijk blijkt dat, ondanks de tamelijk gedetailleerde richtlijnen, nogal wat ondernemingsraden klagen over onder meer de slechte communicatie van de arbodienst richting OR en het gebrek aan onafhankelijkheid. ${ }^{138}$ Deze klachten dateren al van het begin van de verplichte ondersteuning door arbodiensten. Om verbetering te brengen in het functioneren van de arbodienst hebben de gezamenlijke vakbonden in 1997 een protocol Arbodiensten en werknemers opgesteld. ${ }^{139}$ Hierin zijn afspraken opgenomen over onder meer het overleg tussen OR en arbodienst, informatie-uitwisseling, de betrokkenheid van werknemers bij de risico-inventarisatie, en algemene procedurele aspecten. ${ }^{140}$

Een aantal arbodiensten heeft zelf een (aangepaste versie van het) protocol opgesteld. Voor geen van die diensten is het protocol echter een verplicht onderdeel van het contract met de opdrachtgever. Ook in de strategienota Arboconvenanten en werknemersvertegenwoordigingen die in 2000 is opgesteld in opdracht van het ministerie van Sociale Zaken en Werkgelegenheid is een aantal elementen uit het protocol opgenomen.

Al met al is de relatie tussen arbodienst en ondernemingsraad zeer uitgebreid gereglementeerd - overwegend middels privaatrechtelijke afspraken (certificeringsrichtlijn), zij het dat die wel een publiekrechtelijke basis hebben (in casu art. 20 Arbowet). Dat die uitgebreide regulering geen waarborg is voor een optimale relatie tussen OR en arbodienst is hierboven al aangegeven. Een meer gedetailleerde analyse van de feitelijke relatie is opgenomen in paragraaf 4.1.4.

\subsection{OR en Arbeidsinspectie}

De regelgeving op het gebied van arbeidsomstandigheden legt de verantwoordelijkheid voor veilige en gezonde arbeidsomstandigheden primair in het private

137 De geschillencommissie arbodiensten is ingesteld door de Branche-Organisatie Arbodiensten, op basis van een reglement dat op 1 september 1998 in werking is getreden. Werknemers of ondernemingsraden die een klacht hebben over 'hun' arbodienst en daar geen gehoor voor vinden bij die dienst zelf (elke arbodienst heeft een klachtenregeling), kunnen hun klacht voorleggen aan de geschillencommissie. Klachten die niet eerst zijn ingediend bij de arbodienst worden nietontvankelijk verklaard. Overigens hebben die klachten in de praktijk vrijwel uitsluitend betrekking op de bejegening van individuele werknemers.

138 Ook medewerkers van de arbodiensten zelf klagen overigens dat hun onafhankelijkheid onder druk staat. J.H.B.M. Willems, Privatisering van de Ziektewet, in: Medisch Contact, jg. 53. nr.13. 1998, pp. 423ff

139 Protocol Arbodiensten en werknemers, FNV, CNV, MHP en AVC, Amsterdam, mei 1997

140 Uitgebreider: 'Aandachtspunten en aanvullende standaardvoorwaarden voor het contract met de arbodienst', in: R. van Steenbergen (2000). OR en de relatie met de arbodienst, Alphen a/d Rijn: Samsom/FNV Formaat, p. 139-155 
domein, al moet de werkgever uiteraard wel voldoen aan de publiekrechtelijke regels op grond van de Arbowet. In laatste instantie behoudt de overheid dus wel degelijk een toezichthoudende verantwoordelijkheid. De handhavingstaak op het gebied van de arbowetgeving is primair toegewezen aan de Arbeidsinspectie. ${ }^{141}$ Jaarlijks voert de Arbeidsinspectie zo'n 20.000 arbo-inspecties uit: drie kwart hiervan in het kader van het eigen inspectieprogramma (de zogeheten actieve arbozaken), de overige naar aanleiding van ongevallen of klachten (reactieve interventies), ${ }^{142}$

De formele relatie tussen de Arbeidsinspectie en de OR/pvt is vastgelegd in de Arbowet. Zeker bij de reguliere bedrijfsbezoeken in het kader van het inspectieprogramma zal de inspecteur veelal zijn komst vooraf aankondigen bij bedrijfsleiding én OR. Tijdens het bezoek hebben de leden van de ondernemingsraad of de pvt op grond van artikel 12. lid 3, van de Arbowet een aantal rechten, te weten:

- het recht de inspecteur tijdens diens bezoek aan het bedrijf of de inrichting te vergezellen, behalve wanneer deze te kennen geeft daar bezwaar tegen te hebben:

- de mogelijkheid om onder vier ogen met de inspecteur te spreken.

De werknemersvertegenwoordiging heeft tevens recht op de volgende informatie van de Arbeidsinspectie:

- alle rapporten van de Arbeidsinspectie (art. 24, lid 5);

- eventuele schriftelijke eisen van de Arbeidsinspectie (art. 27, lid 6);

- een eventueel bevel tot stillegging (art. 28, lid 6).

Het contact tussen OR/pvt en Arbeidsinspectie kan ook door de medezeggenschappers zélf worden geïnitieerd. Tot de Arbowet 1998 stonden hiertoe twee wegen open. De eerste was dat de ondernemingsraad de Arbeidsinspectie kon verzoeken een onderzoek in te stellen. Dit recht is overeind gebleven in de Arbowet 1998 (artikel 24, lid 7). Het recht om een onderzoek te vragen komt ook toe aan de vakbond. De Arbeidsinspectie is gehouden 'zo spoedig mogelijk' gehoor te geven aan het verzoek. ${ }^{143}$ De tweede mogelijkheid was het zogeheten verzoek tot wetstoepassing. Indien tussen de werkgever en de werknemers een verschil van mening bestond omtrent de naleving van een wettelijke verplichting, dan konden zowel de werkgever als de OR de inspecteur verzoeken een onafhankelijk oordeel te geven over de omstreden kwestie. In de Arbowet 1998 is deze mogelijkheid echter verdwenen. Of

141 In sommige gevallen, zeker bij specifieke strafbare feiten. werkt de Arbeidsinspectie ook samen met het Openbaar Ministerie en de politie.

142 Arbeidsinspectie (2002), Jaarverslag 2001, p. $18 \mathrm{ff}$

143 Ook op basis van een aantal andere wetten kan de ondernemingsraad overigens de Arbeidsinspectie inschakelen. Een voorbeeld is art. 9 van de Wet (Re)integratie arbeidsgehandicapten, die het mogelijk maakt dat de OR de Arbeidsinspectie inschakeit indien de werkgever weigert noodzakelijke voorzieningen voor gehandicapte werknemers te treffen. Vink 2002, p. 275 
met het verzoek om wetstoepassing veel verloren is gegaan, valt te betwijfelen. ${ }^{144}$ De motivatie om het verzoek tot wetstoepassing te schrappen was dat de ondernemingsraad ook het recht had (en heeft) om een klacht in te dienen bij de Arbeidsinspectie. ${ }^{145}$ De basis voor dit klachtrecht is artikel 5 van de Grondwet: "leder heeft het recht verzoeken schriftelijk bij het bevoegd gezag in te dienen." Dat impliceert uiteraard dat ook individuele medezeggenschappers een klacht kunnen indienen. De (geautomatiseerde) centrale registratie door de Arbeidsinspectie van het aantal klachten wordt door de inspectie zelf pas sinds 1997 betrouwbaar geacht. In 1997 registreerde de Arbeidsinspectie 3852 klachten, in 1998 was het aantal klachten 2882. In 1999 werden 2070 zaken gestart naar aanleiding van een klacht. in 2001 was dat aantal 2008. ${ }^{146} \mathrm{Het}$ aantal klachten dat door een medezeggenschapsorgaan is ingediend is echter zeer beperkt: in minder dan één procent van de gevallen is duidelijk dat de klacht is ingediend door een OR-lid (vgl. par. 4.1.5).

De Arbowet zélf bevat geen expliciete bepaling waaruit blijkt dat werknemers een klacht kunnen indienen. Dit recht blijkt impliciet wel uit artikel 26, dat inspecteurs verplicht tot geheimhouding "van de namen der personen door wie een klacht is ingediend of aangifte is gedaan van een overtreding van het bij of krachtens deze wet bepaalde, behoudens wanneer deze personen schriftelijk hebben verklaard tegen de mededeling van hun namen geen bedenkingen te hebben". Werknemers kunnen, schriftelijk of telefonisch, een klacht indienen wanneer zij vermoeden dat hun bedrijf of instelling de wettelijke voorschriften op het gebied van arbeidsomstandigheden niet naleeft. Ook kan eenieder aangifte doen van een overtreding van de Arbowet. De Arbeidsinspectie onderzoekt in beginsel elke klacht die tot haar werkterrein behoort, tenzij de klager aangeeft daar geen prijs op te stellen of de inspectie zelf de klacht ongegrond acht. ${ }^{147}$ In het laatste geval moet de inspectie dit motiveren. Indien de klager niet tevreden is met de afhandeling van de klacht, kan hij een procedure starten op grond van de Algemene Wet Bestuursrecht.

Bij een onderzoek is de anonimiteit van de klager in principe gewaarborgd (art. 26

144 Het verzoek om wetstoepassing is in de praktijk slechts zelden gebruikt. Van Drongelen somt de gegevens op over de periode 1983-1985. In 1983 werd twee maal een verzoek tot wetstoepassing ingediend bij het districtshoofd, waarvan één maal door een ondernemingsraad. Het betrof hier een geschil over de daglichtbepaling, onvoldoende afzuiging, en gebrek aan wasgelegenheid, waarover de directie niet wenste te spreken met de medezeggenschappers in zijn bedrijf. In 1984 is éen maal een verzoek ingediend, en in 1985 in het geheel niet, J. van Drongelen (1991). De ontwikkeling van de Arbeidsinspectie in een veranderende wetgeving, proefschrift Universiteit Maastricht. p. 433, Over de periode na 1985 zijn geen gegevens beschikbaar. Blijkens telefonische informatie van het ministerie van Sociale Zaken en Werkgelegenheid ter zake, is het jaarlijks aantal verzoeken op de vingers van één hand te tellen. De verzoeken worden echter niet geregistreerd. laat staan uitgesplitst naar de indiener van het verzoek.

145 Kamerstukken II, 1998/99, 25 879, nr.3 (MvT), p. 27

146 Jaarverslagen 1998, 1999 en 2001, Den Haag: Arbeidsinspectie. In ongeveer twee op de drie gevallen zet de Arbeidsinspectie een handhavingsinstrument in, in ongeveer $20 \%$ een boete of proces-verbaal.

147 De Grondwet kent overigens geen verplichting verzoeken te behandelen of te beantwoorden. Een voorstel voor een Grondwetsherziening ter zake werd begin 1998 verworpen. Handelingen Tweede Kamer, 1997/98, nr. 16, p. 3384 
Arbowet, art. 2:5 Awb). De Arbeidsinspectie maakt niet bekend aan de werkgever dat het onderzoek plaatsvindt naar aanleiding van een klacht. Desondanks is deze gang van zaken niet volledig waterdicht. In het geval dat de werkgever wél achter de identiteit van de klager komt, is diens rechtspositie ook tamelijk zwak. Dat geldt eveneens voor OR-leden, terwijl die op grond van artikel 21 WOR extra rechtsbescherming genieten. Een geruchtmakend voorbeeld speelde in 1999. Een werknemer van het beveiligingsbedrijf Security Monitoring Centre uit Tiel, tevens kandidaat OR-lid, had via de bestuurder van zijn vakbond de Arbeidsinspectie op de hoogte gesteld van de in zijn ogen onacceptabele werktijden bij SMC. Het kandidaat-OR-lid had zijn klacht geboekstaafd met een gedetailleerde beschrijving van de bewakingsrondes die door de medewerkers verricht moesten worden. De werkgever, geconfronteerd met de melding, vroeg ontbinding van de arbeidsovereenkomst van de werknemer, omdat de gegevens geheim waren en hij verstrekking daarvan aan derden een 'gewichtige reden' achtte voor ontbinding. ${ }^{148}$

Hoewel de kantonrechter in zijn overwegingen meewoog dat de werknemer aanspraak mocht maken op rechtsbescherming ex artikel 21 WOR (sterker nog, ervan uit ging dat hij al lid was van de ondernemingsraad op het moment dat de brief aan de Arbeidsinspectie werd verzonden), wees de kantonrechter het ontbindingsverzoek toe op de subsidiaire grond van gewijzigde omstandigheden. Volgens de kantonrechter had de werknemer de kwestie eerst in de ondernemingsraad aan de orde moeten stellen en vervolgens op reguliere wijze met de bestuurder moeten bespreken. Door de gevolgde werkwijze had hij echter het vertrouwen van de werkgever geschonden, aldus de kantonrechter. Het kwam de kantonrechter aannemelijk voor dat het ontbindingsverzoek níet met het OR-lidmaatschap van doen had.

'Onbegrijpelijk', zo oordeelden juristen over de uitspraak van het kantongerecht. ${ }^{149}$ Verhulp bepleitte een wettelijke regeling, waarbij de geheimhoudingsplicht die op de werknemer rust moet vervallen indien het belang dat is gemoeid met de bekendmaking groter is dan het belang dat de werkgever heeft bij de geheimhouding daarvan. ${ }^{150}$ In de casus SMC zou het belang van de bescherming van de gezondheid van de werknemers dan afgewogen moeten worden tegen het belang dat de werkgever heeft bij het ontduiken van de Arbeidstijdenwet. In het algemeen kan hieromtrent mijns inziens de stelling betrokken worden dat het werkgeversbelang bij een ongebreidelde bedrijfsvoering nímmer zo zwaar mag wegen dat dit ten koste gaat van de gezondheid van werknemers; 'klokkenluiden' omtrent ongezonde arbeidsomstandigheden zou dan ook in principe nooit tot ontslag mogen leiden (en zeker niet zonder ontbindingsvergoeding). In juli 2003 heeft het GroenLinks Kamerlid hiertoe een initiatiefwetsontwerp ingediend bij de Tweede Kamer.

148 Ktgr. Tiel, 10 februari 1999 (JAR 1999/223).

149 L.C.J. Sprengers en R. van de Water, De klok 'luidt' twaalf uur, in: Sociaal Recht, jg. 15 (2000), nr.2, p. 33 Guus Heerma van Voss (2000), Geheimhouding en Arbeidsinspectie, in: $O R$ Informatie, jg. 26, nr. 1, p. 13. Ad Geers (2000), Klagen, in: OR-Informatie jg. 26, nr. 4. p. 9

150 E. Verhulp (2000), Klokkenluider vaak vogelvrij, in: OR-Informatie jg. 26, nr. 4, p. 25 Eerder: Verhulp 1996, p. 352ff. Ook de FNV bepleitte een wettelijke regeling voor werknemers in de nota 'Onder geen beding', maart 1999. 
Ondanks deze laatste bedenkingen zou de ondernemingsraad er baat bij kunnen hebben de Arbeidsinspectie vaker te benaderen als strategische partner om onwillige werkgevers aan te sporen tot een actiever arbeidsomstandighedenbeleid. In paragraaf 4.1.5 zal nader worden onderzocht hoe de relatie Arbeidsinspectie/ondernemingsraad in de praktijk gestalte krijgt.

\subsection{Samenvatting}

De wetgeving op het gebied van arbeidsomstandigheden legt de verantwoordelijkheid voor een veilige en gezonde werkplek primair bij de werkgever. Deze moet een effectief arbeidsomstandighedenbeleid voeren. Hierbij moet hij echter samenwerken met de werknemers in zijn onderneming, in het bijzonder met de ondernemingsraad dan wel de personeelsvertegenwoordiging. In dit hoofdstuk is aangegeven hoe de medezeggenschap van werknemers ter zake geregeld is. Daarbij lag het accent sterk op de formele regeling, in het bijzonder de rechten en bevoegdheden van de OR/pvt en zijn leden. Uiteraard hebben medezeggenschappers ook niet-formele (machts)middelen tot hun beschikking, zoals spontane actie, werkonderbrekingen (anders dan werkonderbreking in geval van acuut dreigend gevaar, zoals is geregeld in artikel 29 Arbowet), het zoeken van publiciteit, contact met de Raad van Commissarissen enzovoort. ${ }^{151}$ Ten dele zullen deze middelen nog worden besproken in paragraaf 4.2. Hier echter gaat het in eerste instantie om een beoordeling van het wettelijk kader, omdat de heroriëntatienota hier ook sterk het accent op legt.

Uit de ontwikkeling van de regelgeving op het gebied van medezeggenschap rond het arbeidsomstandighedenbeleid komt een duidelijke lijn naar voren: in de loop der jaren, vooral sinds de WOR 1979, zijn de rechten en bevoegdheden van medezeggenschappers allengs versterkt (voor een overzicht zie tabel 3.1). De OR is een steeds meer geaccepteerde gesprekspartner, en in de WOR 1998 is op arbogebied de nieuwe medezeggenschapsfiguur van de personeelsvertegenwoordiging in het leven geroepen. Hiermee is de formele vertegenwoordiging van de werknemers rond het thema veiligheid, gezondheid en welzijn bij de arbeid stevig verankerd. De medezeggenschappers hebben in de loop der jaren ook meer faciliteiten gekregen: tijd voor onderling beraad en recht op scholing zijn de belangrijkste faciliteiten.

De bevoegdheden van de OR (en in mindere mate de pvt) zijn eveneens steeds verder uitgebreid. In de loop der jaren zijn steeds meer onderwerpen, zij het niet zonder slag of stoot. onder het advies- of instemmingsrecht van de OR gebracht, en is een aantal onderwerpen getransfereerd van het advies- naar het instemmingsrecht. Met name de reikwijdte van het instemmingsrecht, op het gebied van arbeidsomstandigheden de centrale formele bevoegdheid van de $\mathrm{OR} / \mathrm{pvt}$, is lange tijd inzet geweest van tamelijk vinnige debatten. Uiteindelijk echter is meer duidelijkheid

151 Vgl. A.Teulings (1981), Ondernemingsraadpolitiek in Nederland: Een onderzoek naar de omgang met macht en conflict door de ondernemingsraad, Amsterdam: Van Gennep, p. 66-68 en 117. Minder systematisch R.H. van het Kaar en J.C. Looise (red.) (1999), De volwassen OR: Groei en grenzen van de Nederlandse ondermemingsraad, Alphen a/d Rijn: Samsom. 1999, p. 265 en met name $269 / 273$ 
ontstaan: mijns inziens zijn in feite alle regelingen op het gebied van veiligheid en gezondheid instemmingsplichtig, waarbij ook specifieke veiligheidsmaatregelen als 'regeling' opgevat kunnen worden.

Daarmee is niet gezegd dat de feitelijke gang van zaken zich conformeert aan de steeds fleuriger formele werkelijkheid. De weerbarstigheden in de relatie OR/arbodienst zijn een belangrijke waarschuwing dat, zelfs wanneer de positie van werknemersvertegenwoordigers grondig is verankerd in een hecht netwerk van procedures en andere formele regels, zij niet altijd de rol kunnen spelen die hen op papier is toebedacht. Hoe de medezeggenschap er in de praktijk uitziet, is onderwerp van het volgende hoofdstuk. 
Tabel 3.1 Bevoegdheden en faciliteiten van de OR

\begin{tabular}{|c|c|c|c|c|}
\hline & WOR & Arbowet & Arbobesluit & $\begin{array}{l}\text { Certificerings- } \\
\text { regeling }\end{array}$ \\
\hline Overlegrecht & $\begin{array}{l}\text { 23, lid } 1 \text { en } 2: \\
\text { agenderen op } \\
\text { vergadering } \\
24, \text { lid 1: } \\
\text { bespreking } \\
\text { algemene gang } \\
\text { van zaken } \\
24, \text { lid 1: advies- } \\
\text { of insternmings- } \\
\text { plichtige besluiten } \\
\text { van te voren } \\
\text { aankondigen }\end{array}$ & $\begin{array}{l}\text { 12, lid 1: } \\
\text { samenwerking } \\
\text { tussen werkgever } \\
\text { en werknemers } \\
\text { 5, lid 3: overleg } \\
\text { over jaarlijkse } \\
\text { rapportage } \\
\text { voortgang Plan } \\
\text { van Aanpak }\end{array}$ & $\begin{array}{l}\text { overieg over } \\
\text { gevaarlijke- } \\
\text { stoffenbeleid: } \\
\text { - asbest (4.46, } \\
\text { lid } 2 / 4.50) \\
\text { - biologische } \\
\text { agentia (4.92) } \\
\text { - lawaai (6.7. } \\
\text { lid 4) }\end{array}$ & $\begin{array}{l}\text { § 2.3.2: periodiek } \\
\text { overleg tussen } \\
\text { arbodienst en OR }\end{array}$ \\
\hline Instemmingsrecht & $\begin{array}{l}\text { 27, lid 1d: alle } \\
\text { regelingen op het } \\
\text { gebied van } \\
\text { arbeidsomstan- } \\
\text { digheden en } \\
\text { verzuimbeleid. } \\
\text { tenzij de Arbeids- } \\
\text { inspectie een eis } \\
\text { heett gesteld of } \\
\text { de kwestie } \\
\text { inhoudelijk in } \\
\text { CAO geregeld is } \\
\text { 27, lid 1i: } \\
\text { werkoverleg } \\
\\
\text { zie verder kolom } \\
\text { Arbowet } \\
\text { + } \\
\text { - keuze } \\
\text { arbodienst } \\
\text { - aanwijzen van } \\
\text { functies waar- } \\
\text { voor aanstel- } \\
\text { lingskeuringen } \\
\text { worden } \\
\text { uitgevoerd } \\
\text { - maatregelen op } \\
\text { het gebied van } \\
\text { sexuele intimi- } \\
\text { datie (bijvoor- } \\
\text { beeld het aan- } \\
\text { wijzen van een } \\
\text { vertrouwens- } \\
\text { persoon), } \\
\text { agressie en } \\
\text { geweld } \\
\text { - de voorlichting } \\
\text { en scholing op } \\
\text { het gebied van }\end{array}$ & $\begin{array}{l}\text { Memorie van } \\
\text { Toelichting } \\
\text { Arbowet 1998, } \\
\text { p. 19: expliciete } \\
\text { opsomming } \\
\text { instemmings- } \\
\text { plichtige onder- } \\
\text { werpen } \\
\text { - RIE/Plan van } \\
\text { aanpak } \\
\text { - verplichtingen } \\
\text { rond gevaarlijke } \\
\text { installaties } \\
\text { (arbeidsveilig- } \\
\text { heidsrapport, } \\
\text { calamiteiten- en } \\
\text { rampenbestrij- } \\
\text { dingsscenario's) } \\
\text { - de wijze waarop } \\
\text { de deskundige } \\
\text { bijstand wordt } \\
\text { ingericht (onder } \\
\text { meer het con } \\
\text { tract met de } \\
\text { arbodienst, } \\
\text { maar ook het } \\
\text { inrichten van } \\
\text { een interne } \\
\text { arbodienst) } \\
\text { - het aanwijzen } \\
\text { van de bedrijts } \\
\text { hulpverleners } \\
\text { - de periodiciteit } \\
\text { van het } \\
\text { periodiek } \\
\text { arbeids- } \\
\text { gezondheids } \\
\text { kundig } \\
\text { onderzoek }\end{array}$ & & $\begin{array}{l}\$ 2.3 .1 \text { arbodienst } \\
\text { moet nagaan of } \\
\text { OR heeft inge- } \\
\text { stemd met con- } \\
\text { tract }\end{array}$ \\
\hline
\end{tabular}




\begin{tabular}{|c|c|c|c|c|}
\hline & WOR & Arbowet & Arbobesluit & $\begin{array}{l}\text { Certificerings- } \\
\text { regeling }\end{array}$ \\
\hline $\begin{array}{l}\text { Adviesrecht } \\
\\
\text { Overeen- } \\
\text { stemmingsrecht } \\
\text { Initiatiefrecht }\end{array}$ & $\begin{array}{l}\text { veiligheid en } \\
\text { gezondheid. } \\
\text { m.b.t. verzuim- } \\
\text { beleid } \\
\text {-controle- } \\
\text { voorschriften } \\
\text { - disciplinaire } \\
\text { maatregelen } \\
\text { - arbeidsvoor- } \\
\text { waardelijke } \\
\text { prikkels } \\
\text { 32: eventueel } \\
\text { onderwerpen } \\
\text { vastleggen in } \\
\text { schriftelijke over- } \\
\text { eenkomst of } \\
\text { uitbreiden } \\
\text { instemmingsrecht } \\
\text { 25, lid 1d: invoe- } \\
\text { ring nieuwe } \\
\text { processen } \\
25, \text { lid 1e: reorga- } \\
\text { nisaties } \\
25, \text { lid 1g: inlenen } \\
\text { arbeidskrachten } \\
25, \text { lid 1h: belang- } \\
\text { rijke investeringen } \\
25, \text { lid } 1 \mathrm{k} \text { : nieuwe } \\
\text { technologieên } \\
\text { vraag bij dit soort } \\
\text { adviesaanvragen } \\
\text { altijd om een risi- } \\
\text { co-inventarisatiel } \\
25, \text { lid 1m: milieu- } \\
\text { zorg } \\
\text { 23, lid 3: } \\
\text { voorstellen doen } \\
\text { voor verbetering }\end{array}$ & $\begin{array}{l}\text { 17: maatwerk- } \\
\text { afspraken } \\
\text { (d.w.z. afwijken } \\
\text { van bepalingen in } \\
\text { Arbobesluit) } \\
\text { alleen na } \\
\text { schriftelijke over- } \\
\text { eenstemming } \\
\text { tussen OR en } \\
\text { werkgever }\end{array}$ & & \\
\hline
\end{tabular}




\begin{tabular}{|c|c|c|c|c|}
\hline & WOA & Arbowet & Arbobesluit & $\begin{array}{l}\text { Certificerings- } \\
\text { regeling }\end{array}$ \\
\hline Informatierecht & $\begin{array}{l}\text { arbeidsomstan- } \\
\text { digheden, ten } \\
\text { minste één keer } \\
\text { in overlegverga- } \\
\text { dering bespreken } \\
\text { 31, lid 1: alle } \\
\text { inlichtingen en } \\
\text { gegevens die de } \\
\text { OR voor de } \\
\text { vervulling van zijn } \\
\text { taak redelijkerwijs } \\
\text { nodig heeft } \\
\text { 31a, lid 8: } \\
\text { milieujaarverslag } \\
\text { 31b, lid 1: } \\
\text { sociaal jaar- } \\
\text { verslag, kwantita- } \\
\text { tiet onderbouwd } \\
\text { (onder meer } \\
\text { WAO- en ver- } \\
\text { zuimcijers) } \\
\text { 31c, informeren } \\
\text { OR over het ver- } \\
\text { strekken van een } \\
\text { adviesopdracht } \\
\text { op het gebied van } \\
\text { arbeidsomstan- } \\
\text { digheden }\end{array}$ & $\begin{array}{l}\text { 12, lid 2: werkge- } \\
\text { ver stuurt OR } \\
\text { exemplaar RIE } \\
\text { 14, lid 7: arbo- } \\
\text { dienst stuurt zélf } \\
\text { de OR kopieên } \\
\text { van de adviezen } \\
\text { aan de werkgever } \\
\text { 5, lid 2: jaarlijks } \\
\text { schriftelijke rap- } \\
\text { portage over } \\
\text { voortgang Plan } \\
\text { van Aanpak } \\
\text { 5, lid 1: overzicht } \\
\text { van ongevallen } \\
\text { met verzuim } \\
\text { (zie ook } 9, \text { lid 1) } \\
\text { niet expliciet in } \\
\text { wet wet, wel } \\
\text { wenselijk: infor- } \\
\text { matie over } \\
\text { beroeps- } \\
\text { ziekten of ernsti- } \\
\text { ge ongevallen } \\
\text { zonder letsel of } \\
\text { verzuim } \\
\text { niet expliciet in } \\
\text { wet, wel wense- } \\
\text { lijk: resultaten } \\
\text { periodieke onder- } \\
\text { zoeken (art.18) } \\
\text { 7: exemplaar } \\
\text { veiligheids- } \\
\text { rapporten en } \\
\text { overige beleids- } \\
\text { stukken i.v.m. } \\
\text { zware ongevallen } \\
\text { (indirect via } \\
\text { publieke } \\
\text { informatie) } \\
\text { 24, lid 5: } \\
\text { rapporten } \\
\text { Arbeidsinspectie } \\
\text { 27, tid 6: eisen }\end{array}$ & 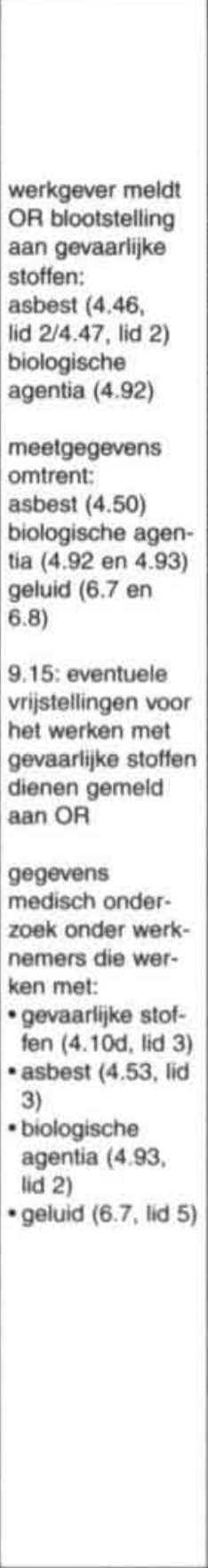 & $\begin{array}{l}\text { \$2.7.1: } \\
\text { arbodienst stuurt } \\
\text { OR exemplaar } \\
\text { van RIE en zijn } \\
\text { advies hierover } \\
\text { \$2.10.2: jaar- } \\
\text { verslag van arbo- } \\
\text { dienst } \\
\$ 2.7 .4 \text { gegevens } \\
\text { medische onder- } \\
\text { zoeken door } \\
\text { arbodienst }\end{array}$ \\
\hline
\end{tabular}




\begin{tabular}{|c|c|c|c|c|}
\hline & WOA & Arbowet & Arbobesluit & $\begin{array}{l}\text { Certificerings: } \\
\text { regeling }\end{array}$ \\
\hline Faciliteiten & $\begin{array}{l}\text { 15, lid 2: instellen } \\
\text { vaste commissie } \\
\text { VGW } \\
\text { 15, lid 3: } \\
\text { scholingsrecht } \\
\text { OR- of } \\
\text { commissieleden } \\
17 \text {, lid 2: recht om } \\
\text { in werktijd te } \\
\text { vergaderen } \\
18 \text {, lid } 1 \text { : recht om } \\
\text { kennis te nemen } \\
\text { van de arbeids- } \\
\text { omstandigheden } \\
18 \text {, lid } 3: 60 \text { uur } \\
\text { onderling beraad } \\
22: \text { kosten voor } \\
\text { rekening werk- } \\
\text { gever }\end{array}$ & $\begin{array}{l}\text { van Arbeids- } \\
\text { inspectie } \\
28, \text { lid } 6: \text { bevelen } \\
\text { tot stillegging }\end{array}$ & & \\
\hline $\begin{array}{l}\text { Deskundige } \\
\text { ondersteuning }\end{array}$ & $\begin{array}{l}\text { 16: inhuren } \\
\text { deskundige } \\
\text { (werkgever vooraf } \\
\text { op hoogte stellen } \\
\text { i.v.m. kosten) }\end{array}$ & $\begin{array}{l}\text { 14, lid } 3 \text { e: } \\
\text { arbodienst } \\
\text { adviseert aan en } \\
\text { werkt samen met } \\
\text { OR }\end{array}$ & & $\begin{array}{l}\text { § } 2.7 .2 \text { arbodienst } \\
\text { overlegt met OR } \\
\text { over de ontwikke- } \\
\text { ling van het } \\
\text { verzuim (op basis } \\
\text { van gedegen } \\
\text { verzuimcijfers) } \\
\text { §2.7.3 arbodienst } \\
\text { overlegt met OR } \\
\text { over de resultaten } \\
\text { van het } \\
\text { arbospreekuur } \\
\S 2.7 .4 \text { arbodienst } \\
\text { overlegt met OR } \\
\text { over het arbeids- } \\
\text { gezondheids- } \\
\text { kundige onder- } \\
\text { zoeken }\end{array}$ \\
\hline Arbeidsinspectie & & $\begin{array}{l}\text { 12, lid 3: } \\
\text { vergezelrecht bij } \\
\text { bezoek Arbeids- } \\
\text { inspectie } \\
\text { 12, lid } 3 \text { : recht de } \\
\text { inspecteur onder } \\
\text { vier ogen te } \\
\text { spreken } \\
24 \text {, lid } 7 \text { : recht om } \\
\text { een verzoek tot } \\
\text { onderzoek in te } \\
\text { dienen }\end{array}$ & & \\
\hline
\end{tabular}





\section{Arbobeleid en medezeggenschap in de praktijk}

Eén van de centrale vragen uit deze studie is: Zijn ondernemingsraden voldoende geëquipeerd om de hun toebedachte rol op het gebied van arbeidsomstandigheden naar behoren te vervullen? In hoofdstuk 3 is aangegeven dat dit in ieder geval formeel wel het geval lijkt te zijn. De faciliteitenregeling is zo op het oog redelijk, en de medezeggenschappers kunnen putten uit een uitgebreid scala van bevoegdheden. Vooral het instemmingsrecht lijkt een machtig wapen om het arbobeleid te beïnvloeden. Of de OR in de praktijk daadwerkelijk gebruik maakt van zijn (machts)bronnen is onderwerp van dit hoofdstuk. Hierbij ligt, zoals gezegd, het accent sterk op de formele bronnen en bevoegdheden. Dit is zonder twijfel een niet onbelangrijke inperking van het mogelijke onderzoeksterrein. Bader en Benschop geven bijvoorbeeld in hun pro-theoretische beschouwing van sociale ongelijkheid en collectief handelen een uitgebreide staalkaart van de vele bronnen die mogelijkerwijs aangeboord zouden kunnen worden door (collectieve) actoren zoals ondernemingsraden, waaronder vormen van coöperatie, informeel leiderschap, prestatiekwalificaties en prestige. ${ }^{\prime}$ Een theoretisch onuitgewerkte en zeker niet uitputtende opsomming van diverse machtsbronnen is opgenomen in schema 4.1.

In dit hoofdstuk zal het gebruik van de niet-formele bronnen echter slechts sporadisch ter sprake komen. Dit hangt samen met de gekozen onderzoeksmethode, te weten een survey onder ondernemingsraden. Die keuze is deels zeer pragmatisch tot stand gekomen. Bij de analyse is primair geput uit de gegevens van het onderzoek De volwassen $O R{ }^{2}$ Een belangrijk doel van dit survey was een replicatie van het eerdere onderzoek van Looise en De Lange. ${ }^{3}$ Dit stelde, mede door de breedte van het onderzoek en de noodzakelijke beperking van de omvang van de vragen-

I V.M. Bader en A. Benschop (1988), Ongelijkheden: pro-theorie van sociale ongelijkheid en collectief handelen, Wolters-Noordhoff: Groningen, p. 129-196. Van Peijpe richt zich in zijn onderzoek naar de ontwikkeling van het loonvormingsrecht sterk op het gebruik van machtsbronnen. Hij identificeert in zijn studie zeven typen machtsbronnen: economische, juridische, politieke en ideologische macht, informatie, kennis en bekwaamheden, organisatie en geweldsmiddelen. T. van Peijpe (1985), De ontwikkeling van het loonvormingsrecht, Nijmegen: Ars Aequi Libri, p. 51-56. Zie ook A. Teulings (1981), Ondernemingsraadpolitiek in Nederland: Een onderzoek naar de omgang met macht en conflict door de ondernemingsraad. Amsterdarn: Van Gennep. p. $66-68$ en 117

2 R.H. van het Kaar, J.C. Looise e.a. (1999), De volwassen OR: groei en grenzen van de Nederlandse ondernemingsraad, Alphen a.d. Rijn: Samsom

3 J.C. Looise en F.G.M. de Lange (1987), Ondernemingsraden, bestuunders en besluitvorming. Nijmegen, ITS 
lijst, grenzen aan het aantal variabelen dat ingebracht kon worden. Bovendien bestond bij de onderzoekers de indruk dat het gebruik van formele regels door ondernemingsraden nu eenmaal de meest gevolgde strategie is (al dreigt hier, eerlijkheidshalve, natuurlijk wel de methodologische valkuil 'zoekt en gij zult vinden'). Deels is de keuze ook meer principieel, in die zin dat de inzet van minder grijpbare bronnen (met name die welke gekoppeld zijn aan de positie van individuele OR-leden of de bestuurder), interne machtsverhoudingen én culturele aspecten zoals legitimering en betekenisverlening een meer proces-gerichte onderzoeksmethode vergen. Een dergelijke diepte-analyse levert allerlei waardevolle informatie op, maar is op macro-niveau minder bruikbaar.

\section{Schema 4.I. Machtsbronnen voor werknemers}

\begin{tabular}{|c|c|c|}
\hline Ondernemingsraad & Vakbonden & Individuele werknemer \\
\hline $\begin{array}{l}\text { - kennis/deskundigheid } \\
\text { - regulier overleg } \\
\text { - strategisch wijzen op } \\
\text { werkgeversbelang (bijv. } \\
\text { kosten/baten-analyse) } \\
\text { - gebruik formele } \\
\text { bevoegdheden (m.n. } \\
\text { instemmings- en } \\
\text { adviesrecht) } \\
\text { - vergaderboycot } \\
\text { - raadplegen achterban } \\
\text { beleggen } \\
\text { actievergadering } \\
\text { onderzoek/enquête } \\
\text { - werkonderbreking } \\
\text { - publiciteit, openbaarheid } \\
\text { - inschakelen deskundige } \\
\text { (bijvoorbeeld arbodienst) } \\
\text { - inschakelen Raad van } \\
\text { Commissarisen } \\
\text { - inschakelen vakbond } \\
\text { - inschakelen } \\
\text { Arbeidsinspectie } \\
\text { - rechtsbescherming } \\
\text { OR-leden } \\
\text { - hoger beroep } \\
\text { (bedrijtscommissie, } \\
\text { rechter) } \\
\text { - OR opheffen }\end{array}$ & $\begin{array}{l}\text { - interne organisatie en } \\
\text { deskundigheid } \\
\text { - regulier overleg } \\
\text { - onderzoek/enquête } \\
\text { - alliantie met } \\
\text { wetenschappers of } \\
\text { non-gouvernementele } \\
\text { organisaties } \\
\text { - demonstraties } \\
\text { - petities, adressen } \\
\text { - politieke lobby } \\
\text { - inschakelen } \\
\text { Arbeidsinspectie } \\
\text { - actiebijeenkomst met } \\
\text { achterban } \\
\text { - druk op CAO-overleg } \\
\text { - collectieve actie' } \\
\text { - stakingen of } \\
\text { stakingsdreiging } \\
\text { - inschakelen rechter }\end{array}$ & $\begin{array}{l}\text { - informatie inwinnen } \\
\text { - regulier overleg } \\
\text { - beroep op wet/CAO } \\
\text { - klachtrecht } \\
\text { - inschakelen } \\
\text { ondernemingsraad } \\
\text { - inschakelen arbodienst } \\
\text { (veelal bedriffsarts) } \\
\text { - inschakelen vakbond } \\
\text { - inschakelen } \\
\text { Arbeidsinspectie } \\
\text { - klokkenluiden } \\
\text { - werkonderbreking } \\
\text { - werkweigering } \\
\text { - ontslag nemen/krapte } \\
\text { op arbeidsmarkt } \\
\text { - dreigen met } \\
\text { letselschadeclaim }\end{array}$ \\
\hline
\end{tabular}


Hoe dan ook: de analyse in dit hoofdstuk beperkt zich tot twee aspecten. In paragraaf 4.1 wordt onderzocht óf ondernemingsraden gebruik maken van de hun ten dienste staande faciliteiten en bevoegdheden c.q. in hoeverre zij daartoe in de gelegenheid worden gesteld. In paragraaf 4.2 wordt nader onderzocht welke factoren van invloed zijn op de bevindingen uit de eerste paragraaf. Hierbij gaat het bijvoorbeeld om achtergrondvariabelen zoals bedrijfskenmerken, de opstelling van de bestuurder, economische positie en concurrentiepositie, en relaties van de OR met vakbonden en de achterban. $\mathrm{Bij}$ deze nadere analyse is aangehaakt bij het model dat ook werd gehanteerd bij de studie van Looise en De Lange ${ }^{4}-$ zij het in een vereenvoudigde vorm aangezien lang niet alle items uit dat onderzoek relevant zijn voor de analyse van het functioneren van de OR op arbogebied (voor een uitgebreider overzicht zie paragraaf 4.2). Deze nadere analyse levert, als het goed is, informatie op die richtinggevend is voor diepgaander kwalitatief onderzoek middels casestudies. Hoewel de resultaten van de analyse in paragraaf 4.2 slechts op een paar punten in een duidelijke richting wijzen, zo zal blijken, is die informatie wel verwerkt in het design voor het kwalitatieve onderzoek. Het verslag van de casestudies is opgenomen in hoofdstuk 6.

\subsection{Arbobeleid en medezeggenschap: univariate analyse}

Bij de analyse van de praktische betekenis van de wettelijke mogelijkheden is, zoals gezegd, met name geput uit het landelijke OR-onderzoek van Van het Kaar en Looise. ${ }^{5}$ In aanvulling op de eerdere rapportage in De volwassen $O R$ wordt in het kader van dit proefschrift echter een aantal methodische verfijningen aangebracht. Zoals in het genoemde rapport al is aangegeven, ging de respons namelijk mank aan een oververtegenwoordiging van grote organisaties ( $>200$ werknemers) en de sectoren 'overheid' en 'overige dienstverlening'. Andere sectoren, met name 'banken/verzekeringen', waren ondervertegenwoordigd ${ }^{6}$ Hoewel deze vertekening in hoofdlijnen geen al te ernstige consequenties had voor de uitkomsten van het survey, is omwille van de precisie toch een aantal bijstellingen doorgevoerd (zie bijlage 4.1). Na deze correcties zijn de gegevens goed te gebruiken voor de onderstaande analyses.

\subsubsection{Taakopvatting}

Zowel de WOR als de Arbowet kennen de ondernemingsraad een tamelijk centrale rol toe op het gebied van arbeidsomstandigheden. Of de OR zich daadwerkelijk van deze taak kwijt, kan worden bepaald aan de hand van een aantal criteria. Het meest voor de hand liggende criterium is de hoeveelheid tijd die de OR aan het thema 'arbo' besteedt. Uiteraard zegt dit nog niet veel over de kwaliteit van de OR-bij-

\footnotetext{
4 Looise/De Lange 1987, p. 14

5 Van het Kaar/Looise 1999. De gegevens in par. 4.1.4 en par. 4.1.5 zijn vooral gebaseerd op het databestand van de Arbosterrengids van de FNV respectievelijk een eigen enquête onder de inspecteurs van de Arbeidsinspectie,
}

6 Van het Kaar/Looise 1999, p. 26-28 
drage aan het arbeidsomstandighedenbeleid. Het kan best zijn dat een efficiënt functionerende OR betrekkelijk weinig tijd aan het arbobeleid besteedt en tóch zeer goede resultaten boekt, en omgekeerd dat een OR die veel tijd in het thema steekt nauwelijks invloed heeft. Een andere manier om achter het (relatieve) gewicht van het onderwerp te komen, is te vragen welk onderdeel van het bedrijfsbeleid van de OR de meeste aandacht heeft gekregen. Ook het aantal instemmingsaanvragen of OR-initiatieven kan een indicatie zijn.

\section{Aandacht}

Uit het eerste grote onderzoek naar het functioneren van ondernemingsraden, uit 1976, bleek dat het onderwerp arbeidsomstandigheden medio jaren '70 zo'n 17 procent van de OR-tijd in beslag nam. ${ }^{7}$ Bijna de helft van die tijd ging op aan louter informatieve activiteiten. Geers concludeert op basis van deze gegevens dat de aandacht van de OR voor veiligheids- en gezondheidszaken beperkt is. ${ }^{8}$ Hiertegenover kan evenwel worden gesteld dat 'arbo', afgezien van het thema arbeidsvoorwaarden, van de inhoudelijke onderwerpen het hoogste scoorde. ${ }^{9}$

Ook uit later onderzoek blijkt dat de zorg voor veilige en gezonde arbeidsomstandigheden wel degelijk een van de speerpunten van de OR is. Blijkens een survey onder ruim 450 ondernemingsraden stond 'arbo' in 1985 hoog op de agenda. ${ }^{10}$ In de periode 1983-1984 had 31 procent van de ondernemingsraden één of meer instemmingsaanvragen op het gebied van arbeidsomstandigheden behandeld. Daarmee nam arbo van alle toenmalige artikel-27-thema's de tweede plek in. " Ook in onderzoek naar de maatschappelijke betrokkenheid van OR'en stond en staat 'arbo' boven aan de lijst van aandachtspunten van de OR (gevolgd door het ziekteverzuimbeleid). ${ }^{12}$ In hetzelfde jaar prijkte 'arbo' ook als nummer één op de lijst onderwerpen die in de OR-vergadering op de agenda staan: 65 procent elke vergadering, 32 procent af en toe. ${ }^{13}$ En uit onderzoek onder werkgevers, twee jaar later,

7 B. Hövels en P. Nas (1976), Ondernemingsraden en medezeggenschap, Alphen a/d Rijn: Samsom, 1976, p. 181

8 A.J.C.M. Geers (1988), Recht en humanisering van de arbeid, Deventer: Kluwer, p. 79

9 Hóvels/Nas 1976, p. 181

10 Reubsaet concludeert rond dezelfde periode echter dat 'arbo' toch nog tamelijk incidenteel wordt geagendeerd. T.J.M. Reubsaet et al. (1988), De Arbowet in uitwoering: Een onderzoek naar ervaringen in de praktijk, Den Haag: Ministerie van Sociale Zaken en Werkgelegenheid, p. 50

11 J.C. Looise en J.Z. Heijink (1986), De OR en zijn bevoegdheden: interimrapport onderzoek ondernemingsraden, Nijmegen: ITS, p. 47. Dat het thema 'werktijdregelingen' hoger scoorde, was met name te danken aan het feit dat de Stichting van de Arbeid enige jaren eerder afspraken had gemaakt over ATV. waardoor OR' en op bedrijfsniveau tijdelijk extra aandacht aan de invulling van werktijdregelingen moesten besteden.

$12 \mathrm{Vgl}$. D.J. Klein Hesselink en G.E. Evers (1994), Maatschappelijke betrokkenheid van ondernemingsraden, Den Haag: Ministerie van Sociale Zaken en Werkgelegenheid, p. 47. H.A. Weening en S.M. Teulings (2001), Betrokkenheid groeit met de tijd: Veranderingen in de agenda van ondernemingsruden, Den Haag: Ministerie van Sociale Zaken en Werkgelegenheid. p. 30

13 T. Feijen. E. de Bruijn en H. van den Tillaart (1994), Arbeidsomstandigheden, arbozorg en VGW-scholing. Utrecht: GBIO, p. II 
bleken de arbeidsomstandigheden eveneens regelmatig onderwerp van gesprek tijdens het overleg tussen bestuurder en OR: in 45 procent van alle bedrijven is het een vast agendapunt, terwijl het in nog eens 32 procent met enige regelmaat aan de orde komt. ${ }^{14}$

In het onderzoek De volwassen $O R$ uit 1999 is eveneens onderzoek gedaan naar de mate waarin ondernemingsraden aandacht besteden aan het onderwerp arbeidsomstandigheden. Het onderzoek bevestigt het eerdere beeld dat 'arbo' één van de belangrijkste aandachtspunten is (zie tabel 4.1.1). ${ }^{15}$ De vraag of de ondernemingsraad in de loop der jaren mér aandacht is gaan besteden aan het onderwerp is moeilijk te beantwoorden. Vergelijking tussen de verschillende onderzoeken is niet mogelijk, omdat de vraagstelling in de opeenvolgende onderzoeken niet exact dezelfde is.

\section{Tabel 4.1.1. Ondenverpen naar meeste aandacht $(n=374)$}

\begin{tabular}{|l|l|}
\hline Onderwerpen naar rangorde & gewogen \% \\
\hline Wijziging organisatiestructuur & 52 \\
Reorganisaties & 48 \\
Arbobeleid & 46 \\
Werk- en rusttijden & 41 \\
Fusie(plannen) & 34 \\
Beloning en functiewaardering & 32 \\
Arbeidsvoorwaarden & 32 \\
\hline Bron: databestand De volwassen OR & \\
\hline
\end{tabular}

Ook aan de hand van het criterium 'aantal instemmingsverzoeken' kan gesteld worden dat ondernemingsraden zich relatief vaak met arbeidsomstandigheden bezighouden. Van de 768 te classificeren instemmingsverzoeken (ongewogen telling), betroffen er 144 een regeling op het gebied van arbeidsomstandigheden (19 procent). ${ }^{16}$ Daarmee neemt het thema arbo (en verzuim) de tweede plek in, net als in 1985 achter werktijden- en vakantieregelingen. ${ }^{17}$

14 A.G. ter Huurne et al. (1997), ZARA-werkgeverspanel rapporage 1996-1997, Den Haag: Ministerie van Sociale Zaken en Werkgelegenheid, p. 119.

15 Ook in andere landen is de veiligheid en gezondheid van werknemers één van belangrijkste aandachtsvelden voor werknemersvertegenwoordigers. Vgl. C. Schäfer (2001), Die WSIBefragung von Betriebs- und Personalsräten 1999/2000 im Uberblick, in: WSI-Mitteilungen 2001, nr. 2, p. $70 \mathrm{ff}$

16 In het onderzoek is gevraagd de drie meest recente instemmingsverzoeken nader te specificeren, 55 procent van de ondernemingsraden heeft echter aangegeven meer dan drie instemmingsverzoeken te hebben behandeld. Het totaal aantal bedraagt 1204. Er is echter, gezien de spreiding onder de drie gespecificeerde verzoeken, geen reden aan te nemen dat de niet-gespecificeerde instemmingsverzoeken qua samenstelling sterk afwijken van de wel-gespecificeerde.

17 Looise/Heijink 1986, p. 47. Dat de werktijden ook nu hoog scoren kan te maken hebben met de Arbeidstijdenwet van 1996, waardoor werkgevers meer vrijheid hebben gekregen om met de werknemersvertegenwoordiging te overleggen over afwijkende werk- en rusttijden. 
Tabel 4.1.2. Instemmingsaanvragen naar onderwerp $(n=768)$

\begin{tabular}{|l|c|}
\hline Onderwerpen naar rangorde & ongewogen \% \\
\hline Werktijden- en vakantieregelingen & 29 \\
Arbeidsomstandigheden en verzuim & 17 \\
Belonings- en functiewaarderingssystemen & 11 \\
Personeelsbeoordeling & 8 \\
Pensioenverzekering/winstdeling/spaarregeling & 7 \\
Personeelsopleiding & 7 \\
Klachtenregeling & 6 \\
Overig & 15 \\
\hline Bron: databestand De volwassen OR & \\
\hline
\end{tabular}

\section{Stimuleringstaak}

De hierboven aangegeven criteria (aandacht/aantal instemmingsaanvragen) zeggen op zich nog niets over de mate waarin de OR zelf warm loopt voor het onderwerp. Het is immers denkbaar dat de ondernemingsraad slechts een 'volgende', d.w.z. reactieve taakopvatting heeft, en zich met het arbobeleid bezighoudt omdat de bestuurder het thema nu eenmaal op de agenda plaatst. Uit de vraag naar de mate waarin de OR zichzelf een stimulerende taak toedicht (op grond van art. 28 WOR), blijkt echter dat ondernemingsraden wel degelijk zélf veel interesse hebben voor de veiligheid en gezondheid op hun werkplek. Slechts een kleine drie procent ziet voor zichzelf geen taak op dit gebied. ${ }^{18}$ Een ruime meerderheid van bijna zestig procent houdt zich intensief met het onderwerp bezig. Daarmee is 'arbo' nummer één op de lijst van stimuleringstaken.

Tabel 4.1.3. Stimuleringstaken OR (gewogen $n=351-357$, in procenten)

\begin{tabular}{|l|c|c|c|}
\hline Onderwerp & intensief & een beetje & niet \\
\hline arbeidsomstandigheden & 58 & 39 & 3 \\
arbeidsvoorwaarden & 48 & 31 & 21 \\
werkoverleg & 44 & 44 & 12 \\
ziekteverzuim & 36 & 42 & 22 \\
milieuzorg & 23 & 46 & 31 \\
\hline Bron: databestand De volwassen OR & \\
\hline
\end{tabular}

18 Ter vergelijking: de OR-taak om de inschakeling van vrouwen, allochtonen of gehandicapten te bevorderen wordt door drie kwart van de ondernemingsraden geheel genegeerd (data-bestand De volwassen $O R$ ). Vgl. Weening/Teulings 2001. p. 30 


\section{Initiatieven}

Dat ondernemingsraden zeggen veel aandacht te besteden aan arbobeleid en de zorg voor gezonde arbeidsomstandigheden, en een laag verzuim te stimuleren. kan echter lippendienst zijn. Een derde indicator voor een actieve opstelling kan zijn dat de OR initiatieven neemt om de arbeidsomstandigheden daadwerkelijk te verbeteren. Als het aantal initiatiefvoorstellen wordt geturfd, blijkt de inzet van de OR minder groot dan de items 'aandacht' en 'stimuleren' doen vermoeden. ${ }^{19}$ In de periode 1996-1997 heeft de helft van de ondervraagde ondernemingsraden geen enkel initiatiefvoorstel ingediend. Ongeveer één op de vijf heeft meer dan één voorstel uitgewerkt. Daarmee zijn iets meer ondernemingsraden initiatiefrijk dan medio jaren 80.20

Tabel 4.1.4. Aantal initiatiefvoorstellen $O R$ (\% van ondernemingsraden over een periode van 2 jaar)

\begin{tabular}{|l|c|c|}
\hline & $\begin{array}{c}1985 \\
(\mathbf{n = 1 8 9 )}\end{array}$ & $\begin{array}{c}1998 \\
\text { (n=374, gewogen) }\end{array}$ \\
\hline Geen enkel & 65 & 50 \\
1 & 13 & 15 \\
2 & 11 & 7 \\
3 of meer & 12 & 14 \\
Niet gespecificeerd & & 14 \\
\hline \multicolumn{2}{|l|}{ Bron: databestand De volwassen OR en Looise/De Lange 1987 } \\
\hline
\end{tabular}

Het aantal initiatieven op het gebied van arbeidsomstandigheden is uiteraard een fractie van het totaal: van de 374 nader gespecificeerde initiatieven hebben er 47 (12 procent) betrekking op thema's als verzuim, werkdruk, arbodienst, rookbeleid, seksuele intimidatie of 'arbo' in het algemeen (ongewogen). ${ }^{21}$ Een decennium eer-

19 Ook uit andere onderzoeken blijkt de OR zich veelal 'volgend', dus weinig initiatiefrijk op te stellen. Vgl. J.W.M. Mevissen et al. (2001), Arbeidstijden in overleg? Evaluatie van de Arbeidstijdenwet, Den Haag: Elsevier/ministerie van Sociale Zaken en Werkgelegenheid, p. 119

20 Looise/De Lange 1987. p. 26 en 36. Het gemiddelde aantal initiatieven per OR lag in 19967 op 2,7 per twee jaar, terwijl dat in het eerdere onderzoek op hetzelfde niveau lag. $\mathrm{Vgl}$. Looise/Heijink 1986, p. 72. Ook Reubsaet et al. (1988, p. 61/62) constateerden dat het grootste deel van de ondernemingsraden nauwelijks initiatief neemt om de arbeidsomstandigheden te verbeteren.

21 Hier is gekozen voor een ongewogen telling, omdat de weging op een aantal punten wel erg zwaar vertekende ten opzichte van het beperkte responsaantal. Het percentage van 12 komt goed overeen met dat in onderzoek van Weening en Teulings, die 14 procent hebben vastgesteld, waarmee 'arbo' het thema is waarop de OR zich nog het meest initiatiefrijk betoont. Weening/Teulings 2001, p. 34 
der was dit ongeveer hetzelfde. ${ }^{22}$ Ondernemingsraden die een initiatief hebben genomen bemoeien zich, voorspelbaar, iets intensiever met het arbo- en verzuimbeleid in hun bedrijf. Deze samenhang is significant voor ondernemingsraden die het arbo- en verzuimbeleid intensief stimuleren.

Tabel 4.1.5. Samenhang aandacht en initiatiefvoorstellen OR (gewogen $n=348$-359)

\begin{tabular}{|l|c|c|}
\hline & $\%$ wel initiatief & $\%$ geen initiatief \\
\hline Veel aandacht voor arbo & 53 & 47 \\
Intensief stimuleren arbobeleid & 61 & 39 \\
Intensief stimuleren verzuimbeleid & 62 & 38 \\
\hline Bron: databestand De volwassen OR & \\
\hline
\end{tabular}

Van de 47 (ongewogen) arbo-initiatieven werden er 36 geheel of gedeeltelijk overgenomen door de bestuurder (77 procent), 6 voorstellen werden afgewezen, de overige 5 voor kennis aangenomen. Daarmee wijkt het beeld nauwelijks af van de reactie van de bestuurder op de initiatiefvoorstellen in het algemeen ( 78 procent geheel of gedeeltelijk overgenomen) noch van de ervaringen in 1985.23

Van de 374 ondernemingsraden uit het onderzoek had dus slechts één op de acht in de periode 1996-1997 een arbo-initiatief genomen. Dat lijkt in schril contrast te staan met de aandacht die ondernemingsraden aan het arbobeleid zeggen te hechten. Een verklaring kan zijn dat de ondernemingsraden die géén initiatief nemen vaker dan gemiddeld te maken hebben met instemmingsaanvragen op het gebied van arbeidsomstandigheden, en de bestuurder dus niet hoeven op te jutten met eigen plannen. Dit is echter niet het geval. Integendeel. De 47 ondernemingsraden die zelf een initiatiefvoorstel indienden, kregen in dezelfde periode ook 27 arboinstemmingsaanvragen te behandelen ( 0,57 per OR). De 327 OR'en die géén initiatief namen, kregen slechts 117 arbo-instemmingsaanvragen ( 0,36 per OR).

Een andere voor de hand liggende verklaring is de hoeveelheid tijd die ondernemingsraden tot hun beschikking hebben. Het uitwerken van een goed initiatiefvoorstel vergt immers de nodige tijd en deskundigheid. Uit de onderzoeksgegevens valt inderdaad te concluderen dat initiatiefrijke OR'en minder vaak met tijdnood kampen: 48 procent geeft aan (ruim) voldoende tijd te hebben, tegen 29 procent van de inerte ondernemingsraden. Ook blijkt uit het survey dat initiatiefrijke ondernemingsraden minder vaak deskundigheidsproblemen signaleren dan hen die géén initiatief hebben ondernomen ( 35 procent tegen 44 procent). Aan de andere kant hebben diverse ondernemingsraden die arbo-deskundigheid zeggen te ontberen wel

22 Looise/Heijink 1986, p. 73. Blijkens onderzock van het CNV is 'arbo' wel het beleidsterrein waarop ondernemingsraden het meest frequent initiatieven ontplooien. Y. van Brummelen en J.P. van den Toren (1998), Medezeggenschap; cen hele ondermeming. Utrecht: CNV

23 Looise/Heijink 1986, p. 74. Vgl. ook Looise/De Lange 1987, p. 121 
degelijk ooit een initiatief genomen. Het percentage initiatiefnemers ligt niet veel lager dan onder het aantal OR'en zónder deskundigheidsproblemen - gebrek aan kennis betekent kennelijk niet dat dús initiatieven uitblijven.

Een derde verklaring, die ook in de literatuur wordt genoemd, is dat het initiatiefrecht toch tamelijk krachteloos is. De bestuurder moet weliswaar gemotiveend aangeven of hij het plan van de OR al dan niet overneemt, maar als hij het initiatief naast zich neerlegt staat de OR geen beroep open. Deze tekortkoming was ook inzet van debat tijdens de wijziging van de WOR in 1996-1998. Hoewel het kabinet het voornoemde knelpunt signaleerde, zag het geen aanleiding de OR een beroepsrecht te geven. ${ }^{24} \mathrm{Het}$ wetsvoorstel om de OR, bij een geschil over een initiatiefvoorstel. het recht te geven de bedrijfscommissie in te schakelen voor bemiddeling, werd door de Kamer niet overgenomen. ${ }^{25}$

Een vierde, en waarschijnlijk de meest interessante verklaring die mogelijk uit het survey gedestilleerd zou kunnen worden, is dat ondernemingsraden die relatief vaak gepasseerd worden door de bestuurder rond instemmingsplichtige of adviesplichtige besluiten ( $v g l$. par. 4.1.3) ook minder vaak initiatieven nemen: een medezeggenschapscultuur waarin de bestuurder de OR passeert nodigt immers niet uit tot initiatieven. Op het punt van de instemmingsplichtige thema's klopt dit beeld. De OR'en die geen enkel initiatief ondernemen zijn ook iets vaker gepasseerd (34 tegen 30 procent). Op het gebied van adviesplichtige thema's daarentegen blijkt juist dat de initiatiefrijke ondernemingsraden váker gepasseerd zijn dan de initiatiefloze ( 46 tegen 33 procent). De gegevens op dit punt zijn dus niet eenduidig. Het beeld kan ontstaan dat ondernemingsraden die rond de strategische thema's worden gepasseerd hun heil zoeken in de sociale thema's.

\section{Conclusie}

Een eerste tussenconclusie die valt te trekken, is dat het thema 'arbo' hoog op de agenda van de OR staat. Twee op de drie ondernemingsraden bemoeien zich in ieder geval behoorlijk intensief met het arbobeleid in hun bedrijf. Daarmee lijkt de overheidsstrategie van decentralisatie van het arbeidsomstandighedenbeleid en werknemersbetrokkenheid op bedrijfsniveau in vruchtbare aarde te vallen: de medezeggenschappers gaan de hun toebedeelde verantwoordelijkheid niet uit de weg - al nemen ze weinig initiatieven. Of de OR daadwerkelijk geëquipeerd is en resultaten boekt op arbogebied is onderwerp van de volgende paragrafen.

\subsubsection{Basisvoorwaarden voor medezeggenschap}

In paragraaf 3.2 is een tweetal basisvoorwaarden voor medezeggenschap geschetst: het overlegrecht en het informatierecht.

24 Kamerstukken II. 1995-1996, 24615, nr. 3 Wijziging van de Wet op de ondernemingsraden en titel 7,10 (arbeidsovereenkomst) van het nieuw Burgerlijk Wetboek; Memorie van toelichting. p. 15

25 Kamerstukken II, 1996-1997, 24615, nr. 36 (motie Van Rooy), resp. Handelingen Tweede Kamer 1996-1997, nr. 36, pag. $7191-7194$ (stemmingen) 


\subsubsection{Overlegrecht}

In de vorige paragraaf is al aangegeven dat het arbobeleid hoog op de agenda van de overlegvergadering staat. In deze paragraaf wordt nader onderzocht in hoeverre overleg is gevoerd over een aantal centrale beleidsonderwerpen: de risico-inventarisatie en -evaluatie, het arbojaarplan (voor 100+-bedrijven), het verzuimbeleid, het arbeidsveiligheidsrapport, het PAGO (periodiek arbeidsgezondheidskundig onderzoek) en het beleid met betrekking tot aanstellingskeuringen. ${ }^{26}$ De resultaten zijn redelijk positief te noemen - althans in kwantitatief opzicht (het is niet mogelijk om op basis van het survey de kwaliteit van het overleg te beoordelen - dat is onderwerp van hoofdstuk 6).

In het merendeel van de bedrijven wordt geregeld overleg gevoerd over de hierboven genoemde thema's - althans, omtrent de drie centrale beleidsinstrumenten (RI\&E, jaarplan, verzuimcijfers): ongeveer 90 procent van de bestuurders voert overleg met de OR indien deze elementen in het arbobeleid actueel zijn (zie tabel 4.1.6). Het overleg over de specifieke onderwerpen laat te wensen over, met name indien een bedrijf aanstellingskeuringen laat uitvoeren: een kwart van de bedrijven voert geen overleg over het veiligheidsrapport, en bijna de helft van de aanstellingskeuringen onttrekt zich volledig aan het zicht van de medezeggenschappers. Na schaslconstructie hliikt dat in onoevear 14 , nrovant uan do hadrijuan hat antho overleg het predikaat matig tot slecht verdient, en in 60 procent goed genoemd mag worden (Cronbach's $\alpha=0.85$ ). ${ }^{27}$

Met ingang van de Arbowet 1998 is het arbojaarplan voor 100+ bedrijven komen te vervallen. Het schrappen van deze verplichting werd beargumenteerd vanuit het gegeven dat sinds 1994 immers álle bedrijven een plan van aanpak moesten maken (vgl. par. 2.5). Anno 2001 was de medezeggenschap over het plan van aanpak echter niet veel beter ontwikkeld dan dat over het jaarplan in de oude Arbowet. Weliswaar beschikte 94 procent van de $100+$ bedrijven over een plan van aanpak (tegen 84 procent in De volwassen $O R$ ), maar in 11 procent van de bedrijven werd

26 Aanstellingskeuringen vielen op het moment dat de vragenlijst werd uitgezet al onder de Wet medische keuringen, die aanstellingskeuringen in principe verbiedt (behalve voor functies die bijzondere eisen stellen aan de medische geschiktheid van de werknemer). Desondanks erkende meer dan een kwart van de werknemers in de $50+$ bedrijven dat zij wél aanstellingskeuringen lieten uitvoeren, waarbij beperking van verzuim/WAO en gezondheidsselectie belangrijker motieven waren dan de medische geschiktheid voor de functic. SZW-werkgeverspanel 1998-1999. Ministerie van Sociale Zaken en Werkgelegenheid, maart 2000, p. 54-55 en p. $121 \mathrm{ff}$.

27 De schalen in deze paragraaf zijn geconstrueerd door simpelweg de somscores van het aantal items gedeeld door het aantal malen dat het item relevant is. Zo is bij de schaal 'arbo-overleg' de somscore bepaald van het aantal malen dat overlegd is (of het aantal malen dat de ondernemingsraad is genegeerd) gedeeld door het aantal relevante onderwerpen in de organisatie. Hierbij hebben de centrale thema's risico-inventarisatie en verzuimbeleid een dubbel gewicht gekregen. De gemiddelden zijn vervolgens in vier gelijke delen gesplitst. Vervolgens is op de schaal een betrouwbaarheidstest uitgevoerd middels Cronbach's alpha (vgl. P. de Heus e.a. (1995). Toegepaste data-analyse: technieken woor niet-experimented onderzoek in de sociale wetenschappen. Utrecht: Lemma. p. 182ff). 
Tabel 4.1.6. Overleg over arbobeleid (gewogen)

\begin{tabular}{|l|c|c|c|c|}
\hline & $\begin{array}{c}\text { \% onderwerp } \\
\text { relevant }\end{array}$ & $\begin{array}{c}\text { \% overleg } \\
\text { gevoerd }\end{array}$ & $\begin{array}{c}\text { \% OR } \\
\text { gepasseerd }\end{array}$ & n \\
\hline RI\&E & 85 & 89 & 11 & 299 \\
Arbojaarplan (100+) & 84 & 94 & 6 & 146 \\
Verzuimcijfers & 89 & 90 & 10 & 311 \\
Arbeidsveiligheidsrapport & 60 & 77 & 23 & 203 \\
PAGO & 66 & 75 & 25 & 224 \\
Aanstellingskeuringen & 49 & 56 & 44 & 162 \\
\hline Bron: databestand De volwassen OR & & & \\
\hline
\end{tabular}

\section{Schaal arbo-overleg}

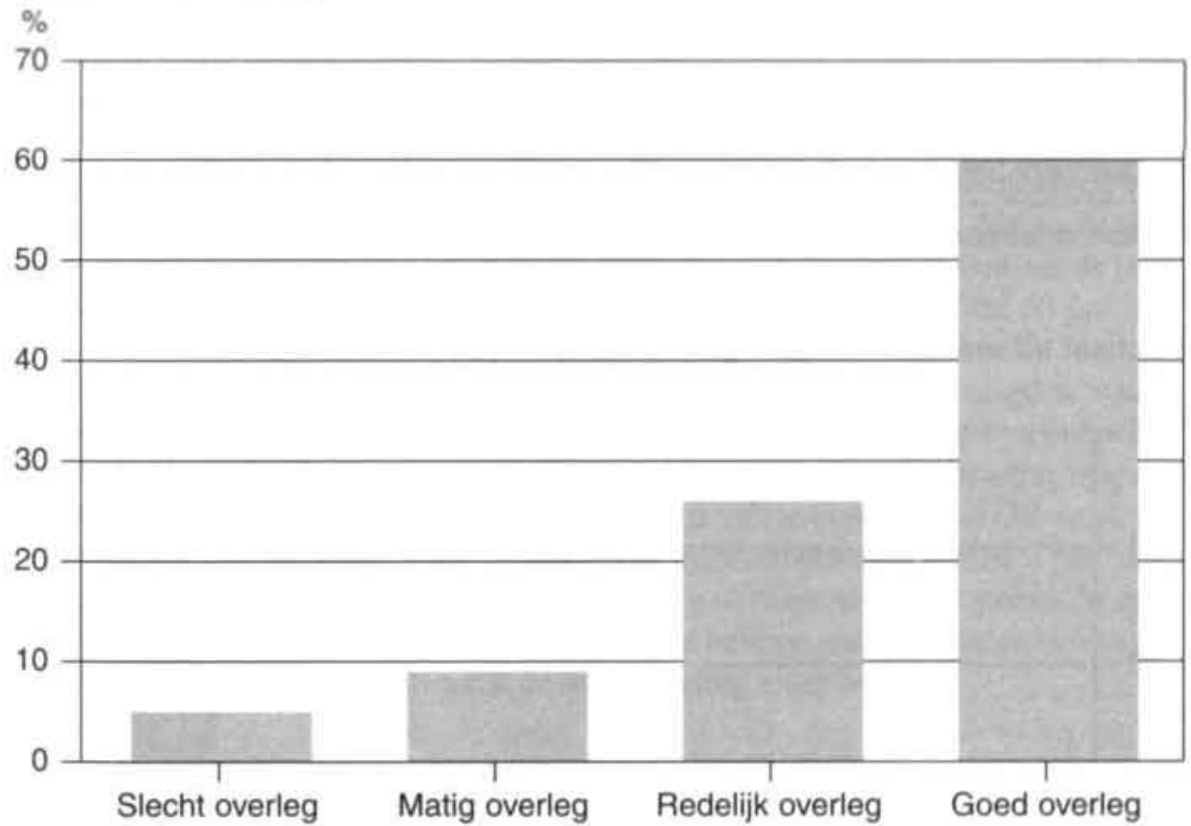

over het plan geen overleg gevoerd met de ondernemingsraad ${ }^{28}-$ minder dus dan $^{2}$ in bovenstaande tabel 4.1.6 (voor een uitgebreider overzicht over de betrokkenheid van de OR bij de risico-inventarisatie en -evaluatie en het plan van aanpak zie par. 5.1.1).

28 Ministerie van Sociale Zaken en Werkgelegenheid (2002), Arbobalans 2002, p. $52-53$ 


\subsubsection{Informatievoorziening}

Het informatierecht van de OR wordt, in kwantitatieve zin, ongeveer op eenzelfde niveau gerespecteerd als het overlegrecht. Ook hierbij scoren de stukken rond het algemene arbobeleid (RI\&E, jaarplan, verzuimcijfers) beter dan de specifieke thema's zoals bijvoorbeeld die over ongevallen en beroepsziekten. Het toezenden van adviezen van de arbodienst aan de OR, één van de hete hangijzers onder de 'oude' Arbowet, bleek in twee op de vijf bedrijven niet te geschieden. Indien ook hier een

Tabel 4.1.7. Informatievoorziening arbobeleid (gewogen)

\begin{tabular}{|l|c|c|c|c|}
\hline & $\begin{array}{c}\% \text { informatie } \\
\text { aanwezig }\end{array}$ & $\begin{array}{c}\% \text { informatie } \\
\text { ontvangen }\end{array}$ & $\begin{array}{c}\% \text { OR } \\
\text { gepasseerd }\end{array}$ & $\mathbf{n}$ \\
\hline RI\&E & 90 & 90 & 10 & 322 \\
Arbojaarplan (100+) & 95 & 92 & 8 & 168 \\
Arbojaarverslag (100+) & 93 & 89 & 11 & 165 \\
Verzuimcijfers & 97 & 89 & 11 & 348 \\
Adviezen arbodienst & 93 & 59 & 41 & 332 \\
Overzicht ongevallen & 78 & 70 & 30 & 280 \\
Overzicht beroepsziekten & 73 & 45 & 55 & 260 \\
\hline Bron: databestand De volwassen OR & \multicolumn{4}{l}{} \\
\hline
\end{tabular}

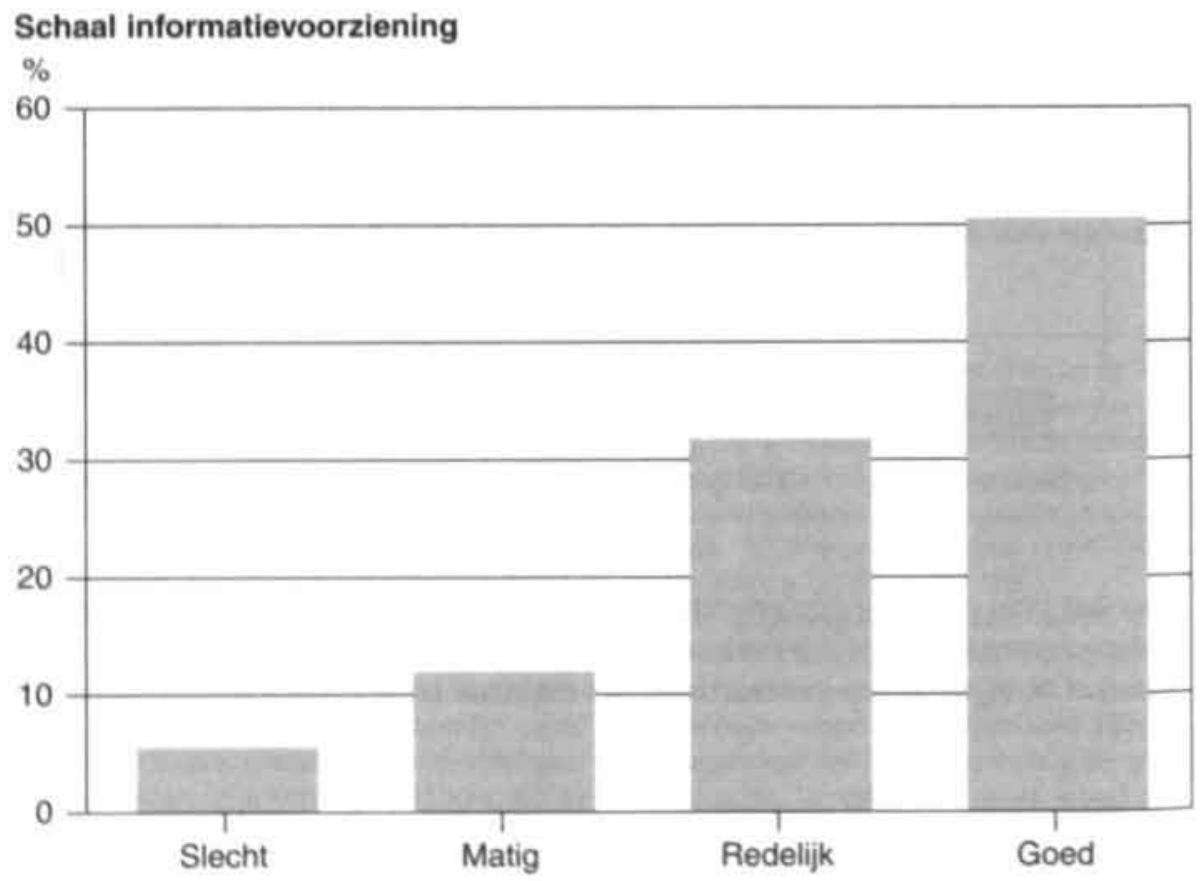


schaal wordt geconstrueerd voor ondernemingsraden waarbij ten minste drie items relevant waren blijkt in algemene zin de informatievoorziening overwegend redelijk tot goed, al is zij in 18 procent van de ondernemingsraden nog altijd matig tot slecht (Cronbach's $\alpha=0.86$ ).

Al met al lijken de basisvoorwaarden voor medezeggenschap - overleg en informatie - in de meeste bedrijven redelijk te zijn ingevuld. Combinatie van beide schalen (Cronbach's $\alpha=0.88$ ) leert dat in 60 procent de basis voor goed te noemen valt. In ongeveer één op de tien bedrijven ontbreekt het echter aan zelfs de meest minimale voorwaarden.

\subsubsection{Tijd en deskundigheid}

Uit diverse onderzoeken blijkt dat gebrek aan tijd en deskundigheid twee persisterende problemen zijn. Medio jaren ' 80 al gaf een behoorlijk deel van de OR-leden aan regelmatig in de knel te zitten wat tijd betrof. Slechts voor een kwart was het geen enkel probleem tijd vrij te maken voor het OR-werk, voor een kwart was het dikwijls of altijd problematisch. In veel gevallen bleef het gewone werk liggen en stapelde het zich op. ${ }^{29}$ De situatie is sindsdien niet veel veranderd. Uit diverse latere onderzoeken blijkt dat flink wat OR-leden onvoldoende tijd hebben om alle belangrijke onderwerpen af te handelen. ${ }^{30}$ Uit onderzoek naar het functioneren van ondernemingsraden op het gebied van arbeidsomstandigheden bleek één op de vier OR'en tijdgebrek als serieuze handelingsbelemmering te ervaren. ${ }^{31}$ Ook uit de herwogen gegevens van het survey De volwassen $O R$, ten slotte, blijkt dat 50 procent van de ondernemingsraden soms en 11 procent vaak krap in de tijd zit. ${ }^{32}$

Opvallend is echter dat, ook al meldt slechts 11 procent van de ondervraagden 'vaak' tijdgebrek, maar liefst 92 procent van de respondenten aangeeft dat zij overbelasting van OR-leden als knelpunt ervaren en 51 procent vreest dat die overbelasting nog zal toenemen. Uit het onderzoek van Bruin en Huijgen valt te lezen dat het OR-werk tot verhoging van de werkdruk leidt. ${ }^{33}$ Tijdgebrek en overbelasting spelen - niet verrassend - met name ondernemingsraden met twee of meer vacatures parten. Vooral ondernemingsraden die over de hele linie moeite hebben om kandidaten te vinden klagen over tijdgebrek en vrezen dat de overbelasting erger wordt. ${ }^{34}$

\footnotetext{
29 Looise/Heijink 1986, p. 119

30 Klein Hesselink/Evers 1994, p. 30; Van het Kaar/Looise 1999, p. 66; Bruin/Huijgen 2000. p. 27

31 Feijen 1994, p, 73

32 In onderzoek van Weening en Teulings meldt 37 procent van de ondernemingsraden onvoldoende tijd voor het OR-werk te hebben. Weening/Teulings 2001, p. 20

33 Bruin/Huijgen 2000, p. 34. Uit ander onderzoek blijkt dat 29 procent van de OR-leden hun OR-werk (zeer) moeilijk te combineren vindt met hun reguliere taken. Weening/Teulings 2001 . p. 20

34 Cramér's V.24. p<.001 resp. Cramér's V.17, p<.05. In de rest van dit hoofdstuk zullen, waar nodig. de significantieniveaus in de lopende tekst worden vermeld, waarbij geldt $"=p<.01 . * *=p<.05$ en ${ }^{* * *}=p<.001$
} 
Op het gebied van deskundigheid valt een zelfde beeld te schetsen als bij tijdgebrek: 88 procent van de respondenten signaleert een gebrek aan deskundigheid onder OR-leden (al vermoedt ruim een derde van de ondervraagden dat dat knelpunt zal afnemen). ${ }^{35}$ Uitgesplitst naar thema blijken de artikel-25-thema's iets vaker tot problemen te leiden dan de instemmingsplichtige besluiten. Van de artikel-27 onderwerpen die de deskundigheid van de OR te boven gaan, is 'arbo' een van de belangrijkste: één op de drie probleemsituaties betreft de thema's arbo- of milieu. ${ }^{36}$ Uit het aangehaalde onderzoek van Feijen bleek dat én op de vier ondernemingsraden gebrek aan deskundigheid op arbogebied als serieuze handelsbelemmering ervaart. ${ }^{37}$ In vergelijking met het eerdere onderzoek van Looise blijkt de ondernemingsraad heden ten dage nauwelijks minder deskundigheidsproblemen te hebben rond instemmingsplichtige thema's dan medio jaren ' 80 , en op arbogebied zelfs iets vaker. ${ }^{38}$ Dat is opvallend, omdat verwacht zou mogen worden dat toegenomen ervaring en scholing een bijdrage zouden leveren aan het opheffen van het kennistekort. De verklaring voor deze ontwikkeling is dat die verwachte 'toegenomen ervaring' nogal tegenvalt: van alle OR-leden heeft de helft hooguit twee jaar ervaring, ${ }^{39}$ en de gemiddelde zittingsduur van OR-leden is slechts 3 à 4 jaar. ${ }^{40}$

Tabel 4.1.8. Deskundigheidspmoblemen bij toepassing bevoegdheden (in \%)

\begin{tabular}{|l|c|c|c|}
\hline & $\begin{array}{c}\text { adviesrecht } \\
\text { (n=352, } \\
\text { gewogen) }\end{array}$ & $\begin{array}{c}\text { instemmings- } \\
\text { recht }(\mathbf{n = 3 3 9 ,} \\
\text { gewogen) }\end{array}$ & $\begin{array}{c}\text { instemmingsrecht 1985 } \\
\text { (n=172, gecorrigeerd } \\
\text { voor 'geen antwoord') }\end{array}$ \\
\hline (Vrijwel) nooit & 38 & 60 & 59 \\
Soms & 50 & 36 & 32 \\
Vaak & 12 & 4 & 9 \\
\hline \multicolumn{2}{|l}{ Bron: databestand De volwassen OR } \\
\hline
\end{tabular}

35 Ook de helft van de bestuurders signaleert een gebrek aan deskundigheid bij ondernemingsraden ( $n=458$, ongewogen). Van het Kaar/Looise 1999, p. 135.

36 Waarschijnlijk is dit nog een al te rooskleurige inschatting van de eigen deskundigheid. Uit evaluatie-onderzoek rond de Arbeidstijdenwet bleek uit de enquêtegegevens dat hooguit de helft van de ondervraagde ondernemingsraden op de hoogte was van de relevante regels, terwijl uit de casestudies een veel geringere kennis bij de OR bleek. Mevissen 2001. p. 82

37 Feijen 1994, p. 73

$38 \mathrm{Vg}$. Looise/De Lange 1987, p. 91. Blijkens p. 93 van dat onderzoek signaleende in $19859 \%$ van de OR-voorzitters deskundigheidsproblemen op arbogebied. In ons onderzoek is dat percentage nog iets hoger: 39 OR'en is bijna II\% van de onderzoekspopulatie. In onderzoek van het GBIO blijken OR' en overigens veel vaker deskundigheidsproblemen te signaleren: $25 \%$ vaak en $51 \%$ soms. Feijen 1994, p. 15

39 H. van den Tillaart (2002), Invloed en herkenbaarheid van OR-werk. Den Haag: Elsevier/GBIO, p. 89

40 M. Brugmans en E. Bruin (1996), VGW-en? een vak apart!' Utrecht: GBIO. p. 2 
Bovendien gaat naar schatting 35 procent van de ondernemingsraden in het geheel niet op cursus. ${ }^{41}$

Een andere verklaring is dat, voor wat betreft het thema arbeidsomstandigheden, het aantal cursusdagen specifiek over dit onderwerp sterk achterblijft bij de verwachting. ${ }^{42}$ Met name het aantal vaste VGW(M)-commissies dat cursussen afneemt valt tegen: terwijl in het registratiesysteem van het GBIO ruim 9000 medezeggenschapsorganen zijn opgenomen, is het aantal VGW(M)-commissies slechts 354 . Dat is nog geen vier procent van het totaal ${ }^{43}$, terwijl zoals zal blijken uit paragraaf 4.1.2.4 ongeveer de helft van de ondernemingsraden een vaste VGW(M)-commissies heeft ingesteld. Ook gaan de bij het GBIO bekende commissies minder frequent op cursus dan de andere medezeggenschapsorganen én minder dagen (4,0 dagen per drie jaar voor de VGW(M)-commissies tegen 5,7 voor de ondernemingsraden). ${ }^{44}$

Uit eerder onderzoek van het GBIO naar de onderuitputting van het scholingsrecht door VGW(M)-commissies komt een aantal mogelijke verklaringen naar voren. In ieder geval geeft maar liefst 61 procent van de VGW(M)-commissies aan belemmeringen te ervaren om op scholing te gaan. ${ }^{45}$ Gebrek aan scholingsdagen, tijd of geld lijken nog de minste problemen, al lijkt die bevinding toch geen recht te doen aan andere onderzoeken waarin tijd voor 33 procent en geld voor 28 procent van de ondernemingsraden wel degelijk een probleem is. ${ }^{46}$ Als belangrijkste struikelblok noemt Brugmans dat de VGW(M)-commissie geen duidelijk beeld heeft van de eigen scholingsbehoefte ( 69 procent). Ook is de arboscholing onvoldoende toegesneden op het eigen bedrijf ( 55 procent) en onvoldoende bruikbaar ( 53 procent). ${ }^{47}$

Een andere mogelijkheid tot het verwerven van deskundigheid is het inschakelen van de arbodienst of externe (arbo-)deskundige, hetzij op basis van het contract met de arbodienst (art. 14, lid 3e, Arbowet, jo. par. 2.7.2-4 Certificeringsregeling) het-

41 B. van Lammeren (2002), Scholingsvraag marktsector groeit nog steeds, in: OR-Informatie. jg. $28 \mathrm{nr} .8$, p. 21

42 GBIO, Jaarverslag 1998, p. 14

43 GBIO 2003, ongepubliceerde gegevens. Over de periode 1993-2001 was het percentage VGW(M)-commissies van ondernemingsraden 3,6 (bron: GBIO, ongepubliceerde gegevens).

44 GBIO 2003, ongepubliceerde gegevens. Uitgaande van een scholingsrecht van 9 dagen per 3 jaar (art. 18, lid 3, WOR) is dat een benuttingsgraad van $44 \%$. Voor de ondernemingsraden is de benuttingsgraad overigens nog lager; $38 \%$ van de 15 dagen.

45 Brugmans/Bruin 1996, p. 47.

46 Feijen 1994, p. 25. Vgl. ook R.H. van het Kaar e.a. (1998), De rechtspositie van OR-leden en de effectiviteit van de SER-aanbevelingen ter zake, Den Haag: VUGA. Hoewel 70\% van de ORvoorzitters signaleert dat er problemen zijn bij de combineerbaarheid van werk en OR-werk, geldt dit volgens de onderzoekers niet zozeer rond deelname aan scholing (p. 32)-maar de $18 \%$ die hier wél knelpunten signaleren is natuurlijk niet gering. In onderzoek onder gemeentelijke OR'en bleek 'drukte op het werk' de belangrijkste belemmering. P. Kerkhof en P.G. Klandermans (1998), Medezeggenschap beter geregeld?. Den Haag: Den Haag: A+O fonds gemeenten, p. 54

47 Brugmans/Bruin 1996, p. 47. Deze conclusie wordt gedeeld door cursusleiders. $\mathrm{Vgl}$. T. Kamphof (1995), De kwaliteit van arboscholing aan medezeggenschapsorganen, Amsterdam. Scriptie UvA, p. 38 
zij op grond van artikel 16 WOR. In het kader van het survey is geen onderzoek gedaan naar het daadwerkelijk inhuren van arbodeskundigheid. Uit de schaarse andere onderzoeken kan echter gesteld worden dat ondernemingsraden slechts zelden gebruik maken van de diensten van de arbodienst. ${ }^{48}$ In de meeste contracten met arbodiensten ligt het accent veelal op verzuimbegeleiding, en niet op preventie. ${ }^{49}$ Specifieke bepalingen over samenwerking met de ondernemingsraad komen slechts zelden voor. Ondernemingsraden waarderen de samenwerking bovendien ruim onvoldoende: op een schaal van één tot tien ligt het gemiddelde rapportcijfer op 3,6 (voor een uitgebreider bespreking van de relatie OR-arbodienst zie paragraaf 4.1.4). ${ }^{50}$ Ook uit onderzoek van Feijen blijkt dat medezeggenschappers zich onvoldoende gesteund voelen door deskundigen. ${ }^{51}$

\subsubsection{VGW(M)-commissies}

Een andere methode om deskundigheid op te bouwen - of althans de OR te ondersteunen bij zijn arbotaken - is het instellen van een VGW(M)-commissie. Het instellen van een commissie kan ook de belasting voor het OR-werk spreiden over meerdere werknemers (met name door het inschakelen van zogeheten 'buitenleden'). In de praktijk wordt vaak gebruik gemaakt van de mogelijkheid een commissie in te stellen. Zo'n 55 procent van alle geènquêteerde ondernemingsraden heeft een commissie ingesteld, waarvan een meerderheid ( 62 procent) het onderwerp 'milieu' heeft toegevoegd. Daarmee is de VGW(M)-commissie verreweg het meest voorkomende type van alle vaste commissies. ${ }^{52}$ Hoe groter de OR, des te vaker een VGW(M)-commissie is ingesteld. In bedrijven met minder dan 100 werk

Tabel 4.1.9. Instellen VGW(M)-commissie (in\%, gewogen $n=357$ )

\begin{tabular}{|l|r|r|r|r|r|}
\hline & $\mathbf{1 0 0}$ & $\mathbf{1 0 0 - 2 0 0}$ & $\mathbf{2 0 0 - 5 0 0}$ & $\mathbf{5 0 0 +}$ & totaal \\
\hline VGW & 12 & 36 & 35 & 20 & 20 \\
VGWM & 19 & 30 & 48 & 63 & 34 \\
Géén & 68 & 34 & 17 & 17 & 45 \\
& 100 & 100 & 100 & 100 & 100 \\
\hline
\end{tabular}

48 Overigens is 'arbo' wel het thema waar de OR het meest frequent een deskundige raadpleegt $(28 \%)$, maar in het algemeen schakelen ondernemingsraden slechts zelden een deskundige in. Wat het karakter is van de raadpleging van de arbo-deskundige is niet geheel en al duidelijk. Weening/Teulings 2001, p. 34

49 Ter Huurne 1997. p. 111. Rapportage 1997. p. 74. Vgl. ook Arbodienstenmonitor '98: Erik Visser, De invloed van de arbodienst op het verzuim is er wel degelijk, in: Rendemens, november 1999, p. 19

50 Jan Popma (1999). Arbosterrengids: Guide Michelin voor or' en. in: OR-Informatie, december 1999, p. $52-55$

51 Feijen 1996, p. 73

$52 \mathrm{Vgl}$. ook Weening/Teulings (2001). p. 15 
nemers hebben twee van de drie géén commissie, in de $500+$ bedrijven heeft 83 procent wél een VGW(M)-commissie. Ook hebben grotere ondernemingsraden het thema 'milieu' significant vaker toegevoegd aan het takenpakket (Cramér's V. $\left.37^{* * *}\right)$.

Het percentage VGW(M)-commissies is vergelijkbaar met dat in onderzoek van Van den Tillaart. Hij komt op een percentage van $60 .{ }^{53}$ Uit eerder onderzoek naar de naleving van de WOR bleek dat in 199246 procent van alle OR'en een VGW(M)-commissie had ingesteld. ${ }^{54}$ Er zit dus enige groei in het aantal commissies.

De aanwezigheid van een VGW(M)-commissie levert, zoals verondersteld, inderdaad een bijdrage aan de deskundigheid van de $\mathrm{OR}$. Ondernemingsraden mét VGW(M)-commissie signaleren iets minder vaak deskundigheidsproblemen rond arbothema's dan OR'en zonder commissie (10.7 tegen 11.1 procent). Deze verschillen zijn statistisch echter niet significant. Ondernemingsraden mét een VGW(M)-commissie rapporteren, zoals verwacht, ook minder tijdgebrek dan de commissieloze OR (V.12**). Desondanks leidt het instellen van een commissie nauwelijks tot een duidelijke reductie van de overbelasting. Dat valt wellicht te verklaren uit het gegeven dat ondernemingsraden mét commissie duidelijk meer aandacht besteden aan arbobeleid dan ondernemingsraden zonder VGW(M)-commissie (V.21***). Ook nemen zij hun stimulerende taak op het gebied van arbo- en verzuimbeleid duidelijk serieuzer (V.25 resp. V.21***). De samenhang tussen de aan- of afwezigheid van een commissie en de actieve opstelling werkt uiteraard twee kanten op: het kan zijn dat de OR actiever is omdát er een commissie is, maar het kan ook zijn dat de commissie is opgericht juist omdat de OR zich actief opstelt.

Tabel 4.1.10. Zelfstandig overleg VGW(M)-commissie (in\%, gewogen $n=183-189$ )

\begin{tabular}{|l|r|r|r|}
\hline & ja & nee & nvt \\
\hline Bestuurder & 77 & 22 & 1 \\
Arbodienst & 86 & 12 & 2 \\
Arbo-coördinator & 91 & 4 & 5 \\
Arbeidsinspectie & 72 & 18 & 10 \\
\hline Bron: databestand De volwassen OR \\
\hline
\end{tabular}

De meeste ondernemingsraden geven hun VGW(M)-commissie redelijk veel vrijheid in het overleg met andere partijen op het gebied van arbeidsomstandigheden,

53 Van den Tillaart 2002, p. 91. Bruin en Huijgen komen op een percentage van $50 \%$ (Bruin/Huijgen 2000, p. 28). Hun verklaring is dat de respondenten in het onderzoek De volwassen $O R$ wellicht ook de arbo-commissie van het bedrijf als VGW-commissie betitelen. Vanuit mijn ervaring als OR-cursusleider lijkt deze verklaring mij zeker plausibel.

54 P.R.A. Oeij en P.A Stoppelenburg (1998), Naleving van de Wet op de ondermemingsraden: Stand van zaken 1997, VUGA/Ministerie van Sociale Zaken en Werkgelegenheid, p. 37 
te weten de bestuurder, de arbodienst, de arbocoördinator en (eventueel) de Arbeidsinspectie.

In het merendeel van de bedrijven mag de OR dus betrekkelijk zelfstandig overleggen, óók met de bestuurder. De overdracht van het instemmingsrecht is echter

Tabel 4.1.11. Overdracht bevoegdheden aan VGW(M)-commissie (in \%, gewogen $n=187$. 195)

\begin{tabular}{|l|r|r|r|r|l|}
\hline & $100-$ & $100-200$ & $\mathbf{2 0 0 - 5 0 0}$ & $500+$ & totaal \\
\hline Zelfstandig overleg met & & & & & \\
bestuurder & 94 & 86 & 77 & 60 & 78 \\
Instemmingsrecht & 23 & 8 & 9 & 5 & 11 \\
Adviesrecht & 16 & 31 & 24 & 34 & 26 \\
\hline Bron: databestand De volwassen OR
\end{tabular}

een zeldzaamheid. Slechts één op de negen ondernemingsraden heeft van de OR zijn instemmingsrecht overgedragen gekregen. Overdracht van het adviesrecht komt iets vaker voor: in ruim één op de vier bedrijven neemt de ondernemingsraad eventuele pre-adviezen van de VGW(M)-commissie over.

\begin{tabular}{|l|c|}
\hline de commissieloze OR & $46 \%$ \\
\hline $\begin{array}{l}\text { de 'staf'-OR, die de VGW(M)-commissie uitsluitend gebruikt ter } \\
\text { ondersteuning van de eigen werkzaamheden, maar het overleg én de } \\
\text { formele bevoegdheden in eigen hand houdt }\end{array}$ & $18 \%$ \\
\hline $\begin{array}{l}\text { de formalistische OR, die wél de overlegtaken heeft gedelegeerd, } \\
\text { maar het advies- en instemmingsrecht in eigen hand houdt }\end{array}$ & $25 \%$ \\
\hline $\begin{array}{l}\text { de professionele OR, die alle voorbereidende taken heeft } \\
\text { overgedragen (waaronder het beoordelen van adviesaanvragen) } \\
\text { maar het instemmingsrecht in eigen hand houdt }\end{array}$ & $8 \%$ \\
\hline $\begin{array}{l}\text { de delegerende OR, die óók zijn instemmingsrecht heeft over- } \\
\text { gedragen aan de VGW(M)-commissie }\end{array}$ & $3 \%$ \\
\hline
\end{tabular}

\section{Typologie van de arbo-OR}

Op grond van de hierboven geschetste items kan een overzichtelijke typologie van de interne organisatie van de OR worden gemaakt. Hierbij zijn vijf typen te onderscheiden:

Vooruitlopend op de nadere analyse in paragraaf $4.2 \mathrm{kan}$ hier worden opgemerkt dat een vergaande delegatie van bevoegdheden in het overleg met de bestuurder (met 
name ook de overdracht van de instemmingsbevoegdheid) een tamelijk sterke samenhang blijkt te vertonen met de overlegcultuur en de opstelling van de bestuurder. In bedrijven waar de VGW(M)-commissie volledig de vrije hand heeft gekregen, is relatief vaak sprake van open overleg, blijkt de bestuurder duidelijk meer geneigd tot concessies én wordt minder vaak arbobeleid gemaakt zonder overleg. In bedrijven waar de commissie wél overleg voert met de bestuurder maar de formele bevoegdheden in handen van de OR blijven, treedt de bestuurder formeler op en heeft het overleg meer het karakter van onderhandelingen. De opstelling van de bestuurder is dus een belangrijke factor in de vormgeving van de interne organisatie van de OR op het gebied van arbeidsomstandigheden.

Uit bovenstaande gegevens kan worden geconcludeerd dat het instellen van een VGW(M)-commissie een positieve bijdrage levert aan het arbo-overleg. Ondernemingsraden mét VGW(M)-commissie hebben vaker overleg, betere informatie, en iets minder tijdgebrek. Ook kunnen zij meer energie steken in het arbobeleid. De delegatie van bevoegdheden aan de commissie lijkt eveneens effectief. Zelfstandige VGW(M)-commissies hebben beter overleg met de bestuurder én de informatievoorziening is duidelijk beter. Ondernemingsraden die wél het overleg uitbesteden aan de VGW(M)-commissie maar uiteindelijk het wapen van de formele bevoegdheden zélf hanteren, hebben een moeizamer relatie met de bestuurder (formeler én met meer accent op machtsverhoudingen) dan ondernemingsraden die alle arbotaken volledig hebben gedelegeerd én dan ondernemingsraden die de VGW(M)commissie puur zien als een 'stafafdeling' van de OR.

\subsubsection{Het gebruik van bevoegdheden}

Zoals aangegeven in paragraaf 3.3 hebben ondernemingsraden een aantal bijzondere bevoegdheden, die ingezet kunnen worden om het arbeidsomstandighedenbeleid in hun bedrijf te beïnloeden: het initiatiefrecht, het instemmingsrecht en het adviesrecht. In paragraaf 4.1 .1 is reeds bekeken in hoeverre ondernemingsraden gebruik maken van hun initiatiefrecht. De conclusie was: 'spaarzaam'. In deze paragraaf wordt bekeken in hoeverre de andere bevoegdheden in stelling worden gebracht. In paragraaf 4.1.3.1 wordt het instemmingsrecht onder de loep genomen, en in paragraaf 4.1.3.2 wordt bezien of 'arbo' een plek heeft in adviezen van de OR.

\subsubsection{Instemmingsrecht}

Ondernemingsraden hebben instemmingsrecht bij regelingen op het gebied van arbeidsomstandigheden. In het onderzoek De volwassen $O R$ is nagegaan of en in hoeverre ondernemingsraden daadwerkelijk gebruik maken van dit recht, en met welk resultaat. Hoe ver het instemmingsrecht strekt, is echter lange tijd onduidelijk gebleven (verg. par. 3.3.2). Met het oog op deze onduidelijkheid is alleen de toepassing van het instemmingsrecht onderzocht rond een aantal thema's waar op het moment van onderzoek duidelijk mocht worden geacht dat de OR inderdaad instemmingsrecht heeft: specifieke regelingen op het gebied van ziekteverzuim, PAGO en aanstellingskeuringen, maar ook rond de keuze van de arbodienst. Dat 
betekent dat met name de gang van zaken rond de risico-inventarisatie en het plan van aanpak niet is onderzocht.

\section{Instemmingsrecht rond arbothema's}

De meeste van deze thema's zijn eerder aan de orde gekomen bij de bespreking van het overlegrecht (paragraaf 4.1.2). Daar bleek dat over het verzuimbeleid nog wel frequent overleg werd gevoerd, maar dat rond de meer specifieke thema's de OR toch tamelijk vaak genegeerd werd. Waar het overlegrecht al niet optimaal gerespecteerd wordt, valt te voorzien dat de toepassing van het instemmingsrecht nog vaker tot problemen leidt, een verwachting die door de cijfers wordt geboekstaafd. Op het gebied van het verzuimbeleid wordt het instemmingsrecht nog het best gerespecteerd: van alle bedrijven die in de periode 1996-1997 een regeling hadden getroffen op het gebied van het verzuimbeleid, heeft 71 procent de OR netjes om instemming gevraagd. Dat betekent echter wél dat bijna één op de drie verzuimregelingen is getroffen zonder de vereiste instemming van de OR. Op de andere punten wordt nog slechter gescoord. Met name aanstellingskeuringen worden in een meerderheid der bedrijven zonder instemming te vragen ingevoerd. ${ }^{55}$

De formele gang van zaken rond arbodiensten voldoet evenmin aan de eisen. In bijna de helft van de gevallen is de OR gepasseerd. ${ }^{56}$ Dat strookt met de resultaten uit eerder onderzoek onder werkgevers. Blijkens het ZARA-werkgeverspanel 19961997 werd in 26 procent van de gevallen helemaal niet overlegd met de OR over de keuze van de arbodienst, en in de gevallen waarin dat overleg wél plaatsvond was

Tabel 4.1.12. Instemmingsaanvragen nondom arbobeleid (in \%)

\begin{tabular}{|l|c|c|c|c|}
\hline & $\begin{array}{c}\% \text { regeling } \\
\text { getroffen }\end{array}$ & $\begin{array}{c}\% \text { instemming } \\
\text { gevraagd }\end{array}$ & $\begin{array}{c}\% \text { OR } \\
\text { gepasseerd }\end{array}$ & $\begin{array}{c}\text { gewogen } \\
\mathbf{n}\end{array}$ \\
\hline Verzuimbeleid & 55 & 71 & 29 & 181 \\
Keuze arbodienst & 64 & 57 & 43 & 215 \\
Contract arbodienst & 70 & 53 & 47 & 235 \\
PAGO & 58 & 57 & 43 & 188 \\
Aanstellingskeuringen & 45 & 40 & 60 & 147 \\
Bedrijtshulpverlening & 67 & 68 & 32 & 222 \\
\hline Bron: databestand De volwassen OR
\end{tabular}

55 Terwijl aanstellingskeuringen zelfs via twee routes onder het instemmingsrecht zouden kunnen worden geschaard: als regeling op het gebied van arbeidsomstandigheden én als regeling op het gebied van het aanstellingsbeleid (art. 27, lid le, WOR).

56 Uit onderzoek van de FNV blijkt dat ondernemingsraden niet alleen vaak niet om instemming wordt gevraagd, maar dat bijna de helft de OR'en (44\%) zelfs in het geheel niet betrokken wordt bij de keuze van de arbodienst, en dat $55 \%$ geen overleg heeft gevoerd over de inhoud van het pakket. J. Hooiveld en G. Kuiperij (1999), Arboprof: Arbosterrengids 2000. Zeist: Kerckebosch/FNV 
35 procent van de werkgevers van mening dat geen instemming gevraagd hoefde te worden aan de ondernemingsraad. In totaal had dus slechts 48 procent van de ondernemingsraden een instemmingsaanvraag ontvangen ${ }^{57}$, tegen 57 procent in ons eigen onderzoek. Over de inhoud van het contract werd blijkens het werkgeverspanel nog minder vaak overlegd: in totaal ontving slechts 37 procent van de ondernemingsraden een formele instemmingsaanvraag ${ }^{58}$, tegen 53 procent in ons eigen onderzoek (uitgebreider: paragraaf 4.1.4).

Herrekening van de bovenstaande gegevens naar een vier-puntsschaal ( $\alpha=0.84)$ geeft het volgende beeld: in de 224 bedrijven waarin ten minste drie instemmingsplichtige thema's aan de orde zijn geweest, wordt één op de vijf ( 21 procent) ondernemingsraden structureel gepasseerd, en heeft ongeveer eenzelfde percentage (18 procent) regelmatig te klagen. Slechts in 37 procent van de bedrijven worden de procedures tot in de puntjes gevolgd.

\section{Schaal instemmingsrecht}

$\%$

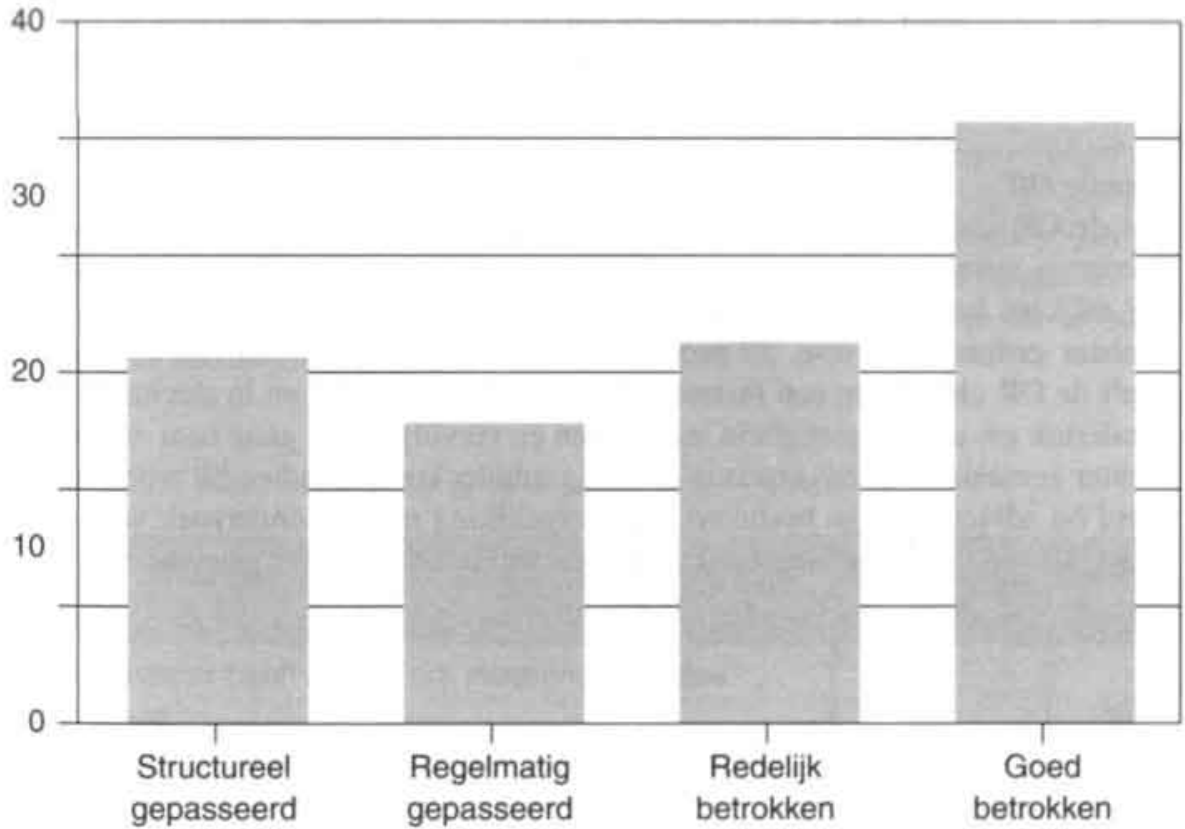

Op basis van bovenstaande gegevens kan, bij wijze van tussenconclusie, worden vastgesteld dat ondernemingsraden veelvuldig worden gepasseerd bij instem-

57 Ter Huurne 1997. p. 121

58 Ibid. 
mingsplichtige besluiten: 40 procent van de ondernemingsraden wordt geregeld of zelfs stelselmatig genegeerd. Een telling van het aantal malen 'OR gepasseerd' komt voor de 374 bedrijven uit het survey in twee jaar tijd op zo'n 500 instemmingsplichtige besluiten die zijn genomen zonder de formele goedkeuring van de $\mathrm{OR}$. Kennelijk hebben de ondernemingsraden zélf echter niet zo scherp in de gaten dat ze links en rechts gepasseerd worden door hun bestuurder. In het survey $D e v o l-$ wassen $O R$ is namelijk ook expliciet gevraagd hoe vaak de OR de afgelopen twee jaar gepasseerd was rond een instemmingsplichtig besluit, en in welke gevallen het een regeling op het gebied van arbeidsomstandigheden betrof. De respons op deze vragen levert een duidelijk rooskleuriger beeld op: slechts één op de vier respondenten geeft aan dat in hun bedrijf de bestuurder één of meerdere keren een besluit heeft genomen zonder de vereiste instemming, en één op de vijf wist het niet zeker. ${ }^{59}$ Van de 77 besluiten die genoemd zijn, betroffen 18 stuks ( 23 procent) een regeling op het gebied van arbeidsomstandigheden. Dit aantal van 18 zelfgerapporteerde gevallen waarin de OR expliciet aangaf gepasseerd te zijn steekt schril af tegen de berekende 500 gevallen waaruit impliciet blijkt dat de OR is gepasseerd. Nogmaals: kennelijk hebben de ondernemingsraden zelf niet in de gaten dat ze worden gepasseerd. Dat kan betekenen dat zij of onvoldoende alert zijn of simpelweg niet weten over welke onderwerpen zij instemmingsrecht zouden mogen claimen

\section{Reactie OR}

Als de OR zich wél bewust is van het feit dat hij gepasseerd wordt, levert dat overigens weinig actie op van de medezeggenschappers. Opvallend vaak heeft de OR blijkens het survey in het geheel niet gereageerd of hooguit zijn ongenoegen kenbaar gemaakt (10 resp. 59 procent). In nauwelijks een kwart van de gevallen heeft de OR alsnog om een instemmingsaanvraag gevraagd, en in slechts een uitzonderlijk geval is de nietigheid ingeroepen en vervolgens de gang naar de kantonrechter gemaakt. ${ }^{60}$ Overigens is de OR nóg minder kordaat indien hij wordt gepasseerd bij adviesplichtige besluiten. ${ }^{61}$ In vergelijking met het onderzoek van medio jaren ' 80 is de ondernemingsraad overigens wel iets assertiever geworden. ${ }^{62}$

59 Dit is een flinke vooruitgang ten opzichte van 1985 , toen $45 \%$ van de ondernemingsraden aangaf dat 'non-decisie' rond instemmingsplichtige kwesties voorkwam in hun organisatie. Looise/De Lange 1987, p. 34.

60 Uitvergroot naar het totale aantal ondernemingsraden zou het gevonden percentage van $3 \%$ overigens impliceren dat er meer dan 200 kantongerechtprocedures per jaar worden gevoerd omtrent arbozaken. Dit is zonder twijfel een extreme overschatting. gezien de zéér beperkte jurisprudentie omtrent arbokwesties (vgl. par. 3.3.2).

$61 \mathrm{Vgl}$. Van het Kaar/Looise 1999. p. 92-93. Van het Kaar signaleert dat "een sterke samenhang [bestaat] tussen non-decisie bij het adviesrecht en bij het instemmingsrecht: ondernemingsraden die relatief vaak gepasseend worden bij het adviesrecht worden ook vaker dan gemiddeld gepasseerd bij het instemmingsrecht en omgekeerd."

62 Looise/De Lange 1987, p. 37 
Tabel 4.1.13. Reactie op onthouden van instemmings- en adviesaanvragen (\% ondernemingsraden)

\begin{tabular}{|l|c|c|}
\hline & $\begin{array}{c}\text { instemming, } \\
\mathbf{n = 7 8}\end{array}$ & $\begin{array}{c}\text { advies, } \\
\mathbf{n = 1 5 1}\end{array}$ \\
\hline $\begin{array}{l}\text { OR heeft daarop niet gereageerd } \\
\text { OR heeft ondernemer zijn ongenoegen laten blijken } \\
\text { OR heeft druk uitgeoefend om instemmingsverzoek' } \\
\text { adviesaanvraag af te dwingen (publiciteit, vergader- }\end{array}$ & 52 & 66 \\
boycot e.d.) & 19 & 9 \\
$\begin{array}{l}\text { OR heeft bemiddeling bedrijfscommissie ingeroepen } \\
\text { OR heeft nietigheid besluit ingeroepen -> besluit }\end{array}$ & 0 & 0 \\
ingetrokken & 4 & 12 \\
OR heeft nietigheid besluit ingeroepen -> & 3 & 100 \\
Kantonrechter ingeschakeld & 12 & \\
OR heeft rechter ingeschakeld & 100 & \\
Anders/meerdere reacties & & \\
totaal & & \\
\hline Bron: databestand De volwassen OR & & \\
\hline
\end{tabular}

Het resultaat van de tamelijk lauwe opstelling van de OR bij 'non-decisie' (het passeren van de OR bij advies- of instemmingsplichtige besluiten) is bovendien niet om over naar huis te schrijven: in ongeveer de helft van de gevallen zet de ondernemer het besluit gewoon door.

Tabel 4.1.14. Reactie bestuurder op de actie van de OR (\% bestuurders)

\begin{tabular}{|l|c|c|}
\hline & $\begin{array}{c}\text { instemming, } \\
n=78\end{array}$ & $\begin{array}{c}\text { advies, } \\
n=151\end{array}$ \\
\hline $\begin{array}{l}\text { Ondernemer heeft alsnog om instemming/advies } \\
\text { gevraagd }\end{array}$ & 40 & 12 \\
Ondernemer heeft niet alsnog om instemming/advies & 49 & 44 \\
gevraagd & 11 & 1 \\
Ondernemer heeft besluit ingetrokken & & 16 \\
undernemer heeft het besluit geheel/gedeeltelijk & 100 & 17 \\
Ondernemer heeft beterschap beloofd & & 100 \\
OR onder druk gezet & & \\
Overig & & 17 \\
\hline Totaal & & \\
\hline Bron: databestand De volwassen OR & & \\
\hline
\end{tabular}


$\mathrm{Na}$ de eerdere tussenconclusie dat ondernemingsraden veelvuldig worden gepasseerd bij instemmingsplichtige besluiten, kan op dit punt als tweede tussenconclusie worden gesteld dat nogal wat medezeggenschappers niet in de gaten hebben dát ze worden gepasseerd. Als ze het wél doorhebben, zo luidt een derde tussentijdse vaststelling, gaan zij relatief weinig tot actie over. Vooral ondernemingsraden in kleinere bedrijven blijken nauwelijks in het geweer te komen tegen een schending van hun instemmingsrecht. $\mathrm{Zij}$ tonen ook minder actiebereidheid, en hebben minder contact met de achterban en de vakbond: twee variabelen die tamelijk sterk samenhangen met de bereidheid van bestuurders om het instemmingsrecht te respecteren.

\section{Moment van inschakelen $O R$}

In het onderzoek De volwassen $O R$ is ook gevraagd naar het tijdstip waarop de ondernemingsraad is ingeschakeld, onderscheiden naar het moment waarop de OR voor het eerst wordt geïnformeerd en het tijdstip waarop formeel instemming is gevraagd. Anders dan bij het adviesrecht, waarbij de WOR vermeldt dat de ondernemingsraad moet worden ingeschakeld op een zodanig tijdstip dat diens advies van wezenlijke invloed kan zijn op het te nemen besluit, is bij het instemmingsrecht geen wettelijke bepaling opgenomen wat betreft het moment waarop de OR moet worden betrokken. Uit het onderzoek blijkt dat de OR overwegend in een vroeg stadium wordt geïnformeerd over een ophanden zijnde regeling - op het gebied van arbeidsomstandigheden overigens iets later dan op de andere deelgebieden. Vergelijking met het eerdere OR-onderzoek van Looise en Heijink leert dat de ondernemingsraad anno 1996-1997 aanmerkelijk vroeger in het besluitvormingstraject wordt betrokken dan een decennium eerder. ${ }^{63}$

Tabel 4.1.15. Tijdstip waarop OR werd geïformeerd

\begin{tabular}{|l|c|c|c|}
\hline \multirow{2}{*}{} & \multicolumn{2}{|c|}{$\begin{array}{c}\text { Instemmingsplichtige } \\
\text { regeling (in \%) }\end{array}$} & $\begin{array}{c}\text { Arbo } \\
\text { regelingen }\end{array}$ \\
\cline { 2 - 4 } & $\begin{array}{c}1998 \\
(\mathbf{n}=704)\end{array}$ & $\begin{array}{c}1985 \\
(\mathbf{n}=419)\end{array}$ & $\begin{array}{c}1998 \\
(\mathbf{n}=118)\end{array}$ \\
\hline Zodra relevante gegevens bekend waren & 54 & 29 & 48 \\
Eerste plan van aanpak gereed & 21 & 41 & 18 \\
Toen directie principe-besluit had genomen & 15 & 20 & 14 \\
Op moment formele instemmingsaanvraag & 9 & 25 & 20 \\
\hline Bron: databestand De volwassen OR en Looise/De Lange 1987
\end{tabular}

Instemmingsprocedure: snelheid

Hierboven is vastgesteld dat de bestuurder nogal eens nalaat instemmingsplichtige besluiten voor te leggen aan de OR. Hiervoor zijn diverse mogelijke redenen aan te voeren: de bestuurder nóch de $O R$ is op de hoogte van de instemmingsplicht of ver-

63 Looise/Heijink 1986, p. 51 
schillen hierover van mening, de bestuurder ziet geen toegevoegde waarde van medezeggenschap of wil vertraging in de besluitvorming voorkomen, of de bestuurder vreest geen instemming te krijgen. Uit het onderzoek blijkt echter dat in ieder geval de laatste drie argumenten geen hout snijden.

Uit het survey De volwassen $O R$ blijkt, ten eerste, dat de meeste bestuurders wel degelijk waarde hechten aan de bijdrage van de ondernemingsraad. De bestuurders zijn overwegend van mening dat medezeggenschap de kwaliteit van de besluitvorming ten goede komt. Bijna twee derde ( 62 procent) van de bestuurders is van mening dat betrokkenheid van de OR tot zorgvuldiger besluitvorming leidt, 44 procent acht de besluiten inhoudelijk beter dan zonder medezeggenschap, en 67 procent geeft aan dat medezeggenschap het draagvlak voor besluiten versterkt. Bestuurders die overwegend positief staan tegenover medezeggenschap blijken de OR duidelijk minder vaak te passeren dan de meer kritische bestuurders - hetgeen uiteraard geen verrassing is $\left(\mathrm{V} .41^{* * *}\right)$. Ook het overleg en de informatievoorziening lijken iets beter, maar deze samenhang is niet significant (voor een meer uitgebreide analyse zie paragraaf 4.2).

Tabel 4.1.16. Het effect van medezeggenschap (in \%)

\begin{tabular}{|l|c|c|c|c|c|}
\hline Effect van medezeggenschap & \multicolumn{2}{|c|}{$\begin{array}{c}\text { volgens } \\
\text { bestuurder }\end{array}$} & \multicolumn{2}{|c|}{$\begin{array}{c}\text { volgens } \\
\text { OR }\end{array}$} & $\begin{array}{c}\text { volgens } \\
\text { werknemers }\end{array}$ \\
\cline { 2 - 6 } & ja & integendeel & ja & integendeel & ja, beslist \\
\hline zorgvuldiger besluitvorming & 65 & 2 & 67 & 1 & - \\
inhoudelijk betere besluiten & 39 & 2 & 52 & 1 & 61 \\
meer draagviak voor besluiten & 64 & 3 & 44 & 2 & 74 \\
betere behartiging van & & & & & 82 \\
werknemersbelangen & 55 & 2 & 78 & 0 & 8 \\
\hline
\end{tabular}

1 A.B. Winder, P. Kerkhof en P.G. Klandermans (1999), De ondernemingsraad volgens werknemers. Vragen naar effectiviteit, communicatie en rechtvaardigheid, Den Haag: $A+O$ fonds gemeenten (het betreft hier overigens werknemers bij de overheid, maar analyse van de gegevens uit De volwassen OR leert dat in ieder geval de bestuurders en or'en in die sector nauwelijks afwijken van het gemiddelde).

Bron: databestand De volwassen OR en Winder 1999

Tegenover de positieve beoordeling van de uiteindelijke resultaten van medezeggenschap staat dat 39 procent van de bestuurders klaagt over vertraging in de besluitvorming, en 12 procent over nadelige effecten op de efficiency - een veelgehoord argument om de OR te passeren. Daar valt ook wel wat voor te zeggen. De instemmingsprocedure rond arboregelingen neemt, blijkens het onderzoek, gemid- 
deld $8 \frac{1}{2}$ week in beslag. ${ }^{64}$ Aan de andere kant: precies de helft van de instemmingsprocedures is binnen één maand afgerond, hetgeen voor zorgvuldige besluitvorming toch heel behoorlijk kan worden genoemd. Bovendien waren vrijwel alle procedures die langer dan acht weken in beslag namen, procedures waarin de OR al in een heel vroeg stadium was betrokken. ${ }^{65}$ Het is niet uitgesloten dat in deze relatief lange periode ook de uitwerking van het voorgenomen besluit door de staf of de directie heeft plaatsgevonden. De kortste procedures daarentegen waren diegene waarin de OR pas op het moment van de formele instemmingsaanvraag werd ingeschakeld, terwijl uit het survey niet duidelijk wordt hoe lang is gewerkt aan de voorbereiding van het besluit vóordat de OR is ingeschakeld. Vroegtijdige betrokkenheid van de OR leidt optisch weliswaar tot een relatief langdurig proces, maar door integratie van beide trajecten is het niet uitgesloten (en mijns inziens zelfs waarschijnlijk) dat de vertraging beperkt is.

\section{Instemmingsprocedure: resultaat}

Een andere reden om de medezeggenschap te ontduiken, zou kunnen zijn dat de bestuurder vreest dat de OR zijn instemming zal onthouden aan een voorgenomen besluit. Hier lijkt in eerste instantie wel iets voor te zeggen. Ook dit argument snijdt bij nader inzien echter geen hout. Uit het onderzoek van Looise uit 1985 bleek dat slechts 60 procent van de instemmingsplichtige besluiten zonder meer op de instemming van de OR kon rekenen. ${ }^{66}$ In onderzoek uit 1989 in middelgrote ondernemingen bleek 78 procent van alle instemmingsaanvragen op het gebied van arbeidsomstandigheden de OR ongeschonden te passeren. Daarmee waren arbeidsomstandigheden, met de pensioenregelingen, het minst omstreden van de zes onderzochte thema's. ${ }^{67}$ Uit het survey van 1998 blijkt 75 procent van de OR'en zonder meer in te kunnen stemmen met alle voorgenomen besluiten.

Weliswaar promoveert een meerderheid van de voornemens dus ongeschonden tot besluit, toch heeft de OR in ruwweg een kwart van de gevallen zijn instemming onthouden - hetgeen de vrees van bestuurders lijkt te bevestigen. Een nadere beschouwing van de gegevens van Looise uit 1986 en het onderzoek uit 1998 leert echter dat van de oorspronkelijk afgestemde voorstellen de meerderheid na wijziging alsnog op de instemming van de OR kon rekenen. Medio jaren ' 80 kon 75 procent van de afgewezen voorstellen na wijziging alsnog worden uitgevoerd, in 1998 lag dit percentage op 55. Van alle voorgenomen besluiten moest uiteindelijk slechts een fractie worden ingetrokken: in 19854 procent van alle instemmingsverzoeken, in 199831 van de 704 geïnventariseerde besluiten (4,5 procent). Op het gebied van arbeidsomstandigheden is het beeld nog iets positiever: van de 114 voorgestelde

64 Daarmee komen regelingen op het gebied van arbeidsomstandigheden overigens iets sneller tot stand dan gemiddeld rond alle instemmingsplichtige thema's ( 10 weken).

65 Ook Looise wijst op de duidelijke relatie tussen snelheid in procedures en het moment van inschakeling door de bestuunder (Looise/De Lange 1987, p. 70), zodat gesteld kan worden dat de vertraging in de procedure toch vooral ook te wijten is aan de opstelling van de bestuurder zélf.

66 Looise/Heijink 1986, p. 52 en Looise/De Lange 1987. p. 118

67 H. Dekkers, P.T. Calkoen en J.H.T.H. Andriessen (1989), Medezeggenschap in middelgnote ondernemingen. Tilburg: IVA, p. 65. 
arboregelingen liepen er slechts 4 op de klippen van het instemmingsrecht ( 3.5 procent). ${ }^{68}$

Al met al kan geconcludeend worden dat slechts een fractie van de voorgenomen regelingen op het gebied van arbeidsomstandigheden schipbreuk lijdt door toedoen van de OR: minder dan vijf procent. Een flinke minderheid van de voorgenomen besluiten moet op aandrang van de OR weliswaar worden aangepast, maar wordt daarna alsnog goedgekeurd. Men mag aannemen dat juist dit soort interventies van de OR bijdraagt aan de door bestuurders ervaren kwaliteitsverbetering van besluiten.

Het aantal keren dat de bestuurder ondanks een negatief oordeel van de OR tóch uitvoering gaf aan het besluit is op de vingers van éen hand te tellen: slechts één regeling op het gebied van arbeidsomstandigheden werd tegen de expliciete wil van de OR ingevoerd, en in het algemeen 11 op een totaal van 704 instemmingsaanvragen. Deze score van 1.4 procent is aanmerkelijk gunstiger dan de 4 procent in $1985 .^{69}$ Kennelijk durven bestuurders de OR de laatste jaren toch minder voor het hoofd te stoten.

\section{Conclusie}

Samenvattend kan worden gesteld dat ondernemingsraden met het instemmingsrecht weliswaar beschikken over een potentieel machtig wapen, maar dat zij zeer regelmatig worden gepasseerd door de bestuurder - of beter nog, gezien het feit dat zij dit zelf vaak niet eens in de gaten hebben én er nauwelijks tegen optreden: zich láten passeren. Slechts in één op de acht gevallen heeft de OR overduidelijk invloed op voorgenomen besluiten - bij díe besluiten die, na een aanvankelijk geweigerde instemming van de OR, door de bestuurder worden aangepast en alsnog instemming verkrijgen of door de bestuurder zijn ingetrokken. Dat de OR in 75 procent van de gevallen instemt met het oorspronkelijke voorstel betekent echter niet dat de OR dus overwegend een ja-knikkersfunctie vervult. Het is niet uit te sluiten dat, bij de voorgenomen besluiten die de instemming van de OR genieten, de te verwachten reactie van de OR op voorhand of lopende de procedure wel degelijk gewicht in de schaal heeft gelegd (zie ook hoofdstuk 6 van deze studie). De bestuurders signaleren althans een zorgvuldiger besluitvorming en inhoudelijk betere besluiten. ${ }^{70}$

68 Ook uit het ZARA-werkgeversonderzoek uit 1996-1997 blijkt het instemmingsrecht rond arbeidsomstandigheden, in casu de keuze van en het contract met de arbodienst, zelden tot aanvaringen te leiden. Van de OR' en die in het ZARA-onderzoek een instemmingsaanvraag hadden ontvangen omtrent de keuze van een arbodienst, weigerde slechts $1 \%$ in te stemmen. Wat het contract betreft toonde de OR zich iets kritischer: $6 \%$ van de OR'en weigerde in te stemmen met de inhoud van het contract. Ter Huurne 1997. p. 121. Eenzelfde beeld doemt op uit de evaluatie van de Arbeidstijdenwet uit 2001: slechts zelden wordt een voorstel van de bestuurder verworpen. Mevissen 2001, p. 167

69 Looise/Heijink 1986, p. 52 en Looise/De Lange 1987, p. 118

70 Ook de ondernemingsraden zelf signaleren een zorgvuldiger en inhoudelijk betere besluitvorming ( 65 resp. $50 \%$ ), Looise signaleerde in 1985 dat bij het opstellen van voorgenomen besluiten "al bij voorbaat met de opvattingen van de OR is rekening gehouden" Looise/De Lange 1987. p. 17 


\subsubsection{Adviesrecht}

Hoewel het adviesrecht niet expliciet gekoppeld is aan het thema 'arbo', kan het wel degelijk ingezet worden om de arbeidsomstandigheden te verbeteren. In zijn advies over een voorgenomen besluit kan de ondernemingsraad immers aandacht besteden aan de gevolgen voor de veiligheid, de gezondheid en het welzijn van de werknemers (vgl. par. 3.3.4). In de meeste gevallen blijkt de OR inderdaad rekening te houden met de arbogevolgen. Op de vraag of adviesaanvragen standaard worden beoordeeld op de gevolgen voor het welzijn en de gezondheid (te denken valt aan werkdruk en regelcapaciteit), stelt een meerderheid van de ondernemingsraden dit inderdaad te doen. Bijna drie kwart van de reorganisatievoorstellen ( 73 procent) wordt standaard beoordeeld op arbogevolgen. Voor investeringen in apparatuur of bij ver- of nieuwbouw is dit 59 respectievelijk 70 procent. Het groepsgewijze inlenen van arbeidskrachten wordt minder vaak op arborisico's beoordeeld ( 44 procent). De onderwerpen milieuzorg, technologische voorzieningen en het eigen-risicodragerschap zijn pas in 1998 onder het adviesrecht gebracht, en zijn daarom niet meegenomen in de vragenlijst.

Tabel 4.1.17. Beoordeling adviesaanvragen op arbogevolgen (gewogen n=374)

\begin{tabular}{|l|c|c|c|}
\hline & $\begin{array}{c}\text { Thema actueel } \\
\text { geweest \% }\end{array}$ & $\begin{array}{c}\text { Aanvraag } \\
\text { beoordeeld op } \\
\text { arbogevolgen \% }\end{array}$ & $\begin{array}{c}\text { Aanvraag niet } \\
\text { beoordeeld op } \\
\text { arbogevolgen \% }\end{array}$ \\
\hline Belangrijke investeringen & 80 & 59 & 41 \\
in apparatuur & 77 & 70 & 30 \\
Investeringen ver-/nieuwbouw & 79 & 73 & 27 \\
Reorganisaties & 73 & 44 & 56 \\
Inhuren arbeidskrachten & & & \\
\hline Bron: databestand De volwassen OR & & & \\
\hline
\end{tabular}

Constructie van een vier-puntsschaal ( $\alpha=0.87$ ) laat zien dat 41 procent van de ondernemingsraden die ten minste twee relevante adviesaanvragen hebben behandeld $(n=310)$ altijd aandacht besteedt aan de arbogevolgen van de genoemde adviesplichtige besluiten, terwijl aan het andere eind van het spectrum 30 procent daar nauwelijks oog voor heeft.

Verwacht zou mogen worden dat ondernemingsraden die een VGW(M)-commissie hebben ingesteld, zeker waar de OR de adviestaken heeft gedelegeerd aan de commissie, meer oog hebben voor de arbogevolgen van adviesplichtige besluiten. Deze verwachting wordt inderdaad bevestigd door de survey-gegevens, zij het dat de gegevens statistisch niet significant zijn.

Het ligt voor de hand dat eventuele knelpunten zoals overbelasting, tijdgebrek en gebrek aan deskundigheid samenhangen met een onvolledige beoordeling van de gevolgen van voorgenomen besluiten. Dit wordt ten dele bevestigd door het survey. 


\section{Schaal aandacht voor arbo bij adviesaanvragen}

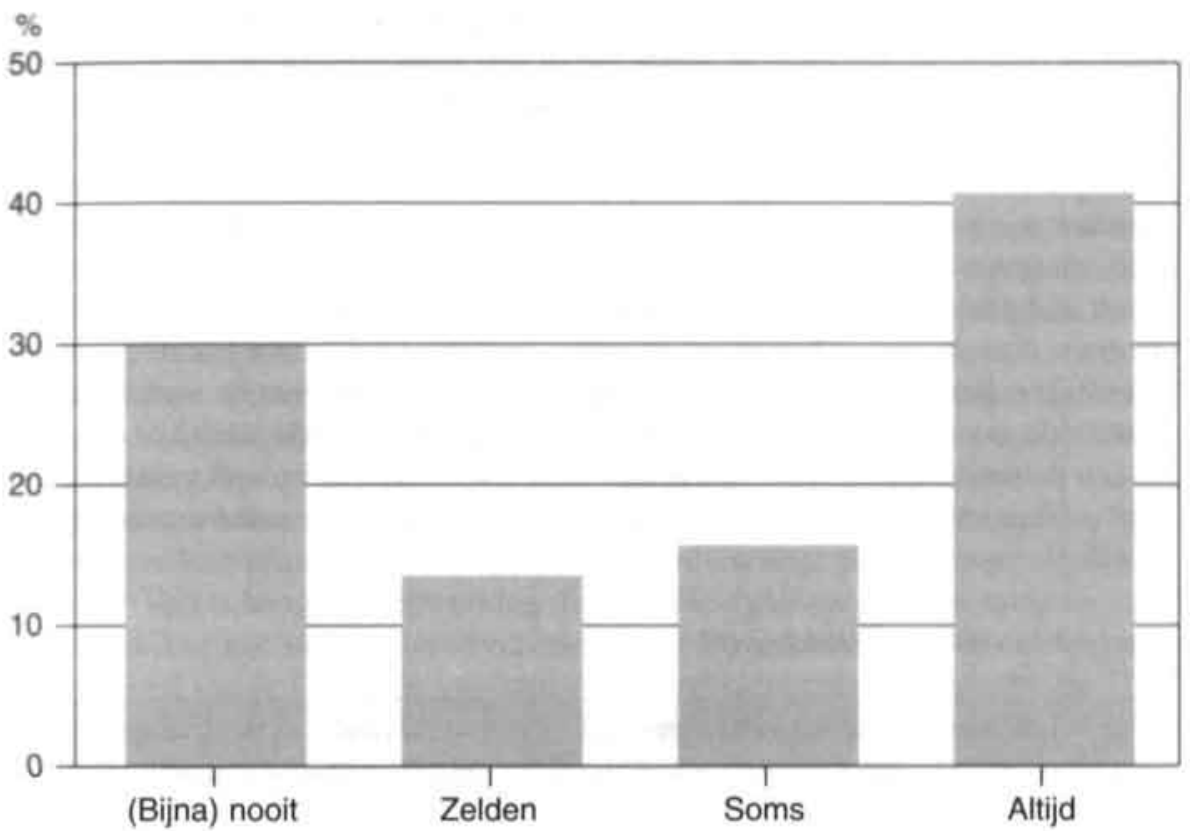

Zeer duidelijk is dat de ondernemingsraden die (volstrekt) onvoldoende tijd hebben voor hun OR-werk minder aandacht schenken aan de arbogevolgen (V.22***). Een soortgelijke samenhang geldt de overbelastingsproblematiek: de weinige ondernemingsraden die zichzelf níet overbelast achten, hebben meer aandacht voor de arbogevolgen bij de beoordeling van adviesaanvragen (V.31***). Ervaren deskundigheidsproblemen leiden niet tot verminderde aandacht.

\subsubsection{OR en arbodienst}

De figuur van de arbodienst is geïntroduceerd in 1994 (vgl. par. 3.4). Hoewel een van de expliciete taken van de arbodienst is samen te werken met de ondernemingsraad (art. 14, lid 3 sub f, Arbowet) is de relatie eigenlijk al vanaf 1994 moeizaam geweest. Deels heeft dat te maken met de opstelling van de bestuurder. Hierboven (tabel 4.1.12) is al aangegeven dat het instemmingsrecht van de OR frequent met voeten wordt getreden: in 43 procent van de gevallen waarin een arbodienst werd geselecteerd, werd de OR niet om instemming gevraagd. De inhoud van het contract kwam in 47 procent van de gevallen zonder instemming van de $O R$ tot stand. ${ }^{71} \mathrm{Om}$ de positie van de ondernemingsraad te versterken, is in paragraaf 2.3.1 van de Richtlijn voor de certificering van arbodiensten bepaald dat de arbodienst, alvorens een contract af te sluiten, moet nagaan of de ondernemingsraad daadwerkelijk heeft ingestemd met de keuze van de dienst - te verifiëren bij het

71 Zie ook Hooiveld/Kuiperij 1999. p. 18 
management en/of de medezeggenschapsvertegenwoordiging (zie ook paragraaf 3.4 van deze studie). In de praktijk blijkt dit lang niet altijd en dan ook nog overwegend bij het management te gebeuren: in nog geen 40 procent van de gevallen wordt de OR geraadpleegd ${ }^{72}$, en indien de OR niet heeft ingestemd is dit geen enkel beletsel om toch een contract af te sluiten. ${ }^{73}$ Ook anderszins lijken de arbodiensten weinig affiniteit met medezeggenschap te hebben. Weliswaar heeft een aantal arbodiensten een protocol voor de samenwerking tussen arbodienst en ondernemingsraad, maar het is zeker geen dwingende eis van de diensten dat dit protocol ook wordt aangehecht aan het contract. Minder dan de helft ( 44 procent) van de arbodiensten doet dit wel, 13 procent meestal - waarmee het in dat laatste geval dus kennelijk onderhandelbaar is. ${ }^{74}$ Voor een aantal onderdelen van de samenwerking hebben de meeste arbodiensten een protocol opgesteld. Ook de jaarlijkse rapportage aan de ondernemingsraad (paragraaf 2.10.2 Richtlijn) is in veel gevallen geregeld - 60 procent van de arbodiensten rapporteert schriftelijk en/of mondeling aan de OR. ${ }^{75}$

Tabel 4.1.18. Werkwijze richting OR

\begin{tabular}{|l|c|c|}
\hline $\begin{array}{l}\text { De dienst hanteert mbt de OR een } \\
\text { protocol aangaande }\end{array}$ & $\begin{array}{c}\text { \% van } \\
\text { arbodiensten }\end{array}$ & $\begin{array}{c}\% \text { bij weging naar } \\
\text { werknemers }\end{array}$ \\
\hline $\begin{array}{l}\text { het overleg met de OR over verzuim, PAGO } \\
\text { en arbospreekuur }\end{array}$ & 57 & 68 \\
de wijze van adviseren aan de OR & 63 & 83 \\
het rapporteren en opsturen van adviezen & 81 & 94 \\
aan de OR & 47 & 53 \\
een helpdesktunctie voor leden OR/VGW(M)- & 69 & 90 \\
commissie & & \\
de evaluatie met de OR van de dienstverlening & & \\
\hline Bron: Van Amstelvan Putten 2002, p. 74 & \\
\hline
\end{tabular}

Onderzoek onder arbodiensten leert dat deze voor ongeveer de helft positief zijn over de samenwerking met de OR. Slechts 11 procent is ontevreden. Wel vindt bijna de helft (46 procent) van de arbodiensten dat het nog beter kan, maar dat de omvang van het contract dat veelal in de weg staat. ${ }^{76}$ Dat ook de ondernemingsraden van mening zijn dat de samenwerking met de arbodiensten voor verbetering

72 R. van Amstel en D. van Putten (2002), Arbodienstenpanel: rapportage vierde peiling, Hoofddorp: TNO Arbeid, p. 72 en A3-22

73 J. Popma, C. van Rij en J. Hooiveld (2001), Arbodienstverlening tussen markt en medezeggenschap. Den Haag: Delwel, p. 53-54

74 Van Amstel/Van Putten 2002, p. 72

75 Ibid. p. 74

76 Ibid. p. 75 
vatbaar is, bleek wel uit de onderzoeken van de FNV: cen gemiddeld rapportcijfer van 4,5 is duidelijk onvoldoende. ${ }^{77}$ Dat was echter in 1999. Uit het hierboven aangehaalde arbodienstenpanel lijkt een beeld op te doemen dat sindsdien de arbodiensten hun leven hebben gebeterd - al is het arbodienstenpanel uiteraard wel een self-report onderzoek, en bleek uit het FNV-onderzoek dat ook in 1999 de arbodiensten al een redelijk hoge dunk van zichzelf hadden.

Het effect van medezeggenschap op het functioneren van de arbodienst en, indirect. op de arbeidsomstandigheden is onderzocht in 2001 op basis van de gegevens van de FNV. De FNV-cijfers geven ten eerste aan dat OR-betrokkenheid bij de keuze van de arbodienst sterk samenhangt met een omvangrijker takenpakket, en ten tweede dat de dienstverlening van arbodiensten die met instemming van de OR opereren aanmerkelijk meer impact heeft dan wanneer de arbodienst zich louter met de opdrachtgever verstaat. Ook indien de arbodienst relatief intensief samenwerkt met de ondernemingsraad, bijvoorbeeld door adviezen mondeling toe te lichten of meerdere keuzes voor te leggen bij de advisering, is de impact significant sterker. ${ }^{78}$ Voorts hangt samenwerking met de OR significant samen met een positieve ontwikkeling van het ziekteverzuim, hetgeen verklaard werd door een positieve invloed van de OR op de kwaliteit van het arbeidsomstandighedenbeleid. ${ }^{79}$ Of medezeggenschap inderdaad een positief effect heeft op de kwaliteit van het arbobeleid is een kwestie die in hoofdstuk 5 uitgebreider aan de orde komt.

\subsubsection{OR en Arbeidsinspectie}

Sluitstuk van het systeem van arbo-zelfregulering is de handhaving door de Arbeidsinspectie. Hierbij kunnen ondernemingsraad en Arbeidsinspectie in twee richtingen met elkaar in contact treden en, in theorie, elkaars positie schragen. Ten eerste kan de OR een klacht indienen of de Arbeidsinspectie verzoeken een onderzoek in te stellen. Zo kan de Arbeidsinspectie worden gebruikt als strategische partner in een eventueel geschil tussen OR en bestuurder. Ten tweede hebben ORleden, in geval de inspectie zélf besluit de onderneming met een bezoek te vereren, het recht om met de inspecteur mee te lopen of hem onder vier ogen te spreken (vgl. par. 3.1.5). Daarbij kan de inspecteur door de medezeggenschappers worden geïnformeerd over de arbosituatie in het bedrijf, en kunnen de OR-leden de Arbeidsinspectie informeren over eventuele misstanden die niet op het eerste gezicht kun-

77 Al wordt dat cijfer vooral bepaald door de externe arbodiensten, en scoren de interne diensten aanmerkelijk hoger met een 6,4 Popma/Van Rij/Hooiveld 2001, p. 70-71. De dienstverlening van de arbodienst wordt overigens ook in het algemeen niet hoog aangeslagen door de ondernemingsraden (ibid), en de waardering van de werkgevers voor de arbodiensten is ook matig (in de periode 1998-2001 zelfs nog gekelderd). Zie Ministerie van Sociale Zaken en Werkgelegenheid (2002). Arbobalans 2002, p. 57

78 Popma/Van Rij/Hooiveld 2001, p. 76-77

79 Ibid. p. 95-98 
nen worden opgemerkt. In de praktijk blijkt van wederzijdse ondersteuning echter nauwelijks sprake. ${ }^{80}$

Het aantal klachten of verzoeken tot onderzoek is bijzonder laag. In 2001 werden ruim 2000 klachten over arbeidsomstandigheden ingediend bij de Arbeidsinspectie. Van slechts 14 van die klachten $(<0,7$ procent) is bekend dat zij door een medezeggenschapsorgaan zijn ingediend. In de eerste helft van 2002 hebben medezeggenschapsorganen zes klachten ingediend. Ook het aantal keren dat de Arbeidsinspectie van de OR of een vakbond een verzoek kreeg om in een bedrijf een onderzoek in te stellen is bijzonder laag. Uit een eigen enquête, begin 2003, onder alle inspecteurs in het kader van deze studie blijkt dat slechts drie procent van de ondervraagde inspecteurs 'vaak' wordt benaderd door een OR. ${ }^{81}$ Ongeveer de helft van de ondervraagden heeft zelden of nooit meegemaakt dat de OR zélf contact opnam met de dienst (zie tabel 4.1.19).

Ook de kans dat de OR op initiatief van de Arbeidsinspectie in contact komt met een inspecteur is beperkt. In $100+$ ondernemingen komt de inspectie ongeveer eens in de vijf jaar langs, en in het midden- en kleinbedrijf nog minder vaak. ${ }^{82}$ In die gevallen is ook lang niet altijd sprake van betrokkenheid van de OR. Begin jaren ' 90 constateerde Wilthagen dat in de helft van de gevallen de ondernemingsraad geen gebruik maakte (of kon maken) van zijn vergezelrecht. ${ }^{83}$ Eind jaren ' 90 bleek uit een OR-enquête door de Arbeidsinspectie zelf dat 40 procent van de ondernemingsraden in het geheel niet op de hoogte was van de aanwezigheid van de inspectie - goeddeels doordat in onaangekondigde of monitorbezoeken de OR niet van te voren kán worden ingeseind. ${ }^{84}$ Indien de OR wél van de komst van de Arbeidsinspectie op de hoogte is, wordt echter lang niet altijd gebruik gemaakt van het vergezelrecht: uit de OR-enquête bleek dat één op de acht ondernemingsraden geen gebruik makt van het recht, en zeer incidenteel dat de bestuurder het niet toestond. ${ }^{85}$ Ook de enquête onder de inspecteurs bevestigt het beeld dat de OR niet altijd gebruik maakt van zijn recht. Uit dezelfde enquête blijkt voorts dat OR-leden

80 Uit een evaluatie van de toepassing van de bestuurlijke boete blijkt dat bedrijven mét OR beter op de hoogte zijn van het bestaan van het boete-instrument. S, van der Kemp en M. Engelen (2002). Het instrument bestuurlijke boete in de Arbowet: Aanknopingspunten voor effectiviteitsbevordering. Den Haag: Ministerie van Sociale Zaken en Werkgelegenheid/Elsevier. p. 46. Dit zou een indicatic kunnen zijn dat ondernemingsraden 'reclame' maken voor de Arbeidsinspectie. De onderzoekers geven echter zelf al aan dat deze correlatie allicht samenhangt met de bedrijfsgrootte.

81 De respons op de enquête was $35 \%$. Binnen de Arbeidsinspectie is echter een duidelijke oververtegenwoordiging van inspecteurs in de hoog-risicobranches (industrie en bouw). Omdat er een significant verschil blijkt te bestaan tussen de verschillende branches, is de respons herwogen naar het aantal bedrijfsvestigingen zoals de Arbeidsinspectie dat zelf hanteert. Arbeidsinspectie. Jaanerslag 2001. p. 14

82 Ibid. p. 24

83 A.C.J.M. Wilthagen (1993), Het overheidstoezicht op de arbeidsomstandigheden. Groningen: Wolters-Noordhoff, p. 134-135

84 J.R. Popma (1999), Ondernemingsraad en Arbeidsinspectie, in: OR-Informatie jg. 25, nr. 15/16, p. XIII

85 Wilthagen 1993. p. 134-135 
maar hoogst sporadisch gebruik maken van het recht om de inspecteur onder vier ogen te spreken. Als mogelijke verklaring mag gelden dat tijdens de rondgang door het bedrijf en een eventueel gesprek met de werkgever en OR samen alle relevante informatie al is uitgewisseld. Het is echter ook goed denkbaar dat de OR-leden de druk van hun werkgever voelen. Indien immers een OR-lid achteraf ook nog eens onder vier ogen met de inspecteur wil spreken, dan worden daar kennelijk zaken besproken die de werkgever niet mag weten.

Tabel 4.1.19. Gebruik bevoegdheden in relatie met Arbeidsinspectie $(n=132)$

\begin{tabular}{|l|c|c|c|}
\hline $\begin{array}{l}\text { Percentage ondernemingsraden dat } \\
\text { gebruik maakt van bevoegdheden }\end{array}$ & $\begin{array}{c}\text { vaak } \\
\text { meestal \% }\end{array}$ & soms \% & $\begin{array}{c}\text { zelden/ } \\
\text { noolt \% }\end{array}$ \\
\hline OR maakt gebruik van vergezelrecht & 47 & 44 & 9 \\
OR spreekt inspecteur onder vier ogen & 3 & 34 & 63 \\
OR neemt contact op met Arbeidsinspectie & 3 & 50 & 47 \\
\hline Bron: eigen enquete onder de Arbeidsinspectie
\end{tabular}

Tijdens de rondgang of gesprekken blijkt overigens de inbreng van de OR beperkt. Wilthagen constateerde dit al begin jaren ' $90^{86}$, en ook blijkt uit de eigen enquête van begin 2003. Ongeveer één kwart van de inspecteurs geeft aan zelden of nooit gevoed te worden met informatie van de werkvloer, terwijl dat toch de belangrijkste toegevoegde waarde van de OR zou moeten zijn. Ook zijn de ondernemingsraden matig bekend met het arbobeleid in hun bedrijf (rapportcijfer 5,8) en is de inhoudelijke arbokennis beperkt $(5,5)$. Het vermogen om knelpunten te vertalen naar beleid is eveneens onvoldoende $(5,5)$.

Ondanks deze tekortkomingen zijn de meeste inspecteurs toch van mening dat de OR soms (48 procent) of meestal (46 procent) een nuttige gesprekspartner is. Bovendien is er vrijwel geen inspecteur die de bijdrage van medezeggenschap aan het arbobeleid van generlei waarde acht (zie tabel 4.1.20).

Multipele regressie-analyse leert dat de Arbeidsinspectie de OR vooral als een nuttige gesprekspartner ziet indien deze de inspecteur voedt met kennis van de werkvloer (tabel 4.1.21). De andere onafhankelijke variabelen zijn niet significant van invloed. Als gekeken wordt welke variabelen volgens de inspecteurs ervoor zorgen dat medezeggenschap een bijdrage levert aan betere arbeidsomstandigheden, blijkt dat drie variabelen significant van invloed zijn: ten eerste creëert de OR draagvlak $\left(.396^{* *}\right)$, ten tweede zal het arbo-effect van medezeggenschap groter zijn naarmate de OR beter geïnformeerd is over de arbosituatie in het bedrijf $\left(.246^{* *}\right)$, ten derde is inhoudelijke arbokennis een significante predictor $\left(.216^{*}\right)$. Het vermogen om arboknelpunten te vertalen in beleid levert geen significante bijdrage. Als gekeken wordt welke factoren bijdragen tot draagvlak dan is dat, in de ogen van de inspec-

86 Ibid. 
Tabel 4.1.20. Functioneren $O R$ in relatie tot $A I(n=132)$

\begin{tabular}{|l|c|c|c|}
\hline & hoog $\%$ & redelijk \% & $\begin{array}{c}\text { nauwelijks/ } \\
\text { niet \% }\end{array}$ \\
\hline Motivatie voor arbo & 13 & 78 & 9 \\
\hline & goed \% & voldoende \% & $\begin{array}{c}\text { onvoldoendel } \\
\text { slecht } \%\end{array}$ \\
\hline OR beschikt over inhoudelijke arbokennis & 10 & 47 & 43 \\
OR is geinformeerd over de arbosituatie in bedrijf & 12 & 65 & 23 \\
OR kan knelpunten vertalen in beleid & 9 & 52 & 39 \\
\hline & meestal \% & soms \% & zelden/ \\
nooit \% \\
\hline OR voedt inspecteur met kennis werkvloer & 28 & 56 & 24 \\
Medezeggenschap levert bijdrage aan arbo & 36 & 53 & 11 \\
Medezeggenschap creeert draagviak & 36 & 59 & 5 \\
OR is nuttige gesprekspartner & 46 & 48 & 6 \\
Rapportcijfer & 6,1 & & \\
\hline Bron: eigen enquête onder de Arbeidsinspectie & & & \\
\hline
\end{tabular}

teurs, voornamelijk de kennis van de arbosituatie in het bedrijf (.420**). Het gebruik van het vergezelrecht is een negatieve predictor, maar bijzonder zwak en niet significant.

Tabel 4.1.21. Nut, bijdrage en rapportcijfer $O R(n=132)$

\begin{tabular}{|c|c|c|c|c|}
\hline & $\begin{array}{l}\text { OR is een } \\
\text { nuttige } \\
\text { gespreks. } \\
\text { partner }\end{array}$ & $\begin{array}{l}\text { OR levert } \\
\text { een nuttige } \\
\text { bljdrage }\end{array}$ & $\begin{array}{l}\text { Medezeggen- } \\
\text { schap } \\
\text { cretert } \\
\text { draagviak }\end{array}$ & Rapporteiffer \\
\hline Motivatie voor arbo & 0,121 & 0,097 & 0,066 & 0,027 \\
\hline OR beschikt over inhoudelijke arbokennis & 0,034 & $0,216^{\circ}$ & 0,140 & $0.194^{\circ}$ \\
\hline OR is geinformeerd over arbosituatie bedrij & 0,051 & $0.246^{*}$ & $0,279^{*}$ & $0,223^{\circ}$ \\
\hline OR kan knelpunten vertalen in beleid & 0,002 . & 0,000 & 0,075 & 0.007 \\
\hline OR voedt inspecteur met kennis werkvioer & $0,369 \cdots$ & 0,005 & 0,105 & $0,208^{\circ}$ \\
\hline Medezeggenschap levert bijdrage aan arbo & 0,045 & & $0,420^{* *}$ & $0,216^{\circ}$ \\
\hline Medezeggenschap creeert draagviak & 0,106 & $0,396^{* *}$ & & 0,008 \\
\hline OR is een nuttige gesprekspartner & & & & 0,134 \\
\hline OR maakt gebruik van vergezelrecht & 0,144 & 0,175 & 0,085 & 0,045 \\
\hline OA spreekt onder vier ogen & 0,046 & 0,092 & 0,061 & 0,157 \\
\hline Constante & 0.041 & 0,288 & 0,017 & 9,941 \\
\hline R2 adj & 0,410 & 0,478 & 0,458 & 0,656 \\
\hline
\end{tabular}


Uit deze analyses blijkt dus dat met name kennis van de werkvloer een belangrijk punt is waarop de OR een positieve bijdrage aan het arbobeleid kan leveren. Het rapportcijfer dat de Arbeidsinspecteurs de OR hebben gegeven, hangt vooral sterk af van de mate waarin de OR geinformeerd is over de arbosituatie in hun bedrijf $\left(.223^{\circ}\right)$. kennis van de werkvloer $\left(.208^{*}\right)$ én de arbokennis van de OR $\left(.194^{*}\right)$. De andere variabelen zijn, afgezien van de positief ervaren bijdrage (maar dat is vrijwel tautologisch) niet significant. Het is dus met name de kennis van de ondernemingsraad die positief gewaardeerd wordt, en niet zozeer of de medezeggenschappers gebruik maken van hun rechten.

\subsubsection{Samenvatting en conclusie}

Om hun taak op het gebied van het arbeidsomstandighedenbeleid naar behoren te kunnen vervullen, dienen ondernemingsraden primair gemotiveerd te zijn. Zonder motivatie bij de OR komt er van een eigen bijdrage uiteraard niets terecht. Voorts dienen zij te beschikken over voldoende middelen en bevoegdheden. In hoofdstuk 3 is aangegeven dat zij, ten minste formeel, inderdaad beschikken over de benodigde faciliteiten en formeel kunnen putten uit een uitgebreid scala van bevoegdheden. In paragraaf 4.1 is onderzocht in hoeverre medezeggenschappers in de praktijk:

- daadwerkelijk een actieve bijdrage (willen) leveren op het gebied van het arbobeleid;

- hiertoe voldoende geëquipeerd zijn;

- gebruik (kunnen) maken van hun formele mogelijkheden;

- resultaten boeken.

De eerste deelvraag kan rekenen op een positief stemmend antwoord. De animo onder ondernemingsraden voor het thema 'arbo' is zonder meer groot. Twee op de drie OR'en hebben het hoog op de agenda staan en dichten zichzelf een stimulerende tak toe op het gebied van veiligheid, gezondheid en welzijn. Ook de bestuurder staat open voor medezeggenschap over het arbobeleid. Met name rond de centrale beleidsthema's (RI\&E, arbojaarplan, verzuimbeleid) zijn het overleg en de informatievoorziening redelijk ( 30 procent) tot goed ( 60 procent) te noemen. Het overleg vertoont ook een behoorlijk open karakter en de bijdrage van de OR wordt in het algemeen als positief ervaren. ${ }^{87}$ Ook worden ondernemingsraden, in vergelijking met eerdere jaren, overwegend vroegtijdig betrokken in de besluitvorming. Ten opzichte van de jaren ' 80 kan dit als 'vooruitgang' worden betiteld. ${ }^{88}$

Het antwoord op de tweede deelvraag stemt echter somber. Hoewel de faciliteiten op papier goed geregeld zijn, blijken ondernemingsraden in de praktijk behoorlijk in de knel te zitten met hun tijd én soms de vereiste deskundigheid te ontberen. Tijdgebrek is voor drie op de vijf ondernemingsraden soms ( 50 procent) of vaak (11

87 Ook Reubsaet merkte, anno 1988, op dat het arbo-overleg tussen OR en bestuurder overwegend open van karakter is, Reubsaet 1988, p. 49. Hetzelfde geldt voor het overleg over arbeidstijden. Mevissen 2001, p. 268-269

$88 \mathrm{Vgl}$. Van het Kaar/Looise 1999. p. 91, 120, 145 en 257 
procent) een probleem, en 92 procent van de OR'en signaleert dat zij overbelast zijn - een probleem dat naar verwachting in de toekomst nog toe zal nemen. Ook de deskundigheidsproblemen nemen eerder toe dan af. Uit het onderzoek blijkt dat 88 procent van de ondernemingsraden een gebrek aan deskundigheid signaleert, waarbij overigens de instemmingsplichtige onderwerpen iets minder vaak problematisch zijn dan de adviesplichtige. In de loop der jaren is echter nauwelijks vooruitgang geboekt - integendeel. Voor Looise was dit aanleiding om te denken dat de OR, gegeven de beperkte deskundigheid en capaciteit, uiteindelijk wel eens zou kunnen bezwijken onder een teveel aan taken. ${ }^{89}$

Op het derde punt, het gebruik van formele bevoegdheden, valt evenmin veel positiefs te concluderen. Het initiatiefrecht van de OR wordt weinig gebruikt (13 procent). Dat het initiatiefrecht nauwelijks tot bloei komt, hebben de ondernemingsraden uiteraard vooral aan zichzelf te wijten - zij het dat tijdgebrek een excuus mag heten. Maar de frequente schending van het instemmingsrecht is, hoewel de verantwoordelijkheid natuurlijk primair bij de bestuurder ligt, eveneens voor een deel terug te voeren op de opstelling van de OR zelf. In 40 procent van de bedrijven wordt de OR regelmatig of structureel gepasseerd, maar de betrokken ondernemingsraden treden hier nauwelijks tegen op - als ze al in de gaten hebben dàt ze worden gepasseerd. De waardering voor het gebruik van het adviesrecht als instrument om de arbeidsomstandigheden te beïnvloeden is een kwestie van half volle en half lege glazen. Dat een belangrijk deel van de ondernemingsraden aandacht heeft voor arbo-aspecten aan adviesaanvragen is zonder meer positief, maar een bijna even groot deel laat deze mogelijkheid helaas onbenut.

Overigens is de laatste deelvraag, naar de uiteindelijke opbrengst van medezeggenschap, natuurlijk de cruciale toets. Zelfs al worden de formele procedures van onder tot boven geschonden, als de OR desondanks resultaten zou boeken zou het eindoordeel toch positief genoemd mogen worden. Hoewel het effect van medezeggenschap op het arbobeleid in een latere paragraaf uitgebreider aan de orde komt, kan tot slot van deze paragraaf al wel een eerste indruk worden gegeven. Uit de bevindingen in deze paragraaf blijkt immers dat medezeggenschap wel degelijk effect kan hebben. In ongeveer één op de tien ondernemingen is over de onderzoeksperiode een arbo-initiatief van de OR overgenomen, en 12 procent van de voorgenomen arboregelingen wordt middels inzet van het instemmingsrecht aangepast naar men mag aannemen twee resultaten die althans de OR tot tevredenheid zullen stemmen en wellicht ook de arbeidsomstandigheden in hun onderneming wel ten goede zijn gekomen.

Zelf zijn, blijkens eerder onderzoek, twee op de drie ondernemingsraden in ieder geval redelijk tevreden over de mate waarin zij een bijdrage leveren aan het arbobeleid. ${ }^{90}$ Ook de bestuurders zijn overwegend positief over de invloed van de OR op het gebied van, in ruimere zin, het sociale beleid - zeker in vergelijking met de andere beleidsterreinen. Ten opzichte van het eerdere onderzoek van Looise lijkt de

89 J.K. Looise (1998-a), Ontwikkelingen rond ondernemingsraden, in: Tijdschrift voor arbeidsvmatgstukken, jaargang 14, nr. 2, p. 171

90 Brugmans/Bruin 1996, p. 38 
invloed echter afgenomen. ${ }^{91}$ Terecht merkt Looise in De volwassen $O R$ op dat het hier gaat om gepercipieerde invloed, hetgeen wellicht afwijkt van de feitelijke invloed, maar het beeid is niet bijzonder positief. Bovendien blijken ondernemingsraden zélf en de achterban nog negatiever over de mate van invloed dan de bestuurder. ${ }^{92}$

\section{Tabel 4.1.22. Invloed OR op diverse beleidsterreinen}

\begin{tabular}{|l|c|c|c|c|c|c|}
\hline \multirow{2}{*}{} & \multicolumn{3}{|c|}{$\begin{array}{c}\text { \% bestuurders anno 1985 } \\
\text { (n=189) }\end{array}$} & \multicolumn{2}{c|}{$\begin{array}{c}\text { \% bestuurders anno 1998 } \\
\text { (gewogen n = 426-467) }\end{array}$} \\
\cline { 2 - 7 } & geen & matig & veel & gering & redelijk & groot \\
\hline Algemene bedriffsbeleid & 34 & 52 & 11 & 45 & 49 & 8 \\
Commerciêle beleid & 70 & 16 & 3 & 89 & 11 & 0 \\
Financieel-economisch beleid & 80 & 15 & 3 & 80 & 20 & 0 \\
Technologiebeleid & 41 & 41 & 14 & 84 & 14 & 1 \\
Organisatorisch beleid & & & & 15 & 65 & 19 \\
Sociaal-/personeelsbeleid & 9 & 50 & 41 & 8 & 52 & 39 \\
\hline
\end{tabular}

In het algemeen is een eindoordeel over de betrokkenheid van de OR en het effect van medezeggenschap op het gebied van het arbeidsomstandighedenbeleid in ondernemingen, mede door het ontbreken van een eenduidige toetssteen, moeilijk te geven. Wanneer is betrokkenheid voldoende, hoe valt de invloed te waarderen? Wat betreft dat eerste: hoewel de rol van de OR op arbogebied niet meer valt weg te denken, is de medezeggenschap op een aantal punten duidelijk voor verbetering vatbaar (tijd, deskundigheid, formele procedures). In paragraaf 4.2 wordt nader ingegaan op de vraag welke factoren op deze punten een significant gewicht in de schaal zouden kunnen leggen. Als duidelijk is welke factoren een optimaal gebruik van de rechten en bevoegdheden in de weg staan, is immers een horizon van mogelijke verbeteringen geopend. Wat betreft het tweede punt: dát ondernemingsraden invloed hebben, lijkt duidelijk - zelfs al maken ze beperkt gebruik van formele instrumenten om die invloed te doen gelden. Of die invloed daadwerkelijk resulteert in betere arbeidsomstandigheden wordt onderzocht in hoofdstuk 5 .

\subsection{Achtergrondfactoren en functioneren $O R$}

In paragraaf 4.1 is uitgebreid ingegaan op een aantal kenmerken in het functioneren van ondernemingsraden: taakopvatting, overleg-en informatierecht, faciliteiten, en toepassing van formele bevoegdheden. Incidenteel is hierbij ingegaan op een

91 Looise/De Lange 1987, p. 128. Ook Looise zelf concludeert in De volwassen $O R$ dat de invloed van medezeggenschap op de diverse beleidsterreinen is afgenomen. Van het Kaar/Looise 1999. p. 126-127.

92 Van het Kaar/Looise 1999, p. 126-127. Vgl. ook A.B. Winder, P. Kerkhof en P.G. Klandermans (2000), Medezeggenschap in kaart, Den Haag: A+O fonds gemeenten, p. 126 
aantal voor de hand liggende bedrijfskenmerken die van invloed zouden kunnen zijn op het functioneren van de OR. In deze paragraaf volgt een meer systematische analyse van de samenhang tussen een aantal achtergrondfactoren en de diverse afhankelijke variabelen in het onderzoek. Hierbij wordt met name gekeken naar het verband tussen organisatiekenmerken en kenmerken van de OR enerzijds en het functioneren van de OR anderzijds.

Het functioneren van ondernemingsraden, en niet alleen op het gebied van het arbobeleid, wordt beïnvloed door een groot aantal factoren: zowel externe als interne. Belangrijke externe invloeden zijn wetgeving, de relatie met de arbodienst en de Arbeidsinspectie, maar ook bijvoorbeeld de economische- of concurrentiepositie van het bedrijf. Het ligt voor de hand dat een bedrijf dat in een benarde positie verkeert meer aandacht heeft voor het pure bedrijfseconomische overleven dan voor de arbeidsomstandigheden. Interne invloeden zijn bijvoorbeeld de opstelling van de bestuurder, de ervaring en deskundigheid van de OR, en het contact met de achterban.

Ook organisatiekenmerken, zoals bedrijfsgrootte en branche, zullen hun effect hebben op het functioneren van ondernemingsraden. Zo ligt het voor de hand dat de bedrijfsgrootte sterk samenhangt met bijvoorbeeld het aantal instemmingsaanvragen. Ook de branchespecifieke arboproblematiek zal van invloed zijn op het aantal instemmingsaanvragen (maar ook het aantal initiatieven van de OR). Anderzijds is er weinig reden om op voorhand aan te nemen dat 'branche' een belangrijke invloed heeft op het moment van inschakelen van de OR (hoewel de cultuur binnen de branche uiteraard een rol kan spelen). Het moment van inschakelen zal eerder samenhangen met de opstelling van de bestuurder en diens waardering van de invloed van medezeggenschap. De opstelling van de bestuurder zal daarentegen nauwelijks invloed hebben op de aandacht van de OR voor arbogevolgen van adviesplichtige besluiten. Voor de hand liggende relaties tussen OR-kenmerken en de toepassing van bevoegdheden zijn bijvoorbeeld de actiebereidheid van de OR enerzijds en het moment van inschakelen of het aantal malen dat de OR gepasseerd is anderzijds. Gebrek aan tijd of kennis zal zich waarschijnlijk doen gelden bij het aantal initiatieven of de beoordeling van adviesaanvragen.

In het hieronder volgende analysemodel, dat goeddeels is geènt op het onderzoek van Looise van medio jaren ' 80 , is getracht de diverse kenmerken van de organisatie én de OR overzichtelijk te relateren aan de toepassing van bevoegdheden zowel in kwantitatieve zin als in kwalitatieve zin. ${ }^{93}$ Hierbij is incidenteel een aantal variabelen samengevoegd om een nog enigszins overzichtelijk geheel te behouden. Een voorbeeld hiervan is het OR-kenmerk 'knelpunten', een constructie op basis van de variabelen deskundigheidsproblemen, tijdgebrek en overbelasting, en vacatures (Cronbach's $\alpha=0.67$ ). De waardering van de bestuurder voor medezeg-

93 Looise/De Lange, 1987. De interne samenhang binnen de onderscheiden clusters van verklarende variabelen wordt hier minder uitgebreid gepresenteend dan in hoofdstuk 7 van Looise/De Lange. Waar dit voor de verklaring van bepaalde functioneringskenmerken van de ondernemingsraden van belang is, zal de interne structuur van de clusters ter plekke nader worden besproken. 
genschap is door Van het Kaar en Looise geoperationaliseerd middels schaalconstructie aan de hand van het door de bestuurder als positief of negatief ervaren effect van medezeggenschap op een aantal aspecten van de bedrijfsvoering. ${ }^{94} \mathrm{De}$ actiebereidheid is een schaalconstructie, gebaseerd op vijf mogelijke machtsmiddelen die de OR zou kunnen inzetten. ${ }^{95}$

Het model ziet er dan als volgt uit:

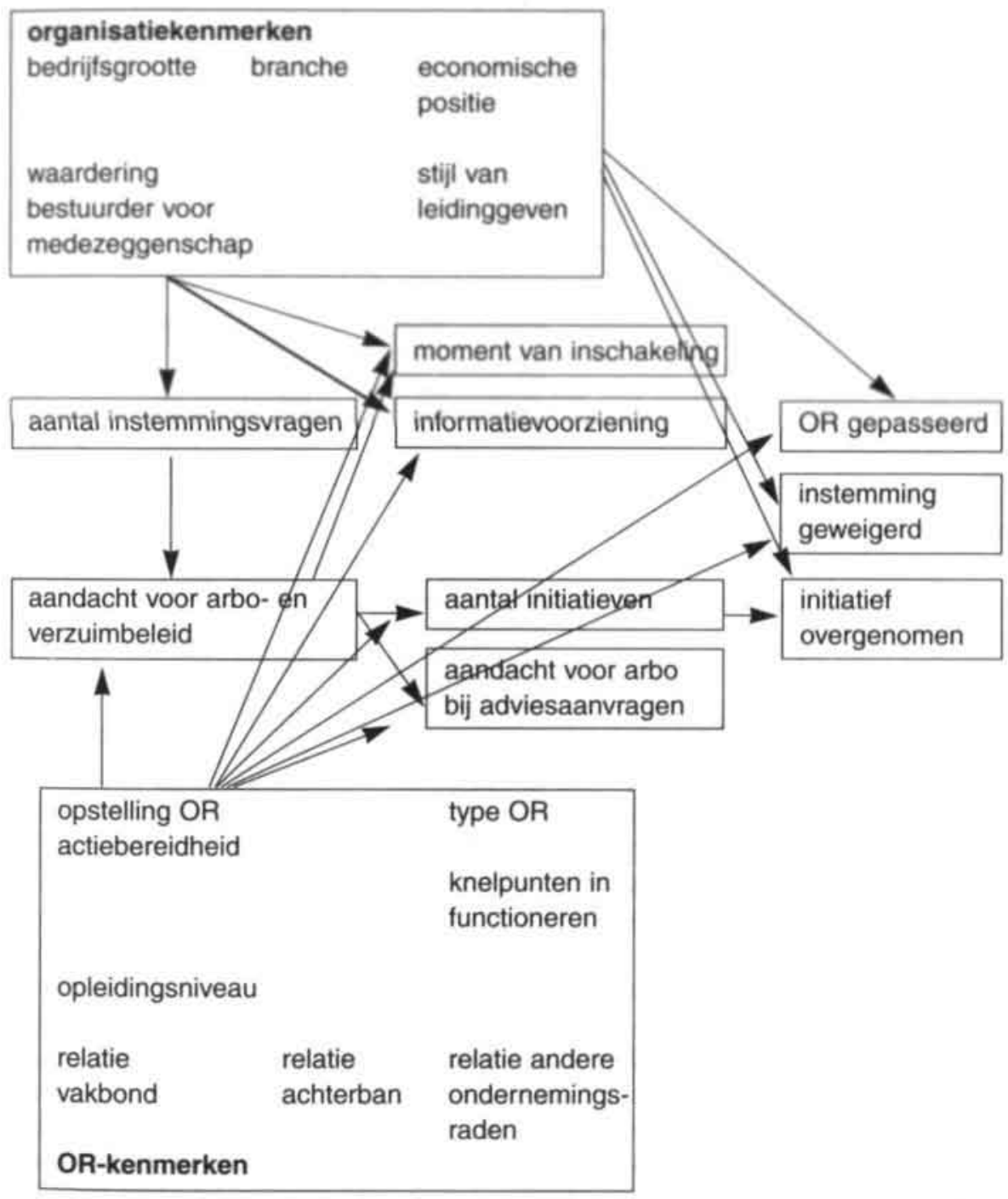

94 Van het Kaar/Looise 1999. p. 301-302 (vraag 54)

95 Ibid., p. 285 (vraag 96) 


\subsubsection{Aandacht voor arbo- en verzuimbeleid}

In paragraaf 4.1.1 is ingegaan op de vraag in hoeverre ondernemingsraden de hun toebedachte rol op het gebied van arbeidsomstandigheden daadwerkelijk op zich nemen. In de desbetreffende paragraaf is al aangegeven dat het thema 'arbo' hoog op hun agenda staat. Het aantal formele initiatieven op arbogebied is echter beperkt. In dezelfde paragraaf is ook kort ingegaan op een aantal achtergrondvariabelen. Hieronder volgt een wat uitgebreidere analyse, waarbij de drie variabelen 'aandacht arbeidsomstandigheden', 'stimuleren arbobeleid' en 'stimuleren verzuimbeleid' ook zijn samengevoegd tot één schaal: arbo-animo (Cronbach's $\alpha=0.77$ ).

\section{Schaal animo voor arbo}

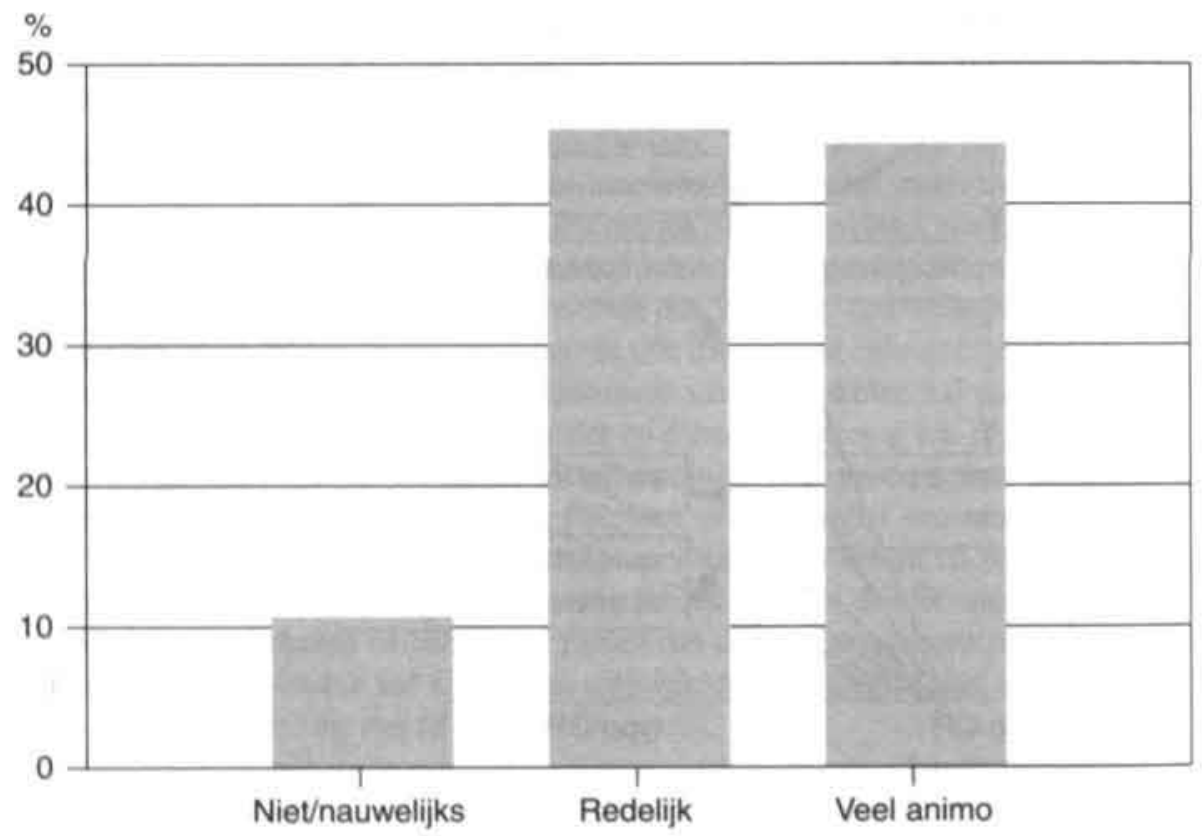

\section{Organisatiekenmerken}

Van de organisatiekenmerken vertonen alleen bedrijfsgrootte en branche samenhang met de animo voor arbo- en verzuimbeleid. In de bedrijven met minder dan 100 werknemers heeft 15 procent van de ondernemingsraden nauwelijks animo voor het thema arbo, in de $500+$ bedrijven is dat slechts 3 procent. Ruwweg kan gesteld worden: hoe groter het bedrijf, des te meer aandacht voor arbeidsomstandigheden $\left(\mathrm{V}, 14^{* *}\right)$. Ook op de afzonderlijke drie items is deze samenhang significant. De statistische samenhang is voor het kenmerk branche nog sterker (V.26***). Actieve ondernemingsraden zijn vooral te vinden in de gezondheidszorg ( 54 procent) en de industrie ( 52 procent). In het bank- en verzekeringswezen en de trans- 
portsector is de animo voor arbo- en verzuimbeleid echter duidelijk minder. ${ }^{96}$ Op zichzelf zijn deze gegevens niet opzienbarend: uit diverse onderzoeken blijkt immers dat de arbeidsomstandigheden in met name de gezondheidszorg zeer bezwarend zijn, en in de zakelijke dienstverlening juist relatief gunstig (hoewel 'nieuwe' arborisico's als werkdruk en RSI juist ook in deze branche sterk in opmars zijn). 97

De waardering van de bestuurder voor medezeggenschap hangt duidelijk samen met de animo voor arbobeleid (V.27**): in bedrijven waarin de bestuurder weinig op heeft met de bijdrage van de OR is relatief weinig animo te bespeuren. Ook waar de OR van mening is dat de bestuurder zich formeel opstelt of geneigd is machtsverschillen te benadrukken, is duidelijk minder animo (V.21*, zie tabel 4.2.1), De OR heeft in dergelijke bedrijven relatief weinig aandacht voor het arbobeleid en neemt nauwelijks een stimulerende rol op zich om het verzuimbeleid van de grond te tillen. Hoewel deze constateringen wellicht niet zeer verrassend zijn, zijn zij wel belangrijk: kennelijk wordt de animo bij ondernemingsraden om zich in te zetten voor betere arbeidsomstandigheden sterk bepaald door de persoon van de bestuurder.

De economische positie van de organisatie hangt niet significant samen met de animo voor het thema arbeidsomstandigheden. Een uitzondering is dat in bedrijven met een wankele economische positie de OR zich minder bekommert om het verzuimbeleid (V.21**). De samenhang tussen arbo-animo en de concurrentiepositie is iets sterker. Bedrijven die weinig te duchten hebben van concurrentie besteden meer aandacht aan arbobeleid, evenals bedrijven die uitsluitend buitenlandse concurrentie hebben (V.36***). Algemeen gesproken valt er echter geen duidelijke conclusie te trekken over de invloed van de economische- en concurrentiepositie op de aandacht voor het arbobeleid.

\section{OR-kenmerken}

De opstelling van de ondernemingsraad in het overleg met de bestuurder hangt niet of nauwelijks samen met het animo van de OR voor arbo- en verzuimbeleid. Of de OR zichzelf nu coöperatief vindt of juist formalistisch, op geen enkel punt valt een significante samenhang met de arbo-animo te vinden. De karakterisering van de OR door de bestuurder hangt wel samen met het enthousiasme van de OR: van de ondernemingsraden die door de bestuurder worden omschreven als 'bereid naar nieuwe wegen te zoeken' heeft 61 procent véél arbo-animo. Voor ondernemingsraden die volgens de bestuurder geneigd zijn zich formeel op te stellen is dit per-

96 Probleem bij het organisatiekenmerk 'branche' is dat voor een aantal branches de ongewogen respons lager was dan $n=20$. Als gevolg hiervan wordt het lastig om methodologisch verantwoord iets over deze branches te zeggen. Het betreft bank- en verzekeringswezen, de transportsector en de nutsbedrijven.

97 CBS/SZW (1988), Arbeidsomstandigheden 1998: Monitoring via personen, p. 29. CBS/SZW (2000), Arbeidsomstandigheden 2000: Monitoring via personen. p. 11 en 17 
Tabel 4.2.Ia. Arbo-animo en opstelling bestuurder in overleg (gewogen $n=265$, Cramér's V.2I **)

\begin{tabular}{|l|c|c|c|}
\hline \multirow{2}{*}{ Opstelling bestuurder in overleg } & \multicolumn{3}{|c|}{ animo \% } \\
\cline { 2 - 4 } & nauwelijks & redelijk & veel animo \\
\hline Bereid tot concessies & 0 & 43 & 54 \\
Bereid te zoeken naar nieuwe wegen & 9 & 39 & 51 \\
Geneigd formeel op te treden & 16 & 57 & 31 \\
Geneigd machtsverschil te benadrukken & 38 & 32 & 32 \\
Totaal & 11 & 42 & 48 \\
\hline
\end{tabular}

Tabel 4.2.Ib. Arbo-animo en waardering bestuurder (gewogen $n=141$, Cramér's V.27**)

\begin{tabular}{|l|c|c|c|}
\hline Waardering bestuurder voor & \multicolumn{3}{|c|}{ animo \% } \\
\cline { 2 - 4 } medezeggenschap & nauwelijks & redelijk & veel animo \\
\hline Negatief & 13 & 35 & 49 \\
Gematigd positief & 3 & 36 & 61 \\
Positief & 16 & 62 & 22 \\
Totaal & 10 & 46 & 44 \\
\hline Bron: databestand De volwassen OR & \multicolumn{4}{|l}{} \\
\hline
\end{tabular}

centage slechts 36 procent. Hoewel de samenhang zeer sterk oogt, mag hij door een matige celvulling niet significant genoemd worden.

De acticbereidheid van de OR hangt evenmin duidelijk samen met de inzet van de OR op het gebied van arbeidsomstandigheden of verzuim. Regelmatig contact met de vakbond daarentegen hangt wél samen met de inzet van de ondernemingsraden. Met name nemen zij hun stimulerende taak op het gebied van arbeidsomstandigheden en verzuimbeleid serieuzer dan ondernemingsraden die nooit contact onderhouden met de vakbond (V.18, resp. V.19***). Kennelijk vinden de vele vakbondsactiviteiten op het gebied van arbeidsomstandigheden weerklank bij hun kaderleden.

Eerder is al een aantal malen gewezen op de sterke samenhang tussen de aanwezigheid van een VGW(M)-commissie enerzijds en de aandacht voor arbo- en verzuimbeleid en de krachtdadigheid van de OR anderzijds. Die relatie ligt natuurlijk ook erg voor de hand. Ondernemingsraden die zich intensief inzetten voor betere arbeidsomstandigheden zullen eerder geneigd zijn een VGW(M)-commissie in te stellen. Omgekeerd zal de aanwezigheid van een VGW(M)-commissie zeer waarschijnlijk de OR aansporen om meer werk van zijn arbotaken te maken. Ondernemingsraden die een VGW(M)-commissie hebben ingesteld scoren dan ook aanmerkelijk hoger op de schaal arbo-animo (V.28***), evenals op de afzonderijke items.

De taakverdeling tussen OR/VGW(M)-commissie valt, zoals we in paragraaf 
4.1.2.4 gezien hebben, te onderscheiden in vijf typen. Deze typologie hangt ook zeer duidelijk samen met de arbo-animo van de OR (V.23***): het zijn vooral de ondernemingsraden die veel taken aan de VGW(M)-commissie hebben gedelegeerd die veel aandacht voor arbo- en verzuimbeleid hebben. Ook hier kan de verklaring twee kanten uitwerken. Ten eerste zal een $O R$ die veel werk maakt van arbo geneigd zijn dat vele werk te delegeren. Ten tweede zal een VGW(M)-commissie die serieus genomen wordt door haar OR geneigd zijn met meer enthousiasme aan het werk te gaan.

Tabel 4.2.2. Arbo-animo en type OR (gewogen n=330, Cramér's V.2.3**)

\begin{tabular}{|l|c|c|c|}
\hline & $\begin{array}{c}\% \text { weinig } \\
\text { animo }\end{array}$ & $\begin{array}{c}\% \text { redelijk } \\
\text { animo }\end{array}$ & $\begin{array}{c}\% \text { veel } \\
\text { animo }\end{array}$ \\
\hline Commissieloos & 19 & 47 & 34 \\
Voorbereidingsmodel & 7 & 47 & 46 \\
Ormalistisch (alleen overleg overgedragen) & 2 & 44 & 54 \\
Professioneel (instemmingsrecht in eigen hand) & - & 33 & 67 \\
Volledig gedelegeerd & - & 11 & 89 \\
\hline Bron: databestand De volwassen OR
\end{tabular}

Ondernemingsraden die in hun arbowerk aanlopen tegen knelpunten in hun functioneren, zouden wel eens minder arbo-enthousiasme aan de dag kunnen leggen. Aan de andere kant zullen ondernemingsraden die weinig animo voor arbozaken hebben ook weinig knelpunten ervaren. Deze verwachtingen worden bevestigd door de cijfers. Ondernemingsraden met weinig animo ervaren duidelijk minder knelpunten. Dit is overigens een tamelijk zinledige vaststelling: die ondernemingsraden doen immers weinig, en ondervinden dus ook geen gebrek aan tijd of deskundigheid. Aan de andere kant van het spectrum echter zijn de ondernemingsraden die veel knelpunten ervaren ook minder dan gemiddeld enthousiast om hun stimulerende taak op zich te nemen. Die constatering is zeker niet van belang ontbloot. Er zijn immers nogal wat ondernemingsraden die knelpunten ervaren in hun werk. Als de overheid ondernemingsraden intensief wil betrekken bij het arbobeleid in hun bedrijf of instelling, dan dient de OR echter voldoende geëquipeerd te zijn. In veel organisaties is dat een probleem (paragraaf 4.1.2.3). Kennelijk is dat voor een deel van de eerste groep een beletsel om zich intensief met het arbo- en verzuimbeleid bezig te houden. Dit blijkt te meer uit het gegeven dat de ondernemingsraden die relatief veel knelpunten ervaren significant (V.26***) hun stimuleringstaak vaker verwaarlozen: 38 procent van die OR'en neemt zijn stimuleringstaak serieus, tegen 59 procent gemiddeld. Deze redenering gaat vooral op voor ondernemingsraden die deskundigheidsproblemen ervaren (V.15*) en die gebukt gaan onder tijdgebrek (V,18***). Overbelasting leidt niet tot een significante verminderde animo. Van de ondernemingsraden die géén deskundigheidsproblemen op het gebied van arbo ondervinden heeft 48 procent véél en 8 procent weinig animo. Van de OR'en die wel tegen kennisproblemen oplopen heeft slechts 18 procent veel en ook 18 procent weinig animo. Deze samenhang is nog sterker op het afzonderlijke item 
'stimuleren arbeidsomstandigheden' (V.21***). Van de ondernemingsraden die géén deskundigheidsproblemen ondervinden houdt 66 procent zich intensief bezig met het stimuleren van arbobeleid, tegen 38 procent van de getroebleerde OR'en. Op de inzet voor een beter verzuimbeleid hebben deskundigheidsproblemen weinig invloed.

Tijdgebrek leidt nog iets sterker tot minder aandacht voor de stimulerende rol van de OR. Hierbij is ook de samenhang met de (beperkte) rol van de OR rond het verzuimbeleid significant: van de ondernemingsraden die wél voldoende tijd hebben beijvert de helft zich intensief voor een beter verzuimbeleid, tegen 36 procent gemiddeld. Twee van de vijf OR'en die tijdgebrek signaleren houden zich in het geheel niet bezig met verzuimbeleid - twee keer zo vaak als gemiddeld (V.21***). Het functieniveau van de OR-leden hangt significant samen met de animo voor arbobeleid (V.18***): vooral ondernemingsraden met relatief veel middenkader en hoger personeel geven aan het belang van een krachtig arbeidsomstandighedenbeleid in te zien, en dan in het bijzonder gericht op het ziekteverzuim. Ondernemingsraden met overwegend uitvoerend personeel bekommeren zich gemiddeld om de veiligheid en de gezondheid, en het middenkader scoort beneden gemiddeld.

\subsubsection{Aantal initiatieven}

Een specifieke vorm van arbo-animo betreft de vraag of de OR al dan niet een formeel initiatiefvoorstel heeft uitgewerkt op het gebied van arbeidsomstandigheden. Hoewel het aantal arbo-initiatieven beperkt is ( $n=47$ ongewogen), is het niet onmogelijk significante samenhang aan te tonen met de organisatiekenmerken of de kenmerken van de OR. Althans, niet vanwege een onvoldoende celvulling. De vraag in hoeverre de samenhang significant is, zal hieronder worden beantwoord.

\section{Organisatiekenmerken}

Verwacht mag worden dat van de organisatiekenmerken vooral de branche en de opstelling van de bestuurder van belang zijn. In sommige branches kunnen de arbeidsomstandigheden immers zeer belastend zijn, waardoor het zin heeft initiatieven te ontplooien ter verbetering van die arbeidsomstandigheden. Ondernemingsraden die te maken hebben met een onwillige bestuurder zullen minder geneigd zijn initiatief te nemen, met het oog op het risico van verspilde moeite. De samenhang met de branche is inderdaad duidelijk: in de gezondheidszorg en de bouw worden meer dan gemiddeld initiatieven genomen, en met name in de zakelijke dienstverlening minder dan gemiddeld (V.20**). Dit zal, in het licht van de bevindingen in paragraaf 4.2.1, niet verrassen. Verrassend lijkt voorts dat in het bank- en verzekeringswezen bovengemiddeld veel initiatieven worden ontplooid. De arbo-animo was immers laag. Maar in paragraaf 4.2 .1 is al angegeven dat dit vooral te wijten is aan gebrek aan aandacht bij de bestuurder - de OR stelt zich juist stimulerend op.

De veronderstelde samenhang tussen de opstelling van de bestuurder en het aantal arbo-initiatieven blijkt inderdaad zeer duidelijk uit de onderzoeksgegevens: in bedrijven waarin de bestuurder volgens de OR geneigd is machtsverschillen te 
benadrukken of zich formeel op te stellen is het aantal initiatieven verwaarloosbaar ( 5 procent), terwijl dit in organisaties waarin de bestuurder bereid is tot concessies nict minder dan 50 procent is (V.39***). Ook een positieve waardering van de bestuurder voor medezeggenschap hangt samen met een groter aantal initiatieven, maar deze samenhang mag vanwege onvoldoende celvulling niet significant genoemd worden.

Tabel 4.2.3a. Arbo-initiatieven en opstelling bestuurder (gewogen $n=281$. Cramér's V.39**)

\begin{tabular}{|l|c|c|}
\hline \multirow{2}{*}{ Opstelling bestuurder in OV } & \multicolumn{2}{|c|}{ aantal initiatieven (\%) } \\
\cline { 2 - 3 } & geen & 1 of meer \\
\hline Bereid tot concessies & 55 & 47 \\
Bereid te zoeken naar nieuwe wegen & 92 & 9 \\
Geneigd formeel op te treden & 90 & 7 \\
Geneigd machtsverschil te benadrukken & 97 & 0 \\
Totaal & 87 & 13 \\
\hline
\end{tabular}

Tabel 4.2.3b. Arbo-initiatieven en waardering bestuurder (gewogen n=141, n.s.)

\begin{tabular}{|l|c|c|}
\hline Waardering bestuurder medezeggenschap & \multicolumn{2}{|c|}{ aantal initiatieven (\%) } \\
\cline { 2 - 3 } & geen & 1 of meer \\
\hline Negatief & 99 & 0 \\
Gematigd positief & 94 & 6 \\
Positief & 85 & 15 \\
Totaal & 91 & 9 \\
\hline
\end{tabular}

De economische noch de concurrentiepositie van de organisatie vertoont samenhang met het aantal initiatieven.

\section{OR-kenmerken}

De vraag of de kenmerken van de OR van invloed zijn op het aantal initiatieven levert geen zinvol antwoord op. De variabele 'opstelling van de OR' gaat mank aan een onvoldoende celvulling. De actiebereidheid en het aantal contacten met de vakbond of andere ondernemingsraden levert evenmin significante samenhang op. Kruising met de variabele 'relatie met achterban' levert wel een significante score op, maar geen betekenisvolle informatie. De aanwezigheid van een VGW(M)-commissie en de specifieke relatie tussen de OR en die commissie levert evenmin iets op, net zo min als de aan- of afwezigheid van knelpunten. Het aantal initiatieven hangt wel samen met de mate waarin de OR zijn stimulerende taak op het gebied van arbo- en verzuimbeleid op zich neemt, maar dat zal uiteraard niet verbazen. 
De vraag welke kenmerken kunnen verklaren of initiatieven al dan niet worden overgenomen is, gegeven het beperkte aantal specifieke arbo-initiatieven ( $n=47$, maar voor bedrijven waar ook de bestuurder de vragenlijst heeft ingevuld slechts $\mathrm{n}=12$ ), moeilijk te beantwoorden. Niet alleen omdat er nauwelijks een lijn in de gegevens valt te ontdekken, maar vooral omdat de uitkomsten, zo er al een lijn lijkt te zijn, statistisch niet significant mogen heten.

\subsubsection{Overleg en informatie}

Behoorlijk overleg en adequate informatievoorziening vormen de basis voor medezeggenschap rond arbeidsomstandigheden (paragraaf 4.1.2). In deze paragraaf wordt bekeken op welke wijze de kenmerken van de organisatie en van de OR samenhangen met die basisvoorwaarden. Een specifieke variabele om te bepalen of de bestuurder het overleg met de OR serieus neemt, is het moment van inschakelen bij instemmingsplichtige besluiten (vgl. par. 4.1.3.1). Op een aantal voor de hand liggende kenmerken van de organisatie en de OR is bekeken of die samenhangen met het moment van inschakelen.

\section{Organisatiekenmerken}

Hoewel statistisch niet significant (wegens onvoldoende celvulling) lijkt het er sterk op dat vooral in de transportsector de basisvoorwaarden voor medezeggenschap met voeten worden getreden. Zowel op het punt van de informatievoorziening als het overleg wordt de OR duidelijk vaker dan gemiddeld genegeerd. In de industrie, de bouw en de zakelijke dienstverlening daarentegen lijken de basisvoorwaarden voor medezeggenschap behoorlijk vervuld. In de grotere bedrijven worden de basisvoorwaarden voor medezeggenschap beter gestand gedaan dan in kleinere bedrijven (V.16*).

De waardering van de bestuurder voor medezeggenschap hangt uiteraard samen met diens bereidheid om te voldoen aan de basisvoorwaarden voor overleg, zij het niet bijzonder sterk: bestuurders die positief staan tegenover medezeggenschap overleggen wel vaker met de OR $\left(\mathrm{V} .23^{* *}\right)$, maar de samenhang met de informatievoorziening is niet significant. Opvallend is dat 15 procent van de ondernemingsraden met een bestuurder die (gematigd) positief staat tegenover medezeggenschap nauwelijks informatie krijgen. De opstelling van de bestuurder legt meer gewicht in de schaal. Bestuurders die volgens de OR geneigd zijn zich formeel op te stellen en vooral bestuurders die de machtsverschillen benadrukken staan duidelijk minder open voor overleg en zijn evenmin scheutig met informatie (beide items V.26***). Dat de opstelling van de bestuurder of diens waardering van de medezeggenschap effect heeft op het moment van inschakelen ligt uiteraard zeer voor de hand. Indien de bestuurder weinig op heeft met de OR verschuift het moment van inschakelen voorspelbaar naar achter in het instemmingstraject. Deze veronderstelling kan niet door het survey worden onderbouwd. primair gezien het gebrek aan celvulling en secundair omdat de beschikbare gegevens geen eenduidig beeld laten zien. Ook voor de andere organisatiekenmerken valt uit de cijfers geen significante informatie te destilleren. 
Een formele opstelling van de OR lijkt duidelijk effect te hebben op zowel het overleg als de informatievoorziening. Interessant is dat een OR die zélf van mening is zich formeel op te stellen weinig te klagen heeft over de informatievoorziening maar wel moeizaam tot overleg komt, terwijl dit precies omgekeerd is in de bedrijven waarin de bestuurder vindt dat de OR zich formeel opstelt (goed overleg maar slechte informatievoorziening). Door onvoldoende celvulling is deze samenhang echter niet significant.

Actiebereidheid en intensieve contacten met de achterban. de vakbond en andere OR'en lijken een duidelijk positief effect te hebben op met name de informatievoorziening en, iets minder duidelijk, de mate waarin het overleg met de ondernemingsraad wordt gerespecteerd (zie tabel 4.2.4). Op vrijwel alle punten is het verband zeer duidelijk significant. Kennelijk loont een opstelling van de OR, waarbij hij enige actiebereidheid toont.

Dat de actiebereidheid van de OR en bijvoorbeeld het contact met de vakbond samenhangt met moment van inschakelen ligt voor de hand: cen OR die (te) laat wordt ingeschakeld zal wellicht eens met de vuist op tafel slaan, de achterban mobiliseren of de vakbond inschakelen. Omgekeerd valt te verwachten dat een bestuurder die een kordate OR tegenover zich weet waarschijnlijk eerder de OR zal inschakelen. Deze samenhang blijkt inderdaad tamelijk eenduidig uit het survey: actiebereidheid en intensief contact met de achterban en de vakbond werpt zijn vruchten af. ${ }^{98}$ Maar opnieuw vanwege de celvulling mag deze samenhang niet significant heten.

Tabel 4.2.4a. Overleg en contact met vakbond (gewogen $n=335$, Cramér's V.20**)

\begin{tabular}{|l|c|c|c|c|}
\hline \multirow{2}{*}{ Contact met vakbond } & \multicolumn{4}{|c|}{ Overleg (\%) } \\
\cline { 2 - 5 } & slecht & matig & redelijk & goed \\
\hline Nooit & 12 & 15 & 30 & 42 \\
Soms & 1 & 8 & 27 & 64 \\
Regelmatig & 6 & 6 & 21 & 68 \\
\hline
\end{tabular}

Tabel 4.2.4b. Overleg en actiebereidheid (gewogen $n=334$, Cramér's V.15*)

\begin{tabular}{|l|c|c|c|c|}
\hline \multirow{2}{*}{ Actiebereidheid } & \multicolumn{4}{|c|}{ Overleg (\%) } \\
\cline { 2 - 5 } & slecht & matig & redelijk & goed \\
\hline Geen & 8 & 12 & 22 & 58 \\
Beperkt & 2 & 5 & 31 & 62 \\
Hoog & 5 & 14 & 22 & 57 \\
\hline
\end{tabular}

98 Dat beide variabelen onderling sterk met elkaar samenhangen ligt uiteraard zeer voor de hand. Teulings concludeerde al in 1981 dat ondernemingsraden met een hoog FNV-gehalte vaker dan gemiddeld bereid waren tot actie over te gaan en machtsmiddelen in te zetten. Teulings 1981 . p. $115-118$ 
Tabel 4.2.4c. Informatievoorziening en vakbondscontacten (gewogen $n=350$, Cramér's V.2I**)

\begin{tabular}{|l|c|c|c|c|}
\hline \multirow{2}{*}{ Contact met vakbond } & \multicolumn{4}{|c|}{ Overleg (\%) } \\
\cline { 2 - 5 } & slecht & matig & redelijk & goed \\
\hline Nooit & 13 & 18 & 23 & 45 \\
Soms & 1 & 15 & 36 & 49 \\
Regelmatig & 7 & 3 & 30 & 58 \\
\hline
\end{tabular}

Tabel 4.2.4d. Informatievoorziening en actiebereidheid (gewogen $n=334$, Cramér's V.15*)

\begin{tabular}{|l|c|c|c|c|}
\hline \multirow{2}{*}{ Actiebereidheid } & \multicolumn{4}{|c|}{ Overleg (\%) } \\
\cline { 2 - 5 } & slecht & matig & redelijk & goed \\
\hline Geen & 13 & 19 & 27 & 41 \\
Beperkt & 0 & 7 & 29 & 64 \\
Hoog & 0 & 8 & 57 & 34 \\
\hline
\end{tabular}

Ook de interne organisatie van de OR en de aan- of afwezigheid van knelpunten hangen duidelijk samen met de mate waarin voldaan wordt aan de basisvoorwaarden voor medezeggenschap. Eerder is al aangegeven dat ondernemingsraden mét een VGW(M)-commissie duidelijk minder te klagen hebben over de informatievoorziening. Zoals gezegd hangt dit niet samen met de bedrijfsgrootte, maar kan als verklaring eerder gelden dat in bedrijven met een VGW(M)-commissie er een duidelijk adres is voor de informatie. Gegeven de nauwe relatie tussen het type OR en de aanwezigheid van een VGW(M)-commissie ligt het voor de hand dat ook hier een sterke samenhang met de basisvoorwaarden voor medezeggenschap valt te ontdekken. Dit is inderdaad het geval, zij het dat die samenhang statistisch niet significant is wegens onvoldoende celvulling. Het lijkt echter evident dat een 'professionelere' taakverdeling tussen OR en VGW(M)-commissie (verdergaande delegatie) samengaat met een sterkere positie van de OR. Hierbij lijkt de meest plausibele relatie dat een OR pas kan gaan delegeren als de basisvoorwaarden voor medezeggenschap naar behoren zijn vervuld.

Ondernemingsraden die meer dan gemiddeld knelpunten ervaren in hun functioneren hebben meer te klagen over de mate waarin zij gepasseerd worden in het arbooverleg. Ook de informatievoorziening is iets vaker een probleem. Verwacht mag worden dat met name gebrekkige informatievoorziening samenhang vertoont met deskundigheidsproblemen. maar uit de data wordt deze veronderstelling niet ondersteund. Problemen in het overleg hangen vooral zeer sterk samen met het tijdgebrek van de OR (V.29***).

Dat de actiebereidheid van de OR samenhangt met het moment van inschakelen ligt voor de hand: een ondernemingsraad die (te) laat wordt ingeschakeld zal wellicht eens met de vuist op tafel slaan of de vakbond inschakelen. Omgekeerd valt te verwachten dat een bestuurder die een kordate OR tegenover zich weet waarschijnlijk 
eerder de OR zal inschakelen. Deze samenhang blijkt inderdaad uit het survey: actiebereidheid en intensief contact met de achterban en de vakbond werpt zijn vruchten af. Vanwege de magere celvulling mag deze samenhang echter niet significant heten.

\subsubsection{Adviesrecht}

Of ondernemingsraden al dan niet aandacht besteden aan arbo-aspecten bij de beoordeling van adviesplichtige besluiten zal, zo valt te verwachten, vooral beînvloed worden door de kenmerken van de OR zélf en niet of nauwelijks door de opstelling van de bestuurder of andere bedrijfskenmerken. Met het oog op het verklaringsmodel en de consistente opbouw van deze paragraaf zal echter toch eerst gekeken worden naar samenhang van organisatiekenmerken met de arbobewuste beoordeling van adviesaanvragen.

\section{Organisatiekenmerken}

Hoewel daar niet op voorhand zinvolle voorspellingen over zouden kunnen worden gedaan, blijkt de alertheid op arbogevolgen in sommige branches groter dan in andere branches (V.19*). Met name in de industrie en de transportsector worden adviesaanvragen vaker beoordeeld op arborisico's dan in andere branches, terwijl in de bouw en bij het bank- en verzekeringswezen opvallend veel ondernemingsraden in het geheel géén oog hebben voor arbo-aspecten van adviesaanvragen. Een voor de hand liggende verklaring zou kunnen zijn de bedrijfsgrootte of de aan- of afwezigheid van een VGW(M)-commissie in de verschillende branches. Deze beide variabelen vertonen echter geen significante samenhang met het item 'arbo-aandacht bij adviesaanvragen'. Een mogelijke verklaring voor het verschil is dat in de industrie en de transportsector de arborisico's zichtbaarder en misschien ook wel ernstiger zijn dan in bijvoorbeeld de zakelijke dienstverlening. Dat zijn ze echter ook in de bouw, dus deze verklaring is niet al te sterk.

Als er al betekenisvolle samenhang valt te verwachten tussen de waardering van de bestuurder voor medezeggenschap en de opstelling van de OR dan is de relatie, zoals gezegd, niet dat een positievere bestuurder de OR alerter zou maken, maar hooguit dat een OR die iets preciezer kijkt naar adviesaanvragen hiervoor waardering zou kunnen oogsten bij de bestuurder. Uit het survey blijkt echter een omgekeerde samenhang, en nog tamelijk sterk ook (V.28*). Ondernemingsraden die adviesaanvragen serieus beoordelen op de gevolgen voor de veiligheid en gezondheid van werknemers oogsten minder waardering dan juist de ondernemingsraden die in feite een gemankeerde werkwijze volgen. Met een wat cynische kijk op de zaak kan hier gevreesd worden dat bestuurders eigenlijk niet op serieuze adviezen zitten te wachten, maar een dergelijke verklaring vereist toch een wat meer inhoudelijke analyse. Het andere kenmerk van de bestuurder ('opstelling tijdens overleg') vertoont bovendien weer een ander (significant) beeld, dat slecht valt te rijmen met de hierboven vermelde constatering. In bedrijven waar de bestuurder geneigd is machtsverschillen te benadrukken besteedt de OR namelijk véél minder vaak aandacht aan de arbo-aspecten van adviesaanvragen dan in bedrijven waar de bestuur- 
der zich coöperatief opstelt (V.22***). Voor dit verwarrende beeld is al met al geen steekhoudende verklaring te vinden.

\section{OR-kenmerken}

Zinvoller informatie valt te verwachten van de kenmerken van de OR. Zo heeft de OR die zelf aangeeft zich wat formalistisch op te stellen in het overleg méér oog voor de arbo-aspecten van adviesaanvragen dan de wat soepeler of de meedenkende OR: 67 procent zegt adviesaanvragen 'vrijwel altijd' op arbo-aspecten te toetsen, tegen 47 procent gemiddeld (V.21***). Dit beeld wordt bevestigd als gekeken wordt naar de opstelling van de OR volgens de bestuurder: de formelere OR gaat beter om met adviesaanvragen (sterke samenhang, maar wegens celvulling niet sig. nificant).

De relatie met de achterban hangt nauwelijks samen met de alertheid van de OR, maar een intensieve relatie met de vakbond zeer duidelijk wél: ondernemingsraden die regelmatig contact hebben met de vakbond hebben ook meer oog voor arbeidsomstandigheden bij de beoordeling van adviesaanvragen (V.20***). Hetzelfde geldt, zij het iets minder duidelijk, voor regelmatig contact met andere OR'en (V.16*).

Verrassend genoeg leidt de aanwezigheid van een VGW(M)-commissie als zodanig niet direct tot een verbeterde aandacht voor arbeidsomstandigheden bij de beoordeling van adviesaanvragen. Dat is weer wel het geval bij ondernemingsraden die relatief veel vrijheid geven aan hun VGW(M)-commissie, al is die samenhang niet bijzonder sterk (V.15**).

Ondernemingsraden die relatief weinig knelpunten in hun functioneren ervaren, hebben ook meer oog voor de arbeidsomstandigheden bij de beoordeling van adviesaanvragen (V.31***). Deze samenhang wordt opvallend genoeg niet zozeer gevonden rond het knelpunt 'deskundigheidsproblemen'. Verwacht mocht worden dat minder deskundige OR'en ook minder secuur naar de adviesaanvragen kijken, maar dat blijkt niet het geval. Overbelasting en tijdgebrek zijn belangrijker verklaringen waarom sommige ondernemingsraden op dit punt steken laten vallen. Van de ondernemingsraden die (volstrekt) onvoldoende tijd hebben, kijkt 76 procent zelden of nooit systematisch naar de arbogevolgen, terwijl dit voor ondernemingsraden die (ruim) voldoende tijd hebben slechts 33 procent is (V. 22***). Het functieniveau van de OR-leden hangt voorspelbaar samen met de aandacht voor arbo bij de beoordeling van adviesaanvragen $\left(\right.$ V. $\left.20^{* * *}\right)$ : ondernemingsraden met relatief veel hoger personeel zijn alerter op de effecten van voorgenomen besluiten op de arbeidsomstandigheden in hun onderneming.

\subsection{5, Instemmingsrecht}

Tot slot van deze paragraaf over de samenhang tussen het functioneren van ondernemingsraden en achtergrondkenmerken wordt aandacht besteed aan het instemmingsrecht: het aantal instemmingsaanvragen (par. 4.2.5.1), het aantal malen dat de OR is gepasseerd (par. 4.2.5.2) en de reactie van de OR op de instemmingsaanvragen (par. 4.2.5.3). 


\subsubsection{Aantal instemmingsaanvragen}

\section{Organisatiekenmerken}

Het aantal instemmingsaanvragen dat een OR overall ontvangt hangt uiteraard sterk samen met de grootte van de organisatie. Althans, dat zou men verwachten. Uit het survey blijkt echter dat ondernemingsraden in grote bedrijven nauwelijks méér instemmingsaanvragen ontvangen dan de kleinere broeders, en de verschillen zijn in ieder geval niet significant. Een significante samenhang wordt wel gevonden met de branche $(\mathrm{V} .23,<.001)$ : in het bank- en verzekeringswezen en de gezondheidszorg worden duidelijk meer instemmingsaanvragen behandeld dan gemiddeld, terwijl ondernemingsraden in de transportsector aanmerkelijk minder dan gemiddeld met een instemmingsaanvraag te maken hebben. In de gezondheidszorg gaat het echter (net als in de bouw) duidelijk vaker dan gemiddeld om arbo-onderwerpen. terwijl het in het bank- en verzekeringswezen vooral om andere instemmingsplichtige onderwerpen gaat. Het aantal arbo-instemmingsaanvragen is te klein om een significante uitsplitsing naar branche te maken.

De waardering van de bestuurder voor medezeggenschap en zijn opstelling in het overleg met de OR hangen eveneens, voorspelbaar, samen met het aantal instemmingsaanvragen. Hoe positiever de bestuurder des te meer instemmingsaanvragen. en ook bestuurders die bereid zijn tot concessies vragen de OR duidelijk vaker om instemming voor voorgenomen besluiten dan de formalistische en zeker de machtsgeoriënteerde bestuurders. Strikt genomen mag de samenhang op deze beide items vanwege een onvoldoende celvulling echter niet significant genoemd worden.

De items economische- en concurrentiepositie leveren weinig zinvolle informatie op. Weliswaar worden in gezonde bedrijven meer instemmingsaanvragen behandeld dan in kwetsbare (V.35***), maar onduidelijk is hoe deze samenhang geïnterpreteerd moet worden. Een mogelijke verklaring die nog wel interessant zou zijn, is dat bedrijven die weinig zorgen hebben over hun voortbestaan wat meer aandacht kunnen besteden aan niet-primaire beleidsterreinen zoals personeels- of arbeidsomstandighedenbeleid. Maar of deze speculatieve gedachte voeding heeft in de werkelijkheid is moeilijk te achterhalen op grond van louter de kale cijfers. Het gegeven dat in bedrijven die weinig concurrentie te duchten hebben het thema 'arbo' veel vaker tot een instemmingsaanvraag leidt dan in bedrijven die wél met sterke concurrentie te maken hebben (V.23**) wijst echter wel in dezelfde richting: arbo is een 'luxe' die bedrijven zich in economisch zwaar tij niet snel veroorloven.

\section{OR-kenmerken}

Hoewel de opstelling van de OR en zijn actiebereidheid waarschijnlijk vooral samenhangen met de mate waarin hij wordt gepasseerd, ligt in het verlengde daarvan ook samenhang met het aantal instemmingsaanvragen voor de hand. Een OR die minder gepasseerd wordt, zal relatief, en waarschijnlijk ook absoluut, vaker een instemmingsaanvraag ontvangen. Wat betreft de opstelling van de OR (coöperatief dan wel formalistisch) blijkt dit niet uit de survey-gegevens. Een grotere mate van actiebereidheid hangt echter wél significant samen met een groter aantal instemmingsaanvragen (V.22***).

Een intensievere relatie met de achterban daarentegen hangt, verrassend genoeg, 
enigszins negatief samen met het aantal (arbo-)instemmingsaanvragen. Verwacht zou mogen worden dat ondernemingsraden die veel instemmingsaanvragen behandelen relatief vaak contact met de achterban hebben, maar uit de cijfers blijkt juist het tegendeel $\left(\mathrm{V} .17^{* *}\right)$. Frequent contact met andere ondernemingsraden daarentegen hangt weer wél positief samen met het aantal instemmingsverzoeken (V.18*). Contact met de vakbond vertoont geen samenhang met het aantal instemmingsverzoeken (althans, niet in het algemeen, maar relatief is het aantal arbo-aanvragen in het bijzonder wél hoger dan gemiddeld).

De aanwezigheid van een VGW(M)-commissie noch de taakverdeling tussen $\mathrm{OR}$ en commissie hangt samen met het aantal instemmingsaanvragen. Hoewel verwacht mag worden dat een groter aantal instemmingsverzoeken tot meer knelpunten leidt (tijdgebrek, overbelasting, gebrek aan deskundigheid) wordt deze verwachting nauwelijks door de cijfers geschraagd - met uitzondering van een (niet al te sterke) samenhang met het item tijdgebrek (V.16**).

\subsubsection{Aantal malen gepasseerd}

Voor de beoordeling van het functioneren van medezeggenschap is simpelweg het aantal instemmingsaanvragen (dat immers goeddeels afhankelijk is van de branchespecifieke arbo-problematiek) natuurlijk veel minder interessant dan het aantal malen dat een OR gepasseerd is. Dát zegt immers iets over daadkracht en (zelf)bewustzijn van de OR, en dus over de vraag in hoeverre ondernemingsraden geèquipeerd zijn om de hun toebedachte rol op het gebied van het arbeidsomstandighedenbeleid naar behoren te vervullen.

\section{Organisatiekenmerken}

Uit de survey-gegevens blijkt dat ondernemingsraden in de gezondheidszorg en de bouw relatief weinig gepasseerd worden. In de transportsector daarentegen wordt de OR juist zeer vaak gepasseerd (V.28***). De samenhang met de bedrijfsgrootte is minder sterk (V.16**), maar wijst uit dat in grote bedrijven de OR minder vaak gepasseerd wordt dan in kleine bedrijven.

Dat bestuurders met een negatieve waardering voor medezeggenschap de OR structureel passeren ligt zeer voor de hand, hetgeen overduidelijk wordt bevestigd door de cijfers (V.41***). Ook bestuurders die volgens de OR geneigd zijn de machtsverschillen te benadrukken of zich formeel opstellen, passeren 'hun' medezeggenschappers duidelijk vaker dan de coöperatief ingestelde bestuurders (V.24***).

Tabel 4.2.5a. Waardering bestuunder en instemmingsrecht ( $n=117$. Cramér's V.4I***)

\begin{tabular}{|l|c|c|c|c|}
\hline Waardering voor medezeggenschap & $\begin{array}{c}\text { structureel } \\
\text { gepasseerd }\end{array}$ & $\begin{array}{c}\text { geregeld } \\
\text { gepasseerd }\end{array}$ & $\begin{array}{c}\text { redelijk } \\
\text { betrokken }\end{array}$ & $\begin{array}{c}\text { goed } \\
\text { betrokken }\end{array}$ \\
\hline Negatief & 32 & 50 & 14 & 5 \\
Gematigd positief & 12 & 10 & 30 & 48 \\
Positief & 40 & 4 & 18 & 38 \\
\hline
\end{tabular}




\begin{tabular}{|l|c|c|c|c|}
\hline Opstelling bestuurder & $\begin{array}{c}\text { structureel } \\
\text { gepasseerd }\end{array}$ & $\begin{array}{c}\text { geregeld } \\
\text { gepasseerd }\end{array}$ & $\begin{array}{c}\text { redelijk } \\
\text { betrokken }\end{array}$ & $\begin{array}{c}\text { goed } \\
\text { betrokken }\end{array}$ \\
\hline Bereid tot concessies & 9 & 28 & 50 & 13 \\
Op zoek naar nieuwe wegen & 20 & 10 & 23 & 47 \\
Geneigd zich formeel op te stellen & 38 & 9 & 19 & 34 \\
Geneigd machtsverschillen te & 53 & 16 & 11 & 21 \\
benadrukken & 53 & & & \\
\hline
\end{tabular}

\section{OR-kenmerken}

De opstelling van de ondernemingsraad noch diens actiebereidheid vertoont een significante samenhang met de mate waarin de bestuurder bereid is het instemmingsrecht van de OR te respecteren, evenmin als intensief contact met de achterban. Het contact met de vakbond daarentegen hangt wel zeer duidelijk samen met het respecteren van het instemmingsrecht: ondernemingsraden die intensief contact met de vakbond onderhouden worden significant minder vaak gepasseerd dan ondernemingsraden die nooit contact met de bonden onderhouden $\left(\mathrm{V} .21^{* * *}\right){ }^{99}$

De mate waarin de OR gepasseerd wordt blijkt ook sterk samen te hangen met de aan- of afwezigheid van een VGW(M)-commissie (V.24*): commissieloze ondernemingsraden worden duidelijk vaker gepasseerd dan OR'en die wél een commissie hebben ingesteld. Met name ondernemingsraden die de verantwoordelijkheid voor hun arbotaken tamelijk vergaand aan de commissie hebben gedelegeerd worden relatief weinig gepasseerd (V.21***). Op zichzelf ligt deze samenhang voor de hand: ondernemingsraden die weten dat hun bestuurder genegen is hun formele rechten te respecteren, kunnen het uitoefenen van die rechten met een redelijk gerust hart overlaten aan de commissie. Waar de bestuurder nogal eens in de fout gaat, zal de OR geneigd zijn machtsmiddelen in eigen hand te houden. Aan de andere kant is die verklaring misschien te simpel: zij veronderstelt immers dat de OR weet dat zijn bevoegdheden inzake het arbeidsomstandighedenbeleid worden gerespecteerd, terwijl eerder is aangegeven dat nogal wat ondernemingsraden zich vaak juist niet bewust zijn dat ze worden gepasseerd. Indien gekeken wordt naar de samenhang tussen de situaties waarin de OR zich ervan bewust is of hij gepasseerd wordt, dan blijkt toch ook dat ondernemingsraden die veel bevoegdheden hebben gedelegeerd minder vaak denken dat ze gepasseerd worden. Het ligt zeer voor de hand dat een meer professionele VGW(M)-commissie simpelweg beter weet waar haar rechten liggen én daar ook alerter op zijn.

$\mathrm{Er}$ is, ten slotte, weinig reden om samenhang te veronderstellen tussen de formele misdragingen van de bestuurder en knelpunten zoals gebrek aan tijd en deskundig-

99 Deze samenhang tussen vakbondscontact en 'non-decisie' werd ook in het eerdere onderzoek van Looise en De Lange gevonden. Looise/De Lange 1987, p. 202. In het algemeen was eerder al vastgesteld dat de aanwezigheid van vakbondswerk in bedrijven in belangrijke mate bleek samen te hangen met de invloed van de OR (Teulings 1981) 
heid aan de kant van de OR. Uit de survey-cijfers blijkt ook van geen samenhang. behalve met het item tijdgebrek: ondernemingsraden die weinig te klagen hebben over tijdgebrek hebben evenmin te klagen dat ze worden gepasseerd door de bestuurder. Een verklaring zou kunnen zijn dat in de betreffende bedrijven de voorwaarden voor medezeggenschap in het algemeen beter geregeld zijn: een bestuurder die zich netjes aan de regels houdt én de OR voldoende tijd en faciliteiten toestaat. Dat lijkt een verdedigbare stelling: in de bedrijven waar de bestuurder negatief staat tegenover de medezeggenschap signaleert de OR vaker knelpunten - op het punt van tijdgebrek zelfs significant (V.19**).

\subsubsection{Reactie OR op instemmingsaanvraag}

Als laatste punt in de analyse van de gang van zaken rond het instemmingsrecht wordt gekeken naar de samenhang tussen de reactie van de OR op instemmingsaanvragen en de kenmerken van de organisatie respectievelijk de OR zelf. Een probleem hierbij is dat het aantal instemmingsweigeringen rond arbokwesties zér beperkt is $(\mathrm{n}=16)$. Daardoor is een specifieke analyse van de arbo-instemmingsaanvragen zo goed als uitgesloten. Om dit kwantitatieve manco te ondervangen is gekeken naar de reactie van de ondernemingsraad op instemmingsaanvragen in het algemeen.

\section{Organisatiekenmerken}

Als gekeken wordt naar de variabelen branche en bedrijfsgrootte, dan valt op dat de OR'en in de transportsector opvallend vaak en in het bank- en verzekeringswezen en de zakelijke dienstverlening opvallend weinig hun instemming hebben geweigerd (V.39***), Ook blijkt de OR in 100-min bedrijven duidelijk minder vaak zijn instemming te weigeren dan in de grotere bedrijven (V.24*).

Er is geen samenhang met de waardering van de bestuurder voor medezeggenschap. Kennelijk heeft een instemmingsweigering van de OR geen al te negatieve invloed op de waardering. Omgekeerd heeft een autoritaire opstelling van de bestuurder wél een negatieve samenhang met het aantal instemmingsweigeringen $\left(\mathrm{V} .26^{*}\right)$ : indien de bestuurder bereid is tot concessies wordt zelden ( 7 procent) de instemming onthouden, terwijl het percentage machtsgeoriënteerde bestuurders dat wel eens op een weigerachtige OR is gestuit maar liefst 63 procent is - een mogelijk aandachtspunt voor de bestuurder.

Als gekeken wordt naar de reactie van de bestuurder op een instemmingsweigering kan. gegeven het beperkte aantal relevante situaties, geen sterke statistische samenhang worden blootgelegd. Zelfs los van de statistische eisen leveren de cijfers weinig op: dat bestuurders die de machtsverschillen benadrukken relatief vaak een besluit doorzetten zonder instemming van de OR is al weinig opzienbarend, en een $\mathrm{n}=3$ is bepaald geen basis voor harde conclusies.

\section{OR-kenmerken}

Ondernemingsraden met een VGW(M)-commissie weigeren iets vaker instemming dan OR'en zonder commissie $\left(\mathrm{V} .21^{*}\right)$. Vooral de formalistische OR, die alle bevoegdheden heeft overgedragen maar het instemmingsrecht in eigen hand houdt. 
trekt vaker dan gemiddeld aan de rem (V.22**). De variabelen rond het thema 'knelpunten' leveren niets op. Slechts het item 'deskundigheidsproblemen' hangt significant samen met het aantal malen dat de OR zijn instemming weigert: vooral medezeggenschappers die onvoldoende deskundigheid hebben op het gebied van arbeidsomstandigheden weigeren relatief vaak hun instemming. Maar een zinvolle verklaring voor deze samenhang valt niet te verzinnen, eerder het tegendeel: wil de OR gegrond weigeren in te stemmen met een arbobesluit, dan moet hij het voorgenomen besluit toch minstens goed kunnen beoordelen.

Ondernemingsraden met overwegend uitvoerend personeel stellen zich iets harder op dan medezeggenschappers uit de hogere kringen: van de ondernemingsraden met overwegend uitvoerend personeel heeft 31 procent ooit zijn instemming onthouden aan een voorgenomen besluit, tegen 9 procent aan het andere eind van het spectrum $\left(\mathrm{V} .17^{* *}\right)$.

De opstelling van de ondernemingsraad in het overleg vertoont geen samenhang met het aantal malen dat de OR instemming heeft geweigerd, evenmin als het contact met de achterban. Een significante samenhang wordt wél gevonden tussen het aantal weigeringen enerzijds en de actiebereidheid en het contact met de vakbond anderzijds (V.21, resp. V.24, beide p<.01). Deze samenhang zal echter niet verbazen. De vraag of een dergelijke activistische opstelling vruchten afwerpt kan helaas, wegens onvoldoende celvulling, niet met grote zekerheid worden beantwoord.

\subsubsection{Samenvatting en conclusies}

In paragraaf 4.2 is het functioneren van ondernemingsraden op arbogebied belicht vanuit een aantal achtergrondkenmerken: structurele bedrijfskenmerken, kenmerken die meer gericht zijn op de overlegcultuur binnen bedrijven, en de opstelling en organisatie van de OR zélf. In deze afsluitende paragraaf worden de gevonden samenhangen bij elkaar gezet en waar mogelijk geduid.

\section{Structurele kenmerken: branche/bedrijfsgrootte/economische- en concurrentie- positie}

Verwacht mag worden dat in een aantal branches 'arbo' een zwaarder wegend the$\mathrm{ma}$ is dan in andere. Deze verwachting wordt vooral gevoed door het gegeven dat in sommige branches de arbeidsomstandigheden nu eenmaal belastender zijn dan in andere. Branches die relatief vaak kampen met belastende factoren zijn de gezondheidszorg en de bouw. ${ }^{100}$ Uit het onderzoek blijkt dat met name in de gezondheidszorg arbo inderdaad een centraal beleidsthema is: er is veel animo, de ondernemingsraden nemen relatief veel initiatieven, en er zijn duidelijk meer instemmingsaanvragen dan gemiddeld. Ook springt de gezondheidszorg er positief uit wat betreft de formele betrokkenheid van de OR: in de branche wordt de OR

$100 \mathrm{Vgl}$. o.a. CBS/SZW (2001), Arbeidsomstandigheden 2001: monitoring via personen, Den Haag/Voorburg: Elsevier. Vgl. ook bijlage 6.1 bij deze studie. Ook Ministerie van Sociale Zaken en Werkgelegenheid (2000), Sectoranalyse WAO 1999: een analyse van 65 sectoren op basis van mesogegevens, p. 14 
relatief weinig gepasseerd. Aan de andere kant van het spectrum staat de transportsector. Het probleem bij de analyse was echter dat de respons voor deze branche te mager was om gezaghebbende uitspraken te doen. Ook omtrent de overige branches valt weinig significants op te merken, behalve wellicht dat in de commerciële hoek iets minder aandacht is voor het thema dan gemiddeld. Ook de bedrijfsgrootte levert weinig opzienbarends op, behalve dat in grotere bedrijven beter is voldaan aan de basisvoorwaarden voor medezeggenschap, en de OR minder vaak wordt gepasseerd. De verwachting dat in grote bedrijven vaker instemmingsaanvragen worden ingediend ${ }^{101}$ wordt door het survey niet bevestigd.

De economische- en concurrentiepositie van de onderneming hangt op vrijwel geen enkele wijze samen met de positie van de OR op het gebied van arbeidsomstandigheden. Hooguit kan gesteld worden dat economisch sterke bedrijven en bedrijven die weinig last hebben van concurrentie wat meer instemmingsplichtige arbobesluiten voorleggen dan bedrijven die bezig zijn te overleven.

\section{Opstelling bestuurder en $O R$}

De meest opvallende samenhangen uit het onderzoek zijn te vinden in de opstelling van de bestuurder en diens waardering voor medezeggenschap. Dit strookt met de bevinding uit het eerdere onderzoek van Looise: ook volgens hem is de interactie bestuurder/OR "verreweg het meest van belang". ${ }^{102}$ De OR bleek op veel aspecten van zijn functioneren afhankelijk van de medewerking van de bestuurder: krijgt de OR wél of géen instemmingsaanvragen, in welke fase van het besluitvormingsproces wordt de OR ingeschakeld, en ervaart hij knelpunten in zijn functioneren. ${ }^{103}$

Dit algemene beeld blijkt ook zeer sterk uit De volwassen $O R$. Een formalistische dan wel machtsgeoriënteerde opstelling van de bestuurder én een lage waardering voor medezeggenschap werkt bepaald niet bevorderlijk. Er wordt relatief weinig overleg gevoerd, de informatievoorziening is beneden de maat, en bestuurders met geringe waardering voor medezeggenschap én machtsgeoriënteerde bestuurders blijken 'hun' OR zeer vaak te passeren bij instemmingsplichtige besluiten. Ook worden initiatieven in bedrijven met een onwillige bestuurder minder vaak overgenomen. ${ }^{104}$

$101 \mathrm{Vgl}$. Looise/De Lange 1987, p. 197, die juist wel een samenhang tussen bedrijfsgrootte en kwanitatieve toepassing van het instemmingsrecht vonden

102 Looise/De Lange 1987, p. 271. Ook uit Australisch onderzoek blijkt stijl van leidinggeven in het algemeen zeer bepalend voor de resultaten van medezeggenschappers: "management style [is] a key variable explaining the incidence and variations in the effectiveness of employee participation" M. Brown en S. Ainsworth (2000), A review and integration of research on employee participation in Australia 1983-1999. Melbourne: Center for Employment and Labour Relations Law, Working Paper No. 18. p. 3

103 Looise/De Lange 1987, p. 272

104 In het algemeen is de opstelling van de ondernemer natuurlijk van cruciaal belang voor het welslagen van pogingen om elementen van het sociaal beleid te delegeren naar bedrijfsniveau. Zo komt ook in een onderzoek naar de succes- en faalfactoren bij de risico-inventarisatie de opstelling van de ondernemer als belangrijkste (de-)motivator naar voren. E.L. van der Steeg et al. (2002), Onderzoek naar de succes- en faalfactoren van de op grond van de Arbeidsomstandighedenwet uitgevoende risico-imventarisatie en evaluatie, Den Haag: Ministeric van Sociale Zaken en Werkgelegenheid (werkdocument 276), p. 165 
De bestuurder krijgt vervolgens de OR die hij verdient: weinig animo, nauwelijks initiatieven, en instemmingsplichtige besluiten van machtsgeoriënteerde bestuurders worden relatief vaak getroffen door een veto van de OR. De opstelling van de bestuurder werkt ook door in het aantal knelpunten die ondernemingsraden signaleren. Een OR die te maken heeft met een onwillige bestuurder signaleert vaker deskundigheidsproblemen en tijdgebrek dan ondernemingsraden met een coöperatieve bestuurder. Wat hierbij oorzaak en gevolg zijn, is lastig in een eenduidige relatie onder te brengen. Het kan immers zijn dat de OR ondeskundig is doordat hij onvoldoende wordt gefaciliteerd door een onwillige bestuurder, maar omgekeerd kan het gebrek aan deskundigheid voor de bestuurder een reden zijn om de OR niet serieus te betrekken.

Tabel 4.2.6. De bestuunder als bepalende factor (Cramér's V)

\begin{tabular}{|l|c|c|}
\hline & $\begin{array}{c}\text { waardering } \\
\text { medezeggenschap }\end{array}$ & $\begin{array}{c}\text { opstelling } \\
\text { bestuurder }\end{array}$ \\
\hline Informatievoorziening & $\mathrm{ns}$ & $.26^{* *}$ \\
Overleg over arbozaken & $.23^{*}$ & $.26^{* *}$ \\
Knelpunten & $\mathrm{ns}$ & $.16^{*}$ \\
Deskundigheidsproblemen & $.30^{* * *}$ & $.17^{*}$ \\
Overbelasting & $\mathrm{ns}$ & $\mathrm{ns}$ \\
Tijdgebrek & $.19^{*}$ & $.17^{*}$ \\
Arbo-animo & $.27^{* * *}$ & $.21^{* *}$ \\
Aandacht arbo & $\mathrm{ns}$ & $.18^{* *}$ \\
Stimuleren arbo & $\mathrm{ns}$ & $.18^{* *}$ \\
Stimuleren verzuim & $.31^{* * *}$ & $.23^{* * *}$ \\
Aantal arbo-initiatieven & $\mathrm{ns}$ & $.39^{* * *}$ \\
Aantal instemmingsaanvragen & $\mathrm{ns}$ & $\mathrm{ns}$ \\
Aandacht arbo bij adviesaanvragen & $.28^{* *}$ & $.22^{* * *}$ \\
Aantal malen gepasseerd & $.41^{* * *}$ & $.24^{* * *}$ \\
Aantal keren instemming geweigerd & $\mathrm{ns}$ & $.26^{* * *}$ \\
\hline
\end{tabular}

In de relatie bestuurder/OR heeft de opstelling van de OR zélf natuurlijk ook effect, al is de samenhang op dit punt duidelijk minder sterk dan de voornoemde punten. Een coöperatieve OR heeft duidelijk minder te klagen over het overleg. Indien de bestuurder de OR als coöperatief bestempelt zijn de positieve signalen (beter overleg, minder gepasseerd), duidelijk sterker dan bij de zelfinschatting van de OR. Deze gegevens mogen door een magere celvulling echter niet significant heten. Aan de andere kant ontvangt een al te meegaande OR minder informatie. Anderzijds hebben ondernemingsraden die zichzelf 'formalistisch' achten minder te klagen 
over de informatievoorziening. Ook actiebereidheid van de OR hangt samen met betere informatie, meer instemmingsaanvragen én vroegtijdiger inschakeling. Intensief contact met de vakbond hangt samen met een stimulerende taakopvatting van de OR, en duidelijk minder 'non-decisie': de OR wordt minder vaak gepasseerd.

Uit deze bevindingen komt het globale beeld naar voren dat het voor een bestuurder effectief kan zijn (en waarschijnlijk is) om zich coöperatief op te stellen: het faciliteren van de OR leidt tot een hogere deskundigheid en open overleg leidt tot soepeler besluitvorming. Omgekeerd kan het voor de OR geen kwaad wat vaker zijn tanden te laten zien. Regelmatig contact met de vakbond lijkt één van de zwaarder wegende factoren te zijn. ${ }^{105}$

De interne organisatie van de OR: $V G W(M)$-commissie/type OR/opleidingsniveau $\mathrm{De}$ aan- of afwezigheid van een VGW(M)-commissie en de mate waarin de OR de commissie heeft bekleed met bevoegdheden heeft duidelijk effect op de betrokkenheid van de OR bij het arbeidsomstandighedenbeleid in zijn bedrijf. Ondernemingsraden mét een VGW(M)-commissie genieten duidelijk betere informatie en beter overleg, worden minder vaak gepasseerd, en ervaren minder knelpunten. Ook de organisatie van het OR-werk heeft effect. Een 'professionelere' OR signaleert minder knelpunten, functioneert beter en wordt minder vaak gepasseerd.

Overigens blijkt bij nadere analyse dat, hoewel bedrijfsgrootte als zodanig niet zeer sterk samenhangt met het functioneren van de OR, controle voor bedrijfsgrootte er wél toe leidt dat de significante effecten van de organisatie van het OR-werk ten dele verloren gaan. Voor de bedrijven tussen 100-500 werknemers blijken de aanwezigheid van een VGW(M)-commissie én een professionele organisatie nog wel positief samen te hangen met goed overleg, een goede informatievoorziening, en minder non-decisie, maar deze samenhang is niet langer meer significant. Voor de 100 - $\min$ bedrijven is de samenhang echter nog wel behoorlijk sterk $\left(\mathrm{V}>2.25^{*}\right)$.

\subsection{Conclusies}

Het onderzoek naar het effect van diverse achtergrondfactoren op het functioneren van arbo-zelfregulering op bedrijfsniveau levert mijns inziens de volgende conclusies op die de moeite waard zijn:

1. Ondernemingsraden zijn formeel voldoende geëquipeerd om een belangrijke bijdrage te leveren aan het arbeidsomstandighedenbeleid in hun onderneming, maar blijkens het survey signaleren zij diverse knelpunten (gebrek aan kennis en vooral tijd) en worden veel ondernemingsraden gepasseerd (zeker waar het de formele bevoegdheden betreft).

2. De invloed is beperkt: hoewel 95 procent van de bestuurders aangeeft dat de OR op het terrein van het sociaal beleid redelijk ( 54 procent) tot veel ( 41 procent) invloed heeft, blijkt het aantal ondernemingen waarin de OR erin geslaagd is een

105 Zie ook Looise 1987. p. 226 en Teullings 1981. 
voorgenomen besluit te wijzigen middels het instemmingsrecht tamelijk beperkt - beide zo'n 12 procent. Daarnaast heeft ongeveer én op de tien ondernemingsraden een officieel arbo-initiatief gelanceerd dat vervolgens is overgenomen door de bestuurder.

Deze eerste twee conclusies zijn overigens uit de categorie halfvolle of halflege glazen: in 60 procent van de bedrijven is voldaan aan de basisvoorwaarden voor medezeggenschap (overleg en informatievoorziening), in 60 procent van de bedrijven worden de formele procedures redelijk in acht genomen, en in 70 procent van de bedrijven houdt de OR (soms) rekening met de arbo-aspecten van adviesaanvragen. Hierbij moet wel worden opgemerkt dat de conclusies zijn gebaseerd op een nogal lage respons. In de methodologische verantwoording (bijlage 4.1) is daarom aangegeven dat het toch al tamelijk negatieve beeld (ondernemingsraden worden vaak gepasseerd en hebben relatief weinig invloed) in werkelijkheid waarschijnlijk nog somberder moet worden ingekleurd. ${ }^{106}$

3. De actiebereidheid van de OR lijkt een positief effect te hebben op de mate waarin hij serieus genomen wordt door de bestuurder. In ongeveer de helft van de bedrijven heeft de OR wel eens een machtsmiddel ingezet. ${ }^{107}$ Schaalconstructie (Cronbach's $\alpha=0.71$ ) leert echter dat slechts 10 procent van de ondernemingsraden werkelijk actiebereid genoemd kan worden.

4. Medezeggenschap werkt duidelijk beter in grotere bedrijven. Dat zou kunnen komen doordat in grotere ondernemingsraden een grotere kans bestaat dat er kwaliteit in vertegenwoordigd is. Kleine ondernemingsraden hebben al moeite om voldoende kandidaten te vinden, laat staan goed gekwalificeerde. Uit de gegevens van De volwassen $O R$ blijkt echter dat grote ondernemingsraden niet minder vaak knelpunten signaleren dan kleinere. De deskundigheidsproblemen zijn niet minder groot $^{108}$, en het tijdgebrek en overbelasting zelfs groter. Een mogelijke verklaring is dat grote bedrijven in het algemeen een meer gestructureerde bedrijfsvoering hebben.

Daarmee samenhangend luidt de in mijn ogen centrale conclusie uit dit hoofdstuk:

5. De mate waarin ondernemingsraden erin slagen een actieve bijdrage te leveren aan de zorg voor veilige en gezonde arbeidsomstandigheden hangt zeer sterk af van de opstelling van de bestuurder. Waar de werkgever het laat afweten, kan ook formele medezeggenschap weinig uitrichten om de arbeidsomstandigheden

106 Ook uit onderzoek van het ministerie van Sociale Zaken en Werkgelegenheid uit 2001 blijkt dat ondernemers die een positievere houding hebben ten aanzien van ondernemingsraden een iets (matig significant) grotere bereidheid hebben om mee te werken aan onderzoek. SZW (2001), De faciliteiten en bevoegdheden van OR-en en de relaties met de achterban, Werkdocument no. 215 Den Haag: Ministerie van Sociale Zaken en Werkgelegenheid. Aardig is dat ook bij de enquête Arbeidersleven in Nederland uit 1907 al gewaarschuwd werd voor positieve vertekening bij enquêtes. G. Harmsen en B. Reinalda (1975), Voor de bevrijding van de arbeid: beknopte geschiedenis van de Nederlandse vakbeweging. Nijmegen: Sun, p. 133

107 Van het Kaar/Looise 1999, p. 121

108 Vgl. echter Mevissen 2001, p. 82 
in het bedrijf te verbeteren. ${ }^{109}$ In het algemeen blijkt dat het thema 'arbo', maar ook verzuim- en reîntegratiebeleid, alleen van de grond komt als de directie overtuigd is van het belang van het onderwerp. ${ }^{110}$

Deze laatste twee conclusies werpen een schril licht op het concept van zelfregulering en de ambities van de overheid. Als medezeggenschap, zoals de overheid denkt, bijdraagt aan betere arbeidsomstandigheden, dan worden de veiligheid, de gezondheid en het welzijn van werknemers in kleinere bedrijven wellicht minder goed beschermd dan in grote bedrijven. Bovendien wordt de zorg voor veilige en gezonde arbeidsomstandigheden ten dele afhankelijk gemaakt van de goedertierenheid van de werkgever. De principiële conclusie die hieruit getrokken kan worden. is dat er ongelijkheid ontstaat waar het een van de grondrechten van de werknemers betreft: de waarborging van de gezondheid. "Als we zelfsturing en zelfregulering serieus nemen, zal dat [..] ongetwijfeld ook betekenen dat er binnen maatschappelijke sectoren meer differentiatie optreedt, ook in de materiële normstelling, met alle gevolgen van dien voor de rechtszekerheid en de rechtsgelijkheid."111

Of dit daadwerkelijk een probleem is, is echter mede afhankelijk van een meer precieze beantwoording van de vraag of medezeggenschap daadwerkelijk tot betere arbeidsomstandigheden leidt. Deze kwestie zal in het volgende hoofdstuk uitgebreid worden onderzocht.

109 K. Frick (1994), Can management control health and safety at work?, Economic and Industrial Democracy. 11 (3), p. 375-399

$110 \mathrm{Vgl}$. onder meer G.E. Evers en F.A. Reijenga (1998), Als het maar geen arbozorg heet .... bevondering van arbozorg in het MKB, Hoofddorp: NIA TNO

111 P.H.A. Frissen (1993), Zelfregulering en besturingsconcepties, in: Eijlander, Ph. e.a. Overheid en zelfregulering: Alibi voor vrijblijvendheid of prikkel tot aktie?, Zwolle: W.E.J. Tjeenk Willink, p. 174 


\section{Het arbo-effect van medezeggenschap}

Uit paragraaf 4.1 kwam een tamelijk somber stemmend antwoord op de eerste subvraag van dit onderzoek: "Zijn ondernemingsraden voldoende geëquipeerd om de hun toebedachte rol op het gebied van het arbeidsomstandighedenbeleid goed te kunnen vervullen?' Formeel zijn de bevoegdheden en faciliteiten weliswaar goed geregeld, maar in de praktijk blijkt dat ondernemingsraden tegen velerlei obstakels aanlopen: tijdgebrek, overbelasting. gebrekkige kennis en ervaring, onwillige bestuurders die met grote regelmaat voorbijgaan aan de OR. Desondanks is in de tussenconclusie (paragraaf 4.1.6) vastgesteld dat medezeggenschap wel degelijk effect kan hebben. Sommige ondernemingsraden nemen zelf initiatieven, die veelal worden overgenomen. Middels het instemmingsrecht worden soms voorgenomen besluiten aangepast. Bestuurders kennen de OR tamelijk veel invloed toe op het sociaal beleid.

Daarmee is een eerste, zij het zéér indicatief antwoord gegeven op de tweede vraag van dit proefschrift:

Leidt werknemersbetrokkenheid bij het arbobeleid tot betere kwaliteit van de arbeid?

In dit hoofdstuk wordt deze vraag, in feite de cruciale vraag, nader beschouwd. Cruciaal, als men althans de mening is toegedaan dat medezeggenschap niet om zich zelfs willen wordt uitgeoefend, maar idealiter bijdraagt aan een betere behartiging van de belangen van werknemers - in casu betere arbeidsomstandigheden. ${ }^{\text {. }}$ Indien betrokkenheid van de ondernemingsraad (of pvt) geen enkele invloed zou hebben op het arbobeleid, hoeft in feite ook niet nagedacht te worden over eventuele oplossingen voor de in hoofdstuk 4 geconstateerde knelpunten.

De invloed van medezeggenschap op de arbeidsomstandigheden is echter lastig te meten. Louter de aanwezigheid van een OR/pvt leidt uiteraard niet als bij toverslag tot veiliger en gezonder werk. Het ligt voor de hand dat het arbo-effect van medezeggenschap bemiddeld is via de invloed van de OR op het arbobeleid. Het effect

I Overigens kan men medezeggenschap $66 \mathrm{k}$ als waarde op zich beschouwen, bijvoorbeeld vanuit het fundamentele recht op zelfbeschikking. Vgl. J.K.M. Gevers (1982), Zeggenschap van werknemers inzake gezondheid en veiligheid in bedrijven. De rechtsontwikkeling in de lidstaten van de Europese Gemeenschap. Deventer: Kluwer, p. 63 
van dat beleid zou dan kunnen worden geoperationaliseerd aan de hand van een aantal min of meer harde indicatoren, zoals ongevalscijfers, het aantal beroepsziekten, het ziekteverzuim(percentage) en de WAO-uitstroom. ${ }^{2}$

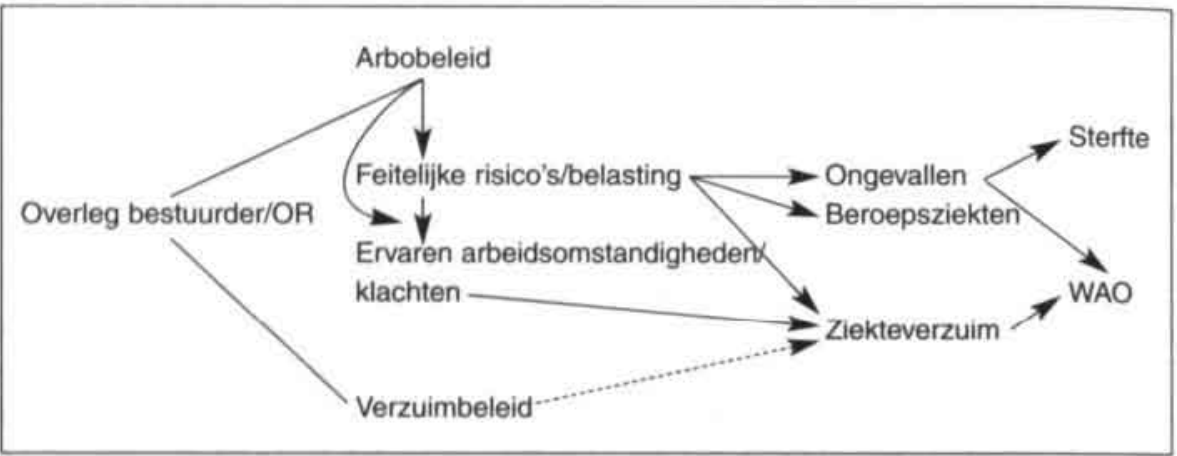

Figuur 5.1

In eerste instantie geven deze indicatoren weinig aanleiding om te denken dat medezeggenschap daadwerkelijk tot een grotere veiligheid en een betere bescherming van de gezondheid leidt. Integendeel: als contra-indicatie mag gelden dat, hoewel eerder (paragraaf 4.3 ) is vastgesteld dat medezeggenschap beter van de grond komt in grotere bedrijven, het ziekteverzuim en de WAO-uitstroom in grotere bedrijven juist hoger ligt dan in kleine bedrijven. ${ }^{3}$ Ook lijkt de ongevallenincidentie in middelgrote bedrijven hoger dan in kleinere, al zijn de cijfers niet een-

2 Deze relatie veronderstelt dat cen goed arbeidsomstandighedenbeleid tot betere arbeidsomstandigheden leidt. Deze relatie is echter zelden onderzocht. Uit de schaarse gegevens ter zake blijkt van geen relatie tussen het arbobeleid en de WAO-uitstroom of het ziekteverzuim. A.G. ter Huume et al. (1997), ZARA-werkgeverspanel rapportage 1996-1997, Den Haag: Ministerie van Sociale Zaken en Werkgelegenheid, p. 122; T.J. Veerman et al. (2001), Werkgevers over ziekteverzuim, Arbo en reïtegratie: Eindrapportage van hat ZARA/SZW-werkgeverspanel, Den Haag: Ministerie van Sociale Zaken en Werkgelegenheid, p. 36. Over de samenhang tussen het verzuimbeleid en het ziekteverzuim zie J. Popma. C. van Rij en J. Hooiveld (2001). Arbodienstverlening tussen markt en medezeggenschap, Den Haag: Delwel, p. 85-90. Voor de definitic van 'arbeidsongeval' en 'beroepsziekte' zie P.E. van der Poest Clement en A.H.M. Broere (2002), Handboek Arbowet: Rechten en verplichtingen toegelicht voor werkgever en werknemer. Den Haag: Sdu ( $7^{\circ}$ druk)

3 CBS (2003), Kwartaalonderzoek ziekteverzuim, in: Sociaal-Economische maandstatistiek $2003 / 1$. p. 84 In bedrijven met meer dan 100 werknemers is de kans om in de WAO te belanden. gecorrigeerd naar leeftijd, geslacht, bedrijfstak en loon. ruim $30 \%$ hoger dan in de kleinste bedrijven (10-). Lisv (2000), WAO-instroom en bedrijfsgrootte, Amsterdam: Lisv, november 2000, p. 17 
duidig. ${ }^{4}$ Dat betekent overigens nog niet dat die negatieve indicaties te wijten zijn aan slechtere arbeidsomstandigheden, of dat die slechtere arbeidsomstandigheden het negatieve bijproduct zijn van medezeggenschap. Verzuim en arbeidsongeschiktheid worden immers slechts ten dele door slechte arbeidsomstandigheden verklaard..$^{5}$ Als belangrijke oorzaken voor het relatief hoge verzuim in grote bedrijven wordt wel gerefereerd aan de betrekkelijke anonimiteit en de betere vervangbaarheid die een lagere verzuimdrempel tot gevolg zouden hebben. Voor de hogere uitstroom richting WAO worden vergelijkbare verklaringen aangedragen. Een andere factor is het gemiddeld oudere personeelsbestand van grote bedrijven, en een hoger percentage vrouwen: twee categorieěn werknemers die bovengemiddeld vaak arbeidsongeschikt raken (ook exclusief zwangerschap). ${ }^{6}$

Dat slechte arbeidsomstandigheden toegeschreven kunnen worden aan de loutere aanwezigheid van een OR lijkt mij theoretisch onaannemelijk, en is bovendien niet met cijfers te onderbouwen. De tot op heden enige cijfers die iets over het effect van medezeggenschap op de arbeidsomstandigheden zeggen, wijzen juist op het tegendeel: in bedrijven mét OR of formele personeelsvertegenwoordiging is in ieder geval het arbobeleid beter - hetgeen dus nog niet per direct betekent dat daarmee ook de arbeidsomstandigheden veiliger en gezonder zijn. ${ }^{7}$

In dit hoofdstuk wordt een poging gedaan om een scherper beeld te krijgen van het effect van medezeggenschap op het arbobeleid en de feitelijke arbeidsomstandigheden in bedrijven. Hiertoe moeten langs twee kanten de variabelen geoperationaliseerd worden. Enerzijds is dit de medezeggenschap.

- Is er een OR of niet? Zo ja, heeft die OR een VGW(M)-commissie?

- Hoe intensief wordt de OR betrokken bij het arbeidsomstandighedenbeleid?

Dit laatste punt kan op een aantal manieren nader worden geoperationaliseerd:

- Hoe vaak wordt overleg gevoerd?

- Ontvangt de OR de vereiste informatie?

4 Klein Hesselink signaleert dat vooral in de bedrijven met 50 tot 500 werknemers de ongevallenincidentie hoog is. D.J. Klein Hesselink (1995), Ongevallenregistratie in bedrijf: over de melding, registratie en analyse van arbeidsongevallen, Amsterdam: NIA, p. 95. De meer recente cijfers van het CBS vertonen juist een tegengesteld beeld. Blijkens de CBS-gegevens komen de $100+$ bedrijven als minst onveilige uit de bus: in 2001 was de incidentie per 100 werknemers in de $100+$ bedrijven 2,1 tegen 2,7 in de kleinste bedrijven (10-) en 3,2 in de bedrijven van 10-100 werknemers. Ministerie van Sociale Zaken en Werkgelegenheid, Arbobalans 2002, p. 45. Ook uit cijfers van Eurostat blijkt dat de onveiligheid in het MKB groter is dan in grotere bedrijven. Eurostat, Statistics in Focus: Population and Social Conditions, nr.16/2001: Accidents at work in the EU 1998-1999. Vgl. ook http://agency.osha.eu.int/publications/reports/405/en/index_37.htm

5 E.A.P Koningsveld en J.C.M. Mossink (1997), Kerncijfers maatschappelijke kosten van arbeidsomstandigheden in Nederland. Den Haag: VUGA/Ministerie van Sociale Zaken en Werkgelegenheid, p. 14

6 Lisv 2000, p. 6. Opvallend in de studie van Klein Hesselink naar arbeidsongevallen is dat oudere werknemers weliswaar veel minder vaak een ongeval krijgen, maar dat de ongevallen wél tot een duidelijk langer verzuim leiden. Klein Hesselink 1995, p. 98

7 Ter Huurne 1997, p. 122 
- Kan de OR zijn formele bevoegdheden in stelling brengen?

- Wat is de (ervaren) invloed van medezeggenschap?

Anderzijds kan de kwaliteit van de arbeidsomstandigheden worden geoperationaliseerd aan de hand van een aantal indicatoren:

1. De kwaliteit van het arbeidsomstandighedenbeleid

- aanwezigheid en kwaliteit van de risico-inventarisatie en -evaluatie;

- aanwezigheid en kwaliteit van het plan van aanpak;

- contract met de arbodienst en het (ervaren) effect van arbodienstverlening.

2. Feitelijke arbeidsomstandigheden

- fysieke belasting;

- psychische belasting/werkdruk;

- RSI/beeldschermwerk;

- gevaarlijke stoffen;

- geluid;

- trillen/schokken;

- veiligheidsrisico's.

3. Ervaren arbeidsomstandigheden

4. De negatieve effecten van belastende arbeidsomstandigheden

- verzuimcijfer:

- WAO-uitstroom;

- ongevallencijfer.

De samenhang tussen deze twee groepen variabelen (medezeggenschap respectievelijk kwaliteit van de arbeidsomstandigheden), zal worden onderzocht aan de hand van twee databronnen. De belangrijkste bron vormt het bestand van de Arbomonitor 2001 van de Arbeidsinspectie. ${ }^{8}$ Deze Arbomonitor, een jaarlijks onderzoek in ruwweg 1600 bedrijven, beoogt een representatief beeld te geven van het arbobeleid en de feitelijke arbeidsomstandigheden in bedrijven. In tegenstelling tot de jaarlijkse monitor van het $\mathrm{CBS}^{9}$ wordt de onderhavige monitor door de Arbeidsinspectie niet uitgevoerd door een vragenlijst onder werknemers, maar door inspecties op het niveau van bedrijven. De inspecties worden uitgevoerd aan de hand van een vragenlijst. In paragraaf 5.1 wordt een secundaire analyse uitgevoerd op het bestand van de Arbeidsinspectie, gericht op de samenhang tussen medezeggenschap en arbobeleid. In paragraaf 5.2 wordt, opnieuw aan de hand van de Arbomonitor, de samenhang tussen medezeggenschap en de aanwezigheid van risicofactoren bekeken.

Een tweede bron is de FNV-enquête 'Arboprof', die de basis vormde voor de zogeheten Arbosterrengids ${ }^{10}$. In paragraaf 5.3 wordt aan de hand van de FNV-gegevens, aangevuld met een aantal gegevens uit het bestand van De volwassen $O R$, gekeken wat het effect van medezeggenschap is op indicator nummer 3, meer in het bijzonder

8 A. Peters en E.C. van Hoorn (2002), Arbomonitor 2001, Den Haag: Arbeidsinspectie

9 Vgl. CBS/Ministerie van Sociale Zaken en Werkgelegenheid (2001), Arbeidsomstandigheden 2001: Monitoring via personen. Den Haag: Elsevier

10 J. Hooiveld en G. Kuiperij (1999), Arboprof: Arbosterrengids 2000, Amsterdam/Zeist: FNV/Kerckebosch 
het ziekteverzuim in bedrijven. " Gegevens over de samenhang tussen medezeggenschap, WAO-instroom en/of ongevallenincidentie zijn helaas niet voorhanden.

Dit hoofdstuk behelst, zoals gezegd, secundaire analyse van twee bestanden. De operationalisatie van de variabele 'medezeggenschap' in beide bestanden verschilt helaas. Bij de Arbomonitor is een beperkt aantal vragen meegenomen die puur gericht waren op het onderhavige onderzoek. ${ }^{12}$ De vragenlijst van de FNV-enquête is echter geheel door de FNV-onderzoekers zelf ontwikkeld. Voor een verantwoording van de steekproef en methode zij hier verwezen naar de Arbomonitor ${ }^{13}$ respectievelijk de Arbosterrengids. ${ }^{14}$

Bij de analyse in paragraaf $5.1-2$ is gebruik gemaakt van het door de Arbeidsinspectie zelf gewogen bestand. Ter toetsing is een vergelijking gemaakt met andere gegevens, zoals het nalevingsonderzoek WOR ${ }^{15}$ en het bestand van De volwassen $O R$. Van de 1589 bezochte bedrijven heeft 17 procent een formele vertegenwoordiging in de vorm van een $\mathrm{OR}$ of pvt. ${ }^{16}$ Dit lage percentage hangt vooral samen met het grote aantal bedrijven met minder dan 10 werknemers, die 80 procent van het total uitmaken. In die kleine bedrijven heeft slechts 9 procent een formele personeelsvertegenwoordiging ingesteld. In de andere bedrijven is het percentage aanmerkelijk hoger - uiteraard vooral in bedrijven met meer dan 50 werknemers, waarvoor de instelling van een ondernemingsraad wettelijk verplicht is (art. 2 WOR). Vergelijking met het nalevingsonderzoek uit 2000 leert dat de gegevens omtrent het aantal ondernemingsraden in de Arbomonitor consistent zijn met de eerdere bevindingen. ${ }^{17}$ Van de ondernemingsraden heeft ruim de helft een VGW(M)-commissie ingesteld. Voor de $100+$ bedrijven zijn de gegevens redelijk consistent met de uitkomsten uit De volwassen $O R$ (zie paragraaf 4.1). Voor de kleine bedrijven worden merkwaardig hoge percentages voor de instelling van een VGW(M)-commissie gevonden (ruim één derde). Aangenomen mag immers worden dat de personeelsvertegenwoordiging juist is opgericht om te overleggen over arbeidstijden en arbeidsomstandigheden, zodat zeker in de 35 - bedrijven het instellen van een aparte commissie in veel gevallen dubbelop lijkt. ${ }^{18}$

11 Het betreft hier een samenvatting van de gegevens in J. Popma, C. van Rij en J. Hooiveld (2001), Arbodienstverlening tussen markt en medezeggenschap, Den Haag: Delwel, p. 61-100. De statistische bewerkingen in dat deel van de publicatie zijn uitgevoerd door Coen van Rij.

12 De Arbeidsinspectie komt dank toe voor de bereidwillige samenwerking bij het opstellen van de vragenlijst en het ter hand stellen van het databestand.

13 Peters/Van Hoorn 2002, p. 6-8

14 Hooiveld/Kuiperij 1999, p. 13-15 en Popma/Van Rij/Hooiveld 2001, p. 117

15 E. Bruin en F. Huijgen (2000), Naleving van de Wet op de Ondernemingsraden: Stand van zaken begin 2000, Den Haag: Elsevier/SZW

16 Bij de analyse is gebruik gemaakt van het gewogen databestand, zoals aangeleverd door de Arbeidsinspectie.

17 Bruin/Huijgen 2000, p. 5. Vergelijking van het aantal personeelsvertegenwoordigingen in kleinere instellingen is lastig, omdat Bruin/Huijgen aangeven dat hun eigen gegevens ter zake wellicht weinig betrouwbaar zijn. Ibid. p. 10

18 Overigens heeft één op de drie $35+$ bedrijven gewoon een $\mathrm{OR}$, waarvoor een aparte commissie uiteraard wel dienstig kan zijn. 


\begin{tabular}{|l|c|c|c|c|}
\hline & \multicolumn{2}{|c|}{ OR of pvt ingesteld } & \multicolumn{2}{c|}{ VGW-commissie ingesteld } \\
\cline { 2 - 5 } & $\begin{array}{c}\text { Arbomonitor } \\
\text { (2001) }\end{array}$ & $\begin{array}{c}\text { Bruin/Huijgen } \\
(\mathbf{2 0 0 0 )}\end{array}$ & $\begin{array}{c}\text { Arbomonitor } \\
\text { (2001) }\end{array}$ & $\begin{array}{c}\text { Volwassen } \\
\text { OR (1999) }\end{array}$ \\
\hline 2-9 werknemers & 9 & & 36 & \\
10-19 werknemers & 23 & & 40 & \\
20-49 werknemers & 34 & & 34 & \\
35-49 werknemers & & 32 & & \\
50-99 werknemers & 75 & 76 & 45 & 32 \\
100-199 werknemers & 87 & 90 & 61 & 66 \\
200+ & 93 & 95 & 75 & 83 \\
\hline
\end{tabular}

In de ondernemingen waar een werknemersvertegenwoordiging is ingesteld, voert 96 procent hiervan regelmatig overleg over het arbeidsomstandighedenbeleid. ${ }^{19}$ In 46 procent van de ondernemingen is 'arbo' zelfs een vast agendapunt op de overlegvergadering, in de grote bedrijuen iets vaker dan in de kleine (Cramér's V.15***). De invloed van de werknemers op het beleid wordt door 31 procent van de werkgevers als 'groot' ingeschat, en 61 procent dicht de OR of pvt een 'redelijke' invloed toe, Slechts 8 procent van de werknemersvertegenwoordigers heeft weinig tot geen invloed op het arbobeleid. Voor de grotere bedrijven komt de geschatte invloed vrijwel exact overeen met de bevindingen in De volwassen OR (zie paragraaf 4.1.6): 9 procent gé́n invloed, 37 procent grote invloed - iets meer dus dan in de kleine. Opvallend is, zo op het oog, dat de kleinste bedrijven ( $2-9$ werknemers) het laagste percentage 'géén invloed' (4 procent) te zien geven. Dit is echter niet vreemd, omdat de personeelsvertegenwoordiging in deze bedrijven meestal juist met het oog op het arbobeleid is opgericht terwijl in de grotere bedrijven vaak een 'algemene' OR functioneert.

Niet verrassend hangt de invloed van de OR sterk samen met het aantal contactmomenten tussen werknemersvertegenwoordiging en bestuurder (V.37***): in bedrijven waar arbo een vast agendapunt voor de $\mathrm{OR}$ is, heeft medezeggenschap in 40 procent van de gevallen grote invloed, in bedrijven waar 'met enige regelmaat' over arbozaken wordt gesproken is dit slechts 25 procent. De aanwezigheid van een VGW(M)-commissie vertoont ook een duidelijk positieve samenhang met de invloed van de OR/pvt - vooral in de $100+$ bedrijven.

19 Dit is hoger dan vijf jaar geleden, toen 'arbo' in $77 \%$ van de bedrijven met enige regelmaat werd besproken. Ter Huurne 1997. p. 119 (vgl. ook par. 4. I.I van dit proefschrift) 


\subsection{Medezeggenschap en arbobeleid}

\subsubsection{Risico-inventarisatie en Plan van Aampak}

De twee essentièle elementen van het arbeidsomstandighedenbeleid zijn de risicoinventarisatie en -evaluatie én het plan van aanpak. Van de $50+$ bedrijven blijkt anno $2001 / 2002$ nog steeds 13 procent niet over een door de arbodienst getoetste risicoinventarisatie te beschikken, in alle bedrijven tezamen is dat zelfs 38 procent ( 26 procent heeft zelfs helemaal geen RI\&E uitgevoend). Van de bedrijven die wél een risico-inventarisatie hebben uitgevoerd, beschikt ongeveer een derde niet over een afdoend plan van aanpak (18 procent heeft zelfs helemaal geen plan van aanpak). Uit het onderzoek blijkt dat deze tekortkomingen duidelijk vaker voorkomen in bedrijven zonder $\mathrm{OR}$.

Als gecontroleerd wordt voor bedrijfsgrootte, dan blijkt de aanwezigheid van een OR vooral in de 100- bedrijven een belangrijke factor. Ook in de grote bedrijven is de samenhang echter nog significant. In bedrijven waarin de OR een VGW(M)commissie heeft ingesteld, is het aantal bedrijven met RI\&E ook significant hoger. Gecorrigeerd naar bedrijfsgrootte blijkt het verband tussen de aanwezigheid van een $O R$ en de aanwezigheid van een plan van aanpak vooral in de kleinere bedrijven iets sterker dan in de grotere bedrijven (Cramér's $V<0.12^{* * *}$ ). Ook hier hangt de aanwezigheid van een VGW(M)-commissie significant samen met vooral de kwaliteit van het plan van aanpak (minder vaak onvolledig).

Overigens wordt in veel gevallen de ondernemingsraad/pvt niet betrokken bij het

Tabel 5.1.1. Aanwezigheid RI\&E en Plan van Aanpak (in \%)

\begin{tabular}{|c|c|c|c|c|c|c|}
\hline & $\begin{array}{c}\text { met OR/ } \\
\text { pvt (alle } \\
\text { bedrijuen) } \\
n=1589\end{array}$ & $\begin{array}{c}\text { zonder } \\
\text { OR/pvt } \\
\text { (alle } \\
\text { bedrijven) }\end{array}$ & $\begin{array}{c}\text { Cramer's } \\
V\end{array}$ & $\begin{array}{l}\text { met OR/ } \\
\text { pvt }(50+) \\
n=622\end{array}$ & $\begin{array}{l}\text { zonder } \\
\text { OR } \\
(50+)\end{array}$ & $\begin{array}{c}\text { Cramer's } \\
v\end{array}$ \\
\hline RI\&E (getoetst) & 91 & 56 & $.27^{\cdots}$ & 91 & 75 & $.23^{\cdots}$ \\
\hline RI\&E (niet getoetst) & 4 & 14 & $.27^{\cdots *}$ & 3 & 5 & $.23^{* \cdots}$ \\
\hline Geen RI\&E & 6 & 30 & $.27^{\cdots} \cdots$ & 6 & 20 & $23^{* \cdots}$ \\
\hline Indien RI\&E aanwezig & $n=1374$ & & & $n=567$ & & \\
\hline OR of pvt betrokken bij RI\&E & 73 & & & 73 & & \\
\hline RI\&E aan OR/pvt toegezonden & 67 & & & 83 & & \\
\hline Plan van aanpak & 76 & 65 & $.12^{* *}$ & 77 & 77 & n.s. \\
\hline Matig Plan van aanpak & 14 & 14 & $.12 *$ & 14 & 9 & n.s. \\
\hline Geen Plan van aanpak & 10 & 21 & $.12^{\cdots}$ & 9 & 14 & n.s. \\
\hline Indien PvA aanwezig & $n=1166$ & & & $n=512$ & & \\
\hline Overleg met OR/pvt over PvA & 87 & & & 90 & & \\
\hline
\end{tabular}


proces van risico-inventarisatie ( 27 procent), krijgt hij de RI\&E zelfs niet toegezonden ( 33 procent), en wordt ook het plan van aanpak zonder overleg vastgesteld (13 procent). In de $50+$ bedrijven is de situatie iets minder navrant, maar de gegevens uit de Arbomonitor zijn ook voor deze bedrijven nog altijd somberder dan die in paragraaf 4.1 van deze studie - terwijl op het moment van het onderzoek door de Arbeidsinspectie (2001) de onduidelijkheden omtrent de medezeggenschapsrechten ter zake toch minder zouden moeten zijn dan ten tijde van De volwassen $O R$.

Over het algemeen zijn de inspecteurs van de Arbeidsinspectie maar matig positief over de kwaliteit van de risico-inventarisatie en het plan van aanpak. Slechts in 68 procent van de gevallen was de inspecteur van mening dat de inhoud van de RI\&E was toegesneden op de situatie in het bedrijf, en 60 procent van de plannen van aanpak kon de toets der kritiek doorstaan. In de grotere bedrijven is de situatie iets beter. Ook kan gesteld worden dat in bedrijven mét werknemersvertegenwoordiging de Arbeidsinspectie minder klachten heeft over de kwaliteit van de risicoinventarisatie en het plan van aanpak, zij het dat het verband niet significant is, ${ }^{20}$

Dat het verband niet significant is, is echter niet verrassend. Alleen de aanwezigheid van een $\mathrm{OR} / \mathrm{pvt}$ is immers nog geen garantie dat de werknemersvertegenwoordiging ook veel invloed heeft, zoals zo-even is gebleken. In veel gevallen wordt de OR/pvt immers gepasseerd. Uit de analyse blijkt dat, volgens de Arbeidsinspectie, de plannen van aanpak waarover is overlegd met de werknemersvertegenwoordiging duidelijk beter zijn dan die waarover niet is overlegd. Van de plannen van aanpak waarover géén overleg was gevoerd met de OR/pvt, werd slechts 54 procent als adequaat betiteld, tegen 73 procent indien de OR/pvt wél overleg heeft kunnen voeren (V.19***). Opvallend is dat in de grotere bedrijven de inbreng van medezeggenschap veel minder effect lijkt te hebben op de kwaliteit van het plan van aanpak, maar dat gegeven is niet significant.

Als gekeken wordt naar de intensiteit van het overleg en de door de bestuurder ervaren invloed van de medezeggenschap, dan blijkt het beeld echter weer tamelijk eenduidig positief: in bedrijven waarin 'arbo' een vast agendapunt is, is de risico-inventarisatie en -evaluatie volgens de Arbeidsinspectie vaker van acceptabele kwaliteit dan in bedrijven waarin zelden of nooit over arbeidsomstandigheden wordt gespro-

20 Opvallend is overigens dat in $20 \%$ van de gevallen de Arbeidsinspectie geen mening heeft over de kwaliteit van de risico-inventarisatic, en maar liefst $28 \%$ van de plannen van aanpak kennelijk niet op waarde is te schatten. Uiteraard komt dit vooral voor in de bedrijven waar de enquête niet is gevolgd door een rondgang door het bedrijf, maar ook in $9 \%$ van de gevallen dat de inspecteur wél een rondgang heeft gemaakt bleek hij of zij geen mening te hebben over de kwaliteit van de RI\&E. Omgekeerd werd ruim 16\% van de risico-inventarisaties voorzien van het predikaat 'toegesneden op de situatie in het bedrijf' zónder dat de inspecteur zich op de werkvloer van de situatic op de hoogte had gesteld. Ook werd $13 \%$ van de plannen van aanpak als adequat betiteld zonder dat de inspecteur een rondgang door het bedrijf had gemaakt. Verder is in $20 \%$ van de gevallen waarin het PvA gén duidelijke prioritering aangeeft de Arbeidsinspectie toch van mening dat de prioritering van het PvA adequat is in het licht van de aanwezige risico's 
Tabel 5.1.2a. Kwaliteit Plan van Aanpak (\%, alle bedrijven: $n=1166$ )

\begin{tabular}{|l|c|c|c|c|}
\hline & Adequaat & Inadequaat & Geen Mening & Cramer's V \\
\hline PvA besproken met OR/pvt & 73 & 4 & 23 & $.19 \cdots$ \\
PvA niet besproken met OR/pvt & 54 & 8 & 38 & $19 \%$ \\
$50+(\mathrm{n}=437$ ) & & & & \\
PvA besproken met OR/pvt & 78 & 3 & 18 & n.s. \\
PvA niet besproken met OR/pvt & 79 & 0 & 21 & n.s. \\
\hline Bron: Databestand Artomonitor 2001
\end{tabular}

ken. Deze samenhang geldt in nog sterkere mate voor de kwaliteit van het plan van aanpak. Ook in bedrijven waarin de OR/pvt volgens de bestuurder veel invloed heeft op het arbeidsomstandighedenbeleid is de kwaliteit van de centrale beleidsinstrumenten bovengemiddeld goed: naar men mag aannemen mede onder invloed van de werknemersvertegenwoordiging. In de $50+$ bedrijven lijkt de risico-inventarisatie en -evaluatie minder goed indien overleg wordt gevoerd met de $O R$, maar die samenhang is niet significant. Opvallend is dat de beleidsinstrumenten ook vaker de toets der kritiek kunnen doorstaan in bedrijven waarin de OR relatief veel invloed wordt toegekend (zie tabel $5.12 \mathrm{~b}$ en c).

\subsubsection{Het contract met de arbodienst}

Vrijwel alle bedrijven (98 procent) hebben anno 2001 een contract met een arbodienst. In bedrijven met meer dan 10 werknemers is dit percentage zelfs 99 procent. In bedrijven mét OR/pvt is het percentage 100 procent, in bedrijven zonder formele medezeggenschap 97 procent. Dit verschil is echter geheel toe te schrijven aan de bedrijfsgrootte en niet significant.

In de Arbomonitor is ook gekeken welke diensten zijn opgenomen in het contract met de arbodienst: arbeidsomstandighedenspreekuur, verzuimbegeleiding, toetsing

Tabel 5.1.2b. Kwaliteit RI\&E/Plan van Aanpak en betrokkenheid OR/pvt $(\%$, alle bedrijven: $n=1166$ )

\begin{tabular}{|l|c|c|c|c|}
\hline & $\begin{array}{c}\text { Arbo vast } \\
\text { agendapunt }\end{array}$ & $\begin{array}{c}\text { Incidenteel } \\
\text { arbo-overleg }\end{array}$ & $\begin{array}{c}\text { Zelden } \\
\text { arbo-overleg }\end{array}$ & Cramer's V \\
\hline Ri\&E toegesneden op bedrijf & 75 & 72 & 66 & $.06 \cdots$ \\
Plan van aanpak goed & 81 & 64 & 63 & $.18^{\cdots}$ \\
\hline & $\begin{array}{c}\text { Grote } \\
\text { invioed }\end{array}$ & $\begin{array}{c}\text { Redelijke } \\
\text { invloed }\end{array}$ & $\begin{array}{c}\text { Beperkte } \\
\text { invloed }\end{array}$ & \\
\hline RI\&E toegesneden op bedrijf & 77 & 72 & 62 & $.09 \cdots$ \\
Plan van aanpak goed & 81 & 71 & 63 & $.19 \cdots$ \\
\hline Bron: Databestand Arbomonitor 2001 & \multicolumn{5}{l}{} \\
\hline
\end{tabular}


Tabel 5.1.2c. Kwaliteit RI\&E/Plan van Aanpak en betrokkenheid OR/pvt (\%, 50+ bedrijven: $n=437$ )

\begin{tabular}{|l|c|c|c|c|}
\hline 50+ bedrijven & $\begin{array}{c}\text { Arbo vast } \\
\text { agendapunt }\end{array}$ & $\begin{array}{c}\text { incidenteel } \\
\text { arbo-overleg }\end{array}$ & $\begin{array}{c}\text { Zelden } \\
\text { arbo-overleg }\end{array}$ & Cramer's V \\
\hline $\begin{array}{l}\text { RI\&E toegesneden op bedrijf } \\
\text { Plan van aanpak goed }\end{array}$ & $\begin{array}{c}72 \\
79\end{array}$ & $\begin{array}{c}74 \\
79\end{array}$ & $\begin{array}{c}78 \\
88\end{array}$ & $\begin{array}{c}\text { n.s. } \\
\text { n.s. }\end{array}$ \\
\hline & $\begin{array}{c}\text { Grote } \\
\text { invloed }\end{array}$ & $\begin{array}{c}\text { Redelijke } \\
\text { invloed }\end{array}$ & $\begin{array}{c}\text { Beperkte } \\
\text { Invloed }\end{array}$ & \\
\hline RI\&E toegesneden op bedrijf & 83 & 67 & 69 & $.13^{* *}$ \\
Plan van aanpak goed & 85 & 74 & 68 & n.s. \\
\hline Bron: Databestand Arbomonitor 2001 & & & \\
\hline
\end{tabular}

risico-inventarisatie en -evaluatie, aanstellingskeuringen en het periodiek arbeidsgezondheidskundig onderzoek (PAGO). Middels een t-toets is onderzocht of in bedrijven mét OR het pakket uitgebreider is dan in bedrijven zonder OR. Het maximum aantal diensten is vijf, het theoretisch minimum is nul. In dat geval is het uiteraard weinig zinvol om een contract af te sluiten. In de praktijk blijkt dit ook niet voor te komen.

Tabel 5.1.3a. Omvang van het contract met de arbodienst

\begin{tabular}{|l|c|c|}
\hline & \% van alle bedrijven & \% van 50+ bedrijven \\
\hline 1 dienst & 18 & 2 \\
2 diensten & 28 & 11 \\
3 diensten & 28 & 34 \\
4 diensten & 21 & 40 \\
5 diensten & 5 & 13 \\
& 100 & 100 \\
\hline Bron: Databestand Arbomonitor 2001
\end{tabular}

Het gemiddelde aantal diensten is 2,67 (voor $50+$ bedrijven 3,51 ). Middels een t-toets valt na te gaan of de aanwezigheid van een werknemersvertegenwoordiging significant samenhangt met de omvang van het pakket. Dit blijkt inderdaad het geval. Uit de t-toets blijkt ook dat de omvang van het pakket van bedrijven mét werknemersvertegenwoordiging $(3,47)$ significant groter is dan dat van bedrijven zonder $\mathrm{OR} / \mathrm{pvt}(2,43)$. Indien gecorrigeerd wordt voor bedrijfsgrootte blijven in alle groepen de verschillen significant.

Grote bedrijven nemen overduidelijk meer preventieve diensten af: in bedrijven met een formele werknemersvertegenwoordiging wordt significant vaker een arbospreekuur gehouden en een PAGO aangeboden. Ook wordt de RI\&E vaker getoetst 
Tabel 5.1.3b. Omvang van het contruct met de arbodienst

\begin{tabular}{|l|c|c|}
\hline Omvang bedrijf & $\begin{array}{c}\text { Aantal diensten } \\
\text { met OA/pvt }\end{array}$ & $\begin{array}{c}\text { Aantal diensten } \\
\text { zonder OR }\end{array}$ \\
\hline 2-9 werknemers & 3,48 & 2,39 \\
10-19 werknemers & 3,14 & 2,57 \\
20-49 werknemers & 3,29 & 2,78 \\
50-99 werknemers & 3,56 & 3,03 \\
100-199 werknemers & 3,66 & 3,06 \\
200+ werknemers & 3,85 & 3,47 \\
totaal & 3,47 & 2,43 \\
\hline Bron: Databestand Arbomonitor 2001 & & \\
\hline
\end{tabular}

én maken de aanstellingskeuringen deel uit van het contract. Voor het verzuimbeleid is de samenhang zwak, maar dit is ook juist waar kleine bedrijven de arbodienst voor inhuren. Als gecorrigeerd wordt voor bedrijfsgrootte, wordt met name bij het arbospreekuur de samenhang minder sterk - zij het nog wel significant.

Tabel 5.1.4a. Inhoud van het contract met de arbodienst (\%, alle bedrijven, $n=1589$ )

\begin{tabular}{|l|c|c|c|}
\hline & Met OR/pvt & Zonder OR & Cramer's V \\
\hline Arbospreekuur & 94 & 60 & $.27^{* *}$ \\
Verzuimbegeleiding & 99 & 96 & $.08^{* *}$ \\
Toetsing RI\&E & 78 & 58 & $.15^{* *}$ \\
Aanstellingskeuringen & 16 & 6 & $.14^{\cdots *}$ \\
PAGO & 61 & 25 & $.29^{* * *}$ \\
\hline Bron: Databestand Arbomonitor 2001 & \multicolumn{3}{|l}{} \\
\hline
\end{tabular}

Tabel 5.1.4b. Inhoud van het contract met de arbodienst (\%, 50+ bedrijven, $n=622$ )

\begin{tabular}{|l|c|c|c|c|}
\hline & Met OR & Zonder OR & Cramer's V & $\begin{array}{c}\text { Arbosterren- } \\
\text { gids' }\end{array}$ \\
\hline Arbospreekuur & 94 & 85 & $.13^{* *}$ & 65 \\
Verzuimbegeleiding & 99 & 95 & n.s. & 86 \\
Toetsing RI\&E & 82 & 81 & n.s. & $66^{2}$ \\
Aanstellingskeuringen & 20 & 6 & $.15^{* * *}$ & 45 \\
PAGO & 69 & 38 & $.25^{* * *}$ & 72 \\
\hline 1 Hooiveld/Kuiperij 1999, p.18 \\
2 In de Arbosterrengids is sprake van 'advies over de RI\&E', en daarnaast nog 'uitvoering \\
RI\&E'. \\
\hline Bron: Databestand Arbomonitor 2001 \\
\hline
\end{tabular}


Opvallend is dat in de kleinere bedrijven het effect van medezeggenschap duidelijk groter is dan in de grotere bedrijven. Kennelijk zijn de grote bedrijven zélf al redelijk doordrongen van het belang van sommige diensten, zonder dat daar aandrang van de $\mathrm{OR} / \mathrm{pvt}$ bij nodig is. Bovendien hebben grotere bedrijven vaker hun interne arbo-organisatie beter op poten, bijvoorbeeld door de aanstelling van een arbocoördinator.

Naast de genoemde 'standaard'diensten in het contract, is het ook mogelijk dat bedrijven buiten het contract om aanvullende diensten inhuren. Te denken valt aan fysiotherapie, psychische hulp voor bijvoorbeeld overspannen werknemers of bij traumatische ervaringen, wachtlijstbemiddeling of hulp bij het opzetten van het arbo- en verzuimbeleid. In de Arbomonitor is gevraagd hoe vaak bedrijven daadwerkelijk dergelijke diensten inhuren. De meeste bedrijven doen dit in het geheel niet ( 87 procent, voor $50+$ bedrijven 63 procent). Slechts 3 procent neemt meer dan twee diensten af (voor $50+$ bedrijven 10 procent). Ook hier is weer een t-toets uitgevoerd, waaruit blijkt dat bedrijven mét ondernemingsraad significant meer aanvullende diensten inhuren dan bedrijven zonder OR, maar gemiddeld nog altijd minder dan één: 0,86 tegen 0,10 .

Tabel 5.1.5a. Aanvullende diensten buiten de arbodienst om (\%, alle bedrijven, $n=1589)$

\begin{tabular}{|l|c|c|c|}
\hline & Met OR/pvt & $\begin{array}{c}\text { Zonder } \\
\text { OR/pvt }\end{array}$ & Cramer's V \\
\hline Fysiotherapie & 21 & 4 & $.26 \cdots$ \\
Psychische hulp & 24 & 1 & $.41^{\cdots}$ \\
Voorlichting en onderricht & 8 & 1 & $.19^{* \cdots}$ \\
Sociaal medisch team & 11 & 1 & $.25^{* \cdots}$ \\
Wachtlijstbemiddeling & 5 & 1 & $.15^{* \cdots}$ \\
Advies over arbobeleid & 1 & 1 & n.s. \\
\hline Bron: Databestand Arbomonitor 2001 & & & \\
\hline
\end{tabular}

Opvallend is hier opnieuw dat in de kleine bedrijven het effect van medezeggenschap veel groter is. Op een aantal punten (psychische hulp bij stress en traumatische ervaringen, SMT) wordt in de kleinere bedrijven zelfs vaker de hulp van een deskundige inroepen dan in de $50+$ bedrijven. Dit heeft waarschijnlijk te maken met het feit dat grote bedrijven veelal deskundigheid in huis hebben middels een ruimer bemensde afdeling P\&O. Opvallend is voorts dat blijkens de Arbosterrengids veel vaker afspraken over SMT en arbo-advisering zijn opgenomen in het contract dan uit de Arbomonitor blijkt. Dit verschil is waarschijnlijk verklaarbaar uit de verschillen in vraagstelling: in de Arbomonitor is gevraagd of deze aanvullende diensten buiten de arbodienst om ingekocht zijn, terwijl ze in de Arbosterrengids juist bij de arbodienst ingekocht zouden moeten zijn. Kennelijk hebben de arbodiensten bij de niet-verplichte taken het grootste marktaandeel. De conclusie die hier getrokken kan worden, dat in bedrijven mét OR/pvt een omvangrijker pakket arbodienstverlening wordt ingekocht, kan nog worden aangescherpt met het gegeven uit de 
Tabel 5.I.5b. Aanvullende diensten buiten de arbodienst om (\%, $50+$ bedrijven, $n=615$ )

\begin{tabular}{|c|c|c|c|c|}
\hline & Met OR/pvt & $\begin{array}{l}\text { Zonder } \\
\text { OR/pvt }\end{array}$ & Cramer's V & $\begin{array}{c}\text { Arbosterren- } \\
\text { gids }^{3}\end{array}$ \\
\hline Fysiotherapie & 17 & 9 & $.09^{\circ}$ & 7 a $19^{4}$ \\
\hline Psychische hulp & 21 & 6 & $.15^{* *}$ & \\
\hline Voorlichting en onderricht & 15 & 8 & $.08^{*}$ & 25 \\
\hline Sociaal medisch team & 8 & 1 & $.12^{* \cdots}$ & 69 \\
\hline Wachtlijstbemiddeling & 5 & 8 & n.s. & 8 \\
\hline Advies over arbobeleid & 2 & 8 & $.12^{* *}$ & 35 \\
\hline \multicolumn{5}{|c|}{$\begin{array}{l}3 \text { Hooiveld/Kuiperij 1999, p. } 18 \\
4 \text { In de Arbomonitor is fysiotherapie in één categorie ondergebracht met rug-/tiltraining. } \\
\text { terwili die activiteiten in de Arbosterrengids waren onderscheiden. }\end{array}$} \\
\hline \multicolumn{5}{|c|}{ Bron: Databestand Arbomonitor 2001} \\
\hline
\end{tabular}

FNV-enquête voor de Arbosterrengids dat formele betrokkenheid van de OR duidelijk samenhangt met het gemiddelde aantal diensten. ${ }^{21}$

Tabel 5.1.6. Gemiddeld aantal werkzaamheden en betrokkenheid

\begin{tabular}{|l|c|c|}
\hline & OR betrokken & OR niet betrokken \\
\hline Betrokken bij de keuze van de arbodienst & 11,7 & 8,9 \\
Op basis van instemmingsrecht & 11,9 & 9,9 \\
Betrokken bij takenpakket & 11,9 & 9,3 \\
Op basis van instemmingsrecht & 12,2 & 10,1 \\
\hline
\end{tabular}

Uit de gegevens van het FNV-onderzoek naar de kwaliteit van de arbodiensten in Nederland blijkt bovendien een duidelijke samenhang tussen betrokkenheid van de OR en de impact van de arbodienstverlening (in de zin van verbetering van de arbeidsomstandigheden). Volgens de ondervraagde ondernemingsraden heeft arbodienstverlening, ondanks alle kritiek die op het functioneren van arbodiensten mogelijk is, namelijk wel degelijk positieve effecten op het arbobeleid. Volgens de helft van de geënquêteerde OR-leden was door arbodienstverlening de aandacht bij de werkgever toegenomen en het arbobeleid verbeterd, investeerde het bedrijf meer in arbo, en was 40 procent van mening dat ook de arbeidsomstandigheden verbeterd waren. ${ }^{22}$ Als alle acht items bij elkaar werden gezet, viel een totaalscore te berekenen, die op zijn beurt weer sterk correleerde met de manier waarop de ondernemingsraad was betrokken bij de keuze van de arbodienst en de inhoud van het contract.

21 Popma/Van Rij/Hooiveld 2001, p. 75

22 Ibid. p. 63 


\begin{tabular}{|l|c|c|c|}
\hline & Betrokken & $\begin{array}{c}\text { Impact indien } \\
\text { OR wel betrokken }\end{array}$ & $\begin{array}{c}\text { Impact indien } \\
\text { OR niet betrokken }\end{array}$ \\
\hline Keuze van de arbodienst & 55 & 5,8 & 5,3 \\
Op basis van instemmingsrecht & 27 & 5,9 & 5,5 \\
Takenpakket van de arbodienst & 45 & 6,0 & 5,2 \\
Op basis van instemmingsrecht & 20 & 6,2 & 5,4 \\
\hline
\end{tabular}

Uit tabel 5.1 .7 blijkt dat, ten minste indirect via de bijdrage van de arbodienst, een duidelijke invloed uitgaat van de medezeggenschap op het arbeidsomstandighedenbeleid en de ervaren arbeidsomstandigheden. Ook de mate waarin de arbodienst van zijn kant aandacht heeft voor samenwerking met de OR en de werknemers blijkt significant te correleren met de ervaren impact. ${ }^{23}$

\subsection{Medezeggenschap en arborisico's}

Weliswaar lijkt medezeggenschap samen te hangen met de impact van de dienstverlening en daarmee indirect met een beter arbobeleid en betere arbeidsomstandigheden, maar de impactscove is een subiectiese schaal gehaseerd op de iuschitting van de geënquêteerde OR-leden. In een poging om het effect van medezeggenschap te toetsen aan een meer objectief criterium, is met behulp van de Arbomonitor 2001 de relatie onderzocht tussen de aanwezigheid en betrokkenheid van de OR en een aantal kwantitatieve indicatoren, te weten een vijftal arborisico's:

- tillen of dragen;

- RSI/repeterende arbeid/statische belasting/beeldschermwerk;

- psychische belasting:

- geluid;

- gevaarlijke stoffen.

In de analyse is gekeken of de aanwezigheid van een ondernemingsraad/pvt samenhangt met de frequentie van de problematiek, het treffen van maatregelen, én de daadwerkelijke uitvoering van die maatregelen. Verwacht mag worden dat de aanof afwezigheid van een werknemersvertegenwoordiging in principe niet samenhangt met de frequentie van de problemen. Aan de andere kant is het natuurlijk goed denkbaar dat in kleine bedrijven met een relatief ernstige arboproblematiek de werkgever zich geroepen voelt een arbobeleid op te zetten en daarom juist een personeelsvertegenwoordiging in het leven roept. Voorts valt zinvol te beargumenteren dat in de $50+$ bedrijven juist de bedrijven zónder de verplichte OR ook op andere terreinen, met name de veiligheid en gezondheid, zich wellicht minder aan de regels gelegen laten liggen. Belangrijker is echter de hypothese dat bedrijven mét $\mathrm{OR} / \mathrm{pvt}$ vaker maatregelen getroffen zullen hebben (bijvoorbeeld op aandrang van 
de medezeggenschappers) én dat die maatregelen beter worden uitgevoend doordat de werknemersvertegenwoordigers de vinger aan de pols houden.

\section{Omvang van de problematiek}

Een globale analyse van de omvang van de problematiek leert dat in bedrijven met OR/pvt op twee punten duidelijk meer problemen voorkomen: RSI/beeldschermwerk en psychische belasting. Nadere beschouwing leert echter dat deze samenhang vrijwel geheel verklaard wordt door de bedrijfsgrootte. Dit heeft vooral te maken met de vraagstelling: 'zijn er werknemers die aan [een bepaald risico] zijn blootgesteld?' Hoe meer werknemers, des te groter uiteraard de kans op een bevestigend antwoord. Uit de rapportage van de Arbeidsinspectie zelf blijkt dan ook dat grote bedrijven op alle punten vaker een 'population at risk' rapporteren ${ }^{24}$. Op zichzelf is dit tamelijk zinloze informatie, hoewel een langjarig perspectief wél kan laten zien hoe de blootstelling aan risico's zich bínnen een grootteklasse ontwikkelt.

\section{Maatregelen getroffen}

Over het algemeen kan worden gesteld dat áls een bedrijf problemen signaleert, dan ook relatief vaak maatregelen worden getroffen. Positieve uitschieter is het lawaaibeleid ( 97 procent), terwijl psychische problemen het minst tot maatregelen nopen. Over de hele linie blijkt dat bedrijven mét werknemersvertegenwoordiging duidelijk vaker maatregelen treffen, met name op het gebied van RSI. De invloed van medezeggenschap lijkt het minst pregnant op het terrein van lawaaibestrijding, maar dat is een problematiek waar de noodzaak van maatregelen kennelijk door de werkgever zelf ook wel wordt ingezien. Er is geen duidelijke lijn te ontdekken aangaande de toegevoegde waarde van een VGW(M)-commissie.

\section{Maatregelen uitgevoerd}

In de enquête is gevraagd of de maatregelen 'adequaat zijn toegepast'. Hierbij waren vier antwoorden mogelijk:

- de aandacht voor de problematiek is structureel verankerd;

- de risico-populatie wordt deels bereikt;

- twijfelachtig;

- nee.

Voor de eigen analyse is alleen het eerste antwoord opgenomen als positieve toets voor een adequate uitvoering. Louter de aanwezigheid van een OR blijkt echter niet significant tot een betere verankering van het beleid te leiden.

De intensiteit van het overleg tussen bestuurder en OR/pvt zou op een aantal punten samen kunnen hangen met de (h)erkenning van arboproblemen, en met name met het aantal maatregelen en de verankering van het beleid. Rond het eerste punt is er weinig zinvols te melden: de aanwezigheid van 'harde' arboproblemen hangt niet of nauwelijks samen met de vraag of 'arbo' een vast agendapunt is in het overleg. Intensief

24 Peters/Van Hoorn 2002, p. 69ff 
Tabel 5.2.Ia. Risicofactoren, maatregelen en OR (\%, 50+ bedrijuen, $n=543$ )

\begin{tabular}{|l|c|c|c|}
\hline & met OR & Geen OR & Cramer's V \\
\hline Tilrisico's & 57 & 52 & n.s. \\
Tilmaatregelen & 95 & 88 & n.s. \\
Aandacht structureel verankerd & 85 & 91 & n.s. \\
RSI-risico's & 81 & 68 & $.13^{*}$ \\
Beeldschermwerk & 93 & 82 & $.13^{* *}$ \\
Maatregelen getroffen & 93 & 77 & $.19^{* * .}$ \\
Aandacht structureel verankerd & 80 & 78 & n.s. \\
Psychische belasting & 57 & 40 & $.14^{*}$ \\
Maatregelen getroffen & 80 & 90 & n.s. \\
Aandacht structureel verankerd & 70 & 80 & n.s. \\
Geluid & 39 & 35 & n.s. \\
Maatregelen getroffen & 98 & 97 & n.s. \\
Aandacht structureel verankerd & 84 & 85 & n.s. \\
Gevaarlijke stoffen & 46 & 50 & n.s. \\
Maatregelen getroffen & 94 & 83 & n.s. \\
Aandacht structureel verankerd & 77 & 83 & n.s. \\
Gemiddeld maatregelen getroffen & 92,0 & 87,0 & \\
Gemiddeld verankerd & 79,2 & 83,4 & \\
\hline Bron: Databestand Arbomonitor 2001 & & & \\
\hline
\end{tabular}

overleg hangt echter wel samen met het treffen van maatregelen. Gemiddeld worden, over de vijf risicofactoren, in bedrijven met intensief arbo-overleg in 93 procent van de bedrijven maatregelen getroffen, tegen 78 procent in de bedrijven met weinig of geen overleg (indien lawaai en gevaarlijke stoffen niet worden meegeteld, is het verschil nog groter: 90 procent tegen 70 procent). Overigens is deze samenhang tweeduidig: het kan zijn dat er meer maatregelen worden getroffen omdat er een $\mathrm{OR} / \mathrm{pvt}$ is die tijdens het overleg aan de bel trekt, maar het kan natuurlijk ook heel goed dat er overleg wordt gevoerd juist omdat de bestuurder maatregelen wil treffen. De samenhang tussen de intensiteit van het overleg en de mate waarin de maatregelen, volgens de inspecteur van de arbeid, structureel verankerd zijn binnen de organisatie lijkt evenwel meer eenduidig. In bedrijven met weinig overleg zijn de maatregelen slechts voor de helft van de gevallen werkelijk verankerd, tegen 84 procent in de bedrijven waar arbo een vast agendapunt is. Kennelijk leidt een regelmatig overleg met de werknemersvertegenwoordiging ertoe dat maatregelen goed inklinken: een OR-strategie van frapper toujours werpt zijn vruchten af, waarbij opnieuw RSI en psychische belasting er duidelijk uitspringen. 
Tabel 5.2.1 b. Risicofactoren, maatregelen en intensiteit overleg $(50+$ bedrijven, $n=447)$

\begin{tabular}{|c|c|c|c|c|}
\hline & $\begin{array}{c}\text { Arbo vast } \\
\text { agendapunt }\end{array}$ & $\begin{array}{c}\text { Regelmatig } \\
\text { overleg }\end{array}$ & $\begin{array}{c}\text { Zelden } \\
\text { arbo-overleg }\end{array}$ & Cramer's V \\
\hline Tilrisico's & 57 & 56 & 62 & n.s. \\
\hline Tilmaatregelen & 94 & 96 & 94 & n.s. \\
\hline Aandacht structureel verankerd & 87 & 83 & 87 & n.s. \\
\hline RSI-risico's & 83 & 78 & 82 & n.s. \\
\hline Beeldschermwerk & 91 & 96 & 82 & $.13^{\cdots}$ \\
\hline Maatregelen getroffen & 93 & 95 & 73 & $20 * \cdots$ \\
\hline Aandacht structureel verankerd & 84 & 79 & 33 & $.24 \cdots$ \\
\hline Psychische belasting & 57 & 59 & 44 & n.s. \\
\hline Maatregelen getroffen & 84 & 80 & 42 & $.22^{* * *}$ \\
\hline Aandacht structureel verankerd & 75 & 66 & 0 & $.25 \cdots$ \\
\hline Geluid & 40 & 38 & 41 & n.s. \\
\hline Maatregelen getroffen & 100 & 99 & 91 & n.s. \\
\hline Aandacht structureel verankerd & 89 & 78 & 82 & n.s. \\
\hline Gevaarlijke stoffen & 45 & 51 & 27 & n.s. \\
\hline Maatregelen getroffen & 96 & 93 & 88 & n.s. \\
\hline Aandacht structureel verankerd & 86 & 71 & 43 & $.22 * *$ \\
\hline Gemiddeld maatregelen getroffen & 93,4 & 92,6 & 77,6 & \\
\hline Gemiddeld verankerd & 84,2 & 75,4 & 49,0 & \\
\hline
\end{tabular}

Een zelfde beeld valt te destilleren uit de samenhang tussen de invloed van de $\mathrm{OR} / \mathrm{pvt}$ (althans, invloed volgens de bestuurder) enerzijds en de gesignaleerde problematiek en de genomen maatregelen anderzijds. Gemiddeld genomen worden in bedrijven waar de werknemersvertegenwoordiging een grote invloed wordt toegedicht niet minder arborisico's gesignaleerd dan in bedrijven waarin de werknemersinvloed gering is, maar worden wél vaker maatregelen getroffen, die bovendien duidelijk beter verankerd zijn: in 94 procent van de bedrijven met invloedrijke medezeggenschap worden maatregelen genomen ter bestrijding van fysieke of psychische overbelasting, tegen 77 procent van de bedrijven met geringe werknemersinvloed. Voor de verankering van de maatregelen zijn de percentages zelfs 92 tegen 50. Samengevat lijkt het duidelijk dat de loutere aanwezigheid van een OR niet als zodanig tot minder arborisico's leidt, maar wél dat een intensiever contact meer en beter verankerde maatregelen tot resultaat heeft.

\subsection{Medezeggenschap en ziekteverzuim}

Zoals bij herhaling is aangegeven, bestaan in bedrijven mét werknemersvertegenwoordiging nauwelijks minder risico's voor veiligheid en gezondheid dan in bedrij- 
ven zonder OR/pvt. De aanwezigheid van arborisico's hangt immers vooral af van de aard van de werkzaamheden. Wél worden, blijkens de voorgaande paragraaf, in bedrijven met medezeggenschap vaker maatregelen getroffen. Interessant is dan of dit ook iets oplevert, in de zin van minder gezondheidsklachten, ongevallen of een lager verzuim. Helaas is er nauwelijks onderzoek gedaan naar het effect van beleid op de feitelijke/ervaren arbeidsomstandigheden of de aanwezigheid van klachten; laat staan naar de bijdrage van medezeggenschap op dit punt.

De schaarse indicaties over het effect van arbobeleid zijn bovendien, contraintuïtief, negatief: de aansluiting bij een arbodienst en de aanwezigheid van een plan van aanpak hangen juist samen met een negatieve ontwikkeling in het verzuim. De verklaring hiervoor is wellicht dat juist bedrijven met een hoog verzuim aanleiding zullen zien om een contract af te sluiten. ${ }^{25}$ Belangrijker is echter de constatering dat de toepassing van diverse beleidsinstrumenten niet tot een zichtbare daling van het verzuim heeft geleid. ${ }^{26}$ Dit zou echter verklaard kunnen worden uit het gegeven dat over de onderzoeksperiode (1996-2000) het verzuim in het algemeen een stijgende lijn vertoonde. ${ }^{27}$

Een stijgend verzuim op landelijk niveau betekent echter niet dat de stijging in alle bedrijven even sterk is. Sterker nog, uit de gegevens van de Arbosterrengids kan worden opgemaakt dat over de onderzoeksperiode (1996-1998) in 21 procent van de bedrijven het verzuim juist daalde. Indien wordt gedifferentieerd naar bedrijf, valt dus te achterhalen welke factoren samenhangen met de ontwikkeling van het verzuim. De invloed van de OR, waar het in deze studie om gaat, kan op een aantal manieren worden geoperationaliseerd (zie boven). Op basis van factoranalyse van de gegevens uit de FNV-enquête zijn twee factoren te destilleren: informatievoorziening aan de OR én formele invloed. ${ }^{28}$ Ook in De volwassen $O R$ is onderscheid gemaakt tussen informatievoorziening en het gebruik van formele bevoegdheden. Daarnaast is in de FNV-enquête een simpele vierdeling gemaakt in de mate waarin de OR betrokken is bij de keuze van de arbodienst.

Om met dat laatste element te beginnen: uit de gegevens van de FNV-enquête blijkt een duidelijke samenhang tussen de betrokkenheid van de OR en de ontwikkeling van het verzuim. In bedrijven waar de ondernemingsraad betrokken was bij de keuze van de dienst of de inhoud van het takenpakket, werd vaker een daling van het verzuim gemeld dan in bedrijven waarin de OR níet betrokken was. Voor betrokkenheid op grond van het instemmingsrecht werd een nog groter verschil gevonden. Bij bedrijven waar de OR instemming is gevraagd (overigens slechts één op de vijf) daalde het verzuim bijna twee keer zo vaak dan wanneer de OR niet betrokken is.

Een iets meer verfijnde maat voor de betrokkenheid van de ondernemingsraad zijn

25 Veerman 2001. p. 35-36

26 Ibid. p. 79

27 In 1994 daalde het verzuim scherp onder invloed van de introductie van het eigen risico in de wet TZ (Tenugdringing Ziekteverzuim), in 1996 nog een klein beetje versterkt door de Wulbz Na 1997 stijgt het verzuimpercentage weer, allicht onder invloed van de conjuncturele ontwikkeling. 28 Popma/Van Rij/Hooiveld 2001, p. 91 
Figuur 5.2 Ziekteverzuim bedrijven (excl. zwangerschap)

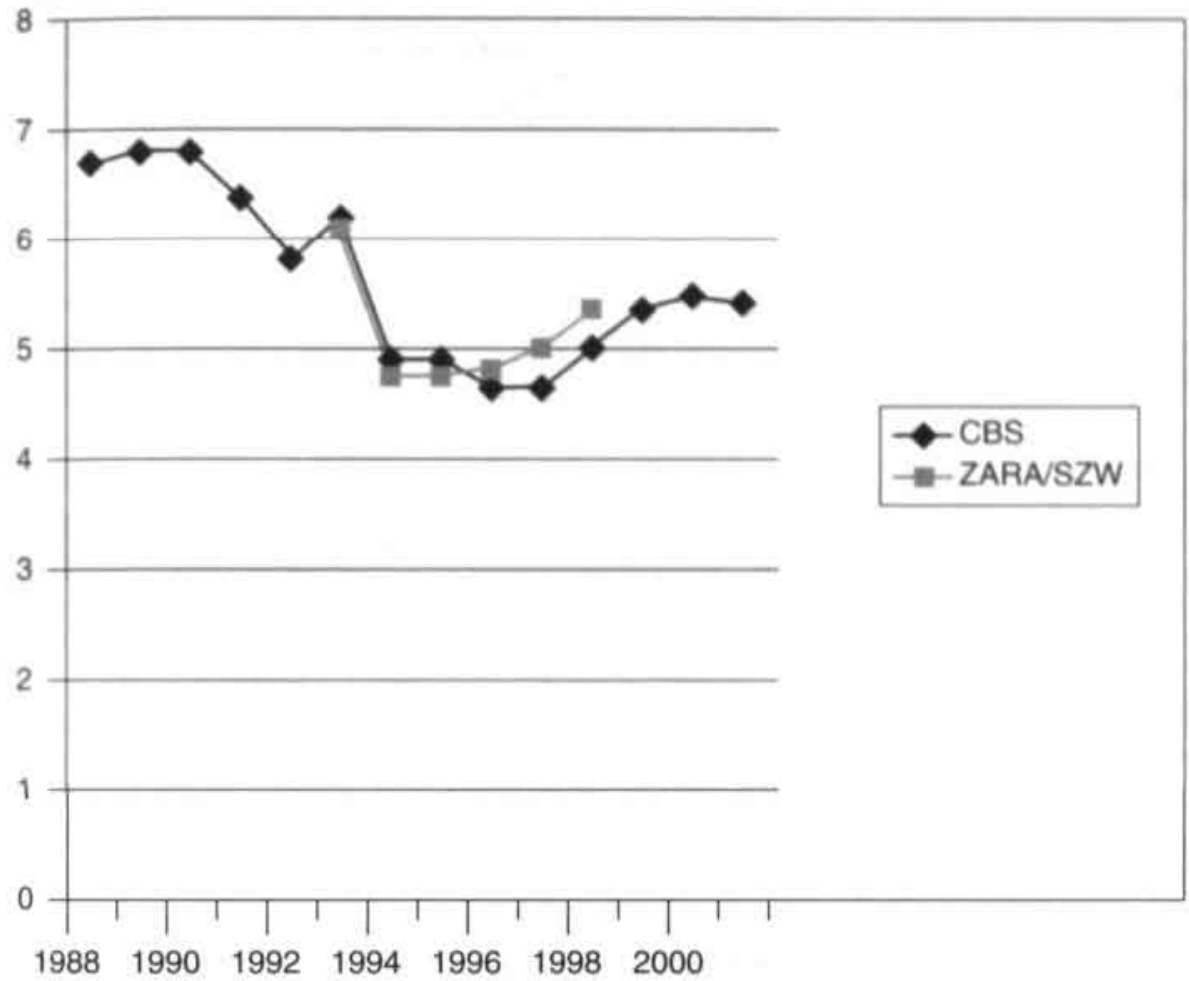

de schalen zoals ontwikkeld in paragraaf 4.1.2 en paragraaf 4.1.3.1 van dit proefschrift. Goede informatievoorziening en het eerbiedigen van het instemmingsrecht blijken significant te correleren met een lager verzuimpercentage in de bedrijven. ${ }^{29}$

Uiteraard is het loutere feit dat de formele procedures worden gerespecteerd nog geen verklaring voor de hoogte van het ziekteverzuim. Het is echter wel een indicatie voor de mate waarin de OR wordt betrokken, en dat de ondernemingsraad waarschijnlijk via invloed op het verzuimbeleid daadwerkelijk bijdraagt aan een lager verzuim. Deze veronderstelling is te toetsen aan de hand van de gegevens uit de FNV-enquête. Het verzuimbeleid kan op basis van die gegevens op twee manieren worden geoperationaliseerd.

Ten eerste is dit mogelijk door berekening van een verzuimscore, een 'rapportcijfer' aan de hand van een twintigtal vragen aan ondernemingsraden over het ver-

29 In de regel kunnen geconstrueerde schalen als 'quasi-intervalvariabele' worden gezien en als intervalvariabele worden behandeld, omdat de meeste technieken redelijk robuust zijn regen afwijkingen van intervalniveau. P. de Heus, R. van der Leeden en B. Gazendam (1995), Toegepaste data-analyse: Technieken voor niet-experimenteel onderzoek in de sociale wetenschappen, Utrecht: Lemma, p. 38 


\begin{tabular}{|l|c|c|}
\hline & $\begin{array}{c}\text { OR wel betrokken } \\
\text { \% ziekteverzuim } \\
\text { afgenomen }\end{array}$ & $\begin{array}{c}\text { OR niet betrokken } \\
\text { \% ziekteverzuim } \\
\text { afgenomen }\end{array}$ \\
\hline Keuze van de arbodienst & 22 & 20 \\
Op basis van instemmingsrecht & 31 & 18 \\
Takenpakket van de arbodienst & 25 & 18 \\
Op basis van instemmingsrecht & 35 & 18 \\
\hline Bron: Popma/Van Rij/Hooiveld 2001, p. 95 & \\
\hline
\end{tabular}

Tabel 5.3.2. Correlatie medezeggenschap en verzuimpercentage (Pearson correlatie)

\begin{tabular}{|l|c|}
\hline & Correlatie met verzuimpercentage \\
\hline Overleg & -.023 \\
Informatievoorziening & $-.282^{*}$ \\
Instemmingsrecht & $-.236^{*}$ \\
\hline${ }^{*} p<.01 .{ }^{*} p<.05$ & \\
\hline Bron: Databestand De volwassen OR & \\
\hline
\end{tabular}

zuimbeleid in hun organisatie. ${ }^{30}$ Deze verzuimscore is een indicatie van de breedte van het verzuimbeleid, en blijkt redelijk te correleren met de ontwikkeling van het ziekteverzuim $(r=.30)$ : in bedrijven met een meer uitgewerkt beleid is het verzuim verhoudingsgewijs vaker afgenomen dan in bedrijven met een minder ontwikkeld verzuimbeleid. ${ }^{31}$

Ten tweede valt middels factoranalyse een vijftal dimensies te destilleren die indicatief zijn voor het accent van het verzuimbeleid. ${ }^{32}$ In veel bedrijven ligt het accent sterk op individuele verzuimbegeleiding. ${ }^{33}$ Sommige bedrijven volgen een meer repressieve strategie, door middel van verzuimcontrole ( 26 procent), of arbeidsvoorwaardelijke prikkels zoals inhouding van loon of invoering van wachtdagen (10 à 20 procent). ${ }^{34}$ Een werkelijk preventieve aanpak, in de zin van verbetering van de arbeidsomstandigheden, krijgt duidelijk minder aandacht dan de individugerichte aanpak ${ }^{35}$, al heeft van de OR-plichtige bedrijven toch een meerderheid wel

30 Popma/Van Rij/Hooiveld 2001. p, $91-94$

31 Ibid. p. 94

32 Ibid. p. 93

33 Veerman 2001, p. 38 en 78

34 Ibid., p. 91

35 Ibid., p. 33, 90. Vgl. Popma/Van Rij/Hooiveid 2001, p. 67, waaruit blijkt dat ook in contracten met de arbodienst het accent duidelijk ligt op individu-gericht verzuimbeleid en veel minder op arbo-advies. 
degelijk activiteiten ondernomen om risico's of belasting in het werk te verminderen (zie tabel 5.2.1). Uit de analyse van de FNV-gegevens blijkt dat drie factoren samenhangen met een dalend verzuim: individuele verzuimbegeleiding $\left(r=.18^{* *}\right)$, cen brede blik (koppeling van verzuim aan ziekmakende arbeidsomstandigheden $\left(r=.22^{* *}\right)$, en met name betrokkenheid van het lijnmanagement bij het ziekteverzuim $\left(r=.30^{* *}\right){ }^{36}$ Het opwerpen van verzuimdrempels blijkt niet significant te correleren met de ontwikkeling van het verzuim. ${ }^{37}$

Tabel 5.3.3. Correlaties tussen type verzuimbeleid en verzuim

\begin{tabular}{|l|c|}
\hline & Correlatie met verzuimpercentage \\
\hline Individuele verzuimbegeleiding & $.18^{* *}$ \\
'Brede blik' & $.2{ }^{* *}$ \\
Verzuimregistratie & $.10^{*}$ \\
Lijnverantwoordelijkheid & $.30 *$ \\
Verzuimdrempels & .09 \\
\hline$*$ p<.01, ${ }^{*} p<.05$ & \\
\hline Bron: Popma/Van Ril/Hoolveld 2001, p.96 \\
\hline
\end{tabular}

Daarmee is echter nog niets gezegd over het effect van medezeggenschap op het verzuim. Als gekeken wordt naar het effect van betrokkenheid van de ondernemingsraad bij het arbo- en verzuimbeleid in bedrijven, dan blijkt medezeggenschap tamelijk duidelijk te correleren met juist een bredere blik op het verzuim én integratie van het verzuimbeleid in de lijn. Middels factoranalyse is een tweetal factoren gedestilleerd - informatievoorziening en daadwerkelijke invloed (middels instemmingsrecht $)^{38}-$, waarbij in zijn algemeenheid kan worden gesteld dat betrokkenheid van de OR sterk correleert met de verzuimscore (i.c. de 'breedte' van het verzuimbeleid), en dat het gebruik van het instemmingsrecht in het bijzonder gewicht in de schaal legt voor de twee meest effectieve elementen van het verzuimbeleid.

\subsection{Conclusie}

Uit de bovenstaande analyses blijkt een duidelijke samenhang tussen de aanwezigheid van en het overleg met een werknemersvertegenwoordiging enerzijds en de kwaliteit van het arbo- en verzuimbeleid, de impact van arbodienstverlening en het

\section{Popma/Van Rij/Hooiveld 2001, p. 96}

37 Veerman et al. concluderen dat de invoering van arbeidsvoorwaardelijk verzuimbeleid een tamelijk sterk effect heeft op de ontwikkeling van het verzuim (op. cit. p. 43). De gegevens op grond waarvan deze conclusie wordt getrokken, zijn echter nogal mager: van de 46 respondenten die aangaven met arbeidsvoorwaardelijke prikkels te werken, waren er 36 kleine ondernemingen in de detailhandel.

38 Popma/Van Rij/Hooiveld 2001, p. 91 
Tabel 5.3.4. Correlaties tussen betrokkenheid OR en type verzuimbeleid

\begin{tabular}{|l|c|c|}
\hline \multirow{2}{*}{ Dimensies van verzuimbeleid } & \multicolumn{2}{|c|}{ Betrokkenheid OR } \\
\cline { 2 - 3 } & Informatievoorziening & Inhoudelijke invloed \\
\hline Individuele verzuimbegeleiding & $0,20^{* *}$ & $0,09 *$ \\
Brede blik & $0,21^{* *}$ & $0,26^{* *}$ \\
Verzuimregistratie & $0,25^{* *}$ & 0,09 \\
Lijnverantwoordelijkheid & $0,31^{* *}$ & $0,28^{* *}$ \\
Verzuimdrempels & $-0,08$ & $0,18^{* *}$ \\
Verzuim-score & $0,64^{* *}$ & $0,57^{* *}$ \\
\hline${ }^{*} p<.01,{ }^{*} p<.05$ & & \\
\hline Bron: Popma/Van Rij/Hooiveld 2001, p.98 & \\
\hline
\end{tabular}

aantal maatregelen anderzijds. Indirect lijkt er ook sprake van invloed van werknemersvertegenwoordiging op de ontwikkeling van het verzuim. Deze samenhang zou overigens nog 'wegverklaard' kunnen worden door een achterliggende factor: de bedrijfscultuur en/of de kwaliteit van het management. Dit geldt zeker voor de OR-plichtige bedrijven. Bedrijven immers die, ondanks de wettelijke plicht daartoe, geen ondernemingsraad hebben ingesteld zouden wel eens een negatieve selectie kunnen zijn van alle bedrijven: zij hebben op het punt van medezeggenschap kennelijk al blijk gegeven niet veel op te hebben met de positie van werknemers, dus ook wat betreft de naleving van de verplichtingen inzake de bescherming van hun veiligheid en gezondheid zouden zij wel eens over een rekbaarder geweten kunnen beschikken. Dat in bedrijven zónder formele werknemersvertegenwoordiging het beleid én de arbeidsomstandigheden minder goed zijn dan in bedrijven mét OR of personeelsvertegenwoordiging, zou dus tegen die achtergrond 'wegverklaard' kunnen worden.

In de bedrijven waarin wél een werknemersvertegenwoordiging actief is, blijkt echter dat ook de intensiteit van het overleg en de ervaren invloed van de OR wel degelijk samenhangen met de kwaliteit van het arbobeleid en het aantal maatregelen om gesignaleerde arborisico's weg te nemen. Dit is toch een zeer duidelijke indicatie dat medezeggenschap een positieve invloed heeft op de arbeidsomstandigheden in bedrijven. Hoe de globale samenhang in de praktijk verklaard kan worden, is een kwestie die meer en detail bekeken moet worden. Dit zal gebeuren aan de hand van een aantal casestudies, die worden beschreven in het volgende hoofdstuk. 


\section{Casestudies}

In de voorgaande hoofdstukken is een aantal statistische relaties vastgesteld tussen het functioneren van ondernemingsraden en een aantal achtergrondkenmerken enerzijds (hoofdstuk 4) en het effect van medezeggenschap op cen aantal arbo-indicatoren in het bedrijf anderzijds (hoofdstuk 5). Al met al is zo een statistisch gefundeerde eerste indruk ontstaan van de bijdrage van ondernemingsraden op het gebied van arbeidsomstandigheden. Statistische samenhang betekent echter nog niet dat daarmee oorzakelijke verbanden zijn gelegd. In dit hoofdstuk wordt een poging gedaan de hiervoor gedestilleerde bevindingen uit de sfeer van percentages en covariantie te trekken, en aan de hand van een aantal casestudies een scherper beeld te krijgen van de procesmatige dimensie van arbomedezeggenschap.

De aanvulling van statistisch onderzoek met een meer procesmatige en contextuele analyse geeft meer reliëf aan de eerdere bevindingen, en de combinatie van methoden (methodische triangulatie) vormt tot op zekere hoogte een waarborg tegen methode-immanente eenzijdigheden. ${ }^{1}$ Ook binnen de respectieve cases zelf is, mede met het oog op methodische triangulatie, gewerkt met 'multiple sources of evidence'. ${ }^{2}$ Althans, dat was aanvankelijk de bedoeling. In de loop van het onderzoek zijn helaas concessies gedaan aan de methodische stringentie, op grond van zowel ervaringen uit de eerste cases als een aantal praktische overwegingen. Die concessies betreffen zowel het aantal cases als de gevolgde methode. Een en ander zal hieronder nader worden toegelicht.

\subsection{Methodologische verantwoording}

De eerste stappen in een goed research-design zijn: een duidelijke vraagstelling, een aantal theoretische proposities, en een duidelijke 'unit of analysis' ${ }^{3}$ De vraagstelling die ten grondslag ligt aan het hele onderzoek, is eerder aangegeven in hoofdstuk 1:

1. Zijn ondernemingsraden voldoende geëquipeerd om hun rol op het terrein van veiligheid, gezondheid en welzijn naar behoren te vervullen?

2. Draagt medezeggenschap bij aan betere arbeidsomstandigheden?

I J.M. Hutjes en J.A. van Buuren (1992), De gevalsstudie: strategie van kwalitatief onderzoek, Meppel: Boom, p. 20

2 R.K. Yin (1994). Case study research; designs and methods, Second Edition. Applied Social Research Methods Series, vol. 5., p. 13.

3 Ibid., p. $20 \mathrm{ff}$ 
Op grond van de hoofdstukken 4 en 5 kan voorts een aantal theoretische proposities worden geformuleerd, die in een aantal subvragen worden uitgewerkt:

1. De opvattingen van de bestuurder omtrent medezeggenschap in het algemeen en de relatie tussen bestuurder en OR zijn zeer bepalend voor de mate waarin de OR invloed kan hebben op het arbeidsomstandighedenbeleid in zijn onderneming (vgl. par. 4.2).

- Wat is de opstelling van de bestuurder met betrekking tot medezeggenschap en arbeidsomstandigheden?

- Wordt de bijdrage van de OR op het gebied van arbeidsomstandigheden serieus genomen?

- Hoe valt in het algemeen het arbo-overleg in de branche te karakteriseren?

2. Een al te meegaande opstelling van de OR werkt belemmerend voor effectieve medezeggenschap (vgl. par. 4.2).

- Gebeurt het wel eens dat ondernemingsraden zich hard opstellen rond het thema arbeidsomstandigheden?

- Beschikt de OR c.q. beschikken OR-leden wel over de middelen om zich sterk op te stellen?

- Welk effect c.q. consequenties heeft die opstelling?

3. Intensief contact met de vakbond/kaderleden leidt tot een effectievere bijdrage van de OR op het gebied van veiligheid en gezondheid (vgl. par. 4.2)

- Wat is de arbobijdrage van de vakbeweging in de branche?

- Hoe verloopt het contact tussen ondernemingsraden en kaderleden respectievelijk bondbestuurders?

4. Medezeggenschap omtrent het arbobeleid draagt bij aan betere arbeidsomstandigheden (vgl. par. 5.1 en 5.2)

- Wat is de belangrijkste bijdrage van medezeggenschap aan het arbobeleid?

- Heeft de OR vooral een initièrende, signalerende of juist een toetsende rol?

Als 'unit of analysis' is uiteraard gekozen voor de eenheid 'bedrijven'; dat is immers het niveau waar het arbo-overleg tussen ondernemingsraad en bestuurder plaatsvindt. Het is echter evident dat de unit 'bedrijf' is ingebed in een relevante omgeving, en bij bedrijfsanalyses uiteraard ook het effect van de economische- of concurrentiepositie, de stand der techniek, de politieke context en maatschappelijke ontwikkelingen in ogenschouw genomen moet worden. ${ }^{4}$ Hiervoor kan een vereenvoudigde versie van het analysemodel uit hoofdstuk 2 dienstig zijn.

De kern is het overleg tussen OR en bestuurder. In dit overleg zijn zowel aspecten als de intrinsieke motivatie van de bestuurder of de deskundigheid van de OR-leden

4 J.J. Boonstra (1992), Integrale organisatie-ontwikkeling: vormgeving van fundamentele veranderingsprocessen, Utrecht: Lemma, p. 9ff. Vgl. ook G.1.J.M. Zwetsloot (1994), Joint management of working conditions, environment and quality: in search of synergy and organizational learning. Amsterdam: Nederlands Instituut voor Arbeidsomstandigheden NIA, p. 39-46 
Op grond van de hoofdstukken 4 en 5 kan voorts een aantal theoretische proposities worden geformuleerd, die in een aantal subvragen worden uitgewerkt:

1. De opvattingen van de bestuurder omtrent medezeggenschap in het algemeen en de relatie tussen bestuurder en OR zijn zeer bepalend voor de mate waarin de OR invloed kan hebben op het arbeidsomstandighedenbeleid in zijn onderneming (vgl. par. 4.2).

- Wat is de opstelling van de bestuurder met betrekking tot medezeggenschap en arbeidsomstandigheden?

- Wordt de bijdrage van de OR op het gebied van arbeidsomstandigheden serieus genomen?

- Hoe valt in het algemeen het arbo-overleg in de branche te karakteriseren?

2. Een al te meegaande opstelling van de OR werkt belemmerend voor effectieve medezeggenschap (vgl. par. 4.2).

- Gebeurt het wel eens dat ondernemingsraden zich hard opstellen rond het thema arbeidsomstandigheden?

- Beschikt de OR c.q. beschikken OR-leden wel over de middelen om zich sterk op te stellen?

- Welk effect c.q. consequenties heeft die opstelling?

3. Intensief contact met de vakbond/kaderleden leidt tot een effectievere bijdrage van de OR op het gebied van veiligheid en gezondheid (vgl. par. 4.2)

- Wat is de arbobijdrage van de vakbeweging in de branche?

- Hoe verloopt het contact tussen ondernemingsraden en kaderleden respectievelijk bondbestuurders?

4. Medezeggenschap omtrent het arbobeleid draagt bij aan betere arbeidsomstandigheden (vgl. par. 5.1 en 5.2)

- Wat is de belangrijkste bijdrage van medezeggenschap aan het arbobeleid?

- Heeft de OR vooral een initièrende, signalerende of juist een toetsende rol?

Als 'unit of analysis' is uiteraard gekozen voor de eenheid 'bedrijven'; dat is immers het niveau waar het arbo-overleg tussen ondernemingsraad en bestuurder plaatsvindt. Het is echter evident dat de unit 'bedrijf' is ingebed in een relevante omgeving, en bij bedrijfsanalyses uiteraard ook het effect van de economische- of concurrentiepositie, de stand der techniek, de politieke context en maatschappelijke ontwikkelingen in ogenschouw genomen moet worden. ${ }^{4}$ Hiervoor kan een vereenvoudigde versie van het analysemodel uit hoofdstuk 2 dienstig zijn.

De kern is het overleg tussen OR en bestuurder. In dit overleg zijn zowel aspecten als de intrinsieke motivatie van de bestuurder of de deskundigheid van de OR-leden

4 J.J. Boonstra (1992), Integrale organisatie-onnvikkeling: vormgeving van fundamentele veranderingsprocessen. Utrecht: Lemma, p. 9ff. Vgl. ook G.1.J.M. Zwetsloot (1994), Joint management of working conditions, environment and quality: in seanch of synergy and organizational learning. Amsterdam: Nederlands Instituut voor Arbeidsomstandigheden NIA. p. 39-46 
van cases $^{5}$, maar het verwerven van analytisch inzicht binnen een zo homogeen mogelijke context waarbij het zicht op het functioneren van de OR zo min mogelijk zou worden vertroebeld door de wisselende invloed van externe factoren (die immers per branche sterk kunnen verschillen). Bij de selectie van cases is daarom gekozen voor een beperkt aantal branches, waarbinnen idealiter de diverse factoren zoals organisatiedoel en strategie, organisatiestructuur, overlegcultuur, technologie en type arboproblemen in de onderzochte bedrijven dezelfde zijn.

Aanvankelijk werd veldwerk voorzien in vier branches: twee met zeer belastende arbeidsomstandigheden en twee met relatief gunstige arbeidsomstandigheden: verpleeg- en verzorgingshuizen en bouw respectievelijk commerciële dienstverlening en overheid (voor de selectie van branches zie bijlage 6.1). Aangezien voor een robuuste analyse binnen een branche toch minstens vier cases ingebracht zouden moeten worden, impliceerde dat een totaal van minstens 16 bedrijven. Bij de bepaling van dit aantal is in eerste aanleg voorbijgegaan aan inhoudelijk triviale overwegingen zoals met name tijdsbeslag. In de praktijk is dit natuurlijk wél een van de meest dwingende randvoorwaarden voor het doen van veldwerk. ${ }^{6}$ Hoewel het alleen al met het oog op 'investigator triangulation'7 én spreiding van werkzaamheden een groot voordeel is met meerdere onderzoekers aan én project te werken, was de onderhavige studie een soloproject. Binnen de beschikbare tijd was het ondoenlijk om 16 casestudies uit te voeren. Reductie van het aantal cases was vereist. Vanuit het streven naar een zo homogeen mogelijke onderzoekspopulatie is daarom de branche 'overheid' geschrapt: niet alleen omvat de noemer overheid een veel heterogener scala aan werkorganisaties dan de andere branches, ook de (politieke) context waarbinnen die organisaties opereren is verondersteld minder homogeen dan in de gezondheidszorg. de bouw en de zakelijke dienstverlening. Uiteindelijk resteerden dus twaalf cases: minder dan het oorspronkelijke ambitieuze plan, maar wel voldoende. ${ }^{8}$ Dit aantal werd later echter nog verder ingeperkt.

\section{Methoden van onderzoek}

Aanvankelijk lag het in de bedoeling per branche vier bedrijven te bezoeken, waarbij diverse onderzoeksinstrumenten ('multiple sources of evidence') zouden worden ingezet. De cerste bron is literatuur en cijfermateriaal omtrent de geselecteerde branches:

- branchegegevens (specifieke arborisico's, ervaren arbeidsomstandigheden, verzuim- en WAO-percentage, functioneren van ondernemingsraden)

\footnotetext{
5 Vgl. J.C. Looise en F.G.M. de Lange (1987), Ondermemingsraden, bestuunders en besluitvorming. Nijmegen: ITS, p. 12. J.W.M. Mevissen et al. (2001). Arbeidstijden in overleg? Evaluatie van de Arbeidstijdenwer, Den Haag: Elsevier/Ministerie van Sociale Zaken en Werkgelegenheid, p. $35 \mathrm{ff}$

6 In meervoudige gevalsstudies in de meest zuivere vorm is, afhankelijk van de diepgang van het onderzoek, meestal slechts een beperkt aantal haalbaar (10 à 15). Hutjes/Van Buuren 1992, p. 28 7 M.Q. Patton (1987). How to use qualitative methods in evaluation. Newbury Park: Sage

8 Volgens Eisenhardt $(1989,1991)$ is een aantal van tien cases in de regel voldoende om algemene patronen te herkennen. F. den Hertog en E. van Sluijs (1995). Onderzoek in organisaties: een methodologische reisgids. Assen: Van Gorcum, p. 137
} 
- algemene bedrijfsgegevens (organisatieschema, functie-indeling, personele bezetting, marktontwikkeling) en beleidsdocumenten omtrent de organisatie van de arbozorg (beleidsverklaringen, arbo-overlegstructuur, opleidingsplannen enzovoort);

- één of, bij voorkeur meerdere (opeenvolgende) risico-inventarisaties en plannen van aanpak (teneinde de kwaliteit van en de ontwikkeling in die beleidsinstrumenten sinds 1994 te beoordelen):

- specifieke bedrijfsgegevens, zoals arbojaarverslagen, verzuimcijfers en WAOinstroom (sinds 1994);

- jaarverslagen (sinds 1994) en relevante notulen van de OR/VGW(M)-commissie:

- contract(en) met de arbodienst.

Een tweede bron van informatie was het bedrijfsbezoek, waarbij een aantal interviews zou worden afgenomen met centrale informanten binnen de organisatie: de bestuurder, de voorzitter van de OR of VGW(M)-commissie, en indien aanwezig ook de arbocoördinator. Door interviews met meerdere partijen ontstond een intersubjectief gekleurd beeld van het arbo-overleg binnen de organisatie en de bijdrage van medezeggenschap aan het arbeidsomstandighedenbeleid. Het risico van informanteninterviews is wel dat de respondenten een onjuist beeld hebben of schetsen van de feitelijke gang van zaken in hun organisatie, bijvoorbeeld omdat zij slecht in staat zijn hun eigen functioneren juist te beoordelen. Deze valkuil van zelfevaluatief onderzoek bedreigt ook de meeste OR-enquêtes, waarbij de vragenlijsten veelal door de voorzitter of secretaris van de OR worden ingevuld. Uit een van de weinige onderzoeken waarbij ook de opvattingen van de achterban in kaart zijn gebracht, blijkt dat de mening van de achterban soms sterk afwijkt van die van de geïnterviewde opinieleiders. ${ }^{9}$ Om deze tekortkomingen zo goed mogelijk te ondervangen, zijn twee aanvullende elementen aan het onderzoek toegevoegd: informatiebron drie en vier. Bovendien doet een beperking van de informatieverwerving tot discursief expliciete zelfkennis tekort aan het impliciete, praktische bewustzijn van de betrokkenen. ${ }^{10}$ Met het oog op dit laatste punt zou in de bezochte bedrijven ten minste één maal een overlegvergadering tussen OR en bestuurder bijgewoond moeten worden. Uiteraard is een eenmalige observatie onvoldoende om onomstotelijk te kunnen vaststellen hoe de verhoudingen feitelijk liggen, maar deze methode biedt toch een eerste impressie en is als zodanig een aanvulling op

9 J.W.M. Mevissen et al. (2001), Arbeidstijden in overleg? Evaluatie van de Arbeidstijdenwet, Den Haag: Elsevier/Ministerie van Sociale Zaken en Werkgelegenheid, p. 146

10 "Where what agents know about what they do is restricted to what they can say about it, in whatever discursive style, a very wide area of knowledgeability is simply occluded from view. The study of practical consciousness must be incorporated." A. Giddens (1984). The constitution of society, Cambridge: Polity Press, p. xxx 
het zelfbeeld van de respondenten. ${ }^{11} \mathrm{Om}$ het zelfbeeld van de OR te corrigeren is onder het personeel van de bezochte bedrijven en instellingen een korte vragenlijst uitgezet waarin de achterban zijn mening over het functioneren van de OR kon ventileren. Daarnaast is in de enquête onder de werknemers een tiental vragen opgenomen over de (ervaren) arbeidsomstandigheden en werkbelasting (voor de volledige vragenlijst, zie bijlage 6.2). Deze vragen waren letterlijk overgenomen uit het periodiek onderzoek leefsituatie (Pols) van het CBS, dat ook ten grondslag ligt aan de jaarlijkse Monitor arbeidsomstandigheden van het ministerie van Sociale Zaken en Werkgelegenheid. ${ }^{12}$ De gezondheidsvragen uit de werknemersenquête dienden een tweeledig doel. Ten eerste is op basis van de antwoorden een totaalscore 'ervaren arbeidsomstandigheden' gemaakt, die gekruist kan worden met de meningen omtrent het functioneren van de OR in het bedrijf. Zo ontstaat een globaal zicht op de samenhang tussen het functioneren van de ondernemingsraad en de kwaliteit van de arbeidsomstandigheden op de werkvloer. Ten tweede is de uitkomst van de werknemersenquête gebruikt ter vergelijking met de cijfers voor de hele branche én de andere cases binnen dezelfde branche én als materiaal voor de cross case analyse - een zeer eenvoudig soort benchmarking. ${ }^{13}$

Met name het laatste onderdeel van het onderzoek, de werknemersenquête, bleek echter een belangrijke hinderpaal bij het werven van bedrijven voor het veldwerk. Van de 16 benaderde verpleeg- en verzorgingshuizen bleek er niet één bereid mee te werken aan het onderzoek, met name omdat in het kader van een CAO-afspraak eerder dat jaar al een werkbelevingsonderzoek was uitgevoerd. Ook van de elf verzekeringsbedrijven bleek er slechts één bereid mee te werken aan het onderzoek in zijn oorspronkelijke vorm. Alleen in de bouwnijverheid lukte het redelijk snel een aantal coöperatieve bedrijven te vinden. Nadat bovendien bij de bouwbedrijven kon worden vastgesteld dat het werknemersonderzoek niet al te veel zinvolle informatie opleverde, is besloten voor de andere branches een minder bewerkelijke methode te hanteren, in de vorm van expertinterviews. Uiteindelijk is onder druk van de

11 Giddens" bewering dat "it would be an error to suppose that non-discursive components of consciousness are necessarily more difficult to study empirically than the discursive" (A. Giddens 1984, p. $x \mathbf{x x}$ ) is wellicht principieel juist (bijvoorbeeld uitgebreide participerende observatie kan een bijzonder waardevolle onderzoekstechniek zijn), maar in de praktijk stuit dit principe toch vaak op het probleem van schaarse tijd - zo ook in het onderhavige onderzoek

12 CBS/Ministerie van Sociale Zaken en Werkgelegenheid (2001), Arbeidsomstandigheden 2001: Monitoring via personen, Den Haag: Elsevier

13 Benchmarking is "een methode om een activiteit, functic of proces van een onderneming te vergelijken met 'best practices' van andere bedrijven en/of organisaties, zodat op basis hiervan de eigen activiteit in belangrijke mate kan worden verbeterd" (J-M de Vries en J. van der Togt (1995). Benchmarking in 9 stappen, Deventer: Kluwer). Benchmarks zijn referentiepunten waarmee de prestaties van een organisatie kunnen worden afgemeten tegen die van vergelijkbare organisaties. De hier gevolgde aanpak is overigens niet benchmarking in strikte zin: dat is vooral leren van exemplarische bedrijven en bedrijven van elkaar: "bilaterale verhoudingen die beide partijen referentiepunten moet opleveren om de kwaliteit van het proces te verbeteren" (R. van der Wal (1994). Benchmarking. Rotterdam: Erasmus Universiteit). Voor een omvangrijke arbo-Toolkit zie het programma Worksafe Australia van de National Occupational Health and Safety Commission (http:/www.nohsc.gov.aw/OHSInformation/NOHSCPublications/fulltext/toc/02697-01.htm) 
tijd bovendien nog besloten het onderzoek in de V\&V-huizen te schrappen. Van de oorspronkelijke ambities waarmee de casestudies zijn opgezet is derhalve weinig overgebleven. Anderzijds is het werken met expertinterviews een zeer gebruikelijke methode bij casestudies, én is uit de interviews toch een redelijk consistent beeld opgeborreld dat op diverse punten wel degelijk een welkome aanvulling op het statistische deel van deze studie betekent.

\section{De opbouw van dit hoofdstuk}

In de paragrafen 6.2 en 6.3 volgt een overzicht van de bevindingen in de bouw respectievelijk het bank- en verzekeringswezen. De paragrafen openen met een korte karakterisering van de branche: aard van de werkzaamheden en specifieke arborisico's, aanwezigheid van ondernemingsraden, maar ook structurele condities zoals relevante regelgeving (CAO's, convenanten) en machtsbronnen (samenwerking met vakbonden, acties). Daarna worden de bevindingen uit het veldwerk op een rijtje gezet, waarna in paragraaf 6.4 de bevindingen uit beide branches naast elkaar worden gezet. Een serieuze cross-case analyse verdraagt zich uiteraard slecht met het eerder genoemde methodologische streven naar optimale invariantie en ceteris paribus, maar levert tentatief toch een aantal algemene inzichten op.

\section{2. Bouw}

De bouw is een sector waarin al sinds jaar en dag veel aandacht bestaat voor veilige arbeidsomstandigheden. De belangrijkste reden hiervoor is dat de risico's voor veiligheid en gezondheid evident zijn. Met name wat ongevallen en fysieke belasting betreft springt de bedrijfstak eruit als hoog-risicobranche. ${ }^{14}$ Hierbij moet opgemerkt worden dat 'de bouw' een zeer heterogene branche is, die zich bovendien kenmerkt door een zeer ongelijke spreiding van risico's over de bouwvakkers en het zogeheten 'Uta' personeel (uitvoerend, technisch en administratief). Zo is de kans op een arbeidsongeval voor bouwplaatspersoneel (11 procent) bijna drie keer zo hoog als voor Uta-personeel (4 procent $)^{15}$, en is het verzuimpercentage onder bouwplaatspersoneel structureel twee keer zo hoog als onder uitvoerders (terwijl bijvoorbeeld ziekte als gevolg van psychische overbelasting onder uitvoerders iets boven het gemiddelde ligt). ${ }^{16}$ Eén op de drie bouwvakkers heeft werkgerelateerde gezondheidsklachten, tegen één op de vier Uta-medewerkers. Het werkgebonden aandeel in het verzuim is onder bouwvakkers aanmerkelijk hoger dan landelijk ${ }^{17}$,

14 Voor een overzicht van de belangrijkste beroepsziekten vgl. Nederlands Centrum voor Beroepsziekten (2002), Signaleringsrapport Beroepsziekten '02, Amsterdam: Nederlands Centrum voor Beroepsziekten, p. 66. In verband met de veiligheid vgl. SZW (2002), Arbobalans 2002, Den Haag: Ministerie van Sociale Zaken en Werkgelegenheid, p. 46. Hieruit blijkt dat het aantal ongevallen met letsel in de bouw bijna $50 \%$ hoger is dan het landelijk gemiddelde.

15 E. Lourens (2002), Arbeidsongevallen in de bouw in 2001. Amsterdam: Economisch Instituut voor de Bouwnijverheid, p. 10

16 EIB (2002), Het ziekteverzuim in de bouwnijverheid in 2001. Amsterdam: Economisch Instituut voor de Bouw, tabel 2.3 resp. 2.9

17 E.A.P Koningsveld en K. Thé (1999), Sectorale kosten van arbeidsomstandigheden in de bouwnijverheid, Den Haag: Elsevier/Ministerie van Sociale Zaken en Werkgelegenheid, p. 16 
en de instroomkans in de WAO daalt de laatste jaren weliswaar richting het landelijk gemiddelde, maar is met 1,64 tegen 1,53 procent nog altijd hoog. ${ }^{18}$ Een erfenis uit het verleden is dat het aantal lopende WAO-uitkeringen $(31,2$ per 100 verzekerden) duidelijk hoger is dan het landelijke percentage (11,5 procent). ${ }^{19}$

Tabel 6.2.1. Arbeidsomstandigheden in de bouw (\% werknemers)

\begin{tabular}{|l|c|r|}
\hline & Bouwnijverheid & Landelijk \\
\hline Spoedeisende eerste hulp na arbeidsongevallen * & 3,7 & 1,75 \\
Kracht gebruiken & 50 & 24 \\
Langdurig zelfde houding & 48 & 45 \\
Repeterende bewegingen & 58 & 44 \\
Beeldschermwerk & 21 & 44 \\
& & \\
Hoge tijdsdruk & 26 & 30 \\
In hoog tempo werken & 38 & 41 \\
Onder tijdsdruk én in hoog tempo & 28 & 27 \\
Instroompercentage WAO** & 1,64 & 1,53 \\
\hline
\end{tabular}

Bron: CBS (" op basis van gegevens St. Consument en Veiligheid, " Konings/Van der Zouw 2002)

De omvang en ernst van de arboproblematiek was begin jaren ' 70 aanleiding tot het oprichten van een aparte voorziening voor bedrijfsgezondheidszorg in de bouw (BGBouw), die in 1986 opging in de Stichting Arbouw. Dit is een vorm van branchespecifieke arbozorg die ook model staat voor arbodienstverlening in bijvoorbeeld het Verenigd Koninkrijk. ${ }^{20}$ Er zijn en worden legio activiteiten ondernomen om inzicht te krijgen in de omvang en oorzaken van de problematiek, en in diverse CAO's in de bouw- en houtnijverheid zijn en worden afspraken gemaakt over verbetering van de arbeidsomstandigheden.

Begin jaren ' 90 werd voorts een vorm van veiligheidscertificatie ingevoerd middels de VeiligheidsChecklist Aannemers (VCA). Dit veiligheidscertificaat werd aanvankelijk verplicht gesteld voor aannemers die onderhoudswerkzaamheden verrichtten in de petrochemische industrie. In de tweede helft van de jaren negentig heeft VCAcertificering echter ook buiten de aanneembedrijven in de petrochemie een enorme vlucht genomen. Inmiddels beschikt 44 procent van de bouwbedrijven over een VCA-certificaat, een percentage dat voor de $50+$ bedrijven zelfs op 91 procent

18 M. Konings en M. van der Zouw (2002). Sectoranalyse WAO 2000: Analyse van 69 sectoren op basis van mesogegevens, Den Haag: Ministerie van Sociale Zaken en Werkgelegenheid. p. 14

19 Lisv (2001). Trendrapportage Arbeids(on)geschiktheid 200I. Amsterdam: Lisv, p. 76. Daar komt nog bij dat in de bouw vrijwel uitsluitend mannen werkzaam zijn, en het aantal WAO-aanvragen onder mannen met 10.2 per duizend nog weer lager is dan gemiddeld.

20 L.Waterman (2001). Proposal for a Feasibility Study into the Establishment of Comprehensive Occupational Health Support for the Constraction Industry. London: HSE, p. 9 
ligt. ${ }^{21}$ VCA-certificering is van belang omdat het bijdraagt aan een systematisch arbobeleid, het is ook interessant omdat één van de verificatiepunten (i.c. punt 5.1) de aanwezigheid van een werknemersvertegenwoordiging voorschrijft. VCA vereist dat de bedrijfsleiding minstens viermaal per jaar vergadert met de werknemersvertegenwoordiging én dat de afspraken met de werknemersvertegenwoordiging bekend worden gemakt aan het personeel. Overigens is verficatiepunt 5.1 géén zogeheten 'must-vraag': ook zonder formele medezeggenschap kan een bedrijf een VCA-certificaat verwerven ( 30 procent van de gecertificeerde $50+$ bedrijven heeft géen OR). 22

Al deze activiteiten lijken duidelijk hun vruchten af te werpen; zo is niet minder dan $96 \%$ van de bedrijven met een VCA-certificaat van mening dat hierdoor de arbeidsomstandigheden positief zijn beinvloed. ${ }^{23}$ De werknemers schatten de veiligheidssituatie positiever in dan 10 jaar geleden ${ }^{24}$, en het aantal werkgerelateerde gezondheidsklachten is eveneens gedaald (zie tabel 6.2.2). Ook is in de loop van de jaren ' 90 de arbeidsongeschiktheid in de richting van het landelijk gemiddelde gedaald. en ligt het verzuim de laatste jaren rond of zelfs iets onder het gemiddelde (anno 20005,1 procent excl. zwangerschap tegen 5,5 procent landelijk). Het aantal boetes door de Arbeidsinspectie daalde in 2002 ten opzichte van de jaren daarvoorvan 973 in 2001 naar 782 in $2002 .^{25}$

Tabel 6.2.2. Arbo-klachten in de bouw (\% werknemers)

\begin{tabular}{|l|c|c|c|c|}
\hline & Bouw 1990 & Bouw 2000 & UTA 1990 & UTA 2000 \\
\hline Veiligheid niet in orde & 22 & 14 & 15 & 9 \\
Psychische klachten & 14 & & 12 & \\
Bovenste ledematen & 32 & 30 & 24 & 23 \\
Onderste ledematen & 35 & 29 & 24 & 22 \\
Nek- en rugklachten & 28 & 24 & 21 & 19 \\
Klachten in relatie tot werk & 40 & 32 & 27 & 24 \\
\hline Bron: Arbouw monitor &
\end{tabular}

De vraag die in het kader van deze studie van belang is, is of die verbetering van de veiligheid en gezondheid mede te danken is aan de bijdrage van ondernemingsraden en, zo ja, wat dan precies die bijdrage behelst. Om deze vragen te beantwoor-

21 Bron: Databestand arbomonitor 2001

23 A. Peters en E.C. van Hoorn (2002), Arbomonitor 2001, Den Haag: Arbeidsinspectie, p. 28

24 De ongevallenincidentie lijkt ook te zijn gedaald, al zijn de cijfers uit 1988 en 2001 moeilijk met elkaar te vergelijken. Statistiek der bedrijfsongevallen 1988, in: D.J. Klein Hesselink (1995), Ongevallenregistratie in bedriif: over de melding. registratie en analyse van arbeidsongevallen, Amsterdam: NIA, p. 45 resp. SZW (2002), Arbobalans 2002, Den Haag: Ministerie van Sociale Zaken en Werkgelegenheid, p. 46

25 Cobouw (2003), Bouw lijkt beter op arbo te letten (5 maart 2003) 
den zijn drie bedrijven doorgelicht én aanvullend zes expertinterviews afgenomen. Voordat de bevindingen worden gepresenteerd, volgt eerst een korte schets van de relevante omgevingsfactoren. Daarbij dient opgemerkt dat de casestudie zich beperkt tot de burgerlijke - en utiliteitsbouw (B\&U).

\section{Invloed economische, technologische en bedrijfskundige ontwikkelingen}

De jaren ' 90 waren voor de bouw in het algemeen, en ook de B\&U-sector, een periode van economische voorspoed. In de periode 1988-1999 steeg de omzet in de $\mathrm{B} \& \mathrm{U}$-sector met 63 procent ${ }^{26}$ De werkgelegenheid groeide eveneens, zij het duidelijk minder sterk (18 procent). ${ }^{27}$ Ondanks de minder sterke stijging van de werkgelegenheid steeg het aantal vacatures in de bouw wél bijzonder scherp: voor de $\mathrm{B} \& \mathrm{U}$-sector was het percentage vacatures 6 procent op een totaal aantal arbeidsjaren van 189.000 (anno 2002). ${ }^{28}$ De chronische onderbezetting is een risicofactor wat betreft de werktijden. Uit monitoronderzoek in het kader van de evaluatie van de Arbeidstijdenwet bleek in 2000 dat in één op de vijf bouwbedrijven de standaardnormen met betrekking tot de werk- en rusttijden waren overtreden, en in een zelfde aantal bedrijven te lang werd overgewerkt. ${ }^{29}$ De wervingsproblemen en het bijzonder hoge verloop in de bedrijfstak zouden redenen kunnen zijn de arbeidsbelasting te verminderen: binnen twee jaar is de helft van de bouwvakkers onder de 25 jaar alweer uit de bedrijfstak uitgestroomd, waarbij de belastende arbeidsomstandigheden ( 18 procent) en werkinhoud ( 26 procent) bijna de helft van het vertrek uit de bouw verklaren. Voor de werknemers die eventueel wel hadden willen blijven, zijn de arbeidsomstandigheden zelfs de belangrijkste reden voor vertrek. ${ }^{30}$ De krapte op de arbeidsmarkt (én de vergrijzing in het personeelsbestand) biedt de werknemers een kans om een krachtdadig arbobeleid te eisen en is een argument dat door de vakbonden ook wel wordt gebruikt.

De technologische en bedrijfskundige ontwikkelingen hebben een tweeledig effect op de arbosituatie in de branche. Zo is sprake van een verschuiving naar grootschaliger productieprocessen, waarbij het accent zeker voor de grote bedrijven steeds meer op projectontwikkeling komt te liggen. Dit blijkt onder meer door het toegenomen percentage Uta-personeel in de branche, terwijl met name het lager geschoolde werk wordt verdrongen door allerhande nieuwe technologieën en wijzigingen in de productieketen (zoals een verschuiving naar pre-fab, fabrieksmatig geproduceerde halffabrikaten en bekistingen). Ook ontwikkelt de branche specifieke technologieën om met name de fysieke belasting te verminderen. Deze ontwikkelingen zijn wellicht ten dele een verklaring voor de dalende fysieke belasting in de bouw. Aan de andere kant leidt de projectmatige manier van werken mogelij-

26 CBS Statline, Historie Bouwnijverheid Anno 2001 beliep de omzet in de B\&U-sector ruim 27 miljard Euro (EIB)

27 CBS (2002), Sociaal-Economische Maandstatistiek, september 2002. p. 14

28 Bronnen: CBS Statline; CWI (2003), Arbeidsmarktmonitor bouwnijverheid, www.werkzaken.nl/arbeidsmarktmonitor/bouwnijverheid/main.htm

29 Mevissen 2001, pp. 130 en 272

30 I.W. Corten. Bouw verliest groot deel van jonge arbeidskrachten aan andere bedrijfstakken. in Bouw Werk, 2002/3, p. 24-25 
kerwijs tot een toename van de psychische belasting en veiligheidsrisico's door de steeds complexere verantwoordelijkheidsverdeling. ${ }^{31}$ Bovendien wordt steeds meer werk uitbesteed aan gespecialiseerde onderaannemers en een toenemend aantal ZZP'ers, waarmee ook een deel van de arborisico's wordt verschoven. Uit de monitorstudie van het CBS blijkt dat de arbeidsomstandigheden van zelfstandigen in de bouw aanmerkelijk zwaarder zijn dan die van werknemers. ${ }^{32}$

\section{Wetgeving, CAO-afspraken en comvenanten}

De bouw is een sterk gereguleerde bedrijfstak. Naast de algemene wettelijke bepalingen in het Arbobesluit over bijvoorbeeld fysieke belasting en het werken met gevaarlijke stoffen, is voor de bouw een aparte afdeling gereserveerd in het Arbeidsomstandighedenbesluit. De naleving hiervan is echter bijzonder matig. ${ }^{33}$ De invoering van de wet TZ in 1994 heeft wel vruchten afgeworpen, in de zin van een toenemende aandacht voor de problematiek en een daadwerkelijk dalend verzuim. ${ }^{34}$ Het bewustzijn van de kosten van verzuim is hoog.

De beide CAO's Bouw ( \pm 150.000 werknemers) en Uta ( \pm 48.000 werknemers) kennen sinds 1987 een apart hoofdstuk arbeidsomstandigheden in de CAO, dat onder meer afspraken bevat over periodieke gezondheidskeuringen en aansluiting bij een reìntegratiebedrijf, én een aantal concrete normen omtrent met name de fysieke belasting en een verbod op het werken met teer of asbesthoudende producten (art. 48 Bouw-CAO). Uitvoerders dienen op grond van art. 8a Uta-CAO over een lijst van veiligheids- en gezondheidsbedreigende stoffen te beschikken. Voorts is in oktober 2001 een arboconvenant bouw afgesloten, met name gericht op de beperking van de fysieke belasting en de werkdruk én van de blootstelling aan kwarts en oplosmiddelen (OPS). ${ }^{35}$ Het ministerie van Sociale Zaken en Werkgelegenheid en de sociale partners hebben hiervoor in eerste instantie beide 3,6 mil-

31 Om deze complexiteit te regelen, is in 1994 het Bouwprocesbesluit Arbowet uitgevaardigd. Dit verplichtte de hoofdaannemer duidelijke afspraken te maken over de verantwoordelijkheidsverdeling gedurende het bouwproces, een veiligheids- en gezondheidsplan op te stellen, én zorg te dragen voor medezeggenschap op de bouwplaats

32 CBS/SZW (2001), Arbeidsomstandigheden 2001: monitoring via personen, Den Haag/Voorburg: Elsevier/Ministerie van Sociale Zaken en Werkgelegenheid, p. 46-59

33 In de praktijk blijkt de naleving van het besluit (thans hoofdstuk 2, afd. 5. Arbobesluit) bijzonder matig: zeventig procent van de opdrachtgevers, vijfenzeventig procent van de aannemers en negentig procent van de architecten kon drie jaar na invoering geen enkele verplichting uit het besluit noemen. N.E.T. Nieboer (1997), Effect van het Bouwprocesbesluit: Bekendheid, toepassing en naleving van het Bouwprocesbesluit Arbeidsomstandighedenwet, Den Haag: VUGA/Ministerie van Sociale Zaken en Werkgelegenheid. Anno 2003 is voorgesteld om een deel van de regelgeving zelfs maar helemaal te schrappen omdat deze zo slecht werd nageleefd

34 EIB (1996), Het ziekteverzuim in de bouwnijverheid in 1994, Amsterdam: Economisch Instituut Bouwnijverheid

35 Daarnaast is een convenant 'arbovoorlichters' afgesloten. Doel van het convenant arbovoorlichters is om twintig WAO-ers uit de bouw om te scholen en in te zetten als arbovoorlichter. De arbovoorlichters worden ingezet om op bouwplaatsen voorlichting te geven en de bewustmaking van arborisico's te stimuleren. Daarbij richten zij zich vooral op de onderwerpen werkdruk, fysieke belasting, kwarts en OPS 
joen euro ingebracht. Omdat de convenantsafspraken op het moment van onderzoek nauwelijks bekend waren bij de onderzochte bedrijven, zal hier niet verder op de inhoud en de doorwerking van het convenant worden ingegaan.

\section{Arbeidsverhoudingen in de branche}

De vakbonden in de bouwnijverheid hebben, mede door de stabiel hoge organisatiegraad (rond de 40 procent) ${ }^{36}$, een tamelijk sterke positie. Zo is de bouwnijverheid de bedrijfstak waar de lonen in de jaren ' 90 het snelst zijn gestegen ${ }^{37}$ - al is dit natuurlijk primair toe te schrijven aan de voortdurende krapte op de arbeidsmarkt. Ook op het gebied van veiligheid en gezondheid spelen de vakbonden een actieve rol: niet alleen door arbo-afspraken op te nemen in de CAO's, maar ook door de herhaalde aandrang van de werkgevers tot verdergaande deregulering of decentralisatie te weerstaan. ${ }^{38}$ Naleving van de CAO is een van de centrale aandachtspunten, en wordt soms onder dreiging van kort geding afgedwongen. Daarnaast ondernemen de bonden regelmatig gerichte acties tegen bijvoorbeeld fysieke overbelasting ${ }^{39}$, OPS $^{40}$, ongevallen ${ }^{41}$ en werkdruk ${ }^{42}$, ontwikkelen zij allerlei voorlichtingsmateriaal, en heeft de Hout- \& Bouwbond $\mathrm{CNV}$ in samenspraak met de Arbeidsinspectie een keurmerk voor veilige bouwbedrijven ontwikkeld in de vorm van de zogeheten Arboster.

Het vakbondswerk in bedrijven van de bouwbonden haakt ook sterk aan bij arbothema's. Zo hielden begin jaren ' 90 kaderleden vier keer per jaar veiligheidsinspecties op de werkplek en werd wekelijks de 'Arboman van de week' aangewezen, die een arbo-aanspreekpunt voor de bouwvakkers was en de signalen van de werkvloer aan de ondernemingsraad door moest geven. In de $\mathrm{CAO}$ is een voorziening opgenomen voor werkplekbezoekers ('busploegen'), kaderleden die met een checklist door het bedrijf gaan. Deze taken zijn de laatste jaren echter overgenomen door de VCA-coördinatoren, waardoor de signalerende rol van de vakbond wat is afgebrokkeld.

De schattingen omtrent het aantal ondernemingsraden in de bouw lopen licht uiteen. Het nalevingsonderzoek en de Arbomonitor 2001 komen tot een nalevingspercentage voor de $50+$ bedrijven van 71 respectievelijk 73 procent - waarmee de bouw- en houtnijverheid de bedrijfstak is waarin artikel 2 WOR het slechtst wordt

36 CBS (2002), Sociaal-Economische Maandstatistiek, september 2002, p. 22 vgl. F. Tros (2000), Decentralisering van arbeidsverhoudingen: Een onderzoek naar de arbeidsvoonwaardenvorming in de Nederlandse private sector in de periode 1982-2000. Universiteit van Utrecht: diss., p. 106

37 CBS (2003), Statistisch bulletin 2003/12, p. 6

38 Tros 2000, p. 140

39 Campagne "Een bouwvakker is niet van steen" (1996)

40 J. Bus (1996), Je hersens op cen nachtkastje. Woerden: Bouw- \& Houtbond FNV

41 Onderzocksrappon "Nul is genoeg" (1998)

42 Zo deed de Rijksuniversiteit Groningen in 1998 onderzoek naar de werkdruk in de bouw, vgl. Bouw- en houtbond FNV (1999), Alles onder controle: Werken zonder stress, Woerden: FNV Bouw, Arbowijzer 14 
nageleefd. ${ }^{43}$ Ongeveer twee derde van de $50+$ ondernemingsraden heeft een VGW(M)-commissie ingesteld. ${ }^{44} \mathrm{Na}$ een aanvankelijk aarzelende opstelling tegenover de OR als werknemersvertegenwoordiging op de bouwplaats, is op het gebied van veiligheid en gezondheid de rol van de $O R$ nu toch tamelijk onomstreden. In artikel 40 van de CAO bouwbedrijf is vastgelegd dat de bonden contactpersonen kunnen aanwijzen om de ondernemingsraden te ondersteunen. Ook zijn er platforms van kadergroepen, waarbij de vakbonden een belangrijke ondersteunende taak hebben. Omgekeend kunnen kaderleden uit de OR de arbeidsomstandigheden in hun bedrijf aankaarten bij hun vakbondsbestuurder. Desondanks blijkt uit het nalevingsonderzoek 2000 dat het contact met de vakbond in de bouw niet als bijzonder intensief gekarakteriseerd kan worden, evenmin als het contact met andere ondernemingsraden. ${ }^{45}$

\section{Drie bouwbedrijven}

In het kader van het onderzoek zijn drie bouwbedrijven bezocht. De bevindingen uit het onderzoek (interviews, analyse arbodocumenten en werknemersenquête) zullen worden geïntegreerd in de bredere bedrijfstakanalyse die hieronder volgt. Ter introductie wordt echter eerst een beeld geschetst van de drie bedrijven.

Bouwbedrijf $\mathrm{BB}$ is een middelgrote bouwonderneming met zo'n 65 werknemers, waarvan 40 bouw-CAO'ers en 23 UTA. Het bedrijf richt zich op de ontwikkeling en uitvoering van met name utiliteits- en industriële bouwprojecten. Het bedrijf is sinds 1996 ISO- én VCA gecertificeerd (inmiddels VCA**). Het bedrijf heeft een arbocoördinator, die tevens voorzitter is van de OR. Deze ondernemingsraad is opgericht met het oog op de ISO-certificering, en in die zin instrumenteel. Vier van de vijf leden worden gekozen, de voorzitter (arbocoördinator) is in functie benoemd door de bestuurder. De OR-leden waren zich niet bewust dat dit een merkwaardige gang van zaken genoemd kan worden en in strijd met de WOR.

Bouwbedrijf $\mathrm{BH}$ is onderdeel van een holding met zo'n 800 werknemers, met een omzet van ruim 160 miljoen euro. $\mathrm{H}$ zelf richt zich op utiliteits- en woningbouw, projectontwikkeling en binnenstedelijke herontwikkeling $\mathrm{Bij} \mathrm{BH}$ werken een kleine 200 werknemers en een omzet van 77 miljoen euro. Het bedrijf maakt de laatste jaren een vrij forse groei door, waardoor ongeveer de helft van het personeel minder dan 5 jaar in dienst is. 42 procent van de werknemers is jonger dan 35 jaar. Ook is het Uta-personeel, gegeven het toenemend belang van de projectontwikkeling, duidelijk oververtegenwoordigd: van de medewerkers valt $47 \%$ onder de CAO Uta. $\mathrm{BH}$ is VCA** en ISO 9001 gecertificeerd sinds 1999. Het bedrijf heeft al sinds 25

43 Bruin, E. en F. Huijgen (2000), Naleving van de Wet op de Ondernemingsraden: Stand van zaken begin 2000, Den Haag: Elsevier/SZW, p. 8. Overigens wreekt zich hier dat de bouw- en houtnijverheid een zeer heterogene bedrijfstak is, met zéér uiteenlopende nalevingspecentages per sub-branche: zo ligt voor de woningcorporaties de naleving boven de $100 \%$ (diverse 50 - personeelsvertegenwoordigingen zijn omgezet in OR'en), terwijl dat voor de schildersbranche rond de $20 \%$ ligt. Bron: FNV Bouw (niet gepubliceerd)

44 Databestand Arbomonitor

45 Bruin/Huijgen 2000 , p. 62 
jaar een ondernemingsraad, en is daarmee een voorloper in de bouw. Volgens de directie is het Uta-personeel ondervertegenwoordigd in de OR.

Bouwbedrijf BR is onderdeel van een holding met zo'n 300 werknemers. Het bedrijf ontwikkelt met name utiliteits- en woningbouwprojecten. BR is de grootste werkmaatschappij van de holding, en heeft ruim 150 werknemers in dienst. Het gemiddeld aantal dienstjaren van het bouwpersoneel ligt rond de negen, van het kantoorpersoneel iets onder de zes. De gemiddelde leeftijd van het bouwpersoneel ligt boven de 40 jaar, hetgeen door de directie in sommige opzichten (met name met het oog op het ziekteverzuim) als problematisch wordt gezien. Van de medewerkers van de bouwmaatschappij valt 72 procent onder de CAO Bouw, de overige werknemers zijn Uta-personeel. BR is, net als de andere onderdelen van de groep, zowel ISO- als VCA** gecertificeerd. Het bedrijf heeft een ondernemingsraad én een VGM-commissie, die overigens geen OR-commissie is maar een functionele commissie van het bedrijf waarin één OR-lid participeert.

\section{De bestuurder}

Hoewel veiligheid en gezondheid voor de meeste werkgevers lange tijd geen belangrijk thema was, zijn zij zich sinds het eind van de jaren ' 80 over het algemeen zeer bewust van de problematiek. Dit geldt zeker voor de grote concerns, maar ook voor het middenbedrijf. De toegenomen aandacht voor 'arbo' is onder meer ingegeven door het hoge verzuim eind jaren' 80 , maar vooral door de introductie van VCA. Deze beide stimulansen hebben ook hun uitwerking niet gemist op de onderzochte bedrijven, al verschillen de accenten per bedrijf. BB richt zich sterk op verzuimbestrijding en kostenbeheersing, terwijl $\mathrm{BH}$ het arbobeleid ook strategisch ziet als instrument van sociaal beleid om personeel aan zich te binden. BR geeft aan beide elementen mee te laten wegen, maar uit het bedrijfsbezoek en de documenten blijkt toch dat het accent zwaar op verzuimbestrijding ligt (waarbij leeftijd als bepalende factor wordt gezien en arbeidsvoorwaardelijke prikkels niet worden geschuwd). De directe invloed van wetgeving of Arbeidsinspectie is volgens de geinterviewde bestuurders beperkt. De wetgeving is redelijk eenvoudig te incorporeren in de VCA-activiteiten.

Het arbobeleid in de onderzochte bedrijven ziet er op papier prima uit. Er zijn uitgewerkte plannen van aanpak die de toets der kritiek redelijk kunnen doorstaan ${ }^{46}$. en belangrijker nog is de (verplichte) aanwezigheid van een VCA-coördinator. Op grond van verificatiepunt 7.1 VCA zouden maandelijks veiligheidsinspecties op de diverse locaties moeten worden gehouden, hetgeen in ruwweg 80 procent van de gevallen ook gebeurt. De uitvoering is in handen van de direct leidinggevenden. soms met ondersteuning van de VCA-coördinator. In twee van de bedrijven gaf de VCA-coórdinator aan dat hij soms een aanjagende rol had om de uitvoerders te motiveren. De scholing van de werknemers is conform hoofdstuk 4 VCA.

46 Uit het gegevensbestand van de Arbomonitor blijkt dat het bezit van een VCA-certificaat sterk samenhangt met de kwaliteit van de risico-inventarisatie (V.55***) en het plan van aanpak (V.26***). 


\section{Overleg bestuunder-OR}

Het overieg met de OR is, zeker in VCA-gecertificeerde bedrijven, op papier goed geregeld en in de praktijk wordt aan de verplichtingen goed gehoor gegeven. Dit geldt zeker voor de grote bedrijven. In de middenbedrijven stuit medezeggenschap nogal eens op bezwaren bij de ondernemer, hetgeen ook blijkt uit de lage instellingsgraad. ${ }^{47}$ De bedrijfscultuur wordt getypeend als 'vrije jongens', zeker in de kleinere familiebedrijven. Kritische OR-leden worden volgens meerdere geînterviewden niet altijd gewaardeerd, en de OR-leden durven zich niet altijd uit te spreken om de verhoudingen niet te verstoren. 'Arbo' is in de bouw een frequent terug. kerend agendapunt; opvallend genoeg is dit in VCA-gecertificeerde bedrijven niet vaker dan in niet-gecertificeerde bedrijven. ${ }^{48}$ De betrokkenheid van de werknemers bij de risico-inventarisatie en het plan van aanpak wijkt in de bouw iets negatief af ten opzichte van het landelijk gemiddelde. In de gecertificeerde bedrijven zijn het vaker de leidinggevenden en de arbodeskundige die, veelal in samenwerking, de risico-inventarisatie dragen.

Tabel 6.2.3. Medezeggenschap bij arbo-overleg (\% bedrijven)

\begin{tabular}{|l|c|c|c|c|c|c|}
\hline & \multicolumn{3}{|c|}{ alle bedrijven } & \multicolumn{3}{c|}{$50+$ bedrijven } \\
\cline { 2 - 7 } & Bouw & Gemiddeld & Cramer's v & Bouw & Gemiddeld & Cramer's v \\
\hline Arbo vast agendapunt & 64 & 46 & $.26 \cdots$ & 67 & 48 & $.27^{* \cdots}$ \\
OR/werknemers betrokken bij RIE & 35 & 40 & $.29 \cdots$ & 66 & 65 & $.26 \cdots$ \\
OR/werknemers betrokken bij PvA & 72 & 65 & $.24 \cdots$ & 78 & 85 & $.14 \cdots$ \\
\hline Bron: Arbeidsinspectie, databestand Arbomonitor 2001 & \\
\hline
\end{tabular}

In de drie onderzochte bedrijven is het beeld positiever. Het overleg wordt als 'open' gekarakteriseerd en de onderlinge verhoudingen als 'goed'. De vergaderfrequentie is bij BB 4 keer per jaar, bij BH en BR 6 keer. Arbo is een vast agendapunt. De informatievoorziening is naar behoren, de ondernemingsraden worden betrokken in de besluitvorming en bij het plan van aanpak, maar de formele procedures worden zelden gevolgd (met name het instemmingsrecht is een onbekend fenomeen). De betrokkenheid van de OR'en beperkt zich in alle drie bedrijven tot het aanhoren van de voortgang van het plan van aanpak, en incidenteel het aandragen van een gesignaleerd knelpunt. De ondernemingsraden stellen zich weinig initiatiefrijk op, hetgeen door alle drie de bestuurders werd betreurd - zij zouden wel meer uitgedaagd willen worden door de OR.

\section{Kenmerken van de ondernemingsraden}

De motivatie voor arbo onder ondernemingsraden is over het algemeen hoog, mede doordat de risico's vaak duidelijk zichtbaar zijn en ook in de praktijk tot ernstige

47 Bruin/Huijgen 2000, p. 54

48 Databestand Arbomonitor 
ongevallen leiden. De ondernemingsraden zijn over het algemeen echter weinig initiatiefrijk. Het functioneren van de ondernemingsraden stuit op diverse hinderpalen. Eén daarvan is de lage vergaderfrequentie ${ }^{49}$, waardoor de continuinteit ver te zoeken is en de werkgever nogal eens geneigd is besluiten te nemen zonder op de volgende vergadering te wachten. Als belangrijkste probleem geldt dat het kennisniveau laag is en de scholingsdagen lang niet worden opgemaakt. Dit heeft onder meer te maken met de instelling, zeker óók bij de OR-leden zelf, dat het werk voorgaat. Vooral bij machinegebonden werk wordt het ondoenlijk geacht zich vrij te maken, omdat dan het werk stil komt te liggen. De opbrengst van de cursussen lijkt ook tamelijk mager, en beklijft slecht. Deskundigheid wordt eveneens zelden extern ingehuurd, ook niet bij de arbodienst. Dit komt niet zozeer doordat de directeuren moeilijk doen, maar vooral doordat de meeste bouw-OR'en geen traditie kennen wat betreft het inhuren van externe ondersteuning. De eventueel wel aanwezige kennis is vaak gebonden aan één of twee OR-leden. De meeste VGW'ers in de bouw blijven steken op operationeel niveau, en willen concrete oplossingen voor concrete problemen. Arbo is vooral het terrein van de praktische jongens, met een fixatie op veiligheid en technische oplossingen. Een meer beleidsmatige aanpak blijkt vaak lastig. Zo krijgen ondernemingsraden over het algemeen wel alle informatie die ze wensen, maar is het weinigen gegeven om bijvoorbeeld achter de verzuimcijfers te kijken en de eventuele structurele oorzaken van het verzuim te doorgronden en op een zinvolle wijze te bespreken.

De enquête onder inspecteurs van de Arbeidsinspectie bevestigt dit beeld. In paragraaf 4.1.5 was al aangegeven dat de kennis van medezeggenschappers in het algemeen te wensen overlaat, en nadere beschouwing van de data leert dat OR-leden in de bouw hier nog eens negatief van afwijken: de arbokennis scoort een mager vijfje en ook zijn de ondernemingsraden matig op de hoogte van het arbobeleid in hun organisatie $(5,4)$. Het vermogen om concrete knelpunten op een hoger, beleidsmatig niveau te tackelen is eveneens onvoldoende $(4,8)$.

De ervaringen in de drie onderzochte bedrijven zijn in lijn met de expertinterviews en de AI-enquête. De bestuurder van BH meldt dat 'zijn' OR een aantal sterke voorzitters heeft gehad, maar dat verder het niveau matig is en ondanks jaarlijkse cursussen ook niet werkelijk lijkt te stijgen. Bij BB is de arbokennis sterk gekoppeld aan de positie van de voorzitter, die tevens VCA-coördinator is. De bestuurder van BR wijst er aan de andere kant op dat de kennis van wet- en regelgeving wellicht matig is, maar dat de bijdrage van de OR juist bestaat uit kennis van de werkvloer - en die is goed.

\section{OR en VCA-coördinator/arbodienst}

De primaire verantwoordelijkheid voor de uitvoering van het arbobeleid ligt over het algemeen bij de VCA-coördinator. Deze stelt vaak de risico-inventarisatie en het plan van aanpak op, en heeft door regelmatige werkplekinspecties een goed beeld van de arboproblematiek op de locaties. In het overleg over de risico-inventarisatie en met name de voortgang van het plan van aanpak is de inhoudelijke bijdrage van 
de OR over het algemeen beperkt. De ondernemingsraden stellen zich ook niet bijzonder kritisch op. Incidenteel wordt wel een punt onder de aandacht van de coördinator gebracht, maar het blijkt voor de OR lastig om dergelijke knelpunten op een beleidsmatige manier op te pakken. Bij de uitwerking van concrete punten, bijvoorbeeld de aanschaf van nieuwe werkkleding, is de samenwerking tussen VCAcoördinator en OR vaak wel positief, omdat de OR-leden weten of bepaalde oplossingen werken in de praktijk. De situatie in de drie onderzochte bedrijven bevestigt het hierboven geschetste beeld dat is ontleend aan de expertinterviews (of beter, de expertinterviews bevestigden het beeld uit de eerdere bedrijfsstudies).

Voor externe arbodiensten zijn OR-leden moeilijk aanspreekbaar, omdat ze vaak niet op de locaties zijn. Bovendien zijn de meeste ondernemingsraden niet erg gemotiveerd om met de arbodienst te spreken. De contacten met de arbodienst verlopen vrijwel altijd via de VCA-coördinator. Heel incidenteel maakt de geĩnterviewde adviseur van de arbodienst wel mee dat een OR-lid meeloopt bij cen bedrijfsbezoek. In die gevallen zijn de ervaringen goed, omdat de OR-leden toch behoorlijk goed weten wat er speelt op de werkplek. Bovendien lijken de werknemers meer bereid om hun verhaal te doen als er ook iemand van de OR meeloopt.

\section{$O R$ en achterban}

Systematisch contact met de achterban, bijvoorbeeld door een eigen rondgang of alleen al door mee te lopen met de VCA-coördinator of de arbodienst, zou belangrijke input kunnen leveren voor een effectief arbobeleid. In de praktijk is de rol van de ondernemingsraad echter beperkt. Het contact met de achterban is weinig intensief, ook in vergelijking met andere branches. ${ }^{50}$ Als belangrijkste verklaring wordt door ondernemingsraden aangedragen dat de achterban niet geïnteresseerd is. Daarnaast wordt contact met de achterban bemoeilijkt door de verspreide locaties. Een mogelijke insteek zou kunnen zijn de achterban te benaderen via de zogeheten toolbox-meetings, waarbij maandelijks een arbothema wordt besproken met het personeel. Van die mogelijkheid maken ondernemingsraden echter zelden gebruik. Sterker nog, juist de verplichte toolbox-meetings (verificatiepunt 5.3 VCA) lijken een actieve inventariserende rol van de ondernemingsraad zélf in de weg te staan. Als er al signalen van werknemers via de OR lopen, dan is dat toch veelal op ad hoc basis en gekoppeld aan persoonlijke contacten van de individuele OR-leden.

Ook in de drie onderzochte bedrijven is het contact tussen OR en achterban matig, en zeker niet systematisch georganiseerd. Raadpleging van de werknemers verloopt in principe via de toolbox-meetings, al lijkt daarbij vooral sprake van voorlichting naar de werknemers en nauwelijks van informatieverkeer in omgekeerde richting. De toolboxes werken bovendien niet altijd optimaal, deels omdat de werknemers of de uitvoerder niet gemotiveerd zijn. Te vrezen valt daarnaast dat de uitvoerder niet alles te horen krijgt vanwege een ervaren afstand tussen de werknemers en hun leidinggevende. 


\section{OR en Arbeidsinspectie}

Bouwlocaties behoren tot de werkplekken die het meest intensief worden geïnspecteerd door de Arbeidsinspectie. ${ }^{51}$ Uit de enquête onder de inspecteurs van de Arbeidsinspectie en een interview blijkt echter dat zij hierbij weinig steun ondervinden van $\mathrm{OR}$-leden. Het gebruik van de formele bevoegdheden wijkt, in negatieve zin, sterk af van de andere branches. Meer dan de helft van de inspecteurs meldde dat de OR-leden zelden of nooit gebruik maken van hun vergezelrecht, en meer dan 90 procent dat de OR-leden zelden gebruik maken van het recht om de inspecteur onder vier ogen te spreken. Dit kan in belangrijke mate worden toegeschreven aan het feit dat de bouwlocaties veelal verspreid zijn, en dat lang niet altijd een ORlid op de locatie aanwezig is. Als zij er wel zijn, gebeurt het desondanks zelden dat aanwezige OR-leden gebruik maken van hun rechten: 'de koffie gaat voor', Bovendien zien OR-leden de inspecteur als een bedreiging voor het eigen bedrijf.

De inspecteurs in de bouw zijn ook aanmerkelijk negatiever over de motivatie van de OR-leden dan in de andere bedrijfstakken: slechts één inspecteur schatte de motivatie hoog in. Daarnaast wordt de inhoudelijke inbreng van de medezeggenschappers matig gewaardeerd: de inhoudelijke kennis van arbozaken is onvoldoende tot slecht ( 91 procent), de OR is maar zelden geïnformeerd over het arbobeleid van de eigen onderneming, en de OR voedt de inspecteur zelden of nooit ( 70 procent) met kennis van de werkvloer. Bovendien is twee derde van de inspecteurs van mening dat ondernemingsraden slecht in staat zijn knelpunten op de werkplek te vertalen naar het arbeidsomstandighedenbeleid.

Hoewel één op de drie inspecteurs helemaal niets ziet in de bijdrage van medezeggenschap aan het arbobeleid, zien de meeste inspecteurs desondanks toch dat medezeggenschap soms (42 procent) of meestal ( 27 procent) van nut kan zijn voor de aandacht voor het arbobeleid. Het is echter duidelijk dat de OR de Arbeidsinspectie nauwelijks ziet als een strategische partner om de arbeidsomstandigheden op de werkplek te verbeteren. Dit geldt ook voor de onderzochte bedrijven.

\section{Samenvatting: de invloed van ondernemingsraden op het arbobeleid}

Het totaalbeeld dat uit de branchebeschrijving kan worden gedestilleerd, is weinig sprankelend: bestuurders staan weliswaar open voor medezeggenschap (mits de OR niet te kritisch is), maar de bijdrage van ondernemingsraden is tamelijk beperkt. Het arbobeleid in bouwbedrijven wordt vooral aangestuurd door de eisen vanuit VCA. Waar een goede arbo-infrastructuur is opgezet en de VCA-coördinator zijn werk goed doet, lijkt de bijdrage van medezeggenschap tamelijk marginaal. Als belangrijkste oorzaken worden gesignaleerd: gebrekkige kennis, weinig initiatief, en een onvermogen om op beleidsmatig niveau tegenspel te bieden tegen de bestuurder of de VCA-coördinator.

Desondanks is, blijkens het databestand van de Arbomonitor (zie tabel 6.2.5). slechts 10 procent van de bestuurders van mening dat de OR geen enkele invloed heeft op het arbobeleid, en 40 procent gewaagt van grote invloed. Opvallend is dat in de $50+$ bedrijven de invloed juist lager is - hetgeen voor een deel wordt verklaard 
Tabel 6.2.4. Functioneren OR in Bouw volgens de Arbeidsinspectie (\%)

\begin{tabular}{|l|c|c|c|}
\hline & vaakmeestal & soms & zeiden/nooit \\
\hline Vergezelrecht & 4 & 42 & 54 \\
Vier ogen & - & 7 & 93 \\
OR neemt zelf contact op met AI & - & 32 & 68 \\
\hline & goed & voldoende & $\begin{array}{c}\text { onvoldoende/ } \\
\text { slecht }\end{array}$ \\
\hline Motivatie OR-leden & & & 32 \\
Inhoudelijke arbokennis & - & 64 & 91 \\
OR is geinformeerd & 8 & 31 & 61 \\
\hline & meestal & soms & zelden/nooit \\
\hline OR voedt inspecteur met kennis werkvloer & 4 & 26 & 70 \\
Kan knelpunten vertalen in arbobeleid & - & 36 & 64 \\
Medezeggenschap levert bijdrage aan arbo & 27 & 42 & 31 \\
Medezeggenschap creéert draagvlak & 24 & 44 & 32 \\
OR is nuttige gesprekspartner & 14 & 57 & 29 \\
Rapportcijfer & 5,28 & & \\
\hline Bron: Arbeidsinspectie, databestand Arbomonitor 2001 & & & \\
\hline
\end{tabular}

doordat in de VCA-gecertificeerde bedrijven de invloed iets lager is dan in de nietgecertificeerde. De invloed van de OR beperkt zich echter vooral tot het signaleren van incidentele knelpunten en, in een enkel geval, invloed bij de uitwerking van concrete maatregelen. Maar zeker als de VCA-coördinator zijn werk goed doet, komen vanuit de OR betrekkelijk weinig signalen bovendrijven die de coördinator niet zelf al heeft opgepikt bij bedrijfsbezoeken. Een belangrijke toegevoegde waarde zou de OR wel kunnen hebben bij het signaleren van 'onzichtbare' risico's zoals werkdruk. Dit vereist een ander contact met de werknemers dan de VCA-coördinator wellicht heeft: het is voorstelbaar dat de werknemers tegen OR-leden iets meer open durven te zijn dan tegen een gedelegeerde van de werkgever. In de praktijk lijken de VGW'ers echter vooral gefocust op veiligheidsrisico's en minder op de organisatorische aspecten van het werk. Wat echter boven twijfel is verheven is de ervaringsdeskundigheid: de OR heeft zicht op de praktijk én kan mee bevorderen dat eventuele oplossingen voor gesignaleerde risico's werkbaar blijven. Dit was voor één van de geïnterviewden aanleiding om, in weerwil van de roep om een sterkere vertegenwoordiging van de hogere functies in de OR, juist een lans te breken voor de man van de werkvloer.

\section{Drie bedrijven: nadere analyse}

De ervaringen uit de drie bedrijfsbezoeken bevestigen het beeld dat hierboven is geschetst. Gevreesd mag echter worden dat de bezochte bedrijven meer dan gemiddeld coöperatief zijn en allicht een iets positieve vertekening geven (zoals hieron- 
Tabel 6.2.5. Invloed van de OR op het arbobeleid (\% werkgevers)

\begin{tabular}{|l|c|c|c|c|c|c|}
\hline & \multicolumn{3}{|c|}{ Alle bedrijven } & \multicolumn{3}{c|}{$50+$ bedrijven } \\
\cline { 2 - 8 } & Bouw & Gemiddeld & Cramer's v & Bouw & Gemiddeld & Cramer's v \\
\hline Grote invloed op arbobeleid & 40 & 31 & $.32 *$ & 26 & 37 & $.28 \cdots$ \\
Géén invloed op arbobeleid & 11 & 8 & $.32 \cdots$ & 17 & 9 & $.28 \cdots$ \\
\hline Bron: Arbeidsinspectie, databestand Arbomonitor 2001 \\
\hline
\end{tabular}

der zal blijken): zij zijn waarschijnlijk vooral exemplarisch voor de redelijk goed georganiseerde, VCA-gecertificeerde bouwondernemingen. Het loont voorts de moeite om te bekijken of uit de werknemersenquête nog interessante informatie te halen valt die een nieuw licht zou kunnen bieden op de bijdrage van medezeggenschap aan de kwaliteit van de arbeidsomstandigheden.

De achterliggende gedachte bij de werknemersenquête was om de kwaliteit van de arbeidsomstandigheden te kwantificeren aan de hand van de prevalentie van een aantal arborisico's. Zo zou ten eerste gekeken kunnen worden of de situatie in de onderzochte bedrijven sterk afweek van de gemiddelde situatie in de branche, en ten tweede zouden de bedrijven onderling vergeleken kunnen worden om vervolgens te analyseren of hier een verband met de opstelling van de OR gelegd zou kunnen worden. Omdat de samenstelling van het personeel, zeker voor BH, nogal afweek van het landelijk gemiddelde, en bovendien het Uta-personeel vaker respondeerde dan de bouw-CAO'ers, is gewogen naar de landelijke verdeling bouw/Uta. ${ }^{52}$

Tabel 6.2.6. Arbeidsomstandigheden in drie bouwbedrijven (\% werknemers)

\begin{tabular}{|c|c|c|c|c|c|}
\hline $\begin{array}{l}\text { Arbeidsomstandigheden } \\
\text { (gewogen naar landelijke } \\
\text { verdeling bouw/Uta) }\end{array}$ & $\begin{array}{c}\text { Bouw landelijk } \\
\text { (CBS) }\end{array}$ & $\begin{array}{c}\text { B8 } \\
n=37\end{array}$ & $\underset{n=74}{B H}$ & $\underset{n=101}{B R}$ & Cramer's V \\
\hline Zwaar werk & 50 & 46 & 32 & 39 & n.s. \\
\hline Fysieke klachten & & 41 & 34 & 28 & n.s. \\
\hline Repeterende arbeid & 58 & 32 & 44 & 57 & n.s. \\
\hline RSI-klachten & & 19 & 19 & 30 & n.s. \\
\hline Lawaai & 15 & 39 & 15 & 12 & $21 \cdots$ \\
\hline Gevaarlijke stoffen & & 8 & 1 & 4 & $.16^{* *}$ \\
\hline Gevaarlijk werk & 11 & 20 & 5 & 3 & $.19^{* *}$ \\
\hline Hoog werktempo/tijdsdruk & 28 & 16 & 18 & 25 & n.s. \\
\hline Psychische klachten & 23 & 22 & 17 & 32 & n.s. \\
\hline Ervaren gezondheid matig/slecht & 13 & 22 & 18 & 15 & n.s. \\
\hline
\end{tabular}

52 De respons bedroeg respectievelijk $59 \%$ (BB). 74\% (BH) en $66 \%$ (BR). Dat maakt de gegevens voor BH en BR representatief voor het gehele bedrijf, in die zin dat de betrouwbaarheid $<0.05$ (bij $95 \%$ waarschijnlijkheid). Voor BB is de betrouwbaarheid 0.068 . 
Wat opvalt, is dat de arbeidsomstandigheden in de drie bedrijven over de hele linie beter zijn dan het landelijk gemiddelde, behalve voor lawaai en gevaarlijk werk in BB. Onderlinge vergelijking leert dat, ondanks dat de personeelsbestanden zijn gewogen en de functiegebonden arborisico's dus in principe 'rechtgetrokken' zijn. de fysieke arbeidsomstandigheden in BB zwaarder zijn dan in BH en BR, terwijl in $B R$ de risico's RSI en werkdruk vaker voorkomen. De verschillen zijn echter niet significant, waardoor het zinloos wordt de bedrijven onderling te vergelijken. Dat zou, gezien de grote gelijkenis tussen de drie bedrijven wat betreft het functioneren van de OR, ook bijzonder lastig geweest zijn. Op dit punt kan opgemerkt worden dat daarmee één van de nevendoelen van de gevolgde werkwijze, te weten: toetsing van het nut van het werken met de werknemersenquête, niet verwezenlijkt kon worden.

Ook analyse bínnen de afzonderlijke bedrijven levert in eerste instantie niet bijzonder veel op. Er zijn weliswaar sterke correlaties tussen fysieke en psychische klachten enerzijds en de ervaren gezondheid anderzijds, maar dat ligt wel erg voor de hand. Wat wél opvalt, is dat voor de hand liggende correlaties tussen repeterende arbeid/RSI en werkdruk/psychische klachten in de drie bedrijven niet of nauwelijks worden gevonden. Ook multipele-analyse waarbij de zes afzonderlijke arborisico's als onafhankelijke variabelen worden ingevoerd, levert afgezien van 'fysieke belasting' geen significante invloed op van de afzonderlijke risico's op de ervaren gezondheid. Kennelijk is pas een stapeling van risico's van significante invloed. Indien de zes belastende factoren bij elkaar worden opgeteld tot één arboscore, is er namelijk wel een lichte correlatie met de ervaren gezondheid $\left(r=.318^{* *}\right)$. De verklaarde variantie is dan echter nog steeds maar 10 procent $\left(r^{2}=0,10\right)$.

Een volgende stap is te kijken in hoeverre de arboscore en de ervaren gezondheid binnen één bedrijf samenhangen met de waardering van de werknemers voor de bijdrage van de $\mathrm{OR}$. Hiervoor zijn twee stellingen voorgelegd aan de werknemers:

1. De ondernemingsraad heeft voldoende oog voor arbeidsomstandigheden

2. Zonder OR zouden de arbeidsomstandigheden in dit bedrijf slechter zijn geweest Daarnaast is de volgende stelling voorgelegd om de opstelling van de bestuurder te waarderen:

3. De bedrijfsleiding heeft voldoende oog voor arbeidsomstandigheden.

De werknemers konden op deze stelling scoren langs een vijfpunts-schaal: geheel eens tot geheel oneens. De uitkomst voor de drie bedrijven is opgenomen in tabel 6.2.7, waarin een aantal dingen opvalt. Ten eerste dat de gemiddelde waardering van de werknemers voor de bedrijfsleiding niet onderdoet voor de waardering die de OR te beurt valt; integendeel. Ten tweede dat de waardering van het Uta-personeel voor de prestatie van zowel de bestuurder als de OR significant positiever is (t-toets: tweezijdige overschrijding <.013): het Uta-personeel is overwegend van mening dat er voldoende oog is voor de arbeidsomstandigheden in het bedrijf, het bouwpersoneel komt op een gemiddelde score. Ten derde dat de stelling 'zonder OR zouden de arbeidsomstandigheden slechter zijn' juist door de bouwvakkers vaker wordt onderschreven, al is de waardering over het algemeen nauwelijks beter dan neutraal. Samengevat komen deze twee laatste constateringen erop neer dat de 
bouwvakkers minder vaak vinden dat er voldoende aandacht is voor veiligheid en gezondheid, en dat zij meer gewicht toekennen aan medezeggenschap.

Tabel 6.2.7. Werknemersoordeel over bestuurder en $O R$

\begin{tabular}{|l|c|c|c|c|c|c|c|}
\hline \multirow{2}{*}{ Vijfpuntscore (landelijk gewogen) } & \multicolumn{2}{|c|}{ BB } & \multicolumn{2}{|c|}{ BH } & \multicolumn{3}{c|}{ BR } \\
\cline { 2 - 8 } & Bouw & Uta & Bouw & Uta & Bouw & Uta \\
\hline $\begin{array}{l}\text { de leiding heeft voldoende oog voor arbo } \\
\text { de OR heeft voldoende oog voor arbo } \\
\text { zonder OR zouden de arbeidsomstandig- } \\
\text { heden slechter zijn }\end{array}$ & 2,84 & 1,65 & 2,16 & 1,89 & 2,33 & 1,92 \\
1= geheel eens, 5 = geheel oneens & 3,05 & 3,65 & 2,35 & 2,58 & 2,52 & 2,90 \\
\hline Bron: vragenlijstonderzoek case-studies & & & & & & \\
\hline
\end{tabular}

Een ander opvallend punt is dat de genoemde items op het oog duidelijk samenhangen: de scores in BB zijn over de hele linie slechter dan in de andere bedrijven. behalve in de waardering van het Uta-personeel voor de aandacht van bestuurder et OR. Aangezien ook de arboscore in BB slechter is dan in de andere bedrijven (6.0 tegen 5,0 resp. 5,1 op een schaal van 0-12 knelpunten), lijkt het zinvol de samenhang tussen de verschillende variabelen te toetsen (tabel 6.2.8).

Opvallend is dat de arbo-aandacht van de bestuurder in alle drie bedrijven duidelijk correleert met de aandacht van de OR. Dit zou kunnen betekenen dat de bestuurder veel aandacht besteedt aan arbeidsomstandigheden omdat hij een arbo-actieve ondernemingsraad heeft. Een omgekeerde verklaring is echter ook zeer wel denkbaar: de OR heeft relatief veel aandacht voor arbeidsomstandigheden omdat de bestuurder het thema op zijn prioriteitenlijst heeft staan. Dit laatste lijkt bij nader inzien de meest voor de hand liggende verklaring: indien middels partièle correlatie gecontroleerd wordt voor de arbo-aandacht bij de OR, blijft de duidelijke correlatie tussen de aandacht van de bedrijfsleiding en de arboscore (BB en BR) overeind. Indien gecontroleerd wordt voor de arbo-aandacht bij de bedrijfsleiding, blijkt er echter geen directe samenhang meer te bestaan tussen de aandacht bij de OR en de arboscore.

Multipele regressie-analyse leert eveneens dat de invloed van de OR niet significant is (zie tabel $6.2 .8 \mathrm{~b}$ ), terwijl het arbobewustzijn van de bedrijfsleiding wél significante invloed uitoefent op de arboscore: voor $B B$ tamelijk sterk $\left(R^{2}\right.$ adj $=.413$, $\left.\beta=.756^{* *}\right)$, voor $B R$ in beperkte mate $\left(R^{2}\right.$ adj $\left.=.114, \beta=.413^{* *}\right)$, in $B H$ niet significant. Het lijkt dus dat de arboscore vooral correleert met de aandacht die de bedrijfsleiding aan arbobeleid besteedt, en minder met de aandacht van de OR. Dit bevestigt ook de conclusie uit paragraaf 4.3 , dat toch vooral de opstelling van de bestuurder de cruciale factor is. Uiteraard is het al te lichtzinnig om op grond van drie cases hier een algemene conclusie aan te verbinden. Het zou echter aardig zijn vergelijkbaar onderzoek in meerdere bedrijven te herhalen. 
Tabel 6.2.8a. Correlaties inbreng en invloed (alleen significante correlaties)

\begin{tabular}{|c|c|c|c|c|c|}
\hline Landelijk gewogen & $\begin{array}{l}\text { Bedrijts- } \\
\text { leiding } \\
\text { heeftoog } \\
\text { voor arbo }\end{array}$ & $\begin{array}{l}\text { OA heett } \\
\text { oog voor } \\
\text { arbo }\end{array}$ & $\begin{array}{c}\text { Positieve } \\
\text { imvloed } \\
\text { OR }\end{array}$ & $\begin{array}{l}\text { Arbo- } \\
\text { acore }\end{array}$ & $\begin{array}{l}\text { Ervaren } \\
\text { gezond- } \\
\text { heid }\end{array}$ \\
\hline \multicolumn{6}{|l|}{ BB } \\
\hline $\begin{array}{l}\text { bedriftsleiding heeft oog voor arbo } \\
\text { OR heeft oog voor arbo } \\
\text { positieve invloed OR } \\
\text { arboscore } \\
\text { ervaren gezondheid }\end{array}$ & $\begin{array}{l}1.000 \\
.763 * \\
.484 * \\
.688^{*} \\
.511^{*}\end{array}$ & $\begin{array}{l}1.000 \\
.462^{*} \\
.489^{*} \\
.497^{*}\end{array}$ & $\begin{array}{l}1.000 \\
.586^{* *} \\
.354^{* *}\end{array}$ & $\begin{array}{l}1.000 \\
.526 * *\end{array}$ & 1.000 \\
\hline \multicolumn{6}{|l|}{$\mathrm{BH}$} \\
\hline $\begin{array}{l}\text { bedrijfsleiding heeft oog voor arbo } \\
\text { OR heeft oog voor arbo } \\
\text { positieve invioed OR } \\
\text { arboscore } \\
\text { ervaren gezondheid }\end{array}$ & $\begin{array}{l}1.000 \\
.627^{*} \\
.333^{*}\end{array}$ & 1.000 & 1.000 & $\begin{array}{l}1.000 \\
264^{\circ}\end{array}$ & 1.000 \\
\hline \multicolumn{6}{|l|}{ BR } \\
\hline $\begin{array}{l}\text { bedrijfsleiding heeft oog voor arbo } \\
\text { OR heeft oog voor arbo } \\
\text { positieve invloed OR } \\
\text { arboscore } \\
\text { ervaren gezondheid }\end{array}$ & $.344^{* \prime}$ & $\begin{array}{l}1.000 \\
.263^{*}\end{array}$ & $\begin{array}{l}1.000 \\
.356^{*}\end{array}$ & $\begin{array}{l}1.000 \\
.300^{*}\end{array}$ & 1.000 \\
\hline \multicolumn{6}{|l|}{$" p<.01, " p<.05$} \\
\hline Bron: vragenlijstonderzoek case-studies & & & & & \\
\hline
\end{tabular}

Tabel 6.2.8b. Invloed van bestuurder en $O R$ op de arboscore

\begin{tabular}{|l|c|c|c|}
\hline & BB & BH & BR \\
\hline Bestuurder heeft oog voor arbo & $.756^{* *}$ & .244 & $.413^{* *}$ \\
OR heeft oog voor arbo & -.041 & .070 & -.085 \\
\hline Constante & -1.217 & 3.990 & 3.809 \\
\hline $\mathrm{R}^{2}$ adj & .495 & .059 & .114 \\
\hline${ }^{*}=p<.05, "=p<.01$ & & \\
\hline
\end{tabular}




\subsection{Bank-en verzekeringswezen}

Het bank- en verzekeringswezen is een branche waarin tot medio jaren ' 90 betrel kelijk weinig aandacht was voor het thema arbeidsomstandigheden, een enke grootbank uitgezonderd. Een van de belangrijkste redenen hiervoor was dat c meest zichtbare veiligheidsrisico's in een kantooromgeving nagenoeg afwezig zij. Ook gezondheidsrisico's sprongen nauwelijks in het oog, en het verzuim in c zakelijke dienstverlening was benedengemiddeld. ${ }^{53}$ Mede naar aanleiding van c wet TZ (1994) en met name de opmars van 'nieuwe' risico's als RSI en werkdro is 'arbo' echter allengs hoger op de agenda komen te staan. In 1999 werd voor h eerst aandacht besteed aan arbeidsomstandigheden (i.c. werkdruk) in de bani $\mathrm{CAO}^{54}$, en in april 2000 werd een intentieverklaring arboconvenant getekend. ${ }^{55}$

\section{Invloed economische, technologische en bedriifskundige ontwikkelingen}

Als oorzaak voor de toenemende arboproblematiek kan worden gewezen op c scherpe (internationale) concurrentic, een aanhoudende golf van fusies en reorg: nisaties, de steeds hoger wordende eisen aan het personeel, en de voortschrijdenc automatisering. ${ }^{56} \mathrm{Al}$ deze ontwikkelingen hebben direct of indirect effect op c arbeidsomstandigheden: (ervaren) werkdruk, werkonzekerheid, intensievere taał belasting en taakverwarring. en beeldscherngebonden werk (RSI)_Uit onderzoe naar de naleving van de Arbeidstijdenwet blijkt voorts dat de zakelijke dienstverlening na de sector transport de bedrijfstak is waar de normen rond de arbeidstijden het meest frequent worden overschreden (met name de standaardnorm voor de dagelijkse/wekelijkse arbeidstijden). ${ }^{57}$ Daarnaast hebben de scherpe concurrentie en het tegenzittend economisch tij sinds 2001 tot gevolg dat de aandacht voor 'arbo' weer ondergesneeuwd raakt door thema's van meer strategische aard. De groei van de werkgelegenheid heeft in de jaren ' 90 ongeveer gelijke tred gehouden met het landelijk gemiddelde, en blijft daar zelfs iets bij achter. ${ }^{58}$ In 2002 werd voor het verzekeringswezen een negatieve groei verwacht (-3,8 procent), en voor 2003 een zeer bescheiden groei van 0,2 procent $\% .{ }^{59}$ Het aantal vacatures in het verzekeringswezen is recentelijk flink gedaald, en de prognose voor de werkgelegenheid is

53 T.J. Veerman en A.G. ter Huurne (1996), ZARA-werkgeverspanel rapportage 1995-1996, Den Haag: Ministerie van Sociale Zaken en Werkgelegenheid/VUGA, p. $32-34$

54 Tros 2000, p. 269. Vanaf 2000 sluiten de grootbanken eigen ondernemings-CAO's af.

55 M. Spinhoven (2000). Arboconvenant bank-en verzekeringswezen, in: Arbo en Milieu jg. 8, nx. 5, p. $14-16$

56 Tros 2000, p. 243-247. Vgl, ook de branchebeschrijvingen Arborisico's in de branche financiele instellingen (www.arbo.nl/content/network/szw/docs/branche/financiele_instellingen.pdf) en Arborisico's in de branche Verzekeringswezen en Pensioenfondsen (http://www.arbo.nl/content/network/szw/docs/branche/verzekeringswezen_en_pensioenfondsen.pdf)

57 Mevissen 2001, p. 130, 272

58 In 1990 werkte $3,2 \%$ van de beroepsbevolking in het bank-en verzekeringswezen, in 2001 was dat $3.1 \%$. CBS, Statine

59 Centrum voor verzekeringsstatistiek (2002), Wenkgelegenheid $\mathrm{CAO}$-verzekeringsbedriif: Ontwikkelingen in 2001, Den Haag: Verbond van Verzekeraars, p. 2 
negatief. ${ }^{60}$ In het bankwezen is het aantal werknemers in 2002 ruim 3.5 procent gedaald in vergelijking met $2001 .^{61}$

\section{Arborisico's, verzuim, beroepsziekten. WAO-instroom}

Zoals aangegeven zijn de belangrijkste risico's RSI en werkdruk. Het percentage werknemers met RSI-klachten ( 28 procent) ligt boven de benchmark ( 24 procent). en 6.6 procent van de werknemers heeft zich wel eens ziek moeten melden in verband met RSI-klachten. ${ }^{62}$ In de periode $1998-2002$ is de werkdruk, ondanks de toegenomen aandacht voor het thema, tamelijk fors toegenomen (sneller dan het landelijk gemiddelde): anno 2001 ervaart 12.5 procent van de werknemers in de banken hoge werkdruk. ${ }^{63}$ De autonomie van de werknemers in het verzekeringswezen is relatief hoog. Desondanks signaleert én op de tien werknemers burn-outklachten. ${ }^{64}$ Banken en verzekeraars worden beide genoemd als sectoren waarin de instroomkans in de WAO als gevolg van psychische ziekte hoog is $(0,67$ resp. 0,76 procent tegen $0,55 \%$ gemiddeld). ${ }^{65}$ Alle indicatoren van ongunstige arbeidsom-

Tabel 6.3.1. Arbeidsomstandigheden in bank-en verzekeringswezen (\% werknemers)

\begin{tabular}{|c|c|c|}
\hline & $\begin{array}{c}\text { Financiële } \\
\text { dienstverlening }\end{array}$ & Landelijk \\
\hline Kracht gebruiken & 2 & 24 \\
\hline Langdurig zelfde houding & 64 & 45 \\
\hline Repeterende bewegingen & 56 & 44 \\
\hline Beeldschermwerk & 78 & 44 \\
\hline RSI-klachten* & 28 & 24 \\
\hline Hoge tijdsdruk & 32 & 30 \\
\hline In hoog tempo werken & 39 & 41 \\
\hline Onder tijdsdruk én in hoog tempo & 21 & 27 \\
\hline Hoge werkdruk* & 12,5 & 14,9 \\
\hline \multirow{4}{*}{$\begin{array}{l}\text { Ziekteverzuimpercentage } \\
\text { (excl. zwangerschap), } 2000 \\
\text { WAO-instroom** }\end{array}$} & & \multirow{3}{*}{5,5} \\
\hline & 5,0 & \\
\hline & 1,29 (banken) & \\
\hline & 1,46 (verzekeraars) & 1,53 \\
\hline
\end{tabular}

60 Centrum voor verzekeringsstatistiek 2002, p. 16 resp. 7

61 NIBE-SVV Bankenboekje (website NVB.nl, kerncijfers)

62 Projectbureau arboconvenant Bankwezen (2003), Onderzoeksresultaten nulmetingen bankwezen, Hoofddorp, p. 3

63 Ibid., p. 5

64 C.G.L. van Deursen en S. van Binnendijk (2001), Arbeidsrisico's, gezondheidsklachten en ziekteverzuim binnen branches, Den Haag: Ministerie van Sociale Zaken en Werkgelegenheid (Arboconvenant reeks)

65 Konings/Van der Zouw 2002, p. 16 
standigheden blijven, afgezien van de RSI-problematiek, weliswaar beneden het landelijke gemiddelde, maar er is voldoende aanleiding voor een krachtdadig arbeidsomstandighedenbeleid - zeker voor de verzekeraars, een sector die één van de snelst stijgende instroompercentages voor de WAO kent en het percentage dertiende-weeks zieken het hoogst van alle sectoren is. ${ }^{66}$

Uit de meest recente Arbomonitor van de Arbeidsinspectie blijkt dat de financiële instellingen zich relatief veel inspanning getroosten op het gebied van arbo- en verzuimbeleid. Afgezien van het openbaar bestuur is de financiële dienstverlening de branche waarin risico-inventarisatie ( 75 procent), plan van aanpak ( 78 procent) en verzuimbeleid ( 67 procent) het best ingang hebben gevonden. ${ }^{67}$ Ook de kwaliteit van de RI\&E en het plan van aanpak wordt door de Arbeidsinspectie hoger aangeslagen dan gemiddeld.

Tabel 6.3.2. Kwaliteit arbobeleid bij financiële instellingen (\% bedrijven)

\begin{tabular}{|c|c|c|c|c|c|c|}
\hline & \multicolumn{3}{|c|}{ Alle bedrijven } & \multicolumn{3}{|c|}{$50+$ bedrijven } \\
\hline & Fin.Inst. & Gemiddeld & Cramer's V & Fin.Inst. & Gemiddeld & Cramer's V \\
\hline RIE aanwezig & 75 & 62 & $.16^{* *}$ & 89 & 87 & $.26 * *$ \\
\hline RIE adequaat & 72 & 50 & $.17^{\cdots}$ & 65 & 67 & $.27^{\cdots *}$ \\
\hline PvA aanwezig & 78 & 67 & $.17 \cdots$ & 93 & 77 & $.16^{* *}$ \\
\hline PvA adequaat & 57 & 49 & $.16^{\cdots}$ & 71 & 63 & $.18^{*}$ \\
\hline
\end{tabular}

Wetgeving, CAO-afspraken en convenanten

In het bank- en verzekeringswezen zijn 150.000 respectievelijk 50.000 werknemers werkzaam. ${ }^{68}$ Veruit het merendeel van het bankpersoneel valt onder het regime van één van de vijf ondernemings-CAO's voor de grootbanken (Rabobank, ABNAMRO. ING, Fortis en SNS). De rest van de werknemers valt onder één algemene bank-CAO voor 44 kleinere banken. De twee CAO's voor het verzekeringsbedrijf bevatten een hoofdstuk arbeidsomstandigheden, dat echter voor het grootste deel aan verzuimvoorschriften en arbeidsongeschiktheid is gewijd. Alleen artikel 7.2 van de veruit grootste CAO (Binnendienst: 45.000 werknemers) bepaalt dat de werkgever aandacht zal besteden "aan de ergonomische aspecten die verbonden kunnen zijn aan het werken met beeldschermen, alsmede aan het onderbreken van de effectieve werktijd." Het aspect medezeggenschap is opgenomen in de bepaling dat de werkgever, in overleg met de ondernemingsraad, zijn medewerkers en leidinggevenden zal voorlichten over het verzuim- en reintegratiebeleid, en dat de

66 Konings/Van der Zouw 2002, p. 36 resp. 79

67 Peters/Van Hoom 2002, p. 59-65

68 Centrum voor verzekeringsstatistiek (2002), Werkgelegenheid CAO-verzekeringsbedrif: Onrwikkelingen in 2001, Den Haag: Verbond van Verzekeraars. p. 5: NIBE-SVV Bankenboekje (website NVB.nl, kemcijfers) 
werkgeversorganisatie ten minste tweemaal per jaar overleg voert met de vakorganisaties om de ervaringen met het ziekte- en reintegratiebeleid te bespreken. De arbo-afspraken in de algemene bank-CAO beperken zich tot verzuimvoorschriften. bepalingen omtrent het PAGO, en een beleidsverplichting tot het voorkomen van seksuele intimidatie. De vijf grootbanken hebben sinds juni 2000 ondernemingsCAO's. Die CAO's zijn weinig ambitieus wat betreft het thema 'arbo', Zij beperken zich, naast de bepaling dat cen risico-inventarisatie zal worden uitgevoend conform de model-RI\&E Banken, tot een verwijzing naar het arboconvenant banken dat eind 2001 is afgesloten.

Dit arboconvenant, dat is afgesloten in 2001, is zeker wel ambitieus te noemen. ${ }^{69}$ De belangrijkste thema's zijn RSI, werkdruk en ziekteverzuim/WAO. Hierover zijn. voor uiterlijk 2004, de volgende reductiedoelstellingen overeengekomen: RSI - 10 procent, werkdruk - 40 procent, ziekteverzuim - 10 procent, en WAO-instroom -20 procent. De totale begroting voor het arboconvenant beloopt 30 miljoen euro (dat wil zeggen zo'n 200 euro per werknemer). In het plan van aanpak zijn elf specifieke maatregelen opgenomen, die in de praktijk nader moeten worden uitgewerkt in ondernemingsgewijze actieplannen (voor bedrijven met meer dan 350 werknemers). De maatregelen hebben betrekking op globale zaken als voorlichting (waarbij zowel werkgevers als vakbonden een rol spelen) en het 'bespreekbaar maken van RSI en werkdruk', maar ook concrete zaken zoals advies over arbocriteria bij inkoop van meubilair en het ontwerp van werkplekken ${ }^{70}$ én de algemene invoering van pauzesoftware (kosten: 6.9 miljoen euro). Opvallend is de afspraak om te komen tot een beperking van het aantal uren beeldschermwerk. De beoogde norm van vijf uur is stringenter dan in de toelichting bij artikel 5.10 Arbobesluit als indicatie is aangegeven. De werkgevers verzetten zich overigens tegen de daadwerkelijk implementatie van de vijf-urennorm, vooral omdat deze norm veel problemen oplevert in de operationele sfeer (herschikking van taken).

Eén van de meest vernieuwende onderdelen in het plan van aanpak is een opleiding tot RSI/werkdruk-consulent voor kaderleden. Deze kaderleden krijgen een scholing van in principe twaalf dagdelen, en zullen daarna op de eigen werkplek een vraagbaakfunctie vervullen. Daarnaast coördineert FNV Bondgenoten (GBIO-)scholing voor medezeggenschappers én beheert zij een website over de voortgang van het convenant. ${ }^{71}$ Voorts hebben ondernemingsraden tegen gereduceerd tarief ( 50 procent) recht op jaarlijks tien uur advies vanuit een deskundigenpool en kunnen zij zich tijdens het intern overleg over het arboconvenant laten bijstaan door vakbondsvertegenwoordigers. De ervaringen op het moment van afsluiten van deze studie waren niet bijzonder bemoedigend. De scholing en het advieswerk stonden voorjaar 2003 nog in de steigers, en zeker het advieswerk is nog nagenoeg onbe-

69 Staatscourant 30 november 2001, nr.233, p. 16. Voor het verzekeringswezen is nog geen convenant afgesloten, terwijl de zorgverzekeraars eind 2001 een intentieverklaring hebben getekend die begin 2003 nog immer niet was geëffectueerd.

70 In artikel 1. lid 10, van het convenant is overigens wel opgenomen dat rekening dient te worden gehouden "met hetgeen gezondheidskundig wenselijk, bedrijfseconomisch haalbaar en praktisch uitvoerbaar is".

71 http://www.arbobondgenoten.nl/arboconvenanten/banken/bankconvenantindex.htm 
kend bij de doelgroep. Ook het aanstellen van R\&W-consulenten verloopt moeizaam, omdat de meeste werkgevers een dubbeling met hun eigen arbodienst vrezen. Alleen bij ABN-AMRO zijn inmiddels consulenten actief.

\section{Arbeidsverhoudingen in de branche}

Door de laatstgenoemde elementen uit het convenant is 'arbo' een thema dat van grote invloed kan zijn op de arbeidsverhoudingen in de branche. RSI-consulenten, OR-advies en ondersteuning bij het arbo-overleg vormen in potentie een belangrijke ingang voor vakbondsvertegenwoordiging op de werkplek. De vakbeweging krijgt, ook voor niet-leden, meer 'smoel' rond een duidelijk herkenbare problematiek. Op dit moment zijn de bonden toch tamelijk slecht vertegenwoordigd op de werkvloer. ${ }^{72}$ Bovendien zullen de RSI-consulenten en OR-adviseurs beter in staat zijn om signalen van de werknemers en ondernemingsraden door te geven aan de vakbondsbestuurders. Het aantal RSI-consulenten is op dit moment overigens nog beperkt, en beperkt zich dan ook nog tot de grootbanken waar de organisatiegraad toch al bovengemiddeld is.

Ook langs andere weg is arbo verstrengeld met de arbeidsverhoudingen in de branche. De sterk toegenomen aandacht voor arbeidsomstandigheden sinds medio jaren ' 90 is hierboven namelijk wel verklaard door het toegenomen besef bij werk. gevers van de werkdruk- en RSI-problematiek, maar daarbij hebben de toenmalige Dienstenbonden een belangrijke rol gespeeld. Zo ondernam de Dienstenbond FNV diverse initiatieven om het thema werkdruk onder de aandacht te brengen, onder meer in de bankensector. ${ }^{73}$ Voorts ontwikkelde de Dienstenbond FNV onder meer pauzesoftware (de beeldschermtachograaf) en introduceerde hij het Zweedse TCOkeurmerk voor beeldschermen in Nederland. ${ }^{74}$ Hiermee hebben de bonden een duidelijke impuls aan het arbobeleid in de zakelijke dienstverlening gegeven.

In het algemeen was de positie van de vakbeweging in de financiële dienstverlening langere tijd overigens niet bijzonder sterk. De arbeidsverhoudingen zijn zeker in de jaren '90, mede door de vele reorganisaties, echter meer uitgekristalliseerd. De positie van de vakbeweging is, zeker bij de grotere werkgevers in het bankbedrijf, inmiddels tamelijk onomstreden. ${ }^{75}$ De organisatiegraad in de financiële instellingen is, na een sterke opleving begin jaren ' 90 , weer dalende. Die daling is scherper dan het landelijk gemiddelde. ${ }^{76}$ De contacten tussen vakbond en ondernemingsraden

72 J.J.M. van den Dungen en R.K.J.M. Latten (2001), Medezeggenschap verzekerd? Onder. nemingsraden binnen verzekeringsmaatschappijen onderzocht. Nijmegen: KUN, p. 60

73 Vgl. onder meer J. Warning (2000), Werkdruk nieuw vakbondsthema: woorbeelden van vakbondsinitiatieven in de dienstensector. Zeist: Kerckebosch. p. 172-186

74 G. Huppes, K.J. Peereboom en K.B.J. Schreibers (1996), RSI bij Beeldschermwerk, Woerden: FNV Dienstenbond

75 Tros 2000, p. $270 \mathrm{ff}$

76 J. van Cruchten en R. Kuijpers (2002), Organisatiegraad van werknemers daalt in de periode 1995-2000, in: Sociaal-Economische Maandstatistiek 2002/9. p. 22. Blijkens de meest recente peiling is de organisatiegraad anno 2001 weer iets gestegen. J. van Cruchten en R. Kuijpers (2003). Organisatiegraad van werknemers 2001, in: Sociaal-Economische Maandstatistiek 2003/3, p. 21 
zijn, behalve bij de ING en ABN-AMRO, weinig intensief ${ }^{77}$ Het lijkt er sterk op dat adequate medezeggenschap vooral is gekoppeld aan de grote bedrijven. Op het gebied van arbeidsomstandigheden, zeker vanuit het arboconvenant, is de invloed van de vakbond echter wel tamelijk groot.

Tabel 6.3.3. Organisatiegraad in bank-en verzekeringswezen

\begin{tabular}{|l|r|c|r|}
\hline & Werknemers & $\begin{array}{c}\text { Totale } \\
\text { organisatiegraad }\end{array}$ & FNV \\
\hline Commerciële verzekeringen & 35.000 & $18 \%$ & $7 \%$ \\
Zorgverzekeringen & 9.000 & $28 \%$ & $14 \%$ \\
ABNAMRO & 30.000 & $25 \%$ & $10 \%$ \\
ING & 35.000 & $25 \%$ & $10 \%$ \\
RABO & 45.000 & $15 \%$ & $3 \%$ \\
FORTIS & 15.000 & $12 \%$ & $4,5 \%$ \\
SNS Reaal & 6.000 & $20 \%$ & $8 \%$ \\
Rest Bankensector & 15.000 & $12 \%$ & $5 \%$ \\
Totaal bank- en verzekeringswezen & 190.000 & $19 \%$ & $7 \%$ \\
Totaal Nederland & & $26 \%$ & $18 \%$ \\
\hline Bron: FNV Bondgenoten & \multicolumn{3}{|c}{} \\
\hline
\end{tabular}

Het aantal ondernemingsraden in de branche ligt, wat betreft de $50+$ bedrijven, boven het landelijk gemiddelde: 89 procent tegen 79 procent gemiddeld ${ }^{78}$ Ruwweg de helft van de 50+ OR'en heeft een VGW(M)-commissie ingesteld. ${ }^{79}$ De waardering van de bestuurder voor medezeggenschap is, blijkens het gegevensbestand van De volwassen $O R$, iets positiever dan gemiddeld en ook iets meer bereid tot concessies - al mogen deze gegevens door de lage respons niet significant heten. Uit de interviews komt evenwel een zelfde welwillendheid bij bestuurders naar voren, al willen zij zeker de laatste jaren meer toegevoegde waarde van medezeggenschap zien.

\section{De bestuurder}

De aandacht voor arbeidsomstandigheden in het bank- en verzekeringswezen is de laatste jaren sterk gegroeid, zeker bij de grote ondernemingen. Deze aandacht is

77 Uit het gegevensbestand van De volwassen $O R$ blijkt dat $70 \%$ van de ondervraagde ondernemingsraden nooit contact heeft met de vakbond. Dit gegeven is echter gebaseerd op een zeer kleine responsgroep en dus niet representatief. Het strookt echter wel met de bevindingen uit de interviews en andere bronnen. Van den Dungen/Latten 2001, p. 60

78 Databestand Arbomonitor 2001. Bij het meest recente nalevingsonderzoek had in de 'zakelijke dienstverlening' drie kwart van de $50+$ bedrijven een $\mathrm{OR}$ ingesteld, $1 \%$ onder het landelijk gemiddelde. J, van der Veen, M. Engelen en M. van der Aalst (2002), Naleving van de Wet op de ondernemingsraden: Stand van zaken 2002, Den Haag: Elsevier/Ministerie van Sociale Zaken en Werkgelegenheid Als in het bestand van de Arbomonitor de financiële en de zakelijke diensten worden samengevoegd, is het nalevingspercentage ook $73 \%$.

79 Databestand Arbomonitor 2001 
mede geworteld in het besef bij het bestuur van de ondernemingen van het belang van arbozorg: zowel wat betreft de kosten van ziekteverzuim en arbeidsongeschiktheid onder het eigen personeel als strategisch. Zo verlenen meerdere organisaties allerlei vormen van arbodienstverlening aan derde bedrijven, vooral gericht op verzuimbeheersing en reïntegratie maar ook op schadelastbeheersing (aansprakelijkheidsclaims). Daarnaast participeren met name de verzekeraars in diverse arbodiensten en reïtegratiebedrijven. De markt voor reïntegratie is snel groeiend en profijtelijk. ${ }^{80} \mathrm{ABN}$-AMRO, ING, Rabobank en Fortis hebben elk een eigen, interne arbodienst die als zeer renderende business-units kunnen worden gekarakteriseerd. ${ }^{81}$ Met name de arbodiensten van $\mathrm{ABN}-\mathrm{AMRO}$ en Fortis worden geregeld genoemd als voortrekkers, zeker op het gebied van RSI-preventie (zo heeft ABNAMRO een eigen RSI-centrum). ${ }^{82}$

\section{Overleg bestuurder-OR}

De houding van bestuurders tegenover medezeggenschap is over het algemeen professioneel te noemen. Er wordt regelmatig overlegd, waarbij de diverse arbothema's frequent op de agenda van de overlegvergadering staan. De ondertekening van het arboconvenant heeft aan het formele overleg duidelijk een stimulans gegeven. Naast het overleg tussen bestuurder en $\mathrm{OR}$ is zeker in de grote bedrijven een sterk ontwikkelde arbo-overlegstructuur opgetuigd, waarbij de arbodienst of de arbocobrdinator samen met de OR/ VGW-commissie overleg voert in een vaste arbo-

Tabel 6.3.4. Betrokkenheid werknemers bij arbobeleid

\begin{tabular}{|c|c|c|c|c|c|c|}
\hline & \multicolumn{3}{|c|}{$\%$ alle bedrijven } & \multicolumn{3}{|c|}{$\% 50+$ bedrijven } \\
\hline & Fin.Inst: & Gemiddeld & Cramer's v & Fin.tnst: & Gemiddold & Cramer's V \\
\hline Arbo vast agendapunt & 47 & 46 & $.26 * *$ & 47 & 48 & $27^{* *}$ \\
\hline VGW-commissie ingesteld & 31 & 40 & $.36 \cdots$ & 49 & 50 & $23 \cdots$ \\
\hline OA/werknemers betrokken & & & & & & \\
\hline bij risico-inventarisatie & 59 & 40 & $29 *$ & 77 & 65 & $.26 *$ \\
\hline OR/werknemers betrokken & & & & & & \\
\hline bij plan van aanpak & 64 & 65 & $24 \cdots$ & 87 & 85 & $.14 \cdots$ \\
\hline
\end{tabular}

80 Reintegratie leverde verzekeraars (die reintegratiebedrijven als Keerpunt. Compaan en Argonaut hebben opgericht) in 2001 ongeveer $€ 14$ miljoen op. Dit bedrag wordt vooral bepaald door beperking van de schadelast van polissen tegen verzuim, ziektekosten, arbeidsongeschiktheid en inkomensverlies (Financieel Dagblad, 11 februari 2002).

81 Verzekeraars als Achmea en Delta L.loyd hebben hun interne arbodienst afgestoten. vooral met het oog op de hoge overhead en de hoge certificatie-eisen.

82 De arbodienst van ABN-AMRO was begin 2003 zelfs één van de vijf genomineerden voor 'De Kroon op het Werk'. De Kroon op het Werk is een werkgeversprijs voor bedrijen die opmerkelijke prestaties verrichten op het gebied van preventie van ziekteverzuim en arbeidsongeschiktheid, arbeidsreintegratie en arbobeleid. 
commissie. Ook is veelal vastgelegd welke taken en verantwoordelijkheden de stafrespectievelijk lijnfunctionarissen hebben. De informatievoorziening aan de $O R$ is overwegend goed, de betrokkenheid van de OR bij de risico-inventarisatie en het plan van aanpak is, zeker in de grote bedrijven, zeer redelijk tot goed te noemen. In het algemeen kan gesteld worden dat de basisvoorwaarden voor een goed arbooverleg van de kant van de ondernemer zeker zijn vervuld - zowel procedureel. organisatorisch als randvoorwaardelijk.

\section{Kenmerken van de ondernemingsraden}

Ook van de kant van de medezeggenschappers zijn er weinig beletsels voor een effectief arbo-overleg binnen de organisaties. Hoewel 'arbo' langere tijd is gezien als een onderwerp van ondergeschikt belang ('veel OR-leden vinden het toch interessanter om over fusies en reorganisaties mee te praten'), waarbij de verantwoordelijkheid door de (C)OR veelal werd afgeschoven naar de VGW-commissie, is het thema sinds het arboconvenant duidelijk meer 'in the picture' komen te staan. Het arboconvenant forceert betrokkenheid van OR-leden, onder meer doordat duidelijker is op welke punten de OR instemmingsrecht heeft. Ook de voorlichting in het kader van het convenant leidt tot grotere aandacht bij medezeggenschappers. De motivatie is niet alleen bij bestuurders groeiende.

De faciliteiten zijn overwegend prima. Zeker bij de grootbanken beschikken de (centrale) ondernemingsraden over een ambtelijk secretariaat, er zijn vrijgestelden en geld is zelden een probleem. Ook bij de verzekeraars zijn de faciliteiten goed te noemen. ${ }^{83}$ De deskundigheid van de OR-leden is, vooral door het bovengemiddelde opleidingsniveau in de branche, redelijk - al zij hierbij opgemerkt dat de specifieke arbokennis minder ontwikkeld is. Deze inschatting uit de interviews correspondeert ook met de gegevens uit een enquête onder de inspecteurs van de Arbeidsinspectie (vgl. par. 4.1.5): deze waren van mening dat de ondernemingsraden wel ruim voldoende geïnformeerd zijn over de situatie in hun bedrijf, maar dat ook in de zakelijke dienstverlening de inhoudelijke kennis van ondernemingsraden maar net voldoende is $(5,8)$. Deskundigheid wordt bovendien hoogst zelden extern ingehuurd, ook niet via de arbodienst. Het gebrek aan specifieke arbokennis wordt ten dele gecompenseerd door het vermogen om nieuw aangedragen informatie redelijk snel te verwerken. Het vermogen om te schakelen naar een meer beleidsmatige aanpak wordt echter als 'beperkt' getypeerd. De algemene indruk is toch dat de medezeggenschappers (en dan vooral de 'buitenleden' van de VGW(M)commissie) zich sterk richten op incidentele knelpunten, en daarbij sterk georiënteerd zijn op technische, concrete oplossingen. Zo wordt voor de problematiek RSI bijvoorbeeld sterk aangedrongen op hardware of op trainingen, hetgeen een aanpak die meer op taakinhoud of organisatie van het werk gericht is in de weg staat.

De medezeggenschappers leunen bovendien sterk op hun formele positie: de OR is zich bewust van zijn rechten en bevoegdheden rond arbeidsomstandigheden (met name instemmingsrecht) en is overwegend zeer gespitst op de formele momenten zoals het plan van aanpak, maar een pro-actieve opstelling mag niet worden ver- 
wacht. Medezeggenschap lijkt soms wel omwille van zichzelf te worden nagstreefd: de OR wil wel allerlei informatie, maar kan daar vervolgens weinig me wegens een gebrek aan visie en haakt snel af in inhoudelijk overleg. De OR-ledo zijn slechts zelden in staat achter de cijfers kijken (met name bij de analyse van vezuimcijfers of PAGO-gegevens), en al helemaal niet in staat om op grond van eo eigen analyse of visie het arbobeleid werkelijk bij te sturen.

\section{OR en arbodienst/arbocoördinator}

Ondernemingsraad en arbodienst (of arbocoördinator) zijn in theorie strategiscé partners. De OR kan proberen de arbodienst aan te sturen op zijn eigen doelstelligen, en omgekeerd kan de arbodienst de OR 'gebruiken' om de ondernemer te ovetuigen van het belang van goede arbozorg. Ondernemingsraden lijken echter nit erg doordrongen van het strategisch partnerschap met de arbodienst: zij hebben zeden een visie op de toegevoegde waarde van arbozorg voor de organisatie of va samenwerking met de arbodienst. De OR ziet de arbodienst nog te veel als bedrijfarts, en te weinig als arbo-adviseur. Doordat beide partners over en weer onduidlijke verwachtingen hebben van de mogelijke bijdrage van de andere partij, s bovendien niet altijd duidelijk wat het doel van het arbo-overleg is.

Het overleg met de arbodienst is procedureel wel goed verankerd. Juist die koppling aan vaste momenten draagt er echter. samen met het gebrek aan een pro-active visie bij de OR, toe bij dat de ondernemingsraden een afwachtende houding aannemen. Het overleg is in hoge mate gecentreerd rond het plan van aanpak. Veelal makt de deskundige een opzet voor een plan van aanpak, die wordt besproken met de OR. Incidenteel brengt de OR een aantal inhoudelijke punten in - soms in de vorm van wijzigingsvoorstellen of aanvullingen, maar echte inhoudelijke verbeteringen komen zelden op initiatief van de OR. Dit zou kunnen komen doordat, zoals één van de arbodeskundigen stelde, de arbodienst bij het opstellen van plannen van aanpak zal anticiperen op de mogelijke reactie van de OR. ${ }^{84}$ Daarnaast wordt veel aandacht besteed aan de voortgang van het plan van aanpak. In dat geval wordt de OR een nuttige rol als bewaker en aanjager toegedicht.

\section{OR en achterban}

Ondernemingsraden in de branche doen zelden aan structurele achterbanraadpleging. ${ }^{85}$ Dit geldt ook voor de risico-inventarisatie of bij het uitwerken van maatregelen in het kader van het plan van aanpak. De input in het overleg met de deskundige is sterk gerelateerd aan de ervaringen van individuele OR-leden. Zo wordt bij de beoordeling van de risico-inventarisatie en het plan van aanpak vooral gekeken of de eigen aandachtspunten erin zijn verwerkt. ${ }^{86}$ In meerdere interviews is de term

84 Met dezelfde strekking Van den Dungen/Latten 2001. p. 61

85 Zie ook Van den Dungen/Latten 2001. p. 71

86 Het gevaar van een eenzijdige visie van de toevallig betrokken OR-leden wordt ook genoemd in recent onderzock naar de succesfactoren voor risico-inventarisatic. E.L. van der Steeg et. al (2002). Onderzoek naar de succes- en faalfactoren van de op grond van de Arbeidsomstandighedenwet uitgevoende risico-inventarisatie en -evaluatie, Den Haag: Ministerie van Sociale Zaken en Werkgelegenheid (werkdocument 276), p. 169 
'stokpaardjes' gevallen. Ook wordt weinig gekeken naar het belang van de organisatie als geheel.

\section{OR en Arbeidsinspectie}

Ondernemingsraden in het bank- en verzekeringswezen hebben weinig contact met de Arbeidsinspectie. In de eerste plaats is de Arbeidsinspectic zelf onderbezet en liggen de prioriteiten bij hoog-risicobranches zoals de bouw en de industrie: de kans dat een dienstverlenend bedrijf een inspecteur op bezoek krijgt is 1.3 procent (in grote instellingen 16 procent) ${ }^{87}$, waarbij de financièle instellingen nog weer minder geinspecteerd worden dan andere dienstverlenende instellingen zoals in de gezondheidszorg of het onderwijs. In de tweede plaats stappen OR-leden zelf vrijwel nooit naar de Arbeidsinspectie. Als er geschilpunten zijn, wordt dat intern opgelost.

\section{Samemvatting: de invloed van ondernemingsraden op het arbobeleid}

Al met al doemt een wat flets beeld op van het functioneren van de ondernemingsraden in de bank- en verzekeringswezen. OR en bestuurder/arbodeskundige functioneren, ondanks het redelijke opleidingsniveau van de meeste OR-leden, op een ander abstractieniveau. Terwijl de bestuurder en de arboprofessionals veel meer strategisch en beleidsmatig georiènteerd zijn, opereren de meeste OR-leden vooral op uitvoeringsniveau. Daarbij is de specifieke arbodeskundigheid van de meeste medezeggenschappers matig, en nemen zij slechts zelden initiatief. Waar een adequaat functionerende arbozorgstructuur is opgezet, bemenst met goed opgeleide professionals, lijkt de invloed van medezeggenschap marginaal.

Desondanks is de invloed van de OR, ondanks alle tekortkomingen, uiteindelijk toch tamelijk onomstreden (zie tabel 6.3.5). In de grote financiële instellingen heeft maar liefst 73 procent van de ondernemingsraden grote invloed, waarmee zij veruit koploper zijn. Weliswaar zijn ook bij de zakelijke dienstverleners de meeste medezeggenschappers (te) sterk gefocust op zichtbare resultaten, maar soms scoren zij daar wel degelijk mee. Die aanjaagfunctie wordt door de geïnterviewden ook duidelijk als positief ervaren.

Tabel 6.3.5. Invloed van de OR op het arbobeleid (\% werkgevers)

\begin{tabular}{|l|r|r|r|r|r|r|}
\hline & \multicolumn{3}{|c|}{ Alle bedrijven } & \multicolumn{3}{c|}{$50+$ bedrijven } \\
\cline { 2 - 7 } & Fin.lnst. & Gemiddeld & Cramer's V & Fin.Inst. & Gemiddeld & Cramer's v \\
\hline Grote invloed op arbobeleid & 35 & 31 & $.32 * *$ & 73 & 37 & $.28 \cdots$ \\
Géén invloed op arbobeleid & 2 & 8 & $.32 * *$ & 3 & 9 & $.28 *$ \\
\hline
\end{tabular}

Bron: Databestand Arbomonitor 200

87 Arbeidsinspectie (2002), Jaarverslag 2001, p. 24. Gemeten naar het aantal werknemers is de kans dat een werknemer ooit een inspecteur door zijn bedrijf ziet lopen $11 \%$. 
De toegevoegde waarde van medezeggenschap ligt dus primair bij het signaleren vas knelpunten op de werkplek (in het bijzonder werkdruk), en vooral de bewaking val de voortgang van het plan van aanpak. Alleen al de aanwezigheid van een $O R$ verplicht de bestuurder of de arbodeskundige te anticiperen op de mogelijke reactie van de werknemersvertegenwoordiging. Ook bij de uitwerking van concrete projecteı (bijvoorbeeld de invoering van een rookbeleid) speelt de OR een rol, als klankkast ét als bewaker van de voortgang. Ten slotte heeft de OR middels zijn instemmingsrech een zware stem in de keuze van de arbodienst, een recht dat incidenteel ook word gehanteerd om invloed uit te oefenen op de werkzaamheden van de arbodienst.

Hoewel diverse geïnterviewden aangaven dat het prettig zou zijn als de OR ook zot kunnen opschalen naar een meer beleidsmatig en/of strategisch niveau, ligt de toegevoegde waarde misschien toch juist op het microniveau: contact met de achterban er signalen van de werkvloer. Het zou wel wenselijk zijn als dit op een meer gestructu. reerde wijze vorm zou krijgen, opdat het berijden van stokpaardjes wordt voorkomen

\subsection{Samenvatting en conclusies}

Op grond van het beperkte aantal cases is het uiteraard niet mogelijk om een defini. tief oordeel te geven over de procesmatige kant van het arbo-overleg binnen ondernemingen. Desalniettemin kan een aantal analytische elementen en methodologi. sche inzichten worden gedestilleerd, die wellicht interessant zouden zijn voor een aanvullend, meer grootschalig onderzoek.

Een eerste analytisch element heeft betrekking op de tweede hoofdvraag van dit onderzoek: leidt medezeggenschap tot betere arbeidsomstandigheden en, zo ja. hoe?

In hoofdstuk 5 is een tamelijk eenduidige positieve samenhang aangetoond tussen de aanwezigheid van een OR en de intensiteit van het overleg enerzijds en een aantal indicatoren voor de kwaliteit van het arbobeleid anderzijds. Uit de cases blijkt dat het voor alle geïnterviewden, ondanks alle mitsen en maren omtrent het feitelijk functioneren van ondernemingsraden, zonneklaar was dat medezeggenschap inderdaad een positief effect heeft op de arbeidsomstandigheden. Ook de werknemersenquête in de bouwbedrijven gaf een positieve score te zien op de stelling 'zonder OR zouden de arbeidsomstandigheden beter zijn'. Dat die score slechts licht positief was, is overigens een nieuwe indicatie dat de invloed van de OR ook niet overschat moet worden.

De cases leverden voorts inzicht op in de manier waarop medezeggenschap van invloed is op het arbobeleid. Hoewel het aantal cases uiteraard beperkt is, is het beeld toch tamelijk eenduidig: de manier waarop de OR zijn invloed doet gevoelen is overwegend reactief. Ondernemingsraden, of dat nu in de bouw of in het banken verzekeringswezen is, zijn weinig initiatiefrijk. Zij hebben wél een signalerende functie, zij het dat de signalen niet echt gegrond zijn in een systematisch contact met de achterban. Daarnaast is louter de aanwezigheid van een OR voor de deskundigen of bestuurders al aanleiding om te anticiperen op mogelijke reacties van de werknemers. Die invloed is moeilijk te meten, maar zonder twijfel toch van belang. Een derde manier waarlangs de invloed van de OR zich doet gelden, is dat 
op afzonderlijke punten (plan van aanpak, concrete arbomaatregelen) de ondernemingsraad soms kan bijsturen.

Een methodologisch inzicht waartoe het onderzoek heeft geleid, is dat de poging om het beeld uit de interviews aan te vullen met een aantal kwantitatieve indicatoren (met name de zes risicofactoren, drie typen gezondheidsklachten én de ervaren gezondheid) niet veel heeft opgeleverd. De verschillen tussen de drie bouwbedrijven waren niet significant, en ook het functioneren van de $O R$ in de bezochte bedrijven was niet zodanig verschillend dat daarmee in het oog springende factoren opdoken die een verklaring zouden kunnen vormen voor de verschillen in de arboscore. Daar komt bij dat, bij nader inzien, het functioneren van de OR modelmatig te mager was geoperationaliseerd. Alleen het element 'aandacht' behelst als variabele een wel zeer beperkt aantal factoren. Het probleem is echter dat de werknemers naar verwachting niet voldoende zicht hebben op het functioneren van de OR om via een werknemersenquête een meer geschakeerd beeld te verkrijgen. Het is zeker niet uitgesloten dat een meer grootschalig onderzoek (bijvoorbeeld in het kader van de pols-monitor) wél interessante gegevens over de samenhang tussen medezeggenschap en arborisico's zou kunnen opleveren.

De eerste hoofdvraag uit het onderzoek, zijn ondernemingsraden voldoende geequipeerd?, is in paragraaf 4.1 al beantwoord met de constatering 'formeel wel, in de praktijk minder'. Dit beeld werd ook in de beide cases bevestigd. Vooral de arbodeskundigheid schiet tekort. De oplossing 'meer scholing' biedt echter maar zeer beperkt soelaas, omdat ten eerste de bestaande mogelijkheden al niet worden benut en ten tweede OR-leden maar tot op zekere hoogte schoolbaar zijn. Vooral in de bouw bleek het vermogen te berperkt om de vertaling te maken van concrete knelpunten naar een systematisch beleid. Dat is een struikelblok dat niet met vijf GBIOdagen per jaar is weg te nemen. In het bank- en verzekeringswezen lijkt het vermogen tot beleidsmatig denken beter ontwikkeld, maar ook daar is de specifieke arbokennis matig. Hieruit kan worden geconcludeerd dat niet veel méér verwacht mag worden van de ondernemingsraad en dat wellicht een andere vorm van werknemersvertegenwoordiging wenselijk is. Deze gedachte zal in het slothoofdstuk nader worden uitgewerkt. De conclusie kan ook zijn, dat wellicht de verwachtingen omtrent de bijdrage van de OR te hoog gespannen zijn. Diverse geïnterviewden, onder meer de drie bouwwerkgevers en de arbocoördinator in het verzekeringsbedrijf, gaven aan dat zij meer tegenspel op beleidsmatig niveau zouden willen krijgen. Wellicht echter is dat een misvatting. De toegevoegde waarde van medezeggenschap is nu juist niet op beleidsniveau te verwachten, maar wél op het niveau van de risico-inventarisatie (die dan wel een stuk systematischer ontwikkeld zou moeten worden) én bij de praktische uitwerking van concrete maatregelen. Zoals twee geïnterviewden aangaven: misschien moet de VGW(M)-commissie juist zo dicht mogelijk bij de werkvloer blijven. Een en ander impliceert overigens wel dat werkgever, arbodeskundige en OR over en weer hun verwachtingen omtrent de bijdrage van alle partijen meer expliciet zouden moeten maken. ${ }^{88}$ 
Als kort gekeken wordt naar de theoretische proposities uit paragraaf 6.1 , dan valt op te merken dat, ten eerste, de cases de aanname bevestigen dat de opstelling van de bestuurder cruciaal is. Die opstelling is langs twee manieren geconditioneerd. In de onderzochte branches werd het belang dat de bestuurder hecht aan arbeidsomstandigheden sterk bepaald door externe invloeden: in de bouw met name de certificeringsvoorschriften, en in beide branches financiële prikkels (kosten van verzuim en arbeidsongeschiktheid). Aan de versterking van de financiële prikkels lijkt een limiet te zijn bereikt. Bovendien wijzen diverse onderzoeken naar de gedragsreacties van werkgevers naar aanleiding van de operaties TZ/Wulbz en de arbeidsongeschiktheidsregeling uit dat financiële prikkels niet de aandacht voor preventie versterken, maar wél het verzuimbeleid in repressieve zin hebben aangescherpt. Het succes van de certificering in de bouw daarentegen kan wel een aantal vingerwijzingen geven voor het stimuleren van de werkgever. Met name de verplichting om een VCA-coördinator aan te stellen heeft in mijn ogen een belangrijk positief effect op het arbeidsomstandighedenbeleid binnen bedrijven. Ook dit punt zal in het slothoofdstuk nader worden uitgewerkt.

De tweede stelling, dat een al te meegaande opstelling van de $O R$ belemmerend werkt voor effectieve medezeggenschap, kan op grond van de casestudies niet zinvol worden onderbouwd. Er zijn simpelweg nauwelijks ervaringen met pittige confrontaties rond arbokwesties. Het effect van harde actie of een krachtdadige opstelling is dan ook niet gemeten. Wel is uit meerdere interviews naar voren gekomen dat OR-leden soms juist bang zijn om zich hard op te stellen, mede uit angst voor verstoring van de arbeidsverhoudingen.

Ook propositie 3, dat intensief contact met de vakbond tot een effectievere arbobijdrage van de OR leidt, is op grond van de cases moeilijk nader te onderbouwen. Weliswaar hebben de vakbonden in beide branches een voortrekkersrol gespeeld en lijkt met name het arboconvenant banken faciliterend voor het functioneren van de ondernemingsraden in de branche. De ervaringen met het convenant zijn echter nog te pril om nu al de effecten in te kunnen schatten. De invloed van de vakbeweging doet zich vooral gevoelen in de grotere concerns (bijvoorbeeld platforms van concern-kadergroepen in de bouw) én naar individuele leden (voorlichting. busploegen). Het is wellicht verdedigbaar dat juist in het middenbedrijf ondersteuning door de vakbeweging veel belangrijker is, maar daarover is te weinig informatie boven tafel gekomen.

Dat medezeggenschap bijdraagt aan betere arbeidsomstandigheden (propositie 4), is positief te onderbouwen op grond van de cases - zij het, zoals gezegd, dat de invloed van medezeggenschap toch vooral gelegen is in de toetsende rol én het aandragen van incidentele knelpunten. Daarnaast kan het contact met de praktijk worden gewaardeerd, ook al ligt daar geen systematische werkwijze (contact met achterban, eigen rondgang door het bedrijf) aan ten grondslag. Mijns inziens zou juist door versterking van deze twee positieve punten de bijdrage van ondernemingsraden aan het arbobeleid kunnen worden geoptimaliseerd. Hiertoe zal in het afsluitende hoofdstuk een tweetal suggesties worden gedaan. 


\section{Samenvatting, bedenkingen en enige ideeën}

Deze studie had tot onderwerp 'het arbo-effect van medezeggenschap', Aanleiding voor de studie was de nota Heroriëntatie arbobeleid en Arbowet uit 1996, waarin toenmalig staatssecretaris Linschoten van Sociale Zaken en Werkgelegenheid zijn plannen voor een nieuwe Arbowet voorlegde aan de Sociaal-Economische Raad. In de nota werd hoog opgegeven van het positieve effect van zelfregulering op het gebied van arbeidsomstandigheden, en in het bijzonder van medezeggenschap rond het arbobeleid: "Het mobiliseren van de inbreng en deskundigheid van werknemers is een belangrijke voorwaarde voor een goed arbeidsomstandighedenbeleid. Actieve werknemersbetrokkenheid is een kwalitatieve prikkel en leidt tevens tot een meer evenwichtige afweging van belangen van werkgever en werknemers." De hoofdvraag van deze studie was: 'is dat zo?'. Formeler gesteld:

\section{Leidt medezeggenschap, in het bijzonder door de ondernemingsraad, tot betere} arbeidsomstandigheden?

Gekoppeld aan deze centrale vraag was de tweede hoofdvraag:

2. Zijn ondernemingsraden voldoende geëquipeerd om de hun toebedachte rol op het gebied van arbeidsomstandigheden naar behoren te vervullen?

Deze vragen zijn bepaald niet zonder belang. Zich verschuilend achter de duale veronderstelling dat medezeggenschap bijdraagt tot betere arbeidsomstandigheden én dat medezeggenschappers voldoende geëquipeerd zijn om op dit punt daadwerkelijk een positieve bijdrage te leveren, maakte de overheid een terugtrekkende beweging als hoeder van de veiligheid, de gezondheid en het welzijn van werknemers. Aangezien de bescherming van de werknemer een fundamenteel grondrecht is (art. 3 ESH, art. 7 IVESCR, art. II-31 Handvest van de grondrechten van de Europese Unie ${ }^{2}$ )

1 Ministerie van Sociale Zaken en Werkgelegenheid (1996), Adviesaamvraag Hemoriëntatie Arbobeleid en Arbowet, p. 20

2 Europese Conventie. CONV 797/1/03. Op het moment van schrijven van deze stotbeschouwing was de precieze status van het Handvest nog onderwerp van discussie in de Europese Conventie. Wel heeft de werkgroep die het onderwerp onder de loep heeft genomen zich unaniem uitgesproken voor "de opneming van het Handvest in een zodanige vorm dat het juridisch bindend wordt en een constitutionele status krijgt". Europese Conventie, 22-20-2002, ontwerpEindverslag van de Werkgroep "Opneming van het Handvest/toetreding tot het EVRM". CONV $354 / 02$, p. 3 
en de bescherming van de burger een grondwettelijke taak ( $\operatorname{art} .19$, lid 2, Gw), is een dergelijke terugtred niet zonder meer acceptabel. Het risico bestaat immers dat zelfregulering níet tot een effectief en evenwichtig arbobeleid leidt maar veeleer tot een tanende arbo-inspanning bij werkgevers. Zo zouden de veiligheid en de gezondheid van werknemers opgeofferd worden aan een ideologisch ingefluisterde operatie, waarbij de mantra 'deregulering, zelfregulering' omwille van zichzelf wordt gereciteerd zonder acht te slaan op de eventuele neveneffecten. De meer principiële vraag die op de achtergrond van deze studie meespeelde, was dan ook:

\section{Leidt zelfregulering tot betere arbeidsomstandigheden?}

In dit afsluitende hoofdstuk wordt een poging gedaan om, aan de hand van de bevindingen uit het onderzoek, een samenvattend antwoord te geven op deze vragen (paragraaf 7.1). De antwoorden geven aanleiding tot enige bedenkingen (paragraaf 7.2), die op hun beurt zijn uitgemond in enige, op buitenlandse ervaringen gestoelde ideeën voor institutionele aanpassing (paragraaf 7.3).

\subsection{Samenvatting van de belangrijkste bevindingen}

De vraag 'leidt medezeggenschap tot betere arbeidsomstandigheden?' is een vraag die nogal wat methodologische problemen oproept, met name wat betreft de operationalisatie van de afhankelijke variabele 'betere arbeidsomstandigheden'. In hoofdstuk 5 is de kwaliteit van de arbeidsomstandigheden geoperationaliseerd aan de hand van een aantal indicatoren, zoals kwaliteit van het arbeidsomstandighedenbeleid, de aanwezigheid van risicofactoren, en negatieve effecten in de zin van ziekteverzuimpercentage. Met betrekking tot indicatoren zoals bedrijfsziekten. WAO-uitstroom en ongevallencijfers waren helaas geen betrouwbare cijfers voorhanden. Uit de diverse databronnen, met name de Arbomonitor 2001 en de FNVenquête in het kader van de Arbosterrengids 2000, is een tamelijk eenduidig antwoord gedestilleerd: medezeggenschap hangt in ieder geval statistisch samen met een aantal arbo-indicatoren.

1. Bedrijven mét ondernemingsraad hebben vaker een risico-inventarisatie en -evaluatie, en in de kleinere bedrijven ook vaker een plan van aanpak.

2. De kwaliteit van de RI\&E en het plan van aanpak, zoals beoordeeld door de Arbeidsinspectie, hangt niet significant samen met de loutere aanwezigheid van een OR. Zeker voor de kleinere bedrijven geldt echter wel dat plannen van aanpak die besproken zijn met de OR/pvt beter de toets der kritiek kunnen doorstaan. Ook hangt de kwaliteit van het plan van aanpak samen met een intensiever overleg met de OR/pvt, al is die samenhang statistisch niet sterk.

Desondanks zijn er in bedrijven met OR niet minder vaak arborisico's te signaleren dan in OR-loze bedrijven. De verklaring hiervoor is dat de aanwezigheid van risico's toch primair afhangt van de aard van de werkzaamheden.

3. Bedrijven mét OR nemen echter wél significant vaker maatregelen om de risico's onder controle te brengen - zeker bedrijven waar frequent overleg wordt gevoerd. 
Deze samenhang is echter niet heel sterk, en beperkt zich met name tot de 'onzichtbare' risico's RSI en werkdruk.

De invloed van medezeggenschap op de arbodienstverlening lijkt sterker:

4. Zowel de Arbomonitor als het FNV-onderzoek laat een duidelijke samenhang zien tussen de wijze waarop de OR betrokken is bij de keuze van de arbodienst en de inhoud van het pakket enerzijds en de omvang van het pakket anderzijds.

5. Ook de door OR'en gesignaleerde impact van de abodienstverlening hangt samen met de mate waarin en de wijze waarop de $O R$ invloed heeft uitgeoefend op het contract én met de 'werknemersvriendelijkheid' van de arbodienst zelf.

6. Bovendien hangt medezeggenschap samen met cen laag ziekteverzuim: zo is er een directe correlatie vastgesteld tussen het verzuimpercentage en de mate waarin het informatie- overleg-en instemmingsrecht wordt gerespecteerd, en indirect via de invloed op het verzuimbeleid.

Al met al kan dus worden geconcludeerd dat de aanwezigheid van een OR, en met name de wijze waarop deze betrokken is bij het arbeidsomstandighedenbeleid, samenhangt met betere arbeidsomstandigheden - zij het, nogmaals, niet bijzonder sterk. Samenhang kan bovendien terug te voeren zijn op een gemeenschappelijke achtergrondverklaring, bijvoorbeeld in het algemeen een sociaal werkgeverschap. Uit een aantal andere gegevens blijkt echter wel degelijk een a-symmetrische relatie tussen medezeggenschap en arbobeleid, waarbij de bijdrage van de OR de verklarende en de kwaliteit van het arbobeleid de afhankelijke variabele is.

7. Uit de Arbomonitor blijkt dat 31 procent van de werkgevers de OR een 'grote' invloed op het arbeidsomstandighedenbeleid toedicht, en slechts 8 procent van de ondernemingsraden heeft nauwelijks of geen invloed. Deze bevinding wordt geschraagd door de enquête onder de inspecteurs van de Arbeidsinspectie. Hoewel de inspecteurs in hoofdlijnen tamelijk kritisch waren over de bijdrage van de OR, werd de stelling dat medezeggenschap bijdraagt aan betere arbeidsomstandigheden toch nauwelijks bestreden. Integendeel: ruim één derde van de inspecteurs was van mening dat medezeggenschap 'vaak' bijdraagt aan betere arbeidsomstandigheden én draagvlak creëert.

Een meer inhoudelijke analyse van het functioneren van ondernemingsraden leert, geheel in lijn met het beeld dat opwelt uit de cijfers, dat het arbo-effect van medezeggenschap wel degelijk aanwezig is maar dat de invloed van de OR toch tamelijk marginaal is. De OR stelt zich overwegend reactief $\mathrm{op}^{3}$, en de taak van de OR ligt voornamelijk in het signaleren van knelpunten, het bespreken van afzonderlijke arbokwesties én het bewaken van de voortgang van het plan van aanpak. Een

3 Ook volgens het onderzoek naar macht en onmacht van de OR ligt bij veel ondernemingsraden het accent sterk op een toetsende rol. H. van den Tillaart (2002), Invloed en herkenbaarheid van OR-werk: Macht en onmacht herzien, Den Haag: Elsevier/GBIO. p. 49. Blijkens CNV-onderzoek uit 1998 verdient $61 \%$ van de ondernemingsraden het predikaat 'volgende medezeggenschap', Y. van Brummelen en J.P. van den Toren (1998), Medezeggenschap: een hele onderneming, Utrecht: CNV 
initiërende opstelling valt van ondernemingsraden kennelijk niet te verwachten, en een meer systematische aanpak lijkt voor de meeste medezeggenschappers te hoog gegrepen.

De belangrijkste reden voor de beperkte betekenis van medezeggenschap lijkt in ieder geval niet een gebrek aan bevoegdheden. Formeel rusten de Arbowet en met name de WOR de ondernemingsraad uit met een waaier van bevoegdheden. In de praktijk blijken de meeste werkgevers ook bereid regelmatig overleg te voeren over het arbobeleid, de informatievoorziening is redelijk tot goed (zeker rond de centrale beleidsdocumenten zoals de RI\&E, het plan van aanpak en de verzuimcijfers), al laat wel de naleving van artikel 27 WOR (instemmingsrecht) nogal eens te wensen over. Het belangrijkste manco is met name het gebrek aan deskundigheid en het onvermogen tot beleidsmatig werken. Zowel uit de Arbeidsinspectie-enquête als uit de interviews in de bouw en het bank- en verzekeringswezen komt een weinig positief beeld naar voren. De arbokennis is overwegend matig, de kennis van het arbobeleid in de eigen onderneming beperkt, evenals het vermogen om concrete knelpunten te vertalen in beleid. Uit eerder onderzoek van het GBIO bleek één kwart van de ondernemingsraden zélf ook het gebrek aan deskundigheid als een serieuze handelingsbelemmering te ervaren. ${ }^{4}$ Tijdgebrek is eveneens een belangrijk struikelblok: zowel de tijd die beschikbaar is voor het arbowerk in de eigen onderneming als voor arboscholing.

Ondanks dit gesignaleerde gebrek aan deskundigheid blijkt met name uit de interviews, maar ook uit de bedrijfsbezoeken, dat OR-leden de arbodeskundige of de bestuurder van hun onderneming wel degelijk met enige regelmaat voeden met signalen vanuit de werkvloer. Zeker voor de minder zichtbare risico's (zoals werkdruk) kan die informatie van grote waarde zijn - zowel voor het arbomanagement als voor de werknemers die aan de risico's zijn blootgesteld. Het is mijns inziens veelbetekenend dat werkdruk en RSI als enige twee risico's naar voren kwamen waar contact met de OR significant vaker tot maatregelen leidt. Twee van de geïnterviewde experts gaven aan dat de toegevoegde waarde van medezeggenschap. zeker in bedrijven waar al een redelijke arbo-infrastructuur is opgezet, juist gelegen is in de kennis van de werkvloer; zelfs al is die kennis maar zelden ontleend aan systematisch contact met de achterban. Daarnaast bestaat de indruk dat bestuurders en/of arbodeskundigen bij de beleidsvoorbereiding al anticiperen op de te verwachten reactie van de ondernemingsraad.

Het antwoord op de tweede hoofdvraag is, al met al: formeel zijn ondernemingsraden goed toegerust voor hun taak, in de praktijk maken zij zélf onvoldoende gebruik van hun mogelijkheden. Zo wordt het initiatiefrecht maar mondjesmaat gehanteerd, zijn veel ondernemingsraden onvoldoende op de hoogte van hun rechten (met name het instemmingsrecht, vgl. par. 4.1.3.1), worden de scholingsdagen bij lange na niet opgesoupeerd en maken ondernemingsraden hoogst zelden gebruik van hun recht om deskundigen in te schakelen. In het algemeen gaan zij slechts zelden strategische allianties aan met mogelijke bondgenoten buiten de sfeer van de

4 T. Feijen e.a. (1994), Arbeidsomstandigheden, arbo-zorg en VGW-scholing: een imventarisatie van scholingsbehoeften, Utrecht: GBIO, p. 73 
eigen onderneming, zoals de arbodienst, maar ook de vakbonden en de Arbeidsinspectic. Juist intensief contact met deze drie partijen lijkt echter een belangrijke factor voor een effectieve bijdrage van de OR aan het arbobeleid.

Blijkens de gegevens uit de Arbosterrengids hangt immers het contact tussen arbodienst en OR (of werknemers in het algemeen) duidelijk samen met de impact van de arbodienstverlening. Uit paragraaf 4.2 bleek duidelijk dat ondernemingsraden die regelmatig contact onderhouden met de vakbond minder te klagen hebben over de informatievoorziening en minder vaak gepasseerd worden door de werkgever. Dat heeft wellicht te maken met het feit dat de vakbeweging zélf de ondernemingsraden ondersteunt met informatie over de bevoegdheden van de OR of afspraken makt in arboconvenanten over de positie van medezeggenschap. Vakbonden houden ondernemingsraden alert én equiperen de medezeggenschap. ${ }^{5}$ En een eenvoudig gegeven uit het jaarverslag van de Arbeidsinspectic, ten slotte, leert dat bij vervolginterventies (een tweede bezoek na eerder geconstateerde misstanden) véel van de eerder gesignaleerde misstanden zijn opgelost. ${ }^{6}$ Het loont dus de moeite af en toe eens de Arbeidsinspectie uit te nodigen voor een gesprek - ook op langere termijn. Uit wetenschappelijke analyse van de effectiviteit van inspecties blijkt dat een bedrijfsinspectie gevolgd door een straf tot 22 procent minder ongevallen leidt gedurende de volgende jaren. ${ }^{\text {? }}$

\subsection{Enige bedenkingen}

Als slotsom geldt dat medezeggenschap inderdaad effect heeft op de arbeidsomstandigheden en zeker op het arbobeleid, maar dat dat effect toch tamelijk beperkt is. Deze conclusie strookt met eerdere bevindingen in het Verenigd Koninkrijk waar, 10 jaar na invoering van de Safety Representatives and Safety Committees Regulations in 1977, het effect van vakbondsvertegenwoordiging op de werkvloer beperkt bleek. Wellicht had de aanwezigheid van safety representatives in bedrijven tot een hoger veiligheidbewustzijn geleid en waren sommige arbothema's op de agenda gekomen, maar "generally they had not had a profound effect on standards of health and safety." 8 Bij wijze van verklaring concluderen Dawson c.s. dat "the push to maintain a strong emphasis on health and safety at both the procedural and substantive levels has to come from within the management hierarchy. [..] Without

5 Walters en Frick komen op basis van diverse casestudies tot een zelfde constatering: "Union supporting structures outside of the workplace makes for a more independent, competent and active local workers participation in OHS matters". D. Walters en K. Frick (2000), Worker participation and the Management of Occupational health and Safety: Reinforcing or Conflicting Strategies, in: K. Frick et al. (eds.). Systematic Occupational Health and Safery Management, Amsterdam/Oxford: Pergamon, p. 45

6 Arbeidsinspectie (2003), Jaarverslag 2002, p. 24

7 W.B. Gray en J.T. Scholz, Does Regulatory Enforcement Work? A Panel Analysis of OSHA Enforcement, in: Law \& Society Review, 1 (1993), p. 177-213. Overigens merkt Havinga terecht op dat die resultaten niet alleen door sancties, maar ook door meer aandacht kunnen zijn veroorzaakt. T. Havinga (1995), Grenzen aan de regulering van ondernemingen, in: P. de Jong et al. (red)., Arbeid, recht en risico, Amsterdam: Siswo, p. 49

8 Dawson, S.. P. Willman, A. Clinton en M. Bamford (1988), Safety at work: The limits of selfregulation, Cambridge: Cambridge Univ, Press, p. 85 
[the] bond of senior management and line responsibility and accountability, [..] it is very difficult to maintain commitment to safety". 9

Zonder arbo-commitment bij de werkgever is de rol van de OR beperkt: een conclusie die ook kan worden getrokken op grond van paragraaf 4.2, waar de opstelling van de bestuurder als veruit de belangrijkste achtergrondvariabele werd geidentificeerd voor zowel de aandacht voor arbeidsomstandigheden als de betrokkenheid van de OR. Dit inzicht is op zichzelf niet zo opzienbarend: in tegendeel. Het plaatst echter wél de derde vraag, 'leidt zelfregulering tot betere arbeidsomstandigheden?' in een meer principiële context. Het antwoord op deze vraag zou, op basis van het antwoord op de eerste hoofdvraag van deze studie, allicht bevestigend kunnen luiden. De vraag of zelfregulering beter werkt dan de oude 'command and control'-aanpak is echter niet zonder meer positief te beantwoorden. In de inleiding van deze studie (paragraaf 1.2) is immers al aangegeven dat op macroniveau bijvoorbeeld het aantal werknemers dat blootgesteld is aan arborisico's nauwelijks is afgenomen en dat een aantal positieve trends (daling ziekteverzuim en WAOinstroom) veeleer aan financiële prikkels zijn toe te schrijven dan aan serieuze preventie. Als echter op macroniveau de som van de hele zelfreguleringsoperatie neutraal is en in bedrijven met effectieve medezeggenschap de balans (licht) positief uitslaat, dan zijn er kennelijk ook bedrijven waarin de arbeidsomstandigheden de afgelopen jaren zijn verslechterd. Wellicht is dit te wijten aan een gebrek aan countervailing power aan de kant van de werknemers (géén of slecht functionerende OR). Deze veronderstelling kan, op basis van de gegevens in hoofdstuk 5, overigens maar ten dele hard gemaakt worden. In paragraaf 5.2 is immers gesteld dat de aanwezigheid van arborisico's niet zozeer bepaald wordt door de aan-/afwezigheid van een OR maar primair door de aard van de werkzaamheden. Wél lijkt er een samenhang tussen OR-betrokkenheid en de ontwikkeling van het verzuim (paragraaf 5.3). Op een meer principieel niveau valt er echter nog wel een kanttekening te maken bij de bevinding dat de effectiviteit van medezeggenschap sterk afhangt van de opstelling van de werkgever. Aannemende dat medezeggenschap inderdaad tot een beter arbobeleid leidt, en constaterende dat medezeggenschap in lang niet alle bedrijven optimaal van de grond komt doordat de bestuurder de OR niet welgezind is, is de zorg voor de veiligheid en de gezondheid van werknemers dus tot op zekere hoogte afhankelijk van de goedertierenheid van de werkgever. De vraag of zelfregulering tot betere arbeidsomstandigheden leidt is ook langs deze weg niet eenduidig positief te beantwoorden: in sommige bedrijven wel en in sommige bedrijven niet. Zelfregulering leidt dus tot differentiatie in de bescherming van sociale grondrechten, hetgeen vanuit juridische optiek problematisch en normatief twijfelachtig genoemd kan worden. ${ }^{10}$

\section{Dawson 1988, p. 89}

10 P.H.A. Frissen (1990), Besturingsconcepties, recht en wetgeving, in: H.A.M. Backx et al., Recht doen door wetgeving. Zwolle: W.E.J. Tjeenk Willink, p. 23. Jaspers merkt terecht op dat de erkenning van het fundamentele karakter van grondrechten impliceert dat zij slechts (heel) restrietief mogen worden beperkt, en dan ook nog uitsluitend op gezag van de regelgever die deze rechten als fundamenteel heeft erkend. A.Ph.C.M Jaspers (2000), Meer respect voor grondrechten van werknemers: internationaal erkenning van dat respect? in: A.Ph.C.M Jaspers et al (2000). Meer respect voor gmondrechten van werknemers. Amsterdam: FNV 
De juridische zowel als de morele vraag of de bescherming van sociale grondrechten wel mag worden gedelegeerd aan intermediaire structuren (bedrijven, ondernemingsraden, vakbonden), en zo ja welke randvoorwaarden daaraan moeten worden gesteld, is uitermate lastig te beantwoorden en zou per grondrecht moeten worden gespecificeerd. "In hoofdlijnen lijkt de communis opinio echter dat zelfregulering op het gebied van sociale grondrechten zeer wel verdedigbaar is. Sterker nog, de staat zou zelfregulering moeten bevorderen "indien zelfregulering door maatschappelijke organisaties een hoger niveau van welzijn op een bepaald terrein dichterbij brengt." 12 De overheid houdt wel een eindverantwoordelijkheid, maar "voor zover zij niet zelf passende middelen in handen heeft, volgt uit de systematiek van onze Grondwet dat de overheid moet bevorderen dat anderen [..] hun aanwezige reguleringspotentieel benutten."13 Dat de overheid op het gebied van arbeidsomstandigheden onvoldoende 'passende middelen' heeft, in ieder geval dat die middelen onvoldoende effectief zijn gebleken, valt wel te concluderen uit de periode van 'command and control" - al zou natuurlijk altijd nog gepleit kunnen worden voor een strengere handhaving (bijvoorbeeld het verdubbelen van het aantal inspecteurs van de Arbeidsinspectie en vervijfvoudiging van de bestuurlijke-boetebedragen). ${ }^{14}$ Dat de overheid de eindverantwoordelijkheid houdt, is voor de overheid zelf onomstreden. Zo hebben opeenvolgende kabinetten bij herhaling aangegeven verantwoordelijk te blijven voor het uitvaardigen van basisnormen. ${ }^{15}$ Blijft de vraag of is voldaan aan alle randvoorwaarden voor optimale zelfregulering. Stout en Huls schetsen, vanuit reflexief-rechtelijke optiek, vier criteria waaraan een 'adequaat zelfreguleringsproject' zou moeten voldoen "wil het verenigbaar zijn met de idealen van de democratische en sociale rechtsstaat". ${ }^{16}$ In een wat aangepaste volgorde betreft het:

- rechtsstatelijke kwaliteitseisen;

- een heldere taakomschrijving;

- een evenwichtige belangenafweging:

- effectieve terugkoppelingsmechanismen;

11 H.R.B.M. Kummeling en S.C. van Bijsterveld (1997), Grondrechten en zelfregulering. Deventer: W.E.J. Tjeenk Willink, p. 219

12 H.R.B.M. Kummeling (1997), Grondrechten en de taak van de overheid in het licht van zelfregulering, in: H.R.B.M. Kummeling en S.C. van Bijsterveld, Grondrechten en zelfregulering. Deventer: W.E.J. Tjeenk Willink, p. 50

13 R.A.J. van Gestel en J.M. Verschuuren (1997), Artikel 21 Grondwet en zelfregulering in het milieurecht. In: H.R.B.M. Kummeling en S.C. van Bijsterveld, Gmondrechten en zelfregulering. Deventer: W.E.J. Tjeenk Willink, p. 152

14 J. Warning (2002), WAO-preventieplan: Pleidooi voor een aanpak bij de bron, Utrecht: FNV Bondgenoten, p. 18-19

15 Integraal Beleidsplan Arbeidsomstandigheden, Kamerstukken II I992/93, 22 959, nr. 1: Kabinetsstandpunt naar aanleiding van het MDW-project arbeidsomstandighedenwet (Kamerstukken II, 1994-1995, 24036, nr. 8, p. 1)

16 H.D. Stout en N.J.H. Huls (1992), Reflexiviteit, autopoiese en rechtsstatelijkheid, in: N.J.H. Huls en H.D. Stout (red.), Reflecties op reflexief rechu, Zwolle: W.E.J.Tjeenk Willink, p. 229-230 
Hieraan zou ik nog willen toevoegen criteria van:

- effectiviteit en doelmatigheid ${ }^{17}$

Ik wil mij hier tot een paar opmerkingen beperken. Onder de rechtsstatelijke kwaliteitseisen valt onder meer het principe van de rechtsgelijkheid. ${ }^{18}$ Hierboven is al aangegeven dat formeel gezien wellicht sprake is van gelijke bescherming van de sociale grondrechten 'veiligheid en gezondheid', maar dat materieel wel degelijk verschillen kunnen ontstaan. ${ }^{19}$ Daarbij moet overigens niet alleen worden gedacht aan de al geconstateerde afhankelijkheid van de luimen der werkgever, maar in het algemeen aan het verschijnsel dat de effectiviteit van medezeggenschap én de kwaliteit van het arbeidsomstandighedenbeleid sterk gerelateerd is aan de bedrijfsgrootte (zie paragraaf 4.2). ${ }^{20}$ Het concept van arbozelfregulering, en zeker de systematiek van risico-inventarisatie en plan van aanpak, lijkt vooral een grote-bedrijvenmodel te zijn. ${ }^{21}$ Wilthagen merkt op dat kleine bedrijven "are not likely to be regulated succesfully by internal management systems." 22 Op grond van deze inzichten, gekoppeld aan de aanname dat zelfregulering en medezeggenschap daadwerkelijk tot betere arbeidsomstandigheden leiden, kan worden gesteld dat de rechtsbescherming van zo'n 2,5 miljoen werknemers in het midden- en kleinbedrijf (50-) minder gewaarborgd is dan in het grootbedrijf. ${ }^{23}$ Daarmee lijkt het principe

17 Ook de nota Zicht op wetgeving noemt doeltreffendheid en doelmatigheid als kwaliteitseis voor regelgeving. Vgl. C. Stuurman (1995), Technische normen en het recht. Beschouwingen over de interactie tussen het recht en technische normalisatie op het ternein van de informatietechno. logie en telecommunicatie, Deventer: Kluwer, p, 162

18 Cf. I.C, van der Vlies (1991), Handboek wetgeving, Zwolle: H.D. Tjeenk Willink, (2e druk) p. 150-180. Ook Stuurman, 1995.p. 163

19 Zie in vergelijkbare zin CJ.M. Schuyt (1973), Rechtvaardigheid en effectiviteit in de verde. ling van de levenskansen, Rotterdam: Universitaire Pers

$20 \mathrm{Vgl}$. ook L.H.M. Bosch en J.M.P. de Kok (1997), Arbeidsomstandigheden en bedrijfsgrootte: Een verkenning met de LISREL-methode, Zoetermeer: EIM, p. 10/11. Dit inzicht was overigens al doorgedrongen in de jaren '50, toen Van der Ven veertig jaar na de Arbeidswet 1919 opmerkte dat grote bedrijven "méér begrip voor de wet en haar strekking hebben" en ook vaker buiten de wet om initiatieven ontplooien. J.J.M. van der Ven, Rechtssociologische aantekeningen bij de Arbeidswet 1919, Vereniging van Arbeidsrecht, 1958, p. 8

21 G.IJ.M. Zwetsloot (2000), Developments and Debates on OHSM System Standardisation and Certification, in: Frick, K. et al. (eds.). Systematic Occupational Health and Safery Management: Perspectives on an international Development, Oxford: Pergamon, p. 394

22 A.C.J.M. Wilthagen (1994), Reflexive rationality in the Regulation of Occupational Safety and Health, In: Rogowski, R. en Wilthagen, T. (eds), Reflexive Labour Law, Deventer/Boston: Kluwer, p. 370

23 Het CBS en het EIM houden een wat andere indeling aan, waarbij het middenbedrijf wordt gedefinieerd als 10-99 werknemers. In het kleinbedrijf (volgens het EIM goed voor 1.5 miljoen werkenden: EIM (2002), Kleinschalig Ondermemen 2002: Structuur en ontwikkeling van het Nederlandse MKB. Zoetermeer: EIM. p. 139) is in minder dan de helft van de ondernemingen enigerlei vorm van medezeggenschap (E. Bruin en F. Huijgen (2000). Naleving van de Wet op de Ondernemingsraden: Stand van zaken begin 2000, Den Haag: Elsevier/SZW, p. 13). De verplichtingen rond risico-inventarisatie en plan van aanpak worden in slechts $60 \%$ van de kleine bedrijven nageleefd. A. Peters en E.C. van Hoom (2002), Artomonitor 2001. Den Haag: Arbeidsinspectic, p. 59-60 
van de rechtsgelijkheid niet optimaal gewaarborgd. Elders heb ik al aangegeven dat ook principes als openbaarheid, kenbaarheid en rechtszekerheid op een aantal punten wankelen onder het idee van zelfregulering. ${ }^{24}$

De vraag of onder het huidige systeem sprake is van een evenwichtige belangenafweging, het derde criterium van Stout en Huls, is natuurlijk een centraal punt in deze studie. Ook hierbij geldt dat in kleinere bedrijven de kans op naleving van wettelijke voorschriften klein is, wanneer de naleving op gespannen voet staat met het winststreven van de onderneming. ${ }^{25}$ Daarbij kan gekeken worden naar de formele kant van de zaak (ondernemingsraden zijn formeel voldoende geëquipeerd), maar ook naar de praktijk (beperkte deskundigheid medezeggenschappers) én naar de inhoud. Zo heeft lang niet elke ondernemingsraad oog voor arbeidsomstandigheden bij het beoordelen van een adviesaanvraag. Het zou interessant zijn om meer en detail te onderzoeken hoe de arbogevolgen van belangrijke besluiten rond bijvoorbeeld productie-innovaties of nieuwe technologieèn worden meegewogen; een taak die expliciet is opgenomen in de bevoegdheden van met name de Zweedse en Noorse paritaire veiligheidscommissies $(50+)$, het Belgische paritaire Comité Preventie en Bescherming op het werk $(50+)$, en het Franse CHSCT $(50+) .{ }^{26}$ Een thema zou kunnen zijn of en in welke situaties 'arbo' als wisselgeld wordt gebruikt voor het bereiken van andere doeleinden. ${ }^{27}$ Een definitief oordeel of de belangenafweging evenwichtig is, is op grond van de gegevens niet zonder meer te geven. Maar in hoofdlijnen kan vermoed worden dat indien de werkgever andere belangen zwaarder wil (of moet) laten wegen dan de veiligheid en

24 J.R. Popma (1999-a), Verprivaatrechtelijking van arbeidsomstandigheden? In: P.F. van der Heijden, R.H. van het Kaar en A.C.J.M. Wilthagen (red.), Naar een nieuwe rechtsorde van de arbeid?, Den Haag: SDU/HSI, p. $171 \mathrm{ff}$

25 Wilthagen 1994, p. 370. De kosten van naleving worden door kleinere bedrijven ook vaak genoemd als een hinderpaal voor de naleving. S. van der Kemp en M. Engelen (2002). Het instrument bestuurlijke boete in de Arbowet: Aanknopingspunten voor effectiviteitsbevordering. Den Haag: Elsevier/Ministerie van Sociale Zaken en Werkgelegenheid, p. 43

26 Voor Zweden en Noorwegen zie L. Vogel (1998), Prevention at the Workplace: the impact of Community Directives on preventive systems in Sweden, Finland, Norway, Austria and Switzerland, Brussel: TUTB, p. 71 resp. 118. Voor België: ACV (2000). Opdrachten en bevoegdheden van het Comité voor Preventie en Bescherming op het werk, de Ondernemingsraad en de vakbondsafvaardiging, Brussel: ACV. p. 23. Voor Frankrijk C. Soudry (2002), Le comité d'hygiène, de sécurité et des conditions de travail, Paris : INRS, p. 14. Het CHSCT bestaat in meerderheid uit gekozen werknemersvertegenwoordigers.

27 Dawson merkt op dat juist het feit dat de safety representatives $66 \mathrm{k}$ andere vakbondstaken op de werkvloer hebben (als shop steward), de behartiging van de economische belangen van de werknemers niet zeldien een krachtdadig optreden op het gebied van veiligheid en gezondheid in de weg staat (Dawson 1988, p. 85). Ook het bestaan van inconveniënten- en overwerk- of onregelmatigheidstoeslagen in diverse Nederlandse CAO's is een indicatie dat een preventief arbobeleid in sommige gevallen ten dele wordt afgekocht. 
gezondheid de ondememingsraad nauwelijks in staat zal zijn serieuze obstakels op te werpen - zo de OR dit al zou willen. ${ }^{28}$

Het vierde criterium, de vraag of effectieve terugkoppelingsmechanismen zijn ingebouwd in het systeem van de Arbowet, scoort positief: althans, formeel. Artikel 5, lid 2, verplicht de werkgever immers jaarlijks te overleggen over de voortgang van het plan van aanpak en de vraag of de risico-inventarisatie nog wel actueel is. In de praktijk bleek echter dat het oude arbojaarverslag slechts vier vijfde van de ondernemingsraden bereikte (paragraaf 4.1.2.2), en de voortgangsrapportage omtrent het plan van aanpak nog minder vaak wordt verstrekt - gegeven het feit dat een flink percentage van de bedrijven in het geheel geen plan van aanpak maakt.

De vraag of zelfregulering op het gebied van arbeidsomstandigheden effectief en doelmatig is - het vijfde criterium -, is hierboven al met veel twijfels beantwoord. Het vergelijken van de effectiviteit van zelfregulering met de "command and control'-benadering stuit op een groot aantal methodologische problemen. Zo zijn bijvoorbeeld de ongevals- en verzuimstatistieken vóór en na 1980 onvergelijkbaar. Het aantal beroepsziekten is al helemaal niet te vergelijken, omdat registratie van beroepsziekten lange tijd nagenoeg niet plaatsvond. Ook over de doelmatigheid valt in vergelijkende zin moeilijk een gefundeerd oordeel te vellen omdat doelmatigheid een weging van investeringen en opbrengsten vergt. Daarbij ontbreken in historisch perepentiof nagenoeg volledig do gegerene en zijn wok hedon ten dage de opbreng sten moeilijk te schatten.

Toch kan wel een kritische noot worden gekraakt. Eén van de doelstellingen van de herorièntatie was het bereiken van meer maatwerk. De vraag kan opgeworpen worden welke bedrijven werkelijk op matwerk zitten te wachten en in hoeverre bestaande regelgeving maatwerk-oplossingen in de weg staat. Van artikel 17 Arbowet (het maatwerkartikel) is tot op heden nog nimmer gebruik gemaakt. Het werken met globale doelvoorschriften in het Arbobesluit en de andere regelgeving heeft geleid tot onduidelijkheden over de interpretatie, een verlangen naar meer eenduidige voorschriften (met name in het midden- en kleinbedrijf) én een toenemend aantal normalisatietrajecten op het gebied van arbeidsomstandigheden. Op het niveau van publieke regelgeving is weliswaar sprake van een verminderde regeldichtheid, maar elders heb ik al aangegeven dat die deregulering toch vooral een cosmetische operatie is waarachter zich een tegenbeweging van private reregulering voltrekt; een beweging die bovendien de toets van de rechtsstatelijke kwaliteit niet altijd doorstaat. ${ }^{29}$ De convenantenaanpak, om nog een vorm van maatwerk onder de loep te nemen, heeft weliswaar geleid tot een toegenomen aandacht voor

28 Eind jaren ' 90 schetste Jacobs een somber beeld van de machtspositie van ondernemingsraden. "De afgelopen decennia is [..] komen vast te staan, dat [ongelijkheids]compensatie [door medezeggenschap], zeker waar het de consultatieverplichtingen betreft, niet veel meer inhoudt dan een spelregeltoetsing. Wanneer de ondernemer zich aan de procedureregels houdt, heeft hij eigenlijk nog steeds vrij spel." A.T.J.M. Jacobs (1997), Kleine Mythologie van de ongelijkheidscompensatie, in: L. Betten et al. (red), Ongelijkheidscompensatie als node draad in het recht: Liber amiconum voor M.G. Rood, Deventer, Kluwer. p. 68

29 J.R. Popma 1999, p. 172 
arbeidsomstandigheden (en naar te hopen valt met positief gevolg), maar dit gaat ten koste van een multiplicatie van overlegcircuits en daarmee gepaard gaande kos$\operatorname{ten}^{30}$

Maar ondanks deze bedenkingen zou een puur zwartgallige slotsom toch misplaatst zijn. Uit deze studie is immers gebleken dat medezeggenschap wel degelijk positief effect heeft op het arbeidsomstandighedenbeleid. De bijdrage is echter op twee manieren beperkt. Ten eerste zal in bedrijven waarin de werkgever de medezeggenschap geen warm hart toedraagt de OR nauwelijks voet aan de grond krijgen. Ten tweede bleek met name uit de casestudies dat in bedrijven waar een adequate arbo-infrastructuur is opgezet of een krachtdadige arbocoördinator is aangesteld 6ók niet bijzonder veel eer valt te behalen. In 1978 al vatte Petersen dit dilemma als volgt samen: "If management takes care of the basic management functions of preparing policy, fixing accountability, training supervisors and employees, selecting and motivating employees well, etc., then safety committees probably are not necessary. On the other hand, if management does not effectively carry out these functions, then using safety committees certainly will not ensure results." Petersen komt tot de wat schampere slotsom: "to say that safety committees are essential to safety results is ludicrous". 31

Dit klinkt wellicht schamper wellicht, maar ook ontnuchterend. Als de bijdrage van de OR niet direct tot groot enthousiasme stemt, kan dat ook te wijten zijn aan overspannen verwachtingen. Uit de interviews bleek dat een aantal arbodeskundigen en werkgevers graag zou zien dat de OR meer tegenspel zou bieden op beleidsmatig niveau: maar wellicht is dat gewoon te hoog gegrepen, zoals ook het idee van de strategisch opererende OR meer een schrijftafelconcept is dan een reële mogelijkheid. ${ }^{32}$ Het idee dat 'safety committees', of in Nederland ondernemingsraden of VGW-commissies, "essential to safety results" zouden zijn, valt evenzo onder het kopje overspannen verwachtingen - maar al zijn ze wellicht niet 'essential' of 'necessary', ze zijn in sommige bedrijven en tot op zekere hoogte wél effectief. Waar het op aankomt, is dat gebruik wordt gemaakt van de sterke punten van arbomedezeggenschappers door de tekortkomingen in het huidige systeem te compenseren. Hiertoe zal in de volgende paragraaf een aantal ideeën worden ontvouwd.

\subsection{Enige ideeën}

Het Nederlandse systeem van arbozorg bestaat, zoals meermalen aangegeven, in hoofdlijnen uit een beperkt aantal elementen:

30 Vgl. J.R. Popma (1998-a), Dialektiek der deregulering, in: De Staatscourant, 12 januari 1998 31 D. Petersen (1978), Techniques of Safety Management, 2nd Ed., Tokyo: McGraw-Hill, p. 4142, geciteerd in K.T. Nielsen (2000), Organizational theories implicit in various approaches to OHS Management, in: K. Frick et al. (eds.), Systematic Occupational Health and Safety Management, Amsterdam/Oxford: Pergamon, p. 107

32 R. Goodijk (1995), Ondernemingsraad en strategische beleidsworming: de meerwaarde van de ondernemingsraad in veranderende organisaties. Assen: Van Gorcum 
1. een zorgplicht van de werkgever ten aanzien van zijn werknemers (én ten aanzien van derden) en de verplichting tot het voeren van een arbeidsomstandighedenbeleid.

2. op basis van een risico-inventarisatie en -evaluatie en een plan van aanpak;

3. met medezeggenschap van de ondernemingsraad, personeelsvertegenwoordiging of de belanghebbende werknemers;

4. daarbij ondersteund door een arbodienst.

Wil zelfregulering op het gebied van arbeidsomstandigheden daadwerkelijk effectief zijn, dan zal een aantal tekortkomingen in het huidige stelsel opgeheven moeten worden.

\section{Zorgplicht en arbo-beleidsverplichting.}

Niet alle werkgevers zijn, om het mild te formuleren, intrinsiek gemotiveerd om aandacht te besteden aan veiligheid en gezondheid. Ook extrinsieke motieven, zoals de financiële prikkels rond verzuim en arbeidsongeschiktheid of de dreiging van boeten, hebben niet altijd het gewenste effect. Ten slotte zijn werkgevers zich niet altijd bewust van de strategische motieven voor arbozorg, zoals het voorkomen van personeelsverloop en wervingsproblemen. Juist de motivatie van de werkgever en het vermogen een relatie te leggen tussen arbeidsomstandigheden en bedrijfsschade zijn echter cruciaal voor het welslagen van arbobeleid. ${ }^{33}$

\section{Risico-inventarisatie en plan van aanpak.}

De kwaliteit van risico-inventarisaties en plannen van aanpak schiet vaak tekort. Uit de Arbomonitor 2001 blijkt dat, volgens de Arbeidsinspectie, in 68 procent van alle gevallen de inhoud van de RI\&E is toegesneden op de situatie in het bedrijf, en slechts 60 procent van de plannen van aanpak kan de toets der kritiek doorstaan. ${ }^{34}$ Ook wordt onvoldoende rekening gehouden met de ervaringen van de werknemers op de werkvloer. De meeste instrumenten gaan toch uit van de deskundigen-optiek. waarbij de risicoperceptie van werknemers vaak onvoldoende wordt meegewogen: in 47 procent van de bedrijven worden de werknemers in het geheel niet betrokken bij de risico-inventarisatie. ${ }^{35}$ Aangezien ook het overleg met de OR/pvt als betrokkenheid is meegeteld, is het zeer waarschijnlijk dat actieve participatie van werknemers in het proces van risico-inventarisatie zélf nog aanmerkelijk lager ligt. Juist de betrokkenheid van werknemers heeft echter directe invloed op de kwaliteit ervan, én draagt bij tot het bewustwordingsproces en de daadwerkelijke implementatie van eventuele maatregelen. ${ }^{36}$

\footnotetext{
33 Bosch 1997. p. 10/11

34 Peters 2002, p. 44 Aangezien slechts $62 \%$ van de bedrijven over cen RI\&E beschikt, betekent e.e.a. dat slechts $42 \%$ van de bedrijven een adequate risico-inventarisatie heeft. In de $100+$ bedrijven is dit $70 \%$. Het percentage bedrijven met een adequaat plan van aanpak is slechts $36 \%$.

35 T. Smid (2003), Deskundigen schatten risico's anders in dan werknemers, in: Arbo\&Milieu. Jg. 11, nr. 4. p. 52; Peters en Van Hoorn 2002, p. 24

36 E.L. van der Steeg et. al (2002). Onderzoek naar de succes-en faalfactoren wan de op grond van de Arbeidsomstandighedenwet uitgevoente risico-imentarisatie en -evaluatie. Den Haag: Ministerie van Sociale Zaken en Werkgelegenheid (werkdocument 276), p. 184
} 


\section{Medezeggenschap.}

Niet alle werkgevers dragen werknemersvertegenwoordiging een warm hart toe of zijn doordrongen van de toegevoegde waarde van medezeggenschap. Ondernemingsraden van hun kant hebben met name onvoldoende deskundigheid, tijd en ervaring om werkelijk als 'countervailing power' op te kunnen treden. Het contact met de achterban is onvoldoende systematisch uitgewerkt, en strategische partners zoals arbodienst. Arbeidsinspectie en vakbond worden onvoldoende ingeschakeld.

\section{Arbodiensten.}

Arbodiensten zijn te veel gefixeerd op verzuimbegeleiding en te weinig op preventie. ${ }^{37}$ Externe arbodiensten hebben bovendien vaak te veel afstand tot de werkvloer en tot de medezeggenschap. Interne arbodiensten lijken effectiever te opereren, ${ }^{38}$ Interne deskundigen blijken beter dan externe in staat de samenhang tussen belastingsfactoren en gezondheidsklachten of verzuim inzichtelijk te maken. Ook heeft interne deskundigheid een positief effect op de risico-inventarisatie. ${ }^{39}$

Het voert te ver om hier voor alle genoemde tekortkomingen in het systeem van arbozelfregulering een oplossing aan te dragen. Dit te meer, daar een goede strategie aansluit bij de diverse stadia waarin bedrijven zich kunnen bevinden ${ }^{40}$; van een pro-actief, volledig geintegreerd arbobeleid (koploperbedrijven), tot een ad hoc aanpak van incidenten en knelpunten of zelfs een weigerachtige opstelling. ${ }^{41}$ Vanuit de systeemtheorie valt te beargumenteren dat het arbeidsomstandighedenbeleid van de overheid moet aansluiten op de systeeminterne axiomata van het te reguleren systeem: zodra bedrijven door wetgeving worden gereguleerd, zien die bedrijven de wetten vanuit hun eigen perspectief. ${ }^{42}$ Als bedrijven gericht zijn op kosten-minimalisatie, zullen zij arbeidsomstandigheden vooral als kostenpost zien én allicht tot actie overgaan door financiële prikkels. Als zij zwaar hechten aan normatieve overwegingen (bijvoorbeeld gezagsgetrouwheid ${ }^{43}$ ), dan is een strategie van strengere handhaving wellicht de aangewezen methode. "A policy of self-regulation incor-

37 "Erkenning van het belang van preventie vertaalt zich [..] slechts beperkt in navenante inspanningen. In de huidige Arbowetgeving ligt de nadruk op verzuimbegeleiding. Het gegeven dat bij $73 \%$ van de bedrijven advisering over verzuimbegeleiding vrijwel het enige element van de advisering vormt en dat Arbo-diensten $80 \%$ van hun omzet daaraan ontlenen, onderstreept dit." Adviescommissie Arbeidsongeschiktheid (2001), Werk maken van arbeidsgeschiktheid, Den Haag, p. 124

38 M. Hertogh e.a. (2001), Enkeltje WAO; de gebrekkige begeleiding van werknemers met psychische klachten tijdens het eerste ziektejaar. Breukelen, Nyfer, J.R. Popma, C. van Rij en J. Hooiveld (2001). Arbodienstverlening tussen markt en medezeggenschap. Den Haag: Delwel, p. 73

39 Bosch 1997, p. 35

40 Zwetsloot 2000 , p. $392 \mathrm{ff}$

41 Zo is $16 \%$ van de werkgevers het simpelweg oneens met de stelling dat de wettelijke arbobepalingen altijd nagekomen dienen te worden. Van der Kemp 2002, p. 42

42 H. Collins (1998), Review van Ralf Rogowski en Ton Wilthagen (eds.), Reflexive Labour Law: Studies in Industrial Relations and Employment Regulation, in: The Modern Law Review Limited 1998, p. 916

43 Van der Kemp 2002, p. 42 
porates legal pluralism, which says that regulatory policy must take seriously the differences among institutions in society and their potential for self-regulation."44

Wat betreft de motivatie van de werkgever is vanuit de overheid het potentiële arsenaal aan instrumenten mijns inziens behoorlijk benut: regelgeving, financiële prikkels (vooral in het kader van de Wulbz, maar ook door bijvoorbeeld de Farbo-subsidieregeling ${ }^{45}$ ), voorlichting, financiering van onderzoek en de arbo-infrastructuur, ondersteuning van convenanten, een breed palet aan handhavingsinstrumenten. Zonder twijfel kan het allemaal beter en meer, of zou de reguleringsmix wellicht wat aangepast kunnen worden (iets vaker uitdelen van een hogere bestuurlijke boete ${ }^{46}$ ), maar in hoofdlijnen lijkt de inzet van de overheid zélf toch boven twijfel verheven in weerwil van het idee dat de overheid zich zou moeten terugtrekken. Versterking van het arbobeleid in bedrijven zelf zou dan toch vooral moeten komen doordat ook ondernemingsraden, al naar gelang de specifieke trigger van hun bestuurder, de ondernemer sterker trachten te motiveren: door te wijzen op het strategisch belang van goede arbeidsomstandigheden, door een berekening van arbokosten en baten ${ }^{47}$. of door vaker de Arbeidsinspectie in te schakelen. Hier valt tegen in te brengen dat met name de eerste twee strategieën natuurlijk wel een niveau van beleidsmatig inzicht of deskundigheid vergen dat de meeste ondernemingsraden niet blijken te hebben. en dat de Arbeidsinspectie ook nú al ingeschakeld kan wordeo maar dat de drempel voor OR-leden toch hoog is. Dit laatste bezwaar zou wellicht opgevangen kunnen worden door een actievere betrokkenheid van de vakbonden.

Aansluiting bij de systeeminterne axiomata is slechts één van de twee basisstrategieèn om tot effectieve zelfregulering te komen. De andere, wellicht cruciale kwestie is dat decentrale regulering van maatschappelijke subsystemen (zoals bedrijven) vereist dat mechanismen worden ingebouwd die het eigen verantwoordelijkheidbesef versterken - en dan met name het vermogen om op die verantwoordelijkheid te reflecteren. Het idee van interne reflexiviteit ligt, in de vorm van (Deming's) verbetercyclus, ook ten grondslag aan de diverse modellen van systematische arbozorg, zoals de OHSAS 18001 en de ILO-OSH 2001. ${ }^{48}$ Afgezien van de ILO-OSH

44 N. Gunningham en J. Rees (1997), Industry Self-Regulation: an Institutional Perspective, in: Law\&Policy. Volume 19, no.4, october 1997, p. 396

45 De regeling "Willekeurige afschrijving arbo-investeringen". een fiscale faciliteit die investeringen in gezonde productiemiddelen wil bevorderen. is ingevoerd per 1 januari 1998 (Sth. 1997.731) en inmiddels zo succesvol dat eind 2002 de subsidiekraan tijdelijk dichtgedraaid moest worden (Stcr. 2002, 220, pag. 43).

46 Vgl. Warning 2002, p. 18

47 H. Dijkman en J. Kok (2001), Geld verdienen met arbo: quickscan brengt kosten en baten in beeld, in: OR-Informatie Jg. 27, nr. 4, p. 22-26

48 ILO (2001), Guidelines on occupational safery and health management systems: ILO-OSH 200I. Geneve: ILO Daarnaast is het concept van permanente verbetering natuurlijk ook fundamenteel aan kwaliteits- en milieurorgsystemen (ISO-9000 reeks resp. ISO 14001 ). Vgl. ook het Nederlandse (5W-)model dat ten grondslag ligt aan de risico-inventarisatie en het plan van aanpak. Ministerie van Sociale Zaken en Werkgelegenheid (1997). Arbo-Informatieblad I: 'Arbo-en verzuimbeleid', Den Haag: Sdu 
2001 is in de meeste systeembenaderingen overigens weinig oog voor de formele positie van werknemersvertegenwoordiging, ${ }^{49}$ In diverse reflexief-rechtelijke bespiegelingen omtrent (zelf)regulering is het belang van medezeggenschap echter wél theoretisch op niveau gebracht. Overleg met werknemers is één van de 'discursieve structuren' die bijdragen aan een versterking van het reflexief centrum van het subsysteem 'bedrijf'. Medezeggenschap is in dit licht niet zozeer een instrument om machtsverhoudingen te neutraliseren. maar om interne reflectie te bewerkstelligen. 50

Versterking van medezeggenschap is dan ook in het belang van het bedrijf zelf. én cruciaal voor optimale arbozelfregulering. Als nu gekeken wordt naar de knelpunten in het functioneren van werknemersvertegenwoordiging in bredere zin, en dus niet alleen van de OR, dan dient een aantal verbeteringen te worden doorgevoerd: meer deskundigheid en tijd, en een meer systematische betrokkenheid van werknemers in het algemeen. Hiertoe zou ik, ter afronding van deze studie, twee ideeèn willen uitwerken.

\section{De arbocoördinator}

De meest voor de hand liggende methode om de bijdrage van medezeggenschap te versterken, is simpelweg meer scholing en meer tijd. De twee knelpunten tijdgebrek en beperkte deskundigheid hangen deels natuurlijk met elkaar samen: het gebrek aan tijd is één van de verklaringen waarom ondernemingsraden hun scholingsdagen niet opmaken, zij het niet de belangrijkste (vgl. par. 4.1.2.3). Het tijdgebrek zou nog wel op te lossen zijn door meer vrijstelling van de OR-leden, bijvoorbeeld naar het

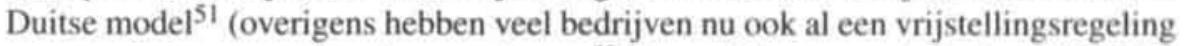
voor met name voorzitters/secretarissen). ${ }^{52}$ Het probleem van de deskundigheid is echter niet oplosbaar met tijd alleen. In paragraaf 6.4 is al aangegeven dat OR-leden slechts tot op zekere hoogte schoolbaar zijn. Met name het vermogen over te schakelen naar een meer beleidsmatig niveau is beperkt 'trainbaar'.

Een alternatief - of beter: aanvulling - kan mijns inziens gevonden worden in de verplichte aanstelling van een arbocoördinator. De figuur van de arbocoördinator is om een aantal redenen een welkome aanvulling op de bestaande driehoek werkgever-OR-arbodienst. Een eerste motief om te pleiten voor een arbocoördinator is dat interne deskundigheid meerdere voordelen heeft, die bijvoorbeeld blijken uit de betere prestaties van interne arbodiensten. Deze voordelen werden aangehaald door de Advocaat-Generaal van het Europees Hof in het geschil tussen de Europese Commissie en de Nederlandse staat over de onjuiste implementatie van artikel 7 van Kaderrichtlijn 89/391 (zie par. 2.5): interne deskundigen kennen het bedrijf van

49 Zwetsloot 2000. p. $402-403$

50 Ton Wilthagen (1992), Recht in een gesloten samenleving: het debat over reflexief recht en autopoiesis, in: Recht der werkelijkheid, jg. 13, nr.1, p. 121

51 Betriebsverfassungsgesetz $\& 38$ kent (naast een werktijdregeling in $\$ 37$ BetrVG) I fte vrijstelling toe in bedrijven met 200-500 werknemers, en 2 fte in bedrijven tussen 500-900 werknemers. Vgl. ook M. Top en J. Cremers (2003), OR-Faciliteiten bij de buren: Een Duits-Nederlandse vergelijking, Den Haag: Reed Business Information/GBIO. p. 67

52 Bruin/Huijgen 2000, p. 58 
binnenuit, hebben meer kennis van de gevaren die aan concrete bedrijfsactiviteiten verbonden zijn, zijn op de hoogte van vroegere voorvallen, en zijn permanent in het bedrijf aanwezig en dus goed aanspreekbaar door de werknemers. De aanwezigheid van arbodeskundigheid op de vloer vergroot bovendien de mogelijkheden om het personeel directer aan te spreken op het belang van veilig en gezond werken, waarbij de eventuele ongemakken daarvan niet als het gevolg van een van buitenaf opgelegde maatregel worden ervaren. ${ }^{53}$ Ook biedt de aanstelling van een arbocoördinator mijns inziens een antwoord op twee andere knelpunten in het functioneren van ondernemingsraden: gebrek aan continuitteit en ervaring. De gemiddelde 'levensduur' van een OR-lid is slechts drie à vier jaar ${ }^{54}$. Verwacht mag worden dat een arbocoördinator langer in functie zal zijn, of bij een eventueel vertrek zijn of haar ervaring meeneemt naar een nieuwe werkgever.

Een tweede, meer formeel motief is dat de aanwezigheid van interne deskundigen is voorgeschreven krachtens artikel 7 van de Kaderrichtlijn. ${ }^{55}$ Invoering van een interne deskundige, bijvoorbeeld in de vorm van een arbocoördinator, zou tegemoet komen aan deze eis. Een derde motief is dat zo een sterker accent gelegd kan worden op preventie, waar het huidige systeem van arbodienstverlening tot een scheefgroei richting verzuimbegeleiding heeft geleid. Een vierde motief, ten slotte, zou kunnen zijn dat de arbocoördinator ook belast zou kunnen worden met toezichthoudende taken en bekleed met de bevoegdheid om het werk stil te leggen in gevaarlijke situaties $^{56}$ en de Arbeidsinspectie in te schakelen - waarmee de druk niet op de schouders van de betrokken werknemers komt te liggen.

De arbocoördinator is cen figuur die in diverse Europese landen voorkomt: in België in de figuur van de preventie-adviseur (in álle bedrijven, al mag dat in bedrijven met minder dan 20 werknemers de werkgever zélf zijn, mits voldoende gekwalificeerd), in Duitsland de Sicherheitsbeauftragte (20+), en in Zweden (5+). Noorwegen (10+), Italië (15+) en Groot-Brittannië in de figuur van de safety representative (vakbondsvertegenwoordigers op de werkplek). De geschatte aantallen arbo-contactpersonen op de werkplek zijn enorm: 225.000 in Zweden, 200.000 in Groot-Brittanniè, en in Duitsland bijna 400.000 Sicherheitsbeauftragte en ruim 100.000 Fachkräfte für Arbeitssicherheit. Het is daarmee uiteraard niet gezegd dat de situatie in de genoemde landen zonder meer optimaal is. Maar hoewel er, dat dient eerlijkheidshalve opgemerkt, bij mijn weten nauwelijks serieuze studies zijn uitgevoerd naar de effectiviteit van arbodeskundigheid op de werkplek ${ }^{57}$, kan naar mijn mening toch gesteld worden dat de Nederlandse situatie mager afsteekt bij de

53 Conclusie van de Advocaat Generaal Ruiz-Jarabo Colomer van 16 januari 2003 in zaak C-441/01 (Commissie van de Europese Gemeenschappen tegen Koninkrijk der Nederlanden). Overweging $18 \mathrm{VgL}$. Ook J. Popma (2003), Het einde van de arbodienst? In: Arbo \& Milieu. Jg. 11. nr. 2

54 M. Brugmans en E. Bruin (1996), VGW-en? een vak apart!. Utrecht: GBIO. p. 2

55 Aldus ook het Europees Hof in zaak C-441/01, arrest van 22 mei 2003

56 Een bevoegdheid die in bijvoorbeeld Belgiè is toegekend aan de preventie-adviseur (art. 5. $13^{\circ}, \mathrm{KB}$ Interne Dienst Preventic en Bescherming. 27/03/1998), en in bijvoorbeeld Zweden en Noorwegen aan de 'safety representative' (Vogel 1998, p. 68 resp. 116).

57 Behalve uiteraard de al aangehaalde studies over safety representatives (bijvoorbeeld Dawson 1988). 
omringende landen. In de bouwnijverheid heeft weliswaar een groot aantal bedrijven een VCA-coördinator ( 70 procent $)^{58}$, maar in de andere bedrijfstakken is de arbocoördinator vooral een figuur in de $100+$ bedrijven. Indien nu, in navolging van Duitsland en Belgiè, bijvoorbeeld alle $20+$ bedrijven in Nederland (naar schatting $z 0^{\prime}$ n 50.000$)^{59}$ een arbocoördinator zouden aanstellen, zou dat mijns inziens de aandacht en zorg voor arbeidsomstandigheden een enorme stimulans geven - zoals ook blijkt uit de bouw (par. 6.2). Alleen al de loutere aanwezigheid van een arbocoördinator in een bedrijf dwingt werkgevers, zelfs al is het contre caur, toch aandacht te besteden aan arbozorg. Zo zal de arbocoördinator in achterlopende bedrijven de dorre grond cultiveren waarop ten minste fets van arbobewustzijn kan opbloeien - een essentiële voorwaarde voor arbobeleid.

Het idee voor veiligheidsvertegenwoordigers is overigens niet nieuw. Al in 1975 werd het geopperd in de adviesaanvraag aan de SER over het ontwerp voor de Arbowet $1980 .{ }^{60}$ In het uiteindelijke wetsvoorstel werd, op advies van de SER ${ }^{61}$. echter van het idee afgestapt en werd aangesloten bij het idee van vertegenwoordigend overleg. ${ }^{62}$ Ook in zijn advies over de wijziging van de Arbowet in 1994 hield de toenmalige Arboraad het idee van interne arbodeskundigen tegen. met name omdat de vakbeweging vreesde voor zogeheten 'arbokabouters'. Die vrees is wellicht ook niet geheel ongegrond. Zeker voor de kleinere bedrijven zou de taak van arbocoördinator waarschijnlijk een combi-functie moeten zijn. Het aantal uren dat aan arbozorg besteed kan worden is immers beperkt, en de scholingslast relatief hoog (voor een basiscursus arbocoördinator is bij de diverse opleidingsinstituten een aantal scholingsdagen van vijf redelijk standaard). Voor de allerkleinste bedrijven zouden daarom toch externe arbocoördinatoren ingehuurd kunnen worden. gedetacheerd vanuit bijvoorbeeld de branche-organisatie. Dit laatste heeft als voordeel dat de 'roving safety reps', zoals die nu in een aantal landen naar ieders tevredenheid bestaan, specifieke kennis hebben van de bedrijfsspecifieke risico's. ${ }^{63}$ In de recente adviesaanvraag aan de SER over de herinrichting van de arbodienstverlening in Nederland wordt deze mogelijkheid ook overwogen, zij het dat de staatssecretaris aangeeft dat de markt hiervoor klein is. ${ }^{64}$ Indien dergelijke branche-instituten desondanks worden opgericht, zou het met het oog op de versterking van de

\section{Databestand Arbomonitor 2001}

59 Overigens is de grens van 20+ natuurlijk tamelijk arbitrair. Denkbaar is uiteraard ook, zeker vanuit de optiek van medezeggenschap, meer aansluiting te zoeken bij de instellingsgrens voor de personeelsvertegenwoordiging ( $a r t$. 35c WOR), te weten 10 werknemers. Voor een zinvolle invulling van de functie van arbocoördinator denk ik echter dat de minimumomvang van het bedrijf toch iets groter zou moeten zijn.

60 Brief van de Minister van Sociale Zaken van 19/6/1975, in: SER (1976). Advies inzake vernieuwing van de wetgeving betreffende de gezondheid en veiligheid bij de arbeid. Den Haag: Sociaal-Economische Raad, SER 76/18, bijlage I, p. 5-6

61 SER 1976, p. 5

62 Kamerstukken II. 1976-1977, 14 497, nr. 3, p. 14

63 Ook bij de werkgevers, die aanvankelijk afwijzend stonden tegenover het initiatief, staan de regionale 'safety reps' goed aangeschreven door hun kennis en vaardigheden. D.R. Walters (2002), Working safely in small enterprises in Europe. Brussel: TUTB. p. 159

64 Adviesaanvraag "Arbodienstverlening: aansturen op vraag", 4 april 2003, p. 19-23 
positie van werknemers wenselijk zijn dat zij onder paritair bestuur vallen - zoals nu bijvoorbeeld de Stichting Arbouw en BGZ Wegvervoer.

Als taken voor de arbocoördinator zouden mijns inziens kunnen gelden:

- risico-inventarisatie en -evaluatie:

- risico-toets op bijvoorbeeld nieuwbouw en bij introductie van nieuwe technologieën;

- opstellen plan van aanpak en voortgangsrapportage;

- voorbereiden concrete arbomaatregelen;

- verzuimregistratie, analyse en rapportage;

- eventuele taken op het gebied van bedrijfsmilieuzorg;

- coördinatie van de bedrijfshulpverlening;

- secretariaat van het arbo-overleg:

- voorlichting aan werknemers (art. 8 Arbowet);

- advies over het gebruik van persoonlijke beschermingsmiddelen;

- toezicht op de werkplek;

- contact met de arbodienst indien aanvullende dienstverlening gewenst is.

Om het risico van 'arbokabouterisme' te beperken, zou naar mijn mening een aantal minimumeisen gesteld moeten worden wat betreft tijdsbesteding en scholings-

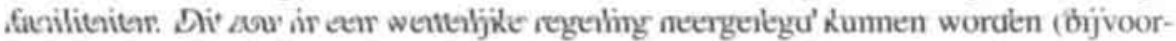
beeld in hoofdstuk 2 van het Arbobesluit), waar eventueel van afgeweken zou kunnen worden bij CAO. Sommige branches kennen nu eenmaal meer en zwaardere risico's dan andere, die daarom een hoger deskundigheidsniveau vergen. Bovendien zou het mijns inziens wenselijk zijn dat er minimumbedragen worden vastgesteld die aan werkelijk preventieve arbozorg besteed moeten worden (en niet aan verzuimbegeleiding) - dit zou bij voorkeur afgestemd kunnen worden in een $\mathrm{CAO}$ of eventueel door een landelijke heffing gekoppeld aan het WAO-percentage (eventueel per bedrijf, maar zeker voor de kleinere bedrijven per bedrijfstak). ${ }^{65}$ Een deel van de extra kosten die de introductie van de arbocoördinator met zich brengt, kan worden ingewonnen doordat de arbocoördinator een aantal taken van de arbodienst overneemt (met name op het gebied van risico-inventarisatie, planvorming en verzuimregistratie).

Punt van aandacht is nog de aanstelling van de arbocoördinator: wie stelt de coördinator aan? Artikel 7 van de Kaderrichtlijn stelt dat de (interne) deskundige wordt aangewezen door de werkgever. Dit zou, als we de stringente en in mijn ogen juiste opvattingen van Gevers ter zake volgen, echter op gespannen voet staan met het vertegenwoordigende aspect van de rol van de interne deskundige (ook de AdvocaatGeneraal wijst hierop in zijn conclusie in voornoemde zaak C-441/01): "Gezien de rechtsgoederen die in het geding zijn, ligt het voor de hand dat werknemers zelf hun vertegenwoordigers kiezen en niet dat vertegenwoordigers - al dan niet in overleg

65 J. Popma (1999), De arbovervuiler betaalt, In: TBV, tijdschrift voor bedriifs- en verzekeringsgeneeskunde, oktober 1999. p. 236-237 
met de werknemers - door de werkgever worden aangewezen." ${ }^{\text {"66 }}$ In GrootBrittannië, Italię, Zweden en Noorwegen worden de safety representatives aangewezen door de vakbond. De Belgische preventie-adviseur wordt aangesteld door de werkgever, zij het slechts met instemming van het (paritaire) Comité Preventie en Bescherming, de Sicherheitsbeauftragte na overleg met de Betriebsrat. Binnen de Nederlandse arbeidsverhoudingen lijkt het me niet denkbaar dat de arbocoördinator direct door de werknemers wordt gekozen of door de vakbond zou worden aangewezen. Wel is het evident dat de ondernemingsraad ter zake instemmingsrecht zou toekomen. In bedrijven zonder OR/pvt zou het wenselijk zijn de kwestie te bespreken in de personeelsvergadering, waarbij de vergadering adviesrecht of wellicht instemmingsrecht zou moeten hebben op grond van artikel $35 \mathrm{~b}$ WOR.

\section{Arbocoördinator, arbocommissie en arbeidsverhoudingen}

Niet alleen de aanstelling van de arbocoördinator is een kwestie van overleg en daarmee van arbeidsverhoudingen. Op een meer principieel niveau, aansluitend bij de opmerking van Gevers, is de positie van de interne arbodeskundige een arbeidsverhoudingenvraagstuk. Hoewel ik verwacht dat de introductie van de arbocoördinator binnen (meer) bedrijven een belangrijke impuls betekent voor het arbobeleid, met name door een meer professionele benadering, is het absoluut niet mijn bedoeling om de zorg voor veiligheid en gezondheid volledig in handen te leggen van professionals. Integendeel. Het voorstel voor een arbocoördinator tilt de arbozorg wellicht op een hoger beleidsmatig niveau, maar zonder solide bindingen met de werkvloer dreigt het beleid in het luchtledige te zweven. Reden waarom mijns inziens zowel organisatorisch als procesmatig ook de invloed van de werknemers versterkt zou moeten worden.

In diverse ons omringende landen is, naast de arbodeskundige op de werkplek, $606 \mathrm{k}$ samenwerking voorgeschreven tussen arbodeskundigen en werknemersvertegenwoordiging, in de vorm van een Comité Preventie en Bescherming (België: $50+$ ), een Arbeitssicherheitsausschuß (Duitsland, 20+), een Comité d'hygiène, de sécurité et de conditions de travail (Frankrijk, 50+), en safety committees (Zweden en Noorwegen: $50+$, Groot Brittannië indien twee 'safety reps' daarom vragen). In alle gevallen betreft het paritaire overlegorganen, veelal met een meerderheid aan werknemersvertegenwoordigers en de eventuele arboprofessionals als adviserend lid. Mijns inziens zou het wenselijk zijn dat ook in Nederland, althans voor de $20+$ bedrijven, aparte arbocommissies in het leven geroepen worden, met als taak onder meer periodiek overleg over (de voortgang van) het arbobeleid én het beoordelen van investeringsplannen (in het bijzonder ver-/nieuwbouw) of de introductie van nieuwe productieprocessen of -technieken. Deze taak is, zoals al is aangegeven. ook toebedeeld aan de arbocommissies in een aantal andere landen. Op dit moment wordt een dergelijke systematische preventieve toets op nieuwe ontwikkelingen

66 J.K.M. Gevers (1982), Zeggenschap van werknemers inzake gezondheid en veiligheid in bedrijven. De rechtsontwikkeling in de lidstaten van de Europese Gemeenschap. Deventer: Kluwer, p. 74 
onvoldoende serieus uitgevoerd door ondernemingsraden. ${ }^{67}$ Het advies van de arbocommissie zou vooraf meegewogen moeten worden in de OR-adviezen op grond van artikel 25 WOR. In kleine bedrijven zonder eigen arbocoördinator (maar met een gedetacheerde) zou de arbo-commissie tevens een toezichthoudende rol kunnen uitvoeren.

De arbocommissie lijkt in hoofdlijnen op de VGW(M)-commissies die veel ondernemingsraden al instellen op grond van artikel 15 WOR en die een positief effect hebben op de betrokkenheid van werknemers bij het arbobeleid (vgl. par. 4.2.6). Een verschil is dat de OR-commissies facultatief zijn. Bovendien kan de bestuurder bezwaar maken tegen de instelling van een OR-commissie (art. 15, lid 1, WOR), al gebeurt dit hoogst zelden. Opname van de arbocommissie in hoofdstuk 3 van de Arbowet maakt het mogelijk dat naleving bestuursrechtelijk wordt afgedwongen door de Arbeidsinspectie. Dit voorkomt dat de werknemers hun nek moeten uitsteken om een onwillige werkgever in het gareel te dwingen. Voor het overige zouden in ieder geval de werknemersleden van de arbocommissie voldoende gefaciliteerd moeten zijn en rechtsbescherming moeten genieten analoog aan de WOR (én artikel 7, lid 2 van de Kaderrichtlijn). De 'rekrutering' van de werknemersleden zou kunnen geschieden door periodieke verkiezingen of door aanwijzing door de OR (afvaardiging door de vakbond zoals in diverse andere landen past, vrees ik, niet binnen de Nederlandse arbeidsverhoudingen).

Overigens draagt een afzonderlijke arbocommissie het risico in zich dat de aandacht voor veiligheid en gezondheid losgetrokken wordt van de rest van het ondernemingsbeleid. Deze zorg kan organisatorisch evenwel worden ondervangen door te bepalen dat in de werknemersgeleding van de arbocommissie ten minste één OR-lid zit, of bijvoorbeeld dat de voorzitter van de commissie vanuit de OR wordt benoemd. De taak van de arbocommissie om adviesaanvragen te beoordelen op eventuele arbogevolgen versterkt zelfs de schakels tussen arbozorg en medezeggenschap. Door de instellingsgrens op 20 werknemers te stellen, wordt 'arbo' bovendien een instrument om de medezeggenschap in kleine bedrijven te versterken. ${ }^{68}$

$\mathrm{Al}$ met al is het voorstel voor een arbocommissie niet bijzonder ingrijpend, zeker niet voor de $50+$ bedrijven waarin de OR zélf al een VGW(M)-commissies heeft ingesteld. Het belangrijkste verschil is dat de arbocommissie verplicht wordt voor alle $(20+)$ bedrijven. Zoals gezegd versterkt dat de arbozeggenschap van werknemers in kleinere bedrijven. Dit is, met het oog op de grondrechtendimensie, al een waarde op zich. Daarnaast blijkt uit deze studie dat, ondanks alle tekortkomingen. de arbozorg toch profiteert van serieuze medezeggenschap. Daarmee wordt het in paragraaf 7.2 aangestipte probleem van de dreigende rechtsongelijkheid ten dele gemitigeend.

67 Al bij de introductie van de arbo-commissie in de Arbowet 1980 werd de verplichting van de commissie om de werkgever te adviseren in plaats van het recht zoals de OR dat heeft, gezien als een duidelijk pluspunt. A.J.C.M. Geers (1988), Recht en humanisering van de arbeid. Deventer: Kluwer, p. 182-183

68 De instellingsgrens van 20 (vergelijkbaar met Duitsland) is tamelijk arbitrair. Analoog aan art. 35e WOR zou de instellingsgrens natuurlijk ook $10+$ kunnen zijn. waarmee alle $10+$ bedrijven de facto verplicht een personeelsvertegenwoordiging dienen in te stellen. 


\section{Risico-inventarisatie}

Een laatste, meer procesmatig voorstel om de zeggenschap van werknemers over hun eigen veiligheid en gezondheid te vergroten, betreft de betrokkenheid van werknemers bij de uitvoering van de risico-inventarisatie - zowel direct door de werknemers zélf als indirect door hun vertegenwoordigers in de arbocommissie. Dit idee heeft zowel een effectiviteits- als een arbeidsverhoudingendimensic. De eerste dimensie hangt samen met het organisatiekundig inzicht dat effectief (arbo-)management optimaal gebruik maakt van de input van 'de vloer', van de 'expert-knowledge of the workshop' 69 Waar lopen werknemers in hun dagelijks werk tegen aan, welke mogelijke oplossingen zien zij voor gesignaleerde risico's, en welke door deskundigen uitgedachte preventieve maatregelen zijn praktisch wél of niet uitvoerbaar? Eerder al is aangegeven dat met name de inventarisatie van 'onzichtbare' risico's als werkdruk, cultuuraspecten en dergelijke dient aan te sluiten op de subjectief ervaren risico's. Het is voor een volledig beeld én voor het draagvlak voor het beleid cruciaal dat die subjectieve beleving serieus wordt meegewogen. ${ }^{70}$ Wat kruidiger uitgedrukt: "unless the workers who are to benefit from the process influence the local defintions of OHS goals, OHS [management] may instead become a sham, in which employers unilaterally manage OHS."71

Theoretisch valt te verwachten dat de werknemers minder geneigd zullen zijn hun grieven te spuien tegenover een afgevaardigde van de werkgever, zoals de arbocoördinator of eventueel een deskundige van de arbodienst. $\mathrm{Al}$ in het eerste kwart van de twintigste eeuw werd dit ingezien - reden waarom de Arbeidsinspectie 'ontwikkelde arbeiders' inschakelde als 'controleur van den arbeid", "die eerder het vertrouwen zouden hebben van hun klassegenooten." 72 Ook in de casestudies werd door sommige respondenten gewag gemaakt van de praktische meerwaarde van het 'meelopen' door OR-leden tijdens een rondgang door het bedrijf. Deze meerwaarde zou gesystematiseerd kunnen worden door een uitvoerende betrokkenheid van de werknemersvertegenwoordigers uit de arbocommissie bij het proces van risicoinventarisatie en -evaluatie. In weerwil van het verlangen om medezeggenschap op een allengs hoger beleidsniveau te tillen, schuilt de toegevoegde waarde van werknemersvertegenwoordiging op het gebied van arbeidsomstandigheden immers juist in de kennis van de werkvloer (vgl. par. 4.1.5), níet in het beleidsmatig denken. Het is zaak deze meerwaarde van de arbomedezeggenschap te versterken. Het toewijzen van een specifieke taak aan een duidelijk identificeerbare uitvoerder vergroot

69 W. Buitelaar (1989), Participation in the management of occupational health and safety improvement: workers 'imvestigation as active risk analysis. Apeldoorn: TNO-STB, p. 15

$70 \mathrm{Vgl}$. ook L. Vogel (1993). Prevention at the Workplace; An initial review of how the 1989 Community framework Directive is being implemented, Brussel: TUTB, p. 26

71 K. Frick en J. Wren (2000), Reviewing Occupational Healt and Safety Management, in: K. Frick et al. (eds.). Systematic Occupational Health and Safety Management. Amsterdam/Oxford: Pergamon, p. 40

72 J.J. Camminga (1934). lets over de taak van de Controleurs van den Arbeid, in: H.A. van Usselsteyn (1934), Gedenkboek naar aanleiding van het feit dat 25 jaar geleden de Arbeidsinspectie gesteld werd onder leiding wan den Directeur-Generaal van den Arbeid, Groningen: J.B. Wolters, p. 59 
bovendien de kans dat de risico-inventarisatie daadwerkelijk wordt uitgevoerd; dit is immers nog steeds niet in alle bedrijven het geval en zeker niet als jaarlijkse routine. Belangrijk is daarnaast het al aangehaalde punt dat bij betrokkenheid van de werknemersvertegenwoordigers meer ruimte zal ontstaan voor de non-expert inschatting van risico's. "If only for epistemological reasons we may not assume that such a thing as risk exists, and that it is only a matter of discovering and investigating it." 73 De inventarisatie van risico's, maar zeker ook de evaluatie van de risico's die uit de rondgang naar voren komen, wordt daarmee ingebed in de arbeidsverhoudingen binnen het bedrijf. Een laatste, in mijn ogen bepaald niet onbelangrijk motief voor intensieve betrokkenheid van de werknemersvertegenwoordigers bij het proces van risico-inventarisatie zou nog zijn dat, juist door duidelijk zichtbaar te zijn op de werkvloer, het contact met de achterban wordt versterkt. ${ }^{74}$ Daarmee wordt 'arbo' een thema waarmee de arbeidsverhoudingen op bedrijfsniveau nieuw elan krijgen. Wellicht zelfs blaast de aandacht voor veilige en gezonde arbeidsomstandigheden het revolutionaire vuur nieuw leven in; dit vuur wakkerde eind negentiende eeuw, mede onder invloed van de enquêtes van de vakbonden ${ }^{75}$, aan bij het verlangen naar menswaardige arbeid.

73 N. Luhmann (1993), Risk: A sociological theory, Berlin/New York: De Gruyter, p. 6

74 De ervaringen met bijvoorbeeld de 'Arboman van de week' of de busploegen in de bouw zijn op dit punt hoopgevende voorbeelden.

75 W. Buitelaar en R. Vreeman (1985), Vakbondswerk en kwaliteir van de arbeid, Nijmegen: SUN. p. 39ff. De vakbonden zouden hierin mijns inziens ook vaker het initiatief moeten nemen. en dan niet door grootschalige maar gezichtsloze telefonische enquêtes onder werknemers, maar door enquêtes op de werkplek te initiëren. 


\section{Literatuur}

Aalders, M. en T. Wilthagen (1994), Onderhandelend bestuur en de regulering van arbo- en milieuzorg: ontwikkelingen, parallellen en toekomst, in: H.D. Stout en A.J. Hoekema (red.), Onderhandelend bestuar. Zwolle: H.D. Tjeenk Willink, p. 115-150

Aalders, M. en T. Wilthagen (1997), Moving beyond Command-and-Control: Reflexivity in the Regulation of Occupational Safety and Health and the Environment, in: Lawd Aolicy, Volume 19. no, 4, october 1997, p. 415-443

Abel. R.L (1985), Risk as an Arena of Struggle, in: Michigan Law Review, 83, p. 773-812

ACV (2000), Opdrachten en beroegdheden wan het Comite voor Preventie en Bescherming op het werk. de Ondernemingsnad en de vakbondsafivaanliging. Brussel: ACV

Adviescommissie Arbeidsongeschiktheid (2001), Werk maken van arbeidsgeschiktheid, Den Haag

Albeda. W. W.J. Dercksen en F.H. Tros (1998), Arbeidsverhoudingen in Nederland, Alphen a/d Rijn: Samsom, zesde druk

Algra. M. (1989). "Wie zwijgt, wordt niet gehoond"; Geschiedenis van de medezgxensichap in Nederland, Den Haag: Deiwel

Arbeidsinspectie (1910), Eenige gegevens omtrent werktijden in de industrieele bedrijven, Den Haag: Departement van Landbouw, Nijverheid en Handel

Ashford, N. en C.C. Caldart (1991), Technology, Law and the Working Emvinonment, New York: Van Nostrand Reinhold

Axelos, K. (1962), Héraclite et la philosophie, Paris: Minuit

Ayres, I. en J. Braithwate (1992), Responsive Regulation: Transcending the Deregulation Debate, New York/Oxford: Oxford Socio-Legal Studies

Bader, V.M. en A. Benschop (1988), Ongelijkheden: pro-theorie van sociale ongelijkheid en collectief handelen, Wolters-Noordhoff: Groningen

Bader, V.M. (1991), Collectief handelen, Wolters-Noordhoff: Groningen

Bakels, H.L. (2000), Schets van het arbeidsrecht, Deventer: Kluwer, I6e druk

Bal. R.A. en C.J.J.M. Stolker (1997), Dereguleren in Arbo-land: Een heroriëntatie op de Arbeidsomstandighedenwet, in: NIB, jg. 72, p. $969-975$

Bal, R.A. (1998) Grenzenwerk - Over het organiseren van normstelling voor de arbeidsplek, Enschede: Twente University Press

Beck, M. en C. Woolfson (2000), The Regulation of Health and Safety in Britain: From Old Labour to New Labour, in: Industrial Relations Journal, vol. 31-1, p. 35-50

Beck, U. (1986), Risikogesellschaft: auf dem Weg in eine andere Moderne, Frankfurt am Main: Suhrkamp

Bekkers, V.J.J.M. (1996). De schutkleuren van het dereguleringsbeleid, in: R.A.J. van Gestel en Ph. Eijlander (red), Markt en wet. Deventer: W.E.J. Tjeenk Willink

Berg. A. van den (1999), De vakbeweging, 1907-1997, in: R. van der Bie en P. Dehing (red.). Nationaal Goed: Feiten en cilfers over onze samenleving (ca.) 1800-1999, Voorburg/Heerlen: CBS

Biemans, W.G. (1994), Case research voor bedrijfskundig onderzoek, in: Bedrijfskunde, 66, p. 51-56 cn p. $95-104$

Bier, L. (1988), Aansprakelijkheid voor bedrijfsongevallen en beroepsziekten: de civielrechtelijke aansprakelijkheid voor de aan de arbeid gerelateerde persoonsschade, Deventer: Kluwer

Bles, A.E (1907-1909), De Wet op de arbeidsovereenkomst, Den Haag: Belinfante, 4 delen

Boer. J.R., P. Diehl en H. Koenders (2001), Handleiding Arbozorg. Alphen a/d Rijn: Samsom

Boix, P. en L. Vogel (1999). Risk assessment at the workplace: a guide for action, Brussel: TUTB

Bolwijn P. T. en T. Kumpe (1998), Marktgericht ondernemen management van continutieit en vernieuwing, Assen: Van Gorcum, vierde druk 
Boonstra, J.J. (1992) Integrale organisatie-ontwikkeling: vormgeving van fundamentele veranderingsprocessen, Utrecht: Lemma, tweede druk

Bosch, L.H.M. en E.T.M. te Brake (1995), Netwerkgerichte aanpak op het gebied van fysieke belasting en stress, Den Haag: VUGA

Bosch. L.H.M. en J.M.P. de Kok (1997), Arbeidsomstandigheden en bedriifsgrootte: Een verkenning met de LISREL-methode, Zoetermeer: EIM

Bottenburg. M. van (1995). Aan den Arbeid!': in de wandelgangen van de Stichting van de Arbeid, 1945. 1995, Amsterdam: Bert Bakker

Bouw- \& Houtbond FNV (1998). Nul is genoeg. Woerden: FNV Bouw

Bouw- en houtbond FNV (1999), Alles onder controle: Werken zonder stress, Woerden: FNV Bouw, Arbowijzer 14

Broeder. A. den (1995), Arbeidsrisico's, bescherming en rechtssociologie, in: P. de Jong et al. (red). Arbeid, recht en risico, Amsterdam: Siswo

Bröring. H.E. (1993), Richtlijnen: Over de juridische betekenis van circulaires, leidraden, aanbevelingen, brochures, plannen, Deventer: Kluwer

Brouwers, A.A.F., F. Vaas, en F.D. Pot (1987), Sociaal Inventief Automatiseren: integratie van arbeid en techniek in de ontwerpfase. Amsterdam: FNV Steunpunt Technologie

Brown, M. en S. Ainsworth (2000), A review and integration of research on employee participation in Australia 1983-1999, Melbourne:

Bruggeman, J. en A. Camijn (1999), Ondermemers verbonden: 100 jaar centrale ondernemingsorganisaties in Nederland, Den Haag: VNO/NCW

Brugmans, 1.J. (1925), De arbeidende klasse in Nederland in de negentiende eeuw 1813-1870, 11 de druk (1978) Utrecht: Spectrum

Brugmans, M. en E. Bruin (1996), VGW-en? Een vak apart!, Utrecht: GBIO

Bruin. E. en F. Huijgen (2000). Naleving van de Wet op de Ondernemingsraden: Stand van zaken begin 2000. Den Haag: Elsevier/SZW

Bruin, E. en H. van den Tillaart (2002). Meetbaarheid van de naleving van de WOR, in: J. Cremers en J. van der Hoek, Een deskundige OR werkt beter. Den Haag: Elsevier/GBIO, p. 37-50

Brummelen. Y, van en J.P. van den Toren (1998), Medezeggenschap: een hele onderneming. Utrecht: CNV

Buitelaar, W. en R. Vreeman (1985), Vakbondswerk en kwaliteit van de arbeid, Nijmegen: SUN

Buitelaar, W. (1989), Participation in the management of occupational health and safery improvement: workers 'investigation as active risk analysis, Apeldoorn: TNO-STB

Buitelaar. W. (1993), Bedrijfsorganisatie en arbeidsverhoudingen, Amsterdam: Amsterdam University Press

Bus, J. (1996), Je hersens op een nachtkastje. Woerden: Bouw- \& Houtbond FNV

Bus, J. en J. Popma (2000), Beschadigd bestaan: een boekje open over benoepsziekten. Amsterdam: FNV Bureau Beroepsziekten

Camminga. J.J. (1934). lets over de taak van de Controleurs van den Arbeid, in: H.A. van Usselsteyn. Gedenkboek naar aanleiding van het feit dat 25 jaar geleden de Arbeidsinspectie gesteld werd onder leiding van den Directeur-Generaal van den Arbeid. Groningen: J.B. Wolters

CBS (1999), Statistisch bulletin 1999/17, Voorburg/Heerlen: Centraal Bureau voor de Statistiek

CBS (2001). Tweehondend jaar statistiek in tijdreeksen, 1800-1999. Voorburg/Heerlen: Centraal Bureau voor de Statistiek

CBS (2002). INDEX, feiten en cijfers over onze samenleving, no. 10 - december 2002

CBS (2003-a), Sociaal-economische Maandstatistiek, Voorburg/Heerlen: Centraal Bureau voor de Statistiek, januari 2003

CBS (2003-b). Statistisch bulletin 2003/12. Voorburg/Heerlen: Central Bureau voor de Statistiek

CBS/SZW (1998). Arbeidsomstandigheden 1998: monitoring via personen, Den Haag/Voorburg Elsevier

CBS/SZW (2000), Arbeidsomstandigheden 2000: monitoring via personen. Den Haag/Voorburg: Elsevier

CBS/SZW (2001), Arbeidsomstandigheden 2001: monitoring via personen. Den Haag/Voorburg: Elsevier

Chang. R.Y. (1997), Benchmarking: vergelijk en verbeter. Zaltbommel: Thema

Christis, J. (1998), Arbeid, organisatie en stress: Een visie vamuit de sociotechnische arbeids-en organisarickunde. Amsterdam. Het Spinhuis,

Clegg. S.R. (ed) (1990), Organization Theory and Class Analysis: New Appmaches and New Issues. New York/Berlin: De Gruyter 
Collins, H. (1998-a), Review of Ralf Rogowski and Ton Wilthagen (eds,), Reflexive Labour Law: Studies in Industrial Relations and Employment Regulation, in: The Modem Law Review Limited,1998

Collins, H. (1998-b). Flexibility and empowerment, in: A.C.J.M. Wilthagen (ed.), Adwancing Theory in Labour Law and Industrial Relations in a Global Contex. Amsterdam/New York/Oxford/Tokio. North-Holland, p. 117-129

Commissie voor de Toetsing van Wetgevingsprojecten (1994), Van Keursliff naar Keurmerk: Wergevingsbeleid voor veilig en gezond werk. Den Haag: Ministerie van Justitic. CTW 94/12

Corten, I.W. (2002), Bouw verliest groot deel van jonge arbeidskrachten aan andere bedrijfstakken, in Botw/Werk 2002/3

Cremer, J.J. (1988), Fabriekskinderen: een bede maar niet om geld, Schoorl: Conserve (tweede druk)

Cruchten. J. van en R. Kuijpers (2002), Organisatiegraad van werknemers daalt in de periode 1995 . 2000, in: Sociaal-Economische Maandstatistiek 2002/9

Cruchten, J, van en R. Kuijpers (2003). Organisatiegraad van werknemers 2001, in: SociaalEconomische Maandstatistiek 2003/3

Ctsv (1999), Augusfusrapportage arbeidsongeschiktheidsverzekeringen 1999, Zoctermeer

Dawson, S., P. Willman, A. Clinton en M. Bamford (1988), Safery at work: The limits of self-regulation. Cambridge: Cambridge Univ. Press

Dekkers, H., P. T. Calkoen en J.H.T.H. Andriessen (1989), Medezegeenschap in middelgrote ondernemingen. Tilburg: IVA

Delvaux, G. et al. (1987), Honderd jaar sociaal recht in Belgię, Brussel: Ministerie voor Tewerkstelling en Arbeid

Deursen. C.G.L. van en S. van Binnendijk (2001), Arbeidsrisico's, gezondheidsklachten en ziekteverzuim binnen branches, Den Haag: Ministerie van Sociale Zaken en Werkgelegenheid

Deursen, C.G.L. van, A.H. Reuling en T.J. Veerman (2000), SZW-werkgeverspanel 1998-1999, Den Haag: Ministerie van Sociale Zaken en Werkgelegenheid/Elsevier

Dhondt. S. en I. Houtman (1998), Indicators of Working Conditions in the Eumpean Union, Dublin: European Foundation for the Improvement of Living and Working Conditions

Dijkman, H. en J, Kok (2001), Geld verdienen met arbo: quickscan brengt kosten en baten in beeld, in: OR-Informatie jg. $27, \mathrm{nr} .4$

Drongelen, J. van (1990), De onfwikkeling van de Arbeidsinspectie in een veranderende wetgeving. Maastricht: Universiteit Maastricht (diss.)

Drongelen, J. van (1998), De Arbeidstijdenwet en de personeelsvertegenwoordiging in 1997, in: Arbeid Integraal, mei 1998, p. 55-59

Dungen, J.J.M. van den en R.K.J.M. Latten (2001), Medezeggenschap verzekerd? Ondermemingsraden binnen verzekeringsmaatschappijen onderzocht. Nijmegen: KUN

Ehn, P. en M. Kyng (1991), De 'Collective Resource Approach'; Een Scandinavische werknemersaanpak van systeemontwerp, in: M. van Klaveren en S. Kooistra (1991), Sociaal Ontwerpen: Werknemers beimvloeden vormgeving en organisatie van hun werk, Utrecht: Jan Van Arkel

EIB (2002), Het ziekteverzuim in de bouwnijverheid in 2001, Amsterdam: Economisch Instituut voor de Bouw

Eijlander, Ph. (1990), Wetgeving en zelfregulering, in: H.A.M. Backx et al. (1990), Recht doen door wetgeving. Zwolle: W.E.J. Tjeenk Willink

Eijlander. Ph. (1993), De wet stellen: Beschouwingen over onderwerpen van wetgeving. Zwolle: W.E.J. Tjeenk Willink

Eijlander, Ph., P. C. Gilhuis en J.A.F. Peters (red) (1993), Overheid en zelfregulering: Alibi voor vrijblijvendheid of prikkel tot aktie?. Zwolle: W.E.J. Tjeenk Willink

EIM (2002), Kleinschalig Ondernemen 2002: Structuur en ontwikkeling van het Nederlandse MKB. Zoetermeer: EIM

Engelen. E. (2000), Economisch burgerschap in de onderneming: Een oefening in concreet utopisme, Amsterdam: Thela Thesis

Engelen, E. (2002). Burgerschap op de werkvloer: De institutionele condities voor post-taylorisering in Nederland, in: R. Batenburg et al. (red.). Met het oog op de toekomst van de arbeid, Den Haag; Elsevier

Engelen, M.. M. van der Aalst en E. Hornstra (2001), Naleving van de Wet op de Ondernemingsraden. Stand van zaken begin 2000 . Elsevier/SZW

Engels, F. (1890), Brief an J. Bloch. 21.9.1890. MEW Band 37

European Agency (1997), Priorities and strategies in occupational safery and health policy. Bilbao: European Agency for Safety and Health at Work

Evers, G.E. en F.A. Reijenga (1998), Als het maar geen arbozorg heet ..... besordering van arbozorg in het MKB, Hoofddorp: NIA TNO 
Evers, G.J.M. (2002), Blind vertmouwen? Een onderzoek naar de toepassing van certificatie ten dienste van de handhaving van wettelijke voorschriften, Tilburg: Schoordijk Instituut

Fase, M.M.G., en L.M. Keijzer (1991), Ziekteverzuim en conjunctuur, in: Economisch-statistische berichten, jg. 76, nr. 3083, p. 372-375

Feenstra, P. W. (1998), Aspecten van arbeidsomstandigheden in cao's, Den Haag: Arbeidsinspectie

Feijen, T. c.a. (1994). Arbeidsomstandigheden, arbo-zorg en VGW-scholing: een imventarisatie van scholingsbehoefien, Utrecht: GBIO

Filoche, G. (2001) Vingt ans de comités d'hygiène et sécurité et des conditions de travail, Paris: CES, Journaux Officiels, 12 novembre 2001

Fluit, P. (2001), Verzekeringen van solidariteit, Kluwer: Deventer

FNV (1995), OR en arbodienst: contacten over contracten. Amsterdam: FNV

FNV (1998-a), Brief aan Vaste Commissie voor Sociale Zaken en Werkgelegenheid, Amsterdam, 19-031998

FNV (1998-b), Brief aan Vaste Commissie voor Sociale Zaken en Werkgelegenheid, Amsterdam, 27-081998

Foucault, M. (198I), Nietzsche, de genealogie, de geschiedschrijving, in: M. Foucalt/G. Deleuze (198I). Nietzsche als genealoog en nomade, Nijmegen: SUN

Frick, K. en J. Wren (2000), Reviewing Occupational Healt and Safety Management, in: K. Frick et al. (eds.), Systematic Occupational Health and Safery Management, Amsterdam/Oxford: Pergamon, p. $17-42$

Frings-Dresen, M.H.W. (1998), Ontstaan en preventie van arbeidsgebonden aandoeningen, Amsterdam: oratie Universiteit van Amsterdam

Frissen, P. H.A. (1990), Besturingsconcepties, recht en wetgeving, in: H.A.M. Backx et al., Recht doen door wetgeving, Zwolle: W.E.J. Tjeenk Willink

Gaupset, S. (2000), The Norwegian Internal Control Reform - an unrealized potential, in: K. Frick et al., (eds.), Systematic Occupational Health and Safety Management, Amsterdam/Oxford: Pergamon, p. 329.350

Geelhoed, L.A. (1986), Deregulering en de grote operaties: Achtergronden en vooruitzichten, in: F.K.M. van Nispen en D.P. Noordhoek (red.). De gnote operaties: De overheid onder het mes of snijden in eigen vlees, Deventer: Kluwer

Geelhoed, L.A. (1993), Deregulering, herregulering en zelfregulering, in: Ph. Eijlander, e.a. Overheid en zelfregulering: Alibi voor vrijblijvendheid of prikkel tot aktie?, Zwolle: W.E.J. Tjeenk Willink

Geers, A.J.C.M. (1988), Recht en humanisering van de arbeid, Deventer: Kluwer

Geers, A.J.C.M. (2000-a), Arbeids(omstandigheden)recht van en in de onderneming, in: C.J. Loonstra (red.). De ondermeming en het arbeidsrecht in de 2le eeuw: Liber amicorum voor prof.mr. F.Koning, Den Haag: Boom, p. 173-189

Geers, A.J.C.M. (2000-b), Klagen, in: OR-Informatie jg. 26, nr. 4, p. 9

Geers, A.J.C.M. (2000-c). Een bekoelde relatie? Nederiand en het Europees arbeidsomstandighedenrecht, in: Sociaal Maandblad Arbeid, jg. 55, nr.7/8

Geers, A.J.C.M. en G.J.J. Heerma van Voss (1995), Inleiding Europees Arbeidsrecht, Deventer: Kluwer

Geers, A.J.C.M. en J.H. Kwantes (1992), Veilig en wel: De Arbeidsomstandighedenwet en de rol van de $O R$. Alphen a/d Rijn: Samsom (3 e druk)

Geers, A.J.C.M. en J.R. Popma (1998), Voorstel Arbeidsomstandighedenwet 1998, in: Sociaal Maandblad Arbeid, jg. 53, nr. 6

Geers, A.J.C.M. en J.R. Popma (1999), Arbowet 1998 niet millenniumproof, in: Sociaal Maandblad Arbeid, jg. 54, nr. 5

Genabeek, J, van (1998), Fabrieks- en bedrijfstakfondsen 1890-1950', in: Jacques van Gerwen en Marco H.D. van Leeuwen. Studies over zekerheidsarnangementen. Risico's, risicobestrijding en verzekeringen in Nederland vanaf de Middeleeuwen, Amsterdam/Den Haag: NEHA

Genn, H. (1993). Business Responses to the Regulation of Health and Safety in England, in: LawdEAlicy, Volume 15, p. 219-233

Genn, H. (1998), Great Expectations: The Robens Legacy and Employer Self Regulation, Paper presented to the Symposium of the British Factory Inspectorate. Universiteit van Amsterdam, 26/04/1988

Gestel, R.A.J, van en J.M. Verschuuren (1997), Artikel 21 Grondwet en zelfregulering in het milieurecht. In: Kummeling. H.R.B.M. en S.C. van Bijsterveld, Grondrechten en selfregulering, Deventer: W.E.J. Tjeenk Willink

Gestel, R.A.J, van, en Ph. Eijlander (red. 1996), Markt en wet, Deventer. W.E.J. Tjeenk Willink

Gevers, J.K.M. (1982), Zeggenschap van werknemers inzake gezondheid en veiligheid in bedrijven. De rechtsonhwikkeling in de lidstaten van de Europese Gemeenschap. Deventer: Kluwer

Giddens, A. (1984). The constinution of society. Cambridge: Polity Press 
Giddens, A. (1993), New rules of sociological method, Cambridge, Polity Press

Giele, J. (1981), Een kwaad leven: de arbeidersenquête van 1887, Nijmegen: Link

Gier, H.G. de (1991), Arbeidsomstandighedenrecht in Eumopees perspectief, Deventer: Kluwer

Gier, H.G. de en A.J.C.M. Geers (1994), Arbeidsverhoudingen en kwaliteit in ondermemingen, Alphen add Rijn: Samsom H.D. Tjeenk Willink

Gier, H.G. de en C. Vos (1995), Europese en Nederlandse arbonegelgeving, Lemma: Utrecht

Goeman Borgesius, H. (1897), De Veiligheidswet, Sneek: Van Druten

Goodijk. R. (1993), Op weg naar een professionele ondernemingsraod?, Assen: Van Gorcum

Goodijk. R. (1995), Ondermemingsnaad en strategische beleidsworming: de meenwande van de onder. nemingsraad in veranderende organisaties, Assen: Van Gorcum

Gray, W.B. en J.T. Scholz (1993), Does Regulatory Enforcement Work? A Panel Analysis of OSHA Enforcement, in: Law \& Sociery Review, 1. p. 177-213

Gunningham. N. en Rees, J. (1997), Industry Self-Regulation: an Institutional Perspective, in: LawdPolicy, Vol. 19, no.4, october 1997, p. 363-414

Hacke, A.H.W. (1931), De sociaal-economische beteekenis der Arbeidswet (19/9), Groningen: Wolters

Hacke, A.H.W. (1940), "Een greep uit het vele": Gedenkboek ter herinnering van het viftigjarig bestaan van de Arbeidsinspectie, Groningen: Wolters,

Haren, I.A.C. van (1991), De medezeggenschap van de werknemers in het arbeidsomstandighedenrecht. in: Geers, A.J.C.M. (red), Schets arbeidsomstandighedennecht, Deventer: Kluwer

Harmsen, G. cn B. Reinalda (1975), Woor de bevrijding wan de arbeid: beknopte geschiedenis van de Nederlandse vakbeweging, Nijmegen: Sun

Hassard, J. en M. Parker (1994), Towands a New Theory of Organizations, London: Routledge

Havinga. T., (1995) Grenzen aan de regulering van ondernemingen, in: Jong. P. de et al. (red)., Arbeid. recht en risico, Amsterdam: Siswo

Heerma van Voss, G.J.J. (1996), Van onmondige arbeid tot calculerende burger: Het mensbeeld in het arbeidsomstandighedenrecht 1946-1996, in: C.J. Loonstra, H.W.M.A. Staal en W. Zeijlstra (red.), Arbeidsrecht en mensbeeld 1946-1996

Heerma van Voss, G.J.J. (2000) Geheimhouding en Arbeidsinspectic, in: OR-Informatie. jg. 26, nr. I. p. 13

Heerma van Voss, L. (1994), De doodsklok van den goeden ouden tijd, Amsterdam: IISG

Heertum-Lemmen, A.H. van en A.C.J.M. Wilthagen (1996), De doonwerking van aanbevelingen van de Stichting van de Arbeid. Den Haag: Sdu

Hees, B. van (1993), Bedrijfsmatige effecten van vakbonden en ondernemingsraden, Leuven/Apeldoorn: Garant

Heijden, P. F. van der (1993), Postindustrieel arbeidsrecht. In: Nederlands Juristen Blad, Jaargang 68 , p. $297-303$

Heijden, P. F. van der en J, van der Hulst (1995), OR en rechtspositie, Alphen a/d Rijn: Samsom

Heijden. P. F. van der (1997-a), Ongelijkheden in beweging, in: L. Betten et al. (red), Ongelijkheidscompensatie als roode draad in het recht: Liber amicorum voor M.G. Rood, Deventer, Kluwer

Heijden. P. F. van der (1997-b), Een nieuwe rechtsorde van de arbeid: op zoek naar een andere architectuur van het arbeidsrecht. In: Nederlands Juristen Blad, Jaargang 72, p. 1837-1844

Herf, J. (1986), Reactionary modernism; Technology, culture and politics in Weimar and the Thind Reich. Cambridge University Press

Hertog. F. den en E. van Sluijs (1995), Onderzoek in organisaties; een methodologische reisgids, Assen: Van Gorcum

Hertogh. M. e.a. (2001), Enkeltje WAO; de gebrekkige begeleiding wan werknemers met psychische klachten tijdens het eerste ziektejaar, Breukelen: Nyfer

Heus, P. de, R. van der Leeden en B. Gazendam (1995), Toegepaste data-analyse; Technieken voor nietexperimenteel onderzoek in de sociale wetenschappen. Utrecht: Lemma

Hoed, A. den (1991). Het complement der industrialisering, in: Binneveld, H. (red)., Een zaak van vertrouwen: Arbeidsinspectie 1890-1990, Den Haag: Sdu

Homan, Th.H. (1995), Medezeggenschap in gedecentraliseerde organisaties. In: Holland Management Review, nr.41.

Hooiveld, J. (1996), Arbosterrengids: Handleiding voor beoondeling medezeggenschap en arbodienst, Amsterdam: FNV Centrum Ondernemingsraden

Hooiveld, J. en G. Kuiperij (1999), Arboprof: Arbosternengids 2000, Amsterdam/Zeist: FNV/Kerckebosch

Hoonakker, P. en J.C, van Duivenbooden (2002), De Arbouw-Monitor: Analyses op de PBGO-bestanden 1989/1990, 1993/1994, 1995/1996, 1997/1998, 1999/2000, Amsterdam: Stichting Arbouw 
Houtman, 1.L.D. et al, (1994), Evaluatie van de monitor-studie naar stress en fysieke belasting. Leiden: TNO-PG

Hövels, B.W.M. en P. Nas (1976), Ondernemingsraden en medezeggenschap: een vergelijkend onder. zoek naar struktuur en werkwijze van ondernemingsraden, Alphen a/d Rijn: Samsom

Hox, J.J. en E.D. de Leeuw (1993), Nonrespons bij schriftelijke vragenlijsten, telefonische interviews en face-to-face interviews, in: Kwantitatieve methoden, jg. 14, nr.43, p. $59-79$

Huijgen, F. en Benders J. (1998), Het vallende kwartje: Directe participatie in Nederland en Europa, in: Tijdschrift voor arbeidsvraagstukken, jaargang 14, nr. 2, p. 113-127

Huls, N.J.H. e.a. (1992), Sturing in de risicomaatschappij, Zwolle: W.E.J. Tjeenk Willink

Huls, N.J.H. (1997), De verburgerlijking van het sociaal recht, in: L. Betten et al. (red), Ongelijk. heidscompensatic als noode draad in het recht: Liber amicorum voor M.G. Rood, Deventer. Kluwer

Huppes, G., K.J. Peereboom en K.B.J. Schreibers (1996), RSI bij Beeldschermwerk. Woerden: FNV Dienstenbond

Hutjes, J.M. en J.A. van Buuren (1992), De gevalsshudie: strategie van kwalitatief onderzoek, Meppel: Boom

Huurne, A.G. ter et al. (1997), ZARA-werkgeverspanel rupportage 1996-1997, Den Haag: Ministerie van Sociale Zaken en Werkgelegenheid

Hyman, R. (1998), Industrial Relations in Europe: Crisis or Reconstruction?, in: A.C.J.M. Wilthagen. (ed.). Advancing Theory in Labour Law and Industrial Relations in a Global Context. Amsterdam/New York/Oxford/Tokio: North-Holland

ILO (2001), Guidelines on occupational safery and health management systems: ILO-OSH 200I, Geneve: IL.O

Iwema, A.M. en F. Verbakel (1994), Belasting en belastbaarheid van ondernemingsraden, Den Haag. VUGA

Jacobs, A.T.J.M. (1997), Kleine Mythologie van de ongelijkheidscompensatie, in: L. Betten et al. (red), Ongelijkheidscompensatie als node draad in het rech: Liber amicorum voor M.G. Rood. Deventer. Kluwer

Janse de Jonge. E.J. (1997), Gescheiden werelden? Een beschouwing over de ontwikkeling in het denken over grondrechten en zelfregulering, in: Kummeling, H.R.B.M. en S.C, van Bijsterveld. Ginulrechten en zelfregulering, Deventer: W.E.J. Tjeenk Willink, p. 11-29

Jaspers, A.Ph.C.M (2000), Meer respect voor grondrechten van werknemers: internationaal erkenning van dat respect? in: Jaspers. A.Ph.C.M et al (2000), Meer respect voor grondrechten van werknemers. Amsterdam: FNV, p. 17-33

P. de Jong, et al. (1995), Arbeid, recht en risico: beweging in de regulering van arbeidsomstandigheden. in: P. de Jong, et al. (red.), Arbeid, recht en risico. Amsterdam: Siswo

Kaar. R.H. van het (red.), De ondernemingsraad (losbladig), Deventer: Kluwer

Kaar, R.H. van het en J.C. Looise (red.) (I999), De volwassen OR: Groei en grenzen van de Nederlandse ondernemingsraad, Alphen a/d Rijn: Samsom

Kaar, R.H. van het, R. Knegt en M, van Velzen (1998), De rechtspositie van OR-leden en de effectiviteil van de SER-aanbevelingen terake, Den Haag. VUGA

Kamphof, A.J.J. (1995), De kwaliteit van arboscholing aan medezeggenschapsorganen, Universiteit van Amsterdam, scriptie postdoctorale opleiding voor arboconsultants

Karageorgiou, A. et al. (2000), Risk assessment in four member states of the European Union, in: K. Frick et al., (eds.), Systematic Occupational Health and Safery Management, Amsterdam/Oxford: Pergamon

Karsten, L. (1990), De achnurendag: arbeidstijdverkorting in historisch perspectief 1817-19/9. Amsterdam: IISG

Kemp, S. van der en M. Engelen (2002), Het instrument bestuurlijke boete in de Arbonvet: Aanknopingspunten veor effectiviteitshevordering. Den Haag: Elsevier/Ministerie van Sociale Zaken en Werkgelegenheid

Kerkhof, P. en P. G. Klandermans (1998), Medezergenschap beter geregeld?. Den Haag: AtO fonds gemecnten

King, G., R.O. Keohane en S. Verba (1994), Designing social inquiry: scientific inference in qualitative reseanch, Princeton: Princeton Univ, Press

Klaveren, M. van en S. Kooistra (1991), Sociaal Onnwerpen: Werknemers beìmloeden vormgeving en onganisatie van han werk. Utrecht: Jan Van Arkel

Klein Hesselink, D.J. en G.E. Evers (1994). Maatschappelijke betrokkenheid van ondememingsraden. Den Haag: VUGA

Klein Hesselink, DJ. (1995-a), Ongevallenregistratic in bedrij: over de melding, registratie en analyse wan arbeidsongrvallen. Amsterdam: NIA 
KJein Hesselink, D.J. c.a. (1995-b). Arbeidstijden en ziekteverzuim: onderzoek naar het effect wan afwijkende werktijdregelingen op veiligheid, gezondheid, vrije tijd en ziekteverzuim van werknemers, Den Haag: Ministerie van Sociale Zaken en Werkgelegenheid

Kloks, D. (1990), Onderzoeksverslag VGW-profiel: een onderzoek naar het functioneren van VGW-com. missies in de industrie. Amsterdam: Industricbond FNV

Konings, M. en M. van der Zouw (2002), Sectonanalyse WAO 2000: Analyse van 69 sectoren op basis van mesogevens, Den Haag: Ministerie van Sociale Zaken en Werkgelegenheid

Koningsveld, E.A.P en J.C.M. Mossink (1997), Kernciifers maatschappelijke kosten van arbeidsomstandigheden in Nederland, Den Haag: VUGA/Ministerie van Sociale Zaken en Werkgelegenheid

Koningsveld, E.A.P en K. The (1999), Sectorale kosten van arbeidsomstandigheden in de bouwnijverheid. Den Haag: Elsevier/Ministerie van Sociale Zaken en Werkgelegenheid

Koukoulaki. Th. en S.Boy (red.) (2003), Globalizing technical standands. Impact and challenges for occupational health and safery, Brussel: TUTB

Kummeling. H.R.B.M. (1997), Grondrechten en de taak van de overheid in het licht van zelfregulering. Kummeling. H.R.B.M. en S.C, van Bijsterveld, Grondrechten en zelfregulering. Deventer; W.E.J, Tjeenk Willink, p. $31-50$

L.A. Geelhoed (1983), De interveniërende staat: Aanzet voor een instrumentenleer, 's Gravenhage: Staatsuitgeverij

Langenhuysen, K. (2001), Omgaan met de OR kun je leren, in: OR-Informatie, jg. 26, nr. 6, p. 36

Leertouwer, H., P.J.M. Martens en H.F. H. Lommers (2002), Meldingsplichtige en dodelijke arbeidsongevallen: Cijfers over het jaar 2001. Den Haag: Arbeidsinspectie, p. II

Leeuw, A.C.J. de (1988), Organisaties: management, analyse, ontwerp en verandering. Assen/Maastricht: Van Gorcum

Leeuw, E.D. en J.J. Hox (1998). Nonresponse in sureveys, in: Kwantitatieve methoden, jg. 19, nr, 57. p. $31-53$

Leisink. P. L.M. (1989), Structurering van arbeidsverhoudingen: een vergelijkende studie van medezeggenschap in de grafische industrie en in het streekvervoer. Van Arkel. Utrecht

Lisv (2000), WAO-instroom en bedrijfsgrootte, Amsterdam: Lisv

Lisv (2001). Trendrapportage Arbeids(on)geschiktheid 2001. Amsterdam: Lisv

LO (1998), Regional Safery Representative: A Guide from LO, Swedish Trade Union Confederation

Looise, J.C. (1998-a), Ontwikkelingen rond ondernemingsraden, in Tijdschrift voor arbeidsuraagstukken. jg. 14, nr. 2, p. 171-182

Looise, J.C. (1998-b) , Gaat de or aan zijn eigen succes te gronde?, in: Or-Informatie (jg 24, nr. 8)

Looise, J.C. en J.Z. Heijink (1986), De OR en zijn bevoegdheden: interimrapport onderzoek ondernemingsraden, Nijmegen: ITS

Looise, J.C. en F.G.M. de Lange (1987). Ondernemingsraden, bestuurders en besluitvorming. Nijmegen: ITS

Looise, J.C., J. de Leede en M. van Beusekom (1996), De ondernemingsraad van de toekomst; de toekomst van de ondernemingsraad, Amsterdam: Welboom

Loonstra, C.J. (1990), Gezag, medezeggenschap en collectieve actie, Groningen: Wolters-Noordhoff

Lourens, E. (2002), Arbeidsongevallen in de bouw in 2001. Amsterdam: Economisch Instituut voor de Bouwnijverheid

Lucardic, E. (1996), Alles goed?! Een onderzoek naar ondernemingsraden en commissies veiligheid, gezondheid en welzijn in de bouw-en houtnijverheid. Woerden: Bouw-en Houtbond FNV

Luhmann. N. (1993), Risk: A sociological theory. Berlin/New York: De Gruyter

Luhmann, N. (1984). Soziale Systeme: Grundriß einer allgemeinen Theorie. Frankfurt a. M: Suhrkamp

Lyotard, J.-F. (1979), La condition postmoderne: rapport sur le savoir, Paris: Minuit

Lyotard, J.-F (1983), Le différend, Paris: Minuit

Marcelissen. F.H.G. en L. Kerseboom (2001). Certificering Arbodiensten: Verslag van een evaluatie. Tilburg: IVA

Massaar, J. (1998), Arbozorg in middelgrote bedrijven: Een verkennend onderzoek, Den Haag: Arbeidsinspectie

Mclvor, A. (1997), State Intervention and Work Intensification. The Politics of occupational Health and Safety in the Britisch Cotton Industry, c. 1880-1914, in: A. Knotter, B. Altena en D. Damsma (eds.), Labour, social policy and the welfare state. Amsterdam: IISG

MDW-werkgroep Arbeidsomstandighedenwet (1995), Maatwerk in Bescherming. Den Haag: 22 juni 1995

Meer, M.J.S.M. (2002), Modernisering van de arbeidsverhoudingen in de bouw, een voorzichtig proces, in: A.G. Nagelkerke en A.C.J.M. Wilthagen (red.). Arbeidsverhoudingen in ontwikkeling, Deventer: Kluwer 
Meijer, E. (1993), Structuren en systemen in de structuratietheorie, in: Q. Munters, e.a, Anthomy Giddens. Een kennismaking met de structuratietheorie, Wageningen: Landbouwuniversiteit Wageningen

Mevissen, J.W.M., R. Knegt et al. (2001), Arbeidstijden in overleg? Evaluatie van de Arbeidstijdenwet, Den Haag: Elsevier/Ministerie van Sociale Zaken en Werkgelegenheid

Michel, F.P. (1995), De visie van directeuren: een onderzoeksverslag in het kader van het 'Project Intensivering Bedrijfsgerichte Arbo-scholing Medezeggenschap', Amsterdam: NIA

Michel, F.P. (1998), Hoe de OR zijn invloed op arbeidsomstandigheden kan optimaliseren, Universiteit van Amsterdam: scriptie postdoctorale opleiding voor arboconsultants

Mihata, K. (1997), The persistence of 'emergence', in: R.A. Eve, S. Horsfall en M.E. Lee (eds.), Chaos, complexity and sociology: Myths, models and theories. Thousand Oaks: Sage

Ministerie van Economische Zaken (2000), MDW Normalisatie en Certificatie: de 64 deelprojecten. Den Haag: Ministerie van Economische Zaken

Mok, S. (1947), De Vakbeweging: ontwikkelingsschets en problemen, Amsterdam: Vrij Nederland

Molenaar, A.N. (1927), Bronnen van Arbeidsrecht, Leiden: Van Doesburgh

Mulder, K. (1992), Werknemersmedezeggenschap bij particuliere ondernemingen in Nederland. Alphen a/d Rijn: Samsom

Nagelkerke, A.G. en A.C.J.M. Wilthagen (2002). De arbeidsverhoudingen aan het begin van de 21 ste eeuw. Op weg naar een institutioneel mozaiek, in: A.G. Nagelkerke en A.C.J.M. Wilthagen (red.) Arbeidsverhoudingen in ontwikkeling, Deventer: Kluwer, p. 1-18

Nederlands Centrum voor Beroepsziekten (2002), Signaleringsrapport Beroepsziekten 'O2. Amsterdam: Nederlands Centrum voor Beroepsziekten

Nichols, T. (1990). Industrial Safety in Britain and the 1974 Health and Safety at Work Act: the case of Manufacturing, in: International Journal of the Sociology of Law, 3, p. 317-342

Nichols, T. (1997), The sociology of industrial injury, London: Mansell

Nicolas, F. (1995), Gemeenschappelijke normen voor bedrijven, Luxemburg: Bureau voor officiéle publikaties der Europese Gemeenschappen.

Nieboer. N.E.T. (1997), Effect van het Bouwprocesbesluit: Bekendheid, toepassing en naleving van het Bouwprocesbesluit Arbeidsomstandighedenwet, Den Haag: Ministerie van Sociale Zaken en Werkgelegenheid/Vuga

Nielsen, K.T. (2000), Organizational theories implicit in various approaches to OHS Management, in: Frick, K. et al. (eds,), Systematic Occupational Health and Safery Management, Amsterdam/Oxford: Pergamon, p. 99-123

Nispen, F.K.M. van (1986), De grote operaties, in: F.K.M. van Nispen en D.P. Noordhoek (red.), De gmo. te operaties: De overheid onder het mes of snijden in eigen vlees, Deventer: Kluwer

NVV/SDAP (1908), Arbeidersleven in Nederland: resultaten der enquete, ingesteld door het Ned. Verbond van Vakvereenigingen in het najaar van 1907 naar de wenschelijkheid en mogelijkheid van beperking van den arbeidsduur voor volwassenen tot 10 uren per etmaal en afschaffing respectieve. lijk beperking wan nacht- en kinderarbeid. Amsterdam: Sociaal-democratische Arbeiderspartij en het Ned, Verbond van Vakvereenigingen

Oeij. P. R.A. en P. A. Stoppelenburg (1998), Naleving van de Wet op de Ondernemingsraden: stand van zaken 1997, Den Haag, VUGA

Paoli, P. en Merllié, D. (2001). Thind European survey on working conditions 2000. Dublin: European Foundation for the Improvement of Living and Working Conditions

Patton, M.Q. (1990), Qualitative evaluation and research methods, Newbury Park: Sage

Peijpe, T. van (1985), De onnwikkeling van het loonvormingsrecht, Nijmegen: Ars Aequi Libri

Peijpe, T. van (1998), The Usefulness of Comparative Methods in Studying Trends in Labour Law. In: Wilthagen, A.C.J.M. (ed.). Advancing Theory in Labour Law and Industrial Relations in a Global Context, Amsterdam/New York/Oxford/Tokio: North-Holland

Peters, A. en E.C. van Hoorn (2002), Arbomonitor 2001, Den Haag: Arbeidsinspectie

Ploeg.T.J. van der en H.J. de Ru (1995). Tussen publiek-en privaatrecht, in: T.J. van der Ploeg. H.J. de Ru en J.W. Sap (red.) (1995), In plaats van overheid: recht scheppen door particuliere organisaties. Zwolle: W.E.J. Tjeenk Willink

Plomp, H.N. (1987), Bedrijven en bedrijfsgezondheidsdiensten: Een studie naar het verloop en de determinanten van professionaliseringsprocessen in organisaties. Amsterdam: VU Uitgeverij

Poest Clement, P. E. van der en A.H.M. Broere (2000), Handboek Arbobesluit: Rechten en verplichtingen toegelicht voor werkgever en werknemer. Den Haag: Sdu (3e druk)

Poest Clement. P. E. van der en A.H.M. Broere (2002), Handboek Arbowet: Rechten en verplichtingen tocgelicht voor werkgever en werknemer. Den Haag: Sdu (7 e druk)

Popma. J. (1991), The worker: on nihilism and technology in Emst Jinger, Brussels: EHSAL. 
Popma, J.R. (1992), Bedrijfsmilieuzorg en werknemersbetrokkenheid: organisatieveranderkundige strategie of medezeggenschap? in: De Bruijn. T.J.N.M. e.a. (red), Milieuzorg in Opbouw, CSTM. Enschede, p. 195-209

Popma, J.R. (1998-a), Dialektiek der deregulering, in: De Staatscourant, 12 januari 1998

Popma, J.R. (1998-b), Nieuwe Arbowet kan beter, in: OR-Informatic, jg. 24, nr. 3

Popma, J.R. (1998-c). Voorstel Arbeidsomstandighedenwet 1998, in: Arbeid Integraal, jg. 1, nr. 5

Popma, J.R. (1998-d), Arbodienst riskeert certificaat, in: OR-Informatie, ig. 24, nr. 11

Popma, J.R. (1999-a), Verprivaatrechtelijking van arbeidsomstandigheden? In: P. F. van der Heijden, R.H. van het Kaar en A.C.J.M. Wilthagen (red.). Naar een nieuwe rechisonde van de arbeid?, Den Haag: SDU/HSI, p. 149-189

Popma, J.R. (1999-b), Ondernemingsraad en arbeidsomstandigheden In: R.H. van het Kaar en J.C. Looise (red.), De volwassen OR: Groei en grenzen wan de Nederlandse ondermemingsraad, Alphen add Rijn: Samsom, p. 177-200

Popma, J.R. (1999-c), De arbovervuiler betaalt, In: TBV, tijdschrift voor bedriifs. en verzekeringsge. neeskunde, oktober 1999, p. 236-237

Popma, J.R. (1999-d), Ondernemingsraad en Arbeidsinspectie, in: OR-Informatie jg. 25, nr. 15/16

Popma, J.R., C. van Rij en J. Hooiveld (2001), Arbodienstverlening tussen markt en medezeggenschap. Den Haag: Delwel

Popma, J. (2003), Het einde van de arbodienst? In: Arbo \& Milieu, jg. 11, nr. 2

Praag, B.M.S. van, J.T. Allegro, DJ. Klein Hesselink en J.P. Hop (1996), De arbozorg onderzocht: Een verkennend onderzoek naar de aand en omvang van de arbozorg in Nederland, Amsterdam: NIA

Quint, A.W. (1940), Twintig jaar Hooge Raad van Arbeid, Haarlem: H.D. Tjeenk Willink

Raajmakers, Ch. A.M. (1908), Arbeidsduur voor volwassen mannen, in: Sociale Studiën. III.5

Rammert, W. (1982), Kapitalistische Rationalitat und Organisierung der Arbeit, in: W. Littek e.a. (1982), Einfïhrung in die Arbeits- und Industriesoziologie. Frankfurt/New York, Campus-Verlag

Rasmussen. E. F. Lamm en B. Snelders (1999), New Zealand: Deregulation of Employment Relations. Occupational Health and Safety and Social Welfare in the Post-1984 Period, in: F. van Waarden en J. Simonis (ed.) (1999), Deregulating imperfect markets; On the role of institutions on markets. Amsterdam: Thela Thesis

Raulier A. en D.R. Walters (1995), Trade Union Training in Health and Safety in Europe, Brussel: TUTB Rees, J. (1988), Reforming the Workplace: A Study of Self-Regulation in Occupational Safety, Philadelphia: Univ. of Pennsylvania Press

Reubsaet, T.J.M., J. Warmerdam en P. A.M. den Boer (1990), De Arbowet bij bedrijfsleven en overheid, in Tijdschrift voor Arbeidsvraagstukken, Nr.1. p. 21-34

Reubsaet, T.J.M., P. A.M. den Boer, P. C.J. Sweere en H.J.M. van den Tillaart (1988), De Arbowet in uit. voering: Een onderzoek naar ervaringen in de praktijk, Den Haag: Ministerie van Sociale Zaken en Werkgelegenheid

Reynaerts, W.H.J. en A.G. Nagelkerke (1982). Arbeidsverhoudingen: theorie en praktijk. Deel I. Leiden/Antwerpen: Stenfert Kroese

Reynaerts, W.H.J. (1983). Arbeidsverhoudingen: theorie en praktijk. Deel 2, Leiden/Antwerpen: Stenfert Kroese

Reynaerts, W.H.J. (1984), Analyses van arbeidsverhoudingen, in: Sociaal Maandblad Arbeid, jg. 39, nr. 9. p. $550-563$

Rhijn, A.A. van et al. (1947). Ondernemingsraden: Rapport uitgebracht op 19 september 1947 door de commissie ter bestudering van het vraagstuk ener wettelijke regeling van de ondernemingsraden. Den Haag: Staatsdrukkerij en Uitgeverijbedrijf

Robens Committee (1972), Safety and Health at Work. Report of the Committee 1970.1972, London: Her Majesty's Stationery Office

Rogowski, R. en Wilthagen, T. (1994). Reflexive Labour Law: An Introduction, In: Rogowski, R. en T. Wilthagen, (eds), Reflexive Labour Law, Deventer/Boston: Kluwer

Rogowski. R. (1998), Autopoietic Industrial Relations and Reflexive Labour Law in the World Society, In: T. Wilthagen (ed), Advancing Theory in Labour Law and Indutrial Relations in a Global Context, Amsterdam/New York/Oxford/Tokio: North-Holland

Roland Holst, H. (1902). Kapitaal en arbeid in Nederland: hijdrage tot de economische geschiedenis der 19e eeuw. Amsterdam: Soep

Romeijn, H.J. (1895), Eenige opmerkingen naar aanleiding van de Arbeidswet, Leiden: Los

Romme, C.P. H. (1940), Vijfig jaar Arbeidswet 1889-1939, Haarlem: H.D. Tjeenk Willink

Rood, M.G. (1991). Staken in Nederland. Schoonhoven: Academic Service

Rose, H. (1991), Case studies, in: G. Allan en C. Skinner, Handbook for research in the social sciences, London, Falmer/Taylor 
Rottier, H. (1998), 'Het poedeltje in de magnetron - enkele onderwerpen uit het wetsvoorstel Arbeidsomstandighedenwet 1998 kritisch beschouwd, in: Sociaal Recht, jg. 13, nr. 6

Sap, J.W. (1995), De organisatie van een maatschappij van organisaties, in: T.J. van der Ploeg. H.J. de Ru en J.W. Sap (red.), In plaats van overheid: recht scheppen door particuliere organisaties. Zwolle: W.E.J. Tjeenk Willink

Sassen, F. (1974), Geschiedenis van de wijsbegeerte der Grieken en Romeinen, Amsterdam: Meulenhoff

Schaapman, M.H. en A.J.C.M. Wilthagen (1998), Regulering van arbeidsomstandigheden en milieueffecten: tussen publiek en privaat, in: G.H. Addink, A.M. Knol en R. Knegt (red.). Privatisering: effectiviteit en legitimiteit, Zwolle: W.E.J. Tjeenk Willink

Schäfer, C. (2001), Die WSI-Befragung von Betriebs- und Personalsräten 1999/2000 im Uberblick, in: WSI-Mitteilungen 2001, nr.2

Schepel, H. en J. Falke (2000), Legal aspects of standardisation in the Member States of the EC and EFTA, vol. I: Comparitive Report, Luxembourg: Office for Official Publications of the European Communities

Schilp, D. (1967), Dromen van de revolutie, Amsterdam: Wereldbibliotheek

Schmid, G. (1994), Flexibilization of the Labour Market through Law? On equity and efficiency in the Regulation of Working-Time?, in: Rogowski, R. en Wilthagen, T. (eds), Reflexive Labour Law, Deventer/Boston: Kluwer, p. 317-345

Schuyt. C.J.M. (1973), Rechtvaardigheid en effectiviteit in de verdeling van de levenskansen, Rotterdam: Universitaire Pers

Schwitters, R.J.S. (1991), De risico's van de arbeid: Het ontstaan van de Ongevallenwet in sociologisch perspectief. Groningen: Wolters-Noordhoff

SER (1961), De ondernemingsraad in de literatuur. Den Haag: Commissie Ondernemingsraden van de Sociaal-Economische Raad

SER (1968), Advies inzake uitbreiding bevoegdheden ondernemingsraden, Den Haag: Sociaal-Economische Raad, SER 68/13

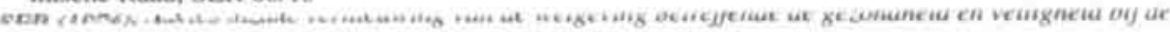
arbeid, Den Haag: Sociaal-Economische Raad, SER 76/18

SER (1994-a), Normalisatie, certificatie en open grenzen. Den Haag: Sociaal-Economische Raad, SER $94 / 11$

SER (1994-b), Normalisatie, Den Haag: Sociaal-Economische Raad, SER 94/33

SER (1997), Advies henoriémtatie Arbobeleid en Arbowet, Den Haag: Sociaal-Economische Raad, SER $97 / 03$

SER (1998), Overwegingen van de Sociaal-Economische Raad over het achterbanberaad van de OR, in: SER-voorbeeldreglement ondernemingsraden, Den Haag: Sociaal-Economische Raad

Smid. T. (2003), Deskundigen schatten risico's anders in dan werknemers, in: Arbo\&Milieu, jg. 11, nr. 4. p. $52-55$

Sol, C.C.A.M. (1999), Arbeidsvoorzieningsbeleid in Nederland: de nol van de overheid en de sociale partmers, Den Haag: Sdu

Soudry. C. (2002). Le comité d'hygiène, de sécurité et des conditions de travail, Paris: INRS

Spinhoven. M. (2000). Arboconvenant bank- en verzekeringswezen, in: Arbo en Milieu, jg. 8, nr. 5. p. 14-16

Sprengers, L.C.J. (1996). Personeelsvertegenwoordiging een ongewenste wetgevingsvrucht, in: Sociaal Maandblad Arbeid, jg 51. nr. 7/8. p. 461-470

Sprengers, L.C.J. (1998), De Wet op de Ondernemingsraden bij de overheid: Op weg naar én arbeidsrecht voor ambtenaren en werknemers?. Amsterdam: Universiteit van Amsterdam

Sprengers L.C.J. (1998), Wijziging art. 24 WOR: wordt de ondernemingsraad nu werkelijk een denktank van de ondernemer?, in: Sociaal Recht, jg. 13, p. $367-370$

Sprengers, L.C.J. en R. van de Water (2000), De klok 'luidt' twaalf uur, in: Sociaal Recht. jg. 15. nr. 2

Steeg. E.L. van der et. al (2002). Ondersock naar de succes- en faalfactoren van de op grond van de Arbeidsomstandighedenwet uitgenoende risico-inventarisatie en -evaluatie. Den Haag: Ministerie van Sociale Zaken en Werkgelegenheid (werkdocument 276)

Steenbergen, R. van (1999), OR en de relatie met de arbodienst, Alphen a/d Rijn: Samsom/FNV Formaat

Steyger, E. (1990), Medeseggenschap bij veiligheid en gezondheid: de Europese regelingen. Deventer: Kluwer

Stichting Beheer Certificatie Arbodiensten (2003), Documenten voor de Regeling Certificatie Arbodiensten, in: Wilders, M.M.W. (red.). Het compleet arbo-regelgevingboek, Amsterdam/Zeist: FNV/Kerckebosch. $6 \mathrm{c}$ druk, p. 907.966 
Stichting van de Arbeid (1999), Nota 'Beperking ziekteverzuim en instroom in de WAO'. Den Haag: Stichting van de Arbeid, Publicatienr. $6 / 99$

Stoop, J. (1982), Geschiedenis van veiligheid en gezondheid in arbeidsomstandigheden in Nederland, Delft: Technische Hogeschool

Stout, H.D. en N.J.H. Huls (1992), Reflexiviteit, autopoiese en rechtsstatelijkheid, in: N.J.H. Huls en H.D. Stout (red.), Reflecties op neflexief recht, Zwolle: W.E.J.Tjeenk Willink, p. 219-236

Streeck, W. (1992). National Diversity, Regime Competition and Institutional Deadlock, in: Journal of Public Policy, Volume 12, p. $301-330$

Streeck. W. (1992), Social institutions and economic performance: studies of industrial relations in advanced capitalist economies. Sage: London

Stuurman, C. (1995). Technische normen en het recht. Beschouwingen over de interactie tussen het recht en technische normalisatie op het terrein van de informatietechnologie en telecommunicatie, Deventer: Kluwer

SVR (1993), Kroniek van de sociale verzekeringen, Amsterdam: Sociale Verzekeringsraad

SZW (1987), Arbeidsomstandigheden in CAO's, Den Haag: Ministerie van Sociale Zaken en Werk. gelegenheid

SZW (1991), Integraal Beleidsplan Arbeidsomstandigheden, Den Haag: Ministerie van Sociale Zaken en Werkgelegenheid

SZW (1994), OR-bevorgdheden in CAO's, Den Haag: VUGA/Ministerie van Sociale Zaken en Werk. gelegenheid

SZW (1996). Heroriéntatie arbobeleid en Arbowet: Adviesaanvraag aan SER, Den Haag: Ministerie van Sociale Zaken en Werkgelegenheid, 22 maar 1996 (ARBO/AIS/96/00812)

SZW (1997), Arbo-Informatieblad 'Arbo- en verzuimbeleid', Den Haag: Sdu/Ministerie van Sociale Zaken en Werkgelegenheid

SZW (1999), Arbocomenanten nieuwe stijl: beleidsstrategie voor de komende vier jaar (1999-2002). Den Haag: Ministerie van Sociale Zaken en Werkgelegenheid, 15 januari 1999

SZW (2001), De faciliteiten en bevoegdheden van OR-en en de relaties met de achierhan, Den Haag: Ministerie van Sociale Zaken en Werkgelegenheid, Werkdocument no. 215

SZW (2002-a). Arbobalans 2002: Arbeidsrisico's, effecten en maatregelen in Nederland, Den Haag: Ministerie van Sociale Zaken en Werkgelegenheid

SZW (2002-b), Arboconvenanten nieuwe stijl: rapportage over de periode 1999-2002, Den Haag: Ministerie van Sociale Zaken en Werkgelegenheid

Takala, J. (2002), Introductory Report: Decent Work - Safe Work, XVlth World Congress on Safery and Health at Work, Vienna, 27 may 2002

Tempel J. van den et al (1923), Bedriifsorganisatie en medezeggenschap: rapport uitgebracht door de Kommissie ingesteld door N.V.V. en S.D.A.P. Amsterdam: Ontwikkeling

Teubner, G. (1983), Substantive and reflexive elements in modern law, in: Law \& Sociefy Review, 17. p. 239-285

Teubner, G. (1986-a), Industrial Democracy through Law? Social functions of law in institutional innovations, in: T. Daintith en G. Teubner (eds.), Contract and Organisation. Legal analysis in the light of economic and social theory, New York: De Gruyter, p. 261-273

Teubner. G. (1986-b), After legal instrumentalism: strategic modeis of post-regulatory law, in: $G$. Teubner (ed.). Dilemmas of Law in the welfare state, New York: De Ginyter, p. 299-325

Teulings A. (1981), Ondernemingsraadpolitiek in Nederland: Een onderzoek naar de omgang met macht en conflict door de ondernemingsraad, Amsterdam: Van Gennep

Tillaart, H. van den (2002), Imvloed en herkenbaarheid van OR-werk: Macht en onmacht herzien, Den Haag: Elsevier/GBIO

Top, M. en J. Cremers (2003), OR-Faciliteiten bij de buren: Een Duits-Nederlandse vergelijking. Den Haag: Reed Business Information/GBIO

Tros. F (2000), Decentralisering van arbeidsverhoudingen: Een onderzoek naar de arbeidsvoorwaar. denvorming in de Nederlandse private sector in de periode 1982-2000. Universiteit van Utrecht: diss.

UWV (2002). Kroniek van de sociale verzekeringen 2002, Amsterdam: UWV

Veen, J. van der. M. Engelen en M. van der Aalst (2002), Naleving van de Wet op de ondernemingsraden: Stand van zaken 2002, Den Haag: Elsevier/Ministerie van Sociale Zaken en Werkgelegenheid

Veenis, J. en A.C.J.M. Wilthagen (1998), Civielrechtelijke arbo-zaken: een verkenning van de praktijk en van de mogelijkheden tot monitoring. Den Haag: Ministerie van Sociale Zaken en Werkgelegenheid

Veerman, T.J. en A.G. ter Huurne (1996), ZARA-werkgeverspanel rapportage 1995-1996, Den Haag: Ministerie van Sociale Zaken en Werkgelegenheid/VUGA

Veerman. T.J. et al. (2001), Werkgevers over ziekteverzuim. Arbo en reintegratie: Eindropportage van het ZARA/SZW-werkgeverspanel, Den Haag: Ministerie van Sociale Zaken en Werkgelegenheid/Elsevier 
Veld, E. ter (1998), Terugtreden overheid maakt sterke or nodig, in: OR-Informatie, jg. 24, nr. 8

Velden, S, van der (2000), Stakingen in Nederland: Arbeidersstrijd 1830-1995, Amsterdam: IISG/NIWI

Veldman, A.G. (1995), Effectuering van sociaal-economisch recht volgens de chaostheorie. Zwolle: W.E.J. Tjeenk Willink

Vergeer, C. (1987), Als een akker in de winter: over het denken van Herakleitos van Efese, Amsterdam: Universiteit van Amsterdam (diss.)

Verhulp, E. (1997), Vrijheid van meningsuiting van werknemers en ambtenaren. Den Haag: Sdu/Sinzheimer Sociale Monografieèn

Verhulp, E. (2000), Klokkenluider vaak vogelvrij, in: OR-Informatie jg. 26, nr. 4

Verschuren, P. J.M. (1994), De probleemstelling voor een onderzoek, Utrecht: Het Spectrum ( $5^{e}$ druk)

Veyne, P. (1979), Comment on écrit l'histoire, Paris, Editions de Seuil

Vink, F.W.H. (2002), Inzicht in de ondermemingsraad: Een toelichting bij de Wet op de Ondernemingsraden, Den Haag: Sdu $\left(14^{e}\right.$ druk)

Vink, F.W.H. en Th.H.A. van Leeuwen (2002), Inzicht in de personeelsvertegenwoordiging: Medezegrenschap in de kleine onderneming, Den Hag: Sdu $\left(2^{c}\right.$ druk)

Vinke, H. (1997), Werknemerscompensatie bij beroepsgebonden schade, Den Haag: Sdu Sinzheimer Sociale Monografieën

Visser, R. en Y. Bonnet (1996), Instrumenten risico-imventarisatie en evaluatie: overzicht en ervaringen, Amsterdam: NIA

Vlies, I.C. van der (1993), Handboek wetgeving, Zwolle: W.E.J. Tjeenk Willink, $2^{e}$ druk

Vliet, G.E. van (1979), Bedrijvenwerk als vorm van belangenbehartiging: Een onderzoek naar het funkfioneren van het bedrijvenwerk van de Industriebond NVV en CNV, Alphen a/d Rijn: Samsom

Vogel, L. (1994), Prevention at the Workplace: An initial review of how the 1989 Community framework Directive is being implemented, Brussel: TUTB

Vogel, L. (1998), Prevention at the Workplace: the impact of Community Directives on preventive systems in Sweden, Finland, Nonway, Austria and Switzerland, Brussel: TUTB

Volkers M. on M. Hessters (2996), Mamdhoed arberibnjivew en meukzeggenschap: georuiksaamwifzing bij de Arbeidstijidenwet, Amsterdam: FNV

Voorden, W. van, A.G. Nagelkerke en W.F. de Nijs (1992), Macht in banen: arbeidsverhoudingen in theorie en beleid, Leiden/Antwerpen: Stenfert Kroese

Vos, C.J. (1982). Arbeidsbeleid en arbeidsverhoudingen: centralisering en fragmentering in het arbeidsbeleid. Deventer: Van Loghum Slaterus

Vos, C.J. en H.P. de Gier (1995), Europese en Nederiandse arbo-regelgeving, Utrecht: Lemma

Vos, P. J. en W. Buitelaar (1996), Arbeidsorganisaties en arbeidsverhoudingen in beweging. Den Haag: Welboom

Vries, H.J. de (1999), Standards for the Nation: Analysis of National Standandization Organizations, Boston/Dordrecht/London: Kluwer

Vries, J-M de en J. van der Togt (1995), Benchmarking in 9 stappen, Deventer: Kluwer

Vroom. B. de (1989), Zelfregulering. in: W. Dercksen e.a. (red.): De terugtred van regelgevers: meer regels, minder sturing? Zwolle: W.E.J. Tjeenk Willink

Waarden, F. van, J. Den Hertog. H. Vinke en T. Wilthagen (1997), Prospects for safe and sound jobs: the impact of future trends on costs and benefits of occupational health and safery. Den Haag: Vuga

Wal, R. van der (1994), Benchmarking, Rotterdam: Erasmus Universiteit

Wallace, M. (1987), Dying for Coal: the Struggle for Health and Safety Conditions in American Coal Mining 1930-1982, in: Social Forces, 2. p. 336-364

Walters, D, (2002). The Framework Directive, in: D.R. Walters (ed), Regulating Health and Safery in: Management in the European Union: A study of the Dynamics of Change, Bruxelles: P. I.E.-Peter Lang. p. 39-57

Walters, D. (2002), United Kingdom: From a piecemeal transposition to a third way, in: D.R. Walters (ed). Regulating Health and Safety in: Management in the European Union: A study of the Dynamics of Change, Bruxelles: P. 1.E.-Peter Lang. p. 235-269

Walters, D. en K. Frick (2000). Worker participation and the Management of Occupational health and Safety: Reinforcing or Conflicting Strategies, in: Frick, K. et al. (eds.). Systematic Occupational Health and Safery Management. Amsterdam/Oxford: Pergamon, p. 43-66

Walters, D. en P. L. Jensen (2000) The discourses and purposes behind the development of the EU Framework Directive 89/391, in: K. Frick et al. (eds.), Systemaric Occupational Health and Safety Management. Amsterdam/Oxford: Pergamon

Walters, D.R. (2002), Working safely in small enterprises in Europe. Brussel: TUTB

Warmerdam. J. en Th. Reubsaet (1989), Overheid en Arbowet: een ondersoek naar ervaringen in de praktijk, Den Haag: Directoraat-Generaal van de Arbeid 
Warning. J. (2000), Werkdruk nieuw vakbondsthema: voorbeelden van vakbondsinitiatieven in de dien. stensector. Zeist: Kerckebosch

Warning, J. (2002), WAO-preventieplan: Pleidooi voor een aanpak bij de bron, Utrecht: FNV Bondgenoten

Weening. H.A. en S.M. Teulings (2001), Betrokkenheid groeit met de tijd: Veranderingen in de agenda van ondernemingsraden, Den Haag: Ministerie van Sociale Zaken en Werkgelegenheid

Werf, C. van der, M. Engelen, M. van Ewijk (2001), Werkgeversaansprakelijkheid bij beroepsziekten. Den Haag: Elsevier/Ministerie van Sociale Zaken en Werkgelegenheid

Werkgroep Economisch-Historisch Seminarium (1972), Medezeggenschap en conjunctuur in de jaren na de Eerste Wereldoorlog. Universiteit van Amsterdam

Wibaut, F.M. (1920), Het socialisatievraagstuk: rapport uitgebracht door de Commissie aangewezen uit de S.D.A.P., Amstendam: Ontwikkeling

Wilders, M.M.W. (red.) (2003), Het compleet arbo-regelgevingboek, Amsterdam/Zeist: FNV/Kerckebosch, $6^{e}$ druk

Wilthagen, A.C.J.M. (1992), Recht in een gesloten samenleving: het debat over reflexief recht en autopoiesis, in: Recht der werkelijkheid, jg. 13, nr.1, p. 119-138

Wilthagen, A.C.J.M. (1993), Het overheidstoezicht op de arbeidsomstandigheden, Groningen: Wolters. Noordhoff

Wilthagen, A.C.J.M. (1994), Reflexive rationality in the Regulation of Occupational Safety and Health. In: R. Rogowski en T. Wilthagen, (eds), Reflexive Labour Law, Deventer/Boston: Kluwer

Wilthagen, A.C.J.M. (1995). Normativiteit en effectiviteit van de regulering van arbeidsomstandigheden, in: P. de Jong, et al. (red.), Arbeid, recht en risico, Amsterdam: Siswo

Wilthagen, T. (1997-a), Occupational safery and health policies in the Netherlands: Coming full circle? Paper presented at the international conference on Institutions, Markets and (economic) Performance: Deregulation and its consequences, Utrecht, 11/12/1997

Wilthagen, A.C J.M. (1997-b), Herorièntatie of desorièntatie?: Waarheen wil de overheid met het arbeidsomstandighedenbeleid. in: Arbo \& Milieu jg. 5, nr. 12, p. 10-11.

Winder, A.B., P. Kerkhof en P. G. Klandermans (1999), De ondernemingsnaad volgens werknemers. Vragen naar effectiviteit, communicatie en rechtvaandigheid, Den $\mathrm{Haag}: \mathrm{A}+\mathrm{O}$ fonds gemeenten

Winder, A.B., P. Kerkhof en P. G. Klandermans (2000), Medezeggenschap in kaart, Den Haag: A+O fonds gemeenten

Windmuller, J.P., C. de Galan en A.F. van Zweeden (1983), Arbeidsverhoudingen in Nederland, Utrecht: Het Spectrum, $4^{e}$ druk

Wissema, J.G., W.M.G. Bouts en B. Rutgers (1996), Medezeggenschap op maat, Assen: Van Gorcum

Woolfson, Ch. (1995), Deregulation: The Politics of Health and Safety, 3rd ed. Glasgow: Computer Publishing Unit of the Univ, of Glasgow

Yin, R.K. (1994), Case-study research; design and methods, Applied Social Research Methods Series. vol. 5

Zeeland, T, van (1993), De juiste katholieke moraal en ethiek in handel \& industrie, in: Tilburg, tijd. schrift voor geschiedenis, monumenten en cultuur, jg. II, nr. 3, p. 62-78

Zwetsloot, G.I.J.M. (1994), Joint management of working conditions, envimnment and quality: In search of synergy and organizational learning, Amsterdam: NIA

Zwetsloot. G.I.J.M. (2000), Developments and Debates on OHSM System Standardisation and Certification, in: Frick, K. et al. (eds.), Systematic Occupational Health and Safety Management: Perspectives on an international Development. Oxford: Pergamon, p. $391-413$

Zwetsloot, G.I.J.M. en P. P. M. Sprengers (1992), Op zoek naar synergie: Het combineren van Arbo-. milieu- en kwaliteitszorg door koploperbedrijven, Den Haag: Ministerie van Sociale Zaken en Werkgelegenheid 



\section{The OHS effect of worker participation}

\section{Summary}

In 1996, the Dutch government launched a 'reorientation' of its occupational health \& safety (OHS) policy and of the Working Conditions Act. This reorientation aimed to decentralise OHS policy from state regulation to self regulation at a company level. The main assumption in this strategy was that increased latitude at a company level would enhance OHS initiatives on the part of employers. The shift towards a company level, however, also entailed greater emphasis on worker participation as a form of countervailing power. According to government: "Mobilisation of the expertise of employees is an important prerequisite for good OHS policy. Active involvement of employees is a qualitative stimulus and also secures a balance between the interests of employers and employees." In the Dutch setting. "worker participation' in OHS policy mainly implied the involvement of works councils. The government contended that the increased importance of worker participation did not imply that the position of the works council needed to be strengthened in relation to OHS. "In general, the position of the works council in both the Works Councils Act and the Working Conditions Act may be deemed adequate."

This $\mathrm{PhD}$ thesis examines some of the above assumptions. The two main questions are:

1. Does worker participation, especially by works councils, lead to better working conditions?

2. Are works councils indeed sufficiently equipped to successfully fulfil their assigned role in the field of occupational health \& safety (OHS)?

A third, more implicit research question is

3. Does self regulation lead to better working conditions?

\section{A short history of OHS regulation (Chapter 2)}

The regulation of occupational health \& safety (OHS) has come a long way since the end of the 19 th century. Until 1874 , no legislation whatsoever existed in this field. The protection of health \& safety was deemed a joint responsibility of the employer and the workers. In 1874, however, the first piece of legislation was issued, mainly aimed at protecting women and children - the so-called personae miserabiles. Working men, according to the then dominant market-liberal ideology, did not require protection by the state. They were considered to aptly fend for themselves. This ideology, however, contrasted sharply with the harsh reality at a shopfloor level. Most employers did not assume their responsibility, and the workers did 
not have the power to enforce protection. Mainly due to the weak position of the Dutch trade unions, it was not until 1919 that male workers were brought under the protection of state issued regulations (mainly in the field of working hours). The 1919 Labour Act meant a breakthrough in principle, stating for the first time that all workers had a statutory right to decent work. After this breakthrough, an ongoing stream of state regulations were issued in the field of OHS, regulations enforceable by public authority (Labour Inspectorate).

Since the 1970 s though, doubt has been cast as to the effectiveness of state regulation. This resulted in a paradigm shift in OHS policy, away from so-called 'command and control' interventionism towards self regulation. A landmark in this shift was a report published by the Robens Committee (1972), stating that "the primary responsibility lies with those who create the risk[s] and those who work with them [...] There is a role for government action, but [that] role should be predominantly concerned with influencing attitudes and creating a framework for better health and safety organisation and action by industry itself." This theoretical framework was embodied in the UK 'Health \& Safety at Work Act' (1974) and also echoed in the Dutch Working Conditions Act (WCA, 1980). Both pieces of legislation imposed a general duty of care upon employers, and also a duty to outline an OHS policy. Furthermore, the Dutch WCA bestowed a right of co-determination upon the workers (notably the works council).

Despite some amendments in the WCA since 1980 (such as an obligation to carry out a risk assessment and the introduction of OHS Services in 1994), this framework of a general duty of care on the employer's side and co-determination on the other side still holds at the end of the 20 th century. Both parties are believed to jointly develop a policy to protect health \& safety at work. This may appear to be a return to the pre- 1874 period, in which the protection of health \& safety was also considered a matter of free deliberation between employer and employees. There is a clear distinction between these two periods, however, as the workers (notably the works councils) are presently much better equipped with legal rights - mainly on the basis of the Works Councils Act.

\section{The statutory position of works councils (Chapter 3)}

The first version of the Works Councils Act (1950) hardly addressed the field of health \& safety. The works council only had the task of monitoring company compliance with all legal OHS standards. In 1971, this supervisory task was transformed into the task to 'stimulate' compliance. More importantly, the 1971 Works Councils Act bestowed a right of approval upon the works council in matters concerning $\mathrm{OHS}$ as well as advisory powers concerning various topics of a more strategic character. The scope of such powers was broadened gradually in subsequent versions of the Works Councils Act. The 1980 Working Conditions Act and its amendments in 1994 and 1998 fleshed out the more general framework laid down in the Works Councils Act.

At the end of the $1990 \mathrm{~s}$, the range of statutory powers enjoyed by works councils in the field of OHS was actually quite broad:

- a consultative right in general and specific consultative rights in the field of OHS:

- a general right to information in all fields and specific rights in the field of OHS: 
- a general right to make proposals;

- various facilities, such as time off work and a right to specific training:

- a right to set up an OHS commission:

- legal protection against specific negative consequence (notably dismissal);

- a right of approval concerning specific rulings in the field of OHS (such as a contract with an OHS service);

- advisory powers pertaining to economic and strategic policy, that may also serve to mitigate the (negative) OHS side effects of these policies;

- a right to consult the Labour Inspectorate.

\section{The use of statutory powers (Chapter 4)}

But, even if works councils are well endowed with statutory powers, they seldom succeed in applying them effectively in practice. The most basic rights - to be consulted and informed - are observed properly: in $86 \%$ of all companies, the works council is consulted regularly and, in $82 \%$, the flow of information may be labelled 'adequate'. Still, over $10 \%$ of all works councils are denied even these most basic rights (adding here that some $15 \%$ of all $50+$ companies have not installed a works council at all). The most noteworthy right in the field of $\mathrm{OHS}$ - the right of appro$\mathrm{val}$ - is violated more often than not. Only in $37 \%$ of the companies, is the right of approval fully respected. In $39 \%$ of the companies, the works council is systematically bypassed. Moreover, analysis shows that most works councils do not even notice that their rights in this field are being violated and, if they do, they seldom stand up to the employer.

In general, the performance of works councils lacks vigour. Over a period of two years, only one in eight exercised the right to submit proposals. One of the main explanations is that no less than $92 \%$ of the respondents in the survey state that the works council is overburdened and lacks sufficient time $(61 \%)$. Also, many works councils lack specific expertise in the field of OHS (and the level of expertise has not risen in comparison to a 1986 survey among works councils). Finally, some $50 \%$ of all works councils hardly ever have contact with the Labour Inspectorate. The labour inspectors themselves are not positive about the performance of works councils either: only some $60 \%$ of all works councils are deemed to be knowledgeable (no more than $10 \%$ perform 'well'). Nonetheless, $46 \%$ of all responding inspectors generally see the works council as a useful partner. Only $11 \%$ of all inspectors state that the works council does not contribute to OHS at all.

Analysing the background factors that may be of significant influence on the performance of the works council, three factors come to the fore. First, works councils that are prepared to take a more active stance appear to be taken more seriously by their employer - they are less likely to be bypassed and they receive better information. The same holds for works councils that maintain relatively close contact with trade unions. However, these more syndicalist types of works councils only constitute a small minority. Second, co-determination by works councils is clearly more effective in larger firms. This does not relate primarily to the qualities of the larger works councils themselves (they are no less overburdened than smaller ones), but it is clear that in larger firms consultative policy making is more developed than in smaller enterprises. The third and most salient conclusion is that the effective- 
ness of worker participation in OHS is very much dependent on management style and the employers attitude towards co-determination. If the employer is sceptical or even condescending about co-determination, the works council will achieve little. This last, not altogether surprising, conclusion raises a question of a more fundamental nature: if worker participation is thought to strengthen OHS policy and thereby contribute towards the protection of health \& safety at work (even though in some companies worker participation does not get off the ground), this implies that in the latter case health \& safety may be more at risk - resulting in inequality in the protection of fundamental human rights. Therefore, experiments in the area of self regulation may be at loggerheads with fundamental principles of the constitutional order. The answer to this question, however, is to be postponed until it has established whether or not worker participation does indeed lead to better working conditions.

\section{The OHS effect of worker participation (Chapter 5)}

Since 1998, the Dutch Labour Inspectorate has carried out an annual OHS Monitor involving some 1,600 companies in order to assess the current state of OHS and OHS policy in the Netherlands in general. On the basis of a secondary analysis of the 2001 findings, it has been possible to estimate the effect of worker participation (by works councils) on matters related to OHS. The qualitv of OHS mav be onerationalised by means of various indicators, such as:

1. The quality of OHS policy (risk assessment, plans of action, contract with an OHS service);

2. Actual working conditions (physical and mental burden, repetitive strain injuries, noise, dangerous substances);

3. The negative effects of poor working conditions (absenteeism, incapacity for work, occupational accidents).

The findings of the OHS Monitor indicate that there is a clear connection between the presence of a works council on the one hand and the presence and quality of both a risk assessment and a plan of action on the other hand. One in five companies $(50+$ employees) without a works council, has also failed to carry out a risk assessment. In companies that do have a works council - this is more than $6 \%$ - pertaining to the presence of a plan of action, the difference is not significant. Plans of action that have not been discussed with the works council, however, are of a significantly poorer quality (according to the inspectors). Also the quality of both OHS instruments increases with the frequency of consultation and the influence of the works council. OHS services also appear to benefit from the influence of the works council. The scope of the contract with the OHS service is significantly more encompassing in companies with a works council than in their counterparts without worker representation. Also, the focus is more on preventive activities than merely absenteeism. Findings from another survey also indicate that the impact of OHS services is stronger in companies in which the works council had been involved in contracting the OHS service.

Regarding the actual working conditions, the presence of a works council seems to be beneficial. The mere presence of a works council does not, obviously, have a great impact on the presence of OHS risks. These go hand in hand with the nature 
of production. Companies in which OHS is a recurrent theme of consultation, however, have significantly more often taken measures to reduce the risks $(93 \%)$ than companies that hardly ever discuss OHS matters with the works council $(78 \%)$. Also, the measures are embedded more thoroughly in the former companies $(84 \%)$ than in the latter $(49 \%)$.

A third indicator of the positive effect of worker participation may be that companies in which the works council has not been involved in the process of contracting an OHS service, absenteeism is at a higher level. Absenteeism appears to correlate significantly with the type of OHS policy, and the works council may to some extent influence the type of policy of both the OHS service and of the employer.

\section{The type of influence (Chapter 6)}

It can therefore be concluded that both the presence and involvement of works councils have a positive effect on OHS in companies. In order to acquire a better picture of the precise nature of the influence of the works council, case studies were carried out in two contrasting branches - the construction industry and the financial services sector (banks and insurance companies). The findings of these case studies do not provide cause for great enthusiasm. Works councils show little initiative, they mainly respond to policy proposals of the employer or OHS staff. Their expertise is meagre, with respect to both the field of OHS and the ability to operate at a policy level. On close examination though, they play a valuable role in pointing out shop floor risks and communicating daily experiences to OHS staff and management. Also, some of the OHS experts stated that in their own policy they anticipate possible reactions of the works council.

\section{Recommendations (Chapter 7)}

On balance, it is beyond dispute that the involvement of works councils in the field of OHS does indeed has a positive effect - albeit marginal, especially in companies that already have established a professional OHS infrastructure (notably in the form of an OHS coordinator). In many companies. however, doubt may be cast as to the effectiveness of worker participation. In the concluding chapter, some ideas are put forward to strengthen the protection of health \& safety at work. These ideas seek to address some of the weaknesses in the current system, mainly the lack of time and expertise on the part of worker representatives. The main idea is that all companies of, say, over 20 workers should be obliged to organise some sort of expertise in the form of internal OHS services or safety experts. Well-trained professionals at a shop floor level may be expected to boost both attention for OHS matters and effectiveness in terms of OHS policy. On the other hand, OHS should not, in my opinion, be left exclusively to the professionals. Professionalism does present the risk of one-sidedness, of an OHS policy in which the shop floor experience drifts beyond the horizon. Therefore, an active role must still be allotted to worker representatives. This role, it is argued, should not primarily be staged at a policy level but rather at a shop floor level. 'Invisible' OHS risks such as stress, organisational culture, and so on may best be brought to the surface by those who are trusted by their co-workers. Hence, a more active role should be played in the process of risk assessment to ensure that non-expert experience is properly included. 



\section{Bijlagen}

\section{Bijlage 4.1: Methodologische verantwoording bij hoofdstuk 4.1}

Het onderzoek De volwassen $O R$ uit 1999 was gebaseerd op een a-selecte steekproef van 3500 bedrijven en instellingen: ongeveer 23 procent van het totale aantal van de naar schatting 15.500 ondernemingsraden in bedrijven met meer dan 50 werknemers $(50+$ bedrijven $) .{ }^{1}$ De respons bedroeg, waar het voorzitters van ondernemingsraden betrof, 407 ( 12 procent) Onder bestuurders lag het percentage op 14 procent $(n=473){ }^{2}$ Na-enquête heeft om budgettaire redenen helaas niet plaatsgevonden, evenmin als non-responsonderzoek.

Een respons van 12 procent is zeer mager. ${ }^{3}$ Voor een totaalbeeld is hij echter toch wel voldoende betrouwbaar. De betrouwbaarheid van de uitkomsten, dat wil zeg. gen de maximale afwijking van de populatiewaarde ten opzichte van de waargenomen waarde in de responsgroep, wordt als volgt vastgesteld. ${ }^{4}$ Eerst wordt de standaardfout $\left(\mathrm{S}_{\mathrm{p}}\right)$ van een proportie bepaald:

$\mathrm{S}_{\mathrm{p}}=\sqrt{(\mathrm{pq} / \mathrm{n})} *((\mathrm{~N}-\mathrm{n}) /(\mathrm{N}-1))$

1 Deze schatting is gebaseerd op E. Bruin en F. Huijgen (2000), Naleving van de Wet op de ondernemingsraden: Stand van zaken begin 2000. Den Haag: Elsevier/Ministerie van Sociale Zaken en Werkgelegenheid. De schattingen zijn tot stand gekomen door vermenigvuldiging van het aantal bedrijven (tabel 1, p.49) met de nalevingspercentages voor de verschillende grootteklassen (tabel 2.3 .2$, p.7). Ander nalevingsonderzoek komt tot een schatting van 13.400 ondernemingsraden. M. Engelen, M. van der Aalst en E. Hornstra (2001). Naleving van de Wet op de Ondernemingsraden. Stand van zaken begin 2000, Elsevier/Ministerie van Sociale Zaken en Werkgelegenheid Over de problematische vergelijking tussen beide nalevingsonderzoeken zie $\mathrm{E}$. Bruin en H. van den Tillaart (2002). Meetbaarheid van de naleving van de WOR, in: J. Cremers en J. van der Hoek, Een deskundige $O R$ werkt beter, Den Haag: Elsevier/GBIO, p.44ff

2 Completion rate, d.w.z. als percentage van de totale uitgezette steekproef. De response rate, d.w.z. de respons gecorrigeerd voor fouten in het steekproefkader (zoals foute adressering of inmiddels opgeheven OR'en) ligt uiteraard hoger.

3 Bij het onderzoek van Bruin en Huijgen lag de respons op 47\%, maar hier betrof het een telefonische enquête. Bij schriftelijke enquêtes, zeker bij aselecte landelijke steekproeven, is de respons over het algemeen lager. Bij de ZARA-werkgeverspanels, die in dit hoofdstuk enige malen zullen worden aangehaald, lag het percentage rond de $27 \%$ ( $90 \%$ van de $30 \%$ bedrijuen die zich in eerste aanleg bereid hadden verklaard langere tijd aan het panel deel te nemen).

4 P.R.A. Oeij en P.A Stoppelenburg. Naleving van de Wet op de ondernemingsraden: Stand van zaken 1997, VUGA/Ministerie van Sociale Zaken en Werkgelegenheid, 1998, p. 74 
Bij een maximaal veilige dichotome verdeling is de uitkomst voor de standaardfout voor de gegeven populatie $(N=15.500)$ en responsgroep $(n=407): .0242$. Bij een waarschijnlijkheid van $95 \%$, hetgeen gebruikelijk is bij sociaal-wetenschappelijk onderzoek, moet deze uitkomst worden vermenigvuldigd met 1.96. In dat geval is de maximale afwijking van de proportie in de populatie (P) .047. Dit betekent dat met $95 \%$ zekerheid gezegd kan worden dat de resultaten van het survey minder dan $5 \%$ afwijken van de werkelijke situatie onder ondernemingsraden. In het vervolg wordt evenwel gewerkt met een iets kleiner bestand $(n=374)$, omdat de bedrijven met minder dan 50 werknemers én een aantal zeer kleine branches (met name de landbouw/visserij en delfstoffenwinning) buiten beschouwing worden gelaten. ${ }^{5}$ Maar ook dan blijft de betrouwbaarheid binnen het gebruikelijke betrouwbaarheidsinterval van P.049 (indien uitgegaan wordt van een aantal OR'en van 13.500. dan geldt overigens nagenoeg dezelfde P). Deze korte exercitie impliceert dat de resultaten uit het survey, althans waar het de totale respons betreft, ondanks de lage respons net voldoende betrouwbaar zijn. Bovendien is het aantal van 407 responderende ondernemingsraden duidelijk hoger dan het vergelijkbare onderzoek van Looise medio jaren ' $80 .^{6}$

Wanneer echter gekeken wordt naar de respons per branche, is de situatie duidelijk minder gunstig. Op basis van het door Bruin en Huijgen becijferde aantal OR'en in de verschillende branches kan een gewenste respons per branche worden berekend,

Tabel B4.1.I

\begin{tabular}{|l|c|c|c|c|}
\hline & $\mathrm{N}$ & gewenste $\mathrm{n}$ & $\begin{array}{c}\text { feitelijke } \\
\text { ongewogen } \mathrm{n} \text { in } \\
\text { De volwassen OR }\end{array}$ & $\begin{array}{c}\text { betrouw- } \\
\text { baarheid }\end{array}$ \\
\hline Industrie & 3056 & 97 & 62 & 0,122 \\
\hline Bouw/woningsbouw-corporaties & 1077 & 92 & 23 & 0,200 \\
\hline Transport & 1215 & 92 & 10 & 0,308 \\
\hline Handel/horeca & 2717 & 96 & 58 & 0,126 \\
\hline Bank/verzekering & 2569 & 96 & 14 & 0,261 \\
\hline $\begin{array}{l}\text { Gezondheidszorg/ } \\
\text { overige dienstverlening }\end{array}$ & 2930 & 97 & 102 & 0,094 \\
\hline Overheid & 1566 & 94 & 97 & 0,093 \\
\hline Nutsbedrijven & 154 & 61 & 8 & 0,331 \\
\hline
\end{tabular}

5 Ook Oeij en Stoppelenburg achtten de betrouwbaarheid van hun gegevens voor deze sectoren onvoldoende. Op. cit. p. 13-14. Idem voor Bruin/Huijgen 2000. p. 6. Voorts zijn in sommige gevallen bij de bewerking van de data de gegevens over de transportsector en de nutsbedrijven buiten beschouwing gelaten, omdat een ongewogen responsaantal van $<20$ nogal onbetrouwbaar is.

6 Het aantal ondernemingsraden in dat onderzoek bedroeg 233. J.C. Looise en F.G.M. de Lange (1987), Ondernemingsraden, bestuunders en besluinorming. Nijmegen: ITS, p. 300 
met een bijbehorend betrouwbaarheidsinterval. Zelfs indien het betrouwbaarheidsinterval op $10 \%$ wordt gesteld, blijft de feitelijke respons ver achter bij de gewenste respons, hetgeen impliceert dat de gegevens niet gebruikt kunnen worden voor een analyse op branche-niveau. Ook moet bij de analyse terughoudend worden omgesprongen met uitsplitsingen naar of conclusies omtrent branches. Zeker voor de branches met een ongewogen responsaantal van $<20$ (bank-/verzekeringswezen, transport, nutsbedrijven) zijn geen betrouwbare uitspraken mogelijk.

Maar nogmaals, op het niveau van alle ondernemingsraden tezamen zijn de gegevens in principe goed te gebruiken. De responsgroep is in ieder geval voldoende omvangrijk. De kwaliteit van de netto steekproef is evenwel niet perfect. Vergeleken met de cijfers van Bruin/Huijgen, die in dit geval als maatgevend worden beschouwd, zijn de sectoren transport/opslag/communicatie en banken/verzekeringen duidelijk ondervertegenwoordigd. Aan de andere kant is vooral de overheid sterk oververtegenwoordigd, evenals de grote ondernemingen. ${ }^{7}$ Deze scheve vertegenwoordiging kan worden gecorrigeerd door post-stratificatie, d.w.z. weging van de respons naar bekende kenmerken, in casu branche en bedrijfsgrootte. Hierbij wordt per branche gekeken hoe de responsgroep in het bestand zich verhoudt tot de landelijke cijfers op grond van Bruin/Huijgen.

Tabel B4.1.2

\begin{tabular}{|c|c|c|c|c|c|c|}
\hline \multirow[b]{2}{*}{ Branche } & \multicolumn{3}{|c|}{ 50-99 werknemers } & \multicolumn{3}{|c|}{$100+$} \\
\hline & $\begin{array}{l}\text { Bruin/ } \\
\text { Huligen }\end{array}$ & $\begin{array}{l}\text { Volwas- } \\
\text { sen OA }\end{array}$ & $\begin{array}{c}\text { wegings- } \\
\text { factor }\end{array}$ & $\begin{array}{l}\text { Bruin' } \\
\text { Huligen }\end{array}$ & $\begin{array}{l}\text { Volwas:- } \\
\text { sen OR }\end{array}$ & $\begin{array}{l}\text { wegings: } \\
\text { factor }\end{array}$ \\
\hline Industrie & $9,0 \%$ & $3,2 \%$ & 2,81 & $11,0 \%$ & $13,4 \%$ & 0,82 \\
\hline Bouw/woningsbouwcorporaties & $4,0 \%$ & $2,1 \%$ & 1,87 & $3,1 \%$ & $4,0 \%$ & 0,76 \\
\hline Transport & $3,9 \%$ & $0,8 \%$ & 4,81 & $4,1 \%$ & $1,9 \%$ & 2,19 \\
\hline Handel/horeca & $11,6 \%$ & $1,9 \%$ & 6,19 & $6,2 \%$ & $13,6 \%$ & 0,45 \\
\hline $\begin{array}{l}\text { Bank/verzekering } \\
\text { gezondheidszorg' }\end{array}$ & $9,4 \%$ & $1,1 \%$ & 8,78 & $7,4 \%$ & $2,7 \%$ & 2,77 \\
\hline Overige dienstverlening & $9.1 \%$ & $4.5 \%$ & 2,01 & $10,0 \%$ & $22,7 \%$ & 0,44 \\
\hline Overheid & $4,7 \%$ & $3,2 \%$ & 1,46 & $5,6 \%$ & $22,7 \%$ & 0,25 \\
\hline Nutsbedrijen & $0,3 \%$ & $0,5 \%$ & 0.50 & $0.7 \%$ & $1,6 \%$ & 0,46 \\
\hline Totaal & $51,9 \%$ & $17,4 \%$ & 2,99 & $48,1 \%$ & $82,6 \%$ & 0,58 \\
\hline
\end{tabular}

Weging komt de representativiteit van de gewogen steekproef zeer ten goede. De analyse heeft dan ook plaatsgevonden op basis van de gewogen cijfers. Aanname hierbij is echter wel dat de gewogen respons verder niet afwijkt van de niet-respon-

7 Vgl. R.H. van het Kaar, J.C. Looise e.a. (1999), De volwassen OR, Alphen a/d Rijn: Samsom p. $27-28$ 
derende populatie (missing at random). Bínnen de branches mag dus geen belangrijk verschil zijn tussen de responderende en niet-responderende ondernemingsraden. Dit vraagt, bij afwezigheid van non-responsonderzoek, een korte theoretische onderbouwing in hoeverre de doelvariabelen in het onderzoek mede bepalend zijn voor de kwaliteit van de respons. Van de factoren die in de latere analyse nog van belang zullen blijken, is aannemelijk dat de responsbereidheid vooral zal samenhangen met ten eerste tijdgebrek bij de OR en ten tweede een negatieve attitude bij de bestuurder jegens medezeggenschap. ${ }^{8}$ Deze factoren zijn niet zonder belang, zoals zal blijken in hoofdstuk 4.2 : beide factoren zijn zwaarwegende variabelen die het functioneren van de OR beïnvloeden. Bij de analyse zal ter plekke worden aangegeven welke implicaties een eventuele niet-representatieve respons heeft voor de resultaten van het onderzoek.

\section{Bijlage 6.1: selectie van branches}

De selectie van branches is primair gebaseerd op gegevens uit de opeenvolgende Arbomonitor-studies: welke branches kenmerken zich door belastende dan wel

\section{Tabel B6.1.1}

\begin{tabular}{|l|c|c|c|}
\hline & Kracht & Tijdsdruk & Combinatie \\
\hline NL & 24 & 31 & 9 \\
\hline & & & \\
\hline Verpleeg- en bejaardentehuizen & 47 & 35 & 22 \\
\hline Schoonmaakbedrijven & 42 & 31 & 17 \\
\hline Ziekenhuizen & 32 & 39 & 16 \\
\hline Horeca & 30 & 36 & 15 \\
\hline Bouw & 52 & 28 & 14 \\
\hline Voedings- en genotmiddelenindustrie & 33 & 33 & 14 \\
\hline & & & \\
\hline Groothandel & 23 & 33 & 8 \\
\hline (Petro-)chemische industrie & 21 & 31 & 8 \\
\hline Grafische industrie & 14 & 44 & 7 \\
\hline Openbaar bestuur & 7 & 31 & 2 \\
\hline Zakelijke dienstverlening/financiêle instellingen & 5 & 39 & 1 \\
\hline
\end{tabular}

8 Uit onderzoek van het ministerie van Sociale Zaken en Werkgelegenheid uit 2001 blijkt dat ondernemers die een positievere houding hebben ten aanzien van ondernemingsraden een iets (matig significant) grotere bereidheid hebben om mee te werken aan onderzock. SZW (2001), De faciliteiten en bevoegdheden van $O R$-en en de relaties met de achterban. Werkdocument no. 215. Den Haag: Ministerie van Sociale Zaken en Werkgelegenheid 
goede arbeidsomstandigheden. Daarnaast is middels de ZARA/SZW-werkgeverspanels gekeken welke branches relatief veel of weinig investeren in arbozorg. De eerste selectie is vooral gebaseerd op de Arbomonitor 1998, die een eenvoudige tabel geeft met een combinatie van de twee meest pregnante arboproblemen: fysieke belasting en werkdruk. ${ }^{9}$

De vraag welke branches veel investeren in arbozorg is beantwoord op grond van twee parameters: het bedrag dat per werknemer wordt gespendeerd aan arbodienstverlening én wat de omvang is van het takenpakket (twee parameters die uiteraard zij het niet noodzakelijk sterk met elkaar zullen samenhangen). De gegevens zijn ontleend aan twee werkgeverspanels, die overigens als manco hebben dat de overheid daarin niet wordt onderzocht. Slechts die bedrijfstakken die ook in de bovenstaande tabel eruit sprongen zijn weergegeven (waarbij de schoonmaakbedrijven moeilijk te plaatsen waren).

\section{Tabel B6.1.2}

\begin{tabular}{|l|c|c|c|}
\hline $\begin{array}{l}\text { Betaald aan arbodiensten (SZW-panel 1998-1999, } \\
\text { tabel 9.3 en 9.4), basiscontract + verrichtingen }\end{array}$ & $\mathbf{5 0 - 9 9}$ & $\mathbf{1 0 0 +}$ & $\begin{array}{c}\text { Totaal alle } \\
\text { bedrijven }\end{array}$ \\
\hline NL & 189 & 243 & 182 \\
\hline Gezondheidszorg & 146 & 184 & 160 \\
\hline Bouw & 173 & 241 & 232 \\
\hline Zakelijke dienstverlening & 179 & 207 & 172 \\
\hline Horeca & 102 & 277 & 116 \\
\hline Voedings- en genotmiddelenindustrie & 266 & 306 & 210 \\
\hline
\end{tabular}

Tabel B6.1.3

\begin{tabular}{|l|c|c|c|}
\hline $\begin{array}{l}\text { Specifieke arbo-inspanningen (ZARA 1997, } \\
\text { tabel TB7.5), maximaal 10 }\end{array}$ & $\mathbf{5 0 - 9 9}$ & $\begin{array}{c}\text { 100+ } \\
\text { (herwogen JP) }\end{array}$ & $\begin{array}{c}\text { Totaal alle } \\
\text { bedrijven }\end{array}$ \\
\hline NL & 5,5 & 7,5 & 2,1 \\
\hline Gezondheidszorg & 5,1 & 7,5 & 2,2 \\
\hline Bouw & 5,2 & 7,0 & 2,3 \\
\hline Zakelijke dienstverlening & 5,0 & 6,8 & 1,9 \\
\hline Horeca & 4,6 & 7,7 & 1,0 \\
\hline Voedings- en genotmiddelenindustrie & 6,7 & 7,8 & 3,0 \\
\hline
\end{tabular}

9 SZW (1998) Arbomonitor 1998, Den Haag: Ministerie van Sociale Zaken en Werkgelegenheid. p. 29 
Op grond van beide selectiecriteria (belastende arbeidsomstandigheden én mate van arbozorg) kwamen in eerste instantie vijf branches in aanmerking. De horeca viel af omdat het ongewogen aantal respondenten in de werkgeverspanels onder het minimum van 20 ( $n=17$ resp. 9) lag en in de Arbomonitor de horeca niet als meest typerende boven kwam drijven. De voedings- en genotsmiddelenindustrie valt op doordat deze branche als enige bovengemiddeld veel investeert in arbozorg maar desondanks de arbeidsomstandigheden matig zijn. ${ }^{10}$ In de nadere selectie is deze bedrijfstak toch als eerste afgevallen omdat ook een aantal andere overwegingen meespeelde - in het bijzonder de aanwezigheid van branchespecifieke onderzoeksgegevens (bouw en gezondheidszorg) én mogelijk gebruik van de gegevens uit het eigen survey-onderzoek (gezondheidszorg en overheid).

- gezondheidszorg: slechtste arbeidsomstandigheden (in het bijzonder verpleegen verzorgingshuizen), minder dan gemiddelde arbozorg, goed vertegenwoordigd in het survey-onderzoek;

- bouw (zwaar werk, minder dan gemiddelde arbozorg);

- zakelijke dienstverlening/financiële instellingen (beste arbeidsomstandigheden. minder dan gemiddelde arbozorg);

- openbaar bestuur (goede arbeidsomstandigheden, goed vertegenwoordigd in het survey-onderzoek).

10 Overigens wordt wellicht door de bedrijfstak juist veel geïnvesteerd omdàt de arbeidsomstandigheden intrinsiek belastend zijn, zoals omgekeend de zakelijke dienstverleners weinig investeren omdat de arbeidsomstandigheden relatief goed zijn - al moet een modern risico als RSI uiteraard niet worden onderschat. 


\begin{tabular}{|c|c|}
\hline \multicolumn{2}{|l|}{ Bijlage 6.2: vragenlijst werknemersonderzoek } \\
\hline \multicolumn{2}{|l|}{ Bedrijf } \\
\hline \multicolumn{2}{|l|}{ Functiegroep } \\
\hline- & \\
\hline \multirow[t]{3}{*}{ Doet u lichamelijk zwaar werk? } & ja, regelmatig \\
\hline & ja, soms \\
\hline & nee \\
\hline $\begin{array}{l}\text { Heeft u de afgelopen } 12 \text { maanden gezondheids- } \\
\text { klachten gehad als gevolg van fysieke belasting? }\end{array}$ & $\begin{array}{l}\text { ja } \\
\text { nee }\end{array}$ \\
\hline \multirow{3}{*}{$\begin{array}{l}\text { Doet u werk waarbij u meer keren per } \\
\text { minuut dezelfde beweging maakt? }\end{array}$} & ja, regelmatig \\
\hline & ja, soms \\
\hline & nee \\
\hline \multirow{2}{*}{$\begin{array}{l}\text { Heeft u de afgelopen } 12 \text { maanden gezondheids- } \\
\text { klachten gehad als gevolg van repeterende arbeid? }\end{array}$} & ja \\
\hline & nee \\
\hline \multirow{3}{*}{$\begin{array}{l}\text { Is er op de werkplek zoveel lawaai dat u hard moet } \\
\text { praten om u verstaanbaar te maken? }\end{array}$} & ja, regelmatig \\
\hline & ja, soms \\
\hline & nee \\
\hline \multirow[t]{3}{*}{ Werkt u met gevaarlijke stoffen? } & ja, regelmatig \\
\hline & ja, soms \\
\hline & nee/weet niet \\
\hline \multirow[t]{3}{*}{ Moet u gevaarlijk werk doen? } & ja, regelmatig \\
\hline & ja, soms \\
\hline & nee/weet niet \\
\hline \multirow{3}{*}{$\begin{array}{l}\text { Moet } \mathrm{u} \text { in een hoog tempo en/of onder hoge tijdsdruk } \\
\text { werken? }\end{array}$} & ja, regelmatig \\
\hline & ja, soms \\
\hline & nee \\
\hline \multirow{2}{*}{$\begin{array}{l}\text { Heeft } u \text { de afgelopen } 12 \text { maanden wel eens het idee gehad } \\
\text { dat het werk } u \text { te veel werd? }\end{array}$} & ja \\
\hline & nee \\
\hline \multirow{4}{*}{$\begin{array}{l}\text { Hoe was uw gezondheidstoestand de afgelopen } \\
12 \text { maanden }\end{array}$} & goed \\
\hline & redelijk \\
\hline & matig \\
\hline & slecht \\
\hline
\end{tabular}




\begin{tabular}{|c|c|}
\hline \multicolumn{2}{|l|}{ Stellingen } \\
\hline \multirow{5}{*}{$\begin{array}{l}\text { De bedrijfsleiding in ons bedrijf heeft voldoende oog } \\
\text { voor de arboproblematiek op de werkvloer }\end{array}$} & geheel mee eens \\
\hline & mee eens \\
\hline & neutraal \\
\hline & mee oneens \\
\hline & geheel mee oneens \\
\hline \multirow{5}{*}{$\begin{array}{l}\text { De OR heeft voldoende oog voor de arboproblematiek } \\
\text { op de werkvloer }\end{array}$} & geheel mee eens \\
\hline & mee eens \\
\hline & neutraal \\
\hline & mee oneens \\
\hline & geheel mee oneens \\
\hline \multirow{5}{*}{$\begin{array}{l}\text { Zonder OR zouden de arbeidsomstandigheden in ons } \\
\text { bedrijf slechter zijn }\end{array}$} & geheel mee eens \\
\hline & mee eens \\
\hline & neutraal \\
\hline & mee oneens \\
\hline & geheel mee oneons \\
\hline \multirow{2}{*}{$\begin{array}{l}\text { Kunt u ten minste } 1 \text { arbo-onderwerp noemen waarbij de } \\
\text { OR resultaat heeft behaald of een initiatief heeft genomen? }\end{array}$} & nee \\
\hline & ja, nl. \\
\hline
\end{tabular}




\title{
Lijst geïnterviewden
}

\author{
Bouw \\ dhr. N. Manshanden (FNV Formaat) \\ dhr. H. van Teijlingen (Odyssee Training en advies) \\ dhr. K. Hulspas (Arbeidsinspectie) \\ dhr. A. van Oort (regiobestuurder Hout- en Bouwbond CNV) \\ dhr. P. van Grunningen (regiobestuurder Hout- en Bouwbond CNV) \\ dhr. N. Swakman (teammanager bouw Arbo-Unie) \\ BB: directeur, VCA-coördinator, voorzitter OR \\ $\mathrm{BH}$ : bestuurder, VCA-coördinator, lid VGWM-commissie \\ BR: directeur KPO, secretaris OR

\section{Bank-/verzekeringswezen} \\ mevr. Y. Koper (SBI) \\ dhr. F. Polhout (bestuurder verzekeringswezen FNV Bondgenoten) \\ dhr. H. Gorter (bestuurder banken FNV Bondgenoten) \\ dhr. J. Everhard (teammanager dienstverlening Arbo-Unie) \\ dhr. H. ten Brink (directeur HRM Fortis) \\ bank/verzekeraar D.: Arbocoördinator, secretaris OR-commissie AZ
}





\section{Over de auteur}

Jan Popma (Alkmaar, 1962) studeerde sociologie en wijsbegeerte aan de Universiteit van Amsterdam. Na zijn studie was hij werkzaam als achtereenvolgens ORtrainer (1992-1994) en arbo- en medezeggenschapsjournalist (1995-2002). In de periode 1998-2002 was hij tevens verbonden aan de vakgroep Publiekrecht van de Universiteit Maastricht, als onderzoeker op het gebied van arbeidsomstandigheden en medezeggenschap. Sinds 1 augustus 2003 is hij onderzoeker/adviseur arbomanagement bij TNO Arbeid te Hoofddorp. 



\section{Trefwoordenregister}

A

aanstellingskeuringen

- instemmingsrecht 135, 178

- overlegrecht 168

Abraham Kuyper 52

achterban raadpleging, ondernemingsraad 116

acht-urige werkdag 54

actief informatierecht 111

actieve recht 111

advies arbodienst 147

- afschrift van 112

adviesopdracht, door OR 111

adviesrecht $74,106,125,186$

- arbo-animo 207

- personeelsvertegenwoordiging

- thema's 141 e.v.

agressic en geweld, instemmingsrecht 135

Algemeen Nederlandsch Werklieden Verbond

(ANWV) 36

ambtenaren, rechtsbescherming van 125

analysemodel 243

anonimiteit, klager 150

arbeid, schaarste van 58

arbeidende klasse 36,50

arbeider

- bescherming van 49

- humanisering van 74

arbeidersklasse 60

Arbeidsinspectic 42

- handhaving 149.189

- toezicht door 48

arbeidsomstandigheden

- bouwsector 247 e.v.

- en zelfregulering 14

- informatieplicht m.b.t. 111

- instemmingsrecht 139

- kwaliteit van 222

- wetgeving 34 e.v.

- zelfregulering en medezeggenschap 19

arbeidsomstandighedenbeleid

- en medezeggenschap 225 e.v.

- Europese 84 c.v.

- herorientatic 91

- Nederlandse overheid 16, 19

- overlegrecht 110

- preventief 126 arbeidsomstandighedenrecht

- en arbeidsverhoudingen 23 e.v.

- historisch overzicht 34 c.v.

- verprivaatrechtelijking van 92

Arbeidsomstandighedenwet, zie Arbowet

arbeidsongevallen, melding van 112

arbeidstijden 54 e.v.

- wetgeving rond 42

arbeidstijdenwetgeving, medezeggenschap

in 64

arbeidsveiligheidsrapport $\quad 112$

- overlegrecht 168

arbeidsverhoudingen

- bank- en verzekeringswezen 268

- bouwnijverheid 252

- conflictueuze 106

- en arbeidsomstandighedenrecht $23 \mathrm{e.v}$.

- institutionalisering van $5 / \mathrm{e}, \mathrm{v}$.

- ontwikkeling van 32

- polisering van 81

- radicalisering van 73

- systeem van 29

Arbeidswet, toezicht op 47

Arbeidswet 1889 , totstandkoming van $38 \mathrm{e} . \mathrm{v}$.

Arbeidswet 1919, totstandkoming van 54 e.v.

arbobeleid en medezeggenschap, praktijk 159

e.v.

arbo-en verzuimbeleid, arbo-animo 198

arbo-animo $198 \mathrm{e.v}$.

arbobeleidscyclus 126

Arbobesluit 86

- informatieplicht 113

arbocommissies 79.296

arboconvenanten 96

Arboconvenanten nieuwe stijl 96

arbocoördinator

- aanstelling van 291

- taken 294

arbodienst

- gecertificeerde 89

- inschakelen van 173

- instemmingsrecht 178

- Kaderrichtlijn 89/391 89

- keuze van 133

- kwaliteit van 227 c.v.

- relatie met ondernemingsraad 119, 145, I87

- taken 145 
arbodiensten, onafhankelijkheid van 90 arbo-effect, medezeggenschap 219 e.v. arbo-initiatieven 166

- arbo-animo 202

arbo-instituten 78

arbojaarplan, overlegrecht 168

arbo-medezeggenschap $103 \mathrm{e.v}$.

Arbomonitor 222

arbo-OR, typologic 176

arbo-overleg 80

- bijdrage VGW(M)-commissie 177

Arboprof 222

Arboraad 78

arborisico's

- bank- en verzekeringswezen 265

- en medezeggenschap $232 \mathrm{c.v}$.

Arboster, keurmerk bouwbedrijven

252

Arbosterrengids 222

arbothema's, instemmingsrecht $177 \mathrm{e.v}$.

Arbowet

- hoofdlijnen 17, 103

- en WOR 1979106

- herorièntatic op 84,91

- informatieplicht 112

Arbowet $1980 \quad 7,83$

- zoggplicht 77

Arbowet 1998

- instemmingsrechr 135

- taken OR 107

- wetsvoorstel 94

arbo-zelfregulering

- effect achtergrondfactoren

- onderroek naar 17

arbozorg, tekortkomingen in 288

asbest, informatic recht 114

\section{B}

bank- en verzekeringswezen

- bevindingen casestudie 269 e.v.

- casestudie 264 e.v.

bedrijfsgezondheidsdiensten 89

bedriffsgrootte

- arbo-animo 214

- effect van medezeggenschap 229

bedrijfskern. medezeggenschapsvorm 62

bedrijfsraden 63

beeldschermwerk, RSI 233

beleidsterreinen, invloed OR op 195

beleidsverplichting, Arbowet 17. 103

benadelingsverbod, OR-leden 123

besluit, aanvechten door $O R \quad 131$

Besluit risico's zware ongevallen (Brzo) $\quad 112$

bestuurder

- en OR 214

- opstelling van 276

bestuurlijke boete, Arbowet 199895

bestuursrechtelijke handhaving. minder ernstige

risico's 93

bevocgdheden OR, overzicht 154 e.v. bijzonder overlegrecht 109

biologische agentia, informatierecht $\quad 114$

bouwsector

- bevindingen casestudie 253 e.v.

- casestudie 247 e.v.

branche

- arbo-animo 213

- functioneren OR 196

- gebruik adviesrecht 207

buitenleden, inschakelen van 121, 174

burgerlijke- en utiliteitsbouw (B\&U), casestudie 250

C

CAO

- convenantafspraken in 96

- instemmingsrecht 131

- opkomst van 61

CAO-afspraken

- bank- en verzekeringswezen 266

- bouwsector 25!

CAO's Bouw 251

cases, selectie van 243

casestudies $241 \mathrm{e.v}$.

centralistic egealecving $08^{\circ}$

centralistische reguleringparadigma 68

centralistische reguleringsstrategie 71

certificatie-eisen, arbodienst 89

certificering arbodiensten 146

civielrechtelijke handhaving, minder ernstige

risico's 93

coalitieverbod 60

collectieve arbeidsovereenkomst, zie CAO

commissie Rochussen 44, 75

Commissic-De Ru 92

commissicloze OR 176

commissiën uit werklieden-vereenigingen, toe-

zicht 48

commissies, instellen 121

concurrenticpositic, arbo-animo 214

contract met arbodienst $147,188,227 \mathrm{c} . \mathrm{v}$.

controleurs van de arbeid 47

convenantafspraken 96

comvenanten

- bank- en verzekeringswezen 266

- bouwsector 251

crisisjaren, medezeggenschap in 64

D

De volwassen OR, onderzoek 159 e.v., 222

decentralisatie 15,81

decentralisatic en arbeidsverhoudingen 66

delegerende OR 176

democratisering 19

- eist tot 77

deregulering 14.92

- Arbowet 82

deskundige ondersteuning $O R$ 
- kosten 120

deskundigen inschakelen 119, 173

deskundigheid $\mathrm{OR}$

- gebrek aan 171

- verbetering van 175

deskundigheidsproblemen

- ondernemingsraad 194

- signaleren van 166

detaillistische reguleringsstrategie 71.72

Domela Nieuwenhuis 40

dringende reden, opzegging 124

\section{E}

economische crisis 99

economische crisis van $1920 \quad 61$

economische ontwikkelingen $58,69,81,98$

economische positie, arbo-animo 214

effect van medezeggenschap

- bedrijfsgrootte 229

- conclusies 274

effectiviteit van medereggenschap, kanttekeningen 281

enquête, ondernemingsraad 128

enquêtes arbeidsomstandigheden. 19 de eeuw 39

Europese regelgeving 99

Europese richtlijnen, arbeidsomstandigheden 84 e.v.

Europese Unie, wet- en regelgeving 84 e.v.

F

fabrieken, veiligheid en gezondheid in 44

fabrieken en werkplaatsen, maatregelen 67

fabriekskinderen 36

faciliteiten, ondernemingsraad $\quad$ I16

formalistische OR 176

functioneren $O R \quad 279$

- achtergrondfactoren 195 c.v.

- onderzoek naar $162 \mathrm{e.v}$.

fysieke belasting, bouw 247

\section{G}

GBIO (Gemeenschappelijk begeleidingsInstituut

Ondernemingsraden) 119

gecertificeerde arbodienst, inschakelen van 89

geconditioneerde zelfregulering $16,84,99$

geheimhouding. Arteidsinspectie 150

geheimhoudingsplicht 114

geluidsmetingen, informatierecht 114

gerechtelijke procedures, kosten voor 120

geschillenprocedure, instemmingsrecht 139

gevaarijike stoffen, informatierecht 114

gezondheid, zie ook arbeidsomstandigheden

Groot Amendement, Ongevallenwet 53

\section{H}

handhaving 93

- Arbeidsinspectic 189

- informatieverplichting 115

handhavingstaak. Arbeidsinspectie 149

harmoniemodel, WOR $1950 \quad 106$

harmonisatie sociale wetgeving. Europa 85

Health \& Safety at Work Act (HASAWA) 17.

73. 76

- zorgplicht 76

heroriëntatic

- arbobeleid en Arbowet 91

- Arbowet 84

herorièntatienota, arbobeleid en Arbowet 11 . 93

historisch overzicht, arbeidsomstandighedenrecht 34 e.v.

Hooge Raad voor de Arbeid, installatie van 62 humanisering, van de arbeider 74

I

informatic, recht op 78

informatieplicht

- Arbobesluit 113

- Arbowet 112

- WOR HI

informatierecht 110,170

informatieverplichting, handhaving van 115

informatievoorziening $\quad 170$

- arbo-animo

initiatiefrecht 127,166

initiatieven nemen, taakopvatting OR 165

inlenen van personeel, adviesrecht 143

instellingsbesluit, VGW(M)-commissies 122

instemmingsaanvragen

- aantal 209

- passeren OR 180210

instemmingsplicht besluit, criteria 137

instemmingsprocedure

- resultaat van 184

- snelheid van 182

instemmingsrecht $74,106,125,128$ e.v., 177

- arbo-animo 208

- Arbowet $1998 \quad 135$

- onduidelijkheden m.b.t. 132

interne arbodeskundige, positic van 295

Internkontroll 87

investeringen, adviesrecht 143

Invoeringswet SUW1, instemmingsrecht

K

Kaderrichtlijn 89/391

- arbodienst 89

- risico-imventarisatic 87

keuze arbodienst, instemmingrecht 138, 133

kiesrecht 56

kinderarbeid 35 
Kinderwetje Van Houten uit 1874 34, 36 e.v. klacht indienen

- bij Arbeidsinspectie 189

- rechtop 78

klachtrecht, Grondwet 150

klager, bescherming van 151

klassenbewustzijn 36,50

kleinere bedrijven, effect van medezeggenschap

230

kosten, medezeggenschapswerk 120

kostenvergoeding, deskundige ondersteuning

OR 120

kredietstelling, adviesrecht 143

kwaliteit arbeid, verbetering van 75

kwaliteit arbeidsomstandigheden, indicatoren

222

L.

Landelijk Komité inzake de Ongevallenwet 5.3 loondoorbetaling 120

- OR-werk 116

\section{M}

maatschappelijke ontwikkelingen

maatwerk, Arbowet $1998 \quad 83,95$

maatwerk-artikel, Arbowet $1998 \quad 140$

machtsbronnen, werknemers 160

machtsongelijkheid 60

MDW-rapport 92

medebeslissingsrecht OR 74

mededelingsplicht, voorgenomen beleid 110

medereggenschap

- arbeiders 62

- arbo-effect van 219 e.v.

- basisvoorwaarden voor 109 c.v., 167 e.v.

- in arbeidstijden- en veiligheidswetgeving 64

- institutionele invulling van 78

- redenen voor 19

- status van 93

- wetsvoorstel-Arbowet 199894

medezegenschapsrechten $125 \mathrm{e.v}$.

meerderheidsbesluitvorming 85

milieujaarverslag 112

minimumvoorschriften, Europese 85

\section{$\mathbf{N}$}

niet-formele (machts)middelen 152

nietigheid, besluit |31

non-decisie, reactic OR 180

normatieve factoren, strijd om sociale wetgeving 59

nota herorièntatie arbobeleid en Arbowet 11. 93

$\mathbf{0}$

onafhankelijkheid, arbodienst onderling beraad OR, tijd voor 116

onderneming, systeem 27

Ondernemingskamer 110,136

- beroep, bij 144

ondernemingsraad (OR)

- en Arbeidsinspectie 148, 189

- faciliteiten 116

- formele positie 103 e.v.

- functioneren van 195 e.v.

- gebruik van bevoegdheden 177 e.v., 194

- inschakelen van 182

- instelling van 64

- interne organisatie 216

- opstelling van 276

- rechten en bevoegdheden $125 \mathrm{e.v}$.

- relatie met arbodienst 145,187

- taak 104 e.v.

- taakopvatting 161 e.v.

- toerusting van 275

- typen 176

- uitbreiding bevoegdheden 74

onderzoek zelfregulering 17

ongevallen 51 e.v.

- bouw 247

Ongevallenwet 1901, totstandkoming van 51

e.v.

ontplooiing 75

ontslagverbod, OR-leden 123

ontwerp-Lely, Ongevallenwet 52

ontwerp-Lely II, Ongevallenwet 53

opgelegde geheimhouding 115

optimalisering arbeid 75

opzegverbod, OR-leden 124

OR-commissies 121

organisatickenmerken, invloed op OR 196

organisatieveranderingen, adviesrecht 143

OR-lid, rechtsbescherming van 123, 125

OR-platform 117

overbelasting. OR-leden 171

overdracht bevoegdheden, aan commissie 122

overeenstemmingsrecht OR 95, 125, 140

overheidsregulering 14

overleg, arbo-animo 204

overlegrecht OR $108,109,168$

overlegrechten, ondernemingsraden 80

overlegvergadering WOR 109

overlegvergadering 106

overlegverplichting

- Arbowet 108

- WOR 109

overnames, adviesrecht $\quad 143$

\section{$\mathbf{P}$}

PAGO (periodiek arbeidsgezondheidskundig onderzoek), overlegrecht 168

passeren van $O R$, instemmingsaanvragen 180 .

210

passief informaticrecht

periode 1870-1919, wetgeving 34 e.v. 
periode 1919-1963, wetgeving 61 e.v. periode 1960-1982, wetgeving 72 e.v. periode 1980-1999, wetgeving 82 e.v. periodisering, ontwikkeling arbeids-

verhoudingen 33

personae miserabilis 50,56

personeelsvertegenwoordiging (pvi) 114

- formele positie 103

- adviesrecht 143

plan van aanpak 112

- instemmingsrecht 138

- kwaliteit van 225

- overlegrecht 168

praktijk, arbobeleid en medezeggenschap

e.v.

preventiebeleid, arbeidsrisico's 88

preventief arbeidsomstandighedenbeleid 126 prioritaire arbeidsrisico's, branchespecificke 97

professionele OR 176

psychische belasting, effect van medezeggenschap 235

publiekrechtelijke bedrijfsorganisatie 63 publiekrechtelijke regulering, ernstige risico's 93

\section{$\mathbf{R}$}

reactie OR

- i.v.m. instemmingsrecht 180

- instemmingsaanvraag 180,212

rechten OR, overzicht 154 e.v.

rechtsbescherming

- ambtenaren 125

- OR-leden 151

-OR-en commissieleden 123

rechtssubject, positie werknemer als 107

rechtstheoretisch aspect medezeggenschap 20

recursiviteit 25 e.v.

regelgeving, niveaus van 28

Regeling Certificatie Arbodiensten 146

registratieverplichtigen, zware ongevallen 112

reguleringscrisis 84

reguleringsfilosofie 76

reguleringsstrategie 70,76

reintegratiebeleid, instemmingsrecht 135

Renum Novarum (1891), pauselijke encycliek

45

\section{RI\&E}

- adviesrecht 143

- Arbowet 112

- betrokkenheid werknemers bij 296

- instemmingsrecht OR 137

- Kaderrichtlijn 89/391 87

- kwaliteit van 225

- overlegrecht 168

- verplichte 145

Rijksverzekeringsbank $\mathbf{5 2}$

RIS, bank-en verzekeringswezen 265

risico-inventarisatie en -evaluatic, zie RI\&E
R.K. Bedrijfsradenbeweging

Robbens Committee 76,83

RSI 280

-beeldschermwerk 233

S

samenloop, WOR 1999 en Arbowet 130

samenwerking. OR en arbodienst 187

samenwerking met andere onderneming, adviesrecht 143

samenwerkingsplicht

- Arbowet 198077

- Arbowet $1998 \quad 107$

samenwerkingsverplichting, Arbowet 17, 103

Schaepman 41

Schaper 55

scholing, OR-Ieden 118

scholingsdagen 118

scholingskosten, OR-leden 118

scholingsrecht

- benutten van 173

- OR-leden 118

SDAP

- acht-urige werkdag 55

- medezeggenschap 63

seksuele intimidatie, instemmingsrecht 135

SER-voorbeeldreglement ondernemingsraden

116

Sociaal-Democratische Bond 40

Sociaal-Economische Raad (SER) 82, 93, 100

sociale beleid, informatieplicht m.b.t. 111

sociale onrust 56

sociale wetgeving 60

- strijd om 59

staf-OR 176

staking, verbod op 60

stakingsactiviteit 69

stemrecht 56

Stichting van de Arbeid 69

stimuleringstaak 106

- taakopvatting OR 164

strijd om sociale wetgeving, normatieve factoren

59

structuratietheorie 25 c.v.

systeemtheorie 20

taakopvatting. OR I6I e.v.

$\mathbf{T}$

taylorisme, bedrijfsvoering 70

technologische innovatie

- adviesrecht 143

- invloed op arbeidsomstandigheden 29

technologische ontwikkeling 59

tijdgebrek 193

- OR-leden 171

tijdregeling, OR-werk 116

toetsing, wetgevingskwaliteit 83

toezicht, wetgeving 47 
toezicht Arbeidsinspectie, Arbowet 17, 103

toezichthoudende instantie, instelling van 42

\section{$\mathbf{U}$}

uitbreiding werkzaamheden, adviesrecht 143 uitstroom werknemers, gegevensverstrekking

111

unit of analysis 242

univariate analyse, arbobeleid en medezeggenschap 161

Uta-CAO 25I

Uta-personeel, bouw

\section{$\mathbf{v}$}

Van Houten, Kinderwetje 1874 34, 36 e.v.

VCA-certificering 248

veiligheid, zie ook arbeidsomstandigheden

Veiligheidsbesluiten $\mathbf{8 2}$

VeiligheidsChecklist Aannemers (VCA) 248

veiligheidscommissies 79

- instelling van 65

veiligheidsrapport, Brzo $\quad 112$

veiligheidsvertegenwoordigers 79

Veiligheidswet, toezicht op 47

Veiligheidswet 1895, totstandkoming van

e.v.

Veiligheidswet 1934, totstandkoming van 66

veiligheidswetgeving 42

- effect medereggenschap 106

- medezeggenschap in 64

verantwoordelijkheid arbeidsomstandigheden

104

Vereeniging tot voorkoming van ongelukken in

fabrieken en werkplaatsen 44

Vereeniging van Nederlandsche Werkgevers

(VNW) 52

verplaatsing onderneming, adviesrecht 143

vertegenwoordigd overleg, dualisme in 73.

105

vervangende zelfregulering 16

vervreemding 75

verzock om wetstoepassing, aanvechten beshuit

131

verzocken tot instellen onderzoek, aan

Arbeidsinspectie 149, 189

verzuimbeleid

- effect van medezeggenschap 236

- instemmingsrecht 178

- overlegrecht 168

- zie ook arbo- en verzuimbeleid

verzuimregelingen, instemmingsrecht $O R \quad$ I35

vetorecht, m.b.t. overeenstemming 140

VGW(M)-commissie 118

- bijdrage aan OR 216
- instellen van 122,174

- scholing 173

voorlichting, recht op 78

W

WAO, gegevensverstrekking 111

welzijn 75, 106

- WOR 130

werkdruk 280

- bank- en verzekeringswezen 265

- OR-leden 171

werknemersbetrokkenheid, effect van 219

werknemersverantwoordelijkheid 105

werknemersvertegenwoordiging 19

werkoverleg, verplichte 78

werkplaatsen, veiligheid en gezondheid in

werven van personeel, adviesrecht 143

Wet op de ondernemingsraden, zie WOR

wetgeving

- bank- en verzekeringswezen 266

- bouwsector 251

- veiligheid en gezondheid 34

wetgevingskwaliteit 92

- toetsing van 83

wetstoepassing, verzoek tot 150

wijziging binnen de organisatic, adviesrecht

143

WOR, informatieplicht 111

WOR 195068,105

WOR 197173,105

- instemmingsrecht 129

WOR 1979

- en Arbowet 106

- instemmingsrecht 129

WOR 1990, instemmingsrecht 130

WOR 1998, taken OR 107

Z

zelfbeschikkingsrecht werknemers 19

zelfregulering 76,83

- begrip 15

- effect van 278

- en arbeidsomstandigheden 14

zelfreguleringsproject, criteria 283

zelfstandig overieg, VGW $(\mathrm{M})$ commissie 175

ziekteverzuim

- effect van medezeggenschap 235

- gegevensverstrekking 111

Ziektewet $1929 \quad 70$

zorgplicht

- Arbowet 17

- Health and Safety at Work Act 76

zuivere zelfregulering 15

zware ongevallen, registratie van 112 

De Arbowetgeving verplicht werkgevers een gedegen arbeidsomstandighedenbeleid te voeren. Bil de vormgeving van dat arbobeleid hebben de werknemers medezeggenschap, een recht dat in grotere bedrijven veelal wordt vitgeoefend door de ondernemingsraad. Deze studie geeft een overzicht van de rechten en bevoegdheden van de OR én schetst de ervaringen in de praktijk. De centrale vraag die daarbij aan de orde komt is: wat is het arbo-effect van medezeggenschap? Anders gezegd: leidt betrokkenheid van een ondernemingsraad tot betere arbeidsomstandigheden?

Jan Popma (Alkmaar, 1962) was in de periode 1998-2002 verbonden aan de vakgroep Publiekrecht van de Universiteit Maastricht, als onderzoeker op het gebied van arbeidsomstandigheden en medezeggenschap. Momenteel is hil onderzoeker bij TNO Arbeid te Hoofddorp. 